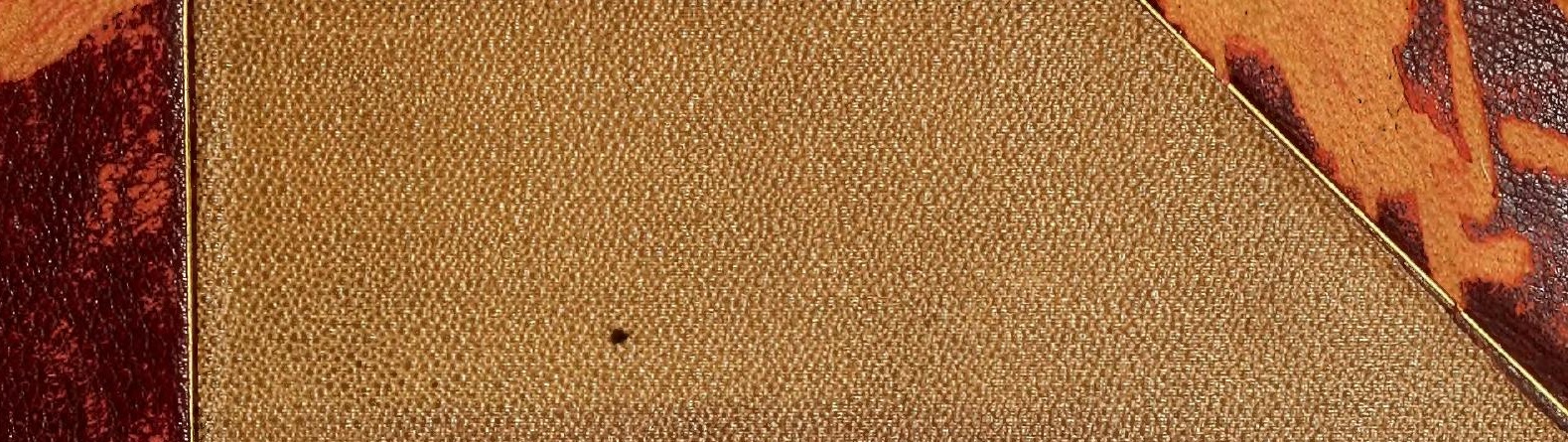

준 


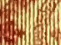

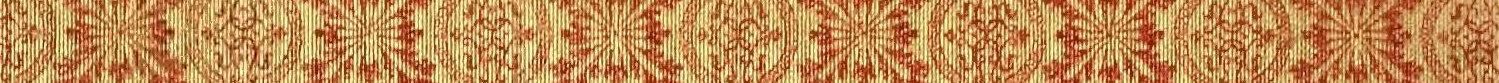
P. (6) -

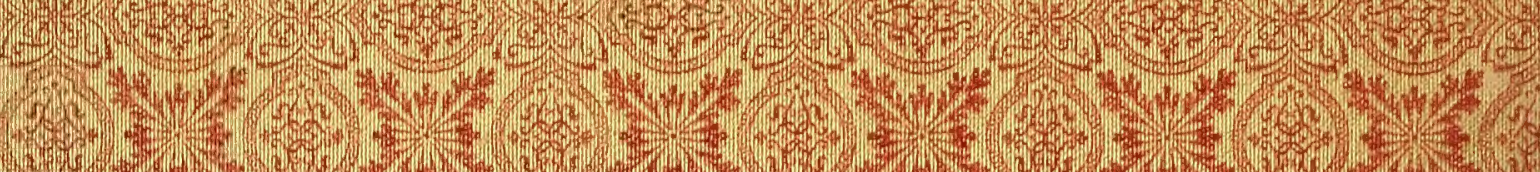
(2. - a

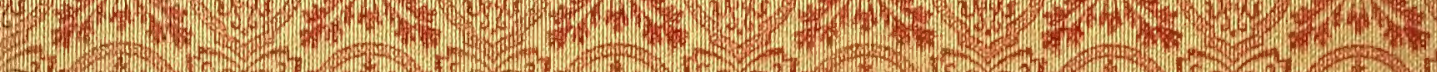
-7.

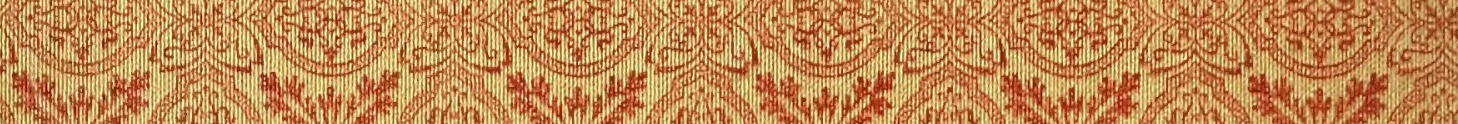

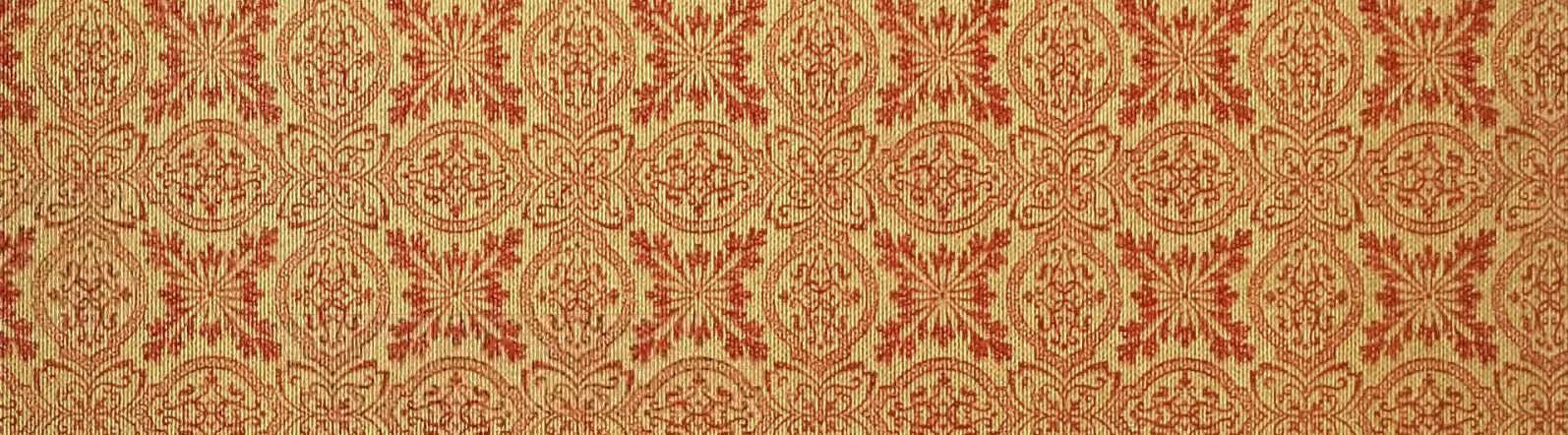

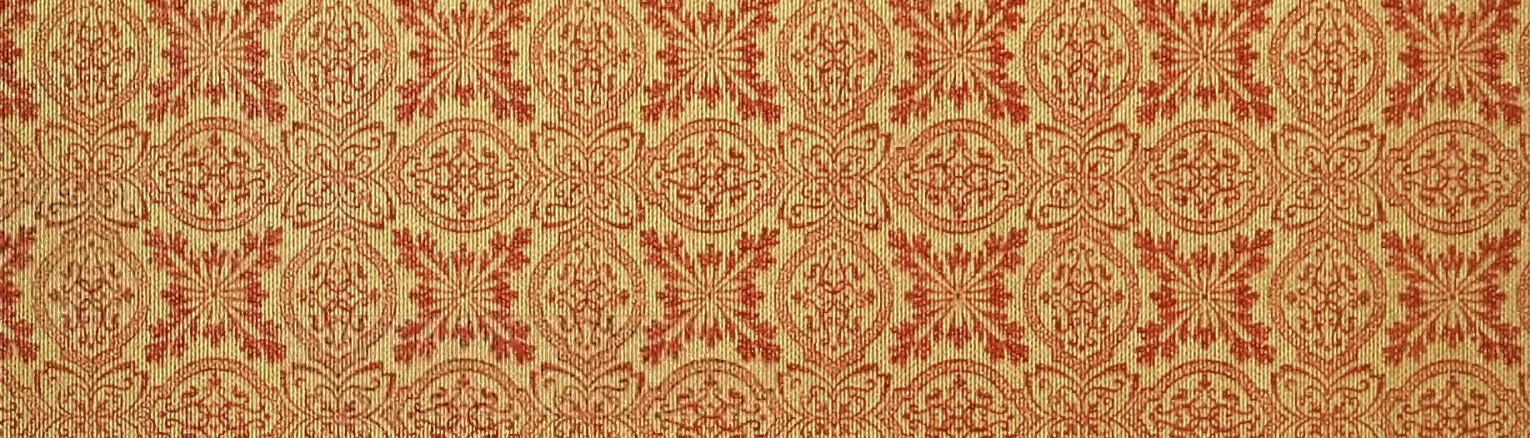

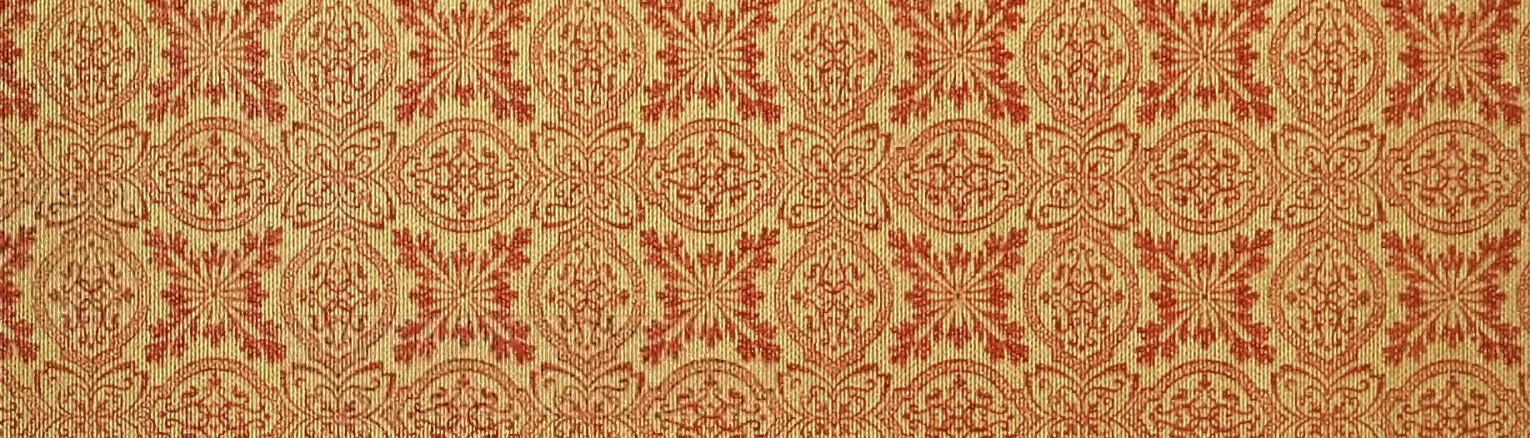

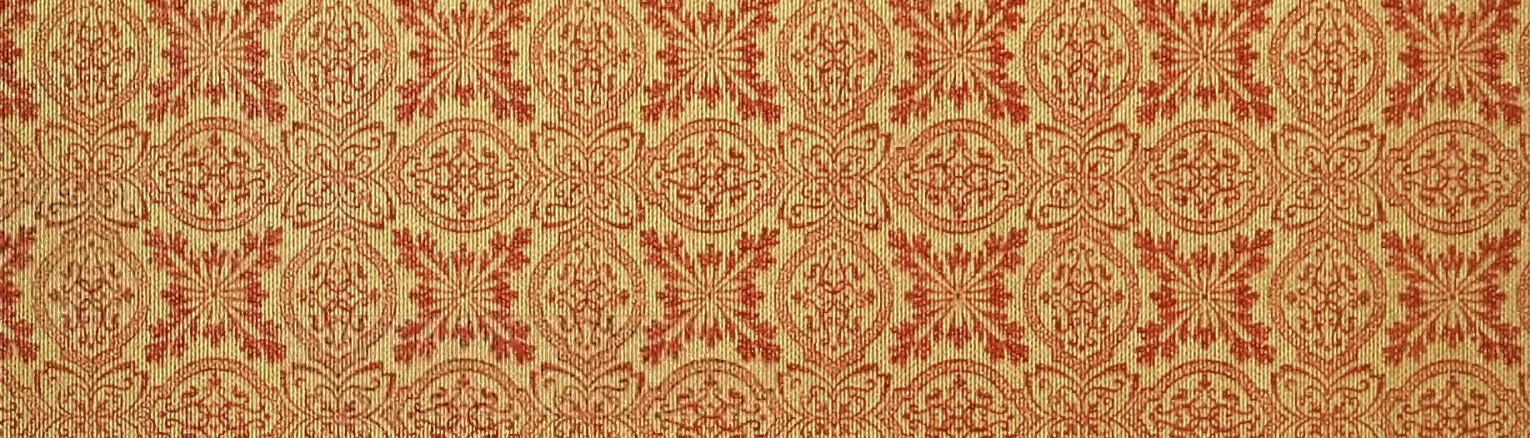

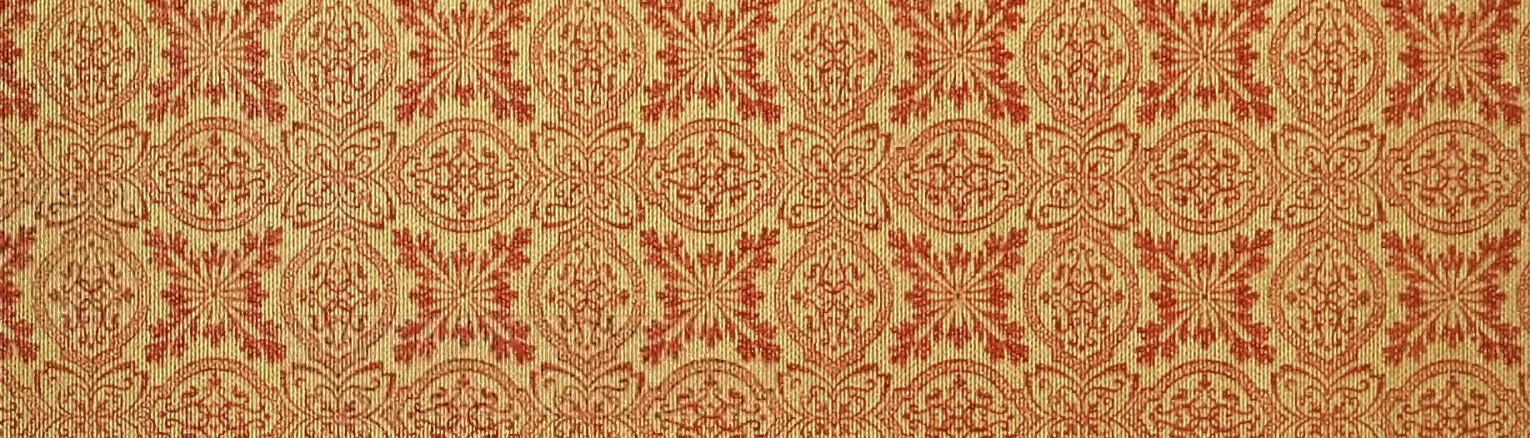

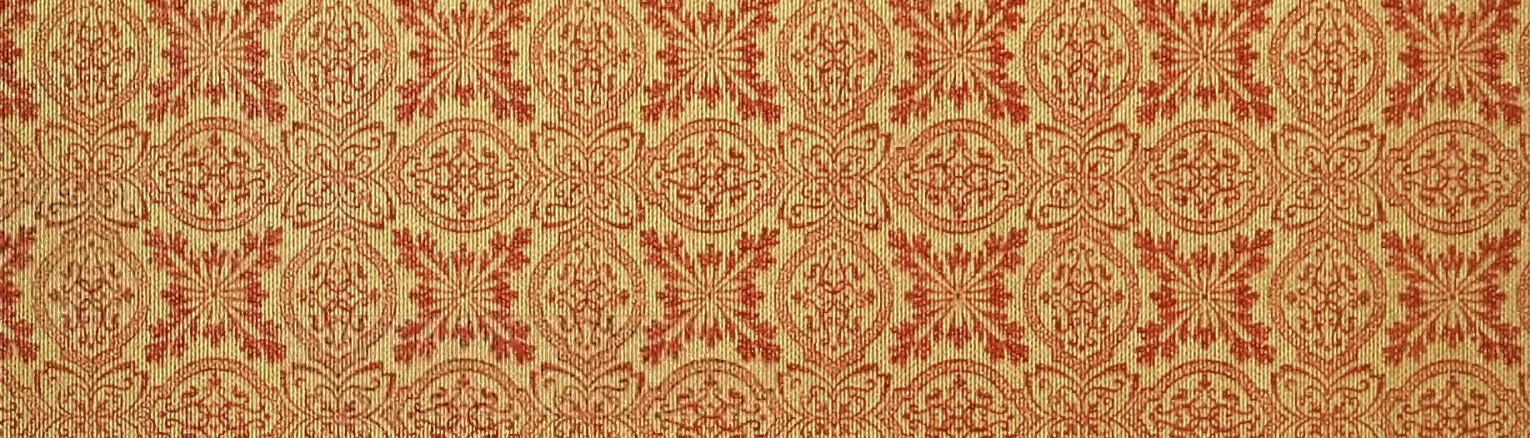

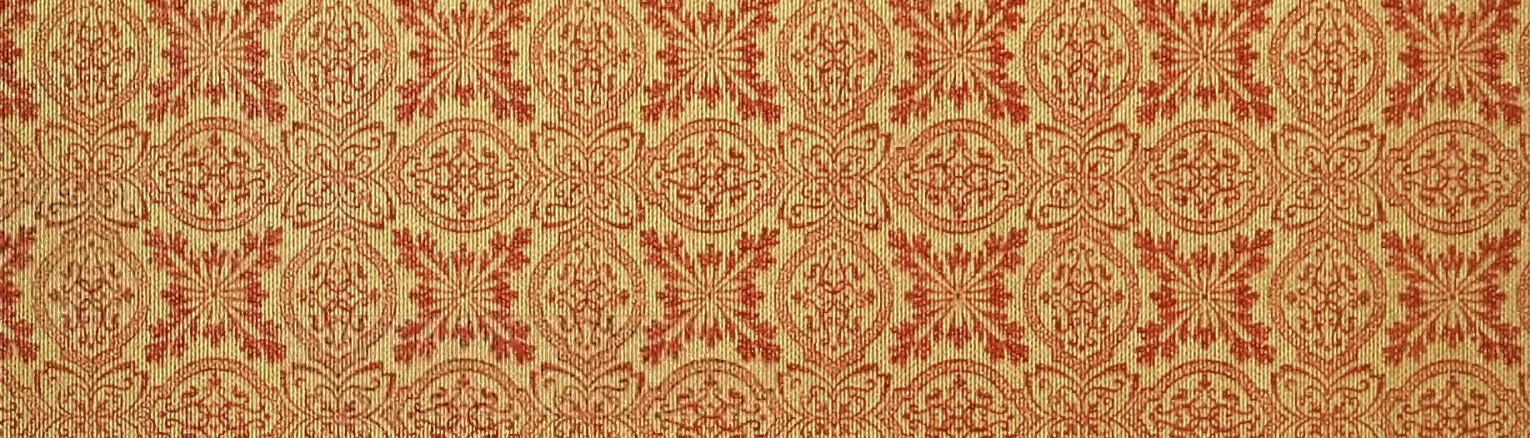

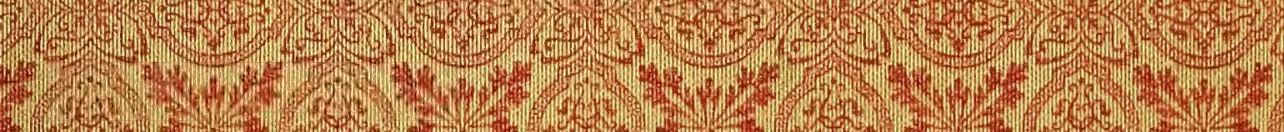

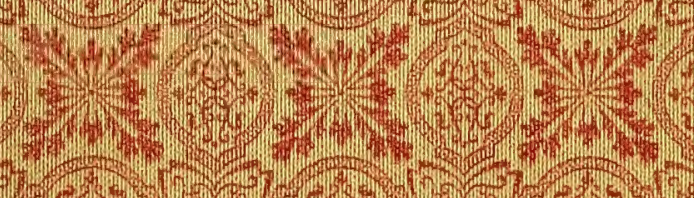

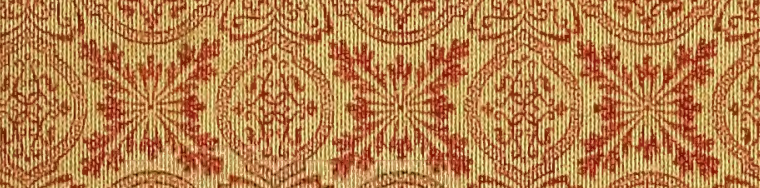
-

(3)

(2) -

$x^{2}$ (1)

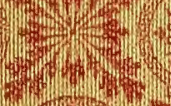
(4) $y^{2}$

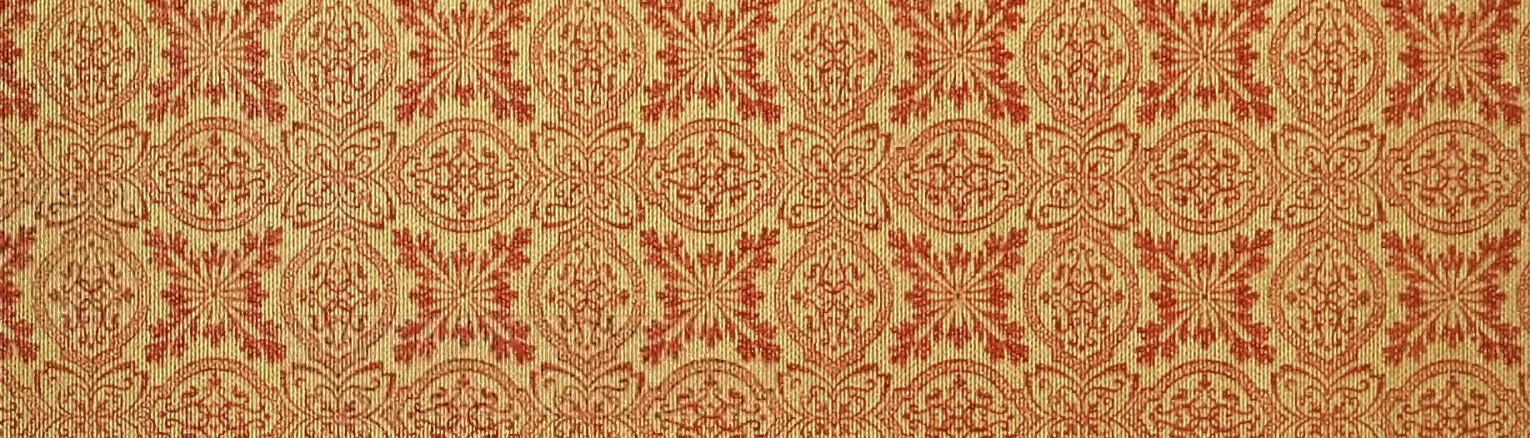

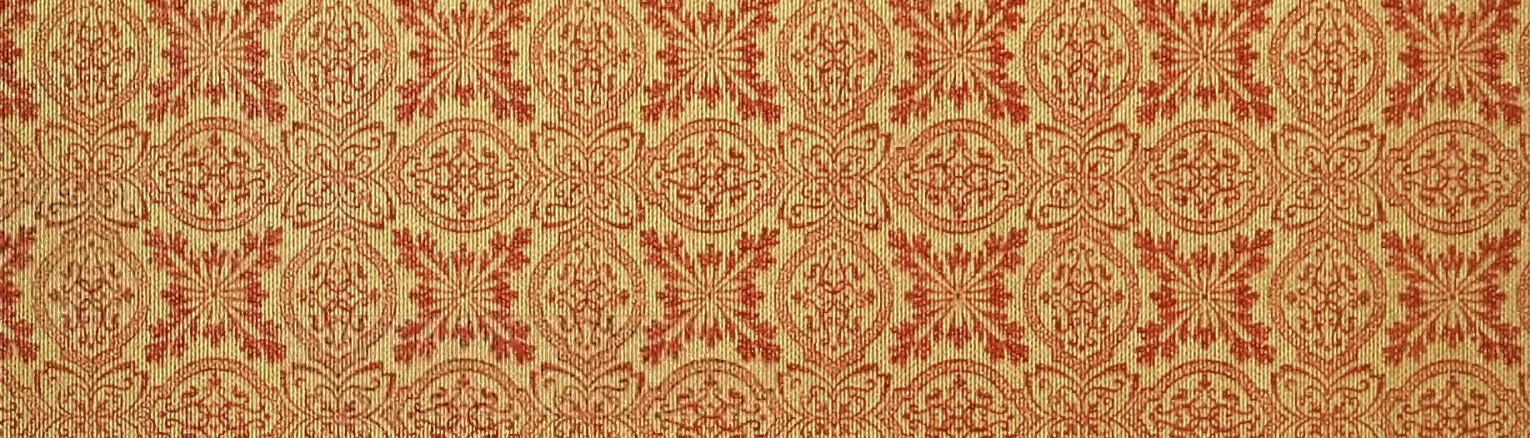

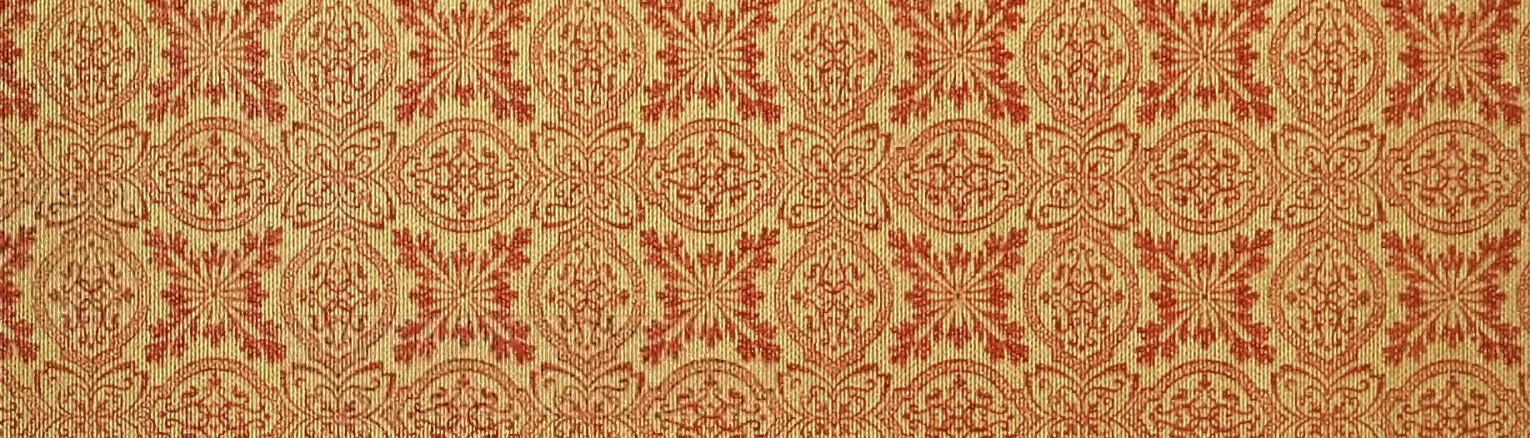

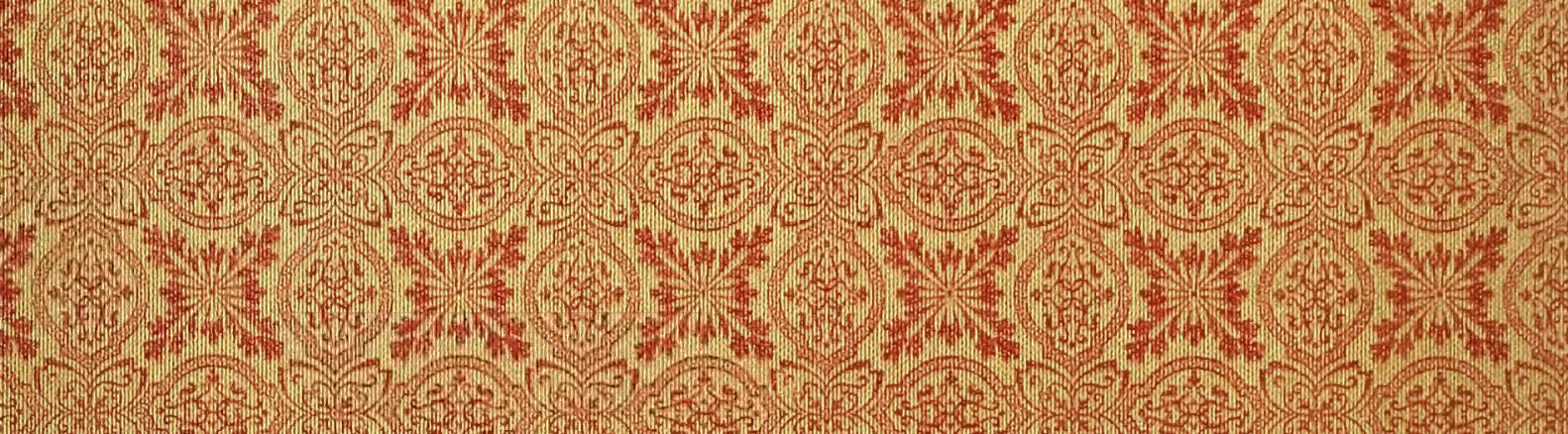

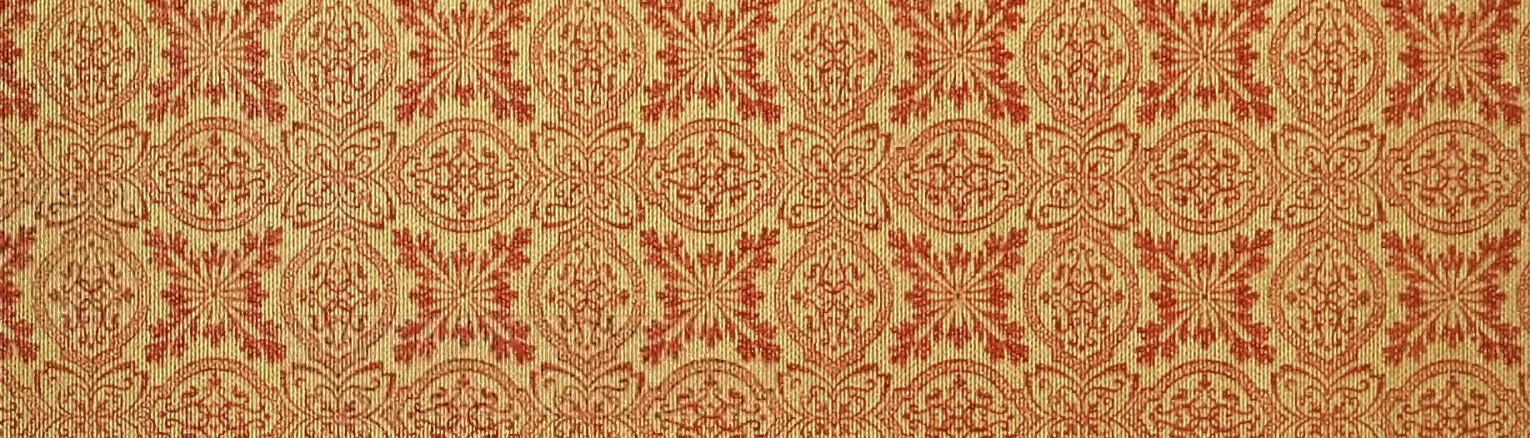
14. 4 -

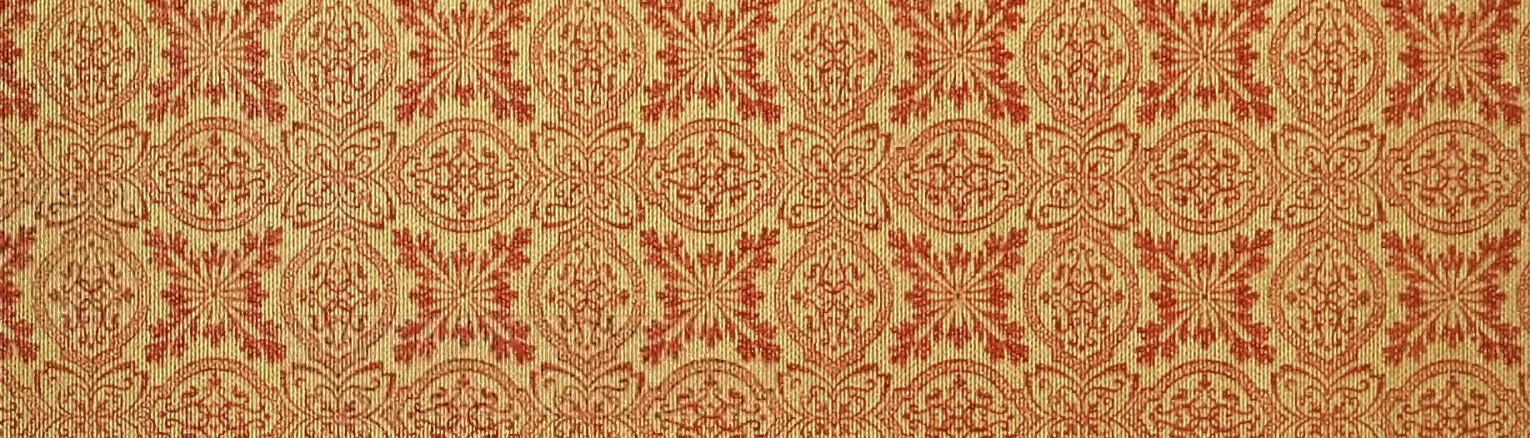

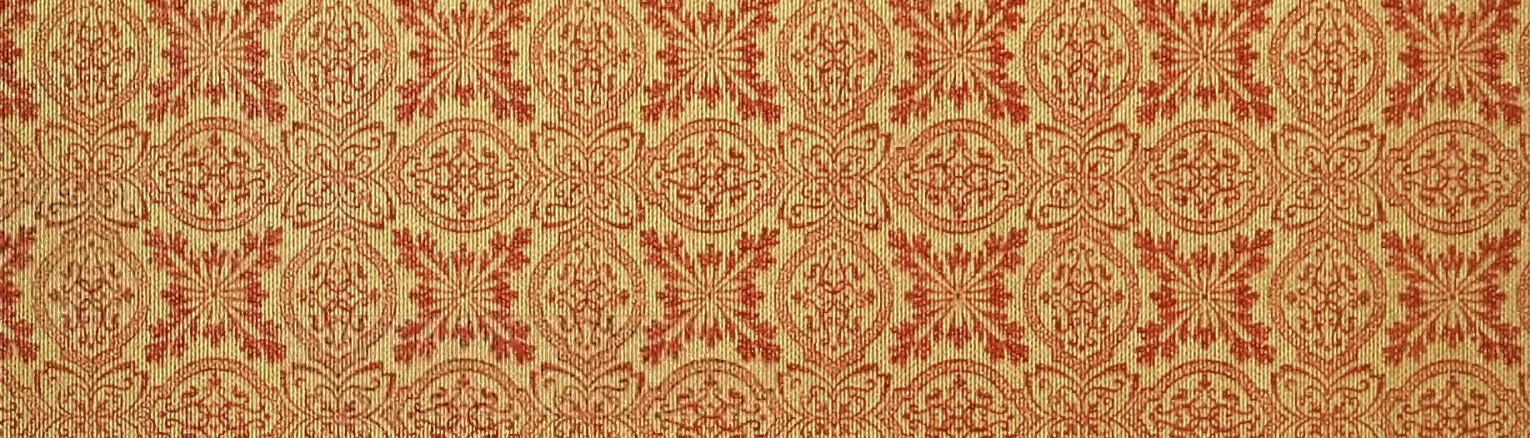

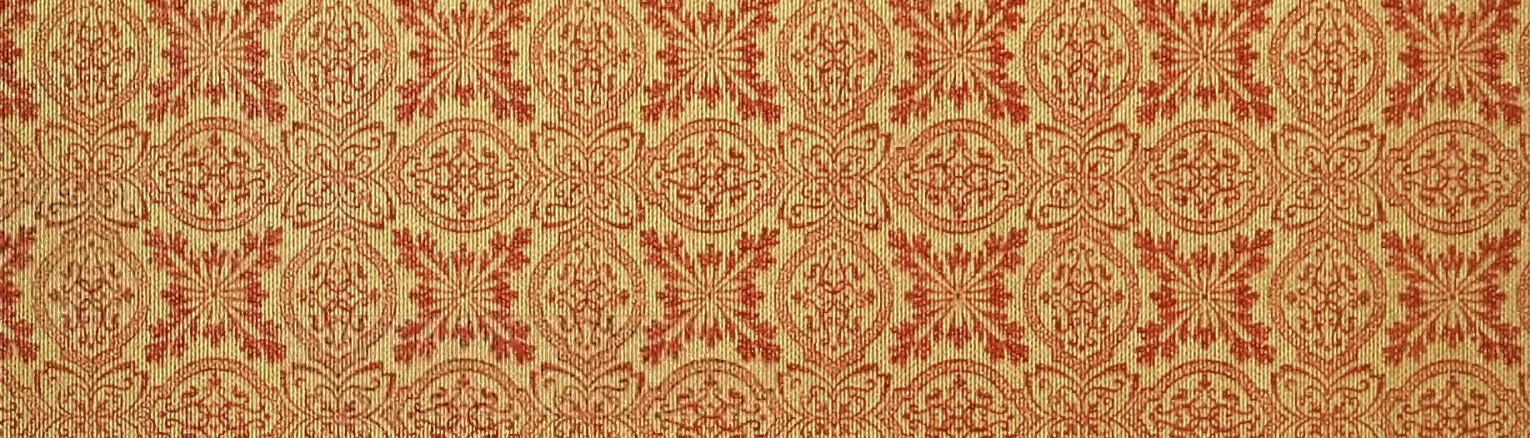

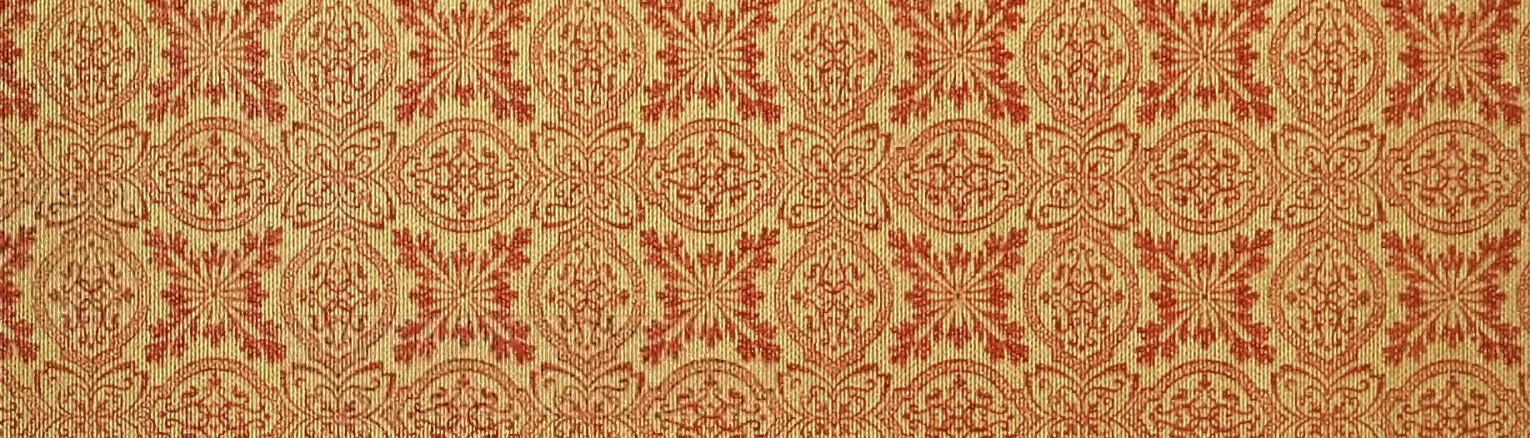

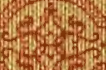




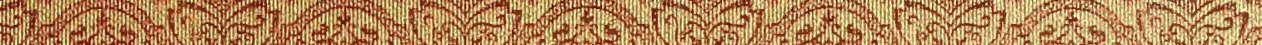

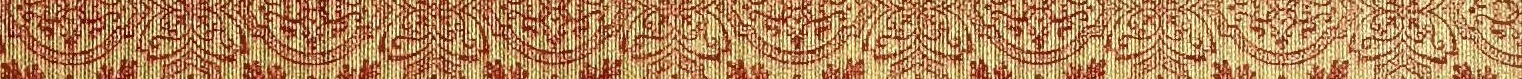

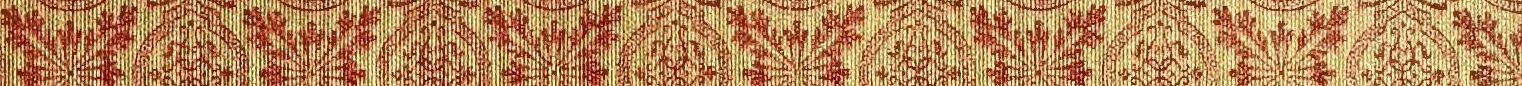

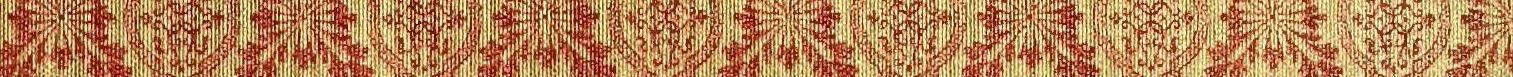

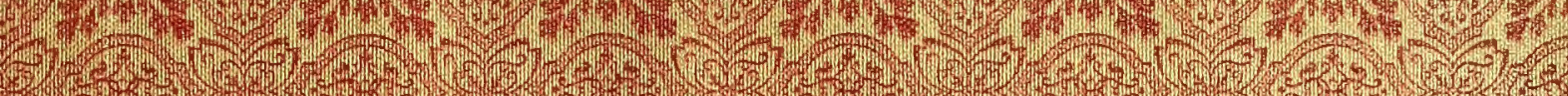
-

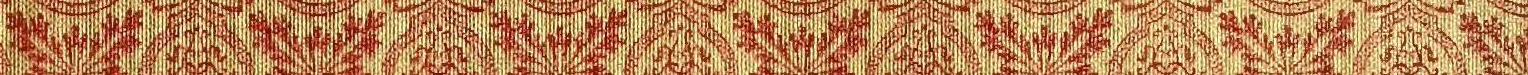

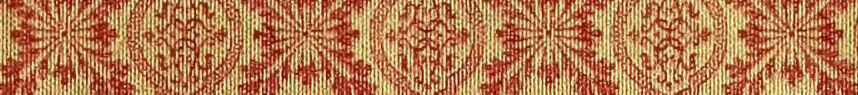
(2) (2) (1)

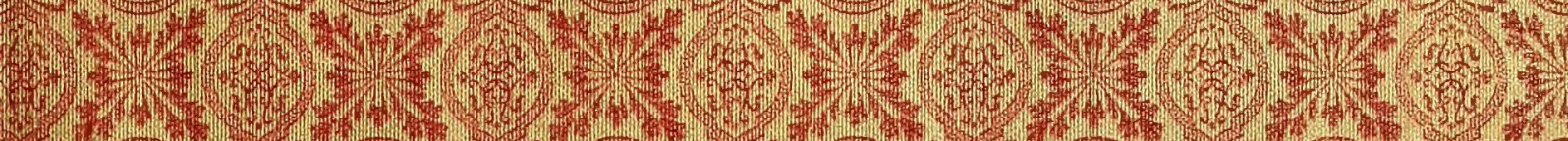

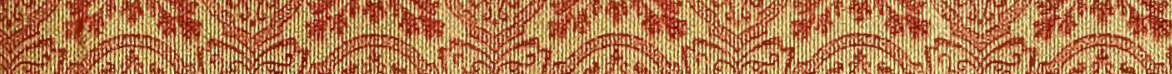

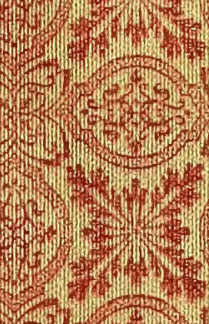

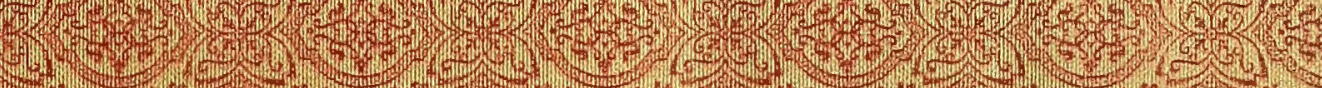

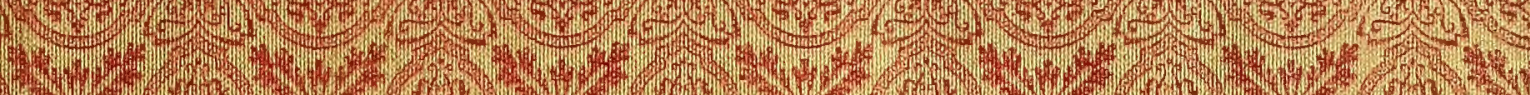

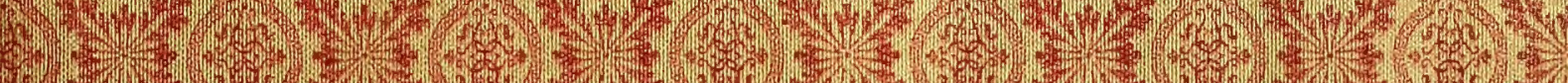

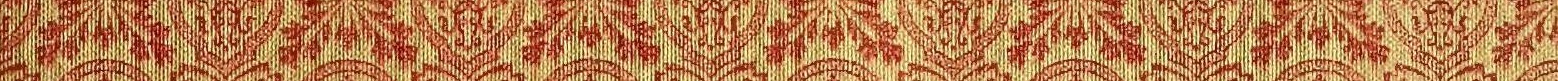

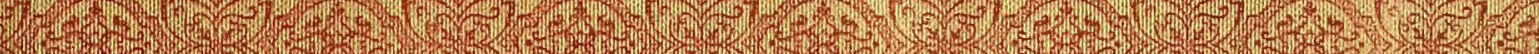

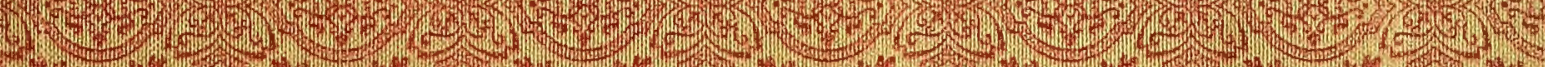

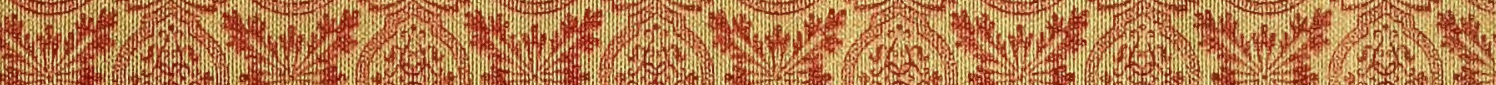

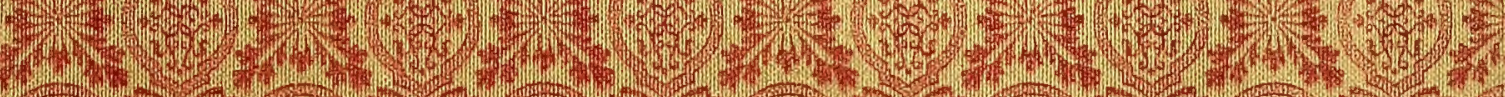

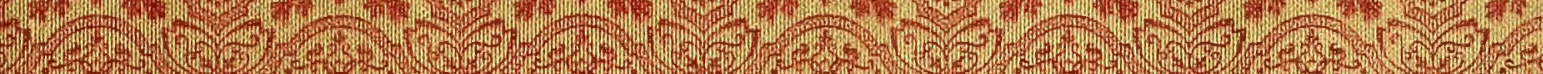
17.

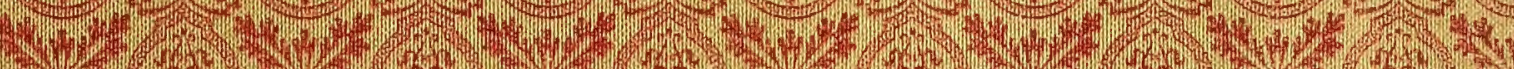

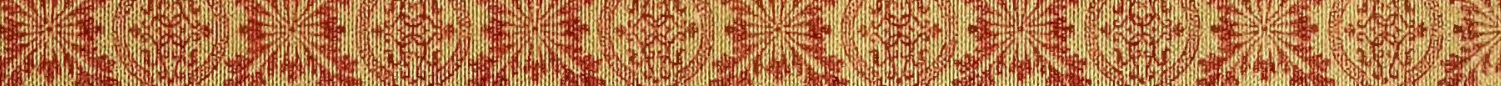

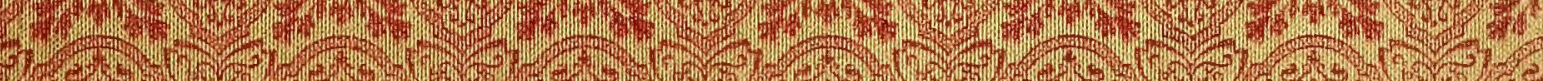

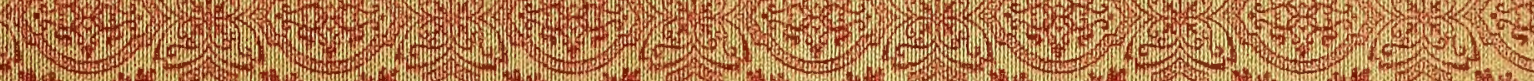

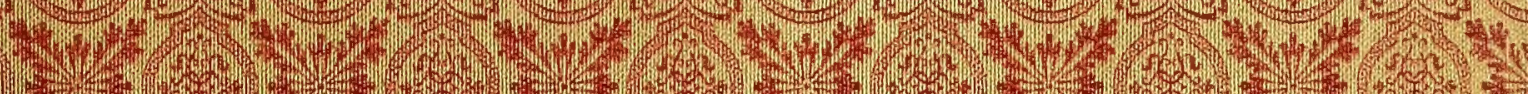

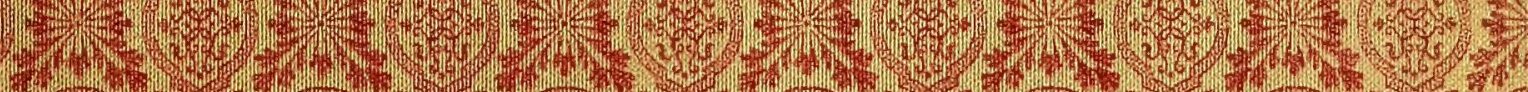
1.8. (2)

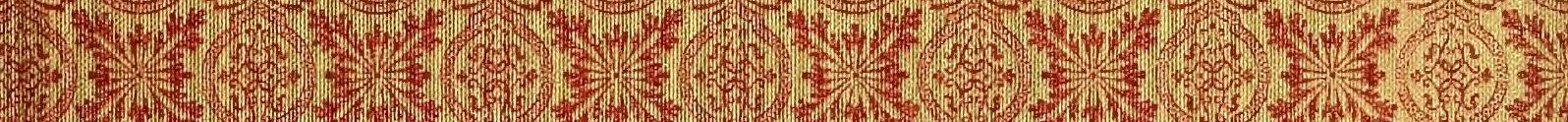
(7-

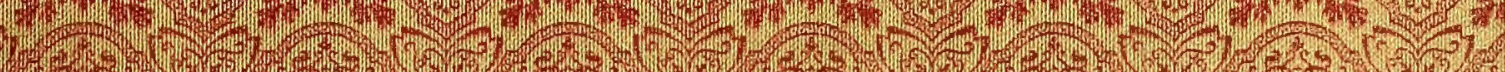

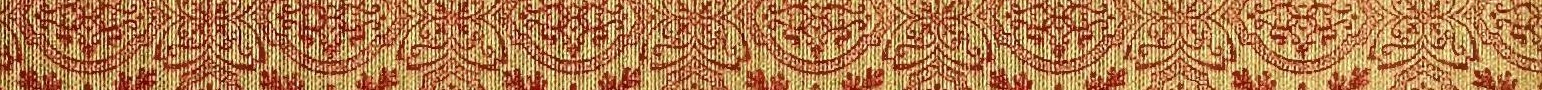

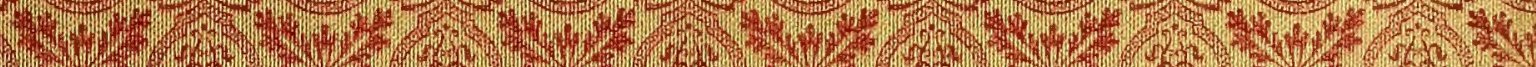

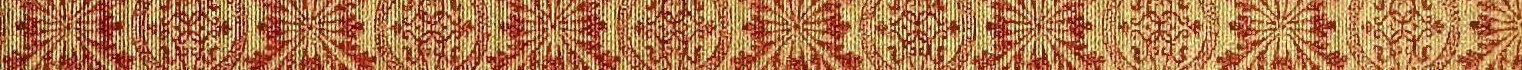

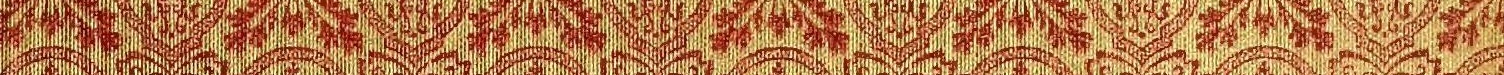

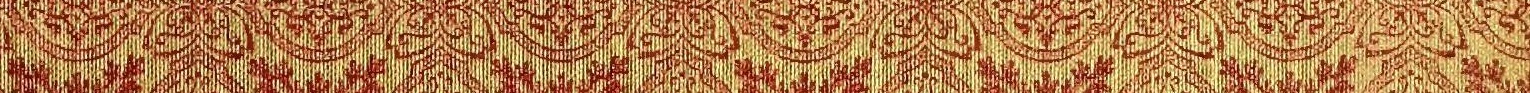



$014^{\circ}$
$c^{a}$ 


CRUTSE OF H.M.S. CURAÇOA. 


$$
\text { LONDON : PRINTED BT }
$$

BPOTISTOODF AND CO., NETV-STREFT SQEART AXD PARLTAYHAT STREFT 



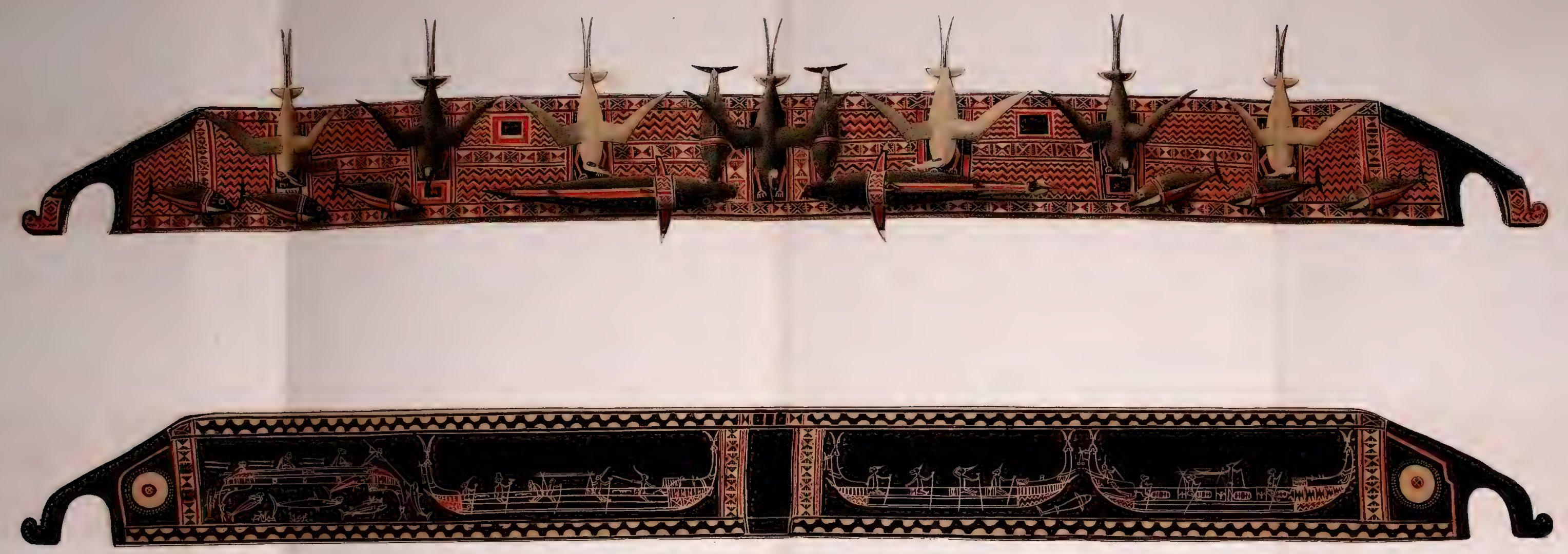

THE TWO SIDES OF A TIE-BEAM FROM A VILLAGE HALL. UJI. SOLOMON ISLANDS 



\section{JOTTINGS}

DURING TIE

\section{CRUISE OF H.MIS. CURAÇOA}

AMONG

\section{THE SOUTH SEA ISLANDS \\ IN \\ I 865}

$\mathrm{BY}$

JULIUS L. BRENCHLEY, M.A., F.R.G.S.

With NUMEROUS ILLUSTRATIONS and NATURAL HJSTORY NOTICES

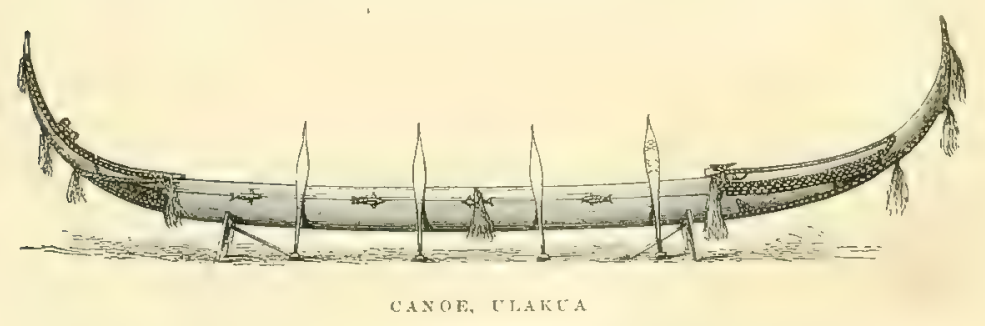

\section{LONDUN}

L O N I A N S, GRE R, A N D CO. 1873 



\section{PREFACE.}

Towards the end of the month of May 1865, I was at Sydney at the time H.M. steam frigate 'Curaçoa, commanded by Commodore (now Admiral) Sir William Wiseman, was preparing to leave for the purpose of displaying the British flag in the different archipelagoes of the Western Pacific. The Commodore, whose acquaintance I had been fortunate enough to make at Sydney, taking a kind interest in my love of exploring, and authorised by a circular letter which I had obtained from Lord John Russell, invited me to accompany him, and obligingly proposed to me to become his guest during the Cruise. I at once availed myself, as may be easily imagined, of this most agrceable and unexpected offer. It is pleasing to me to remember that the courtesy shown me by the Commodore was shared by his officers, to two of whom I must specially refer, the Hon. Herbert Meade and Mr. Foljambe. The former, prematurely lost to the service and to his friends by a melancholy accident, gave me, in his last moments, a tonching proof of his friendship, by desiring that a part of his 
journals should be consigned to me. To: my regret a variety of circumstances prevented my making use of the valuable bequest of this most intelligent and distinguished young officer, and I eventually returned the papers to his fumily, thus losing the invaluable opportunity of enriching my own work, whenever it should appear, by blending it with some parts of his. His journals have since been published by his family, and achieved a success which they eminently deserved. The loss, therefore, has been entirely my own.

To the kindness of MLr. Foljambe I am indebted for some illustrations which will be found in this work, and which had already appeared in an agreeably and well written work of his own, published only for private circulation, entitled 'Three Years on the Australian Station,' \&c., a part of which contained a concise but spirited account of our Cruise. These illustrations were from his own drawings.

In these days of rapid progress and rapid change, when the 'latest news' - a phrase which might, once imply an interval of months or even years-has now reference to nothing longer than weeks or days, or hours, the publication of facts observed seven years ago has I am aware an archaological tint about it. But various and long wanderings since my journal was written, and different causes of delay unconnected with it, retarded its appearance for a long while.

At length, when the opportunity - not entirely free from interruptions - of bringing it forth did occur, I felt it really necessary, as a sort of excuse for publishing it at all, to 
render it as attractive as I could by artistic illustrations, some of them of scientific interest, which have been great consumers of time. This has been a source of considerable delay.

If the rapidity of our Cruise did not allow me much opportunity of studying the manners and social characteristics of the different islands, it kept me thoroughly engaged in forming and preserving a considerable collection of utensils, weapons, birds, ferns, shells, and other objects of interest. Of these some have been thought of sufficient value to be placed in the British Museum, while the great bulk, now arranged in the museum at Maidstone, contributes, as I am assured, much to the amusement and instruction of its inhabitants. In collecting, arranging, and preparing these materials-rather troublesome work on board ship, where room is scant, sea-water sometimes intrudes, and steadiness à la Bessemer is unknown-I was assisted by Mr. Wall, as taxidermist, and Mr. Brazier as shell-collector.

I must not omit here to return my thanks to the various missionaries I came in contact with for their personal civilities to me, and also for the notes they furnished me respecting the islands in which they resided. If I have had occasion to criticise some of them it is because, while believing them to be honestly devoted to the great task of civilising the natives of these regions, I have thought it a duty to record my impressions as to why they mar their own purpose, and expend their energies, sometimes, in an 
unprofitable way. This is the more necessary as the time is rapidly approaching when the process of missionary enterprise must be carried on in modes, and on principles, very different from those which were recognised when they devoted themselves to their task. If it be necessary to give a proof of this I will refer to the Dean of Westminster's remarkuble sermon on the Day of Intercession-that day set apart for summoning England to the support of missiouary enterprise. He there warns the missionary that dogmatic teaching is not to be the sole or principal lever by which the civilisation of those he is in contact with is to be upraised. In earlier times, he says, it was the practice to send forth to the heathen, missionaries whose special object was religious teaching; but the time, he tells us, has arrived when a much more comprehensive and practical scheme of instruction is requisite. 'Let us not,' he observes, 'measure, as has been well said, this great work by the number of communicants and converts.' But this is precisely the measure which is too often employed by the missionaries when estimating and proving the amount of their civilising success.

But of what avail can be the fittest missionary, though using the fittest means of civilising, when the ground he has to till is bristling with passionate recollections, and fierce resentments that thwart him at every step? In the Western Pacific Ocean there is hardly an island the traditions of which do not record, or the existing generations of which have not experienced, outrages that cause their 
inhabitants to distrust, fear, or resent the approach of the stranger-race. How is he to face those carriers of demoralisation who, to use the apposite language of the "Times," when commenting on the subject, "spread themselves over the world, following everywhere the bent of their own nature, doing their own will, following their own gain-too generally doing and being nothing that a heathen will recognise as better than himself,' or by many degrees as good? Even a missionary of the highest qualifications, such as we now aspire to have but rarely possess, might be baffled by such foes; how then, we ask with the same journal, 'iean a feeble missicnary, who would too often be thought but a poor creature at home with every advantage in his favour, hope to stem with a few phrases the torrent of profligacy he finds already in possession of the ground?' The remedy proposed is ' to convert our masses at home:' unfortunately this suggestion, besides being too commonplace, too rational, and too little ostentatious, indicates a process too slow to ineet the urgency of the case. But what could be done, if the country were in earnest, would be to take care that at least the most prominent offences of these destroyers and corruptors should inevitably meet the punishment which they deserve.

It is time. In various parts of this book will be found evidence enough of the pressing need of such a policy. But if more were required, the frightful incidents brought to our notice recently in connection with the 'Carl,' a slavetrader, pretending to be an emigrant ship, supply a 
horrible supplement. What a hideous emblem of our civilisation is that bloodstained vessel throwing out, like the fangs of a grim monster, its grappling-irons to clutch and upset the canoes of the unsuspecting natives, then sending its boats to pick up sueh of them as had not made for land, ol were not drowned; hustling and closely packing them in its hold, and, when its captives, driven mad by excitement and suffering, quarrelled among themselves, firing shot upon shot at them through the latches during the night, killing and wounding seventy ; and finally, when morning broke, throwing the dead and the wounded fastened to one another into the sea! Surely if there were felt but a liundredth part of the interest in the fate of the Polynesian that was once, and is still, taken in the fate of the African, there would have been a shout of indignant remonstrance from one end of the land to the other. But where now is the Anti-Slavery Society? Where is the really benevolent Society of Friends? Where is there the slightest flash of that frenzy of indignation not long since exhibited in the case of the Jamaica black? But philanthropy has often its pet victims on whom it lavishes all its affection, and hence is to be seen fervid and flaming in one direction, while it is cold to rigidity in another, where the claims upon its sympathy are very similar, if not the same. It is to be hoped that some member of Parliament will endeavour to divert his colleagues for a moment, from matters more interesting to themselves, perhaps, and fix their attention upon one, than which none more concerns the honour of 
the nation, and that is the necessity of pressing the Government to make itself a vigilant and efficient representative of justice and humanity in these seas.

Into the question of incorporating into the empire any one of the chief groups, as for instance, the Fiji Islands, I do not pretend to enter. No doubt the bringing them into official comection with the supremacy of the Crown, would furnish us a status in this region that would enable us to do incalculable good. Perhaps the semblance of a reason for such an annexation may be derived from what has recently occurred in New Caledonia. Commanding, as we are told on good authority this island does, the communication of Australia with India, China, Panama and California, it is clear that were its colonial resources to be considerably developed, it might be necessary to have some counterpoise to its influence in these seas. Now the late extensive deportation of the Communists and their families might very well constitute the germ of a vigorous colonisation. For whatever may be thought of the political and social views of these men, there cannot be a doubt that very many of them must efficiently represent the mechanical and industrial skill of their native country. But, on the other hand, such are the vicissitudes of French politics that it is quite possible they may one day hear the signal of recall, to which every man of them would respond, hearing it, perhaps, under circumstances leading them to expect that their re-entrance into the capital from which they had been expelled, would be graced with all the triumplal pomp that 
honoured the restored ashes of Napoleon, who, for a moment, execrated like them, had been, like them, proscribed. What advantage New Caleclonia may derive from their exile is, therefore, a matter of doubt.

In acknowleclging my obligations to the gentlemen whose zoological notices will contribute to the interest of my work, it is painful for me to remember that two of them, Mr. George Gray and Dr. Baird, have passed from among us and are beyond the reach of my thanks. A thankful remembrance of the interest they took in my collections is, however, a tribute I can and do offer to their memory.

Folkestone: Januany.

Since the substance of the above.Preface was communicated to the friend who writes this postscript, and put by him into the desired form, Mr. Brenchley-then very illhas himself passed away.

A vigorous constitution, severely tried by years of incessant travel, after showing some premonitory symptoms of decay, suddenly broke down under a complication of maladies which rapidly overpowered a muscular frame, endowed with exceptional strength, at the comparatively early age of fifty-six. From 1849 to $\mathbf{1 8 6 7}$, some brief returns home excepted, he was continuously indulging what he justly called his 'passionate love of wandering '-sometimes in company, sometimes alone - welcoming all sorts of hardships, rumning all sorts of risks, exposing himself to 
all varieties and extremes of climate, and always finding himself at home and happy, whether in the cities or the deserts, in traversing the plains or climbing the mountains of distant lands. From New York, to which he went in 1849, after having for some months led a forest life among its Indian tribes, he proceeded to St. Joseph, on the Missouri, thence over the Rocky Mountains to the coast of Oregon and Fort Vancouver, and from the latter to the Sandwich or Hawaiian Islands. This was his first unbroken journey. Four years were then spent in exploring every part of these interesting islands in company with a French gentleman, M. Jules Remy, a naturalist, whose acquaintance he was so fortunate as to make there, and who, it turned out, was to be his companion in the greater part of his future travels. At the end of this period Mr. Brenchley, following his friend, sailed for California, and, after reaching San Francisco, undertook, accompanied by M. Remy, his remarkable and adventurous journey from that place to Salt Lake City, the capital of the Mormons. This was in 1855. On their way back to San Francisco they went to New Mexico, and, returning to California, explored every part of it. Next year they went to Panama and Ecuador, and ascended Pichincha, down the crater of which Mr. Brenchley, having slipped in his descent, was carried to a formidable depth, from which, with the utmost difficulty, by sheer determination and strength, he finally succeeded in regaining the summit. The next excursion was up Chimborazo; after which they visited Peru, Chinchas 
Islands, and Chili. In 1857 they went to the United States, where, having visited the Canadian Lakes, he and his friend descended the Mississippi from its source, in a bark canoc, to Saint Louis, and, thence making their way to Nerv York, embarked for England, where Mr. Brenchley once more appeared, after an absence of eight years. In 1858 and 1859 what may be called a home tour was taken, including Algeria, Morocco, Spain, and Sicily.

Some literary engagements now caused a pause; M. Remy being occupied in writing from his own and Mr. Brenchley's notes an account of their visit to Salt Lake City in 1855. This work, written with great ability-unluckily more philosophical than sensational-and with a critical appreciation of Mormon institutions, by no means too lenient, but perhaps too impartial for the prejudices of ordinary readers, was published in Paris in 1860. The description of the journey was preceded by an admirable introduction ' On the Religious Movement in the United States,' of remarkable interest and value, and followed by a brief but very satisfactory sketch of Mr. Brenchley's adventures when crossing the Rocky Mountains. In the following year the travellers came over to this country to superintend an English translation of the work, which, brought out in too expensive a form for a subject not exciting any very great interest, did not secure the circulation it deserved. ${ }^{1}$

1 II. Remy is the author of several works, among others of 'Analecta Boliviana, seu nova genera et species plantarum in Bolivia cres. 
This interruption over, Mr. Brenchley, once more at liberty, left England with his friend for Bombay; after a little stay at which place they went on to the Nilgherries, Madras, Calcutta, the Himalayas, and Benares; and then, being both taken ill, they returned for medical advice to Calcutta. Leaving that place, they went to Ceylon, on their way to China; but here M. Remy's indisposition increasing, he was obliged to take leave of his friend and return to France.

Mr. Brenchley then proceeded on his way alone to China and Mongolia, made a trip to Japan, and, returning to China, went to Australia and thence to New Zealand, towards the end of 1864 . While in Auckland in December of that year-there being just then a suspension of hostilities between the warring tribes-the Governor, Sir George Grey, being anxious that some Europeans should visit the friendly tribes in the vicinity of Lake Taupo, as a mark of attention which would be highly valued, Mr. Brenchley, in conjunction with the late Lieutenant Meade, undertook the expedition. Sir George Grey has borne witness to the great benefit derived from this hazardous journey, the details of which have been set forth with great spirit by Lieutenant Meade in his 'Ride through the Disturbed Districts of New Zealand,' \&c. Soon after this Mr. Brenchley left Auckland for Sydney, whence he proceeded on the centium;' 'Excursion botanique à travers les Ardennes françaises;' 'Ascension de Pichincha;' and of 'Ka Mooololo Hawaii, Histoire de l'Archipel Havaiien; texte et traduction, précédés d'une introduction sur l'état physique, moral et politique du pays.' Paris, 1862. 
cruise which is the subject of this book. On his return to Sydney he devoted some time and trouble in organising, for the amusement of the people there, an exhibition of the curious and interesting objects which had been collected. At the close of this he went again to China, and thus made his way back to Europe by the Great Desert of Gobi, Sibcria - in the depth of winter - and Russia.

Though he has left a large amount of notes made during his journeys, he was more interested in collecting material objects, illustrative and commemorative of his varied travels, than in devoting himself to literary descriptions of them; the present work was the result of a promise. Of the rich and varied collection which was the product of his visit to the South Seas and other places, a portion, as observed in the Preface, has found its way into the British Museum; but the principal part-consisting of birds, fishes, insects, weapons, shells, canoes, models, and objects of various kinds, illustrating the industry and arts of the different countries through which he passed, including fine specimens of the artistic and industrial products of Japan, China, Siberia, and Russia-has been presented to the museum of his native town, Maidstone, to the enlargement and embellishment of which, in various ways, he has also munificently contributed. Thus, though travelling for his own instruction and amusement, he spared neither cost nor trouble in procuring what he thought would contribute to the instruction and gratification of others. 


\section{CONTENTS.}

\section{CHAPTER I.}

NORFOLK ISLAND.

(JUNe 9 TO 13.)

Leare Sydney-Lord Howe Island-Ball's Pyramid-Nepean Island and Philip Island-Sydney Bay and Cascade Bay-Ride from the coast to the town-The Pev. Mr. Nobbs and his adventures-The old penal settlementAracaria-Character of the new colonists-Their hospitality-Account of a murderous attack upon the crew of Bishop Patteson's yacht-An American and his flag . . . . . . . . 1-16

\section{CHAPTER II.}

NIUE OR SAVAGE ISLAND.

(JUNE 29.)

Ranl Island-Off Nine-Tiger-sharks-The missionary-Excursion in the island-Familiarity of the natives-General aspect of the island-Its productions-Animals-Population-South American slave-dealers-Policemen -Costumes-Language-Manners and customs-Past and present character of the natives-Contradictory statements . . . .. . 17-35

\section{CHAPTER III.}

\section{TUTUILA-SAMOAN GROUP. \\ (JणLY 1 то 4.)}

Pango-Pango Harbour-Appearance of the natives-Statements by the missionaries-A pilot who takes his ease-Dwellings-Visit to the missionaryTrip into the interior-Village of Fungatele-American artisan-Native women-The chief dines on board-Native dance-Christian church-Manners-Progress due to Christianity-Indigenous products . . 36-60 


\section{CHAPTER IV. \\ UPOTU-SAMOAN GROUP-continued. \\ (JULY 5 so 10.)}

Apin Bay-Consul Williams, son of the Martyr of Eramanga-Mischief caused by a hurricane-Resident strangers-Baptisms on board-Sunday at ApiaCatholic bishop-Protestant missionary-Missionary disputes-History of a Bible in the Ellice Islands-Unfair treatment of natives-Visit of the great chief Malietoa-Inconsistent appreciations of native character-Remarkable testimonies in favour of the Samoans-Natives and whites-Manners and customs-Ancient crater-Cascade-Island products . 61-87

\section{CHAPTER V. VAVAU-TONGA GROUP. \\ (JULY 10 TO 15.)}

Boscrven and KeppeI Islands-Sandy point-Excursion nn shore-Missionaries-Village of Neiafu-Visit to the governor David Unga-His singular mutilation-The guide Papalangi-Roads and convicts-Volcano of Latte - Curious natural grottoes-Population-Diseases-Government-LawsProducts

\section{CHAPTER VI.}

\section{TONGATABU-TONGA GROUP-continued.}

(JULY 17 TO 22.)

Numerous islands-Volcano of Latte-First trip cn shore-Royal palaceSchools-Muscular Christianity-The Wesleyan Mission and its chapelCaptain Croler and the siege of Bea-Catholic and Protestant missionaries -Their mission houses-Their mutual criminations, and recriminationsVisit to King George--The hing's return visit-His Majesty dines on board - Fear of the French-A dinner at the king's-Catholic moissionariesCouncil-house-The Kava Ring-Public school examinations-Native diversions-Tongan Stonehenge-The island and its productions-ClimateMaladies - Population-The race and its customs - Christianity and its effects-Relations of the Tongans with the Fijians-Government and constitution

$$
\begin{aligned}
& \text { CHAPTER VII. } \\
& \text { OVALAU-FIJI GROUP. } \\
& \text { (JULY } 26 \text { TO 29.) }
\end{aligned}
$$

The Island of Neau-Anchorage at Levuka-A visit on shore-The consul and bis clerk absent-A French lady and her turn for natural historyExcursion into the interior-Method of kindling rood-Canoe buildingAppearance of the natives-Sharks and sword-fish . . . . 143-152 


\section{CHAPTER VIII.}

$M B A U$ AND VTTI-LEVU-FIJI GROUP-continued.

(JuLY 29 To AUgust 2.)

Mbau Roadstead-Boat expedition in Viti-Levu to Rewa up Wai-Levu River -Interview with Tui-Drakiti, King of Rewa-Courteous reception-Hospitality of the Rev. Mr. Carey, Wesleyan missionary-Trip in canoe up to Darui-Levu-Visit to the Per. Mr. and Mrs. Baker-Capsized on way back to Rera-The natives and their huts-Return from Pewa to Mbau-King Thalumbau-Exchange of civilities and arms - The great Kava bowl -The Akau-tabu-Conjecture respecting cannibalism-Cruel practices in Fiji-Not unparalleled in civilisation-Intellectual and moral characteristics of the Fijians-Jackson's praise of them-Captain Erskine's confirmation of it-Their intelligence and acuteness-Their songs and hymns-Their proverbs-Their capacity of conrersing-Their love of fun and jest-What value they attach to truth - Singular ceremony at Mbau - Interesting pic-nic . . . . . . . . . 153-175

\section{CHAPTER IX.}

\section{KANDATU-FIJI GROUP-continued.}

(AdGust 3.)

Levuka Bay and village-Peculiar form of the island-Mountain cliff of Buke-Levu-Village of Yawe-Visit of H.M.S. 'Esk'-Letter of crnoemen to her commander-Notes on the Fiji group-Chiefs-Languages-'Their mythology-Deification promised to a missionary-'I am a God'Character of their gods, and its results-Impediment to civilisation-Climate and soil-European population-Native notions respecting property and land-Difficulties thrown in the way of its acquisition-Improved prospects for settlers-Exports—Commerce-Future resourees . . . 176-192

\section{CHAPTER X.}

\section{ANATOM-NEW HEBRIDES.}

(AvGUST 6 то 10.)

Striking appearance of the island-A vessel belonging to the Presbyterian mission-Climate-Causes of decreased population-Character of the natives -Progress due to Christianity-Chiefs-Productions . . . . 193-200

\section{CHAPTER XI.}

\section{TANNA-NEW HERRTDES-continued.}

\section{(AUgust 10 To 13.)}

Uea Harbour-Useless negotiations with offending chiefs-BombardmentMen landed and property destroyed-Incidents of the attack-Effect pro- 
duced on the enemy-Description of the island-Climate and diseaseDisposition of the people-Morality-Usages-Creeds-Government-Marum, or council-house-Fruitless efforts of the missionaries-Languages-

Volcano of Asur and its environs-Productions and exports . . 201-214

\section{CHAPTER XII.}

TATE OR SANDWICII ISLAND-NEW IIEBRIDES-continued.

(AUGUST 16 To 18.)

A day at Eramanga-Stop at the port of Vila-Anchor in Havanuah Harbour -The 'Dayspring' again - Costumes of the natives - Excursion in the islandDwellings-Fisherwomen-Cannibalism-The Rev. Mr. Turner's account of them-Favourable notices of them by various visitors-Decrease of population-Language-Government-Customs-Artistic skill-Creeds-Teachers and their extravagant tales-Products . . . . . .215-232

\section{CHAPTER XIII.}

VANUA-LAVA-BANKS' ISLANDS.

(AvGUst 21 то 23.)

Through the northernmost islands of the New Hebrides-Uncertain navigation -Port Patteson-The 'Southern Cross' and Bishop Patteson-Appearance of the natives-Trip in the island-Vegetation-Dwellings and club-houseRiver of hot water-Jets of vapour-Eggs of Megapodius-CustomsClimate-Diseases-Vegetation . . . . . . 233-242

\section{CHAPTER XIV.}

SANTA-CRUZ ISLAND.

(AUGUST 25.)

Vanikoro Island-Ocili Harbour-Port Graciosa in Santa-Cruz-Volcano of Tinakoro-A swarm of canoes-Barter . . . . . 243-247

\section{CHAPTER XV.}

ULAKUA-SOLOMON GROUP.

(ATGEst 27 TO 29.)

Singular fact-1sland of Santa-Anna-Arrive in sight of the Island of Ulakua - Natives and their canoes-Ornaments and dress-Trip on land-HutsWomen-Parrots . 
CHAPTER XVI.

UJI-SOLOMON GROUP-continued.

(A

Alarm on board-Pigeon shooting in the trees-Natural history-Ornamental tie-beam-A village hall . 258-263

\section{CHAPTER XVII.}

SAN-CHRISTOVAL-SOLOMON GROUP-continued.

(AdGust 30 to September 4.)

Anchor at Wanga-Arrival of canoes-Barter-A walk in the island-A native carving resembling a European hat-A grimly decorated canoe-houseOpossum-A glutinous. fruit-Village-Women entirely naked-Human skulls-Curious groups of natives-Constant state of warfare-Fishing in a river-Anchor at Hada-A self-styled king-A nigger who treats the natives as niggers-The bishop and the murderer of one of bis teachers-Appearance of the natives. . . . . . . . . 264-273

\section{CHAPTER XVIII.}

GUADALCANAR-SOLOMON GROUP-continued.

(SEPTENTER 4 to 5.)

Marau Sound-Curaçoa Harbour-Visit ashore-MIrrshes-Dwellings-Men and women-The Island of Malata in the distance . . . . 274-276

\section{CHAPTER XIX. \\ FLORIDA-SOLOMON GROUP-continued.}

(SEPTEuber 5 to 7. )

Aspect of the island-Gulf of Mboli, and anchorage in Port Wiseman-Native canoes-Ornaments-Barter-Judicious advice not to land-Fishing on the reef-Uneasiness caused by the prolonged absence of our hydrographic officer-Important result of Mr. Scudamore's survey . . . 277-285

\section{CHAPTER XX. \\ YSABEL-SOLOMON GROUP-continued. \\ (Septender 7 to 10.)}

At anchor in St. George's Bay-Cockatoo Island-Barter-Ebony trees-Trip inland-Difficult walk-A convoy of women-Houses perched in treesPigeon Island. 


\section{CHAPIER XXI. \\ ERANANGA-NEW HEBRIDES.}

(SERTEMBER 25 TO 26.)

View of a fortified village and a tree-house-Man overboard-Tedious navigntion-A gale-Calms-At anchor in Dillon's Bay-News from land-Trade in sandal-wood-Mr. Ifenry-Lime from coral-A bomb-shell in the hands of savages-The Rev. Mr. Gordon-Hostile state of things-Two ill-disposed. chiefs-The master of the 'Curaçoa' attacked by natives-The village of Sifu bombarded by the 'Curaçoa'-A missionary who never laughedRemarkable censure of the local missionaries connected with these proceedings against the natives - $\mathbf{A}$ more equitable course of action required-Notes on the island-Epidemics-Missionary labours-Government-Nanners and customs-Religious creeds-Trade in wood and women--ProductionsIndustry

\section{CHAPTER XXII.}

\section{NEIV CALEDONIA-LOYALTY ISLANDS.}

(Septemiber 28 to October 8.)

Loyalty Islands-Aspect of New Caledonia-Harannah Passage-Praslin Bay-Canoes-At anchor in Port-de-France-Visit from the governorVisit returned-Madame Guillain-M. Guillain-Government-house and gardens-The governor and the Protestant missionaries-The capital of the colony-The model farm of Yahove-A new kind of plough-Coffee treesThe aborigines-Religion-Jlanners and customs-Infamous usage of natives by whites-Captain Cook's farourable notice of them-Basset, chief of Yengen-His house in the interior-Appearance of the country-Trimlyliept houses-Poles surmounted by skulls-Remarlable irrigation-Remains of ancient aqueduct-Return to Sydney-Conclusion .. . . 323-350

NATURAL HISTORY NOTICES.

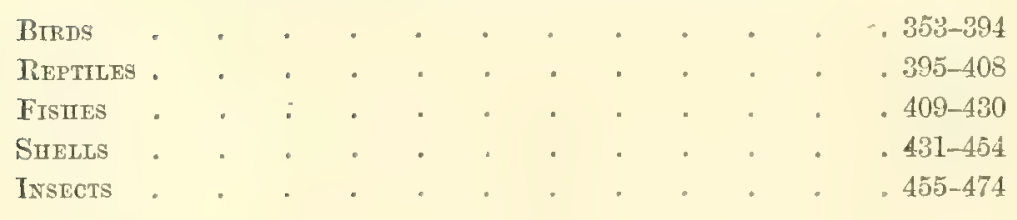




\section{LIST OF ENGRAVINGS.}

MAP.

Chart of the South Sea Islands

End of the book

\section{CHROMO-LITHOGRAPHS.}

The two sides of a tie beam from a village hall, Uji, Solomon

PAGL Islands

Frontispiece

A village hall, Uji, Solomon Islands . . . . To face 262

SEPARATE ENGRAVINGS ON WOOD.

*** The woodcuts to which an asterisk is prefixed were engraved by Mr. G. Pearsor, from Photographs made upon the spot: those with a $\uparrow$ were lent by hr. FurJusue.

* Natives of Tutuila . . . . To face 40

* Levuka . . . . . , . 145

* Natives of Ovalau . . . . . . . 152

* Weapons, South Sea Islands . . . . " " 222

* Scene in Banks' Islands . . . . . . . . . 233

* Canoe House, $\mathrm{U}_{\mathrm{ji}}$. . . . . . . 258

* Natives of Ysabel Island . . . . . . . . 287

* Natives and Canoe, Ysabel Island . . . " " 291 


\section{ENGRAVINGS IN THE TEXT.}

* The Barracks, Norfolk-Island

FAGE

* Mission House, Niue

+ Fungasa, or Massacre Bay

* Wife of Maunga .

* Native Teacher

* Samoan Chief in war costume

* King George's House, Tongatabu

* Queen of Tonga.

* King George of Tonga

+ Stone monument, Tongatabu

+ Double canoe

+ Pools at the waterfall of Waitoba

* King Thakumbar and his son .

* The great Kava bowl of Fiji

160

163

* Natives of Tanna

.206

+ Native houses, Vate

.215

+ Hat Island, entrance to Havannah Harbour

. 216

+ Mota, or Sugar-loaf Island

.234

* Natives of Banks' Islands

. 210

+ Tinakoro .

. 244

* Ear ornaments . . . . . . . . . 246

* Ear-drop made of sharks' teeth . . . . . . . . 247

* Nose ornaments . . . . . . . . . . . 250

* Specimens of necklaces . . . . . . . . . . 252

* Mother of pearl nose ornaments . . . . . 254

* Native girls, Uji . . . . . . . . . . . 259

+ Native carving, San Christoval . . . . . . . 267

†Two-tree Island . . . . . . . . 277

† Ass's Ears, Florida Island . . . . . . 278

* Chief"s shield and two-handed clubs . . . . . 281

+ Tree Fort, Ysabel Island . . . . . . . 292

† Southern Cross : . . . . . . . . . 295

+ Mu Island, Port-de-France, T̂le des Lapins . . . . 330

+ Port-de-France, from Signal Hill . . . . . 336

* Model Farm, New Caledonia . . . . . . . . . . . . . . .

* Clubs . . . . . . . . . . . . . . . 
OBJECTS IN NATURAL HISTORY.

BIRDS.

PLATE

1. Accipiter albogularis .

Draver by J. Smit.

PACil:

2. Collocalia hypoleuca

" uropygialis .

do.

To face : : $;$. 1 .

3. Eurystomus crassirostris

4. Glyciphila caledonica . , flavotincta.

5. Philemon sclateri<smiles>C1=CC=CCC=C1</smiles><smiles>C1C[I-]C1</smiles>

356

6. Anthochæra aubryanus

7. Zosterops flavifrons .

$$
\text { do. }
$$

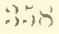

$\cdot\}$

do.

(i)

" xanthochroa

do.

86.2

do.

do.

36.1

8. Myiagra melanura .

" caledonica . . .

9. Rhipidura spilodera .

10. Lalage banksiana

11. Pachycephala chlorura

12.

", moriariensis

13. Eopsaltria caledonica , cucullata.

14. Lorius hypoinochrous.

15. Trichoglossus massena

16. " " palmarum

17. Cuculus bronzinus

18. Carpophaga brenchleyi

19. Macropygia crassirostris

20. Megapodius brenchleyi

21. Eulabeornis lafresnayanus

do.

do.

do.

do.

$3(i)$

do

368

371

$87=$

35

376

do. $\quad 378$

do., 380

do. , 382

do. $"$ "38\%

do. $\quad$ " 386

do. $\quad 388$

do. $\quad, \quad 390$

do. $\quad 392$

do. $\quad, \quad 394$

\section{REPTILES.}

22. Eremias brenchleyi .

Euprepes haplorhinus.

Eremias multiocellata.

. Draven by G. H. Ford. ", 396

23. Mocoa micropus

$.

to.

40 른 
J.ATH

YAGE

21. Gymnodactylus multicarinatus
Hinulia tetragonurus. Drawn by G. H. Ford. To face 404

25. Namoscincus fuscus.

Peripia cyclura

.

do.

406

FISHES.

20 and 27. Dicerobatis draco

17o. $\quad \% 13$

28. Serranus cylindricus .

Plectropoma annulatum

to. $\quad, \quad \$ 1 \%$

29. $"$ ocellatum

do. $\quad$, 116

30. Chilodipterus truncatus

lo. $" 418$

31. Scolopsis xenochrous .

Cubiceps pauciradiatus (not

do.

$40(1)$ figured)

32. Julis guentheri (fig. A.)

Percis alboguttata (fig. B.) .

do. $\quad$ 1?2

33. Ophichthys filaria (fig. $\Delta_{*}$ ) - )

Salarias coronatus (fig. B.) .)

c7o. $\quad 424$

34. Chœrops brenchleyi .

(l)

do.

$4 \cdot 26$

Clupea pinguis (not figrred) .

35. Ophichthys pinguis " Misolensis

do.

1311 figured)

SHELLS.

36. Fusus (colus) similis .

to.

4,2

37. $"($,$) brenchleyi$

Defrancia albo-strigata

do.

$4: 34$

Terebra (leiostoma) parva

38. Nassa bifaria .

Phasianella wisemanni

Stylifer dubius

Neritina subrugata.

do.

4:31;

Nerita stricta.

2, Novæ-Caledoniæ

39. Hydrocena similis

Realia (omphalotropis) lrevis .

do.

440 
PLATE

39. Realia (omphalotropis) bicari-

nata .

Melampus (tifata) ovuloides .

Dromby G. H. Fond. Tu fum 1 .

40. Melania brenchleyi

"1 cylindroides.

Chiton (onithochiton) amico-

rum.

Helix laqueata

"Varauensis

"Samoensis

do.

44

41. Helicina brenchleyi

" fulgurat

, multifasciata

, julii

, strigata

do.

" Novæ Caledoniæ (not figured)

Tellina Noræ Caledoniæ

" bifaria.

42. Venus roseo-tincta

Arca Novæ Caledoniæ

" (byssoarca) dubia

Pecten similis

Perna (isognomon) Samoensis

do. $\quad$ " 45

INSECTS.

Hrmenoptera Acureata.

43. Thynnus brenchleyi

$"$ conspicuus.

" pulchralis .

$"$ unifasciatus.

do:

456

Pompilus pictipennis

Priocnemis polydorus.

44. Priocnemis affectatus .

ephippiatus

Sphex aurifex .

$"$ decorata

" prætexta

Stizus pectoralis

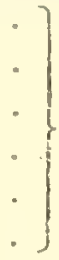

do.

$\pm 60$ 
Diploptera.

15. Paragia vespiformis

Discoclius insignis

Eumenes sinensis

Rhynchium magnificum

Megachile monstrosa .

Stenotritus smaragdinus

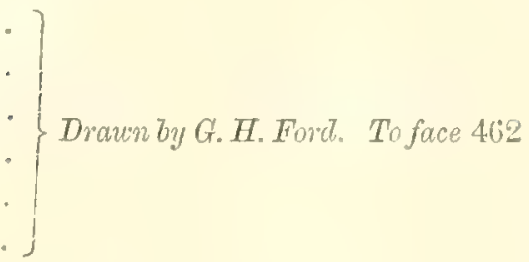

IN:PIDORTERA.

46. Enplcen brenchleyi . Drown by A. G. Butler. " 464

47. $\left." \begin{array}{llll}\begin{array}{l}\text { lorenzo } \\ \text { imitata }\end{array} & . & .\end{array}\right\}$ do. 466

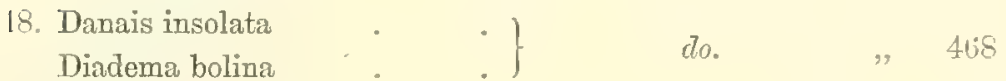

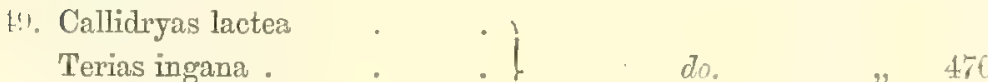

Appias melania . . . . .

ii. Papilio (Ornithoptera) cassandra do. $\quad 474$

Erratun.

Page 261, line 17, for Ballistes read Balistes. 
THE

\title{
CRUISE OF THE 'CURAÇOA'.
}

\author{
CHAPTER I. \\ NORFOLK ISLAND.
}

(JUNE 9 TO 13.)

Leare Sydney-Lord Howe Island-Ball's Pyramid-Nepean Island and Philip Island-Sydney Bay and Cascade Bay-lide from the Coast to the Town-The Rev. Mr. Nobbs and his Adventures-The old Penal Settlement-Araucaria-Character of the new Colonists-Their HospitalityAccount of the murderous Attack upon the Crew of Bishop Patteson's Tracht - History of an American and his Flag.

Iт was a beautiful Sunday afternoon, June 4, 1865, when I left Sydney and went on board the 'Curaçoa' at 2.15 P.M. I found there the Commodore together with the Spanish Consul General, Don Edouardo San Just, and some other visitors, who had come off to bid their friendly adieus. We weighed a little before 3, and proceeded under steam somewhat beyond the heads of Port Jackson, the band playing appropriate airs as we went down the harbour. When we had a good offing we raised the screw, and set sail with a nice breeze, which freshened the farther we 
receded from land during the night. Thus satisfactorily began our pleasant cruise.

In addition to the ship's company there were, besides myself, whom the Commadore had kindly invited to be his guest, Mr. Veitch, the son of the well-known nurseryman, who had permission from the Admiralty to accompany us for the purpose of collecting plants; Mr. Wall, for many years Curator of the Sydney Museum, who was going out as taxidermist; and Mr. Brazier as shell collector. Science being thus represented, our creature comforts had also been attended to. A good cow and calf, seventeen sheep, and a quantity of poultry were our guarantees for these. We had also canine companions not a few, belonging to the officers, including a kangaroo dog, and two pretty spaniels of the Commodore's. Thus provided for in a variety of ways we went on our course NE. by E. half E. The weather was fine for the first two days, with bright starlight nights, the moon getting on to the full. The wind having freshened a good deal the ship rolled considerably, and it did not much add to my comfort to have my berth drenched by the water coming through the port when the sea dashed against it. Soon after daylight on the 6th we sighted Lord Howe Island and Ball's Pyramid; the former of which can be seen twenty miles off in clear weather, and the latter twelve. Lord Howe Island is the southernmost of the outlying islands and reefs of the east coast of Australia. It is said to be of volcanic origin, is mountainous, well-wooded, and fertile in the lower parts. Its highest point is Mount Gower, 
which has an elevation of 2,834 feet, and rises abruptly from the south end. Ball's Pyramid, a remarkable peak, is 1,810 feet in height, towering abruptly from a rocky islet lying twelve miles from Lord Howe Island. On the 7 th we came across a dismasted barque, that had probably come to grief in the squall of the preceding day. She appeared to have as much sail as she could carry in her crippled state. It is said such mishaps frequently occur in these seas.

Proceeding slowly with very little wind, and aided by two boilers, we on the 9th at daybreak sighted Norfolk Island, and soon afterwards were able to discern the pine-trees that flourish on Mount Pitt, its most elevated point, rising, it is said, to the height of 1,000 feet, and also the well-known windmill on its coast. We could at the same time observe Nepean and Philip Islands near to Norfolk Island, but much smaller than it.

Nepean Island, lying low and of a naked appearance, is separated from Norfolk Island by a channel 900 yards in width; it is about 400 yarcls long from north to south, and about as wide from east to west. There are only three trees on this island, which are visible at a great distance.

Philip Island, distant somewhat more than three miles from Norfolk Island, is much larger and more elevated, being more than 2,000 yards long and 900 wide. Certain parts of the cliff of this island have a very decided reddish tint, others are of a bright yellow, others again of a violet colour. To judge by the appearance of the soil one would be apt to suppose that it was of volcanic origin; I was not; 
however, able in passing by it to discern anything which resembled an extinct crater.

A little before mid-clay we dropped anchor in Sydney Bay, at least two miles from the centre of the settlement, after a capital run of 950 miles in less than five days. The northern coast is steep, undulating, of a reddish tint, and tolerably well wooded. On the shore, beyond the breakers, we perceived a group of people, several of whom presently manned an eight-oared boat, which, forcing itself through the breakers, made its way to the 'Curaçoa.' Its crew was soon upon deck. One of them was George Adams the son of a mutineer of the 'Bounty,' a man sixty-one years of age, accompanied by his son about forty years old. There were also Quintal, Christian, and others whose names the history of the Pitcairn settlers has, made familiar to many of us from our childhood. Though reputed to be total abstainers from spirituous liquors these people made no difficulty in accepting a glass of brandy or wine, which they drank while conversing in an English that was tolerably correct. They were badly dressed, and seemed to me to be of a browner complexion than I had expected, and than, indeed, I had reason to expect, knowing they were half-castes, or descendants of half-castes. They advised the Commodore, as a matter of precaution, to seek an anchorage in Cascade Bay on the north-east coast of the island. We accordingly weighed anchor, and the 'Curaçoa' made for the point indicated. In sailing past Philip Island we were informed by them that it is thronged with rabbits, 
whose principal and almost only food is the bark of trees. At 2 P. M. we reached the anchorage in Cascade Bay, a charming spot adorned with picturesque clusters of trees, above which soar, giant-like, magnificent specimens of the famous Norfolk Island pine. As soon as we anchored, the Commodore invited me to accompany him ashore. George Adams, who was with us, pointed out the best spot for landing, about a mile from the ship. The sea was fortunately calm, and we were able without difficulty to clamber up the rocks which edged the shore.

We now saw Mr. Rossiter coming to meet us with several horses. This gentleman is both the schoolmaster of the settlement and the agent of the Governor of New South Wales for superintending the affairs of Norfolk Island. The horses thus obligingly placed at our disposal were the pick of the island, but as very a company of nags as ever looked forward with confidence to being speedily relieved from their troubles by the knacker. Our gear was in perfect harmony with our steeds. The saddles were all rotten, the girths and stirrup-straps mended in various places with string of all possible kinds; no trifle this for one whose avoirdupois endowments require a stout hunter or hack, with appointments to match. So equipped and so horsed, it was not without ludicrous difficulty we worked up a hill from which we had to descend into the town. No wonder that the natives thus mounted frequently lose their lives when indulging in horsemanship. The distance we had to pass over was about three miles, upon a road 
leading through a pretty country, where we saw herds of cattle enjoying themselves amid rich pastures. We passed by Cascade Station, a village to the left, near the top of the hill, in which we observed a number of people chiefly engaged in the cultivation of the potato, which is their principal food. On our way we saw numbers of fine lemontrees loaded with fruit, which are cultivated in preference to orange-trees that are said to fruit less well and less easily. As we proceeded we came upon the Rev. Mr. Nobbs, the Church of England clergyman of the settlement, in company of the Bishop of Melanesia (Patteson), who had arrived the evening before by the mission schooner 'Southern Cross,' which was standing off and on the coast, waiting for orders to make for the Loyalty Islands, which the Bishop was about to visit on behalf of the Church of England mission. Mr. Hood, ${ }^{1}$ in his "Cruise of the "Fawn," has a notice of the Rev. Mr. Nobbs, from which it appears that he has had a most chequered carcer, and that there is a strange contrast between his earlier and later occupations. He began life as a midshipman in the Royal Navy, and commanded one of the boats under Lord Dundonald in the brilliant cutting-out affair in the Basque Roads. Subsequently he went to Chili, where he was made prisoner and sentenced to death; escaping that, he was forced to labour in irons on the roads; and, after various other adventures, made his way with a single companion in a little craft of

1 "Notes of a Cruise in H.M.S. "Fawn" in the Western Pacific in 1862,' by T. H. Hood, p. ๒230. 
twenty tons to Pitcairn Island. After some residence there he was driven away by an impostor, who pretended to be an agent of the British Government; but, the fraud being discovered, he returned to the island. He subsequently went to England and was ordained, after which he returned to his old friends, and accompanied them when transferred to Norfolk Island. He left upon me the impression of an amiable man.

After crossing something like a public garden, no longer used, we descended as far as the house of the former governor of the island, consisting of a single story, a sort of stone bungalow, furnished with a good verandah, and in front of it a flas-staff from which floated the Union Jack. It is here Mr. Rossiter resides as agent of the Queen's representative, now his Excellency Sir John Young. There are other houses in the neighbourhood of similar construction, but less roomy, which are occupied by persons privileged to live in them rent free.

The old convict prison, capable of holding 1,700 prisoners, is a large four-storied building, surrounded by high walls, as is the case with the commissariat, and the two barracks in its vicinity. The prisoners, who were all males, and transported for life, slept in hammocks slung so as to occupy the least possible space. At the sides of the great prison were much smaller buildings containing cells for the confinement of such as were sentenced to death, and dungeons in which no light apparently could enter. The buildings for the warders, superintendents, and those which served as 
workshops for the convicts still exist. They are all of them in such a state of preservation as to appear at a little distance comparatively new, and one is surprised that they should have been so long in use; the windows, however, are for the most part broken, the roofs are falling in, and some part of the wood-work has been carried off for fuel. The chapel of the old penal settlement forms part of the great prison.

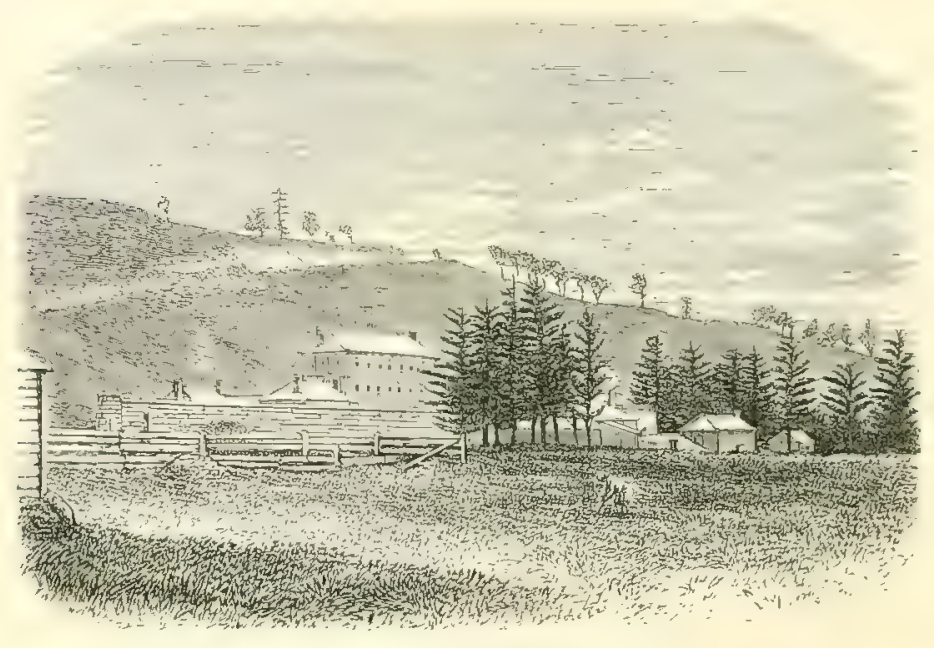

THF BATIACKS, NORFOLK ISLAXD.

The actual settlers occupy the houses which were built by government for the use of the officials attached to the penal settlement. The greater part of them are in need of repair; but, unluckily, the trowel and the hod are, as yet, mysteries unrevealed to the islanders. Their incapacity in this respect is thought to be accounted for by the indolence so natural in a people, who, at the cost of the least possible exertion, can obtain the satisfuction of the greater part of their wants. A more satisfactory reason surely is that 
having, when their change of quarters took place, found houses ready to receive them, they were under no necessity of learning the art of construction, either of a civilized or uncivilized fashion. But as houses will decay, and habitations when required, must be constructed, and cannot be made to grow, it is a matter of surprise that no attempt is making to teach them to preserve such as they fortunately have, and with which they would be sorry to part.

After having been for half a century a land under a curse, Norfolk Island has become a little terrestrial paradise. Of the old penal settlement nothing remains but its material relics, and, in the place of criminals who once thronged it, are now to be seen only properly conducted and happy people, the well-disposed descendants of the mutineers of the 'Bounty.' The particulars of their history are too well known to be repeated here. We may merely observe that, after living on Pitcairn Island from 1790 to 1855 , and, finding themselves cramped for want of room on a rock the surface of which did not exceed 800 acres, they petitioned Government to transfer them to Norfolk Island when they learnt it was no longer to be used for penal purposes. Their petition was successful, and in 1856 they were transferred to their new dwelling-place to the number of 193 persons, of whom 40 were men, 47 women, 54 boys, 52 girls, where they have since lived happily, and full of thankfulness to their mother country, with the exception of forty who returned homesick to Pitcairn.

Their little town, Kingston, is agreeably situated facing 
the sea, at about 500 yards from the shore. The principal street, in which the best houses, stone villas with gardens surrounded by walls of the same materials, are found, is composed of fincly-broken stone, and, though ill kept up, is still in tolerable condition. This stone, taken from a quarry, is a sort of concrete sand. A pretty little brook, about five feet wide, has been lwought from the environs to irrigate the town, and amply suffices for the wants of the inhabitants. A small quantity of taro (Caladium esculentum), used occasionally for making poi, is grown on its banks. The hill from which the stream springs, and at the bottom of which the town is built, is from 360 to 370 feet high. Formerly there were several roads branching off from this hill towards different parts of the coast, but which, from want of being attended to, are already-in a very bad state, and rapidly disappearing. The officials who lived in the island while a penal settlement passed, it is said, their time pleasantly enough, and contrived to make it a tolerably comfortable place of residence, having good horses and carriages at their command for making pleasure trips; nothing of which is now to be found.

Sydney Bay, near which the town is built, is bounded on the wrest by Point Ross, and on the east by Point Hunter near the windmill. When the tide is out a coral reef is seen stretching from the shore at varying distances of from 100 to 700 yards. Boats landing are obliged to cross the reef. The sea all along the coast is of great depth.

The undulating surface of the soil, the woods and verdure 
which clothe it, give Norfolk Island a most charming aspect. What imparts to its scenery a special character is the presence of the famous Norfolk Island pine (Eutassa, or Araucaria excelsa), a magnificent tree of colossal proportions, small specimens of which most people may have had an opportunity of admiring in various public gardens of Europe.

I had no opportunity of meeting with any very large ones in the part of the island which I visited, but Adams told me he had recently cut one down which was thirty-six feet in circumference and more than 210 feet in height; and he further assured me he had seen some larger still. In addition to this tree, there are other very pretty arborescent species on the heights where they constitute what are really woods or forests. At the time of the arrival of the present settlers numbers of wild hogs were to be found at large in these woods, but they have been almost entirely destroyed for the sake of their flesh. On all sides oxen and sheep were to be seen in the pastures, and fowls and turkeys about the divellings. Venomous reptiles are unknown; on the other hand, numbers of centipedes are to be found beyond the usual size.

The fortunate settlers on Norfolk Island are of a joyous and engaging disposition. Their cheerful ringing laugh, ever ready to burst forth, and in perfect harmony with the lively expression of their faces, predisposed me immediately in their favour. This gaiety, most conspicuous in the women, is however common to both sexes; in a word, they 
completely won me at first sight by their apparent amiability: I say apparent, having had experience of the manners of the half-castes of Hawaii, who are perpetually smiling and making the most gracious advances, but who, at bottom, are nothing more than actors skilled in inspiring kind feclings which they do not reciprocate. But I will say at once, and sincerely too, that nothing authorizes me to throw doubts upon the sincerity of these islanders.

On June 10, 11, and 12 we remained on shore, contrary to our expectation and our intention, but by no means to our regret. Foul weather had compelled the 'Curaçoa' to put out to sea the night of our landing, and she did not return to her anchorage till the morning of the $12 \mathrm{th}$, which gave us an opportunity of testing the hospitality of the inhabitants; and, we one and all acknowledged, they neglected nothing that could speed on the time agreeably, which the capricious elements had ordained we should pass among them. They placed themselves entirely at our disposal; housed us as best they could; made us a hearty offer of what they possessed; and even went so far as to beg us to take any peculiar specimens of their workmanship which their houses contained. As they neither make nor import spirituous liquors of any sort, it was impossible to attribute their extremely kind treatment to any passing and factitious excitement; and the warmth of their manner proved very clearly to us that their offers proceeded from no formal and routine politeness, such as is to be found among more than one people of Europe. 
Dancing and singing are their principal means of recreation. After having, for two hours each evening, charmed our ears with their strains in a great hall, wherein the whole island was collected, they began dancing, which, on one occasion, was continued until almost diybreak. Our young officers were so much pleased with these diversions as to declare them the most charming and delightful of any they had ever experienced; some went so far as to say they had never met so many pretty girls collected together in one ball-room. The sober truth is, there was not a single girl of any very striking beauty, but the majority of them were attractive, and very pleasant to look upon. Admirable figures, fine eyes, good teeth, and remarkably clear, slightly olive-tinted complexions, were no mean constituents of personal comeliness. But not the least of their attractions was their sparkling gaiety.

We passed a Sunclay in the jsland, and were present at moming service in the ci-devant convict chapel. Bishop Patteson confirmed a number of young people, among whom the girls appeared to great advantage in their white dresses, and veils hanging from the back of the head to the feet. The ceremony concluded, the Bishop delivered a touching address, in which he introduced an account of the painful affair that happened in the island of Santa Cruz at the time of his last voyage, which may be told in a few words. The Bishop, when touching at Norfolk Island, had taken on board two of the most respectable youths of the place, one 
a son of the Rev. Mr. Nobbs, the other a member of the Christian family. They had but just landed at Santa Cruz, when, from certain appearances, they began to suspect that some foul play was intended. They therefore thought it prudent to return to their boat, and were not a moment too soon, for, when in the act of pushing off, they saw clearly that it had been the intention of the natives to prevent their doing so, and immediately after learing the shore their boat was enveloped in a shower of arrows, which wounded Nobbs in the wrist and Christian in the jaw, while one of the boatmen was struck on the breast by an arrow which passed through him. The two first died of lock-jaw two days after the attack, while the third, more seriously wounded to all appearance, survived and got well.

The Bishop's narrative cansed a good deal of emotion among his hearers, composed in great measure of the relatives and friends of the two victims. I took an opportunity of asking Bishop Patteson if he had any clue to the motives of this brutal attack. He told me he was all the more puzzled to account for it, inasmuch as he had been well received by the savages on his first visit; but that, after much reflection on the subject, he had come to the conclusion, that their altered conduct was an act of retaliation for some outrage upon them by seafaring men. He added, in a general way, that he had grounds for attributing the hostility of the South Sea Islanders to the whites, to acts of violence and injustice to which they were exposed by their contact with lawless traders; and this view of the case I 
myself eventually adopted after having seen with my own eyes of what the people who navigate these seas are capable. Hence it happens that tribes we treat as savages with a certain air of superiority might, were the barbarous acts attributed to them carefully enquired into, find favour in the eyes of civilized nations, which have not always reason to be proud of the adventurers who represent them in distant seas.

During our stay at Norfolk Island a deputation of the inhabitants waited on the Commodore to complain of an American who, residing there, obstimately persisted in hoisting the American flag every Sunday on the top of his house, which is government property. The settlers looked upon this as an insolent pretension, offensive to their loyalty and patriotism. Sir William Wiseman undertook to appease their irritation, and succeeded in some way or other in doing so. The name of this eccentric American was Bates. When in command of a Yankee whale ship he had touched at the island short of provisions. While getting in his supplies he fell in love with Mr. Rossiter's, the schoolmaster's, sister, and married her. Having done this on condition of remaining on the island, he sent away his ship under the care of his mate; and having thus taken up his quarters he amused himself every Sunday with this tolerably harmless display of his nationality.

Before taking final leave of our amiable hosts we invited them to pay a visit to the 'Curaçoa.' Several of them accepted the invitation and came and spent an hour or two 
on board, and we availed ourselves of the opportunity of pressing on their acceptance a few trifles likely to be of use to them, of which they manifested a thankfulness far in excess of the obligation. Determined not to be outdone in liberality they sent us, just as we were about to set sail, a gigantic turkey and a prodigious assortment of fruits. We shall see in our progress islands of more curious interest, settlements of more importance, stranger usages, and less familiar products; but I question whether we shall carry away from any other place recollections so agreeable, and such charming in tpressions of friendly feelings, sincereiy reciprocated, as from this first visit of our cruise. ${ }^{1}$

1 The same testimony to the beauty of the island, the remarkable amiability of the inhabitants, and the even and happy tenor of their lives, is borne by Mr. Hood, 'Cruise of the "Fawn," " p. 242. 


\author{
CHAPTER II. \\ NIUE, OR SAVAGE ISLAND.
}

(JUNE 29.)

Raoul Island-Off Niue-Tiger Sharks-The Missionary-Excursion in the Island-Familiarity of the Natives-General Aspect of the Island-Its Productions-Animals-Population-South American Slave Dealers-Policemen-Costumes-Language-Manners and Customs-Past and present Character of the Natives-Contradictory Statements.

ON June 13, before nightfall, we weighed anchor with the intention of shaping our course towards Niue Island. For several days albatrosses, Cape pigeons, and other birds, followed in our wake. At first we had head winds and rain, followed by calms, which obliged us to get up steam. In the evening of the 15 th we were all thrown into confusion by the captain of the main-top contriving to let himself fall from the main-topsail-yard on the larboard gangway; his fall having been fortunately checked by his coming into contact with several parts of the rigging, he got off for a sharp contusion on his spine, from which he recovered in a few days.

On the 23rd, about seven o'clock in the morning, we sighted Raoul or Sunday Island, the most northern of the Kermadec group. The land is high, its greatest point of elevation reaching and perhaps exceeding 1,600 feet. Its 
banks appeared to us to be steep. It is certainly of volcanic origin, and is about five miles long by three wide. We observed a fire upon the coast, and some animals, which, in the distance, looked like sheep. The island is covered with verdure, with the exception of its cliffs, in which I thought I perceived columnar basalt. It is said to have been inhabited in 1840 by an American named Halstead and his family, and it was on its shores that Captain Denbam, of H.M.S. 'Herald,' buried one of his sons in 1854. Whalers stop here occasionally to procure water, vegetables, and poultry. We could not discern the slightest trace of Twelvefoot Rock, marked on the chart as being distinctly visible on account of its breakers.

On the 29th, about 9 o'clock in the morning, we hove to about two miles from Niue Island. An aged native, of remarkably good appearance, who had been on board a whaler, immediately came on board to inform us that the missionary's wife was ill. Soon afterwards a number of canoes rapidly approached the 'Curaçoa' laden with spears, shells, fruit, models of canoes, and other objects intended for barter with the sailors. All these canoes were small sized; I did not see one which carried more than six persons, the greater part not more than four. As our stay was to be very short, I hastened to land. In the remarkably transparent waters off the coast I saw several of those sharks which the sailors call tiger sharks, but which, to all appearance, are not so dangerous as they are supposed to be, since the islanders swim among them without manifesting any apprehension. 
The Commodore, who remained on board, amused himself with his rifle, firing at them; he killed several, to one of which the natives made fast a rope and hauled it upon deck.

The island appeared to me bright with verdure; it lies tolerably low, rising in no part more than 250 or 260 feet above the level of the sea. There is a cliff from ten to twenty feet high on the west coast. The coral reef where I landed did not appear to extend far from the shore. The boat not being able to land me high and dry, I was obliged to wade a lirtle way through the water and thus reach the shore, where, to my surprise, I found a wooden landingplace with steps, which, in such a spot, at first considerably puzzled me until I connected it with the missionaries. A number of natives, among whom I did not perceive a single woman, were ranged on the shore, and many of them came and shook hands with me. Among them was a young Albino with reddish-yellow hair and with a fine clear skin. Supposing, as a matter of course, that he was of white blood I spoke to him in English, but was instantly convinced that I had made a mistake, and that he did not understand a word I had said. He was a pure-bred native, less dark than his fellow-islanders, who themselves, indeed, had much lighter skins than I expected; I should describe them as of a bright brown colour. They saluted me with the word 'Alofa' (love), to which I replied by 'Aloha,' which is a form used in Hawaii on these occasions, meaning the same thing.

On leaving the landing-place I made for the village of 
Alofi, and called at the house of the Rev. Mr. Lawes, a nember of the London Missionary Society, settled in the island with his wife and two children since 1861. His house is large, solidly and tastefully built, with a roof of sugar-cane leaves, which, extending beyond the walls, forms a sort of verandah. The interior is divided into three compartments, the partitions of which do not reach to the

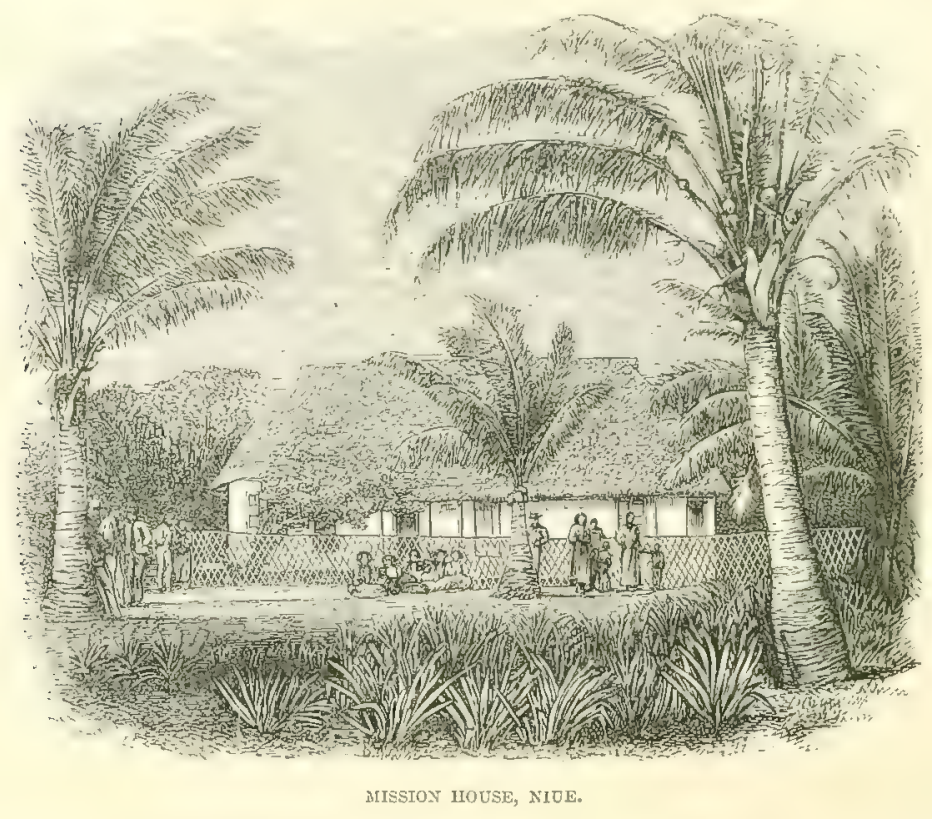

ceiling. Mr. Lawes received me in the middle one, where I found Dr. Picken and Mr. Halpin, of our ship, who had hurried to visit his wife, who was suffering from a very serious affection complicated with delirium and persistent want of sleep. The missionary is an agreeable looking man of rather dark complexion and slight make. He was dressed entirely in white, and after expressing his regrets at being 
unable, on account of his wife's position, to show his fellowcountrymen the attentions he could have wished, he offered me some cocoa-nut milk, which I drank with pleasure, enormous oranges with very thick rinds, and baked bananas, which I found not at all bad. I led him to chat with me about his island, and it is to him I am indebted for part of the information which I shall presently detail. Near the Missionary's house is a tolerably large church, also thatched with sugar-cane leaves, which seems to be the case with all dwellings of the natives, that are extremely clean, some of them having their walls whitewashed and openings screened by what looked like rude imitations of Venetian blinds.

I set out to examine the island with a young lad, attached to the mission, as my guide. Some ten of the natives followed me, shouting in such a way as to deafen me. I gave them all jew's-harps, which appeared to amuse them much, and to put them in great good humour. One of them seemed bent on allowing himself the privilege of trying each of them before choosing, but I took the liberty not to gratify this fancy; others wished to smoke my pipe, which I could prevent only by telling them it was tabu. They gave me the title of Kapena, that is to say, captain. I did hope they would tire themselves out at last and have done with their deafening cries, but all in vain: I do confess I found their noise a thorough nuisance. On my way I met numbers of natives carrying poles on their shoulders, as do the Hawaiians, to the two ends of which were tied pigs, yams, and other catables. For a space of four miles I proceeded on

$$
\text { \% } 3
$$


a road firm and strong in some places, and with a gentle rise. As I went along I met with a plantation of young cocoanut-trees, sugar-canes, yams, and other vegetables; and I had the opportunity of shooting some small birds. The sun was very hot, and there was a total lack of shade, the natural vegetation of the soil consisting for the most part of low shrubs. Even the cocoanut-trees were small, either from being yet very young or of a dwarf species. At length I came upon a sort of wood, and left the road to take shelter under the trees, not one of which was of any considerable height, or as much as two feet in diameter; in fact, I did not meet with a single fine tree, but it struck me that all of them had smooth bark. I noticed some Aleurites and Calophyllum. The ferns did not seem to abound in varieties, though they were very numerous; they all had large fronds, but I did not see a single specimen of an arborescent species A Dracæena attracted attention by its flowers of fine red. I did not hear the song of a bird; but, on the other hand, I saw a great number of pretty little lizards, some handsome butterflies, a large species of spider, and a grasshopper. I picked up three species of small landshells. I found the walking in the wood fatiguing, the surface being so uneven, and filled with loles not always very easy to perceive: The soil, of a reddish tint, superficially was very moist; and yet I could not find a drop of drinkable water.

Towards 3 o'clock I turned back with the intention of making a longer excursion next day. Several of the 
natives, who had followed me, took a fancy to feel my legs, arms, and hands, in order, I suppose, to get some notion of my strength, which seemed to surprise them, and as they expressed a wish to have me try the force of my hands upon theirs, I satisfied them by a grip which made them shout out, and appeared to astonish them. I may notice that the children occasionally placed one of their hands upon their mouth in passing before me. When I arrived at the top of the cliff I found a great number of women assembled, who seemed to have come there together by appointment during their husbands' absence. 'They laughed like mad, and my appearance did not in the least disconcert them. Several were very pretty and engaging; one of them appeared delighted at my taking notice of her baby. I took leave of them, saluting them with the word Alofa, which they reechoed with one voice.

On returning to the 'Curaçoa,' I picked up on the rocks several curious Alga for my collection. I found the ship's deck covered with natives, and I learnt that at least fifty canoes had boarded her during my absence. The Commodore had found these visitors so annoying, so importunate, so wearisome, such obstinate beggars, that he was impatiently waiting my return to stand out to sea again; and thus it was that, contrary to my expectations, I was obliged to limit my observation of the island to a few hours' survey. Our boats were hoisted in, and the signal for sailing soon given. It was then a very striking scene presented itself: as soon as the ship began to move, the natives who had 
manifested no disposition to retire before, leapt into the sea and swam back to their canoes. Several had expressed a most eager desire to accompany us as far as Samoa, but the Commodore did not think proper to gratify it.

Niue Island may be some nine miles in breadth. A road thirty-three miles in extent passes round the island, at some points diverging considerably from the coast. The formation of this road is due to the influence of the missionary, the only white man living in the island, and it is owing to him that it is kept in good repair by means of natives condemned to hard labour for crimes or offences. The island is entirely a coral formation, and must have been gradually upheaved, as would appear to be indicated by three distinct layers evidently of successive superposition, which are observable in one spot. It seems, moreover, from an inspection of the banks that this uprising or upheaving action has not yet exhausted itself. To it may no doubt be attributed a narrow deep fissure which extends nearly a mile into the interior. Lime abounds in many places, as well as a great quantity of sea shells. The aspect of the island is of a uniform character; so that a walk of two miles, no matter in what direction, supplies an accurate conception of the whole. The water in the wells is brackish, which in general obliges the natives to confine themselves to cocoanut milk. In the interior are to be found pools of not more than two feet in diameter, which contain fresh water, the level of which seems affected by the tides, a fact noticeable in some parts of the island of Oahu. It was in these holes 
or pools that the natives used formerly to collect the stalagmites, which they made use of as projectiles in their combats and which they adroitly threw without the aid of a sling.

The layer of vegetable earth which lies on the coral is almost everywhere from five to six feet in depth, and appeared to me much more fertile than the missionary had led me to suppose. It grows the cocoanut-tree, the guava, the orange-tree, the banana, plantain, and the melon; all, except the first which is indigenous, are of recent introduction into the island. Among other vegetable products I may notice the yam, arrowroot, sugar-cane, and taro; I also met with a white pea growing wild. There exists but one indigenous mammifer in the island, a small rodent of a size between a water-rat and a mouse. I must not, however, pass over a great bat which I saw flying at a remarkable height. With the exception of fowls, which are reared everywhere, there are but few birds; among them are pigeons or doves of a green colour, parrots, a pretty little green bird with white feathers under the tail, a small martin or swallow, the tropic bird or the boatswain, whose tail feathers are used to make elegant fly-brushes, the handles of which are neatly bound round with plaited human hair. I had not time to make any observations respecting the fish, but I noticed quantities of sharks constantly accompanied by their little pilots, and beautiful small fish about an inch long, of the deepest blue colour, but which I could not succeed in catching among the rocks by 
the shore. The cow, goat, pig, and dog have been introduced; at all events I am not aware that the latter animal was known to the natives before the arrival of the white man. They breed a great quantity of pigs, which struck me as being generally small and rather meagre. There is but one horse in the island and that belongs to the missionary; not a venomous reptile is to be found, and even the centipede is unknown.

The things most in request by the natives in their barter with the whites, are gaily-printed calicoes, hardware, and silver coin. They give in exchange cocoanut fibre, pumpkins, fowls, and other produce. Occasionally they offer cotton, which they as yet cultivate on much too small a scale. The average temperature during the rainy season is about $80^{\circ}$ Fahrenheit, and this would seem to be pretty nearly the case throughout the year. The climate is healthy, the diseases ferw, and with the exception of dysentery, which made its appearance once during the last ten years, no cpidemic has been known, or, at all events, remembered. The population increases in a ratio of $2 \frac{3}{4}$ per cent. annually. In 1864 the number of inhabitants amounted to 5,001 , distributed in the six following villages: Avatele, 1,075; Alofi, 1,011; Hakupu, 631 ; Mutalau, 910; Liku, 334 ; Tavahiki, 1,040.

In the course of the years 1862 and 1863 , some Peruvian slavers, which roved through these seas as unmistakable pirates, inflicted great mischief on their way on the natives of this island, killing several of them, and carrying off 
about 100 young men from a village, which has been in consequence so depopulated, that scarcely any other than widows and orphans are to be found in it. Since these barbarous attacks, the islanders have been beseeching the missionary to acquaint the British Government with their unanimous desire to be taken under its protection.

The inhabitants of Nine are good-looking, well and strongly built, of a good height, of a cheerful temperament, and, as they now appear, of a gentle disposition. Their skin is free from blemish, and I did not meet with a single instance of a scurfy surface. The only case of elephantiasis I remarked was that of our pilot, who had a slight affection of this sort in his two legs. But I was assured by the Albino, already mentioned, that there were eight other cases in the island.

The natives of both sexes go generally bare-headed, with the exception of the missionary's policemen, who wear a four-cornered hat, sometimes black with a white or red cross, sometimes in silk with a front of red or white paper ; which said police officials, I must own, looked to me like ' regular Guys.' I saw very fer men wearing shirts and pantaloons; the majority had nothing else on than a skirt, apparently made of bark, which is fastened round the loins, and descends to the middle of the thighs.

The toilette of the women is exactly the same as that of the men, save as respects the young girls, who in addition 
wear a kind of pinafore, which covers their: breasts and reaches to the skirt. Like the men, too, though exceptions are to be found among these, they wear their hair short; I did not see a single instance to the contrary. They are well nuade, have splendid teeth, and soft hands with delicate taper fingers. In the course of my ramble I met a young woman fit to be, from head to foot, a model for a sculptor; never did I see anything like or even approaching it in New Zealand.

These people, so well knit, vigorous, and active, are endowed with an intelligence which makes them easily receptive of instruction. Not a single pagan exists any longer in the island, and nearly everybody knows how to read and write, thanks to the schools established in each village.

The language has a great affinity to that of Hawaii, so much so that the ten first numerals are almost identical in the two languages, and that many substantives are precisely similar: as, for instance, ihu, nose; vavae, leg; lima, hand; mate, death, \&c.

It appears that they were once ferocious in their wars, though there is reason to believe they never were cannibals. Their principal arms were spears, tomahawks, and missiles made of the stalagmites, rounded by the action of water, to which I have already referred. The form of government was formerly aristocratic or feudal; but in a revolt at a comparatively recent period, the chiefs were all 
slain, and now it has become in some sort patriarchal, the head of each family managing his own private affairs as he pleases, and coming to an understanding with others, under the missionary's direction, in matters of common interest and in the control and punishment of delinquents. The morality of this little population is remarkable: the laws of marriage are respected, adultery and illicit intercourse are rare. Theft is frequent enough, especially as regards food in general; it is punished like other crimes by hard labour on the roads.

As the change supposed to have taken place in the disposition and social condition of these islanders is cited as one of the most marvellous instances of missionary success, it is a matter of some interest to ascertain to what extent this pretension is justified. Niue was first visited by Cook in 1774, who, having attempted a landing, was furiously set upon by the natives, and not being under any necessity of spilling blood, humanely took his leave, satisfied with the innocent revenge of calling it 'Savage Island.' From this time the island was regarded as being the nest of an exceptionally truculent people. The first missionary notice is thought not to dispel this idea. In 1830, Mr. Williams landed two teachers upon it; they were presently set upon by the savages, who tore their clothes to fragments, and scemed as if they would serve them in a similar manner, which, on the supposition of their assailants being the rudest of uncivilized men, it is rather singular they did not. But, at all events, they frightened the teachers away. The 
next visit, we are informed by Mr. Murray, ${ }^{1}$ was in 1840, by a party from Samoa in a small schooner, but with no permanent result; for what with 'great dangers' from the savages, which are not specified, and the roughness of the weather, from both which they were of course 'mercifully preserved,' they returned to Samoa, taking with them an 'immense quantity of weapons,' which they were glad to purchase in order to "disarm the noisy and ungovernable barbarians who surrounded their little craft in numbers that made them feel anything but secure.' It is manifest that the mercifully preserved party had been doing a little welcome barter-they pleasantly call it ' disarming' - with the savages who had been so dangerous to them, and that those savages were much better pleased to sell their weapons than to use them. Moreover, three natives had spontaneously gone on board the schooner and been quietly taken away without let or hindrance from the wild multitude around it. This is evidently inconsistent with any notion of supreme savagery, and, so far then as the testimony has gone, it is clear that the inhabitants have not yet deserved the hard names they have been called.

Six years after this two missionaries visited the island, and landed a teacher, a native of it, who had been many years at Samoa. He was, of course, exposed to great perils; but it seems that, on the day following his arrival, after

1 'Missions in Western Polynesia,' \&c. by A. W. Murray, twentyfive years a Missionary in Western Polynesia, in connection with the London Missionary Society, pp. 360-381. 
giving up the contents of his chest, he was safely housed and left unmolested; a result by no means discreditable to the 'ungovernable barbarians.' In 1849 Mr. Murray himself, ${ }^{1}$ to whom we are indebted for these details, visited the island, and reported all things quiet, and, so far as missionary prospects were concerned, in a hopeful state; nevertheless, writing in 1862, and referring to this visit, he says of the islanders that they were then (1849) 'the wildest heathens he had ever seen.' Luckily we have some other evidence, not missionary, which enables us to test the value of this judgment. In the same year (1849) a most competent observer, Captain Erskine, in H.M.S. 'Havannah,' lay off the island for a day, during which the ship was surrounded by and thronged with natives, and this was the conclusion he came to: 'Altogether they impressed me very favourably with their disposition, nor did they seem wanting in natural capacity.' ${ }^{2}$ No trace here of the 'wild ungovernable barbarism' from which there had been lately so 'merciful a deliverance,' nor of the exceptionally. wild heathenism that had been so manifest to the missionary.

Our next witnesses are again two missionaries, Messrs. Murray and Sunderland, in 1852. They inform us, that Paulo, a native teacher, having converted two or three hunAred of the islanders, being over 4,000 in number, the con-

I 'Missions in Western Polynesia,' \&c. p. 363.

2 "Journal of a Cruise among the Islands of the Western Pacific, \&c,, in H.M.S. "Havannah," ' by John Elphinstone Erskine, Captain, R.N. He adds that, ' $w i t h$ few exceptions, the expression of their countenances was intelligent and prepossessing.' 
verts desired to build a chapel, whereat the heathen majority, very unreasonably, of course, took offence, and threatened violent opposition; but no such opposition was made, and not a single outrage, or attempt at outrage, is recorded. But when we reflect how jealous much more civilized people are of any invasion of their religion, it seems to me that this tolerance is highly to the credit of the uncivilized." And so docile and willing were they to be taught, that we actually find, by the same authority - in 1853 — that ' the desire for teachers is now universal, and we hope very shortly to occupy the island fully.' We are not very much surprised, therefore, at finding Messrs. Herbert and Drummond, in 1857, confirming Captain Erskine's favourable impression, and declaring that the 'Savage Islanders are a remarkably mild and intelligent looking people,' though we cannot quite ascribe these national characteristics to the efforts of our good friend Paulo-the unassisted native teacher-who some five years before had gathered round him only 300 converts. National character does not change with such railroad speed; nor will even the missionaries, we suppose, credit the teacher Paulo with powers of conversion exceeding those of the Apostle Paul. Finally, in 1862, Mr. Murray, as he himself informs us, visited Niue; and this is what he says: "My last visit to the island was at the close of 1853 . At that time it was much in the same state as when it was

1 The Chinese are not savages, but we see, by the recent massacre at Tien-tsin, what passions are aroused by the intrusion of a foreign religion. 
discovered by Cook. Now how changed! how marvellously changed!' That it was 'at that time 'much in the same state as when Cook saw it, it is easy for me to credit; but how Mr. Murray professing to believe in its extreme savagery at that period could say so, after having told us only a few pages before, when speaking of this year of similitude 1853 , that 'the desire for teachers is now universal, and we shall very shortly occupy the island,' would be inexplicable, were we not aware of the irresistible propensity of the missionaries to proclaim marvels, and, by means of vague generalities, to give a semblance of support to their highly-coloured statements. Captain Erskine, though far from underrating the value or merit of their services, has protested strongly against their exaggeration of the difficulties with which they have to contend, and of the habit of some of them-less usual, it is true, with those of the London Society than some othersto be perpetually giving accounts of 'miraculous deliverances,' and, he might have added, of miraculous successes. At all events, taking Niue as a test of their descriptive accuracy, I think evidence enough has been adduced to show, that their sombre unsubstantial sketches of the aborigines do not obtain confirmation when placed by the side of clearly ascertained facts. Hence it is not surprising that, when to minds influenced by these sketches the opportunity of direct observation arrives, there should be the astonishment which was experienced by the officers of H.M.S. 'Fawn' in 1862, when such an opportunity was 
offered. 'Instead,' says Mr. Hood in his interesting notes of the cruise of that ship, 'of the uncouth ferocious savages we had expected, we found them pleasant good-looking fellows, of a light olive complexion, with well-shaped features, clean, quite sufficiently attired for the climate, merry and happy, but quiet and well-behaved.'1 But how then, it will be asked, are we to account for the ferocity displayed by these people for which Cook gave their island the bad name? The missionaries can help us to the explanation, though they make no ethnological use of it. 'The natives,' says Mr. Murray, ' had a great dread of disease, and they had an idea that if foreigners were admitted among them they would introduce disease, and when any of themselves left the island and returned, they were regarded in much the same light as foreigners, and the consequence was, were nearly in as much danger.' Now this peculiar prejudice is merely mentioned to enhance the difficulties the missionaries have had to contend with; but it is of much more use, as showing why, when this notion was in full vigour, there must have been intense excitement whenever any foreigners attempted to land, and that their ferocity towards strangers no more implies a social ferocity of disposition and manners than did the cruel persecution of witches imply a general barbarism among our ancestors in the days of the dread of witchcraft. Since Cook's time the prejudice has evidently abated; and as, since then, there has been a sort of invasion by the 
Tongans, some of whom remained and settled in the country, it is possible that this has been one of the causes of its abatement. At all events, enough has been said to remove their progress in civilization out of the category of the marvellous, and to make us regret that we have not been made acquainted with the real original character and condition of this manifestly prepossessing people, ${ }^{1}$ at the time they were first made known to us.

1 That this epithet is warranted will be seen from the following passage, in which Mr. Hood is alluding to the departure of the "Fawn." 'At sunset we reluetantly bade them farewell; and, after another general hand-shaking with old and young, who pressed round the boat, some swimming alongside to bid us good-bye, we left the shore of these highly interesting and pleasant people, and their adventurous instructors, in whose future fate we shall all feel an interest, although I entertain no fear for their safety.'-Hood, p. 26. 


\section{CHAPTER III.}

\section{TUTUILA-SAMOAN GROUP.}

(JULY 1 TO 4.)

Pango-Pango Harbour-Appearance of the Natives-Statements by the Missionaries-A Pilot who takes his Ease-Dwellings-Visit to the Missionary -Trip into the Interior-Village of Fungatele-American Artisans-Native Women-The Chief dines on Board-Native Dance-Christian ChurchCascade-Population-Climate-Manners-Progress due to ChristianityIndigenous Products.

ON the evening of the same day that we arrived at Nine, we set sail for Tutuila Island, one of the Samoan or Navigator group. Favoured by a pleasant trade-wind, the 'Curaçoa,' under sail, went ahead at about the rate of nine knots an hour. On June 30 we met with several squalls which darkened the sky, but which had not much effect on our way.

In our course we passed Manua, where we hove to for about an hour. One of our officers, Mr. Foljambe, who landed at the little village of Feleasau and walked along the coast to the missionary's house at Tau, described the path as being kept in good repair by prisoners who have been guilty of public offences. Erskine ${ }^{1}$ speaks of Feleasau as 'a beautifully 1 Erskine, p. 36. 
kept village," where he and his party, on landing, were taken to a large house, the Falatele, or public house of reception, in which strangers are entertained at the public expense. He adds that he had never seen a people more prepossessing in appearance and manner. $\operatorname{Hood}^{1}$ also bears witness to the hospitality shown to Captain Cator and several of his officers, who passed a night in the village. The scenery is described as beautiful, but the heat (July) very oppressive.

On July 1, at daybreak, we came in sight of Tutuila, at about a distance of six miles. This island is mountainous, intersected by deep ravines, and well wooded. Some steep faces of the coast were covered with verdure only; on other spots, where the land was lower, the soil was dotted over with clusters of cocoanut trees, which were much larger and prettier than at Niue. We passed close to the islet of Anuu, also referred to by some navigators under the name of Cocoanut Island. The Commodore, judging from his charts that he ran some risk in searching for a safe anchorage, lay to for a pilot, who soon made his appearance in a whale-boat. This pilot was a native of Honolulu, who spoke a little English and who lived upon Anuu islet. $\mathrm{He}$ told us he had not seen a ship for two months. He directed us to cast anchor in Pango-Pango Bay, the best port of the Archipelago, which we did about nine in the morning in twenty-two fathoms, after having entered the harbour through a very narrow passage. The scenery was magni1 Hood, p. 30. 
ficent. Some features are well described in the following passage, which I extract from my lamented friend and companion Lieutenant Meade's journal. 'Nothing', he says, 'could be more superb. At sca the contrast between the brilliant cobalt blue within the reefs which skirt the shores, and the dark olive-green of the deeper waters, separated by lines of foaming breakers on the coral walls; on land the black lava rocks along the shore, with intervals of white sand dazzling in the sunlight and fringed with cocoanuts, palms, and bananas, bending to the sea breeze, and interspersed with the thick-thatched domes of the native houses; the whole surmounted by the towering crater sides smothered with the densest foliage to the very crest, save in one direction, where a single lofty cliff rears its grey walls against the sky, as grimly and as bare as when, thousands of years ago, the volcano was in the plenitude of its power.'

To complete this picture I am tempted to add the following description of this remarkable locality from Mr. Hood. ${ }^{1}$ 'To those who have never beheld tropical scenery, it is difficult to give any description which will enable them to realise the singular beauty of these islands. Here high rugged mountains, clothed with dense green forests, sink sheer down to the water, a grey precipice now and then relieving the eye. Against the blue sky the outline is broken by a graceful palm or some high pinnacle, or by the waving bamboo or banana. Silvery sands stretch along in front of the narrow plain, shaded by thick groves of cocoa1 'Cruise of the Fawn,' p. 40. 
nut trees, whose leaves wave and dance, reflecting the rays of the bright sum, underneath which are the scattered villages of the natives. Upon the narrow fringing coral reef the dark green waves break dazzlingly, while at the head of the bay the white cottage and mission church give an air of quiet civilization to the scene, enlivened by numbers of canoes, with their picturesque occupants, moving about in all directions.'

A great number of women were busy on the shore catching shell-fish. By means of my glass I perceived, though not able to distinguish accurately her features, a young girl who was entirely naked; as soon as she thought she was observed, she burst into a laugh and covered herself with a banana leaf. Dwellings were to be seen on the points of the bay wherever there was sufficient space for building, and all of them were shaded with cocoanut trees, the fruit of which supplied the drink of the inhabitants. Presently a multitude of outrigger canoes swarmed off to the 'Curaçoa,' so small for the most part as to contain not more than one or two persons; nevertheless, that there were very large ones in use by the natives we had ourselves an opportunity of observing. They contained both men and women, as well as unripe bananas for sale. Neither sex appeared to be so well-looking, or so clean, as the natives of Nine Island. Their skin was covered with spots and scars, arising either from the itch, or some other disease. I observed everywhere on their backs, shoulders, legs, large blackish pimples, such as frequently present 
themselves in the Hawaiian Islands. Their noses are very flat as compared with those of the Niue Islanders, and the nostrils much dilated. The men are tall and stout, but their muscles appear Habby; many are tatooed from their middle down to their legs, and the designs are so full and well executed as to give the impression of their wearing pantaloons. They smear their hair with lime, which gives it a reddish tint. The women have no other covering than an apron made of bark attached to their loins; they make a practice of whitening their hair with a paste, which looked to me like arrowroot. These islanders are not quite so noisy as those of Niue, but they are not a particle less inconsiderate or inquisitive. A woman seemed to be mightily amused by thrusting her head through a port-hole in order to have a good view of one of our officers who was in the act of dressing; and it was hardly to prevent his being maware of what she was doing, that she cried out audibly to him, 'Say! say!'

Soon after we had anchored, one of the two missionaries of the island, Mr. Powell, paid us a visit in a ten-oared boat. He was accompanied by Maunga, the chief of PangoPango, a man of mature age, of a calm and dignified deportment, who had for the occasion donned a black coat over the shirt and waistcoat which constituted his usual attire. ${ }^{1}$

1 Maunga is described by Erskine as being 'in 1849 a fine looking young man, in a sailor's loose jacket and an ample flowing robe of coloured siapo,' who had recently arrived from Manua to assume the chieftainship of this island.- 'Islands of the Western Pacifie,' p. 42. 


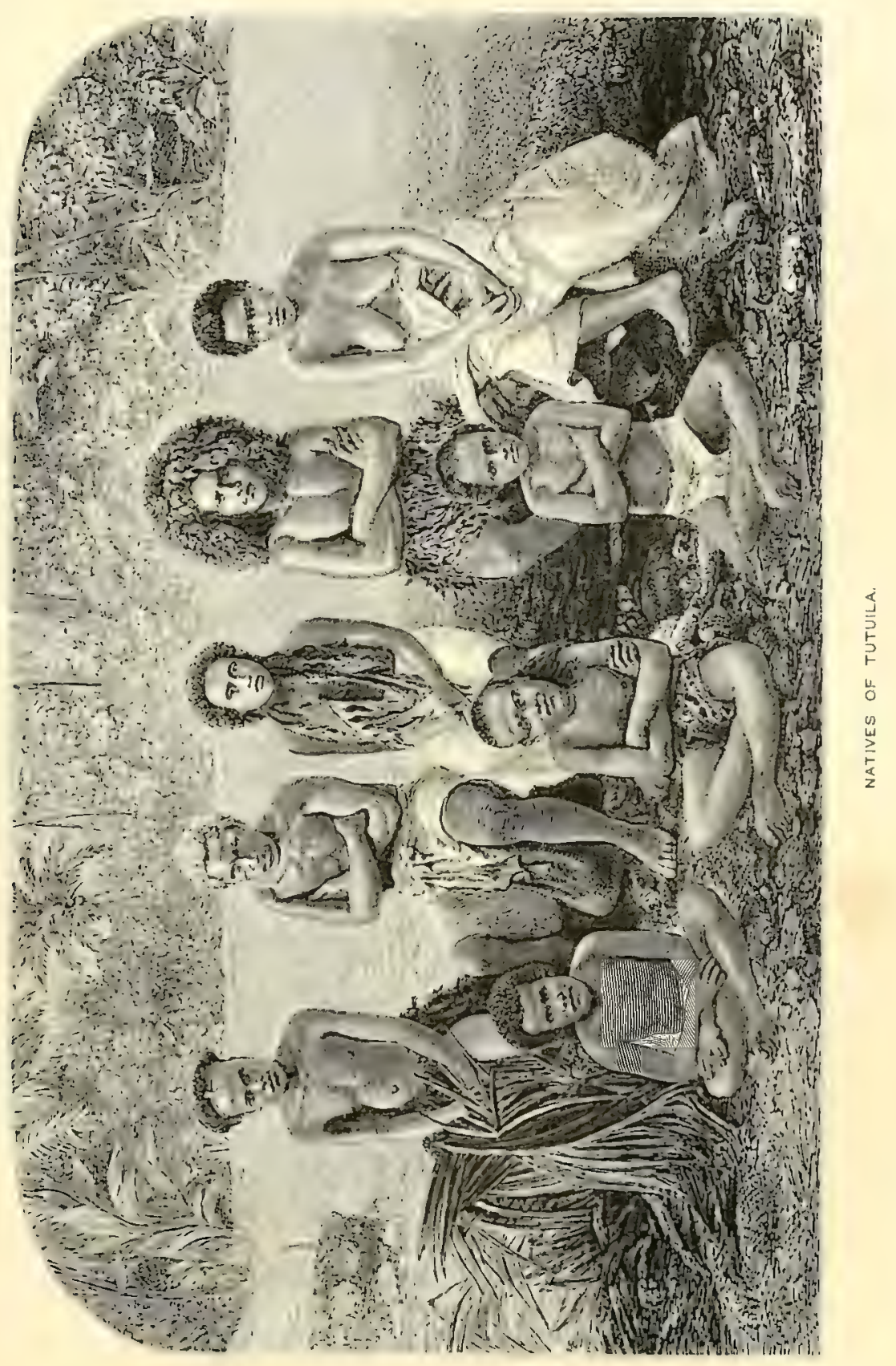



The missionary told us that, only five weeks before, there had been a tolerably bloody fray in the island on account of a woman about whom two chiefs had quarrelled. In reference to this matter he observed, that since the introduction of fire-arms among the natives their contests had been much less murderous than before. He informed us also that they were exceedingly anxious to place themselves under British protection, that neither France nor any other nation might take possession of the isle; and he preferred a request to the Commodore, in their name, to authorize them to hoist the English flag, to which Sir William replied, the thing was not possible. It appears from what he told us, that, two years before, the Governor of New Caledonia had compelled the Protestant missionaries to abandon the Loyalty Islands, where they had settled; and that, in consequence, a deputation had been sent from London to the Emperor of the French, who immediately gave orders that the Protestant missions were not to be interfered with. He added that, in consequence, Bishop Patteson was then on his way to ascertain if the imperial instructions had been carried out.

While the missionary was talking to us about all these matters, the pilot had remained on board, and got so very drunk that he could not stand, which did not prevent his proposing to the officers a fishing-party. The Commodore, displeased, but not wishing to be uncivil, asked him repeatedly why he did not leave the ship; but all in vain; he either did not comprehend or would not go, and caused all 
manner of annoyance to the sailors busy in swabbing the decks.

About half-past threeSir William placed at my disposal his gig, as I wished to make an excursion on land. I had considerable difficulty in passing the coral reef by a very narrow and shallow channel, in which I observed some admirable specimens of madrepores. I landed at a village agreeably situated in the midst of cocoanut trees, the inhabitants of which came out to meet me, and appeared very friendly and good-natured. I spoke to them in Hawailan, which they seemed to understand without much difficulty. The Samoan houses are so prettily and ingeniously constructed that I will insert here a minute account, given by Mr. Hood, ${ }^{1}$ of one of them, in which he passed a day and a night. "Upon a raised platform of rough stones, covered with gravel, varying in diameter according to the size of the building, beyond which it extends from ten to twenty feet, stands what at a distance looks like a huge mushroom, the usual size being about a hundred feet in circumference. It is, in fact, a great dome-shaped roof, raised from the ground upon posts about four feet high, and the same distance apart, between which a sort of blind made of plaited cocoanut leaves is let fall at night or in stormy weather. - This roof is so constructed that it can be removed in three or four parts, and is sometimes taken by sea on a raft of canoes. It is supported in the centre by three posts, about twenty-five feet high. Rounded beams,

1 Hood, 'Cruise of the Fawn,' p. 32. 
cut from the heart of the bread-fruit tree, which treated thus is very durable, are placed at equal distances horizontally, and tied firmly and very neatly with sinnet to the cross pieces. To these are lashed closely a great number of small battens, also of the hard part of the bread-fruit tree, in rows of six, generally of darker and lighter shades alternately. To this the thatch is made fast in a very ingenious manner, being composed of the long leaves of the sugar-cane pinned like a fringe to reeds with the rib of the cocoanut leaf. This part of the work is done by women; and one, if she works hard, can prepare about fifty of these reeds in a day. Each is about five feet long, and, in the way they are laid on, about four thousand are required for the roof of a good-sized house. The effect inside of these numerous reeds of the same size, carefully lashed with cocoanut cord, is very pleasing. The floor, of fine gravel, is covered with mats, clean ones always being laid for strangers. The house contains but one apartment; but bedrooms are formed at night by the mosquito tents, which are about eight feet long and five wide, made of dark siapo, and are let down at equal distances around the central posts. On either side of it is a fire-place, a circular hollow ten or twelve feet in diameter lined with clay. In several of the houses were women seated upon mats, who showed such of the sailors as were curious to have a peep a whitish preparation of food baked in leaves.'

I advanced as far as a rivulet bordered by a picturesque rock with a very high peak, from which there was a 
splendid view. I endeavoured to procure some cocoanuts of an old native; but the miscrly fellow having asked me an absurd price for half-a-dozen nuts, which he had knocked down and unhusked, I refused to buy them, whereupon he at once offered them to me for a small piece of tobacco. I met here several men who wore their hair in a strange fashion: short and black on the top of the head, but long and reddish below and all round. I returned to the shore without difficulty, and had myself carried to the canoe, which I preferred to wading and getting my boots wet. The water was extremely shallow, and the boat grazed the bottom several times on its way to the ship. At ten in the evening the thermometer stood at $85^{\circ}$ on deck and $105^{\circ}$ in the gun-room. The trawl which I had thrown overboard before going to land brought me twenty species of shells, generally small, and of little interest.

The next day, being Sunday, about half-past three I landed with the Commodore, under a brilliant sky, to pay a visit to the missionary, whose house is built on the top of the hill at some distance from the sea. We found only his wife, who at once presented us with a cup of milk. Mrs. Powell, the mother of six children, is suffering from elephantiasis, of which she hopes the climate of England will cure her in a year, whither she is on the point of going with all her family after an expatriation of twenty years. She said the people had a great aptness for learning, and with the exception of some old men and children, every- 
body knew how to read, write, and cypher, ${ }^{1}$ and that there was in each village a schoolmaster, fed, clothed, and paid by the natives. She showed us several books printed in the native language; among others a Bible, a work on geography, and a dictionary. With respect to this language I may say, it seemed to me that the Samoans use an ' $F$ ' wherever the Hawaiians use an ' $H$ ' or ' $W$;' for instance, they say fafine (woman) for waline, fai (water) for wai, \&c. About five o'clock, after his Sunday duties, the missionary returned. He called our attention to the very fine view from his house, and showed us over the various parts of his residence, the roof of which he had constructed himself, well executed, but, of course, not so skilfully done as that which the Alofi natives had made for Mr. Lawes. The form of government in the island, he told us, was patriarchal; also that there is a chief in every village, that all the chiefs are equal one with another, and that they confine themselves entirely to the affairs of their own districts. He spoke highly of the inhabitants, who almost all of them buy Bibles bound in calf at nine shillings each, and who contribute a very considerable sum (1,200l. in 1864) to the support of foreign missions. While we were conversing, tea and bread and butter were brought in. Among other things, we were told that an American blacksmith, who had been settled thirteen years in the island, made harpoons and fish-hooks for the whole archipelago, which he disposed of in exchange for cocoanut oil. Tutuila pro-

1 This, as we shall find (at p. 59), is an over-estimate. 
duces annually 130 tuns of oil at $22 l$. or $23 l$. a tun, payable in silver coin or merchandise. Soap and white calico are the articles most in request by the females, who are so cleanly that they are always busy washing.

Mr. Powell conducted us to the shore. On our way I picked up several land shells, one of which was very pretty. My attention was called to the Tutui or candle-nut (Aleurites triloba), which grows natarally in the island, and the cotton plant under cultivation, which seemed to me to be well grown. There is said to be a great variety of wood exceedingly well adapted for wheelwright work and carpentry, which was formerly used by the natives for making their weapons, that are now laid aside for ours. On the sides of our road grew an Asclepia, with flowers of a reddish orange tint, with fruit full of a white and shining silk-like substance, of the same species, it seemed to me, as that which is so common in India, China, and Hawaii. Musquitoes, which are abundant here, very much annoyed us in our walk. I saw two white birds flying very high over a valley, which I took for hawks, but which the missionary asserted were terns.

The next day, in the morning early, I again went on shore, accompanied on this occasion by Messrs. Foljambe and Veitch, with the intention of crossing the island to visit Massacre Bay. We stopped a moment at the missionary's, who was good enough to provide us with two stout natives and a young boy as guides. After passing through some brushwood, we crossed a brook in which women were busy 
washing their linen, which they rubbed and beat upon stones, as I had seen done by the Chinese and Hawaiians. This practice, still so common among the French, once existed in England, as we learn from a letter of Dr. John London, one of the visitors of religious houses in the reign of Henry VIII., to Lord Cromwell, making it a ground for granting a new town hall 'to the honest men of Readinge.' For, he says, 'their Town Hall is a very small howse, and stondeth upon the Ryuer wher ys the common wassching place of the most part of the town, and in the cession dayes and other court dayes ther ys such betying", with batildores as oon man can nott here another nor the guest here the charge given.. "I I saw cocoanut trees, breadfruit trees, the fruit of which had not yet attained half its full size, plantations of plantains and bananas, patches of taro set in a dry soil, contrary to the Hawaiian practice in localities like this, on the seaboard, which exclusively confines its cultivation to artificial marshes. These marshes are formed in this way. A piece of land, varying in size, is surrounded by an earth bank; the ground being then turned up and irrigated by some neighbouring stream, is worked up by the hand and trodden until it becomes of so miry a nature that you may sink two or more feet in it. The soil being thus prepared, the tops of the taro plants are set in rows, about a foot or so apart, where they are allowed to remain until their tuberculous roots are fully formed, when they are ready for use. In Hawaii, some taro is also cultivated in a dry soil; but this is in the

1 Ellis, Original Letters, first series. 
uplands, where there is more rain and a lower temperature; it grows less quickly, but is considered to be of a finer quality. I also observed pine-apples, but the cultivation of them in general appeared to me slovenly. We now got into a path with a slight ascent, which shortly brought us into the midst of extensive woods. Here we were surprised by a rattling shower, which obliged us to take shelter under a bushy tree nearly three feet in diameter, with dark green foliage; my guides brought me a large banana leaf, which made me a capital umbrella. When the rain was over we quitted our shelter, the atmosphere still continuing moist and thick. I saw a tolerable number of trees of different species, and a very great variety of ferns, among which were several tree-ferns, which sometimes, I was told, attained the height of forty feet, but I had not the chance of seeing any of such a growth. It was a fine forest; it had not, however, so tropical a character as I had expected. I saw arrow-root, tutui (Aleurites triloba), and ginger, which looked very pretty, with its cluster of white flowers tinged with pink, resembling somewhat in shipe a bunch of white grapes. The farther we advanced the steeper the path became, as well as stony and difficuit. The boulders, formed of a sort of broken lava, were so slippery that I was obliged to make use of my hands to prevent my slipping back some feet each time I planted my foot. The ground was strewed with dead land-shells, while live ones were to be seen upon the ferns and other plants. In two or three little brooks I crossed I saw several varieties of live shells, some of them of a remarkably handsome form. 
The rain soon began to fall again, but we made the best of it, and set to work shooting some small birds, several of which were lost in the brushwood. Among those which we found were a sort of kingfisher, a small species, very much resembling the laughing jackass of Australia. I also killed a bird of fair size, like in its plumage and shape to a hen blackbird, but larger, and also a bird of a pretty brown colour, with bright yellow about it, and yellow flaps below the eyes. In the interior of a small white egg $I$ found a little black lizard, about an inch and a half long, so extremely nimble that I had considerable difficulty in getting hold of it, though just released from its shell. As at Nine, the greater part of the trees I saw in my way had a smooth fine bark; which, according to my impression, appears to be a usual type in tropical countries, where I do not recollect to have often met with roughish bark like that of the elm and oak.

Having reached the highest point of the island, I could see the sea and Bay of Funga-sa, or sacred bay (PangoPango Bay is called Funga-loa, which means deep bay). Some fields of taro are to be found on these heights; but I did not stay long on the spot, wishing to go on exploring. At first I found the descent as steep and abrupt on this side as the ascent had been on the other; afterwards it became more gradual and less rough, and our way still lay through the wood, which extends equally far down on this side as on the other. Having reached the extreme limit of the road, I found myself within a few steps of the village of Funga- 
tele, where I arrived all dripping with rain. I entered the nearest house, and found there Mr. Carr, our photographer, busy dressing the wounds in one hand and leg which he had got in scaling the heights.

The house belonged to an American of the name of Braidwood, who had been settled in the island for two or three years, where he gained his livelihood by working for the missionary and natives. While a torrent of rain

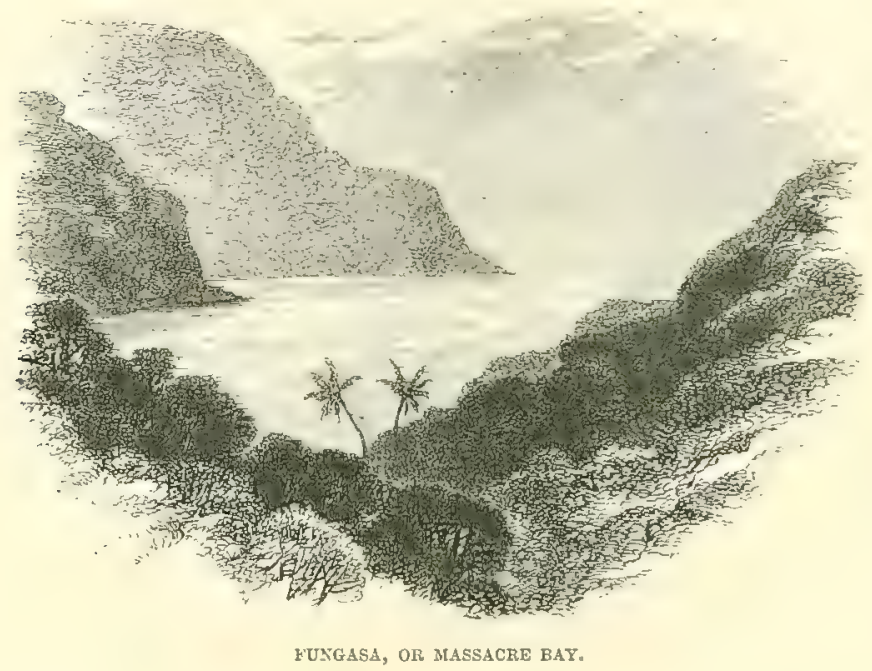

detained us under his roof, he had some ava prepared by the villagers, who masticate it after the fashion of the Hawaiians, of which I drank about half a pint in a cocoanut bowl. This liquor appeared to me very weak, and I do not recollect ever to have drank any that was more so in the Sandwich Islands. Our host said the natives never make it stronger in the Samoan group than this he gave us ; it did not at all meet the fancy of our sailors. Recol- 
lecting that this drink is severely prohibited through the Hawaiian archipelago by the missionaries, I was rather surprised to learn there is no prohibition of the kind whatever either here or at Niue. The American carpenter was very emphatic in his praise of the hardness of most of the woods of Tutuila, which are very handsome. He gives the name of iron-wood to the Toa (Acacia heterophylla), employed not long since by the natives for making their spears, clubs, and tomahawks. We found at Braidwood's another American, him whom I have mentioned above as a blacksmith, and whom no one knows by any other name than that of Sam. Both these men have been sailors in the merchant service, and both are bachelors. Braidwood suffers from asthma, and has a sickly look. He asserts that the climate is very unwholesome for the whites, and says that this season, which to me appears extremely damp, is called the dry season, or winter. He requested me to shoot a pig, which he desired to give the sailors who had come to visit him. The pig was immediately committed to the native oven, and I have reason to believe that our men found it very much to their liking. The village of Fungatele, situate about 400 yards from the sea, upon a soil which is covered with broken stones, contains at the utmost a dozen dwellings of tolerable size, each occupied by a single family; they are of the same form as those previously mentioned, and are all paved within with small stones covered with mats made of pandanus leaves. Our appearance at Braidwood's attracted a good many of the 
neighbours. The women whom I saw had nothing on but a strip of cotton or tapa depending from their waists to the middle of their thighs. Several of them had flowers in their hair ; a head-dress which showed them off to advantage; those who were mothers had breasts loose and falling, those who were not had them firm and very pointed. The men for the most part were tattoed from the breast to the knees with clever designs of a bluish tint, which gave them the appearance of being clothed. They offered me for sale spears, tomahawks, and shells; I offered a dollar for a club which a woman handed to me, but after having taken my money she returned it to me, saying it was worth double. I left the carpenter's house about 2 o'clock, on my way back to the ship, while Mr. Carr was still trying to obtain some photographic sketches. - I stopped a moment on the summit of the pass to light my pipe, and was again overtaken by a heavy shower. Having reached the coast about 3 o'clock, I fired two shots to announce my return, and as a signal for a boat. But the shots not having been heard, I was obliged to have recourse to the natives for one, which I did not get until after half an hour's haggling, and showing them the money which I intended for their wage. I assisted the paddlers the whole way, and at length reached the 'Curaçoa,' thoroughly drenched, where I found the Commodore at dinner, having the Missionary and the Chief Maunga for his guests.

This chief, whom some sailors have honoured with the title of king, was suffering from elephantiasis, a common 
malady of the country, but which did not at all prevent him,-any more than his wife,-finding the champagne very much to his taste. Maunga was seated at dinner opposite his wife, a good and simple person, with a very pleasing expression of face (not shown in the wood-cut), who was con-

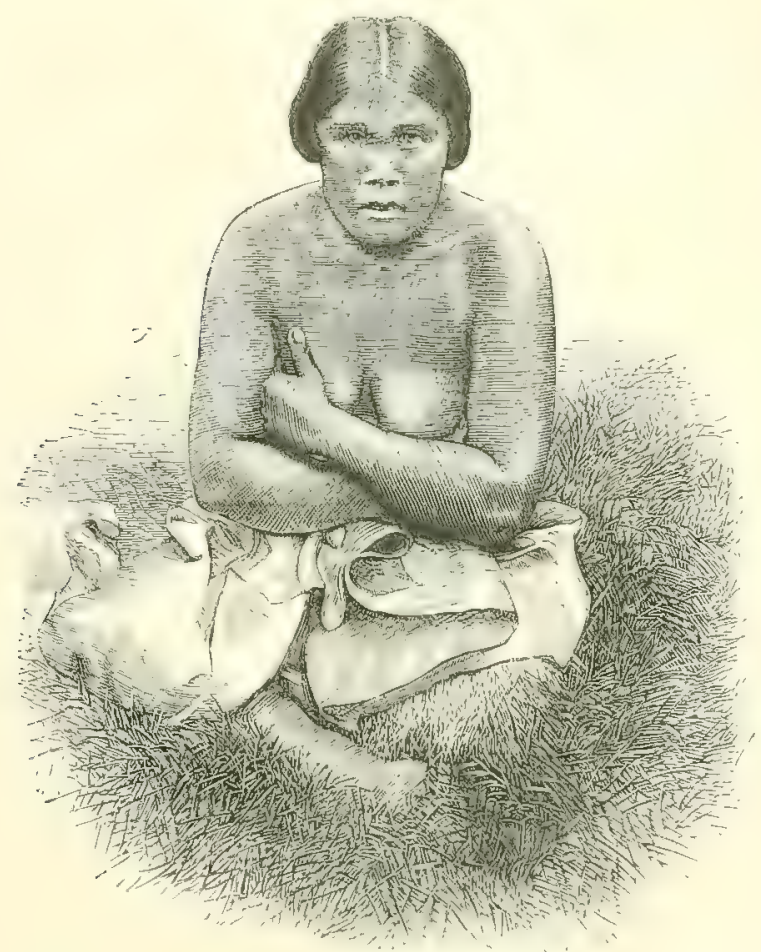

WTIE OF MATNGA,

stantly suckling her baby at table. These august guests, as also the Missionary's children, greatly amused us by the surprise they testified at the sight of a piece of ice; a thing utterly unknown in the country. An ice-cream was then served, and poor Maunga at once sputtered out the first 
mouthful under the impression it had burnt his tongue fearfully. But a plate of potted salmon, to which he was helped, he found so delicious that he could not sufficiently express the delight it gave him. In a word the chief appeared to be delighted with his dinner, and especially with the music, which they took good care not to omit for his amusement. He said little, which I attributed to his suffering state; but he listened attentively, and it seemed to me he understood a little English and Hawaiian.

After dinner, the chief gave us on board the exhibition of a native dance. It was opened by some half-dozen fine and well-knit fellows, whose oiled skins, and aprons of red Dracæna, glittered in the light of our lanterns as, to the sound of a small drum, they executed a series of irregular movements in perfect unison with each other, and keeping time with a chant and clapping of hands by the group of native spectators of whom there may have been between eighty and a hundred. Of some the heads were bound round with large beads of the pearl nautilus, while those of others were radiant with wreaths composed of the flowers of the scarlet Hibiscus. The women next took their turn, similarly ornamented, and performed their part in first-rate style. The effect was charming. 'It may seem incredible,' says one who had witnessed these Samoan dances, "to our fair sisters in England, that a young lady arrayed in no other garment but a mat tied round her waist should look handsomely dressed; but could they see the Samoan belles enter the circle in their full evening costume, with 
their coronets of nautilus shells and scarlet Hibiscus, and their necklaces of red and yellow flowers, I believe they would admit that their appearance is highly imposing.' ${ }^{1}$

The marked peculiarity was the enormous head of hair worn by each dancer. The hair is suffered to grow long and bushy, from the top round on either sides, and the long black hair being tied round with a string close to this mop is suffered to fall down behind, producing a singular effect. Had these dances been performed on shore, there would have been, we were assurcd by the Missionary who remained below while it was going on, some very indecent additions to it; on which account he had felt it his duty to discountenance and suppress this and other native dances. It is probable, however, that dancing of any kind, no matter how inoffensive, would have been regarded as profane according to the usual missionary estimate. Towards the close of the dance I went and sat near the chief, who had been sitting talking to Mr. Powell in a line with the door, so that he could see and hear what was going on. Being next the chief, he kept nudging me, putting his fingers to his mouth, and then looking sometimes at me and sometimes at Mr. Powell, conveying to me the impression that he would like to have a smoke if the Missionary were not present. Suggesting this to Sir William, the latter asked the chief if he did smoke, to which he signified that he did, whereupon Sir William let him know that at all events he had his' permission to smoke.

1 "Cruise of the "Fawn," p. 50. 
After the Commodore had dismissed the performers and his guests, Yankee Sam paid a visit on board. He had a conversation with the Commodore, in which he exaggerated, and scemed to romance, to such an extent, that it was impossible to know whether one ought to believe a single word he said. The next day I went ashore with some of the officers to see the Missionary's collections and a double war-canoe, from seventy to eighty feet in length. Afterwards I visited the school and church, as well as a great public building used chiefly for public meetings, convoked and presided over by the chief. The church is built after the same fashion as the houses, except instead of being round it is elliptic, and has windows furnished with outside blinds. There are religious services in it twice a week, and the congregation is seated on benches with frames or desks to put their books on.

There is a cascade in the island, called by the natives Pishi-tali (the Great Cascade), which is said to be more than 2,000 feet high. One of the officers, Lieutenant Meade, who went to see it, found it to be extremely striking and fine, but was of opinion that it did not reach one-half the height reported.

The island of Tutuila, which seemed to me to be partly composed of basaltic strata, varies in width from two to five miles, by seventeen miles in length, and is said to be sixty miles in circumference. There are plenty of paths, but nothing resembling a road. There are forty-three villages, of which the principal are Leone, with a safe and good 
anchorage in the usual trade winds, Aoloat, and Ast, the latter situate on the bay of Funga-sa, generally known to Europeans as Massacre Bay, on account of the sanguinary attack in 1787 by the natives on several officers and sailors of the expedition commanded by the brave and unfortunate La Perouse. ${ }^{1}$ The total population consists of 3,948 souls distributed thus: 1,293 men, 1,191 women, 765 boys, 699 girls. For many years this number has been stationary, the deaths equalling the births, being 1 in 391. There are 14 strangers in the island, one Frenchman, three Americans, one Irishman, and the rest English (i.e. the Missionary and his family). There is a difference of opinion respecting the salubrity of the climate. According to my view, it cannot be considered bealthy; for, in the first place, it scems to have a remarkable tendency to develop brain diseases, especially lunacy. Then again there is a disposition to a fever which develops elephantiasis in Europeans as well as natives; scrofula, phthisis, a form of opthalmia, and intestinal diseases caused by worms, especially lumbrici, are also to be found. Influenza, diarrhœa, dysentery, frequently assuming an epidemic character, as well as whooping-cough, which has appeared only recently.

The Tutuilans are less intelligent, industrious, and skilful in whatever they undertake than the people of Nine, whose tapa cloths are certainly better finished. As for the rest

1 According to a tradition in the island, it was an act of reprisal for the death of a native, accidentally or otherwise killed on board the 'Astrolabe.' 
they are inoffensive, naturally indolent, hating work in general, but setting a very high price on the least trifles they produce. The Missionary, who, by the way, is as much liked as any white man could be in this country, recom. mended me to pay a dollar for the slight service rendered me by a native for acting as my guide in one of my rambles. Silver is highly valued among them, as is the case among all the tribes in these seas. Next comes tobacco, which is in great request. Theft is the prevailing vice, and is unfortunately on the increase. In the course of twenty years there has been but one case of assassination, and the criminal suffered death. Prostitution seems to be unknown; but, on the other hand, sexual intercourse between the unmarried, and adultery, are common enough, if the white residents are to be believed; yet the men, it is said, are extremely jealous, and keep a sharp look-out upon their wives, especially when there are any ships in port; a state of marital vigilance which makes it somewhat difficult to understand how adultery can be a common practice. ${ }^{1}$ Marriages take place by elopement, or according to native usages, or through the agency of the Missionary. Marriage according to local custom is distinguished by a singular, and, as measured by our ideas, grossly indelicate ceremony, which requires a woman to establish the fact of her virginity in public; when the proof is not satisfactory, they are brutal enough to kill the woman. ${ }^{2}$ It appears from

1 See infra, p. 80, what Captain Erskine reports as to their manners.

${ }^{2}$ See Deuteronomy xxii. 20, 21, where the same penalty is imposed a similar want of proof. 
what the Missionary told me, that this singular usage is now so far modified that two or three aged women suffice as investigators and witnesses in the case.

Christianity was first introduced into this island in 1830 by Messrs. Barff and Williams. Now-a-days there are no more adherents to the old faith, but they are all Christians in some fashion or other. Mr. Powell puts the number of Roman Catholics at from 20 to $30,{ }^{1}$ and that of the Mormons from 70 to 80 ; the rest of the population is Protestant. Among the latter there are 307 church members and 284 candidates for church membership. We have already mentioned the very large contribution in support of the "propagation of the gospel; ' all which is undoubtedly evidence of a strong religious movement; but whether it indicates a rich harvest of religious results, is a point which is fairly a matter of mere conjecture. The number of individuals who are said to be able to read amounts to 1,138.

With respect to vegetable products I may mention Malay apples, papau apples, hog-plums, lemons, citrons, a small kind of Cape gooseberry, different sorts of small wild figs, several varieties of bananas, and plantains, two or three species of nutmegs never used, wild long peppers, ava, wild ginger, turmeric, thirty-two varieties of the bread-fruit tree, taro, yams, sweet cassava, the cocoanut tree, the banyan tree, cotton-plant, fan palm, rattan cane, 130 species of ferns, and ninety varieties of mosses.

1 I hear they are rather gaining ground lately, owing partly to the attractive doctrine of remission of sins by confession to the priests, and partly because the converts to Romanism are not expected to pay anything. 
The mouse and pig ${ }^{1}$ are said to be indigenous. The cow, the goat, and horse have been imported. Some twenty species of birds have been recognized. As respects reptiles there are only lizards, geckoes, ${ }^{2}$ and the green turtle, which is found around the island, and whose eggs are collected in great abundance by the natives. There are no sharks, but a great abundance of fish of different species, all exceedingly good with scarce a single exception. But one exception we were informed there is in a little fish of a round shape, and only a few inches long, which is said to differ from all other known fish in having its fins and scales setting towards the head instead of towards the tail; so deadly and rapid is the action of its poison, that some one, either from ignorance of their venomous property, or doubts as to the reality of it, having eaten one or two of them, expired almost instantaneously afterwards.

1 Pigs abound, but they have the honour of being principally reserved for public festivals. As many as seventeen hundred have been killed to celebrate the opening of a chapel-Erskine, p. 59.

2 A genus of Saurian reptiles, having Ieaf-like expansions at their" toes, which enable them to climb and adhere to smooth surfaces, such as walls, ceilings, \&c. The name is supposed to have been taken from the peculiar sound it emits. 


\section{CHAPTER IV. \\ UPOLU-SAMOAN GROUP-(continued). \\ (JULY 5 TO 10.)}

A pia Bay-Consul Williams, son of the Martyr of Eramanga-Mischief caused by a Hurricane-Resident Strangers-Baptisms on Board-Sunday at Apia -Catholic Bishop-Protestant Missionary-History of a Bible in the Eilice Islands - Visit of the Great Chief Malietoa-Ineonsistent Criticisms-Natives and Whites - Manners and Customs-Ancient Crater-Cascade-Island Products.

THE 'Curaçoa' weighed anchor on July 4 at 5 o'clock in the afternoon, and steamed out of the bay of Pango-Pango, the channel of which is not more than a third of a mile in width. As soon as the ship got out to sea a gentle breeze sprang up and enabled us to set sail. Towards sunset the mountains and coast of Tutuila assumed so beautiful an appearance that we could not turn our eyes away from them. During the night the breeze so slackened that, with all sail set, we did not make more than from three to four knots an hour, and yet the air was agreeably cool. Next day at dawn we got up steam in order to run along the northern coast of Upolu as far as the entrance into the port of Apia. The shore was exceedingly picturesque, with its bends and high lands gradually sloping towards the sea. The mountains, which at their highest point reach to 4,000 feet, were here and there lost in clouds. A cascade fell 
from the heights like a silver thread; and in the distance was to be seen a large island, that of Savaii, the domeshaped summit of which reminded me of the famous Mauna-loa of Hawaii. The whole of Upolu seemed covered with verdure, and well-wooded up to its topmost points. At the entrance of Apia Bay a pilot came off to us in a whale boat; he was a Yankee of small stature, as dark as a Portuguese; he appeared to detest the English, having been, as we were afterwards informed, expelled from Savaii, where he had settled, after being fined 1,000 dollars for killing one of the natives.

A coral reef, of a crescent shape, incloses Apia Bay, which is accessible by a large opening through it. We came to anchor, about 9 o'clock in the morning, in five fathoms. The whole shore of the bay is lined with dwellings built under cocoanut trees; the flags of the English and American consuls, the houses of the whites, the Catholic church, and the huts of the natives were distinctly visible to us. The British consul, Mr. Williams, came on board at an early hour in his official costume to pay his respects to the Commodore. This gentleman not only recommends himself by his personal qualities, but he inspires a peculiar interest as being the son of the celebrated missionary, who died a martyr's death under the blows of the savages of Eramanga. On leaving the ship he received, according to custom, a salute of seven guns. We speedily rejoined him on shore, where our first visit was to him. He received us in the midst of his family in a large house, surrounded by a verandah, 
and which he had himself built with the assistance of a single native, as, in like manner, he had made his principal pieces of furniture out of the most precious woods of the island. It would be hard to find a man of more varied resources than Mr. Williams. He has built two ships, one of 25 tons, another of 200 tons. He is skilful as a photographer, and occasionally practises medicine, not shrinking, if needs be, from performing a surgical operation, a proof of which we had in the case of two natives, one of whom had had his arm and the other his finger successfully amputated. He showed us portraits in oil of his father, who was killed in his forty-first year, of his mother, and other relatives. He told us that he had been engaged in the coal trade in Sydney, and lost all he had in it; after which he came to Samoa, where for the last ten years he has been English consul, with a salary of 400 l. a-year. He possesses about 100 acres of land, seventy of them planted with cotton, which yields an excellent staple. He informed us that the cocoanut trees of Upolu are reputed to be the finest of any in the South Seas; an assertion which I am not at all disposed to qualify, for they are unquestionably very lofty, very bushy, and very vigorous. We learnt from him that all that part of the bay, which is comprised within the two rivulets, is reserved exclusively for the use of the consuls and missionaries, a privilege they have obtained through their influence with the chiefs. The Americans, of whom there are many in this island, had just celebrated the anniversary of their Independence by 
races and various festivities which were: described to us. We met at his house the chief of the place, a very common-looking person, who did not open his mouth in our presence.

Mr. Williams appears to be thoroughly qualified for his position. He takes a proper and deep interest in the just and equitable treatment of the natives, for which, as we may easily conceive, he does not obtain the thanks of those settlers whose only object is to make profit and capital out of them. ${ }^{1}$ No man, it is allowed, understands the native character better than he does; a knowledge which renders him eminently qualified to assist and direct their development.

It was raining when the Commodore and myself left Mr. Williams, but we took a short walk on the shore until Sir William thought it time to return on board. Our attention was drawn to the traces of the damage done by one of those terrible hurricanes to which the island is now and then exposed. A small carriage-way on the edge of the bay had been so completely covered over with black sand that they had not yet had time to clear it. At a place near the reef, and not far from our anchorage, were risible the masts of a Hamburg bark, which had gone down at anchor with all her crew during the same storm, in January 1865. In the hope of recovering the oil with which the

1 We are indebted to his kindness for the communication of several notices respecting the South American slave-traders. 
bark was laden, and which was contained in iron tanks, the owner, Mr. McFarland, requested the Commodore to lend him some help in attempting to blow up the wreck. We could not, however, accomplish the task, though we made two efforts to do so, by trying to explode barrels of powder by means of a fuze inserted in a gutta-percha tube; the fuze burnt in the tube, but the water extinguished it before it conld communicate with the powder.

Consul Williams gave a dinner to the Commodore and warklroom officers of the 'Curaçoa,' to which the principal residents were invited; among others $\mathrm{Mr}$. Cole, the American consul, who is married to a native woman; Mr. Webber, the Hamburg consul; and a rich Irish merchant, Mr. MeFarland, married to Mr. Williams's sister. I hat also the pleasure of being included in the invitation. On approaching Mr. Williams's house it was evident that his intended hospitality had caused great sensation. The gate was beset by a large crowd, and facing it was a sentinel with a very important look, and armed with a whip to keep order. He was, we were told, one of the chief's guard in the uniform of his corps, namely, a scarlet coat made of woollen serge, of the tightest possible adjustment, and terminating behind in strange appendages, which we boldly conjectured were intended to represent swallow-tails-those once indispensable parts of military costume. A pleasant feature of the entertainment was our being waited on by native girls, who at intervals fanned, when not otherwise serving, us. 
Mr. McFarland complained that the influence of the missionaries was too great in the country, and expresser unreservedly his desire to see it diminished. The arrival of the 'Curaçoa' was a welcome event to him, as he was in a difficulty about the baptism of his children, the missionaries refusing to perform this rite, because, as was alleged, he was a member of the Church of England. But why these missionaries, so eagerly baptizing the children of heathens, should refuse to admit into the Christian fold the children of a Christian, differing from them only in sect, is unintelligible. It was not the fault of Mr. McFarland's children that their parent was in this fallen state, why then object any more than in the case of the offspring of the heathen? The only way I am able to account for it is, by supposing that Mr. McFarland wished the rite performed in the language, and according to the form, of the Church prayer-book, a proposition which would of course be horrible to the 'dissenting' missionaries, and therefore a very unreasonable one to make. But if the fact be as stated to us, the sooner these missionaries are sent about their business the better it will be for the race with which they are in contact. ${ }^{1}$ The request of this gentleman, that the Commodore would permit the ceremony to take place on board the ship was, of course, immediately acceded to, and it was accordingly performed by the Rev. Wm. Payne,

1 As respects the Baptists, who do not practise infant baptism, they could not possibly comply. In fact the reason given seems highly improbable. 
the Curaçoa's chaplain and naval instructor. The Commodore and myself standing godfathers to the two children by his desire.

Sunday is very scrupulously observed by the natives, as we had some opportunity of seeing by attending the afternoon service. A native teacher officiated, dressed en-

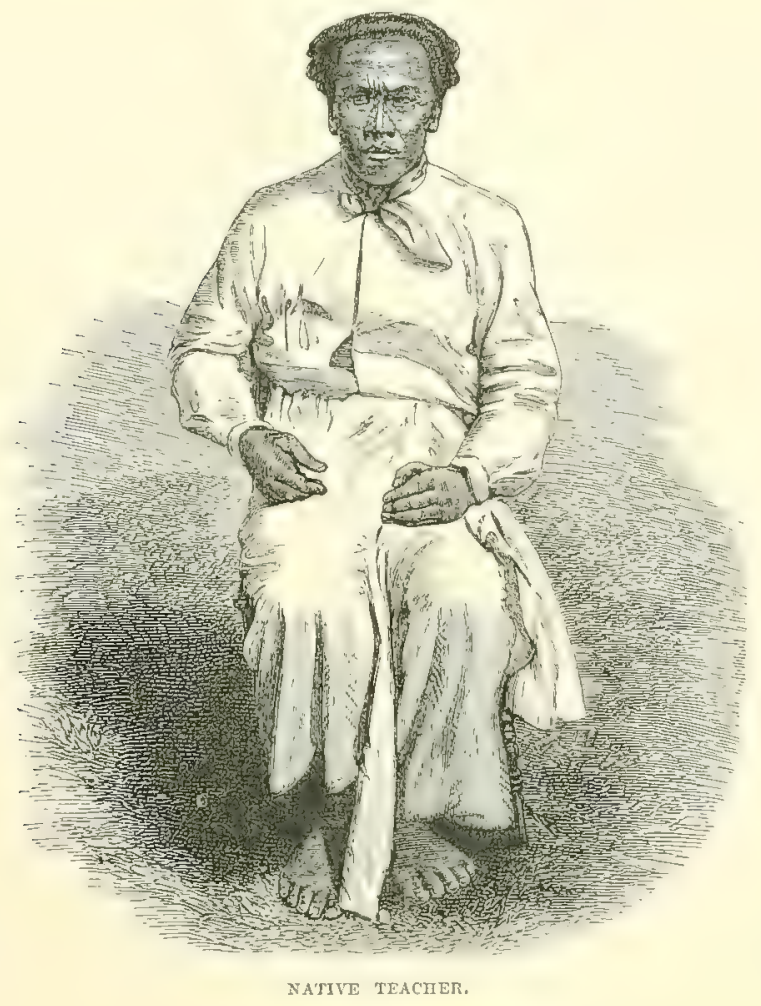

tirely in white, and without any canonicals. He was a man in whom devoutness scemed to be incarnate. Standing while the congregation was seated, he began by reading a hymn, then made an extempore prayer, read a chapter of Joshua, gave out another hymn, preached at great length, 
and, after another liymm, concluded the service by a short prayer. The congregation, the men of which sat on one side and the women on the other, exhibited throughout a devout attention. When the chapter from the Bible or the hymn was being read, all present took up their books and followed the reader. The preacher expressed himself very distinctly; so much so that, with my knowledge of Hawaiian, I had no great difficulty in understanding much that he said. The singing was not exactly what it ought to be; an organ would have been useful in keeping the roices in unison. The chapel, though spacious enough, has by no means an ecclesiastical aspect. It stands where it is partly shaded by a fine bush tree, and is thatched with sugar-cane leaves. In the inside there is a marble slab on which there is the following inseription: "To the memory of the late Rev. John Williams, founder of the Samoan and other missions in the Sonth Seas, who was barbarously murdered on the 20 th of November 1839, in the 41st year of his age, on the Island of Eramanga, while attempting to plant the gospel of peace among its cruel inhabitants. "Father, forgive them for they know not what they do" (Luke xxiv. 34)." At the side of the chapel is a small cemetery, surrounded by a vall; in it are five or six graves of white men, one of which contains bones brought from Eramanga, supposed to be the remains of John Willians, but his son doubts the fact of their being such.

During my stay at Apia I visited several foreigners, among others the Roman Catholic Bishop, a very fine man, 
tall, thin, upright, with a quick eye, and a long beard almost white. This striking looking prelate has been engaged in missionary duties for thirty years in the South Seas, and by his chance intercourse with Englishmen, whom he has met on their way, has learnt to speak English tolerably well. He received us very politely, insisted on our drinking a glass of Bordeaux, and chatted agreeably with us on matters of local and European interest. In the rear of the mission houses is a garden of large extent, very pretty and picturesque. His church, which is built of stone, with a spire of some height, has a very effective appearance.

On leaving the Roman Catholic missionaries, I paid a visit to the chief ' of the Protestant missions, Mr. Murray, who had also spent thirty years of his life in this region. He is a tall, spare man, intelligent, and agreeable. He is the author of a book entitled 'Missions in Western Polynesia' (8vo. London, 1863). His wife, who is in very delicate health, has kept her bed for three years. The incriminations and recriminations which are perpetually going on in these islands between the missionaries of different sects are in general not worth reporting. But a charge is preferred by Mr. Murray against the Catholic missionaries in reference to an asserted practice, which must be so very tempting to a religious belligerent as to favour the presumption of its probable occurrence. It is that, whenever a chief gets tired of the matrimonial bonds which the Protestant missionary has imposed upon him, and is anxious either for freedom, or a change of servitude, he goes to the 
Catholic priest who tells him that the Protestant obligation is worth nothing, and that he is liberated from his former tie, or warranted in contracting a new one, provided that in changing his wife he changes his sect. Mr. Murray is naturally, and, if actuated solely by interest in his flock, is justly indignant at this species of ecclesiastical kidnapping. Nevertheless the Catholic missionary, when he does this, is but acting on a principle of his Church, which it must everywhere carry into action, if not restrained by the civil power. In a society like this, it has full play; therefore fiat experimentum in corpore vili. The liberties which are taken with the natives in the name of religion, and the impositions practised upon them, were curiously illustrated by a story which Mr. Murray said he had heard in the Ellice Islands. Some of the natives, it seems, had been partially converted to Christianity by some one who, being obliged to leave the island, and having no Bible to leave with them, impressed upon them the importance of obtaining one as soon as possible, as a thing indispensable to their salvation. No sooner, therefore, did another ship make its appearance, than our new converts rushed on board to obtain the precious volume. The opportunity was not missed by the acute trader, who said he was fortunate enough to have a 'Word of God' on board, but that it was far too costly an article to part with without a consideration, and it was accordingly agreed that 120 gallons of oil, of at least $20 \mathrm{l}$. value, should be the price for it; a very fair remuneration, seeing that the original 
price as marked upon the cover was $3 s$. The talisman thus obtained was, of course, as regards its contents quite unintelligible; but, after being carefully folded up in tapa, it became for many years a sacred deposit in a chief's house, where it was subsequently produced to some native teachers, who visited the island for the purpose of conversion. How it came into Mr. Murray's hands I do not know, but, if I remember rightly, he showed it to us. It is probable good care was taken not to let in light upon the fraud which had been practised, otherwise the natives would have had an odd conception of the morality taught in it, as thus practically exhibited by the believers in it. Well might Rajah Brooke observe to the missionaries, when he permitted them to come into his dominions (under the proviso that they would not teach their converts to quarrel with one another), that he much feared their moral instruction would hardly be a match for the immoral instruction of all kinds practically taught by the traders. Nor is it only by gross people of the latter class that civilization is exhibited to savages in anything but an attractive and elevating form. A circumstance, mentioned by Captain Erskine in connection with this island, very forcibly illustrates the examples of unfairness and one-sided advantage, which are set before the natives by those who ought to know better, but whose practical illustrations of civilized equity are by no means commendable. It appears that when the well-known Mr. Pritchard arrived at Upolu, invested with consular func- 
tions, he brought with him from 'Tahiti several young horses and mares, the first ever seen in the island. Suffered to go loose these strange creatures leapt over enclosures, trampled down provision grounds, and terrified the children, upon which the natives speared one or two of them during the night. ${ }^{1}$. Now it is manifest that these people would inevitably think they had as much right to destroy Mr. Pritchard's horses as he had to permit his horses to destroy their property, and endanger the lives of their children, and yet, we are gravely told that no compensation could be obtained, because the perpetrators could not be discovered. It would appear from this, that our Missionary Consul, who, in either of his capacities, was bound to set an example of equity, would have actually exacted compensation from the parties offending him, but without, as far as we can learn, in any way compensating those injured by him, who could prove their non-participation in the act of retaliation. It is obvious that they are not the best teachers of civilization who give their lessons in this fashion.

Malietoa, ${ }^{2}$ the head chief of the Samoan group, came on

2 That it was no fanciful apprehension on their part may be inferred from what Captain Erskine says of the Tongans, namely, that they destroyed all the horses left by Captain Cook, from fear of mischief to the provision grounds, and discouraged their importation for this reason.

At p. 406, vol. ii. of 'Fiji and Fijians' is a wood-cut illustrating 'the fright of natives at first seeing a horse,' in the village of Nandi, on the coast of Vanua Levu: some are runuing away in frantic terror, and others seeking safety in the trees.

${ }^{2}$ In 1849, Malietoa, then thirty-five years of age, was described as having a mild expression of countenance, and being quiet and gentlemanlike in his manners. His dress was a long white linen coat, and 
board the Curaçoa to pay a visit to the Commodore; he was accompanied by his talking-man, who carried a whisk of cocoanut fibre to drive away the flies, not unlike the flybrush used by grooms in Calcutta. He came with an escort of twelve natives, large well-grown muscular fellows, who

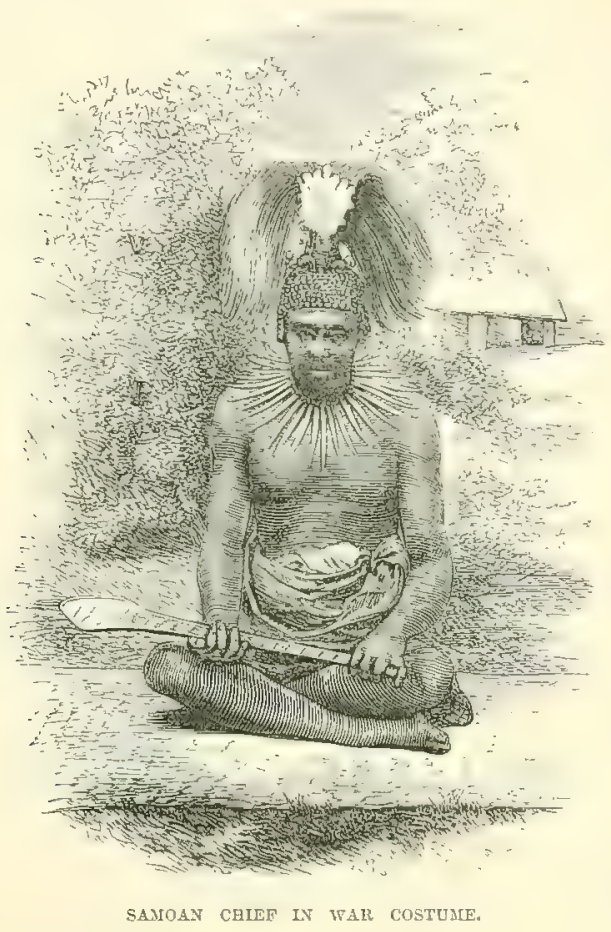

seemed to have been selected from among the finest men in the archipelago. Some of them wore shirts, others had white mats round their loins; others again had feathers on their heads. One of them had a splendid head of hair redened with chinam or coral lime, the national cosmetic.

one of the fine mats made from strips of the pandanus leaf, ornamented with a border and tufts of red worsted, hanging from his waist nearly to his feet.-Erskine, p. 76. 
I was told that a headgear of this sort was admired by the natives as the thing, and that it is worth a pound sterling. The chief was correctly dressed in European style, from which we concluded that he could at least speak English; but nothing of the kind; he knew nothing beyond his own native tongue. Malietoa, Malietau, are titles signifying the brave warrior, the generous warrior; they were given to one of the chief's ancestors by an enemy whom he had conquered, and whose wives, waving the customary rights which victory gave him, he had respected. The chieftainship of Malietoa is recognized and accepted by all the isles of the Samoan group, with the single exception of Tutuila, which, and it is a matter of general regret, is not subject to this central and paternal authority. The honours of the ship were done to him, every part of, which he examined. An Armstrong gun was fired off which greatly astonished and pleased him, without his seeming to have much idea what it was all about.

As respects the character of the people of the Samoan group the reports are highly favourable. They are represented as being sober, quiet, inoffensive when not excited; but, if roused, the savage very soon gets the uppermost; a result however which is not uncommon among people of a much older civilization. Such qualifying remarks, natural enough in the mouths of missionaries prone to exaggerate the roughness of the materials with which they have to build, are not, it must be allowed, confined to them; for nothing, indeed, is more curious than the sort of shyness 
with which writers commend the good qualities of uncivilized or semi-civilized people. A remarkable instance of this is furnished by Captain Wilkes, ${ }^{1}$ who, in his notice of the Samoans, has had manifestly every desire to be just to them. Having remarked that when this group was first discovered the natives were represented as being ferocious and treacherous, he fairly accounts for this as being the result of the sanguinary conflicts with the boats of La Perouse's squadron, which originated an impression apparently sustained by various acts, arising not unfrequently out of a just resentment caused by wrongs committed upon them by lawless traders. So far they are whitewashed, but presently, he adds, "the instance of Oportuno, however, shows that this idea of their character is not without foundation.' Now this chief Oportuno, of Savaii, was a brutal fellow, who was detested by the other chiefs for his outrages; and it is not easy to understand why his personal and exceptional brutality is to be taken as illustrative of the Samoan character any more than the atrocities of the lawless traders in these regions can be made evidence as to British character. This little disparagement disposed of, then follows a little eulogium: "Both sexes show great kindness for their children, and age is so much respected, that only old men are admitted to council.' Now, again, the turn comes for a little disparagement: 'As a shade on this picture they are covetous, indolent, fickle, and little reliance can be placed upon them.' Fortunately, we get 1 'United States Exploring Expedition,' vol. ii. pp. 126, 127. 
what is called an illustration of some of: these features. First, as to their covetousness. When a chicf receives a visitor, his first question is, "What present will you take?' He then places everything he has at his guest's disposal, though he might be awfully mortified were his offer accepted. But how this proves the charge is not very clear, especially as a similar custom has always existed in Spain, and, as I know from experience, exists in Russia, without carrying with it the reproach of either covetousness or deceptiveness. Moreover, when this formal offer has been made, we find that, as soon as the ceremony-or, as it is called, 'the risk of acceptance ' was over, "they were but too happy to supply us with cocoa-nuts and fruits.' But then, this liberality is said to be only apparent, since what they do is in expectation of a full return. Nevertheless, such is the general hospitality and kind social feeling, that when provisions fail in one district, they who are in want freely visit those of other districts where provisions abound, ready to do the same kind offices to their entertainers when the conditions are reversed. Thus, while the abstract charges are deteriorating, the illustrative facts are encomiastic, as respects their liberality.

Next, as to their indolence. Their habits are described as regular. They rise with the sun and breakfast; they bathe and oil themselves to go to their daily occupations, comprising the cultivation of taro and yams, building houses and canoes, fishing and bird-catching sufficient for the day's supplies. 
Dining at one, they spend the rest of the day in amusement, and after supper go to bed at nine. The men do all the hard work, even the cookery, which is varied and complex, the women simply preparing the food. The latter, who are treated with great respect, undergo no drudgery, but take care of the houses, and exhibit great industry in making mats and tapa. Their attention to order and neatness surprised Captain Wilkes, who says he had seldom seen a place where more attention was paid to cleanliness than at Sagana. A similar regard to neatness he found prevailing in the walks about the village, and in the cultivation of taro, melons, and bananas, which is carried on in the immediate vicinity. A broad path leading to the cultivated grounds passes through fine shady groves, and the careful preservation of these paths appears to be, we are assured, rather an amusement than a labour to the villagers. Captain Erskine furnishes evidence of the same kind. ${ }^{1}$ The description he gives of the Samoan villages in general affords a pleasing impression of the existence of much industry and order. They are usually in the midst of cocoanut groves, (the certain indications of inhabited places), and the approach to them is by a neatly kept path through provision grounds enclosed by low walls of broken coral, and containing bread-fruit trees, bananas, yams, taro, and ava. The huts are regular and detached, the communications between them kept cleanly swept, as is also the open space before the Fala-tele. In some places the missionaries

$$
1 \text { "Cruise of the "Havannah," p. } 45 .
$$


have introduced houses of coral plastered with lime, and the natives have learnt to divide their houses into separate rooms. ${ }^{1}$

Alluding to one of these Fala-teles Erskine says, 'we walked up to a beautiful village (Feleasau in Manua) and entered a large house, which our American interpreter called the 'Town,' where clean mats were spread for us, and we were invited to eat or smoke. This is, in fact, the house of reception for travellers, who may remain as long as they please; their food being supplied by the inhabitants as long as they make themselves agreeable. ${ }^{2}$ In these Fala-teles their public meetings are held, the decorum and order of which are something very remarkable, worthy, as has been observed, of our Houses of Parliament. When two speakers arise simultaneously, as there is no speaker's eye to catch, they remain standing until one gives way, the meeting meanwhile being perfectly quiet. As, however, the privilege of precedency is fully admitted, and each district has a generally acknowledged position attached to it, such difficulty rarely occurs. Nevertheless it does sometimes. Erskine, at Apia, was lucky enough to see an instance. When he entered the meeting two speakers were on their legs, neither, apparently, inclined to give way, but each, occasionally, addressing the other in an undertone; at the

1 It is to be hoped that the new houses are not built without reference to external appearance, and that the native taste is in this respect not left undeveloped.

2 "Cruise of the "Havannah,", p. 36. 
expiration of half-an-hour, the younger of the two yielded the point, observing however, first, that ' the staff on which he leant was known to all ; by which he meant, that in surrendering his place he did not surrender his claim to it. The other then addressed the assembly with great fluency, eliciting applause or smiles as his argument was serious or ironical, the audience occasionally expressing its approval by words, 'malu, malu,' sweet or good, uttered in a subdued tone. It would be a gross breach of order to walk across the circle round which the chiefs are seated; and when occasionally, as Mr. Hood ${ }^{1}$ informs us, 'a white man, looking upon himself as so far superior to the "savages," that he may infringe all their rules, marches carelessly with his pipe in his mouth in front of the speaker, the only remark they make is, "Oh, poor white pig, he knows no better." And there is good reason for their contempt, for, as the same writer informs us, the Samoans are a "nation of gentlemen, and contrast most favourably with the generality of Europeans who come amongst them.' Take, as another proof of this, the following testimony of Captain Erskine. Speaking of Mumui and old Vacateuola, two chiefs of Tonga, to whom he pays the compliment of saying that they equalled in polish Samoan chiefs, and who, being his guests at dinner, were dressed in a robe of flowing native cloth, leaving neck and shoulders bare, he says, "their behaviour at table was that of finished gentlemen.' In the evening, being on deck listening to the drums and fifes, and the air 1 "Cruise of the "Fawn," " pp. 49-60. 
cold, "they unrolled the train of their robes, and wrapping it gracefully round the upper part of the body close to the chin, somewhat after the manner of a Spanish cloak, stood listening to the music, looking like beautifully draped statues, until it was time to depart. ${ }^{1}$ The same writer thus concludes his notice of the Samoans: "It would be unjust not to allude to their remarkable cleanliness and habits of decency, which these islanders carry to a higher point than the most fastidious of civilized nations. Nor however low the morals of both sexes may have originally been, did any example of an indelicate word or action come under my notice during our stay of seventeen days. ${ }^{2}$

It is evident from these interesting details, that though the Samoans may be, as is affirmed, less energetic than the people of some other groups, they" are, nevertheless, distinguished by some remarkable qualities, which, if not deteriorated by so-called civilized people, give promise of a superior civilization. It is much to be regretted that they are not assisted in their advance by men of a more polished order than the greater part of those who have undertaken to elevate them. At all events it is greatly to be apprehended that the present miscellaneous instructors of these people will have but little sympathy with the highly distinguished manners that have so much astonished those who know how to appreciate them. Yet manners have a great influence on the character and development of a society; at least, such is the opinion of a great authority. 
'Manners,' says Burke, speaking of them in combination with some other things, 'are required sometimes as supplements, sometimes as correctives, always as aids to law. Manners are what vex and soothe, corrupt or purify, exalt or debase, barbarize or refine us, by a constant steady uniform insensible operation like that of the air we breathe.' It would be interesting to ascertain, if possible, how the Samoans have come into so rich a possession of these important adjuncts.

That there must have been a valuable peculiarity in the mental and moral coustitution of this interesting people is manifest from what we know as to their religious practices, and what we are told as to their theological belief. As regards the former, Williams, in his 'Missionary Enterprises,' says of them, 'that they have neither marais, nor temples, nor altars, nor offerings,' to 'which he adds the very significant remark, 'and consequently none of the sanguinary rites ohserved at other groups.' Hence he informs us they were regarded as an inferior race, and in some quarters the word Samoan became synonymous with 'godless.' It seems safe to conjecture that this exemption frum sanguinary religious rites arising possibly from a natural repugnance to violence must have had a beneficent effect upon their character. There can be no doubt that the fierce passions of nations have been fed and sustained by that ritual homage, as it were, paid to violence and ferocity,-the natural expression of an early condition of society, which is more or less visible in all religions. Ex- 
planatory of this abstinence from religious violence is a certain feature of their theology (if we may depend upon the account of it which Captain Wilkes tells us he received from the heathen or non-christianised natives), namely, their notion of a supreme God which seems to have excluded the attribute of violence or war-patronage. But, inasmuch as there is an inevitable tendency to war which must have supernatural patronage, they admitted three subordinate deities, one of whom enticed them to war, another who led them to it, and a third, like Bellona, who encouraged them to fight. In thus placing their supreme God above the instigation or superintendence of human destruction and slaughter, their views had the advantage over those of the Mosaic scheme, which regarded God as the Lord of hosts. So sensible, indeed, had some of the Jewish people just before the birth of Christianity become of this blot in their own faith, that we find one of the most eminent of them, the famous, patriotic, and pious Jew of Alexandria, Philo, earnestly and eloquently protesting against the belligerent character ascribed to God in the Old Testament, declaring it to be a temporary accommodation to uninstructed minds yet incapable of higher conceptions, and looking beneath the rudeness of the letter for an interpretation more in harmony with a belief in a beneficent deity, the object of veneration and love.

The population of Upolu is about 15,000, including 120 Europeans. A slight increase has taken place since the census of 1854. With the exception of two or three 
families, which remain there, everybody else is Christian; the Roman Catholics are reckoned at 3,000; the rest are Protestants. The native population of the whole group is estimated at 40,000 souls, and that of the whites at 200 , including the missionaries and their families.

The average temperature is $82^{\circ}$ Fahr., and the climate. is regarded as healthy, though phthisis and dysentery are not rare, and elephantiasis, influenza, fever, and ague sometimes take an epidemic form. Smallpox had never appeared in Upolu up to the time of our visit, but this had not prevented the nations from having themselves vaccinated as a measure of precaution. The morality of the Samoan group is said to exceed that of the other South Sea islands; but in spite of this flattering repute, several of the officers of the Curaçoa are inclined to think that the colony of Apia is by no means a model of all the virtues, and that the natives are, thanks to some of the whites, kept in a state of corruption which rivals that of many a seaport. It is not only the English consul who is sceptical on the subject of the chastity of the native girls, but the greater part of the whites also, whence we may conclude that this article is still more rare in the neighbouring groups. The Samoans carry the 'tokens-of-virginity' system to an indecent extreme. A sheet is laid down in the most public place in the village; the inhabitants assemble round it, and then the bride and bridegroom consummate their marriage for the first time in broad daylight and in the public gaze, after which the 
"tokens-of-virginity' ' are exhibited. Girls who have remained chaste up to marriage agree to undergo this process (though not otherwise immodest) in order to demonstrate the fact of their virtue. But owing mainly to the sexual relations subsisting between boys and girls from a very early age, these ceremonies are very rare; one had occurred about five months before our arrival, and another was to take place in about three weeks time.

As respects the internal communication of the country, they are of the rudest kind, mere tracks, or rather paths too narrow for any vehicle; neither the influence of the chief, nor the presence of the whites, seem to operate any improvement in this direction.

Here, as in other places we have visited, the ratives have exchanged their ancient implements of war for those used by Europeans, with the exception of the tomahawk, which they still retain. They are very fond of firing off guns, an amusement they have recourse to on every possible opportunity; the very night before our departure the report of gun-shots was to be heard all along the bay, on the occasion, as we were informed, of the death of a petty chief.

No mineral of any value or utility has hitherto been found in these islands. The chief natural curiosities of Upolu are an ancient crater and a cascade. The crater, situated twelve miles from Apia, is filled with a lake which covers about twelve acres, and on the borders of which grow palm-trees and large ferns. The cascade, which may

I Denteronomy. See Note at p. 58 . 
be seen from the sea at a distance of ten or twelve miles, has a fall, apparently of about two hundred feet.

Various kinds of bananas, the mountain plantain, some thirty varieties of bread-fruit trees, the wood of which is never attacked by worms, the vi, or Brazilian plum (Spondias dulcis), the ifi, the cocoa-nut tree; the yam, taro, and other esculent roots; the pandanus, sundry palm trees, the the malili, the taina or ati (Calophyllum inophyllum). Woods adapted to ship-building are indigenous to the island.

The chief commercial products of Upolu are bêche de mer, cocoanut-oil and fibre, arrowroot, and cotton. Fifty thousand cocoa-nuts yield. 500 gallons of oil; that is to say, one hundred nuts make a gallon. This oil sells at from $35 l$. to 40 . a ton. In the preparation of it there is yet much to be desired, the mode of producing it being of the rudest kind; and it is a matter of regret that presses are not used such as are employed in Ceylon, though even there the process is so imperfect as to cause a considerable waste. Cotton succeeds admirably, two excellent varieties of which are grown, one of them decidedly of the first quality. The value of the exports annually is 200,000 dollars; that of the imports is somewhat less. Among the latter the things most in request are calico, cotton-prints, handkerchiefs, ribbons, guns, powder, shot, axes, cutlery, tobacco, wine, and spirituous liquors.

In the port of Apia are to be had regetables, beef, pork, and excellent water. The watering-place is not conveniently situated, it being difficult to get really fresh water 
withont taking the boats too high up the stream to be able to float out again before the next tide.

The rat, the flying fox, or large fruit-eating vampire bat (Pleropus), the pig, are indigenous throughout the group; the dog, the cow, the horse, have been imported. Birds are tolerably numerous and remarkable. The most singular of all is the Didunculus strigirostris, or tooth-billed pigeon, of which I have met but two specimens, one alive, the other preserved in spirits of wine, and making part of my collection." It has the feet of a pigeon, short legs, the beak large and strongly hooked at the tip like a bird of prey, with three teeth on each side of the lower mandible, fitting into corresponding cavities in the upper. The plumage is dark and uniform in colour, the body of the shape and size of a pigeon. This bird is so rare here that the natives were unable or too lazy to find any specimens, though stimulated by the promise of $10 l$. for every bird they brought. It is said to be found only in one valley on the mountain. I saw honey-suckers with yellow plumage, resembling those I had seen in Tutuila. I shot some brown birds like hen blackbirds, and pretty little birds with pink feathers about their heads and some parts of their bodies. The foliage being thick it is hard to get a shot at them. Also several pretty white and black birds. I saw two parrots in a cocoa-nut tree, with fine blue and brilliant green

1 Since this was written I have presented it to the British Museum. There is said to be another specimen in the Imperial Museum in St. Petersburg. 
about their heads, a fine white bird, and a beautiful bird with a short beak and brilliant variegated plumage, \&c. I got a good many beautiful little crabs with a single claw, in some red, in others yellow, and the backs beautifully spotted with bright blue. A peculiar feature of the place was the great number of holes, from two to five inches in diameter, burrowed deep in the earth by the large land crab. Crabs of this description, they say, live in the mountains, from which they descend once a year in great numbers for the purpose of depositing their spawn in the sea, and having done this return to their mountain quarters. It is stated that, when on these expeditions, they will go over everything that comes in their way. At one place I came upon some muddy stagnant water, in which I saw some curious looking things with pointed tails, rather large heads resembling somewhat those of the iguana, and two feet; they were very shy and jumped about so nimbly that I could not catch one; in fact, I had not even time to examine them closely. Centipedes are to be found here, scorpions and cockroaches also. There is a great variety of fish, and many sharks which, I was informed, are not dangerous. 


\section{CHAPTER $\nabla$. \\ VAVAU-TONGA GROUP.}

(JULY 10 TO 15.)

Boscawen and Keppel Islands-Sandy Point-Excursion on ShoreMissionaries-Village of Neiafu-Visit to the Governor-The Guide Papalrugi -Roads and Convicts-Volcano of Latte-Curious Natural Grottoes-Population-Diseases-Government-Laws-Products.

True Commodore had intended to get under sail on Sunday morning, but he altered his intention in deference to a remark of the consul, Mr. Williams, that the Curaçoa would be the first ship which had left the port on the Lord's day; that it would be regarded as a great indecorum; and that the Missionaries would be exceedingly distressed by it. It was not, therefore, till Monday, July 10, about 7 A.M. that we put to sea, under steam, from the port of Apia. The pilot soon after left us, and we were scarcely five miles from the reef encircling the island, when we suddenly came upon low banks of coral, which occasionally did not leave much more than three fathoms water. After some anxiety we got free of this dangerous passage, and, at about half-past 3 P.M., the Commodore, taking advantage of a light breeze, gave orders to set sail. We looked back much pleased at the southern coast of Upolu, which seemed as if it were covered 
with a forest of cocoa-nut trees; and, for a long while, with the aid of our glasses, we were able to see the spire of the Catholic Church. The air was delightfully cool, a very welcome exchange for the damp heat we had experienced at our anchorage. We passed between Upolu and Savaii, and coasted along two pretty islands, the one called Paluale, the other, Manono; the latter somewhat elevated, on which were to be seen some dwellings and many cocoa-nut trees. The island of Savaii appeared to much advantage in the distance; its coast, rather low, was set off by some hills, which are probably ancient craters. Next day, about midday, while bending our course south-west, we sighted Boscarven or Cocos Island, a truncated cone of picturesque appearance, 2,000 feet in height, obviously suggesting the idea of its being a crater more or less ancient. Some time afterwards, at thirty miles distance from Boscawen, and within seven miles from the ship, we came in sight of a reef of more than a mile long, with its huge breakers. On sounding, we found a depth of six fathoms. This reef is not marked on any of the Admiralty charts, though it was upon an old chart in the Commodore's possession. We next saw Keppel Island, much longer than Boscawen Island, but also, at the same time, much lower. The following day the wind freshened, and in the evening we could perceive the island of Vavau in the distance.

On July 13, the weather extremely fine, and the sea beautifully calm, we came to anchor at Sandy Point, the port of Vavau, at 10.30 A.M. in seventeen fathoms. The 
island seemed entircly clothed with vegetation, among which the casuarina, the pandanus, and cocoa-nut trees, were easily distinguishable; the latter appearing to exist in greater abundance than I had ever before remarked in any one place. We saw a building resembling a church, with graves around it, and on the shore a whale-boat, two things indicative of civilization. There were also a good many canoes and canoe houses. The Curaçoa was speedily surrounded by canoes with red-headed men, their hair cut close to the scalp. These natives, who are of a brightish brown colour, are very well made, but with faces which, owing to their extremely flattened noses and very wide nostrils, are by no means pleasant to look on, as compared with the natives of Savage Island. The greater part of their canoes were small; I saw one double one, the ends of which were ornamented with milky cowrie shells (Cyproa lactea). A man, calling himself an Englishman, about thirty years of age, and of an appearance very far from prepossessing, came on board, and informed us he was the friend of the chief, and that he lived in a village called Neiafu, a portion of which was visible at the point of the island. We learnt afterwards that he is a sort of vagabond who conceals his real name, and that the natives have given him the sonorous appellation of Papalangi Jonah Pokahorse, which indicates, among other things, his principal occupation - that of a horse-gelder.

In the afternoon I went on shore in the dingey. After crossing a reef, where I saw several varieties of madrepores, 
I found a convenient landing-place on a jetty of coral. On reaching the shore there were a few natives who treated me with great respect. Seeing a little hillock before me covered with grass, I took a fancy to go to the top, and there found a pretty house surrounded by an enclosure made of cocoanut leaves very neatly intertwined. I learnt it was the dwelling of the governor, David Unga, the son of King George of Tongatabu. Thence I followed a broad path leading gently downwards covered with grass, and edged with two lines of cocoa-nut trees, forming an avenue, leading to the Protestant Mission, which consisted of two houses erected very near to each other. The two resident missionaries informed me they belonged to the London Wesleyan Missionary Society: their houses had glass doors, and it appeared to me they were living there very comfortably with their wives and children. They showed me some implements, weapons, and curiosities, which they had on sale for the benefit of the mission; it struck me the greater part of the tomahawks, spears, and bowls for drinking ava had come from the Fiji Islands. After having cxamined these things, I requested them to give me a guide, and took hasty leave of them, for the purpose of making a little round in the neighbourhood. The country appeared to me very pleasing, pretty even, with convenient roads, or rather paths, in all directions, continuously shaded either by the leaves of the cocoa-nut tree, the bread-fruit tree, or the kukui (Aleurites). The temperature was slightly lower than that of the Samoan group, but the air so much drier that I 
found it much more enjoyable than at Pango-Pango, or Apia, where I always felt as if $I$ was in a vapour bath. I saw but two species of land shells, very small and like those of Apia; the small birds, also, that I killed were similar to those I had previously met with. I saw fields of yams, of taro of two kinds, sweet potatoes, bananas of three varieties, and pine-apples not yet ripe. A hibiscus covered with large yellow flowers was in abundance everywhere; the papaw apple, orange tree, pammelo or shaddock, the lemon, citron, and other trees, grow marvellously well in the island, and yield, it appears, fine large fruit. No trees that I saw were at all remarkable for their circumference or height. A species of ti-tree (Draccena) here and there showed its flowers and fruit of a fine red. I also saw some plantations of ava, and frequently came upon patches of land in good condition for receiving crops. The ferns did not appear to me very numerous; those I saw were of the same species I had previously met with in the Samoan Islands. I passed through several villages, and met a good many natives; the women for the most part had their bosoms covered with a sort of small pinafore, which only reached to the waist, and all of them had their hair cropped so close as to make them undistinguishable, as far as their heads were concerned, from the men; and, by means of lime paste (chinam), they brought the colour of their hair into a kind of harmony with that of their skin, making their hair of a redder tint than is usual in Samoa. The people of Neiafu and the neighhourhood appeared to me very orderly and industrious. 
On all sides was to be heard the sound of the mallets used in making tapa, which, far from being disagreeable to me, had something, as it were musical, in its hollow tone. I obtained some particulars respecting the mode of preparing this fabric; the bark employed is never more than two inches wide; small narrow strips are first manufactured, and then glued together by means of arrowroot, so as to form picces of any length or width desired. Oil also appears to be a product. much attended to, as we saw in every hamlet two or three canoe-shaped bowls filled with cocoanut pulp, which is submitted to the sun's action for the purpose of being converted into it. Compared with anything I had yet seen, all around me appeared clean and comfortable. Many of the houses were surrounded, as with walls, by palisades made of cocoa-nut leaves cleverly twisted; though generally resembling in their forms and roofs those I had already seen in other places; they had this peculiarity about them, that they have mats of cocoa-nut leaves closely attached to each other hung round them; they have each two large entrances facing each other, the sleeping part being separated by a partition of mats. Of the chapel at Neiafu, which is of an elliptical form, with a roof carefully and even elegantly made, I am tempted to give the following description by Captain Erskine, ${ }^{1}$ as illustrative of the artistic skill of the natives: "This building is of large dimensions, being 100 feet long by 45 wide, and 28 or 29 high. In general design it resembles those of Samoa, having I "Cruise of the "Havannah,". p. 117. 
curved ends and a high-pitched roof. It differs from them in having two rows or orders of columns, every three of the lower supporting a short beam, from which springs the second order, bearing the ridge-pole. This, as well as all the horizontal beams, is most beautifully ornamented with cocoa-nut plait, so arranged as to give the appearance of Grecian or Italian mouldings, of infinite variety and delicate gradations of colour, black, with the different shades of red and yellow, being those employed. Different combinations of interlacing diamonds or rectangular figures formed the groundwork of these designs; but the same one was seldom twice repeated, and, the size of the pattern being nicely proportioned to the distance from the spectator's eyes, the effect was very artistic and pleasing.' The natives were busy, when I saw them, making 'for the love of God' a handsome road round it. There is, moreover, in the village a house for the use of the council, a sort of town hall.

Next day I went with some of the officers to the governor's, hoping to find horses on which we could make an excursion into the interior. This personage, David Unga, is, as I have said, son of King George, sovereign of the Friendly Islands, which comprise the Haafuluhao Islands (improperly called the Vavau group), the Hapai Islands and the Tonga group including Tongatabu. David is heir apparent to King George, being his son by one of the wives His Majesty discarded, on becoming Christian, at the instance of the Missionaries; the only one he had by 
the wife he retained having died. The governor is a very tall, imposing looking man, in spite of the loss of an eye, the result either of an accident, or a wound in war. He was also minus two fingers cut off as a tribute, according to the custom of these islands, to some deceased relatives. ${ }^{1}$ David has the reputation of being a great warrior, and a friend of civilization; he speaks a little English, provided there be no missionary within earshot. I found him dressed in a piece of tapa, which he told me he changed every three days, and which covered all his body with the cxception of his legs and feet. He has a bed and some old furniture of European make; his flag, the same as his father's, is red with a cross of the same colour on a white ground in the upper corner. He has two children, a girl and a boy: his daughter twelve years old is strongly built, and has her breasts perfectly developed, as is usual in a country where the women are generally mothers before they are thirteen. His son, who rejoices in the name of Wellington Ngu, is an intelligent looking boy about ten years old. David says he is going to send him to Sydney to be educated, and adds, he will gladly pay 300l. a year for his education.

Papalangi Jonah Pokahorse was with the governor at the time of our visit, and appeared to be on terms of great intimacy with His Excellency. This self-styled Briton,

1 In Hawaii a similar tribute is paid by breaking off a tooth to the gum. I have seen many men and women who have had several teeth broken off in this way. 
from whose lips issued more lies than truths, told us he had been in the island four years, the fact being, as we were not long in learning, that he had only been there some weeks, having been expelled for theft from some other island where he had been living. It was this person, nevertheless, whom the governor instructed to procure horses for us, and to be our guide.

We proceeded on horseback by a pretty road shaded by cocoa-nut and pandanus trees, and fragrant with the white Howers of a leguminous plant resembling the pea. Being informed that any one might at pleasure make use of the cocoa-nut trees which border the roads, I did not fail to do so, more especially as no water was to be found on our way. We passed groups of prisoners of both sexes, busy in constructing a road, which is to cross the island with a stretch of nine miles. I was informed that there are offences, adultery for instance, which are punished by a fine of from twenty to thirty pounds sterling, or by hard labour for a year, and even more. Hard labour involves the making and keeping up of roads, which are thus generally maintained in good condition. Our ride did not add much to the sum of our knowledge respecting the island, but we were all of opinion it would be difficult to find a more agreeable one, so pretty and well shaded were the roads. At a hut where we stopped, I purchased different native' articles, such as an ava-bowl, which cost me a dollar, and some spears at two shillings each, \&c. I also procured a curious wooden pillow, such as young women receive as 
presents when they are about to be married, and which they keep, it is said, without ever making use of them; but the one I have seems to have done good service; it is made of a hard dark wood, and covered over with a greyish paint or enamel.

The soil of Vavau is of a dull red, and of so friable a nature that it crumbles in the hand like the ashes of Pompeii. Lava is to be found in many places, and a white stone riddled with holes, which some refer to the coral, but which appears to me to be rather a species of lava, like that formerly thrown out by Vesuvius, and which is still found in the Bay of Naples. This stone is very hard, heavy, and susceptible of a very fine polish. The igneous origin of these countries is, moreover, proved by the little island of Latte, situated some miles to the west, where there is now an active volcano, which I was sorry not to have visited. There exist on the coast of Vavau some curious caves which were visited by my friend, Lieutenant Meade, from whose MS. I have borrowed the following description:- The first cave was well worth inspection; the mouth was broad enough to admit our two boats easily, and there was sufficient water in nearly every part to float a frigate. The stalactites and columns under the highdomed roof resemble gothic arches. The bright sunlight streaming through the narrow gateway of the cave, through the singularly clear water, and reflected up from the sparkling stones, and coral at the bottom full five fathoms deep, shed a beautiful series of lights and tints, shades of 
delicate blue and green, over every part of the walls and vaulted roof. At the innermost end of the cave there is an upward slanting passage over rocks and under arches, the further end of which is lighted by some direct communication with the open air above. One or two of our men scrambling up to explore the place, now in sight, now hidden from view, almost comically reminded one of the "Robber's Cave" business in an opera. The next cave we visited was smaller and less remarkable. We then made sail before the wind to a cave with a submarine entrance. This is the scene of the romantic adventure in Byron's poem, "The Island," wherein it is well described under the name of "Neuha's Cave." The native tradition is that the family of a certain chief having been condemned to extermination for rebellion, one of the daughters, a very beautiful girl, was prevailed upon by her lover to accompany him by night to this cave, which he had accidentally discovered not long before, while diving for turtle. Here he kept her concealed, visiting her nightly with food and fresh water, till an opportunity occurred of escaping together by canoe to the Fiji Islands, where they remained undisturbed in their connubial bliss, till the death of the Tongan viceroy enabled them to return to Vavau. Two sticks placed crosswise over a ledge of rock marked the position of the entrance to the cave, which would have otherwise been very difficult to discover; for above water there was no sign whatever of an opening, nothing but an unbroken and almost overhanging cliff. When, on the boats stopping, the 
water was still for a second, becalmed by the boats, or when the fierce glare of the sun being kept off the glancing surface of the waters by the overhanging rocks made the sea transparent, then a darker patch than usual among these coral covered rocks was seen some eight or ten feet deep. This was the entrance. One of the natives - skilled diverswho accompanied the chief, went overboard from the galley with the end of the boat's laad-line. The first time he seemed to fail, and rose again almost immediately; the second time he clisappeared in the direction of the cavernous darkness, and remained out of sight for eight or ten minutes, when he returned after having made fast the end of the line in the cavern, and rose again to air and daylight. The chief (David), who had talked so glibly of taking down one of us in each hand, now did not secm very anxious to distinguish himself in that line; so the captain, who, whether in the hunting field or elsewhere, is always "to the front," persuaded two of the most expert to take him down into the cave. ${ }^{1}$ After entering the passage the skipper became unable to withstand the natural tendency of his body to rise, thereby repeatedly striking against the sharp projections which form the roof of the passage, and the natives grasping him, one by each arm, had to keep forcing him down through nearly all the length of the passage, which the lead-line showed to be about 30 feet.

1 The officer referred to was Captain Lnce, of H.M.S. 'Esk,' to which. ship Lieutenant Meade was transferred soon after the arrival of the 'Curaçoa' at Sydney. 
This to a man not accustomed to protracted diving was rather exhausting, and cn reaching the surface of the water within the cavern he had to be helped across the short distance which separated them from a ledge of rock, just visible in the dusk, whereon they sat and rested. The little light within the cave was derived solely from the reflection through the mouth of the submerged passage, save when the waters within were disturbed by the swimmers, then the phosphorescent light displayed was more beautiful and brilliant than anything of the sort he had ever seen elsewhere, and he induced the natives to cross the cave in all directions for the sake of admiring the streams of liquid fire which followed every motion of their limbs. In returning, after having passed the lowest point of the passage, the glare of light, shining downwards throigh the waves from the open air beyond, repeatedly caused him to attempt too soon to rise, thereby coming into collision with the rocks orerhead. The natives now refused to take anyone else down; they said that " the men of the sea are too short-winded," and that after the difficulties they had had to keep the chief of the great war-canoe clear of the roof of the passage, they feared that an accident might happen should they attempt it again. And, in truth, the appearance of our worthy chief was such as in a great measure to cool the ardour, and lessen the disappointment of those who had been most anxious to follow his example; for his exhaustion for a minute or two was such that, on showing above water, he had to be helped to the boat, only a yard or two distant; his complexion had 
turned to a colour of blended yellow and green, and after having been lifted into the boat his first act was to appease the fishes, whose sanctum he had invaded, by feeding them most liberally. The natives said the correct way to proceed is to clive in the ordinary manner to the entrance of the passage, and then, turning on one's back, keep off the roof with hands and feet till the cave is reached. By the captain's account the interior of the cave, as far as he could judge by the fitfuI light, fully bore out Byron's description. The legend that we heard agreed with that given in Mariner's "Tonga" in the main, but some of us were told that, whether from want of air or anxiety during her stay in this submarine or subterranean prison of refuge, the young bride's hair turned grey. At the time of our visit I had never read "The Island," nor, oddly enough, was I or" most of my messmates aware that this was the cave described by Mariner and the theme of Byron's poem ; and, diving being at all times not only disagreeable but painful to me, I had not concealed the fact that the retiring modesty of my nature would prevent the cave from ever being inconveniently crowded by my adding to the number of its inmates. I fancy that if ever I should revisit the spot, I should feel inclined to try the experiment of letting a deep sea-lead slide down the line, which would lodge at the lowest point of the bight, and so afford a fair leader to keep one clear of the rocks above.'

The population of Vavau and of the small adjacent ${ }^{1}$ Meade MIS., H.M.S. 'Esk,' 'i. pp. 18-25. 
isles, included by the natives in the general name of Haafuluhao, now amounts to 4,000, a number indicating a considerable diminution within a few years. The causes of this are supposed to be emigration to other groups, shipwrecks, and the destructive effects of certain epidemics, such as intermittent fevers, diarrhœa, whoopingcough, which have very recently done great mischief. The population has also suffered from other diseases such as dysentery, phthisis, scrofula, affections of the bladder, ophthalmia, different kinds of ulcers, and a disease known by the name of tona, which very much resembles frambosia. Though the climate is very debilitating to the whites, it is said not to be "worse than that of the other Friendly Islands, nevertheless the average temperature of Vavau is higher, reaching to $90^{\circ}$ in the shade through the greater part of the year.

The actual form of government may be defined a limited monarchy; but it is right to observe that the country is in a state of transition, caused by the effects of Christianity which the Wesleyan Missionaries have introduced, and which has been embraced by the greater part of the inhabitants, including a very small number who have become Roman Catholics. The laws have been collected into a printed code, and there is reason to believe that morality is on the increase in spite of the bad examples set by the whites who occasionally visit these islands. Illicit sexual intereourse, adultery, theft, backbiting (very civilized features by-the-by) are the most usual offences. 
The island possesses no indigenous mammifers, those now found in it being of recent introduction. On the other hand, there is a great quantity and variety of fish and crustacea. The birds, as I have already remarked, present no great variety of species, and resemble those previously met with during our cruise.

Besides the vegetables I have mentioned, cabbages and onions are cultivated. The principal product of the island is cocoa-nut oil; sugar-cane is grown, but on a very small scale; the same may be said of the cotton-plant. 


\section{CHAPTER VI. \\ TONGATABU-TONGA GROUP-continued.}

(JuLx 17 to 22.)

Numerous Islands-Volcano of Latte-First Trip on Shore-Royal PalaceSchools-Muscular Christianity-The Wesleyan Mission and its ChapelCaptrin Croker and the Siege of Bea-Visit to King George-The King's Return-visit-His Majesty dines on Board-Fear of the French-A Dinner at the King's-Catholic Missionaries-Council Ifouse - The Kava-ringPublic School Examinations-Native Diversions-Remarkable MonumentThe Island and its Productions-Climate-Maladies-Population--The Race and its Customs-Christianity and its Effects-Relations of the Tongans with the Fijians-Government and Constitution.

ON July 15, at seven o'clock A.M., we left the deep waters of the port of Vavau, and steamed towards Tongatabu. We took what is called the passage of the 'Astrolabe, and saw a number of islands which, though lying low, that is to say, not more than from five to ten feet above the level of the :sea, presented a very pleasing appearance by their verdure, and their trees growing down to the water's edge. The smallest are of a roundish form, but the largest are oblong. Pretty bays gracefully indent their coasts; the soil of all of them appeared to me to be volcanic. On our starboard side, but at a distance from us, rose the volcanic cone of the little isle of Latte, from which a whitish smoke issued. In the afternoon we sighted the low isles of the Hapai group; towards evening our soundings showed only ten 
fathoms, and it became obvious that we were but a short distance from a reef, from which proceeded an odour strongly resembling that of fish. The wind that had been always ahead since we left Norfolk Island contirued to be unfavourable, which compelled us almost the whole time to keep up our sterm.

On July 17, after passing through some twenty small islands of but slight elevation, and all covered with vegetation, we cast anchor about one o'clock P.M. in the port of Tongatabu, just opposite the King's house. The most striking object in this regal village is the church; it stands about 60 feet above the level of the sea, on a small hill covered with a variety of trees. The island appeared to us to lie very low, and, after the church and some dwellings, what most attracted our attention was the sandy shore with a coral reef about 150 yards distant.

Numbers of small canoes with outriggers soon crowded about the ship freighted with pigs, poultry, large branches of bananas, cabbages, onions, yams, cocoa-nuts, oranges, shaddocks, limes, madrepores, shells, and small white cowries, which are made use of to ornament their canoes and the roofs of their huts. They were soon followed by two Protestant missionaries, Messrs. Whewell and Moulton, who came to visit the Commodore.

Meanwhile I went ashore with some of the officers, and as it was ebb tide our launch could not approach the shore, so we were obliged to be carried to land, which was effected by means of a litter consisting of two long bamboo poles, 
connected in the centre by a piece of strong netting, which made a safe and comfortable seat, and was supported by a man at each end. The King has resolved to have an opening cut through the reef, which has been partly done, but it is much to be feared that it will not be very soon accomplished. We proceeded to the palace, which stands on a pretty lawn ornamented with casuarinas, and surrounded by a fence of cocoa-nut leaves. The casuarinas had been

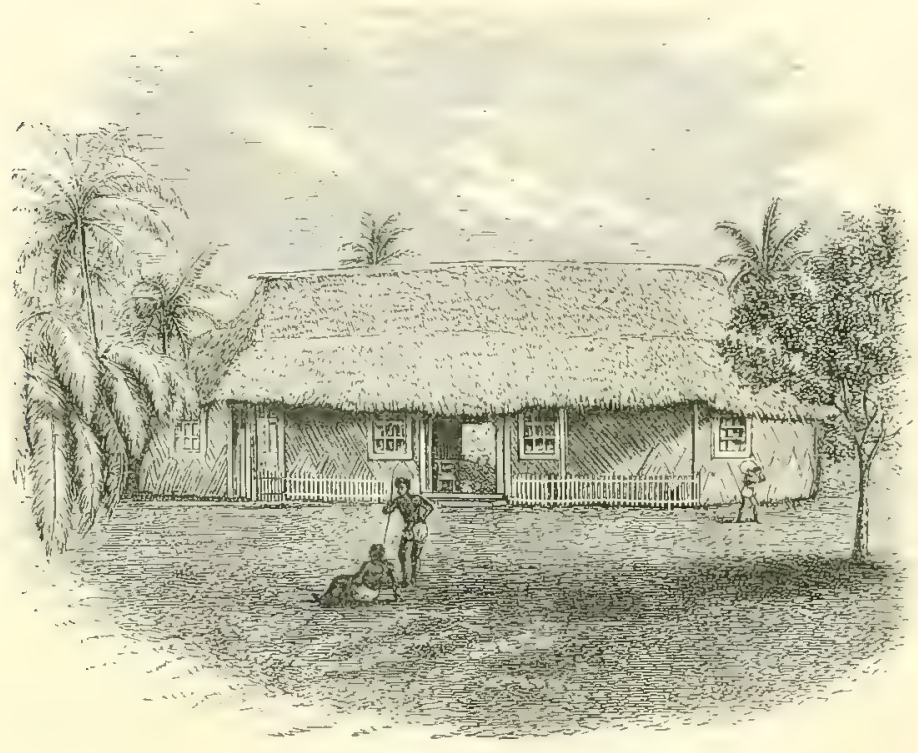

KLNG GEORGF'S HOUSE, TOXGATABU.

planted, so we were told, in memory of a beloved son, who had died at 19 years of age. It is said that, since this loss, the King"s disposition has been so much altered by his grief, that he has become very melancholy and silent, which, however, has not prevented his adopting other children, among whom we were shown the one that is his favourite, whose 
name is Maafu. At the palace gate were two sentinels or guards in red shirts, conts not alike, black trousers, without any weapons but a switch or small stick. The royal mansion is not large, but very neatly built, and the woodwork of the roof is prettily wrought after the fashion of the country. The interior is divided into three compartments or chambers, by partitions made of cocoanut-leaves.

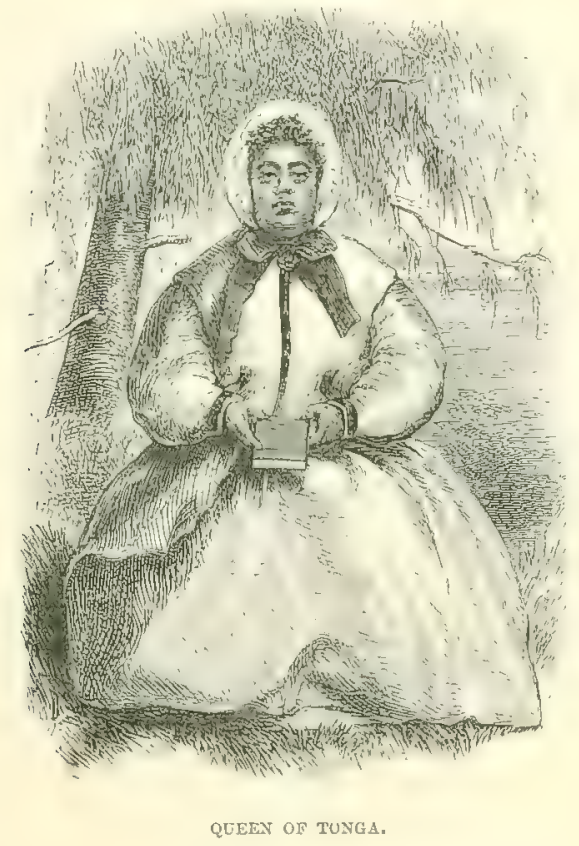

The Queen, who, as we were informed by our photographer, was a most portly personage, occupied the first of these compartments, and as she was at the time ill we could not see her; the second is the King's room; as to the third, into which I could barely get a peep, it seemed to be a sort of lumber-room. Mats made of the leaves of the pandanus 
cover the earth-floors of the three rooms. From the beams of the roof were suspended two sofas, and along side of them the sail and oars of the King's gig. The furniture, of German make, is of wood stained purple and green; it appeared quite new, and consisted of sofas, a sideboard, a drawing-room table covered with a red cloth, and purple

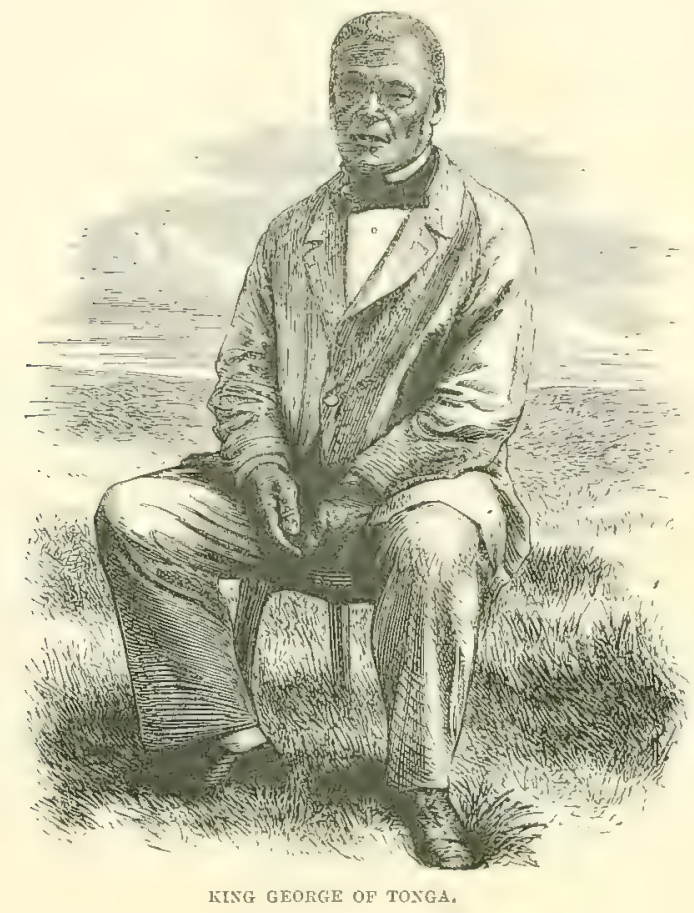

and blue chairs; upon the sideboard were bottles of various forms, some containing champagne, two bottles of port wine, and a tumbler full of cigars. The King is a very tall man with an intelligent countenance, and, in spite of his colour, has an imposing air. He may be about 65 years old, and has the reputation of having been in his youth a distinguished warrior. He was extremely reserved, and did 
not exhibit to us anything approaching to a smile. We communicated with him through an Englishman, named Moss, who is his interpreter and private secretary. We were offered a glass of wine which we declined. After having thus paid our respects to the King we asked his permission to make a tour in his clomains. He replied that he had great pleasure in granting it, and we retired from the royal presence.

We crossed through the village by the principal street, which was filled with natives. The houses, oblong in shape instead of round as at Samoa, are for the most part surrounded by a small inclosure shut in by the usual fences made of cocoa-nut leaves, and are shaded by bread-fruit and other varieties of trees. We went to the public school, then to the college, which is called 'The Institution,' situated behind the former on the same grass-plot. There we met with the two Wesleyan missionaries with their children, who were waiting to show us over their establishments. The public school was empty; as in those I had already seen, it was void of benches or desks, the scholars being in the habit of sitting on mats. The Institution, which is intended for training masters and mistresses, who must pass an examination before they are qualified to teach, consists of twenty small houses built in two lines parallel with each other, with a broad road running between them. These houses or huts are covered with sugar-cane leaves, and are divided into three compartments, by the usual cocoanut-leaf partitions; one of them serving as a bed-room, 
another as a study, the middle one being the dining and sitting room. To each hut is attached a small garden prettily laid out, where the students grow bananas, pineapples, sugar-cane, cabbage, onions, lettuce, sweet potatoes, $\& c$, also some ornamental plants, such as the native croton with its brilliant yellow and green leaves. Some of the students are married, of which I had evidence in the case of a young woman whom I saw asleep with her baby under a tapa.

On leaving the Institution, we met on the road a tall handsome young man who was galloping on a horse which the Rev. Mr. Whewell had ordered him to bring. The heedless servant had, I suppose, disobeyed the orders of the missionary, who having made him get off in quick time gave him on the spot six or seven smart raps on his bare back and shoulders with a small stick he had in his hand. The delinquent, who was big and strong enough to have doubled up his master had he been inclined, received the chastisement without the least wincing, and went about his business, while we continued our walk. On expressing our surprise that this young native should have suffered himself to be thrashed in this way by a man so much his inferior in strength, Mr. Whewell told us he was often obliged to treat the natives in this way, because, having been accustomed to receive them from their chiefs, they thought nothing of a fer blows; and that occasionally it was necessary to stir them up in this way to make them attentive and heedful. It is to be observed, however, that a certain consequential bearing tewards the natives seems rather a peculiarity of the Wesleyan 
missionaries. Captain Erskine was much struck at Vavau and Lifuka with the difference in this respect between these missionaries and those of the London Society, in the Samoan Islands. At Lifuka, to his great surprise and disgust, one of the missionaries sharply reproved a chief of high rank for daring to speak to him standing. No doubt this arrogance will hereafter have a reverse. We shall one day have some lamentations like that of missionary Woon, who, when speaking of the New Zealanders, ${ }^{1}$ says: "They now eat the finest wheat; many are dressed with comfortable clothing, and ride on horses like gentlemen; while they ride the missionary walks.' These melancholy facts are given to show 'that their spiritual does not keep pace with their temporal prosperity,' and that 'they have yet to learn the scriptural lesson, that it is more blessed to give than to receive.' A lesson, however, which in his own case he does not seem to have appreciated. It is sad to think that the delicate and difficult process of civilization should be left to people often so little intelligent as to be capable of uttering such rubbish, or so strangely selfish as to be envious of the well-being of those whom they undertake to elevate. The youth's indiscretion arose, no doubt, from the passion of the natives for horses, about sixty of which are to be found in the island.

Shortly after witnessing this singular scene we went in with the missionaries to pay our respects to their wives. Mrs. Whewell seemed a nice sensible woman. Mrs. Moul1 'Life of Leigh,' p. 496. 
ton was not entirely a stranger to some of us; she had come out from England to Australia in the same ship with Mr. Veitch, the able horticulturist attached to our expedition, who was glad to meet her again. This estimable lady had left her country for Sydney expressly to marry the missionary, and had reached Tongatabu with her husband a few weeks only before us. About the mission houses were to be seen some old women with old-fashioned bonnets on their heads, which made them look like perfect frights. In one of these mission houses we saw a pretty green and blue parrot with a bright brown breast; this bird, common enough in the Fiji Islands, is very rare in the Tongan group, where it is only found in the small island of Eoa to the southeast of Tongatabu, from which this specimen came.

The Protestant church is a handsome edifice, completely finished, divicled into three naves by two rows of triple columns of iron-wood, which they have made the mistake of painting. The internal walls are neatly boarded up to the roof, and have large windows in them; the framework of the roof is of cocoanut-wood, and the thatch is made of sugar-cane leaves, tastefully bound together with fine string. The pulpit is of handsome dark-coloured wood. In the place of stone there is a floor made of wood brought from Sydney. Benches there are none, the congregation squatting on the floor; and in this way about 800 persons have sufficient room. 350 workmen were employed for six months in building this church, and yet the total expense did not exceed $600 l$; the labour for the most part being given free 
of charge, otherwise it would have cost five times as much, the day's wage of a native being on an average two shillings.

Near the church door is the tomb of Captain Croker, who was killed in the assault on the fortress of Bea. A brass plate nailed on a piece of wood, shaped like a tombstone, bears this inscription: "Sacred to the memory of Walter Croker, Esq., commander of H.B.M. ship "Favourite," who was killed in an attack upon the blockade of Ben, June 21, 1840. Renewed by H.M.S. "Juno," October 1856. J. Bresnahan sculpsit.' Bea is five miles from Nukualofa, the village where the King dwells. It was, at the time of the assault, a village fortified by an earth embankment surmounted by a stockade fence made of cocoa-nat leaves. Captain Croker advanced against the embankment with a six-pound carronade and a small field piece, and led the assault against the 'heathen' with a sword in one hand and a Bible in the other; for the attack was a crusade against idolaters, not improbably suggested by King George and the Missionaries. ${ }^{1}$ When he had reached an opening which was used as an entrance into the inclosure, the captain received a shot in the body and a bayonet thrust in the arm, which compelled him to fall back as far as a large tree, where he received another shot which finished him. Several of his men were

1 This fanatical conjunction between the Bible and the Sword, so farailiar to us in the history of Europe (though perhaps less literally expressed), 'all for the glory of God,' seems still more strangely revolting when exhibited in these remote and comparatively peaceful regions. 
killed or wounded and the canion taken by the besieged, who were thus masters of the field of battle. Croker was buried on a height, at a spot pointed out by himself to the Missionaries when setting out for the attack. At some yards below the fortifications of Bea are to be seen the tombs of two missionaries who were massacred by the natives. Speaking of tombs I will mention here that the natives bury their dead in graves they dig not far from the sea; when visited the burying-ground my attention was called to the tomb of the father of the reigning King, undistinguishable from the rest, and whitened over as they were. All these graves are found upon a slight elevation, and are properly attended to; some of them had stripes upon them from one end to the other-a stripe of white stones on one side, black stones or a sort of red coral in the middle, and green stones on the other side. It had a very good effect.

The day after our arrival I accompanied the Commodore in his official visit to King George. Apprised of our coming by his secretary, the King had the polite attention to send us four men with a bamboo litter to take us from our boat, and bring us dry shod to shore. The royal flag, red, with a cross of the same colour in the middle of a white square in the upper corner near the staff, floated upon a stone platform near the palace. On entering we found the King dressed in a blue coat with naval buttons, a white waistcoat and shirt of the same colour, with a black satin neckeloth, black trouser's, and shoes. At his side were Mr. Moss his secre- 
tary, and Mr. Whewell the missionary, who acted as our interpreter. Tall and robust as he is, the King is not precisely corpulent; his feet are large, and his left foot scems to be partially paralyseci. I was a good deal struck with the very dignified air with which he received us. We were told that he understands English tolerably well, but that he has never spoken it. The Commodore briefly addressed him as follows:- 'I am very glad to see the King of the island, and to find him in good health. It gives me great pleasure, as Her Majesty's representative, to find your country in so peaceable a state, and your subjects so Christian-like. I should be very glad to offer you any assistance in my power." The King replied through his secretary, that he was 'very happy to see Sir William, and that it was now a long while since a British man-of war hat visited Tongatabu.' It was then arranged that the King should come on board the next day at half-past nine A.M., to examine in detail the largest ship he had ever seen, and we took our leave, after a promise from his majesty that he would come and dine on board the 'Curaçoa' the day after he had visited the ship. We saw that a new wooden palace was being put up with a verandah all round it, the whole of which had been made at Sydney on the plan of the bungalows of Norfolk Island: it was nearly finished, there being only wanting a few planks that were expected from Australia.

It would seem as if the King had a fancy for house building, inasmuch as when he was visited by Captain Erskine 
at Lifuka, in 1849, he was occupying a house temporarily until the new one was finished. The arrangements were pretty much the same as here described; there was a table and two chairs, but the King and Queen were found seated on the ground. The King at that time was a fine-looking man about 45 years old, tall and powerfully built. He was lightly draped in native cloth, as was also the Queen, a strong handsome woman, with her only son, an intelligent boy seven or eight years old, seated by her. He was attended by a page of about 14, named George, who being sent on board with a message caused infinite fun by his clever boyish impudence, making hirnself quite at home, returning joke for joke, and rendering himself so popular as to be sent back to shore loaded with presents.

King George has a nice, smooth-built, fast-looking galley, and a small sailing schooner, which I saw at anchor near his residence; he has also one of the few carriages to be found in the island. Next morning at half-past nine, as had been agreed upon, the King came on board our ship. To his costume of the day before he had added a pair of hussar's epaulettes, a cocked hat and feathers, which he held constantly in his hand, while his secretary and factotum, Mr. Moss, kept on his cap. The 'Curaçoa' paid his majesty the honours which were his due, and the 'Falcon,' that had arrived the evening before with our despatches and letters, and the news of the assassination of President Lincoln, did the same. After 'God save the Queen' by the band, the King was conducted through every part of the ship, and, to 
amuse him, some Armstrong guns were discharged, the shells and balls of which made so powerful an impression upon him- that he could not help saying, "had he not been aware that we were made of flesh and blood, he would have taken us for supernatural beings.' Having himself been in his youth a distinguished warrior, it can be easily understood what attractions our ship must have had for him. Indeed, whatever reminded him of his warlike exploits, and of everything associated with war, could not fail to be extremely agreeable to him, for at his outset he was merely the chief king of the middle group, that of Hapai, and it was by right of conquest that he added the other two groups to his crown.

The day following, the King came to dine with the Commodore, who of course treated him with every luxury that the situation was capable of. Our royal guest had sent a turtle on board, and an attempt had been made to turn it into soup, but so unsuccessfully that it was to nobody's taste, which we all seriously felt was a disgrace to the British flag. Though he had made a voyage to Sydney, where he had the opportunity of seeing ice, the King had never drank iced champagne; great therefore was his surprise and great his joy when be tasted that which the Commodore gave him, but of which he drank moderately, for besides being temperate he is accustomed to drink port wine and champagne at his own house. In a word his manners were thought excellent, his dress unexceptionable; he knows how to behave in a society of gentlemen, and is never for a 
moment deficient in true dignity. The ship's band played throughout dimer; towards the end the Queen's health was drunk and that of the King. In fact his Tongan majesty had good reason to be satisfied with his entertainment, and instructed his secretary to convey his thanks to the Commodore. This secretary, Mr. Moss, of whom I have already spoken, is an intelligent man, though not so well educated as might be wished; he is very shy or very nervous; at table he could not sit on his chair without continually fidgetting with his head and hands: it is said that, before he was in the King's service, he kept a shop on the shore. He informed us that the King has had a mistrust of the French since they took him unawares, by making him drunk on board one of their ships, for the purpose of inducing him to sign a document to which he objected, and which he certainly never would have signed with a cool head; hence, as Mr. Moss added, he does not like the French, and all the more so, because he feels he has been their dupe. I have heard it said too that the natives of the Friendly Islands, as well as those of Samoa, are apprehensive that the French may one day come and carry off the Protestant missionaries, as they did in the Loyalty Islands.

It was the King's pleasure to make a return to the Commodore for the attentions he had received on board the 'Curaçoa, and he therefore gave us a dinner at his palace, where we sat down eight. The courses consisted of a sort of Julienne soup, several dishes of fish and crabs, two fine turkeys, trvo pigeons, a pair of fowls, a delicious dish of 
taro baked in banana leaves, and. seasoned with cocoa-nut milk and sugar-cane juice, \&c. \&c. Ruinart's champague was twice served round; English bottled beer flowed copiously. There were also bowls of cocoa-nut milk, besides port wine, pale and brown brandy. There was no sherry, this wine not being to the King's fancy. At dessert appeared enormous fruit pies, plum puddings, and cheese. Wewere waited on by two women, the one stout and fat, of pure native blood, the other a half-caste, of a trimmer figure, who spoke English well. Everything went on with great deliberation, and the dishes were as cold as if they had been prepared the day before. We learnt afterwards that the King had not only himself ordered the dinner, but had also superintended the cooking of it, and we regretted that he had not instead thought of offering us a simple repast after the fashion of the country. Cigais were brought in at the end; there was no question of coffee. The King again instructed his secretary to express his thanks to the Commodore for having been treated by him in a manner he had never experienced from any other person, and the better to testify his sense of the obligation he declared himself ready to do whatever would be agreeable to him; an offer of which we could not doubt the sincerity, for lis majesty had been so thoughtful as to order his subjects to get for us a great number of pretty live seashells.

Two French missionaries favoured the Commodore with a visit, I acting as interpreter. They were M. Chevron, "provicaire apostolique,' a very amiable old man, and M. Samaze, 
Catholic missionary. I took them over the ship, of which they noted the cleantiness and admired the machinery. The first informed me that he had been for thirty years in the Pacific, and that he had lived with Bishop Bataillon, the actual bishop of the Samoan group, whom I had seen at Apia. We chatted a long while, and I heard them cxpress very decidedly their doubts of the natives being disposed to accept as the King's successor the person he might nominate. They seemed to think it was impossible to foresee what would happen at the King's death.

The Commodore and myself returned the visit of the two missionaries. They live at the village of Maofanga, situated at about one mile from the King's residence, and to the east, on the seashore, in the midst of trees. They came out to meet us as soon as we were in sight, and then showed us their church, which is a tolerable one, but very far from being as pretty or clean as that of their rivals the Wesleyan missionaries. It is ornamented with a representation of the nine stations, poorly enowgh executed. The bell is suspended between two posts fixed in the earth outside the church. They then took us into their house, built at the bottom of a large garden, and as poor in appearance as in reality. We remained half-an-hour chatting in a little dark room, while a crowd of natives stood about the door to have a look at ns. The missionaries were much gratified by our visit, and distributed cocoa-nuts among our boat's crew. They then led us across the village, picturesquely situated under the shade of trees, and called our attention to a ditch and em- 
bankment inclosing a part of it which formerly served for a fortification. We next walked along the curve of a little bay, when our attention was directed to a pandanus, or screw pine, which threw out from its top roots that descended to the ground. We returned to the ship during a glorious sunset, the horizon being draped with magnificently gilded clonds.

I have just remarked that the church and mission house of the Catholic missionaries contrasted unfavourably in appearance with those of the Protestant missionaries, producing an impression of much less attention to order and cleanliness. And, in point of fact, Captain Erskine informs us, that the people here struck him as being less clothed and cleanly in their persons and homes, than others of their fellow-natives. ${ }^{1}$ This difference, to the disadvantage of the converts to Romanism, is a matter of general remark, and is also an unavoidable result. For, while the Catholic missionary, for the most part, glorying in his poverty and privation, is content to invest his religion with a certain physical squalor, the Protestant missionary, having no such ambition, labours to associate his with much attention to physical well-being, The pattern set before the natives by the former, is copied more or less from the habits of the anchorite, and is so far incapable of instructing them in the

1 Erskine, p. 149. He adds: ' $\mathrm{I}$ heard also among the younger officers of our party, complaints of pockets picked and handkerchiefs stolen, showing a more lawless state of life, and a retention of their old habits, which were so obnoxious to their early European visitors.' 
habits, the needs, and the tastes of civilized men. The Protestant missionary, on the contrary, though he may, especially if he be a Wesleyan, gloomily dislike the gayer aspects of social life, and have no repugnance whatever to making his converts sombre and sad, has a decided desire to see them comfortable and clean, and in possession of those household and other appointments and resources which continuous exertion and industry can alone supply. While, moreover, in the Catholic missionary, the natives see an indifference to many personal matters that would hardly be tolerated in their native priests, they must also remark, in connection with him, an absence of that momentum and energy of action which in the white excites their surprise and commands their respect. It is reasonable to infer, therefore, that such of them as embrace the Catholic faith belong to the most languid and unenterprising of their race, and that they should exhibit a decidedly inferior capacity of progress as compared with those of their fellownatives, who have been stimulated into action by more energetic men.

That a most deplorable feeling of enmity should exist between these rival teachers is unhappily a matter of course. It is by no means a new phenomenon in this quarter of the world. Years ago it was remarked and lamented in New Zealand that, whatever might be the amount of religious proficiency, sectarian controversy was at all events conspicuous, and that 'disputes between Weteri, Hahi, and 
Pikopo (that is, between the followers of Wesley, the Church, and Bishop of Rome) were carried on through the length and breadth of the land.' ${ }^{1}$ Fortunately things are somewhat better in Eastern Polynesia, where Weteri and Hahi, finding they cannot hunt harmoniously together, have agreed to confine themselves to their separate hunting grounds. But now comes in Pikopo to poach on the manors of both; and violent indignation is the necessary result. The Wesleyan and Roman Catholic missionaries are especially bitter against each other. A curious illustration of the kind of warfare which they carry on to one another's annoyance is to be found in the account of the Rer. James Calvert's missionary labours in Fiji. ${ }^{2}$ It appears that when Sir J. Everard Home, of H.M.S. 'Calliope,' visited Rewa, the priest of that place wrote to him complaining of the conduct of the Wesleyan missionaries, stating, among other things, that they were in the habit of exhibiting pictures representing the cruelties formerly practised by those they styled 'Popish persecutors.' This the gallant officer in his reply admits; but, on the other hand, he reminds the priest, that he, 'with several officers of his ship, had seen hung up) in the priest's houses at Tongatabu pictures representing a tree, from the branches of which all who did not adhere to

1 'Quarterly Review' for June, 1854. See also Dr. Thomson's 'The Story of New Zealand,' vol. i. p. 327. He says, that at Taranaki the feud between Weteri and Hahi ran so high, that the partisans of the one set actually erected a fence and lined it thickly with fern, so that the other might not see them ! - p. 325.

2 "Fiji and the Fijians," vol, ii. pp. 182, 183. 
the Popish Church were represented as falling into hell fire.' Such are the weapons with which these godly men contend against each other, for the honour of propagating a religion of which charity and love are allowed to be the eminent characteristies; and such are the weapons they will continue to use to the manifest degradation of that religion, until the stern common sense of society refuses to permit the nobler instincts and aspirations of Christianity to be sacrificed to the narrow interests of Weteri, Hahi, and Pikopo.

Having visited the two mission establishments I took the opportunity of visiting the council-house, where a public meeting was to be held. It is a large building containing a single room, with a number of doors or entrances; the floor, which is of earth, was covered with mats as in the native houses. The King I found seated in a chair at one end of the hall, and Mr. Moss at the other; in the middle some twenty of the principal chiefs were squatted on the mats. I heard several speakers discoursing on state affairs as if it had been the exclusive business of their lives. The costume of these senators appeared strange enough to European eyes; tattooings for pantaloons, and around their waist a large piece of flowing tapa; they spoke without rising. Mr. Moss's principal business was to take down the speeches in shorthand. The subject of the actual discussion had reference to the plantations of the coffee tree, which grows admirably well in the island, and the object was to determine how many of these trees each inhabitant should be bound to plant. 
At about three miles from the royal village is to be found a shallow piece of water, but just deep enough for very small canoes holding a couple of persons, and thither I went to have some duck shooting, which affords capital sport here. This lake, the water of which is brackish, is bordered with bushy mangrove trees, into which the wounded birds escape when they do not choose to do so by diving. I saw a quantity of ducks and killed some, besides an owl and a heron. In this excursion I saw several fields of kava very stronig and vigorous. This plant plays so important a part on occasions of great public ceremonies, that I am tempted to give an account of the curious processes of preparation and distribution as I find them described by the Rev. Mr. Williams in his account of the Fiji Islands and their inhabitants, ${ }^{1}$ and by Mariner, whose account of them Mr. Williams cites as being one of the most accurate that has yet appeared :-

'More form attends the use of this nareotic in Somosomo than elsewhere. Early in the morning the king's herald stands in front of the royal abode, and shouts at the top of his voice, "Yaqona!" Hereupon, all within hearing respond, in a sort of scream, "Mama "- "Chew it!" At this signal the chiefs, priests, and leading men gather round the wellknown bowl and talk over public affairs, or state the work assigned for the day, while their favourite draught is being prepared. When the young men have finished the chewing; each deposits his portion, in the form of a round dry ball, 1 'Fiji and the Fijians,' vol. i. p. 141. 
in the bowl, the insicle of which thus becomes studded over with a large number of these separate little masses. The man who has to make the grog takes the bowl by the edge and tilts it towards the king, or, in his absence, to the chief appointed to preside. A herald calls the king's attention to the slanting bowl, saying, "Sir, with respects, the yaqona is collected." If the king thinks it enough, he replies in a low tone, "Loba" ("Wring it"), an order which the herald communicates to the man at the bowl in a louder voice. The water is then called for, and gradually poured in, a little at first, and then more, until the bowl is full, or the master of the ceremonies says "Stop!" the operator, in the meantime gathering up and compressing the chewed root. Now follows,' adds Mr. Williams, 'the science of the process, which Mariner describes so accurately, that I cannot do better than transcribe his account. The strainer is composed of a quantity of the fine fibrous vau (hibiscus), which is spread over the surface of the infusion, on which it floats, and "the man," says Mariner, "who manages the bowl now begins his difficult operation. In the first place, he extends his left hand to the farther side of the bowl, with his fingers pointing downwards and the palm towards himself; he sinks that hand carefully down the side of the bowl, carrying with it the edge of the vau; at the same time his right hand is performing a similar operation at the side next to him, the finger pointing downwards, and the palm presenting outwards. He does this slowly, from side to side, gradually 
descending deeper and deeper, till his fingers meet each other at the bottom, so that nearly the whole of the fibres of the root are by these means inclosed in the vau, forming, as it were, a roll of above two feet in length, lying along the bottom from side to side, the edges of the vau meeting each other underneath. He now carefully rolls it over, so that the edges overlapping each other, or rather intermingling, come uppermost. He next doubles in the two ends, and rolls it carefully over again, endeavouring to reduce it to a narrower and firmer compass. He now brings it cautiously out of the fluid, taking firm hold of it by the two ends, one in each hand (the back of the hands being upwards), and, raising it breast high, with his arms considerably extended, he brings his right hand towards his breast, moving it gradually onwards; and, whilst his left hand is coming round towards his right shoulder, his right hand partially twisting the vau, lays the end which it holds upon the left elbow, so that the vau lies thus extended upon that arm, one end being still grasped by the left hand. The right hand, being now at liberty, is brought under the left forearm (which still remains in the same situation), and carried outwardly towards the left elbow, that it may again seize in that situation the end of the vau. The right hand then describes a bold curve outwardly from the chest, whilst the left comes across the chest, describing a curve nearer to him, and in the opposite direction, till, at length, the left hand is extended from him, and the right approaches 
to the left shoulder, gradually twisting the vau by the turn and flexures principally of that wrist. This double motion is then retraced, but in such a way (the left wrist now principally acting) that the vau, instead of being untwisted, is still more twisted, and is at length again placed on the left arm, while he takes a new and less constrained hold. Thus the hands and arms perform a variety of curves of the most graceful description; the muscles, both of the arms and chest, are seen rising as they are called into action, displaying what would be a fine and uncommon subject of study for the painter; for no combination of animal action can develop the swcll and play of the muscles with more grace or with better effect. The degree of strength which he exerts when there is a large quantity is very great, and the dexterity with which he accomplishes the whole never fails to excite the attention and admiration of all present. ... Sometimes the fibres of the vau are heard to crack with the increasing tension, yet the mass is seen whole and entire, becoming more thin as it becomes more twisted, while the infusion drains from it in a regularly decreasing quantity, till at length it denies a single drop." The man now tosses the dregs behind him, or, with a new lot of vau, repeats the operation, until the liquid is clear and fit for use. The yáqona being ready for use, a person approaches in a sitting posture, with a cup, or frequently with two, one holding water to be drunk after the infusion; the vau is laid over the cup, and the liquor poured through until it is full, when the herald, addressing the cup-bearer, says, 
'A woi ceri caki!' 'Stand up!' While the man obeys, the herald offers prayer thus:-

'Me Ioma vinaka na kalou

A lutu mada na tokalau.' I

The cup-bearer, in a stooping attitude, presents the cup to the king, who pours ont a few drops-the libation-and then drinks, while the whole company chant, 'Ma-nai-di-na: La-ba-si-ye: a-ta-mai-ye : ai-na-ce-a-toka: Wo-ya! yi! yi! yi!" All now clap their hands together, producing a quick and merry measure, finishing abruptly. The triple yi! is uttered in a high key, and followed by a shout, in which the people round the house join; those who are more distant catch and repeat the sound, until it is carried far beyond the boundaries of the town. Not to shout would be considered disloyal.

After the king, the herald names the next in rank, who notifies his position by slowly clapping his hands twice or thrice, and the cup-bearer carries him his draught, which, whether it measure one half pint or three, is drained without pausing. Other individuals are named in the same way, until all have had their morning cup. There are some variations in the details of this ceremony in different localities, but the main features are the same.

During our stay, the commodore presided at a distribution of prizes among the children of all the Protestant schools, assembled for the occasion. Arrangements were made to

1 'Let the gods be of a gracious mind, and send a wind from the east.' 
render this ceremony, which took place in the Wesleyan chapel, as effective as possible. The band of the 'Curaçoa,' placed around the pulpit, played a variety of airs. Besides the two missionaries already mentioned, there was a third, the Rev. Mr. Stevenson, who resided at Mua, twelve miles in the interior. The scholars, boys and girls, were clustered in the church under the superintendence of their respective masters. Some of the girls, in addition to their crinolines, wore muslin gowns with flower patterns. After singing a hymn, the examination, at which I assisted as one of the judges, began; first, the scholars were directed to write upon slates, which some of them did excellently well; the best of them being the young Rachel, a schoolmaster's daughter, a girl about sixteen years of age, as pretty as intelligent. There was then an examination in reading from the Bible, which proved that the natives as quickly acquire the capacity of reading well as the whites. This was followed by an examination in arithmetic as far as the rule of three. This question was put: "If a piece of tapa measures so much, how many will it require to reach from Tongatabu to London, the distance being, say, fifteen thousand miles?" a sum which the majority of the scholars worked with surprising rapidity. Sir William distributed as prizes to the winners tiwo books, one of which was the Bible, three small hatchets, some pieces of red cotton print, and some pockethandkerchiefs. He then addressed them in a short speech, congratulating them on their proficiency, and telling them ' that their reading and writing would compare with that 
in very many schools in England; that they should be thankful for the advantages of schooling with which they were blessed, and try to improve themselves, and be grateful to their missionaries and teachers for the trouble and time they had bestowed upon them.' The Rev. Mr. Whewell undertook to translate to the scholars what had been said.

There was room to believe that the education of the children at Nukualofa, which had been neglected, but was now vigorously attended to, owed this benefit to the intrusion of the Catholic priests, against whom it was a defensive measure. ${ }^{1}$ It would seem to be the fate of education everywhere to excite no interest except as it may be made an auxiliary of sect. Tonga in this respect is no worse off than England has been.

In the afternoon of the same day the scholars took their turn to give us a fête. It came off on the lawn of the Wesleyan mission house, where a great number of young girls and some boys had assembled in order to play what they called the game of 'One-y, two-y, three-y, four-y,' which words are sung in a monotonous tone by some, while others answer with the same equivalents in the Tongan tongue, 'Taha, na, tolu, fa.' Thus singing they go round in rings, dwelling some little time on each leg, and bending up the other and trotting round with a bent knee, and flapping their hands up and down in the air, and then smacking them against their bodies, the upper parts of which were

1 Erskine, ibid., p. $1 \check{4} 4$.

$$
\text { * } 52
$$


naked and thickly smeared with oil. Around their hips they had a roll of tapa, with a garland of pandanus nuts, flowers, grasses, creepers, \&c., nicely plaited up with leaves into a girdle, with a fine white underbark hanging about it in long shreds. They varied in appearance. The teachers led the game, and, when tired, all halted awhile. They executed all sorts of figures. Many of the natives came as spectators of these games, and among the dancers were to be seen several pretty well-made girls, some having their hair tinted red, some white, and others again yellow, this latter hue being derived from powdered sandal-wood. When the game was over, the dancing girls advanced towards the commodore, and having divested themselves of their ornaments and dress, laid them at his feet in a great heap. Sir William carried off all these trophies in his boat, not choosing to hurt the feelings of the young ladies by refusing their offerings.

At the back of the island, about twelve miles from Nukualofa, one of our officers, Mr. Foljambe, who went there by boat, found a very curious object which had already been mentioned by Mr. Moss. It consisted of two perpendicular rectangular blocks of stone about thirty feet in height, supporting a large slab across the top surmounted in the middle by a large bowl of the same material. Its history seems to be entirely unknown, but it is very natural to suppose from its form, that it was connected with some ancient kava ceremonies, and it is a remarkable fact if, according to the information which Mr. Foljambe received, 
the stone composing it is not to be found in any other part of the island. The Island of Tongatabu is thirty-six miles in length from east to west, and eight miles in width from north to south; its form being that of a crescent with irregular edges. The soil is fertile, and seems to be composed of lava, and covered here and there with a layer of coral, with indications of a slight anterior upheaval. I observed here, as at Vavau, a heavy compact stone like the white lava

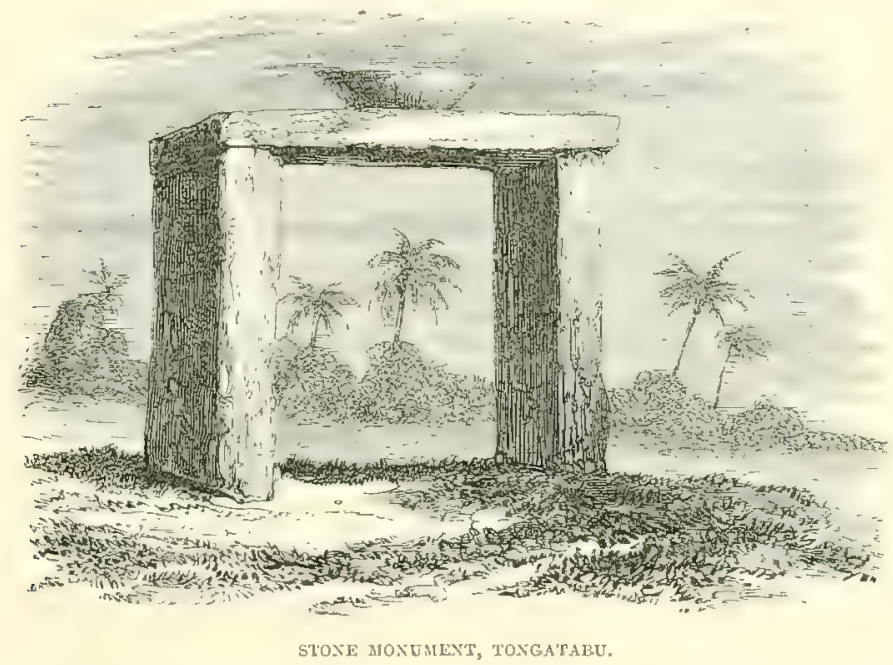

found on the shores of the Mediterranean, of which bracelets are made at Naples. Neither rivers nor freshwater springs are to be met with; the wells that are sunk yield nothing but brackish water; to remedy this inconvenience, deep notches are made in many of the cocoa-nut trees for the purpose of catching rain water. An excellent road, some twenty feet wide, goes from one end of the island to the other, throwing out branches towards each village. 
The principal indigenous plants are the cocoa-nut tree, sago, breadfruit tree, the $v i$, or native apple, the taoa (a kind of plum), the titika (a kind of pear), garlic, and the tilia, something like the almond, the shaddock, the banana, the kukui, Aleurites triloba or candle-nut tree, and different varieties of taro, and yams; of the last several specimens were sent on board the 'Curaçoa' by the king, measuring two feet and a half in length, with a diameter of from six to eight inches. There are besides several less succulent roots, which are resorted to in times of scarcity or famine. The ferns are less abundant, less numerous in species than in the islands previously visited by us, and do not appear to be specifically different from them; but one species only is arborescent. These plants are more numerous in the island of Eua, the Flora, as well as the Fauna, of which are said to be remarkably different from those of Tongatabu.

The plants introduced are the orange, the lime, the lemon, and citron ; pomegranate, custard-apple, china-apple, tamarind, the loquat, fig, cape-gooseberry, pine-apple, coffee tree, cotton plant, kumala, or sweet potatoe, carrot, cabbage, turnip, parsnip, cucumber, melon, pumpkin, lettuce, onion, parsley, mint, peas, beans in great quantity; there is also, as at Vavau, growing everywhere a white pea said to have been introduced by the French missionaries. Peaches and nectarines have been also cultivated, but without success.

We heard of no indigenous mammifers in the island. The ox, horse, sheep, pig, goat, dog, rat, rabbit, ass, are imports. 
Birds are numerous. Among them are the parroquet, the wild and tame pigeon, duck, fowl, curlew, the biki (a kind of grouse), the kalia (something like a guinea fowl), the crane, turkey, the tu (a kind of pigeon), the grey owl, the bekebeka (a kind of swallow), a grey bird with a head large and out of proportion, a beautiful species of redbreasted parrot, peculiar to Eua, the moho a beautiful bird of which the natives say that 'its plumage is made up of the choice feathers of all other birds.' I also observed some butterflies.

Of fish there is an endless variety; turtles abound on the coast, and oysters about the neighbouring islands. There are also centipedes, a small white scorpion, like that of Vavau, lizards and water-snakes. These snakes are said not to be venomous; but on examining one, two feet long, scarcely as thick as my little finger, and marked with pretty rings alternately white and black, I perceived two small fangs that are characteristics of venomous serpents.

As regards weapons, the natives have adopted those used by the whites. They still retain their drums, which are made of part of the trunk of a tree hollowed out, and which they beat with a small mallet. They use donble canoes.

The commercial products of Tongatabu are cocoa-nut oil, about 100 tons annually, of the value of $£ 7000$; arrowroot, tapioca, cocoa-nuts, and husks, and cotton. The king has in late years planted some 20,000 coffee trees, and it is 
hoped that this example will be followed. Turning his attention to cotton planting, he required that every mau should plant a certain number of cotton trees; this was done, of course, but in spite of the most stringent regulations the crop had never been gathered in anything like a satisfactory state; time and practice will however cure this.

The principal articles of commerce in request by the natives are clothing, cotton prints, hardware, \&c., which they pay for in silver or in oil, yams, pork, and poultry.

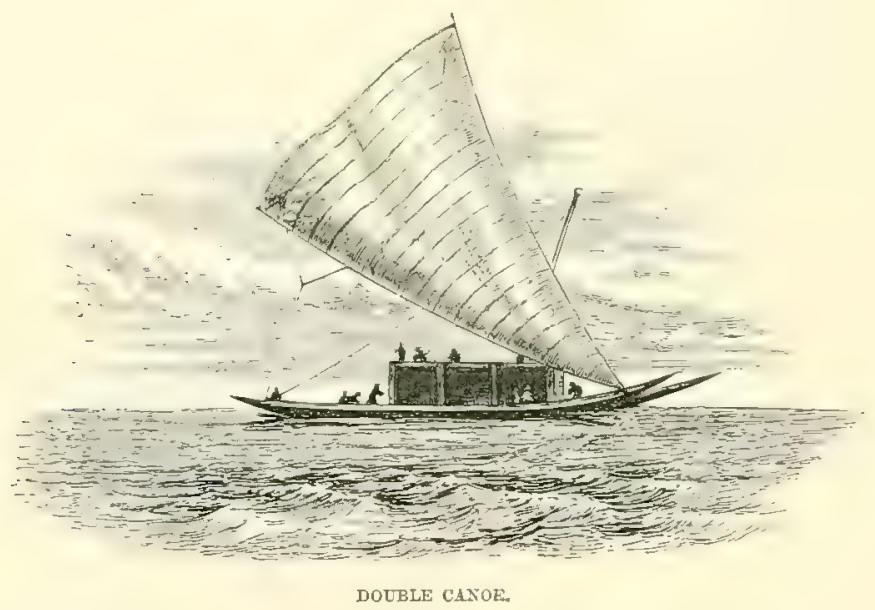

The climate is very moist during the summer, with a mean annual temperature of $84^{\circ}$ Fahr. in the shade. The months of December, January, February, are debilitating in the extreme on account of the excessive heat and heavy rains in that season. Intermittent fevers, dysentery, phthisis, scrofula, are the most common diseases. Hooping-cough, which made its first appearance in 1864, has been fatal in a number of instances. In ordinary years the mortality 
among adults is $3 \frac{1}{2}$ per cent., and among children it exceeds $4 \frac{1}{2}$ per cent.

The population is diminishing in Tongatabu; it consists of nearly 9000 souls, and, in the small islands which make part of the group, is distributed as follows:-Eua, 500 ; Eua-iki, 100; Atata, 100. The Island of Kaaffa, or Pilstaart, is at present uninhabited, its population having latterly emigrated to Eua. Kaaffa is but three miles in its greatest length, and without any anchorage; it is the most southern isle of the group, and also the most elevated, having an altitude from 600 to 800 feet. The number of whites at Tongatabu is fifty-four. The inhabitants live in villages which do not exceed sixty-eight in the whole of this little group. The natives generally intermarry with their own relatives, and it would seem that there is but little acquaintanceship between one village and another.

The Tongans belong to the great Malayan family, as do the Hawaiians, the Tahitians, the Marquesans, the Samoans, and the New Zealanders. They are a fine race, tall, robust, of a lighter complexion than the inhabitants of the other isles that we have visited in this cruise. They have little or no beard. Though their noses are flat and their nostrils wide, many of the men and women might pass for handsome types. The higher class among the Tongans is very distinguishable by its physical characteristics from the common people, being of loftier stature, and lighter colour, from better nourishment in childhood, and less exposure afterwards; their manners are as courteous as those of the 
Samoans whom they greatly resemble; but those of the lower class are less polished than the corresponding class in the Samoan group. ${ }^{1}$

It is a pity that the women, following the fashion of the men, cut their hair very short and stain it with chinam, which gives it a reddish tint; two customs which they put down to the score of cleanliness, as being preventives against vermin. The women are accustomed to leave their breasts bare; to check this there is a law imposing a fine of five dollars on any woman seen outside her fence with her bosom uncovered, but this does not appear to be very strictly carried out. ${ }^{2}$

The Tongans were formerly addicted to cannibalism, but in a very restricted way it seems-that is to say, in only exceptional cases ; they have now for years abandoned this savage custom, and have become a very decent sort of people. The offences most frequent among them now are petty thefts, fornication, and sometimes burglary; assassination is rare, but two cases having occurred within ten years. The London Mission Society attempted the conversion of these islands as far back as 1797, but was compelled by the war to abandon its project; in 1822, the first Wesleyan missionary landed at Tongatabu, but owing to a variety of circumstances, the mission was not fully established until 1826. There 1 Erskine, p. 156.

2 Ibid., p. 158.-Descent is by the female line, as in the Sandwich Islands, and consequently the women have an honourable position. Their domestic relations are said to bear comparison with those of any civilised state. 
are no longer any avowed heathens; all the natives have embraced Christianity, the greater part of them as Wesleyans, the remainder, about 1200, as Roman Catholics.

Primary instruction is so extensively diffused that nearly everybody knows how to read. ${ }^{1}$ But what is regretted is that the people have not, as means of increasing their knowledge, other books than those that are merely religious, and, for the most part, translations published by the missionaries themselves. Though there are to be found in the country artisans, both European and American, it is said, and the fact is curious enough, that there is not a single native acquainted with any handicraft. In spite of a well-regulated government, and a code of laws in complete action, the mass of the people has scarcely made any advance in industrial pursuits since Captain Cook visited these islands. This slackness of progress is attributed to the climate, which renders clothing unnecessary, to the abundance of breadfruit trees, which furnish fruit to the inhabitants nine months of the year, and to the small amount of industry required for their sustentation during the other three months. The Tongans are more indolent than many others of the Ocean tribes to which they presume to think themselves superior, and are entirely indebted for their reputation to the personal merit of their king, who is far beyond his subjects in his zeal for progress and his thorough appreciation of the bene-

1 English is said to be tolerably understood by the Tongans, but little spoken in consequence of the difficulty presented by the pronunciation of the consonants. Ibid., p. 162. 
fits of civilization; hence it may be asserted without fear of error, that the cause of progress in these islands is to be found exclusively in the king's personal influence, and the example which he sets. Taxation is exceedingly heavy; on defult of payment a man's whole property becomes forfeit to the government. There is a poll-tax of four dollars annually.

The Tongans were the first in the Western Pacific to embrace Christianity, and this has been in no small degree the cause of the vast influence which they possess over their neighbours, whom they furnished with their first teachers. In spite of this the Tongans, who have been in commercial relations with the whites for more than thirty years, decrease every year their demands for European merchandize. They have not left off the use of their native stuffs, and they prefer paying their debts by the sale of their lands to discharging them by any sort of labour whatever, by the preparation of oil for instance.

The intercourse between the Tongans and the Fijians has given rise to a cross breed which combines the leading characteristics of the two people. This mixed race, which occupies the windward Fiji Islands, always takes part with the Tongans in any discussions which occur between the two groups. Moreover, three islands of the Fiji group belong to the Tonga Islands, the supremacy of which they have recognized for several generations; these are the islands of Moalo, Mataku, and Vanua-Lava. Though there are not more than two hundred Tongans in the Fiji Islands, the superiority 
of their intelligence and courage, combined with the patriotic feeling which unites them, renders them formidable enough to make their alliance eagerly sought for in the contests between the different tribes. Those who obtain it, however, have no particular reason to be gratified by any victory obtained by the aid of allies whose rapacity is such that they never leave a district until they have completely ravaged it.

The states of King George Tuboa, whose royal title is Tuikanakubulu, comprise the three groups of Tonga, Hapai, and Vavau. About thirty years ago they were independent or each other, and it was the reigning king who subjugated them, for the purpose of assuring the possession of them to his successors. The plan he adopted was that of destroying the power of the principal chiefs by taking possession of their lands, and giving them, as an indemnity, an annuity secured upon the public revenues. To the natives in general he gave as much land as they could advantageously cultivate, and he granted to several whites temporary holdings on moderate terms; but on the ground, so at least he puts it, of his territory being of small extent, he prohibits the sale of any land to any foreigners. It is thought his successor will be Maafa, one of his adopted children, but this is anything but certain. In a trip he made to Sydney, King George was so delighted with the nature and form of constitutional government, as to desire to introduce it into his own kingdom ; unfortunately, he composed his parliament of the chiefs he had dispossessed, and, as is natural, the object of these is to recover their power, or at all events to augment 
their allowance from the state; the consequence of which is that the taxation is very heavy.

The present constitution was adopted by the parliament on June 4, 1862. The chiefs then assembled under the presidency of the king, at Nukualofa, were in number fifty-seven; a catalogue of their names, as given in the Australian 'Missionary Notices,' is highly suggestive, including, as it does, those of Joel, David, Lot, Caleb, Josiah, Naphthali, Zebulon, Israel, Samuel, Isaiah, Darius, Arminius, \&c. The regulations enacted by this Tongan senate will be found in Appendix B. 


\section{CHAPTER VII. \\ OVALAU-FIJI GROUP.}

(JULY 26 то 29.)

The island of Neau-Anchorage at Levuka-A visit on shore-The consul and his clerk absent-Russell and his wares-A French lady and her turn for natural history-Excursion into the interior-Pools at the waterfall of Waitoba-Method of kindling wood-Appearance of the natives.

ON July 22, a little before midday, the 'Curaçoa' weighed and stood off from Tongatabu in order to make for the Fiji Islands. The 'Falcon,' which was going to New Zealand, left at the same time, having on board Commander Duff, whose wound, received more than a year before in a fight with the Maories, would not heal in the climate of these islands; the commodore replaced him by Lieutenant Dent, who had already on several occasions acted in this capacity.

We had calculated upon taking with us the chief Maafu as our pilot and interpreter, but, at the last moment, King George objected to this, on the plausible ground that during a previous stay in the Fiji Islands the young chief had given himself up to drink.

A gentle breeze and a superb sea enabled us to go under sail all the way. On July 24, in the afternoon, we threaded our way through some twenty small islands of different sizes, 
all much more elevated than those of the Friendly Group. After having passed through the passage between the reef of Bocatatanoa (or of the great Argo) and the Reids Islands, we found ourselves in the waters of the island of Neau, in face of the anchorage of Lakemba, where the commodore had an idea of stopping, but at the moment of standing in, he changed his mind, and determined to bear off for the purpose of reaching Levuka in the island of Ovalau. The weather was very fine, though the heat and humidity were greater than at Tongatabu. Huge swarms of flying fish sported around our ship as we made our way between the reef of Mothe, at the southern extremity of the isle of Nairai, and the island of Ngau. All these islands and others which we sighted were surrounded by reefs and breakers. We saw in the distance a pretty little cutter, which was making its way in the direction of Tongatabu, having a number of natives on board, among whom we fancied we saw two white men.

On July 26, at dawn, the weather glorious, the 'Curaçoa' got up her steam to pass through a number of islands of considerable elevation, curious forms, and all of them surrounded by reefs. They had the appearance of being rolcanic, some fertile, some barren, the highest of them attaining a clear elevation of more than 2000 feet. We were not long in coming upon the island of Mbau, while in the distance before us, the outline of the island of Viti-Levu, the largest of the Fiji group, began to disclose itself. We now bore down upon Levuka, the port of Ovalau, which pleased 



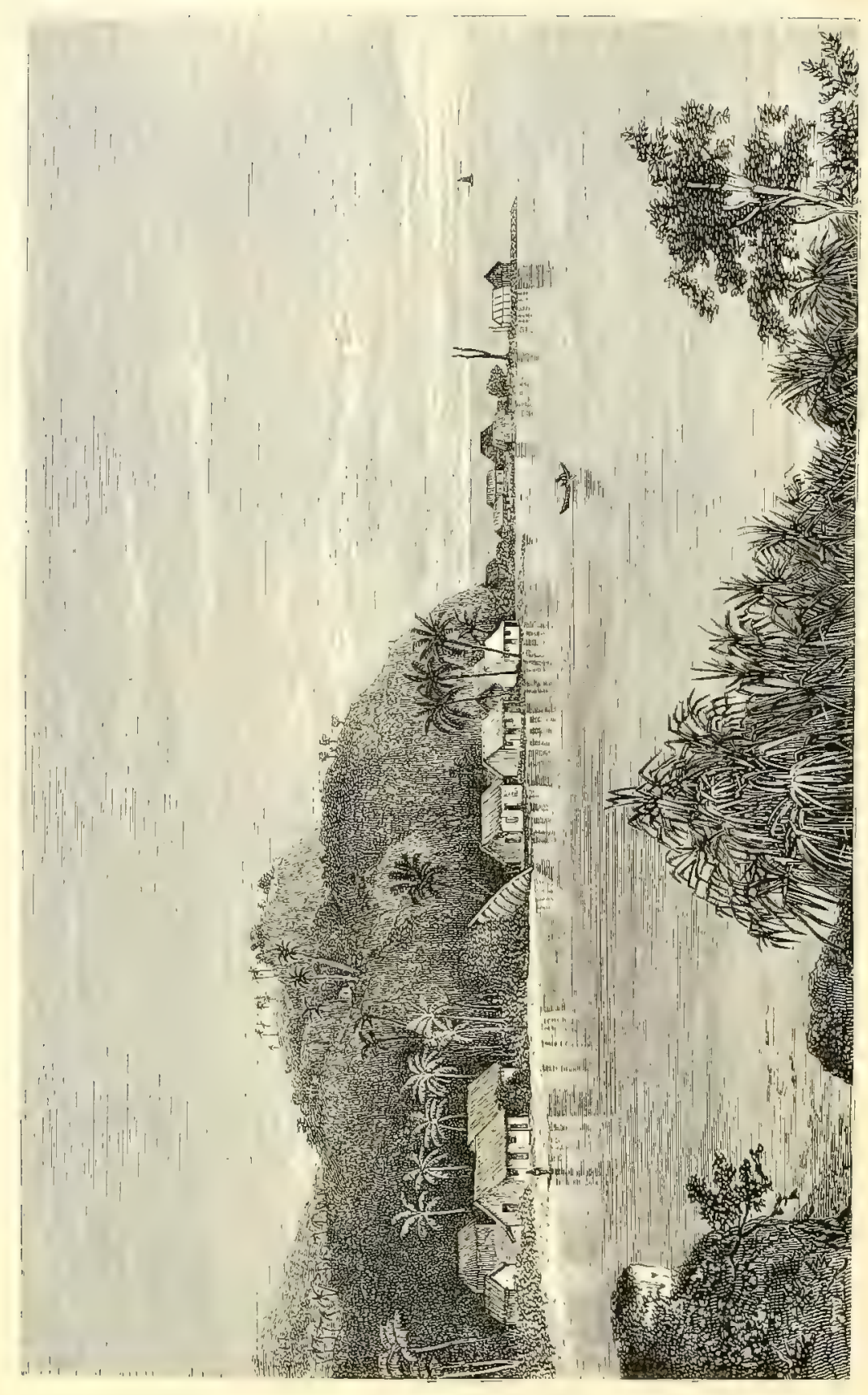


us exceedingly by the pretty configuration of its coast and uplands. Before reaching the reef, which bars the port, a boat-full of natives came out to meet us, and put on board one of its crew who spoke English well, and could act as our pilot. The channel is quite wide enough to be easily run into under sail in a fair wind, and of course was easy of access and without any danger under steam. The water within the reef was calm and smooth as glass. A number of houses were visible on the shore, and the surrounding landscape was remarkably picturesque, with its valleys and deep gorges. We dropped anchor about half-past 12 P.M. in thirteen fathoms close to the shore, under a high cliff which comes down to the beach.

To lose no time I went ashore in the boat, which had brought the pilot, and made at once for the English consul's. The only person I found there was a clerk, a Mr. Scott, from whom I learnt that the consul, Captain Jones, who has received the Victoria Cross, had left a week before for the purpose of exploring the interior of Viti-Levu, a place quite unknown to the Whites, and of attempting to cross it at its greatest width which is fifty miles, its length being about eighty miles. Mr. Scott informed me that the Commodore would have had a good many matters to settle had Captain Jones been upon the spot. This of course made our regret at his absence all the greater. I learnt from Mr. Scott that there are 60 Whites in the island, and 350 in the whole group; that it is in the three Fiji Islands belonging to the 
Tongans that these islanders come to build those large canoes on the construction of which the labour of years is employed; that cotton is cultivated in the island of Ovalau, and that at Rewa, on the island of Viti-Levu, several foreigners cultivate it on a certain scale; and that orange cowries are only to be found on the western coast of Viti-Levu, between the point of Rewa on the south-east and the island of Liku on the south-west. The Consul's secretary had a single specimen of this shell, but so handsome and perfect that he proposed selling it for not less than $£ 3$. I visited several vendors of curiosities who all set an exorbitant price on their articles; a notion of which may be derived from the sum asked me by an old sailor of the name of Russell for a root of sandalwood weighing twenty pounds, for which he wanted fifty dollars, or about ten shillings a pound, because, as he said, this kind of wood was selling at the port from $£ 50$ to $£ 65$ the ton; he also asked me $£ 2$ for a Pandanus mat from Rotuma, which I had reason to know was not worth more than ten shillings. I saw nothing in the business line could be done with this cunning, bronze-faced old tar, but when on the point of leaving him he asked me if I should like to see his two babies, to which paternal proposition I, of course, assented. He then, to my surprise, brought me two old wooden goddesses-native idols, dressed in long baby clothes, with very flat faces, mother-of-pearl eyes, with their sexual characteristics clearly defined and very remarkably developed, observing, as he handed them to me, 'Aint it curous that these people should wuship such things 
as these; I can't make it out.' The costume of these divinities was an addition of his own. ${ }^{1}$ Another salesman showed me a model of a buri, or Fijian temple, made entirely of sinnet, for which he would not take less than four guineas; two specimens of these buris formed part of my collection. ${ }^{2}$

In the midst of a crowd which had gathered on the shore, on account of our appearance in port, I was very much surprised to see two white women, and to hear them speak French. One of them, an English woman, was the schoolmistress, who had lived in France from six to seven years, the wife of a man that deserted her after the birth of a daughter married in the island to a Mr. Moakler, the owner of an estate on which he intends cultivating coffee. The other was a very nice-looking French woman from MIontpellier, the wife of Dr. Graaffe, a German naturalist, in the employ of the house of Grodefroy of Hamburg, then absent, having accompanied Captain Jones in his exploring visit to Viti-Levu. Madame Graaffe came with the greater part of the foreigners living in the island to pay a visit to the Commodore. On this occasion she requested to be introduced into my workshop; and there every thing she did and said proved to me that she was at least the assistant naturalist of

1 Williams, 'Fiji and the Fijians,' vol. i. p. 177, speaks of 'grim, immodest representations of the human figure about eighteen inches long, which are used on the larger islands to terrify the children into quietness.' My friend's goddesses may have belonged to this category. The probability is, that all such images have relation to that worship of the principle of generation everywhere diffused.

${ }^{2}$ One of them has been presented to the Christy Museum. 
her husband, and that she had hit upon her right vocation in marrying a collector. I saw her touch the most disagreeable objects which were in process of preparation, such as skins partly flayed, plunge her fingers into arsenical soap, smell at everything, try the strength of the forceps, handle dissecting instruments, none of which assuredly tended to perfume her hands; in a word, she was fond of her occupation, and not ashamed to show it. As a matter of course she invited me to visit her curiosity shop, which I took good care to do. I went there that very evening with Lieutenant Meade, an officer not only full of professional zeal, but anxious for every kind of information. Madame Graaffe lived in a very small wooden house, umpleasantly warm from all the windows being closed, and in which there was scarcely room to turn about, so crammed was it with objects belonging to the doctor's collection. Two women servants, natives of the Samoan Isles, were asleep on a mat in the first room with their mistress's baby between them. The collection being particularly rich in mollusks, I begged Madame Graaffe to make a selection of shells for me peculiar to the Fiji Islands. She was lively and communicative; what with her chat first about herself, then her shells, and then her husband, I began to think I should never get away. When the selection was made of shells and other things, then came the packing up; and, as there were a great many minute species of laud-shells, they required careful packing; the consequence was, it was past 12 P.M. before all was ready. Now came another important part of the process, paying for the whole. I 
asked what she wanted for the lot, and she said she would leave it to me; a most objectionable way of proceeding. All I could say she would not name a price, laughing and talking all the time. So finding it useless to try any more, I said, three pounds, then four, and paused, and asked her if she were satisfied; and seeing clearly she was not, I said five pounds, intending to go no further, and then asked if she were not satisfied now; she said she was; whereupon I laughingly took the liberty of suggesting to her she might as well have stated her price at once. While all this . was going on the rain fell in torrents, and, what is unusual at this time of the year, there were from time to time claps of thunder. I was then obliged to face the storm, and got back to the ship about one in the morning.

Among the white men who visited the 'Curaçoa,' and whom the Commodore received in a friendly way, was a man wearing two silver medals, an old English soldier, who had come to the island I know not how, and was keeping a boarding-house, which did not seem to be very profitable. Sir William offered refreshments to all his visitors, and at the same time ordered the ship's band to play different pieces for their amusement.

There is but one missionary in the island, Mr. Moore, who lives with his wife on a slight eminence about half a mile from the sea. I paid him a flying visit one day as I was on my way into the interior of the island. He told me he was born in Sidney, and was obliging enough to procure me guides. I walked for two miles along the foot of a 
high crag, which appeared to me composed of coarse conglomerate. I then went as far as a cascade, which had nothing remarkable in it, and clambered up its rocks in search of ferns.

Mr. Foljambe in his rambles was fortunate enough to meet with a fine waterfall, of which we have here his sketch, about a mile and a half from the settlement, which consisted of a succession of falls terminating in deep, narrow pools. Natives were found jumping down the falls from one pool

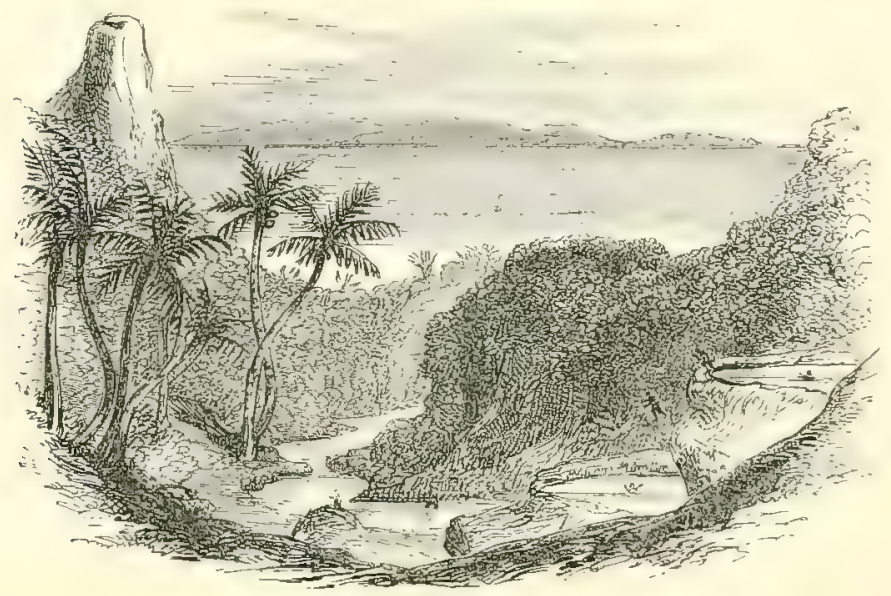

POOTS AT THE WATERFALE OF TVATTOBA.

to another, the jumps varying from twenty to thirty feet in height. The sport seemed so attractive that Mr. Foljambe and his friends were tempted to join in it, and pleasant sport they found it.

In many places I saw plantations of taro watered by a rill which comes out of the cascade. To my great surprise, I saw no birds. The path I was following was stony and formed of lava. Gorges and valleys covered throughout with 
a dense vegetation gave the country about a most picturesque aspect. On reaching the top of the ridge the heat became insupportable, especially as there was not a breath of air stirring. I gave up proceeding any further, and laid down under the shade of a banyan tree, beneath which several species of parasite plants were growing. During this halt my guides amused themselves with lighting a fire by a process I had often seen employed in the Hawaiian Islands, that is, by the friction of one stick upon another.

My halt over, I set out on my return to the ship. On my way I picked up some flat circular fruit, two inches in diameter and one in thickness, - enclosed in a thick fibrous bark -which I had boiled, and found to have a taste of chesnut. I also saw some arborescent ferns. On nearing the coast, I entered a village overshadowed by cocoanut trees, and was soon surrounded by a crowd of natives, men, women, and children, who appeared to me very ugly with their immense mouths, and large prognathous jaws; in fact, in the lower part of their faces they resemble monkeys more than human beings; in general they wore, both men and women, a piece of tapa round their loins. Their hair, harsh to the touch, was more or less tinted red or yellow by chinam. They brought me several articles which they wanted me to buy, and among other things cocoanuts, at, as it seemed to me, an unreasonable price. I bought for a shilling rather a fine root of ava; but it was with great difficulty that I could get them to give me, for anything like a fair sum, a little brackish water to quench my thirst. Most of the women had their 
little finger amputated on one hand, and sometimes on both; I also saw a man with his little finger off: In the crowd I observed several persons tolerably robust and strong, but not one of them so well made as the natives of Niue, or of the Samoan or Tongan groups. Towards nightfall, just as T was going on board, I saw some small birds and a pretty green parroquet, but, unluckily, the dusk did not allow me to kill more than a couple of them. 


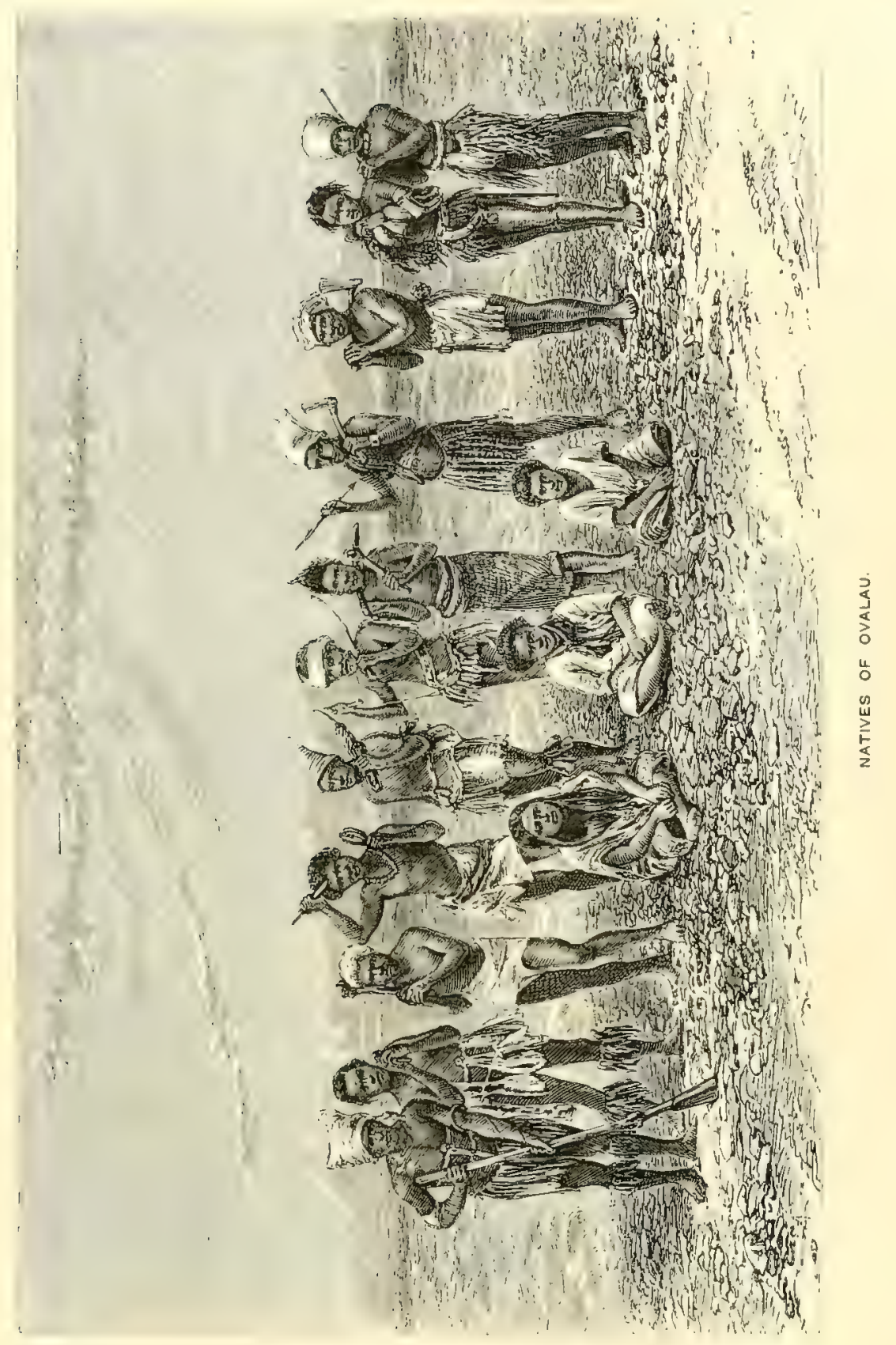





\title{
SHAPTER VIII.
}

\author{
IIBAU AND VIII-LEVU.
}

(JULY 29 to AUgUST 2.)

\begin{abstract}
Mbau Roadstead-Boat Expedition in Viti-Leva to Rewa up Wai-Levu River-Interview with 'Tui-Drakiti, King of Rerra-Courteous ReceptionHospitality of Rev. Mr. Carey, Wesleyan. Missionary - The Natives and their Huts-Retum from Rewa to Mbau-King Thalumbau - Exchange of Civilities and Arms-The great Kara Bowl-Stranger's House-Cannibalism-Intellectual and Moral Charncteristics of the Fijians-Singular Treatment of Somo-Somo Chiefs at Mball-Interesting Picnic with the Queen of Somo-Somo.
\end{abstract}

Tre 'Curaçoa' left the excellent port of Levuka for the island of Mbau on July 29 at half-past eleven A.M., leaving behind a planter to whom the Commodore had promised a passage, and who was now seen coming in hot haste in a canoe, having exceeded by two hours the time appointed for him to be on board. We took with us as pilot, giving him two dollars a day, a half-white named Charley Wise, the son of a Fijian woman and an American who, deserting his wife and child, had returned to the United States, and had never since been heard of. When we had got out to sea some distance the breakers bursting over the reefs had a very fine effect, and we could at the same time see the picturesque outlines of Ovalau. Moturiki and other islands, surrounded by reefs and rocks, were in sight. A light 
breeze soon permitted us to crowd on sail, for the purpose of making the twenty-five miles which separated the anchorage of Ovalau from that of Mbau, where we came to anchor at half-past three P.M., about three miles from the beach. Mbau is a low isle, very near the S.E. cxtremity of Viti-Levu, and has now the honour of being the capital of the Fijian group, from its being the residence of the celebrated Thakumbau, formerly a great heathen warrior and cannibal, now a Christian king.

The day after our arrival the Commodore was apprised by a written deposition and formal complaint, that a white man, of the name of Creelman, a small cotton planter in the island of Viti-Levu, had been beaten and wrongfully used by some natives on the banks of the Wai-Levu. Being further informed from another source, that the offenders had escaped punishment owing to the protection of two petty chiefs of the interior, the one a heathen, the other a nominal convert to Christianity, Sir William thought proper to despatch an officer to the King of Rewa, the suzerain or liege-lord of these two chief's, to call his attention to this matter, until he could send the Esk to sift it to the bottom. Accordingly, that very evening, a little before midnight, the cutter, well armed and provisioned, left the 'Curaçoa' on its way to the town of Rewa, in the island of Viti-Levu. The expedition was under the orders of Lieutenant Meade, with Charley Wise as pilot and interpreter, and I got permission to accompany it. We had eight oars, which we reduced to six for the sake of room, and in order to give the men the 
benefit of more frequent changes at the oars. The night being dark and rainy, we for some time could steer only by the lights of the 'Curaçoa,' and when we lost sight of these we had recourse to the spirit compass, which was so thick that we found it necessary to take out the screws, and clean the glass. We grounded for an instant on a reef, and were apprehensive that we should be obliged to remain in this very awkward position till the flood tide. We pushed back and got off the reef, and then took a large circuit round, after running aground several times. We at length reached a bay, which is the Wai-ni-ki or Kaba mouth of the WaiLevu, or Great River of Viti-Levu. We then entered the Wai-ni-ki, both sides of which were covered with mangroves, and were rather flat. We met about 4 A.M. a boat with six oars, and a number of people in it. They were under the bank of the river, and we did not see them at first. But they hailed us, and said they were ten white men going down to see the Commodore, for the purpose of presenting a petition to him, referring to the object of the expedition. Creelman, who had been beaten by the natives, was on board together with his witnesses. After a short parley they were desired to proceed on their course, and not return with us as they proposed. On our way we saw some ducks a little after daybreak, and, as they happened to be on Meade's side of the boat, he got all the shooting. These ducks appear to be the same as the common brown duck which is found in Australia. I shot a hawk, which fell in the cotton plantation of a white man, who had a 
house upon the point of an island in the river, and who seemed ashamed or afraid to come near us. We landed in search of the victim of my gun, but could not find it, and the shy or sulky fellow would not assist, though it fell close by him. We passed a fer native houses, and saw nothing agreeable in the way of scenery, the banks being flat, wooded, and uninteresting. The river grew narrower until we reached the Wai-Levu, or Big River, which was about 300 yards accoss. We saw a great many native houses on the banks of the latter which are muddy, and a great many canoes going up and down upon it mostly laden with yams. There are many islands in it, and also many shoal places, on which we often got aground. At length, about 10 A.M., we reached Rewa, where we came upon a small schooner, manned by some half whites, and having the King of Rewa, Tui-Drakiti, on board. His Majesty, who has the reputation of loving his glass when he can get it, was sitting, somewhat jolly, in the stern of the boat. He appeared to be about fifty years of age. He was just off to do homage to the memory of a Fiji chieftainess, recently deceased, taking with him a fine turtle as a tribute, which, on this account, he could not divert to another purpose, more agreeable and personal to ourselves. Meade gave him the official letters from the Commodore, addressed to the culprit chiefs in the interior, which the King consented to have forwarded at once by a messenger. The object of them was to rebuke the chiefs for allowing the people to take the law into their own hands, when there was a consul to ap- 
peal to, from whom they might obtain redress. The King regretted he could not show us the hospitality, which it would have been his wish to do had he not been compelled to make his intended visit. After taking leave of him and his party we proceeded on our way, still observing a great number of native houses on both sides of the river thatched with wild sugar-cane leaves, which plant has very thin stems, and grows in great abundance. Occasionally the houses were raised on piles, and sometimes rested on a bed of coral. They were not large, had two very small doorways, the inside very dark, a hole at top to let out the smoke, and mats on the ground generally; none of them are open round the sides, as in Samoa.

At length, about 11 A.M., we reached the house of Mr. Carey, the Wesleyan missionary, situate near the river, but raised considerably above it, and opposite to a point at which the river separates into two branches, which border it on each side, producing, as it were, the effect of its being at the junction of three strearns. It was built of wood and reed, and surrounded by a verandah thatched with wild sugar-cane leaves. We were received very kindly by the missionary. The men were quartered at the King's palace, where, through Mr. Carey's kindness, they were well attended to. Immediately after our arrival, Mr. Foljambe, engaging a canoe, proceeded with the interpreter and a native up to Viria, passing by Mr. Baker's mission station, where they entered the mountain district, and made their way to Naitasiri, which Mr. Foljambe speaks of as a large native 
settlement. He found a dense population on the banks of the river, which he says were well cultivated all the way up. He delivered the letters to the two chiefs to whom they were addressed, Tui-na-Viria and Koya-ma-kululu, whom he found at Viria, a settlement of some size. His instructions were not to wait for replies, which were to be sent to the Missionaries. He therefore, after having been provided with something to eat, and exchanging a few presents, returned to Rewa, which he reached at 2 A.M., and was not sorry to find a berth in Mr. Carey's house. The rest of the party were fast asleep.

In the course of the day natives brought us a number of things for sale, among them were clubs, spears, mats, pottery, \&c. Some of the pottery was very curious, consisting principally of sangas or water vessels, with rather tasteful designs; some representing turtles; others a bunch of three cocoa-nuts, \&c., with one handle, and all communicating internally with each other. The substance of this pottery is thin and friable. It is glazed, while hot, with the gum or resin from the Dakua, or Fijian Kauri-pine (Dammara vitiensis, Seem.), somewhat similar to the Dammara Australis, or Kauri-pine of New Zealand. Some of this gum I procured at Rewa, together with other objects of interest, which were not dear. ${ }^{1}$ The natives were civil and obliging, and bore out in appearance the good character which Mr. Carey gave them.

I Some of this pottery, \&c., is to be found in the Christy and Maidstone Minseums. 
At six A.M. next day, after a welcome bathe in the river, we set off on our return to the ship. The river presented a lively scene, being full of natives, generally wading up or down along the banks, carrying loads upon their heads, or coming towards us to offer things for sale. The greater part of the men that we saw had their clubs with them. A fair wind carrying us down the stream rapidly we had little opportunity for sport. Meade killed a few waterfowl, and I brought down a long-tailed parrot, with brilliant plumage. We reached the mouth of the river at half-past one P.M., with oars and sails, and got on board the ship two hours afterwards, which was waiting for us with steam up, ready for departure, by which we unfortunately lost the opportunity of a visit to Mbau. ${ }^{1}$ We further paid the penalty of our expedition by missing the opportunity of seeing the monarch of the country, who, with his portly wife, had paid a visit to the Commodore during our absence. He was described to us as being a finer-looking man than most Fijians, as having some beard, and wearing a white shirt and

1 If instead of following the Wai-levu, or Rewa river, up its circnitous course to nearly its junction with the Wai-manu and then descending upon Rewa by another branch, the Wai-ni-Mbokasi, we had taken the Kele Musu Canal, about four miles from the Wai-ni-ki mouth, communicating in a direct line with the Wai-ni-Mbokasi, we should have materially shortened our course. This canal is figured in the map of the river Rewa and its tributaries attached to Mr. Macdonald's very interesting paper in vol. xxvii. of the 'Journal' of R. G. S., article XIII. p. 232. According to Dr. Seeman the canal is two miles in length and sixty feet wide, and navigable for large canoes. Nothing appears to be known as to the time when, or any special purpose for which, it was made. 
tapa, or native cloth, rolled round his body, as will be seen by the woodcut copied from the photograph taken on board.

Captain Erskine, who saw him about fifteen years before our visit, appears to have been greatly struck with him.

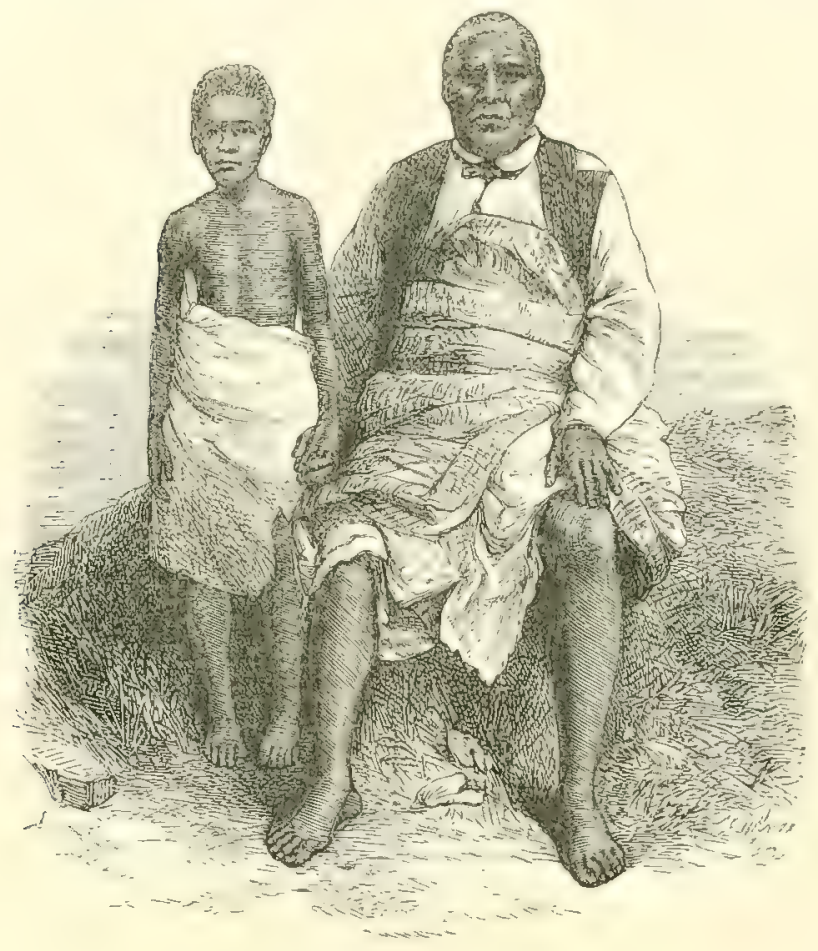

KING THALUMBAU AND JIS SOx.

'It was impossible,' he says, 'not to admire the appearance of this chief. Of large, almost gigantic size, his limbs were beautifully formed and proportioned, his countenance with far less of the negro cast than among the lower orders agreeable and intelligent, while his immense head of hair covered and concealed with gauze, smoke-dried and slightly tinged 
with brown, gave him altogether the appearance of an Eastern sultan. No garments confined his magnificent chest and neck, or concealed the natural colour of the skin, a clear but decided black; and, in spite of this scantiness of attire, - the evident wealth which surrounded him showing it was a matter of choice and not of necessity - "he looked every inch a king." "1 But, as respects the gigantic size, thus and generally ascribed to him, Dr. Seemann ${ }^{2}$ was surprised to find, on placing himself near him, that he was only six feet high, the doctor himself being six feet two inches. He attributes the exaggeration, however, partly to the fact that persons not accustomed to see people in a state of nudity are usually deceived about: their size, and partly to the fact of his having worn, previous to his conversion, the large head of hair alluded to by Erskine, which must have added greatly to his apparent height.

The following notice of this remarkable person and his habits will not perhaps be thought superfluous. 'I visited,' says Lieut. Pollard, 'Thakumbau, or Tui Viti, soon after anchoring, and found him at dinner by himself, but with several chiefs sitting or crouching near him, which is the native posture of respect. I was struck with the remarkable cleanliness observed in serving his food; the

1 Erskine, p. 186.

2 'Viti : An Account of a Goverument Mission to the Vitian, or Fijian Islands in the years 1860-61, p. 73:' by Berthold Seemann, Ph.D., F.L.S., F.R.G.S.; author of the "Narrative and the Botany of H.M.S. "Herald;" " 'Popular History of Palms,' \&c. \&c.

3 Erskine, p. 292. 
boards on which it was served, like small butcher's trays, were very clean, and covered with banana-leaves, and the food rolled up in small balls, and also covered with green leaves. He had several different dishes, each on its own tray, and each removed when finished by a little boy, who crawled up to it and crawled back again. Lastly, he had water brought to wash his hands and mouth, and when he had finished there was a general clapping of hands by all present.

With a countenance not only void of ferocity, but expressive of good humour, and with a character which has shown itself consistent with the requirements of civilisation, it is difficult to conceive that he should once have been a cannibal $\dot{a}$ outrance, and have been in the habit of indicating with his club the bodies suspended by their feet in the royal larder, which were to have the honour of being served up for his repast. There was an interchange of civilities between him and the Commodore and also of presents. The Commodore gave him his orvo rifle, a Westly-Richards, with which he was delighted, so delighted that in return he gave the Commodore his great kava bowl. In heathen times it was around this bowl that the great ceremonies and mysteries of the country were celebrated. It was in its presence that the ancestors of Thakumbau, and this chief himself, if not actually crowned, received and had confirmed to them the sovereignty of their dominions. Many a sad tale could doubtless be told of the frightful orgies-committed, and of the scenes of carnage that were 
enacted, when the legs of this bowl were seen steeped in human blood.

Happily these scenes have now passed away, a brighter day has darned upon the land, and Thakumbau, once the terror of his countrymen, has now become a professing Christian, and it is to be hoped that ' the lion and the lamb' may ' lie down together.'

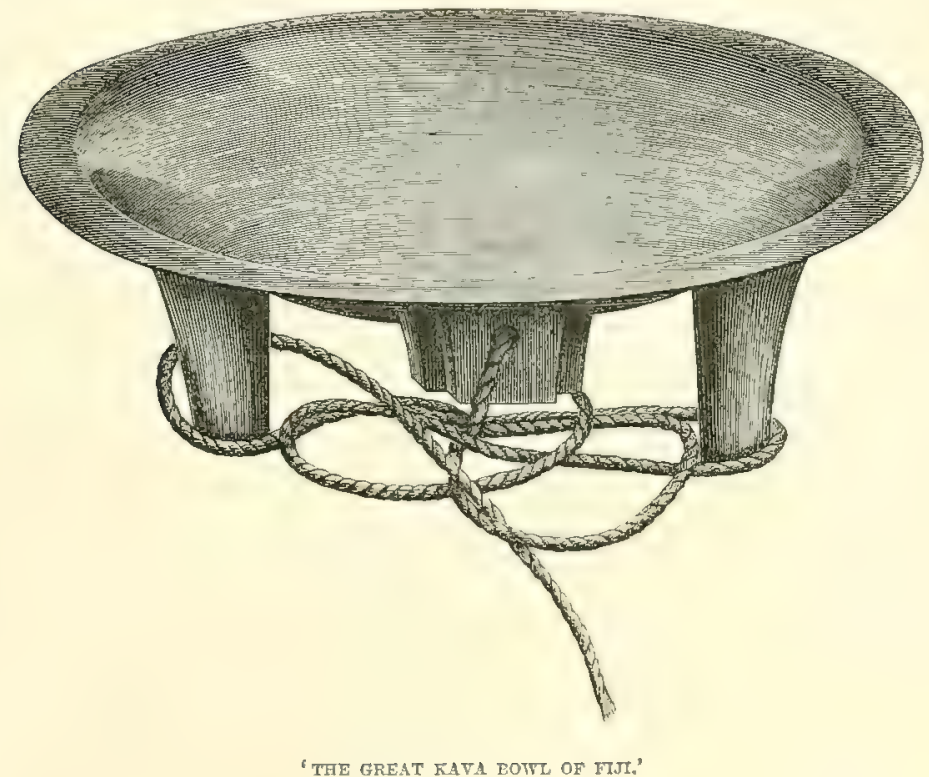

We had no time to go and see the principal town of Mbau, which is said to be very dirty. ${ }^{1}$ We could see a small fort

1 Speaking of the open place at MIbau, where all the ordure of the sacred city was deposited (Erskine, p. 191), remarks that it was the only occasion on which he saw anything of the kind; the natives being scrupulously delicate in this respect. The explanation of this exception was the confined limits of the city, and the inaccessibility of the beach. 
there, mounting four guns, from which Thakumbau saluted the Commodore on leaving.

Before we left, news arrived that Thakumbau's warriors had taken eleven villages or towns, which they waited his orders to burn.

There is a hillock in the centre of the island, on which is the mission house, and below is the dancing-ground, where in the old time were held war and licentious dances, accompanied by the murder of prisoners and by cannibal feasts. The ground, smooth and hard from the tread of thousands of feet, is overshadowed by a great banyan tree, into the thick trunk of which a slah of stone four or five feet square is sunk, and forms a sort of table. This tree is the Akautabu, the sacred tree, or, 'the tree with the forbidden fruit.' Before cooking the victims, sometimes even before their death, certain parts of the bodies of both sexes used to be cut off, and hung in the branches of this tree, which was sometimes perfectly loaded with this singular and repulsive fruit. Behind this is a row of slabs of stone erect, with their lower ends emberded in the ground, one of which was used for dashing out the brains of the victims. Thakumbau, before his conversion, has been known to amuse himself by catching up by the heels the children of his cnemies, and flinging them at the slabs with his own hands. The same sportive old fellow, on one occasion, cut out the tongue of a captive chief, who had used it to beg for a speedy death, and jocosely ate it before his face. Some officers of our ship were shown another braining stone situated in a different 
part of the town, used by the fishermen tribe, something like a milestone, but too sharp at the top to be used as a seat. The mode of braining was this: the victim was seized by two natives, one on each side grasping an arm and leg with the head foremost; they then ran with him as hard as they could across the dancing ground, increasing their speed till his head was split against the stone, a part of which; two feet above the ground, has been worn smooth, it is said, by the thousands of heads that have been knocked against it. Near the stone is a double row of raised seats, or slabs of stone, where sat the chiefs to direct the massacres, and enjoy the spectacle. It is impossible to form an estimate of the number of those who have been put to death in this manner; but it is a common saying among the Fijians, that all the waters of the ocean could never wash away the blood with which that soil has been saturated.

There is unquestionable evidence that cannibalism . will soon cease to disfigure any part of Fiji. Many places, it would seem, have strongly protested against it; as, for instance, Nakelo, on the Rewa river; and it is owing to the aid of this opposition that the missionaries and consuls have been, it is said, so successful in its general suppression. ${ }^{1}$ It would appear, too, that it has always been tabu, or forbidden, to the common people and women of all classes, the chiefs alone having the monopoly.

The origin of this practice is uncertain. It was, of course,

1 'Viti,' by Dr. Seemann, p. 179. 
an act of supreme revenge upon a fallen enemy, and we are informed that the most violent exhibition of wratlı one man can manifest to another is to say to a person, "I will eat you.' 'In any action,' observes Dr. Seemann, 'where the national honour had to be arenged, it was incumbent upon the King and principal chiefs-in fact a duty they owed to their exalted station-to avenge the insult offered to their country by eating the perpetrators of it.' But the same writer thinks it worth enquiry, if their practice of cannibal feasts did not in some degree partake of a religious ceremony. His supposition, he thinks, countenanced by a very singular fact. Not only are the ovens used for this purpose never appropriated to any other use; but, whereas, every other kind of food is eaten with the fingers, three or four pronged forks made of hard wood-generally of a species of Casuarina_ are used for eating human flesh. 'Every one of these forks,' he says, 'is known by its particular-often obscene_name; and they are handed down from generation to generation; indeed, they are so much valued, that it required no slight persuasion, and a handsome equivalent, to obtain specimens of them for our ethnological coliection; and, when they were afterwards shown to persons who did not know how we came by them, they always looked grave, and were especially anxious that they should not be displayed, especially before children.' 'My handling

1 'Viti,' by Seemann, p. 179, 182. See also p. 192 of the same work for an able comment on some of the charges against the character of these islanders based upon some of their most repugnant practices. 
them seemed to give as much pain as if I had gone into a Christian church and used the chalice for drinking water.'

There has hitherto been a tendency to ascribe most of the revolting practices of the Fijians, such as launching their war canoes over the bodies of their captives, using them, in fact, as rollers, interring them at the base of the posts supporting the chief's houses, or boiling or baking them alive, to what is supposed to be an innate ferocity and love of cruelty in these islanders. But it is admitted, that the peculiar features of their religion, and the use made of them by their priests, must have tended to infuse a taste for these revolting practices. It requires, however, no great knowledge of the antecedents of European civilisation, to be aware that the greatest refinements of cruelty, and the most brutal disregard of human suffering, have been, at one time or other and in various places connected with religion at comparatively advanced periods of national progress. Baking and boiling alive have a terrific sound, and are regarded as indications of a very savage condition; but the slow combustion by fire of the living heretic, the frightful tortures of the Inquisition, or the peine dure et forte, and other brutalities of the civil process, are facts equally remarkable for their cruelty, equally depreciatory of our nature, yet were not deformities belonging to our savage state. We must be careful, therefore, how we ascribe the ferocities of the Fijians to some radical imperfection in their character.

In truth, there is evidence to prove there is no lack in 
them of the kindlier qualities. It is thius that a witness, who had great opportunity of observing, having lived among them, and who has thrown no veil over their defects, bears this testimony to their disposition :

'They are not deficient in courage, manliness, and even humanity, which some people foolishly assert they are entirely strangers to, judging from the long-maintained fashions of the country, instead of scrutinising their natural feelings, and making allowance for everything that has been created by example. I should say, instead of being deficient naturally, they have a greater share of those qualities than Europeans, as far as I can judge from my acquaintance with them.

'There is one thing I am certain they possess, which, of course, must proceed from humanity, and that is universal hospitality, which some people erroneously attribute to the spontaneous growth and production of their articles of food, \&c. I never saw any difference with respect to their goodnature and liberality, not even when they were surrounded by the worst of privations, which was very often.' 1

Captain Erskine indorses this favourable opinion of them

1 The witness here alluded to is an English sailor of the name of Jackson, who lived nearly two years in Fiji, and mastered the language. After acting as interpreter to Captain Oliver, of H.M.S. 'Fly, he was engaged in the same capacity by Captain, now Admiral, Erskine, on board H.M.S. 'Havannah;' who was so convinced of the trustworthiness of his statements as to induce him to have them committed to writing, and published at great length in the Appendix to his own very interesting work. See p. 273. 
where he says, it is to be inferred that there must be much that is attractive in their character, "not only for the esteem and respect they are held in by their Tongan neighbours, but from the voluntary choice, by many respectable English and Americans, of these islands as a permanent abode.' He deposes to one fact, which it were much to be wished were common among us, viz. "that they are good-tempered in their cups, from which we may give them credit for naturally kind dispositions. When Thakumbau and Navinde departed from the "Havannah" in a half-drunken state, no one seemed to apprehend any cruel or outrageous act in consequence.'

They are accused of cowardice, though Jackson is evidently not of that opinion; and there is a Fijian saying, which certainly implies the sense of the dignity of courage. To the enquiries, "Where is the brave man?' the answer is, "Being dragged (i.e. to the oven);' and to 'Where is the coward,' the reply is, 'Talking of his deeds in the town.' They are a people of considerable intelligence and acuteness; but what we should hardly expect to find in them is a certain amount of literary capacity. Yet the missionary, Mr. Williams, ${ }^{1}$ has given us some specimens of their metrical productions, which he says "take the shape of dirges, serenades, wake songs, war songs, and hymns for the dance; the last class being the most numerous, and including much that might be termed heroic.' Of course, the merit of these productions is not very striking. Their proverbs are more 1 'Fiji and Fijians,' vol. i. p. 110. 
interesting; and as the proverbs of a nation are supposed to be illustrative of their character, they are well worthy of notice. I therefore cite specimens of them given by the same writer in his interesting account of this people. First, there is a couplet in which greediness is reproved:-

Your evil eye esteems your share too small, And prompts you greedily to aim at all.

The next speaks for itself,

$O$ what a valiant man you are,

Who beat your wife, but dare not go to war.

That with increased means comes increased care is noted thus,

If you have a great canoe, Great will be your labour too.

Idleness and too much attention to personal ornament are warned that 'No food is cooked thereby.' Improvidence and want of forethought are thus censured: 'The Nakondo people cut the mast first,' that is, prepare the mast before securing the canoe. 'The saucy,' it is said, 'take reproof like water;' that is, swallow it without thought. Again, it is said, 'An unimproved day is not to be counted.' These proverbial sayings are certainly proofs that good sense and wise purpose are not deficient in the intellectual qualifications of these islanders. Their remarkable addiction to fun and jest, and sensational exaggerations of a comic nature have exposed them to a character for trifling and untruthfulness which they do not entirely deserve. Mr. Williams speaks of their conversational powers, and adduces 
the evidence of a witness on whom he can rely, who says, 'That in the course of much experience, the Fijians were the only "savage people" he had ever met with who could give reasons, and with whom it was possible to hold a connected conversation.' ${ }^{1}$

It may be as well to note that in this missionary's interesting and minute account of the Fijians, we find specimens of the same inconsistent statements and criticisms, which are so conspicuous in the writings of persons who describe the manners and customs of uncivilised people. Thus, at p. 132, we find him dwelling upon the cowardice of the Fijians, and giving instances of it, which show that it is childish and effeminate to an excess, and yet five pages afterwards he says, "Violent quarrels are not frequent; nor need they be, if those I have seen were specimens, ending, as they did, with the axe and club, wounded heads or broken arms,' certainly no decided proofs of poltroonery. In the same style, the label of gross falsehood is attached to them, and, immediately afterwards, he tells us that 'on matters most lied about by civilised people, the native is the readiest to speak the truth. Thus, when convicted of some offence, he rarely attempts to deny it, but will generally confess all to any one he esteems.' Then he gives an illustration to prove that, 'lying, per se, is condemned and considered disreputable. A white man, notorious for falsehood, had displeased a powerful chief, and wrote asking

1 The person alluded to is Mr. Hadley of Wenham, cited by Dr. Pickering in his 'Races of $\mathrm{Man}^{\text {' }} \mathrm{p} .173$. 
me to intercede for him. I did so; whien the chief dismissed the case briefly, saying, 'Tell him that no one hates a foreigner; but tell him that every one hates a liar!' It is certainly not easy to understand that, where lying is condemned and considered disreputable, it can also be considered permissible, venial, or reputable to lie. With respect to all or most of these charges, if our verdict cannot be 'Not guilty,' it must in fairness be 'Not proven.' I will just add that the observation of the chief cited above, "Tell him that no one hates a foreigner, indicates a fact of considerable interest in connection with these islanders, and that is, that they have been always ready to welcome foreigners.

The strangers' house in Mbau is a curious sight. It is the lorgest building in the group, lofty, with many doors, and divided inside into a great number of mess places, each with its own fire stoves, for the accommodation of the many other tribes who are continually visiting Mbau, either as tributebearers, or allies for a war party.

In connection with tribute-bearing, nothing is more curious than the extremely servile position of the Somo-Somo chiefs in their relations with Mbau, though otherwise persons of importance. When they come to pay their annual tribute to that city, they are not allowed to enter Mbau Bay until they have asked permission to do so; they are then obliged to wait three days before they can approach, and, in doing so, are not permitted either to use their sails, or stand up to scull, to evade which last prohibition they engage Tongans to work the sculls. On their arrival another humiliation 
awaits them; for three days they are not allowed to sleep in a house, or wear clothing, and, in going about the town, they must assume a crouching posture, stop when they meet anyone, be he who he may, holding their hands clasped between their knees, and crying out, 'Dwa, wa, wa..' They are, at the expiration of this ceremony, allowed to go into the 'strangers' house,' a large building, where they are well fed, each family being assessed in some particular way for the supply of their wants, whether in pigs, yams, firewood, \&c. Thus, a part of the last-mentioned contribution was being brought by no less a person than his majesty Thakumbau, who, loaded with a bundle of firewood, and smoking a cigar, was the bearer of his family's assessment. The explanation of this was that, while his father old Tanoa lived Thakumbar was not one of the chiefs of Mbau to whom the tribute was due. The origin of this tribute, and the humiliating ceremonies connected with it, are traced to an old tradition that their principal spirit, a rat, having been wrecked in his canoe, and asked assistance in vain from some Somo-Somo men, was picked up by some Mbau people who took him to their town, where after three days'suffering he recovered. In consequence of this he mate Somo-Somo tributary to Mbau, and prescribed the humiliations we have mentioned. ${ }^{2}$

1 The wail of the Sandwich. Islanders is much the same-'Auwe, auwé, auwé:'

2 The above facts are taken from Lieut. Pollard's 'Journal' of his visit to the Fiji Islands in H.M.S. 'Bramble' in 1850; Erskine, p. 294. Lieut. Pollard witnessed the curious ceremony of reception. 
This ceremonial humiliation of Somo-Somo is the more curious because its chiefs were persons of importance. Thus Golea, the younger brother of the King, who had retired to Wariki, and left the sovereignty of Somo-Somo to him, was married to Eleanor (she had become a Christian), 'Thakumbau's niece, who was of superior rank to her uncle. Dr. Seemann, who saw her in 1860, speaks of her as being a fine woman, of dignified deportment, and manifestly intelligent as well. A party of gentlemen having made arrangements to ascend to the summit of Somo-Somo, the queen expressed her intention of joining it, which she did with a large suite. Girdled with a fold of white calico, her head wreathed with fern leaves, the purple blossom of the Chinese rose pendent from her ear, and a necklace made of shells, such was the total of her toilette. 'No other garment,' says the fascinated doctor, ' graced her stately person, and yet she looked truly majestic.' The ladies of her court, unencumbered with the girdle, and borrowing no superfluous covering from portions of banana and cocoa-nut leaves freshly cut, were sent forward as pioncers to make a track, and shake off the moisture from the over-lying branches. Alert, as light-footed as lightclothed, they soon distanced the heavy-dressed, and found their way to the top, where, en attendant, they amused themselves with opening cocoa-nuts, and smoking cigarettes made of dry banana leaves instead of paper. The view from the summit commanding the straits of Somo-Somo was very fine, but there was close at hand another charming tableau 
which is worth describing. On reaching the top, the agile nymphs had kindled a fire, and made every thing ready for a picnic.

'The queen was seated on the top of a rock, the maids of honour grouped around her. It was a pretty sight. The dark beauties, the really artistic effects of their ornamental leaves and flowers, the easy grace of their movements, made them look like so many nymphs that one reads of in classic story, but never seems to meet with nowadays.' 1 One would be apt to suppose that the writer had warmed himself into a pardonable exaggeration, if the polish, engaging gracefulness, and dignity of carriage, which mark the highest classes of the natives of these islands was not attested by every competent observer who has recorded his impressions. It is to be regretted that her majesty's arguments in defence of polygamy, as seen from her point of view, have not been reported, as it would have been interesting to have compared them with those of the ingenious lady in support of the same cause whom I met at Deseret city, the well-known capital of the Mormons. ${ }^{2}$

1 Seemann, pp. 26, 27.

2 'A Journey to Great Salt Lake City, by Jules Remy and Julius Brenchley, M.A., with a Sketch of the History, Religion, and Customs of the Mormons, and an Introduction on the Religious Movement of the United States; by Jules Remy, 1861,' vol. ii. pp. 97-109. This work is a translation of the French edition published in Paris in 1860. 


\section{CHAPTER IX.}

KANDAVU-FIJI GROUP-contiaued.

(Atatst 3.)

Levula Bay and Village-Peculiar Form of the Island-Mountain Cliff of Bule-Levu-Village of Yawe-Visit of H.M.S. 'Esk' - Letter of Canoe-men to her Commander-Notes on the Fiji Group-Chiets-Languages-Their Mythology-Deification promised to a Missionary- ' I am a God '-Character of their Gods and its Results-Impediments to Civilisation-Climate and Soil-European Population-Native Nctions respecting Property and Land -Difficulties thrown in the way of its Acquisition-Improved Prospects for Settlers-Exports-Commerce-Future Resonrces.

Steaved out of Mbau on August 2 at eleven A.M.; and directing our course towards the island of Kandavu, at half-past nine P.M. on the following day we dropt anchor in Levuka Bay. This is an open bay on the northern coast of the island, and has its southern point bounded by a mountain 3,800 feet high, being a precipitous cliff on its seaward side. Pleasantly situated on the bay is the village from which it takes its name, one of the neatest we have met with; and it is here that the Protestant mission is located, the resident missionaries being Messrs. White and Nettleton. Stretching from east to west the island is saich to be about twenty-four miles long, and, at mid distance, narrows so much as to form an isthmus, over which canoes 
are dragged for the purpose of effecting a direct passage between north and south, thus avoiding much circuitous coasting. The use to which it is put is denoted by its name, Yarabali, literally ' haul across.' 'The island has a population of between 10,000 and 11,000 , the whole of which has been Christianized. Its surface is very hilly, but it is reported to be well cultivated. The great mountain cliff of Buke-Levu was ascended by Mr. Pritchard and Dr. Seemann in 1860 (the first white men who had ever visited it), who found patches of cultivation as high as 1,500 feet. Between Levuka and Buke-Levu is the village of Yawe, the place most famous in Fiji for its pottery. ${ }^{1}$

At the end of the year 1866, more than a year after the Curaçoa's being there, H.M.S. 'Esk' went to make a longer stay in Kandavu than we did. Captain Luce, who commanded the corvette, and the Hon. Mr. Meade, who accompanied him as gunnery lieutenant, visited the missionhouses, with which they were highly satisfied, and of which they gave me a pleasing account. I may here insert, in reference to this visit, a translation of a letter which some native canoe-men addressed to the captain, thanking him for some small presents he had sent them as an acknowledgment of a slight service they had rendered him. This letter has struck me as noteworthy, if only as evidence of the present disposition of a people once so barbarous :-

1 Seemann, pp. 138, 215. 
'Richmond, Kandavu, Fiji,

'November 24, 1866.

'Sir,-I write to inform you that the things which you kindly sent for us, the boatmen of Mr. Nettleton, arrived safely, and we have each received our share, for which we greatly thank you. We rejoice greatly that you thought of us kindly, and sent us things that will be very useful. We rejoiced much on the day that we pulled the missionary to Galoa, to see the man-of-war and its captain; when we got to the side of the ship, we saw the great land guns and admired them; when we looked about we saw the officer standing at the gangway, and we said: "Oh! that one would speak for us, that we might be allowed to look over the vessel!" Then I spoke to him, and he nodded his head, so we then got on board, and looked over the hold, and saw the men who were in great number, and very industrious at their work; we beheld them and respected them greatly. Then we looked around us and saw the very great guns and the swords in great number. We saw the chiefs of the ship and reverenced them greatly. Then we went again on deck and talked among ourselves and said: "We young men of this generation were born in blessed times to see such a ship as this; our fathers saw no such sight, we are living in better times, and we are very thankful for it.

' $\mathrm{My}$ letter is finished.

'We send our love to you, sir, all of us, the boatmen.

I am

'Thomas Natiemba, your friend.'

"To the chief of the man-of-war steamer, "Esk." " 
Before taking a last farewell of the Fiji Islands, we will add some notices we were able to obtain in a hurried way from the Whites, with respect to this interesting group.

These islands are situate nearly half way between Australia and Tahiti. A sailing vessel takes about twenty days to go from Sydney to Levuka, their chief commercial port; the return voyage on an average does not occupy more than fourteen days, owing to the favourable winds which usually quicken their speed. The island of VanuaLevu, or North Fijian island, contains about 3000 square miles. The superficies of Viti-Levu, or South Fijian island, is about 3,750 square miles. The interior of this great island is entirely unknown; no one, either native or European, was able to say anything respecting the central districts, it not being even known whether or not they are inhabited. The surfaces of the other islands of the group range from ten to 400 square miles. The entire population of all the islands is estimated diversely at from 100,000 to 300,000 souls; but the former number is presumably nearest the truth. The island of Kandavu, the population of which exceeds 10,000 souls, is the most peopled in proportion to its surface, which is only 150,000 square miles; there are numerous villages, containing generally 200 souls, but rarely as many as 500 .

There is no central or regular government; on the other hand, a very large number of small chiefs, whose influence varies respectively according to the power which each possesses. Sometimes one of them has been known to make himself so formidable to his neighbours, as to feed himself 
and his whole retinue at their expense." But it is believed no attempt has ever been made to establish a single kingdom throughout the islands. Some thirty years before the visit of the 'Curaçoa,' an Mbau chief, assisted by some runaway sailors armed with muskets, succeeded in bringing a considerable number of chiefs under his dominion; but he soon saw this ephemeral ascendancy pass away, of which now-a-day remains but a sort of purely nominal presidency, which is acknowledged by the other chiefs.

The number of dialects in the island is so great, and the difference between them so marked, as to give rise to an impression at first that they were distinct languages. This diversity is probably due to the murderous wars continually waged between the petty chiefs, and which rendered any communication dangerous between one district and another, and even one village and another. Each tribe could only consider itself safe from its enemies while keeping within its own natural frontiers.

The mythology of the Fijians abounds in divinities. The special functions of some of them being, if correctly represented, somewhat singular. Thus one has the title of "The God just returned from slaughter;' another, a professed miracle-worker, has the significant name of 'Spit-wonders ;' one with eight eyes is the 'God of wisdom;' another is the 'God fond of turtles ;' and another the 'God fond of human brains.' But the most curious feature of their religion is the preservation of that practice of deification which is to be found in the earlier stages of all religions. Mr. Hazlewood 
has furnished interesting evidence of the fact in a speech at a missionary meeting in Hobart Town. After observing that any man who can distinguish himself by murdering his fellow-men (the missionary mode of describing war amiong savages, but among savages only) may be sure of deification, and that friends are sometimes deified and invoked, he says, 'Tuikilakila, the chief of Somo-Somo, offered Mr. Hunt. a preferment of this sort, "If you die first," said he, "I shall make you my god." In fact, there seems to be no certain line of demarcation between departed spirits and gods, nor between gods and living men, for many of the priests and old chiefs are considered as sacred persons, and not a few of them will also claim for themselves the right of divinity. "I am a god," Tuikilakila would sometimes say, and he believed it too. They were not merely the words of his lips; he believed he was something above a mere man. 'I

Nothing of course is conceivable in this impression when in the common opinion of people the gods have like passions with themselves; when they love and hate, are proud and revengeful, make war and kill and eat each other, and are in fact savages like themselves. Philo, as has been already observed, conceived analogous icleas in the Old Testament to be a false colouring to meet the requirements of barbarous and uninstructed men. The mischief has been that such conceptions, the fruit of extreme ignorance, and the rudest possible appreciation of supernatural porver, which

${ }^{1}$ Seemann, p. 247.

* $\mathrm{N} 3$ 
would have passed away with increase of intelligence, have been artificially prolonged in all countries for the purposes of state-craft and priest-craft to the demoralisation and great injury of society. Hence religion is first moulded by barbarism, and is afterwards employed in perpetuating it. Such a result is well indicated by Erskine, where, after the passage from Hazlewood just cited, he says of the Fijians, "With their deep religious convictions, therefore, it is not surprising that all indulgence of the gentler feelings of the heart, in which the Fijian nature is not deficient, is condemned as a weakness, and great pains are taken to instil into the youthful mind a contempt for passionate impulse, and an admiration for relentless cruelty.' $\quad$ A striking illustration of the wrong which supernaturalism often does to nature.

The progress made by the islanders in the way of civilisation is by no means so great as has been generally represented. ${ }^{2}$ In endeavouring to lead them on the path of progress, the chief difficulty is to find some motive to induce them to advance. It is not an easy matter to prove to them that it is to their advantage to adopt the civilisation of the Whites. The love of ease or indolence is the ruling passion, and anything discordant with it will find no favour in their eyes. One great cause of the poverty of the natives is the habit that prevails throughout the South Seas of begging from each other whatever they may require, or strikes their

1 Pickering, 'Races of Man,' p. 247.

2 The matter contained in this and the following pages of this chapter is slightly varied from Mr. Consul Jones's report to the Foreign Office, 'On the Present Condition of the Fiji and Tonga Islands. 1865.' 
fancy. There is no limit to these demands: a house, a boat, a new dress, even the food that a man has prepared for his family, is Tiable to be taken from him by any one his equal or superior; for it is considered disgraceful to refuse a request made in this manner, and for the lower classes who have so many superiors it is useless, it is said, to attempt to acquire anything.

If they require anything from the white traders, as for instance a waist-cloth, a knife, or a musket, they make cocoanut oil for the price asked. Notwithstanding the natural fertility of their lands, the people suffer severely from scarcity of food whenever the hurricanes injure their breadfruit trees. Pigs and fowls are by no means plentiful, and the lower orders seldom eat any animal food; the general custom is to collect together for a periodical feast all the surplus provisions in the district, when one-half is eaten and the other utterly wasted. Whenever usual food fails them, the natives support themselves on wild yams, wild beans, arrowroot, Tahiti chestnut, and the fruit of the mangrove.

The climate is healthy. The thermometer ranges during the year from $63^{\circ}$ to $100^{\circ}$ Fahr., the hottest months being January and February, the coldest June and July. Dysentery is the only prevalent disease. Notwithstanding the good climate, the population has not increased of late; if it has decreased, it is in an imperceptible degree. Various reasons are assigned for the depopulation of the South Sea Islands, which appears to have been simultaneous with the arrival of the Whites; but it is doubtful whether it should be attri- 
buted to the introduction of spirituous liquors, the use of woollen clothing, and the spread of syphilitic diseases; for in many islands, where none of these exist, the inhabitants are still diminishing in numbers.

The soil is fertile and capable of producing everything that requires a tropical climate, together with many of the plants of the temperate zones. At present Fiji produces cotton, coffee, and tobacco, of the best quality; the nutmeg, indiarubber and gutta-percha trees are found in the forests, and excellent shipbuilding timber and valuable furniture woods abound throughout the islands of the group. ${ }^{1}$

The European population of the group may be calculated at about 300. Civilisation has been but lately introduced into Fiji, and it is uncertain how far it may suit the temper of the natives; as they are ruder and more savage than their neighbours, they less readily adopt foreign customs. The class of settlers that has hitherto come to Fiji is dependent on manual labour for its livelihood; but the fertility of the soil and the salubrity of the climate will no doubt continue to attract others from the neighbouring colonies. The islander, nevertheless, gains little from his contact with Europeans. His hut, built of reeds, is well suited to the climate, and sufficiently commodious in his eyes. When he has exchanged his stone hatchet for an iron one, his club for

1 'The rapidity of the vegetation as described by the Missionaries is remarkable. Turnips, radish, and mustard seed show themselves above ground in twenty-four hours. Melons, cucumbers, and pump. kins in three days; beans and peas in four; radish and lettuce fit for use in four weeks, marrow-fat peas in five.'-Erskine, p. 268. 
a musket, and his paper-cloth for calico, civilisation can offer him nothing farther which would compensate him for the labour required as an equivalent. The fancy or caprice of the head chiefs may give a spasmodic extension to trade, ${ }^{1}$ as the purchase of a small vessel, or a hundred muskets, requires a large quantity of oil in payment; but wherever the authority or influence of the chief has declined, the trade of that district has likewise fallen away. In many places the natives, after having adopted some of the habits of civilisation, have voluntarily abandoned them, and returned to their national customs.

Before the arrival of European speculators, the natives never considered unoccupied land worth claiming. Wherever a man planted his yams, tobacco, or taro, that land was his so long as it was occupied by his crops; but, as soon as these were dug up, it was free for any one to make use of it for the same purpose. About the time ${ }^{2}$ that the sovereignty of these islands was first proffered to Great Britain, many speculators from the Australian colonies purchased land in Fiji, seldom caring to enquire into the nature of the titles they obtained. A common practice was to draw up the deeds in English, to have them translated to the native chief by some one professing to understand the Fijian language, but generaliy as ignorant of it as the principal who employed him, and the

1 But, according to Captain Erskine, "the Fijians have a decided turn for commerce, a constant internal trade being carried on in their own canoes, which we constantly saw either arriving or sailing, heavily laden with bales of eloth, rolls of cordage and quantities of earthen pots.' Seemann, p. 269. This is confirmed by what I myself saw on the Rewa river.

2 In 1862. 
transaction was complete when it received the chicf's mark, who was induced to sign it by threats or cajolery, but frequently by making lim drunk beforehand. As the boundaries of these cstates are generally very vaguely laid down, and as the class most interested in these lands have been seldom consulted in these sales, it is probable that many of the purchasers will find great opposition whenever they come to take possession of their property.

As each tribe for security confined itself to a certain tract of country, the White settlers have chosen now to recognise every such tract as the property of the tribe. This idea facilitated the purchase of land, and the natives were pleased to find that they possessed something to which the White traders attached a value. When paynent came to be made for the purchased land, every one considered that he had a right to be separately dealt with, if he had ever been connectid with any part of the land in question; so the head chiefs, the minor chiefs, and each owner of a yam patch, or cocoa-nut tree, required compensation and a share of the purchase money. When unsuccessful, they endeavoured to throw every obstacle in the way of those who proposed to enjoy the purchased land.

The value of exports has shown an upward tendency lately, having increased from $£ 13,000$ in 1863 to $£ 20,000$ in 1864. This remarkable increase has occurred principally in cotton, cocoa-nut oil, and fibre; other exports are tortoise shell, Beche-de-Mer, and wool.

The cultivation of cotton has now become the principal 
concern of both natives and settlers. Various kinds have been experimented upon. The variety known as 'Kidneyseed ' is the most common, though very far from being the most profitable; but as, until now, from the want of machinery, cotton is exported with the seed in it, and in this condition has always found buyers at eight cents a pound, the planters have come to the conclusion that the increase of weight caused by the seed was a compensation for other drawbacks. The most intelligent of the growers show the greatest preference for the variety known by the name of 'Sea-island' cotton, which flourishes hxuriantly, bears a far greater quantity of pure fibre, in proportion to the age of the plant, than any other variety, and compared with the kidney cotton its value in that respect is as five to one. The cotton plant here is a perennial, and after the first outlay of clearing and planting, the subsequent expense is trifling. The island of Kandavr and the banks of the Rewa river, in the island of Viti-Levu, are the positions most in favour with European planters. The facilities that both these places offer for transport and communication have caused this selection. The Rewa river, so disproportionate to the size of the island in which it rises, is navigable for boats of twenty tons for more than forty miles from its mouth, and for seventy miles of its course rafts and flat-bottomed boats could be used to transport the cotton from the upper country without meeting any obstacle in the shape of rocks, cascades, \&c. The fertility of the soil, the salubrity of the climate, and the supply of cheap labour that can be obtained, will enable 
the cotton-grower of Fiji to compete successfully with any other in the market of Europe, as the quality of fibre that can be produced here is considered by competent judges to be equal to any that can be supplied by the Southern States of America. The high charges for freight to Sydney are the most serious drawback that the island traffic suffers for cotton. In the badly-pressed state in which it leaves Fiji, the freight is $9 l$. per ton. Until the quantity of cotton exported shall be sufficiently great to allow of a direct trade with Europe, there is no probability of any reduction in the charges.

The supply of cocoa-nut oil will continue to increase for some years to come, if the demand is as brisk as heretofore. A thousand tons could be furnished by this group alone. To the natives it can hardly prove a profitable article, as their process of manufacture is tedious and laborious. Machinery has been employed to extract the oil, but the result was not so profitable as was generally expected by the introducers, who frequently found their labours brought to a standstill by the refusal of the natives to supply them with nuts in sufficient quantity, as they looked with jealousy on an undertaking that threatened to deprive them of the means of purchasing cloth, knives, \&c., from the traders, inasmuch as the oil that each could personally make was the only article of barter he possessed. Whenever the cultivation of cotton shall give them a better return for their labour than oil-making, they will of course have no further objection to supplying the oil-mills with any quantity of nuts they may require. 
Cocoa-nut fibre can be supplied in any quantity.

The disputes which took place latterly between the fishermen on the coast of Illacuata have diminished the yield of Beche-de-Mer; nevertheless, the price is good, being 1,200 dollars per picul of 140 pounds, and for inferior 1,000 dollars.

As to the sugar-cane, though it is to be found in all these islands, and is used as food by the natives, no attempt has yet been made to cultivate it on a large scale.

The coffee tree has been introduced from Tonga, and there are now more than 20,000 trees doing well. It was calculated in 1865 that two-thirds of these trees would fruit the year following. The berries hitherto produced have been used as seed, it being found that trees from seed produced on the spot yielded more abundantly than those grown from imported seed.

Arrowroot and tapioca are found as troublesome weeds throughout the South Sea Islands, but the tedious operations necessary to prepare these articles for European markets prevent the traders from exporting them. In all the islands the supply far exceeds the demand, and the price they fetch in the colonial markets seldom exceeds $2 \frac{1}{2} d$. per pound.

Tobacco grows well, the leaves are large and fine; but the European settlers are content to use it prepared in the native manner.

Throughout the year, but especially in the months of Nay, June, and July, large numbers of whales are found around the coasts of Fiji. Sperm and Humpback whales 
especially abound. Before the civil war broke out in the United States, Fiji was a favourite station for Amerizan whalers, as many as nine calling here in one season.

As yet no other minerals than some specimens of malachite and graphite, both of fine quality, have been found.

The articles most in demand in the Fiji trade are the following: cotton prints (those known as navy blues being preferred to all others), blue dungaree, turkey reds, unbleached calicoes, blue and red blankets, red serge shirts, red worsted, cotton thread, wedge axes, bench axes, hatchets, twelve and fifteen inches butchers' knives, razors, scissors, muskets, flints, powder, lead, fishhooks, needles, vermilion, beads, small white venetian.

At the time just alluded to, when there was a chance of these islands being recognised as a British possession, the horde of immigrants attracted by it having no requisites for success returned penniless. Their misfortune procured for Fiji an evil reputation, from which it is now freeing itself. Nevertheless there are few countries where one can live with less personal exertion than in Fiji, which recommendation caused it to be selected by the number of runaway seamen who composed the European population about eight years before. The natives growing impatient of their incessant demands forced them at length to Iaboux for their own support, and at present few of this class are to be found in the group. The present settlers do not lack either industry or enterprise. The rapid progress that cotton cultivation has made in these islands during the 
year 1864 is due, in a great measure, to the individual efforts of the settlers, for the most part men without any capital, who, having obtained some land from the natives, cultivate it by their own personal labour.

In former times, before European intercourse had reduced the natives of these islands to order, the sanguinary jealousy that made every village distrustful of its neighbours compelled the inhabitants to fortify themselves on the most inaccessible heights, and prevented them from cultivating any land beyond the few feet around each man's dwelling. If more was required, the cultivator, afraid to descend into the plain, discovered some spot in the recesses of the mountains, where he might plant his yams secure from molestation. This system of scanty cultivation has been so long followed by them, that it is still difficult to persuade a native to plant on an extensive scale. He still endeavours to procure all that he may require in the small patch of soil around his habitation, and in this manner they have hitherto planted cotton so close that the trees have no room for development, and the produce is proportionally checked.

Land is easily purchased in the group, and labour, up to the present time, has not been found wanting. The general salubrity of the climate is well attested, and a European can work in the open air throughout the year without inconvenience. Life and property are secure; a result due, in a great degree, to the labours and influence of the Missionaries. In the generality of cases where disputes arise between the natives and settlers, the latter will be found to be the aggressors. 
On the northern shores of the Fiji Islands are extensive tracts free from timber, and admirably adapted for pasture lands. Large tracts have been already purchased for the purpose of sheep farming, and the prospects of success are encouraging. In many cases, however, the sheep, on arriving from Australia, have suffered severely from the effects of the long voyage. When acclimatised they do well. Dr. Brewer, the U.S. consul, after an experience of four years' sheep farming in Fiji, finds no sign of the wool degenerating into hair. The average weight of the fleece is-merino, three pounds; Leicester, four pounds; and it sells on the ground at eightpence per pound unwashed. There are in Fiji about 3,500 sheep and 70 head of horned cattle; the latter succeed remarkably well. The flocks increase rapidly, and good pasture land́ can be purchased at an average rate of $£ 2$ per acre. In addition, the abundant supply of water, and the fertility that everywhere characterises the soil, offer advantages to the settlers in Fiji not always to be found in the Australian colonies. ${ }^{1}$

1 As this is passing through the press I find in a brief paper published in the November number of Fraser's Magazine for 1871 (the writer of which states that he has recently visited Fiji), that the settlers on the banks of the Rewa have come to the conclusion, that the sugar-cane could be cultivated there to much greater advantage than cotton, and are prepared to substitute the former as soon as they can obtain a sufficiency of sugar-plants for that purpose; the incessant rain that falls being, it appears, as beneficial to the sugar-cane as it is unfavourable to the cotton plant. 


\section{CHAPTER $\mathrm{X}$.}

ANATOMI-NET HEBRIDES.

(A Uatost 6 то 10.)

Striking Appearance of the Island--A Tessel belonging to the Presbyterian Missions-Climate-Causes of decreased Population-Character of the Natives-Progress ascribed to Christianity_Chiefs-Productions.

Or August 3 at four P.M. we left Kandavu for the island of Anatom, the most southern of the New Hebrides. This run of 470 miles was not marked by any particular incident, and was in every respect agreeable.

On August 6 we reached Anatom, and came to anchor between the bay and Whale Island. The harbour is spacious and sheltered from all winds except the west, to which it opens. It is easy of ingress and egress, the entrance being wide and free from obstruction. Anatom is a beautiful island, well wooded and watered; its general character is mountainous; hill and valley, mountains of every shape and size, intersected by deep ravines, cultivated spots, and barren tracts, covered with shrub or entirely without vegetation, diversify the scene, and give it a lively and picturesque appearance. Large quantities of Kauri pine were found of excellent quality, and a great variety of other wood, which might be turned to valuable account. 
Lying in the harbour was H.M. ship 'Esk, with our mails. On board her was the master of a sandal-wood vessel as a prisoner, who had shot his mate with a revolver; his explanation of the act was that he had done it in self-defence, the latter, after mutinous disobedience of orders, having threatened to cut him down with an adze; but, in the opinion of a naval court held on board the 'Esk,' this statement was considered, after due inquiry, so doubtful, that he was sent to Sydney for trial on the charge of manslaughter.

Here we found the Presbyterian mission brig, 'Dayspring,' with several missionaries on board, and anong them Messrs. Paton and Gordon. Both these gentlemen were bent on dangerous enterprises, in which they hoped to succeed by favour of Her Majesty's guns, that were soon to be employed in punishing and terrifying the natives of Tanna and Eramanga for their misdeeds. Relying on the presumed results of the intended discipline, $\mathrm{Mr}$. Paton was about to return to Tanna, though he had suffered frightfully from the effects of the climate during three years' residence there, and had been driven from it some ten months since, after having had his house pillaged, and being indebted for the preservation of his life to a friendly chief, who secreted him until he had the opportunity of getting on board a vessel which called at the island. In addition to his other sufferings while there was the death of his wife, by whose grave, he says, he was obliged to watch several nights, gun in hand, to prevent the body from being stolen for cannibal purposes. It is surprising that, while thus employed, he was 
not destroyed by such ill-disposed natives, and that they should have obligingly left him unmolested during the day.

Mr. Gordon was on his way to Erananga to resume the work which had been interrupted by the murder of his brother, Mr. Gordon, who with his wife had been slaughtered recently by the natives of that island.

An attempt has been made to establish a whale fishery on the little adjacent island, called Whale Island, which, I believe, has been so far successful. Erskine, when off Anatom in the 'Havannah,' was surprised at the number of whales he saw spouting about,- - the man at the mast-head had counted twenty in a few minutes, - and thought, if this occurrence were not an exceptional one, that it would be well worth considering whether, when, during the winter months in high latitudes, whaling cannot be pursued, this island might not be turned to good account in the interim.

It is fourteen miles long, and eight wide. Its highest mountain is about 2,800 feet above the level of the sea.

The climate is somewhat humid, in general agreeable, and, to those who are careful, not unhealthy. The thermometer had never fallen below $58^{\circ}$, and seldom below $62^{\circ}$; it has never risen above $94^{\circ}$, and seldom exceeds $89^{\circ}$ in the shade. The island is well watered; droughts are unknown, and more or less rain falls every month throughout the year. Thunder-storms are of unfrequent occurrence, violent hurricanes, on the contrary, often occur.

The population of the island is about 2,200. The inhabitants do not live collected in villages, but separately in 
the midst of their cultivated patches; but the island is, nevertheless, divided into districts or settlements about sixty in number. Three fearful epidemics have visited the island within the last forty years. About the year 1836, an epidemic like cholera carried off above one-third of the population; about 1842 a similar one took off another third ; and in 1861 a third epidemic of measles, followed by dysentery, scourged what was left.

The debilitating effect of these diseases was very prejudicial to the constitution of the natives, and since that time the decrease in the population has been about 300. When we were there in August, 1865, the births and deaths as yet had been about equal. Before the third epidemic made its appearance, the mortality was about three per cent. per annum; since that time it has averaged six per cent. per annum. A large proportion of children die under two years of age. Previous to the first of the epidemics I have mentioned, the population, it is said, could not have been less than 12,000. In 1859 it amounted to 3,500 .

The language is peculiar to the island, though allied to some extent in words, and much more closely in grammatical structure, to the other dialects spoken in the New Hebrides.

The natives are docile and eager for knowledge, and evince a considerable aptitude for general improvement. They are naturally timid, but kind, warm-hearted, and confiding.

The morals of the people are upon the whole very cor- 
rect. There is no drunkenness, or crime. There has not been a case of murder for the last thirteen years. There have been, however, a few cases of manslaughter, which have been severely punished. Theft is of very rare occurrence.

The entire population has been professedly Christian for the last seven or eight years. The whole of the New Testament has been in their hands for two years, with detached portions of the Old Testament, as well as various elementary books. Every person above five years of age attends school, and can read more or less. Two-thirds of the entire population are reading in the New Testament, and one-fourth are members of the church. There are fiftythree schools in the island, conducted by native teachers. There is not a native living on the island more than fifteen minutes walk from a school. A considerable number can write, and a few can do a little arithmetic.

According to the eulogistic testimony of Missionaries, war, murder, and infanticide, as well as their peculiar customs of cannibalism and strangulation of widows have been abolished. At the time of our arrival, the last case of cannibalism had occurred in 1852. Life and property being everywhere secure, the people are all living in peace, and beginning to develop the resources of the island.

Teachers from the eastern islands were placed on Anatom in 1841. Two missionaries, Messrs. Gordon and Powell, were located here in 1848. Considerable difficulties were encountered in the first years of the mission, the natives being as degraded and as savage as on any island of the 
group. Since 1852, the progress of Christianity and civilisation has been steady and continuous, and the prospects of the island are highly encouraging. This change however, it is argued, is so recent, that the natives have not attained the amount of knowledge and strength of principle and character to enable them to resist temptation, or make much advance, without the constant superintendence and instruction of Missionaries.

Besides the two mission families living on the island, there was a family of Whites at each of the two sandalwood stations, and also a few others, perhaps about twenty people in all, in addition to those connected with the four or five vessels sailing out of the harbour.

The island is governed by chiefs. There are three principal chicfs, each having several petty chiefs under him. Their power is not well defined, and in many cases they have little influence. In some cases, however, their word is of great weight.

The island is of voleanic origin, but surrounded in many places by coral reefs. No minerals have as yet been found. The roads were originally mere tracks, and are still so to a great extent; but, since the arrival of the Missionaries, a number of these native paths have been greatly improved, and the island can be traversed on foot in all directions. Carriage roads there are none, and of horse tracks only a few.

The principal indigenous fruits and vegetables are the breadfruit, the banana, the cocoanut, a large edible sort of 
horse chesnut, the sago-palm, another species of palm tree bearing small nuts, called in the country Nakoai, the sugar cane, the taro, which is the staple article of food, another plant resembling taro, but much coarser than it, yams in small quantities, sweet potatoes and arrowroot, both abundant, the latter of excellent quality, and more than a hundred species of ferns. The kinds introduced are the orange, the lime, the lemon, the citron, the pine-apple, custard-apple, papau-apple, all of which, as well as melons and pumpkins, have succeeded. The cultivation of the cotton plant has also begun, and as much as 1,900 pounds of cotton had aiready been exported in 1864. In the same year were exported 2,600 pounds of arrowroot, and 6000 pounds of French beans, which grow admirably well, and find a ready market at Sydney.

A small dun-coloured rat is the only indigenous quadruped. Pigs abounded when the island was discovered. Whales are plentiful in the season: upwards of $\$ 2,000$ worth of whale oil has been obtained from whales caught round the island in one year. Horses, cows, goats, sheep, dogs, and cats have been introduced, and, with the exception of sheep, thrive well. The English rat is common. There are three or four varieties of the cat.

Birds are not numerous: four species of pigeons, two of hawks, one owl, one species of swallow, which is like the sand-martin, and builds its nest in caves and rocks; one species of wild duck. The common fowl, but small in size, was plentiful when the island was discovered. Geese, 
ducks, turkeys, and guinea fowls have been introduced, and thrive, but not so well as the common barndoor fowl.

There are no venomous reptiles in the island. There is a large serpent, about four feet long, the back dun-coloured, the belly a dirty yellow. One other snake is found on the shore, about four feet long, with alternate bands of black and white across the body. There are three or four species of small lizards, and two kinds of turtle.

More than a hundred species of fish are found at Anatom. They are nearly all different from those found in the northern hemisphere, and not at all equal to them as food, being, with few exceptions, hard and dry. Sharks are numerous, and shell-fish too.

Butterflies abound, some very beautiful. Beetles of different kinds, both large and small. Locusts, grasshoppers, flies, mosquitoes, spiders, ants, lice, and fleas. Fleas are said to have been brought by Europeans.

The common articles of barter among the natives are fishing baskets, nets, sleeping mats, hand baskets, pigs, fowls, taro, and cocoa-nuts. With foreigners, pigs, fowls, taro, bananas, cocoa-nuts, sugar cane, \&c. are given for articles of European clothing, hatchets, knives, fish-hooks, \&c. The natives use spears, clubs, bows and arrows; their spears, like most I procured in this group, are very crooked, and more rudely made than those I met with in any other island. 


\section{CHAPTER XI. \\ TANNA-NEW HEBRIDES.}

(AUGUST 10 TO 13.)

Uea Harbour-Useless Negotiations with offending Chiefs-BombardmentMen landed and Property destroyed-Incidents of the Attack-Effect produced on the Enemy-Description of the Island_Climate and Diseases - Disposition of the People-Morality-Usages-Creeds-GovernmentMarum or Council House-Fruitless Efforts of the Missionaries-Languages - Volcano of Asur and its Environs-Productions and Exports.

ON August 10, at daybreak, the 'Curaçoa' stood out from Anatom on her way to Port Resolution Bay, in the isle of Tanna, about forty-five miles distant, where we anchored the same day at a quarter past one P.M. The mission brig 'Dayspring' was in company with us. In our course we passed, first, the island of Fotuna, or Erronan, flat and square-shaped, and the low island of Niua (the native name), or Immer, which, according to Captain Erskine, ${ }^{1}$ is placed in all the charts closer to Tanna than it really is. The passage into the harbour is narrow, and on the west side towers an active volcano, constantly sending forth its jets of fire, smoke, and lava, being, as it were, the avant garde of lofty hills ranging over the island, and bright with verdure.

Next morning early the ship was in busy preparation for inflicting capital or other punishment on the refractory 1 Page 303. 
natives who had taken the liberty of ejecting the Missionary from their island. Very soon our big guns loaded with shell began to carry very unpleasant messages to the culprits, while our cutter further enlightened them by discharging rockets among a great crowd of natives that clustered about the harbour. This overture continued for some hours, when the more serious business of the day began by the landing of some $170 \mathrm{men}$, who were to penetrate into the island, and commit such devastation as was in their power. The task, however, was not an easy one. The natives of course, incapable of resistance, fled from the coast, and concealed themselves in the bush, which presented an almost insurmountable barrier to an invading force. No guide had been found, and the advance had to be made as best it might. Taking advantage of a most unpromising path that led upwards from the beach, Commander Dent led up his men in the direction of an open space on the hill top, which the Missionary had pointed out from the ship as being the dancing ground, and which was to be the place of rendezvous. This spot, after a prodigious expenditure of creeping, crushing, and other fatiguing exertion in forcing a way through the intricate tangle of the bush, was at length reached. But no sooner was this effected, than a volley from the rear showed that the natives had been following on their track. A dash was made at them, and they immediately vanished. Their fire had been harmless, but, in their flight, they came across one of the men who was stooping in the act of cutting down sugar canes, whom they 
fired at and mortally wounded. At this moment Midshipman Heatheote having come up, attempted to fire at the assailants with his revolver, which had missed fire four times, when a native rushed forward to club him with his musket, whom in the act of doing so he cut down with a single blow. There was reason to believe that this native was one of the leading chiefs of the island, and that his death had caused great consternation. The man Holland, supposed to have fallen by his hand, was an excellent seaman, and a V.C. man, and had served unhurt in the Indian Mutiny, the Crimean War, and in New Zealand. Such was the obscure termination of a gallant career. He was carried on board, where he died in less than an hour, and his body which, on account of certain propensities of the Tannese, could not be interred on shore, was committed to the deep.

It was fortunate there was no greater loss, for I was assured by the officers that, had the natives known how to make use of their opportunity, the position of the little force would have been critical. Fortunately Commander Dent, finding his men helplessly exposed, and satisfied with having destroyed several villages--some of them, however, not containing more than four houses - and wasting some provision grounds, gave orders to return to the beach, which was luckily effected without further opposition. While this was gcing on ashore, another party in the boats, under the command of Mr. Scudamore the master, was engaged in destroying all the canoes they could find along the coast. A tolerable amount of retribution, no doubt; what its effect 
had been may be gathered from the following document, said to be the declaration of the offending chiefs, whom Mr. Paton met immediately after the attack at a friendly visit, where he landed, and to which he has given expression in the following form :-

'Formerly we had been guilty of so many murders that we feared men-of-war would come and punish us; we all thought and said they durst not try, and so we delighted in our bad conduct. Then we had no idea of the multitude of fighting men in a man-of-war, and of her awful power to destroy us and our lands; but now we have seen it, and our hearts have failed us. We are all weak and crying for fear. The great inland chief, Quatangan, who came to help us to fight the man-of-war, was cut down by one of his chiefs (officers), and many more are hurt, and we know not how many are shot and dead. Our canoes, our houses, and our lands are laid waste by his fighting men. We never saw any thing like this before. Now we are all weeping for our evil conduct. Go and plead with the chief of the man-of-war not to punish us any more, but to go and leave us, and truly we will obey his word. Tell him to inform your good Queen Victoria that we will kill no more of her people, but in future be good, and learn to obey the word of Jehovah.'

The alarm created by our operations seems to have been general throughout the island, and promises of amendment for the future came in from different quarters.

As it was impossible for me to make any visit to land 
while off the island, the Curaçoa leaving at daybreak of the morning after the attack, I will here state what I have been able to learn respecting these islanders from the Missionaries on board.

In the language of the country the word Tanna signifies land, as in the Malay language; and the natives give their island the name Aipere or Aepari, while their neighbours of Anatom call it by another name, that of Aipegerouma.

Tanna is about twenty-five miles in length, twelve miles wide, and about sixty-five miles round. The population is estimated at from 15,000 to 20,000 . The inhabitants live in villages scattered over the island, but occasionally clustered in some districts. The thirty villages which are found round Port Resolution are included in six districts, which bear respectively the names of Jukahe, Raseau, Fituapo, Samoa or Ilupuroup, Irurye, Jukaruk. The people or tribe inhabiting each district has a special name, as for instance Nasebine, Naraimine. The occupiers of the villages frequently change their locality during war, which appears to be the only and almost continuous occupation of the men, while on the women devolve all the labours unconnected with war. Their mode of warfare consists, for the most part, of skirmishes, rarely of regular battles, or personal encounters.

The average annual temperature is $86^{\circ}$, thunder is frequent, and there are often heavy downfalls of rain which are soon over. The climate for four months of the year is damp, giving rise to fever and ague; but it is agreeable 
during the other eight months, which are not unhealthy, provided some precautions be taken. Since European weapons and diseases have been introduced, there has been a sensible decrease of the population. The infant mortality is considerable; deaths, too, occur from sunstrokes, and

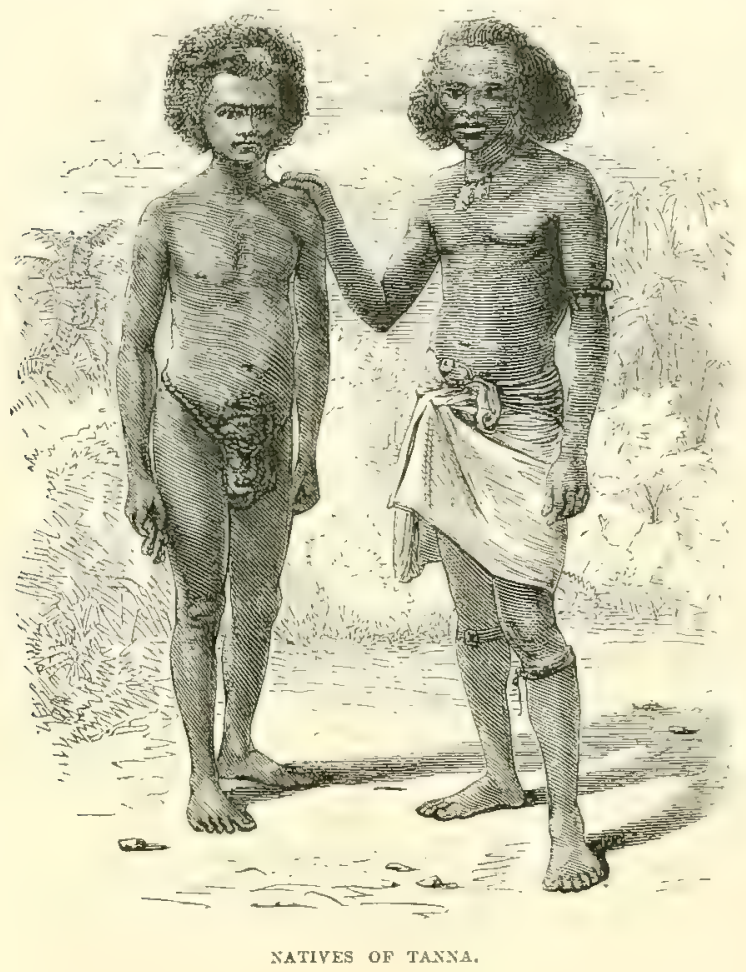

poisonings attributed to the flesh of certain fish. But the greater part of the adults are slain in war, or massacred by the killing stone. Small pox has visited the island, and carried off a considerable number of the inhabitants. In 1861 measles destroyed about one-third of them. The sick are well cared for; local bleeding is made use of in almost 
all illnesses, and is effected, not by opening a vein, but simply by making incisions with a split bamboo. In grave cases, or such as are considered dangerous, they have recourse to a heroic method, that of cauterising the sole of the foot. They incase their dead in layers taken from the stem of the banana tree, and bury them the day after their death in the following manner : they first dig a hole about four or five feet deep, and then scoop out from one of its sides a horizontal niche in which they deposit the corpse.

Tannese people are under the middle stature, with few exceptions: Their colour is darker than that of any other islanders I had met with. They dye their bodies and faces red or black. Red is the favourite colour, and it is obtained from a red earth they get principally from Anatom. Black is the sign of mourning; they make it with oil and pounded charcoal. Their hair is frizzled, and often of a light brown colour, rather than black. The women wear it short, but have it all laid out in a forest of little erect curls, about an meh and a half long. The men sometimes do up their hair in long pendent tails. They pierce the septum of the nose to insert a small piece of wood or reed, and wear ear-rings of tortoise shell half an inch wide, and from two to four inches in diameter, sometimes half a dozen of various sizes in one ear, which enlarges the aperture so fearfully, that a child's hand might pass through some of them. They do not tattoo. The women are covered with girdles hanging down below the knees, made from the rolled and dried fibres of the banana stem. The clothing of the men is as 
sparse and locally limited as exhibited in the woodcut. All wear some ornament rount the neck, beads, locks of hair, and whale's teeth. They wear from one to six armlets made of the cocoanut shell above the elbow, and to them they suspend their spear-thrower and sling.

The morality of this people is in some respects of a very low character. The natives assert that the present excessive licentiousness was introduced by the Whites, who formerly resided on the island. It is a question. The chiefs have a sort of pride in getting drunk on Kava every night; intoxication indeed appears to be their greatest delight. It is an accepted maxim among these islanders, that it is quite permissible for any one to steal whatever he likes, provided he be not detected, or fail in his purpose; otherwise it is a disgrace, as it was in Sparta. Murder is frequent; sometimes children and old people are got rid of in order to save the cost of supporting them. They strangle the wives on the death of their husbands, and, however little attached these may be to the defunct, they submit to this barbarous custom without hesitation, and even with eagerness, thus showing they have a firm belief in a future state. All imaginable crimes are committed, and to the great satisfaction, apparently, of the islanders. Polygamy exists, but does not appear to be common. Adultery is restrained by the fear of the revenge of the injured person. Though they sometimes kill their children, it is but just to say that they generally treat them with affection, spoil them even, girls as well as boys. Circumcision is a general practice 
about the age of seven. Cannibalism exists to a very large extent; they eat their enemies either slain or captives; occasionally they eat their orvn dead; or sometimes exchange them for the dead of another tribe when they happen to have a particular regard for the deceased. During $\mathrm{Mr}$. Paton's residence in the island, there were two festivals, at one of which seven prisoners, at another ten, were slaughtered. It is a common thing for two or three individuals to be slain at these banquets, which are but too frequent. They find human flesh preferable to that of pork, and the connoisseurs in this line prefer the flesh of a native to that of a White, the latter having, they say, a salt taste.

The religion of theze islanders is not much known. They do not build temples, but perform their religious rites under the shade of banyan trees, which are thus esteemed sacred by them. They have no idols, and it seems that the spirits of their ancestors are their gods. They address prayers, and make offerings of food to the souls of the dead they have deified. Here and there in the woods are certain stones for which they have a species of veneration. The veritable gods of Tanna, those which are certainly the most formidable, are certain sorcerers, who pretend to have the power, by means of certain antics, of summoning at pleasure rain, thunder, sickness, musquitoes, and all sorts of pests; and they are all the more feared and reverenced on account of the popular belief in their supernatural power.

There is no head chief at Tanna ; each village has its chief, who ranks after the principal chief of the district. The 
power of the chiefs is nominal, except when there is question of war; and there is scarcely a dispute which is settled otherwise than by a fight. The title of chief is hereditary, but might makes right, and the strong puts down the weak. The men never go out unarmed; their weapons were killing stones, clubs, spears, bows and arrows, and kawas (stones about the length of an ordinary counting-house ruler, only twice as thick), which they throw with deadly precision when their victim is within twenty yards of them. All these weapons are now laid aside for firearms and tomahawks.

Every village has a clear circular space under the shade of a large banyan tree for their mamu, or place of public meeting. There all the men of the settlement assemble about sundown for a cup of Kava, and their evening meal. The women and girls have their meals apart from the men, and totally abstain from Kava drinking. Public feasts, night dances, and political ineetings are held in the marum. In public discussions there are special orators, one or more in every village, who chant their speeches, and walk about in peripatetic fashion from the circumference into the centre of the narm.

There was not a single White man in the island at the time we were there. Formerly there had been Missionaries and some settlers engaged in the sandal-mood trade. In 1862, when the Protestant mission was driven away, it was computed that there were 500 natives who had embraced Christianity, and renounced war, camnibalism, infanticide, 
the destruction of old men, \&c., and who observed Sunday as a day of rest and prayer. Two chiefs, Nowar and Manumai, together with their people continue to live in peace, and to adhere to Christianity; but most of the other Christians have been slain by their unconverted fellow islanders since that period. The mission had succeeded in teaching a considerable number of them to read and write, when it was compelled to fly.

There are in Tanna at least two languages peculiar to the country, each of which contains various dialects, some of them materially differing from others. The natives living on one coast cannot understand those who live on the other. Their mode of counting by fives is by reckoning on their fingers and toes; but the names of the numerals differ very much in one place from those in another; for instance five is called grimum in one spot, katilum in another, kulkulup in a third. The dialects appear to be copious and harmonious, and it is said that their pronouns have not only a dual but also a trial number.

The active volcano of Asur is situate four miles from Port Resolution; its eruptions, which, as I have already remarked, occur every six or eight minutes, are more violent in the months of January, February, and March than in any other months of the year; they are always accompanied by a roar audible at a great distance, and resembling the discharge of a battery of artillery. Besides lava, the volcano throws up, to the height of 200 or 300 feet, blocks of stone, which generally fall into the crater; 
clouds of ashes are also cast up, which are carried by the wind far and wide to the great annoyance of the eyes. The slopes of the mountain, on which are several villages, are covered with vegetation; and in certain spots it seems as if one were walking on a hot iron plate. 'The summit is denuded, and split here and there into fissures, whence, from time to time, rise jets of smoke and sulphurous vapours. At its base, on the western. side of the port, are to be found in the midst of rocks close on the sea hot springs, well known to the islanders, and used by them as remedies in certain maladies, and especially in the cure of sores and ulcers. Several of these springs have a temperature of $190^{\circ}$ (Fahrenheit), and there are others in which it nearly reaches the boiling point. Women are to be seen daily dressing their yams and other vegetables in them. Neither is it at all unusual to see fishermen standing. on the rocks harpooning fish in the sea, and casting them into the water behind them, where they are cooked without farther trouble. But what is not less striking is, that by the side of these bot springs are to be seen issuing from fissures in the rock other waters which are quite cold. Shocks are common and often very sharp. Sulphur of firstrate quality exists in abundance in these volcanic districts; but it can be obtained from the natives in only the smallest possible quantities, in barter for powder and fire-arms. Obsidian is also to be found there, and a stone which has all the appearance of the Nephrite of Nerv Zealand, and of which the natives sometimes make bracelets. 
The natural products of the island are the cocoa-nut tree and other palms; a great variety of ferns, the banana, and breadfruit tree, the rose apple, taro, arrow-root, sweet potato, a sort of fig-leafed cabbage, and sugar-cane. The yam is very extensively and carefully cultivated. The Missionaries had some four feet long, and weighing forty and even up to fifty pounds. The plants introduced are, the orange, lemon, citron, the pine-apple, the papau, the coffee plant, and pepper tree. I have already observed that the ava (Piper Mephysticum) is plentiful.

Rats and different kinds of bats are the only indigenous mammals. Pigs, cats, and dogs have been introduced. The attention of the islanders is principally directed towards raising pigs. Whales abound on the coast.

Barndoor fowls thrive well. Parrots, parroquets and pigeons are seen in great numbers, and of beautiful plumage. Swallows are plentiful, and varieties of small birds are seen in twos and threes. In the vicinity of the volcano is found a large bird that lays its eggs on a mound of earth, which it has made for the purpose; it does not fly, but runs so swiftly that it is seldom caught.

As to serpents it is questionable whether any exist. There are four kinds of lizards, and, moreover, a large black species of which the natives are much afraid; they say its bite is deadly, and connected with it they have a tradition of the fall. Two species of turtles are often speared in the bays round the island.

Many species of beautiful fish are taken, but they are dry 
and inferior as an article of food. Sharks are numerous. Natives frequently die from eating fish which are poisonous at one season of the year, and good at another. Some fish are poisonous all the year round, and when eaten there is no remedy.

There is a variety of shellfish ; one, when touched, ejects a fluid which is poisonous, and generally proves fatal in a short time.

There are large numbers of beautiful butterflies, and beetles of all sizes, mosquitoes, grasshoppers, locusts. Fleas, lice, and flies are very numerous; there are large wasps and venomous spiders also.

Native barter consists of sleeping mats, baskets, female dresses, native cloth, fishing lines, and implements of war. With foreigners, pigs, fowls, and yams are given in exchange for fire-arms, powder, ball, axes, fishhooks, beads, \&c. As many as 5,000 pigs have been taken from the island in one year by two traders. 


\section{CHAPTER XII.}

VATE, OR SANDWICH ISLAND-NEW HEBRIDES.

(AUgust 16 то 18.)

A Day at Eramanga - Stop at the Port of Vila - Anchor in Havannah Harbour-The Dayspring again-Costumes of the Natives-Excursion in the Island-Dwellings-Fisherwomen-Cannibalism-Decrease of Population-Language-Gorernment-Customs-Artistic Skill-Creeds-Teachers and their extravagant Tales-Products.

ON August 13 the 'Curaçoa' stood off from Tanna, bending its course towards Eramanga, which it reached the same day before nightfall. We passed the 14th off this island, celebrated for its massacres of missionaries and settlers, to which we shall take another opportunity of referring.

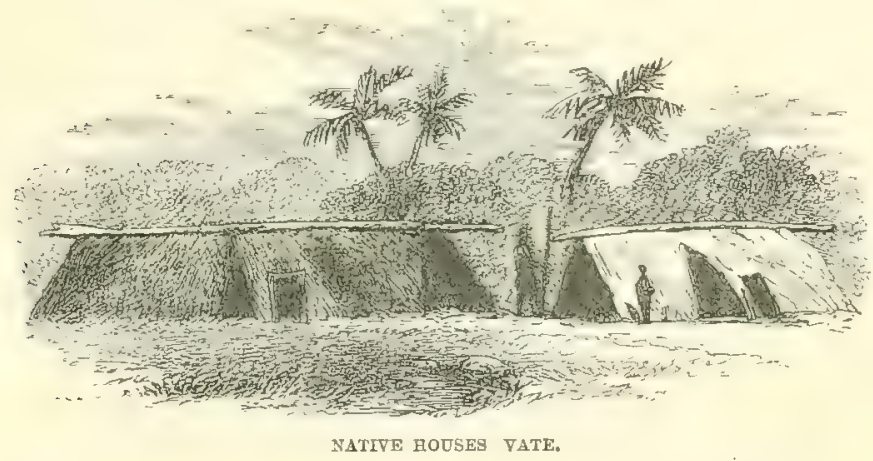

On the 15th we left Eramanga for the island of Vate, where we came to anchor, on the 16th, at Malapoa Point, in the port of Vila. 
The next day, at half-past seven A.M., we were off again for IIavannah Harbour, situated some thirty miles to the northward. As soon as we had got sufficiently clear of the const, we took advantage of a fivourable breeze to hoist sail; the Missionaries' brigantine, 'Dayspring,' being in company with us. The island of Vate, high abore the sea and of an irregular surface, was distinguished by some fine bold features. We could see high mountains whose summits seemed clad with verdure, while the thick woods

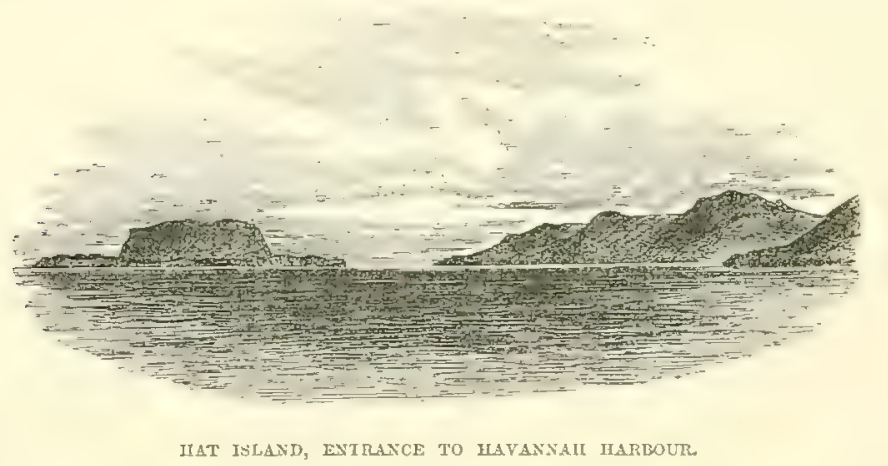

towards their base formed, as it were, a girdle which spread downwards as far as the beach. We were soom obliged to get up our steam again in, order to round Hat Island, so called from its rough resemblance to the article from which it borrows its name. At midday, having reached the entrance into the port, we passed between Protection and Deception Islets, and afterwards before a small island covered with verdure and looking like an ancient crater. At half-past one P.M. we dropped anchor in twenty-two fathoms, in Havannah Harbour, which is extensive and deep, stretching for a considerable distance inland, thus affording 
a most safe anchorage, and being at the same time a most picturesque spot; the finest harbour, in a word, of this charming island, which has many excellent ones.

The 'Dayspring,' which had not the advantage of steam to help her on against the north-easter, did not arrive until four o'clock. She is a good sailer, and a smart little craft, painted all white, of 150 tons, built at Halifax, Nova Scotia, with accommodation for eighteen passengers. Her crew was composed of natives of the South Seas, belonging principally to the island of Vate. She is the property of the Preshyterian society of Malifax missions, which supplies missionaries to the New Hebrides.

The 'Curaçoa' was soon surrounded by several small canoes, ill made, having outriggers dipping at their ends, and fastened by three wooden cross pieces. The men on board these frail craft were remarkable for their ugliness. Their whole attire consisted of a maro, attached to a wide yellow belt made of bark or grass matting, with white and black patterns in it. Their hair was tied in a lump behind their head, and formed, as it were, a bundle of wool, surmounted, in some of them, by a wooden stick or ornament, in others by the long points of crabs' claws hanging from either side of the head. For earrings they had small sticks or shells, according to each man's fancy. Many of them had the cartilage of their noses transfixed for the purpose of inserting ornaments, which consisted, for the most part, of small round pieces of wood. Many had a large, round, flat piece of shell suspended from their necks, the upper side 
resembling mother-of-pearl. Several of them presented the remarkable peculiarity of having breasts, which appeared as large and full as those of many women. The majority of the women whom I saw afterwards wore pretty nearly the same ornaments as the men.

There came, subsequently, in a raised whale-boat schoonerrigged, with a crew of native boatmen, a German, who was trading in sandal wood on account of Mr. Underwood, of Whale Island, near Anatom. This person spoke as to the good disposition of the natives, and assured us we might land without apprehending the least molestation from them. But, in spite of this, we thought it more prudent to wait until the next day before attempting to explore the island.

At dawn I went on board the 'Dayspring, where the Rev. Mr. Morrison, the Eramanga missionary, was so obliging as to put at my disposal two native guides who spoke a little English. I left, accompanied by Messrs. Veitch and Brazier. The Commodore, who had some misgivings as to the appetite of the cannibals, would not permit Wall's and Brazier's boys to go with me, on the ground that this young flesh was too tempting. They were not indeed without anxiety on board the 'Dayspring,' so much so that the Missionaries would retain as hostage the chief of the district which I proposed to visit. We landed at about a mile below the spot pointed out to us as the sandal wood station. Scarcely were we on our way before eight natives were on our track; luckily they gave signs of friendly feeling, besides which their number was, of their 
own accord, soon lessened by one-half. The paths leading into the interior were very narrow. That which we took was partially barred by a split cocoa-nut leaf, fixed across two sticks stuck in the ground, which we were given to understand was a public notice that the cocoa-nut trees were tabu. We passed over ground covered with high reed grass and wild sugar-canes some ten feet high. We hat soon to cross a river that flowed on with its clear waters, and which, seen from the bank, appeared of great depth, though in reality not more than one foot deep. We perceived a great number of huts as well as plantations of banana trees. But few birds were to be seen, and these so timid that they would not suffer us to approach within gun shot. One, however, I did shoot which was perching on a large tree; it was a honey-sucking parrot, with a long tongue, short, red, and yellow beak, and plumage of blue, red, black, yellow, and green mixed. I also saw some swifts and swallows. Cocon-nut trees abound in great numbers around the huts, and we were liberally presented with their fruit for our refreshment. There were also papaus and two kinds of bananas, one with small fruit and another with larger. I constantly came upon a plant which first appeared to be the ava, but which, on close inspection, I found to be something quite different. Ferns were few, and I saw but a single species which was arborescent, and this had at its base pulu or coarse down. There were several beautiful crotons with their variegated foliage, bright with green, yellow, and red. 
The paths appeared to be constantly returning upon themselves, and we were always finding ourselves nearly at the same spot; so much so, that I began to think that it would be extremely difficult for us to retrace our steps, had we not the sun and mountains for our guiding points. We found large banyan trees with their adventitious roots hanging down to the earth, and on which were hung quantities of yams, for the purpose, I conjecture, of saving them from the ravages of the pigs which were running about everywhere in considerable numbers. There must also be some of these animals in a wild state, if I may so judge from some sixty lower jaws with long tusks, which I saw arranged upon a fence along with six jaws of porpoises, and two skulls upon two points of the fence, which were no doubt the relics of a cannibal feast. In one place I observed some twenty posts, from ten to twelve feet high and about fourteen inches in diameter, placed in a circle a foot distant from each other. In the centre there was one larger than the others, on which was rudely sculptured a man's face. These posts were hollowed out from eighteen inches to two feet in length, so as to be sonorous when they were struck; and this is the use they are put to by the natives, who come and dance around them, of which the worn-out appearance of the turf about them was proof. ${ }^{1}$

1 At Vate, Erskine was received in a building 100 feet by 28, in which the interior of the roof was concealed by the bunches of bones hanging from the rafters: "they were of all descriptions-vertebri of pigs, or points of their tails, clusters of merry-bones of fowls, bones of every 
The ground was covered with a great deal of dust, and had almost everywhere a slaty tint; the soil seemed to me of good depth and rich. No rocks or stones were to be seen anywhere except in the bed of the river; about the huts the ground was carefully swept, and not a particle of herbage of any kind was to be seen within a certain distance of them. We passed near two of the chiefs' houses, one of them having an arched roof, in which he kept his pigs. Wherever we came upon huts we found numbers of people, attracted by curiosity for the most part, with whom I had some barter, and from whom I obtained for a few beads some fine round-shaped shells coming from the watercourses. The huts in general are open all round, but as the roof has such a very low pitch, in order to get in beneath it I was obliged to crawl on my hands and knees; occasionally we met with some standing in the midst of little inclosures prettily shut in by a fence of wild sugar-cane. Around the fields under cultivation the fences are sometimes nine or ten feet high. We everywhere saw an endless amount of dogs, and regular curs they were. From a small nest that I found in the shape of a full-blown rose, I had proof of the existence of a species of hornet in this island.

We came upon a group of a dozen men armed with spears, clubs, hatehets or tomahawks with long handles, variety of birds and fishes, intermingled with water-shells and sharksfins. No human bones were recognised. The origin of this curious custom could not be ascertained; but that it is still in full vigour is evident from the fact that a traffic in these bones is carried on, not only within the island but with the adjacent ones.' 
and bows with arrows slightly made, and with poisoned points.

Besides being tattooed, and having their noses and ears pierced to admit shell ornaments, they wore round their arms above the elbow very pretty armlets made of dises of shell ground into the shapes required, black and white disposed alternately. They were often so tight upon the arm that neither I nor the wearers could remove them. 'Garters of a green leaf were often tied tight round the leg under the knee; and in one or two instances the crisp hair, which was in general of a moderate length, was gathered up into a large topknot coloured yellow by lime, and a neat plume of cock's feathers attached to the scratching pin inserted in it.' 1 Their bows and arrows 'were of beautiful designs, the heads being either carved with barbs resembling the finest Gothic work, or composed of several prongs (which they told us were poisoned), and kept wrapped up in banana leaves, inserted in sockets prettily ornamented with red and white plaited cord, and decorated with a bunch of cock's feathers." ${ }^{2}$ It is evident that in artistic skill and taste they are not deficient. They consented to part with some of their arms for a tritle; their bows were not strongly marle, and the strings were thick but not strong; the bottom of the arrow is made without

I Erskine, p. 325. Murray cites this and other of Erskine's descriptions, which he says are exact, in his 'Missions to Western Polynesia,' p. 226.

2 Ibid. 
Frontispiece

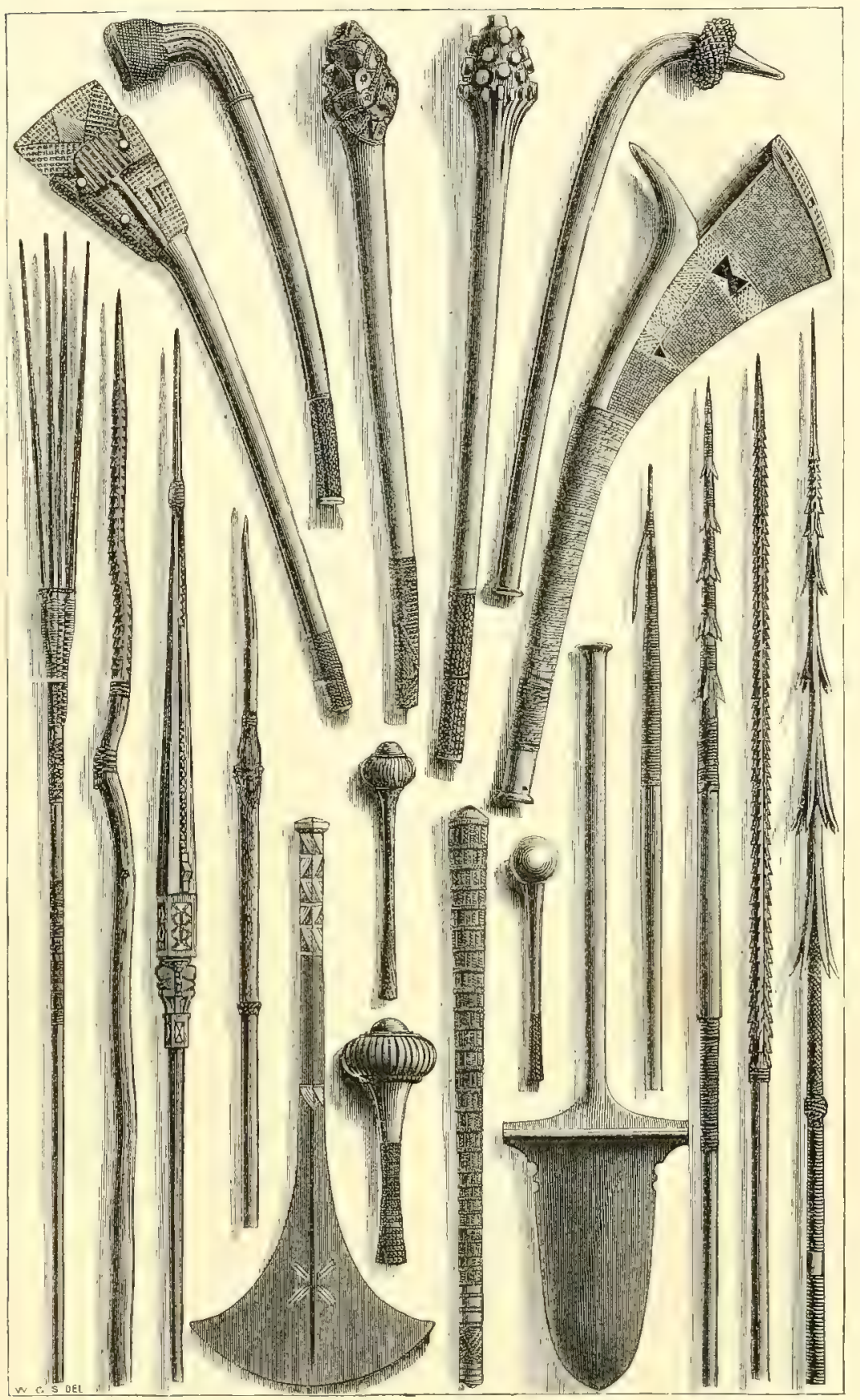

WEAPONS, SOUTH SEA ISLANDS, 

a notch; and they are therefore in the habit of resting them upon a knot in the string. It appears that the district from which these men came is but ill furnished with firearms, but towards the point of the bay weapons of foreign manufacture are less rare.

Under engagement to take back my guides to the 'Dayspring,' which was to sail at midday, I was obliged, to my great regret, to put an end to my excursion. On returning to the beach we found it crowded with women just returned from fishing, and bearing baskets full of mollusks and crabs. These women appeared as civil, good-humoured, and as well disposed as the men; they were for the most part sitting on their haunches on the sand, with their knees up, and their legs wide apart. A fine-grown plump young woman, not so dark as the others, seemed to have some sense of modesty; she turned her side towards me, and covered her breast with her hands. Excepting this one, they were all very ugly, with short curly hair, pendent breasts, and thin spare legs. They had nothing wherewith to cover their nakedness save a narrow strip of maro; some of them had merely their thighs wrapped up in a piece of stuff or tapa, which was tinted yellow by a sort of ochre. ${ }^{1}$

I returned with my two guides to the 'Dayspring." The Rev. Mr. Paton, whom I met there, made me a present of

1 In addition to this, they sometimes have depending from the belt a broad strip of worked grass matting, expanding at the end into a fringe a foot and a half long, and reaching to the calf of the leg, looking very much like a tail.-Erskine, p. 332, where there is a woodcut representing this appendage. I bave some specimens of it in my collection. 
the skull of a native who had been killed and eaten some few years ago here after the following fashion. Four men of Vila Island, New Hebrides, of the Fal tribe, came over to Vate or Sandwich Island by invitation. The next morning one of the Vate men (the coast men or fishermen) called out to his unsuspecting guests from the beach, who had never seen a ship, 'Ship oh!" or 'Sail oh!' in their language, when they in their eagerness to sce the ship, and little suspecting the treachery of their hosts, rushed out without their arms, and were immediately attacked and clubbed, with the exception of one who succeeded in getting off. A new banquet was now got up, the three victims of this piece of treachery supplying the material, and it is the skull of one of these that is now in my possession, showing distinct traces of two blows from a club.

The chief, who was detained as hostage during my little tour, paid a visit to the 'Curaçoa' in company with several other chiefs, one of whom had been on board the "Dayspring' while we were bombarding Port Resolution; and he gave such a highly-excited account of it, that they had all of them the appearance of being thoroughly intimidated. When he had concluded, they bound themselves by oath for ever henceforth to respect the life and property of British subjects. They said with great simplicity that they had seen many ships of war before, but they were very far from conceiving that any one of them could contain so many men, show itself so formidable, and cause such terrible ravage. 
In conformity with the desire expressed by the chiefs, the Missionaries of the 'Dayspring' left two native teachers in the isle of Vate whom they had trained in their schools.

This island was named by Captain Cook, who discovered it in 1774, Sandwich Island; the natives call it Vate, or Fate, or sometimes Efat. It is from thirty to thirty-five miles long, and about half that in width : it is subject to frequent shocks of earthquake, which are sometimes tolerably violent; in the year 1864 there were as many as six sharp ones. The soil is of remarkable fertility.

Nothing positive is known respecting the amount of population, which is variously computed at from ten to twenty thousand inhabitauts, distributed in some sixty villages, more than half of which are on the coast. The climate, without being precisely unlealthy, is tolerably damp; but there is no assignable cause for the decrease of population reported by the only missionary and white man who has hitherto lived in the island. According to his calculation, in 1864, it would appear that a tenth of the population had died in the village where he lived, but this amount exceeds the average; it secms, however, certain that the deaths are always in excess of the births. Influenza constantly occurs; in 1861 the island was severely scourged by an epidemic attack of measles accompanied with dysentery:

- The language has a great affinity to those of the neighbouring islands. It is said there are three distinct dialects, one of them spoken in the isles of File, Mele, and the adjacent islets, another all round the coast, and a third in 
the interior; the coast dialect is the best known, and is simpler in construction than the languages of the southern isles of the group; as in English the subject comes first, then the verb, and then the object.

The government is more in the hands of elected than hereditary chiefs, the right of governing being by common consent assignied to the most influential of the tribe. In general, each village is independent in itself, and possesses a council of petty chiefs, whose principal business it is to accept or modify more or less the decisions of the head chief.

The people of Vate pass for being eminently cruel and savage. Their taste for human flesh is perhaps more decided than it is anywhere else, since it leads them to violate the graves of their enemies, in order to carry off dead bodies, after being some days buried, in order to bake and eat them. When one of two fighting parties feels it has had enough of it, and wants peace, it puts to death one of its own people and offers him to the enemy, who accepts or rejects the offer, accordingly as the corpse is in a more or less tempting condition. Polygamy exists; in general, the woman will not consent to rear more than two or three children; beyond this number the newborn infant is instantly thrown into a hole dug for the purpose. This execrable practice is more the act of the woman than the man, for there are cases where husbands oppose it, and require that their wives should either suckle their intended victims, or transfer them to persons disposed to adopt them. 
Such is the account I received on the spot, which however, there is great reason, as is usual in these dark portraits of uncivilised people, to believe is greatly exaggerated.

In the 'Samoan Reporter' for September 1845, the Rev. Mr. Turner, of the London Mission, says of the people of Vate, "They are upon the whole the most inviting heathens we have seen, though polygamy abounded, and the burden of manual labour devolving on the woman, she never rears more than two or three children, burying them alive as soon as they are born.' He also describes the wars between the tribes as anything but sanguinary. But, in the year 1849, Mr. Hardie, who was there in order to remove the teachers, gave on their authority an unfavourable account of them, and described them as cruel and gluttonous cannibals. Erskine, ${ }^{1}$ however, who notices these somewhat opposite statements, expresses his regret at not being able to make a longer stay among them, as the little opportunity he had of judging impressed him in their favour. It may be observed in support of this view, that the missionary Murray ${ }^{2}$ gives us an extract from a report by himself and Hardie, purporting to be a story told by the teachers (natives of other islands) of their miraculous deliverance on a certain evening, which is by no means of a nature to make us place any reliance on the statements on which Mr. Hardie founds his opinion.

It is an account of a visit paid them by a number of 1 Erskine, p. 334.

2 'Mission in Western Polynesia,' p. 244. 
' armed men' from a neighbouring village on the coast, who came with the design of murdering and robbing them. They reach the mission house at night, rouse up the teachers, and, though they are thirty in number, make the singular request that the teachers would come out and help them to pull the canoe out of the water, meaning, as soon is they got them outside the house, to despatch them; a singular intention, seeing that if the village were aroused they would certainly be captured and destroyed, and that the best chance of effecting their murder would be within the house. Providentially (for this is the gist of the narrative) the teachers declined to comply with the request, but for a rather mysterious reason, namely, that it was 'not agreeable to their notions of propriety.' So, apparently forgetting their boat, they all went to sleep quietly under the teachers' roof, and breakfasted with them the next morning. This over, the day, it seems, was spent by the guests in waiting for an opportunity to take their hosts unawares; the teachers however, for some reason or other, refused to be lured out; why is not explained, but it could hardly be from any suspicion, otherwise they would have alarmed the village, and thus got rid of their visitors by vulgar human means.

At length the day closed in, and these 'savage men' all went in to the teachers' house with their hatchets, and, it being the hour of prayer, they all sat down with the family to worship. One of them, however, keeping his hatchet over his shoulder, placed himself opposite the teacher con- 
ducting the service; and declined; on being requested, to lower it. The teachers now began to be alarmed, and kept a sharp look-out; presently the savages rose, and lifted up their hatchets; "but their hands trembled, and their hearts failed them '-they felt the teachers were looking at them. The service went on, and again the savages made a move as before, but 'again their hands trembled, and their hearts failed them.' Now came the teachers' turn to bully. Closing the prayer abruptly they peremptorily ordered the savages out of the house; the latter asked to remain, but on the teachers rising from their knees, and insisting on their going, "they then all rushed out of the door, and shutting it after them, made for their canoes, and were seen no more.' Such is the galimatias, which is called by Mr. Murray and his friend ' a remarkable deliverance,' 'a miraculous deliverance,' 'a merciful interposition of the Lord.' But there is a sort of appendix to the story which must not be omitted. It seems that on these fellows going back to their villages, and reporting with much disappointment their failure, the people of an adjoining district laughed at them, and determined to succeed in the same venture; with this purpose they set off in three canoes, and with sixty men, but on their way were overtaken by a tempest, which dashed their canoes to pieces, and compelled them to trudge back by land, though they had got two-thirds on their way. The opinion of Messrs. Murray and Hardie is, that the teachers referred their deliverance to the right cause, when they said, 'God alone saved us.' It is clearly not to such men we 
must apply, if we would know the real facts respecting these native populations, whose character no doubt frequently suffers from that sort of misrepresentation, which is one of the forms of a species of deception well known to history by the name of "pious fraud.'

There is scarcely anything ascertained respecting the religion of these islander's, save that they believé in another life; that they adore two divinities, Manitikitiki and Tamakaia, whom they regard as the creators of all things; that they have no idols, and involie the spirits of the dead; that they place the other world in the west, and give it the name of Lakinatoto Like the natives of the other islands, belonging to the New Hebrides, they attribute diseases and death to the occult power of sorcerers, who are, probably, in point of fact, no other than their priests. No sooner is a man taken somewhat seriously ill than the first thing he does is to try to ascertain who can be the cause of his indisposition, and as soon as he has discovered this, he eudeavours to appease him by presents, in the hope that he will conjure away the evil he has laid upon him; and as there are always plenty of people ready to tum this credulity to account, there never is much difficulty in finding some one who will make himself responsible for the cliarm.

It was about the end of the year 1845 that some natives of the Samoan group came and tried to sow the first seeds of Christianity among these Vate savages. Up to nearly the time of our visit these teachers had maintained their ground in the face of all sorts of difficulties, and it was but recently 
that a white missionary had come to their assistance. A village named Frukor has become entirely Christian, and another village is spoken of which seems inclined to do so; but with these two exceptions, the whole island is under the yoke of its religion. The unconverted majority are (it is of course asserted) very depraved, giving themselves up to all sorts of immoralities, besides the barbarous customs we have already mentioned, such as cannibalism and the making away with old men and children. In the Christian village these abominable practices and vices have, for the most part, disappeared, and the Missionary affirms that his property is fully respected. ${ }^{1}$

There are to be found at present in the island, pigs, goats, dogs, cats, rats, bats, flying-foxes, and tortoises. There are three species of lizards and a harmless snake about two feet long, of a brownish colour, and very heavy in his movements. There are two kinds of pigeons, hawks, owls, and a considerable variety of small singing birds. Turkeys and barndoor fowls have been introduced. Among the fish of every sort of shape which are caught at Vate some are venomous, but the greater part are fit for food. There are also sea-crabs and land-crabs, the common pearl oyster, and other kinds of this mollusk. Of insects there is a large variety.

Two species of the cocoa-nut tree, the sago palm, and bread-fruit tree, the papan, a large horse chesnut, the coffee plant, and various nut trees, supply the uatives with

1 As usual-black yesterday, white to-day. 
food; as also the yam, the common taro, water melons, pumpkins, cabbage, bananas, and plantains. There is a tree, the leaf of which is used as a vegetable; and a large species of taro, to which the natives have recourse whenever there happens to be a scarcity of other food. There is, it is said, a great variety of ferns, some of which are of unusual beauty. The articles offered or obtained in barter are, on the one hand, mats, baskets, yams, taro, pigs, dogs, native arms; on the other, clothes, pipes, tobacco, muskets powder, lead, beads, knives, \&c. 


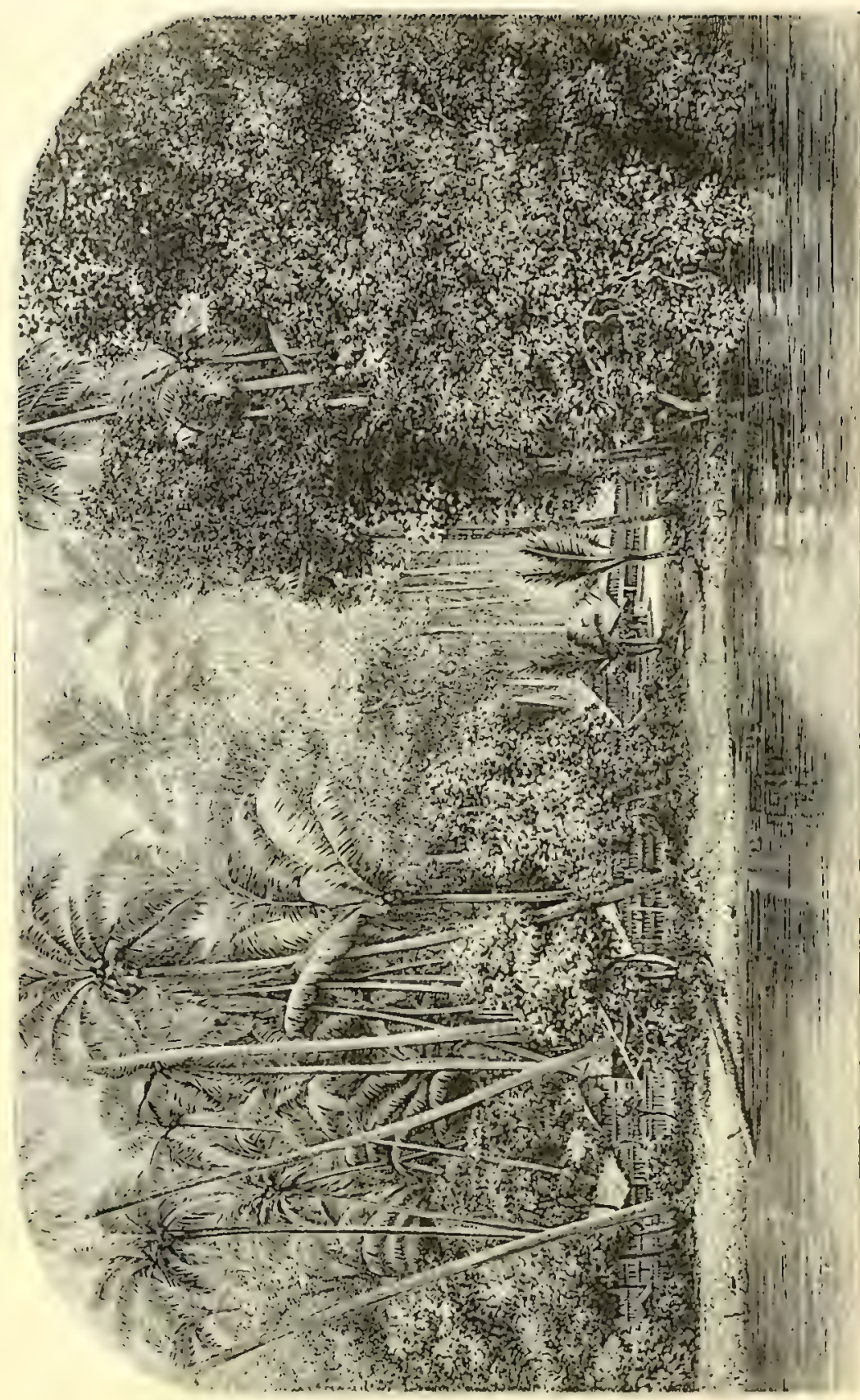




\section{CHAPTER XIIT.}

\section{VANUA-LATA-BANKS' ISTANDS.}

(AUGUST 21 то 23.)

Through the Northernmost Islands of the New Hebrides-Uneertain Navigation-Port Patteson-The 'Southern Cross' and Bishop Patteson-Appearance of the Natives-Trip in the Island-Vegetation-Dwellings and Club House-River of Hot Water-Jets of Vapour-Eggs of MegapodiusCustoms-Clinate.

Or August 18, about four P.M., we steamed out of Havannah Harbour, laying our course for Banks' Islands, while the 'Dayspring' took an opposite course on her return with some Missionaries to the Port of Vila. The 'Curaçoa's' direction enabled us to see on our starboard side Hinchinbrook Island in the distance, and further on still Api Island. She then entered the channel, having on its east side Paum and Ambrym Islands, and on its west the great Island of Malicolo, which we next morning neared more than was necessary, because the Commodore, having given up the intention of stopping there, wished to give us a sight of it. Passing by Port Sandwich, near its south-eastern extremity, with a fair and rather fresh breeze we reached Espiritu-Santo, the largest and most northern of the New Hebrides, and whose mountains were wrapped in mist. We had thus passed through the whole length of the New Heb- 
rides, the islands of which are all elevated, and which present, so it struck me, landscapes much prettier and more striking than those of all the other islands we had seen, without excepting even those of Fiji. The want of good charts for these seas, combined with the impossibility of taking any observation on account of the mistiness of the atmosphere, caused us to mistake the island of Vanua-Lava for another island, and so to pass it, by which we lost nearly a day.

'The islands, composing Banks' group, in the midst of which we were then sailing, appeared to me to be high and mountainous, like those of the larger groups we had

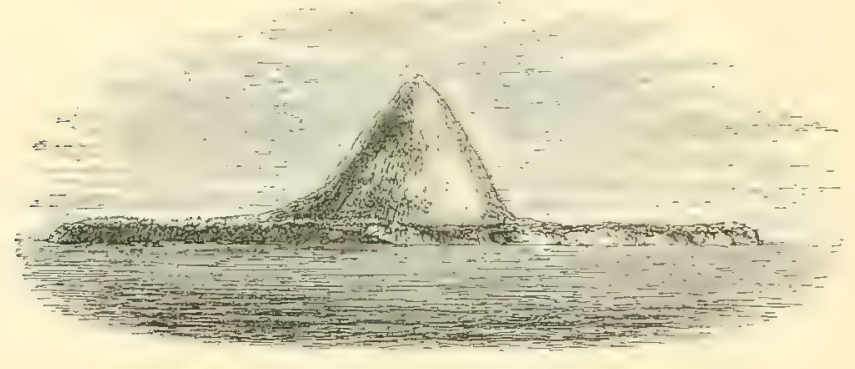

MOTA, OR SUGAR-LONE ISLAND.

just quitted. We approached Bligh Island near enough to get a distinct view of it. We saw Sugar-loaf Island, the fine cone of which resting on a table-land presented a spectacle as curious as striking. On August 21, towards half-past three P.M., after having turned Low Island, we dropped anchor in eleven fathoms in the port of Vanua-Lava, called Port Patteson in honour of the judge of that name, the father of the missionary bishop. The 'Southern Cross,' the same schooner we had met with at the beginning of our cruise, and which the Commodore had appointed to meet 
him on August 20, anticipated our arrival by a whole week. The bishop, who was on board of her, immediately paid a visit to the 'Curaçoa,' accompanied by Commander Tilley; R.N., who had obtained four years' leave to occupy himself with the hydrography of these and other islands of these seas. A thick fog so obscured the light as to prevent our. having a distinct view of the mountains by which this fine port is environed. After our arrival we met with an accident which we regarded as a positive disaster for our stomachs, and all the more su, as proceeding north we were every day getting nearer the focus of heat, - the icemachine which had made us so happy came to grief in the steward's hands, thus putting an end to the cool beverages to which we had been so much accustomed.

Several canoes filled with men only came paddling around the ship. They were completely naked, without a maro, without even the slightest rag of covering, so that we could very distinctly perceive that they did not practise circumcision. They were entirely unarmed, and appeared quiet and inoffensive. They made the sailors understand that they were very desirous to have empty bottles, which they seemed to prize beyond anything. Their canoes are short and heary, wide and deep, larger than those of the New Hebrides, and like the latter fitted with an outrigger.

The day after our arrival, early in the morning, I went, accompanied by Mr. Veitch and Brazier on board the 'Southern Cross,' to take up Bishop Patteson, who, with his usual kindness, had been good enough to offer to pilot us 
into the interior of the island. This model of missionary bishops had apprised me I should find the natives not only inoffensive but kindly disposed, and I feel a sincere pleasure in at once declaring that his anticipations were fully sustained by the facts. At his request three natives served us both as guides and an escort. We had hardly advanced a few steps before we were obliged to cross a small stream, into whose sandy bottom I sank up to my middle. I picked out of the sand a pretty little mussel of a deep green, and a curious thing with back and legs of a crustaceous character and with a long back terminating in a point, and which might probably be some of the parasites peculiar to fish; then on the banks of the stream I gathered some insects, two lizards, two centipedes, some land shells, and a small species of fresh water mussel. We then walked along the beach for a mile and a half upon a sandy soil, without the sign of a stone, which extended to a neighbouring forest, into which we plunged under high pandanus trees laden with their golden globe-shaped fruit. The soil was here and there thickly covered with a square fruit rising to a point, resembling a priest's cap. We trod, as we walked, upon ferns quite new to me, one species of which had a rounded frond with a fruiting spike in the centre. We saw a tree which bore very nice egg-shaped fruit of a deep purple when ripe, containing a hard stone surrounded by a pulp, and enclosing a kernel three or four times larger than our ordinary almonds, and as pleasant to the taste as a young filbert. There was a green 
fruit of the shape of the date, with a round soft kernel, very crisp, and with a slight acidity exceedingly agreeable. We saw on our way large banyan trees, several pretty varieties of crotons all new to me, several sorts of fine bushy trees but of low growth, wild banana trees, an aroid with leaves veined with green, white, and yellow, a bush with wide leaves, and flowers of a fine red massed upon a stalk from twelve to eighteen inches long. There was also a beautiful species of palm with a trunk not more than two inches in diameter having fan-shaped leaves bent down at their outer edge, and bunches of fruit of a fine green, about the size of an ordinary cherry. We passed a group of natives going towards the port, carrying cocoa-nut milk in bamboos of more than an inch in diameter, about four feet long, and ornamented at irregular intervals with narrow and wide green stripes. They had likewise crabs and eels, which I procured from them in exchange for a few trifles.

The rain soon began to fall so heavily that we were in a few minutes wet to the skin. The forest with its drip resembled an immense shower bath, and the soil, of a chocolate colour tending to red, was thoroughly soaked. The path, naturally slippery, was threaded over with roots which made it still more so, while huge creepers and pendent branches of trees scarce three feet from the ground barred the way. Of course our progress was horribly impeded by these obstacles, and nothing could be less pleasant. It was therefore a lucky chance to be able to kill a flying fox 
upon a tree, and two or three little birds, one of which was very pretty with a light yellow breast. We got sight of swallows which looked like those of the New Hebrides. I heard occasionally the notes of small singing birds, but without being able to see them. I picked up a handsome grasshopper, with claws so formidable as to wound $\mathrm{my}$ finger through my glove.

Having reached the middle of the wood, we came upon a village in which the greater part of the huts were shut up, the occupants being out on their business. These huts, low and of a mean appearance, are thatched with wild sugarcane and banana leaves, and have extremely small entrances. There was but a slight amount of cultivation round about the village, and neither cocoa-nut nor banana trees exist in any quantity. The bishop pointed out to me a large building which he called by the name of 'Club house,' seventy-three feet in length by ten feet in width, divided into seven compartments, freely communicating with each other, very cleanly kept, though having no other floor than the soil, while in the centre of each of them was a circular fireplace or oven, from eight to ten inches deep, and eighteen in diameter. Near these ovens were heaps of cocoa-nut husks with which to light their fires by the usual method of rubbing two sticks together, the one being harder than the other. This building, the bishop said, built at the public expense, was intended to receive those who, at certain times, came from all parts of the district on public business; a fact which he thought rather tended to prove 
the correctness of what is asserted, that they do not acknowledge such an institution as a government by autocratic chiefs. I was also informed that this club house was the smallest of several others that are to be found in the island.

At this spot I procured by barter bows and poisoned arrows, some rather pretty fresh-water dead shells, and other curiosities besides. I observed in a hut a number of pieces of wood made in the shape of cutlasses, which these people make use of for cutting up the yams and other roots used in their cookery. Inside several of these huts I saw old women with skinny pendent breasts, who, when they perceived I was observing them, seemed to show a feeling of shame, and lowered their hands to cover their nakedness, which was very ineffectually concealed by a girdle of only an inch wide. I observed, however, a well-made young woman who had not even this thread around her, but who, as she stood, supported without the least embarrassment our gaze.

On returning to the beach, the rain still at times pouring down in torrents, we had to cross another river about thirty yards wide, the water of which was limpid and impregnated with sulphur, and which as I forded it reached my chin. I did not remark, though others had been struck with it, that the water of this river was warm; but that some of these streams are hot was confirmed by what Brazier told we whom I had sent up the mountain, and who, as he went along, fell in with a river at a point where it was rolling on with great swiftness, and so very 
hot he could not keep his hand in it. Another opportunity: gave us, what we thought, conclusive proof of the existence of hot springs in this locality. The next morning, the sky being beautifully clear and bright, we pereeived an enormous quantity of vapour escaping from a large hole or perhaps crater, situated in a gorge of the mountain. It

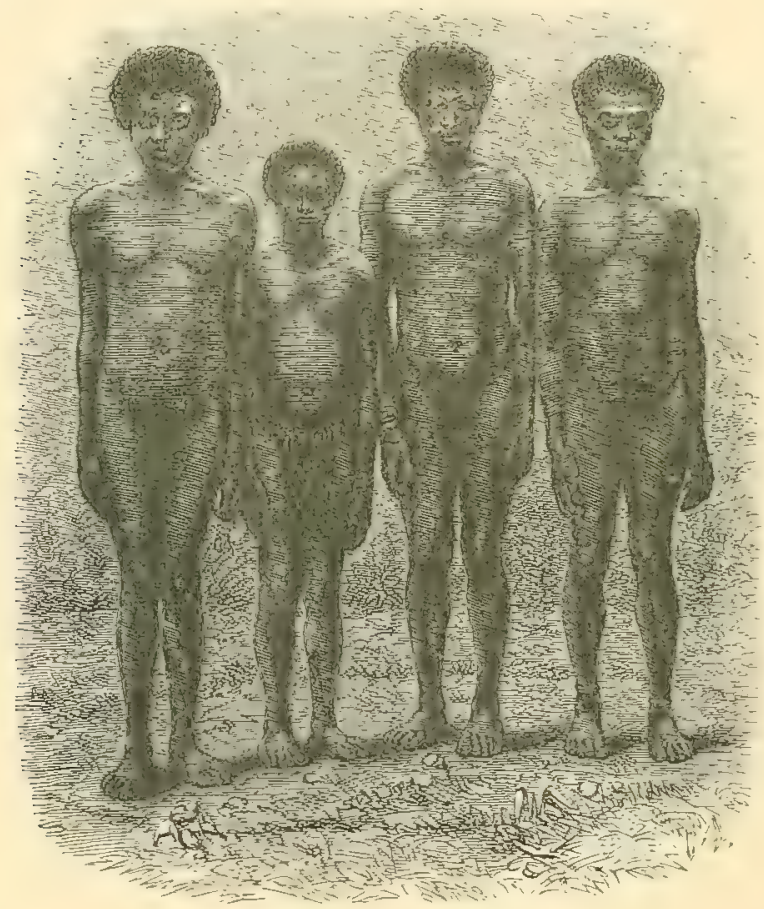

NATIVES OF BANKS ISLANDS.

roiled upwards in great clouds, and so rapidly as to imply the presence of a vast rescrvoir of hot water. Beyond this jet of vapour, and higher up in the mountain, we saw another which was very like it.

The natives brought me three large eggs of a bird which 
lives in the vicinity of these hot waters, that Wall was of opinion belonged to the genus Megapodius. These eggs, of much greater length than width, and pretty nearly the same size at either end, were of a pinkish tint; they reminded me that when at the island of Vate, at the Christian village where Mr. Morrison lived, a native offered me two eggs exactly similar, which I declined from fear of breaking them. I have heard that a large bird is to be found also in the neighbourhood of the volcano of Tanna.

The natives of Vanua-Lava are better featured, not so ugly, so dark, nor so savage-looking, as those of some of the New Hebrides. Their hair gives you the impression of a bundle of wool on the top of their heads. They were very friendly, and seemed to be living on very good terms with each other; but it is stated that a good deal of fighting goes on among them, on which occasions they still make use of their hereditary weapons, ours being unknown to them. They have neither chiefs nor government of any sort, so it is said; it is the natural chief, the father of the family, who cares for and directs his household as seems good to him. The natives are polygamists, and appear jealous of their wives; it is positively asserted they are not cannibals.

Bishop Patteson is of opinion that the population does not exceed 800 souls in this comparatively large island, while in Sugar-loaf Island he supposes there are 10,000. The climate of Vanua-Lava, owing doubtless to the marshes which extend from the sea to the foot of the mountains, is 
unwholesome. Intermittent fever, or fever and ague, is prevalent, at which I am not at all surprised after seeing the natives, who accompanied us, shivering in the rain. The soil is everywhere of a marvellous fertility, and the vegetation most luxuriant.

It was in this island that Bishop Patteson had a year before interred the two young men who died of the wounds received in the island of Santa Cruz, to whom I have referred in the chapter on Norfolk Island. 


\section{CHAPTER XIV. \\ SANTA CRUZ ISLANDS.}

(AUGUST 25.)

Vanikoro Island-Port Graciosa in Santa Cruz-Volcano of TinakoroA Swarm of Canoes-Barter.

Or August 23, a little after midday, the 'Curaçoa' left the island of Vanua-Lava, taking in tow the 'Southern Cross,' which was to accompany her. On our leaving port, Sugarloaf Island seemed to us of a form perfectly different from that which it had when we entered it, as often happens when we look at an object from a new point of view. We bent our course towards the island of Vanikoro, made famous in geographical annals by the fate of Laperouse's expedition. This mountainous island, remarkable for its picturesque beauties, is almost completely surrounded by a recf, the western part of which goes by the name of the Astrolabe and its unfortunate commander. On the morning of August 24 we touched for a moment at the port of Ocili in the island of Vanikoro, in order to pay a species of homage to the memory of the celebrated navigator, and immediately after left this large, deep, well sheltered, and excellent harbour. In veering round, the Commodore ordered 
those guns, which had remained shotted since the affair at Tanna, to be fired off.

Towards evening of the same day we sighted the island of Santa Cruz, otherwise called Nitendi. In the middle of the night the wind began to blow very hard, and, for three hours, the rain fell in such quantities that the ship was as it were swamped, and for my part I had my bed and things completely drenched. At daybreak on August 25 we kept along the east coast of Santa Cruz, then doubled its northern point in order to lay our course to the west, and towards midday found ourselves abreast of Port Graciosa, where

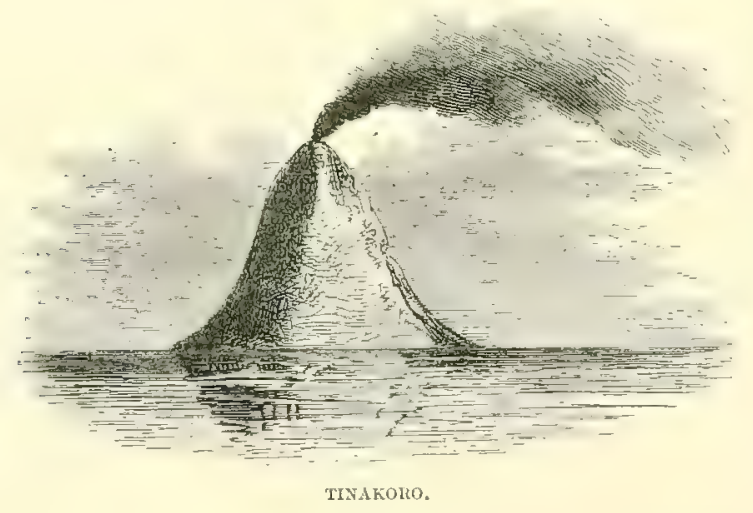

we hove to at a distance of three or four miles from the coast. We were not very far from Tinakoro or Volcano Island, a cone emerging from the sea, the top of which appeared to us to be continuously covered with clonds or smoke, and at times with both at once. We got sight in the distance of some large villages on the coast of Santa Cruz. As we were not to put foot on land, we were apprehensive for a moment that we had come thus far, and yet should not 
get sight of a single inhabitant, but luckily it did not turn out so.

More than a hundred canoes, with a couple of men in each, swarmed round the 'Curaçoa,' bringing all sorts of articles for barter with our crew ; there were bows, arrows, four-sided clubs, painted, fringed, and running up to a point curved up at the end, pretty mats of fine texture, little neat and well ornamented bags, containing small gourds filled with chinam; also poultry, yams, bananas, and cocoanuts.: The swell was so great, that several of the canoes capsized alongside, as it were for our amusement, such accidents being of no consequence to these fellows, who swim like fish. I saw one of them dive down and recover a string of blue beads, very much the colour of the sea.

Their canoes are well made, and with outriggers which differ in their fixings from any thing we had yet seen. There was a kind of wicker platform, which went across the canoe in the centre between the poles of the outriggers. The opening on the top of the canoes was so very narrow, they could barely get a leg into the opening, and therefore sat on the top, one leg before the other.

These savages seem muscular and well made, and have short woolly hair, which they dye yellow with chinam. Their mouths are large, and their teeth are all black from the effect of betel nut, which they chew incessantly; for clothing they have only a maro made probably of bark or tapa, and a girdle very tight round their waist, sometimes of tortoise-shell in narrow bands. All had attached to their 
noses a thick piece of tortoise-shell, which hung down over their lower lips, making them look hideous, especially when they opened their mouths to speak. From their cars were suspended from six to twelve rings, made of large shells, half an inch thick. Their arms above the elbow were decorated with armlets of black and white shells. On

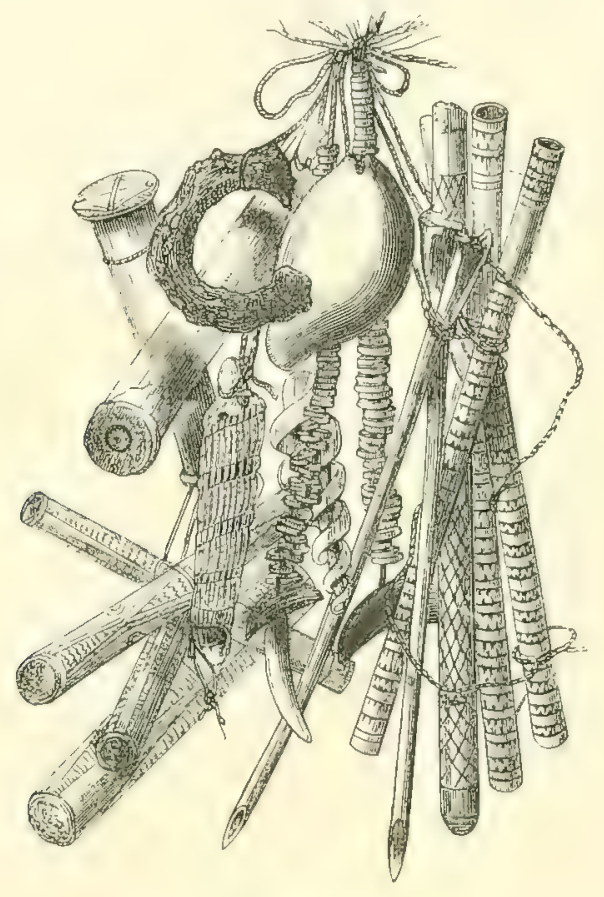

WAR ORNAMEFTSS.

their necks they wore necklaces made of small black and white rings, to which were attached little pieces of mother of pearl. Others had a round shell, black and white cord necklace, and a great many of them the large round mother of pearl shell; some of them wore an eardrop made of sharks' teeth. They rattled on, talking all at once. I did not observe that they were in the least 
tattooed. Iron and beads they seemed to care for more than anything else. Iron hoop cut up into pieces, about seven or eight inches long, was a most marketable article with them. It was amusing to see some of our officers and midshipmen hoisting up things by a rope, and letting down their pieces of iron.

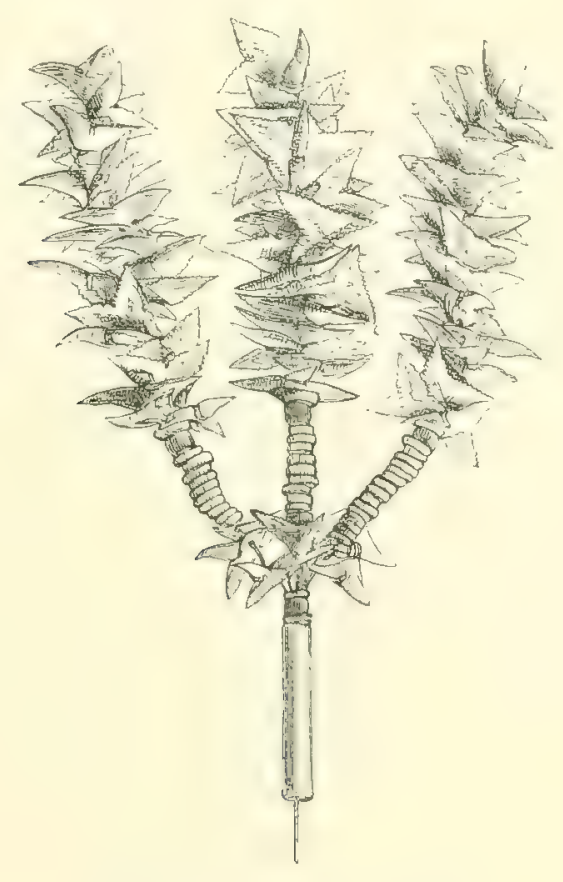

TAR-DROP MADE OF SHARK' TEITI

These natives seemed most excitable people, up in a moment. The men of two canoes alongside had a row together, because they were pushing each other out of their places. One hit the bow of the other's canoe with a club, the latter took up his bow and arrow, and, I think, if the other had pushed his canoe again, he would have shot him. 


\section{CIIAPTER XV. \\ ULAKUA-SOLOMON GROUP.}

(AvGUSt 27 то 29.)

Singular Fact-Island of Santa Anna-Arrive in sight of the Island of Ulakur -Natives and their Canoes-Ornaments and Dress-Trip on Land-HutsWomen-Parrots,

Our stay on the coast of Santa Cruz was very short; reaching it at mid-day, we hoisted sail at 2.20 P.M. and made for the Solomon Islands. Before nightfall, between four and five o'clock, we felt strong vibrations throughout the whole ship, accompanied, as some said, by a rumbling noise. These shakes appeared to follow each other in quick succession; they only lasted a few seconds, but probably they were severe elsewhere. We ascribed them to an action on the bed of the sea, proceeding from the volcano of Tinakoro, from which we were not far distant. Before sunset we had lost sight of the high lands of Santa Cruz. The next day about noon we sighted the little island of Santa Anna, situated at the southern extremity of the Solomon group. Then steering N.N.W. we sailed along the large island of San Christoval.

On August 27, about noon, we arrived near the island of Ulakua, called also Ulana and Contrariétés Island, where 
we had the intention of making a short stay. We found ourselves in more than 100 fathoms with a rocky bottom. In the afternoon, the Commodore sent the master in the life-boat to sound the bay and find an anchorage; he returned before nightfall, reporting he had found twenty-eight fathoms close to land. The Commodore determined to stand off and on the west coast until morning.

On August 28, without letting go anchor, the long boat was lowered, into which many of the officers got, with the intention of landing, taking the 'Southern Cross' in their way, which was at some distance from the 'Curaçoa.' The schooner was surrounded by numbers of canoes, so many indeed that I could count ninety with my own eyes. They were entirely different from anything I had before seen; their two ends were alike, they were without outriggers, and generally carried two, rarely three men; their paddles were short, narrow, with a pointed blade. At each extremity the canoes were ornamented with tassels, made of strips of pandanus leaf dyed red at intervals, and also with motherof-pearl let in in different patterns. Their crews made a great clatter in conducting their barter; thick iron hoop for tomahawks, together with hatchets and fishhooks, seemed the great desiderata; they would scarcely look at my beads, knives, \&c. They were, if possible, more loaded with ornaments and knick-knacks than the natives of Santa Cruz. They have bead-bracelets and armlets, some much wider at the top than bottom, like a gauntlet, and of a great variety of patterns. Armlets of thick solid white shell 
are worn above the elbow, and also thick, massive, white rings one on each arm, varying from half an inch to three and a half inches in width, and so very nicely polished as to imply a good deal of labour in making them. Their nose ornaments, as here figured, include tortoise-shell rings,

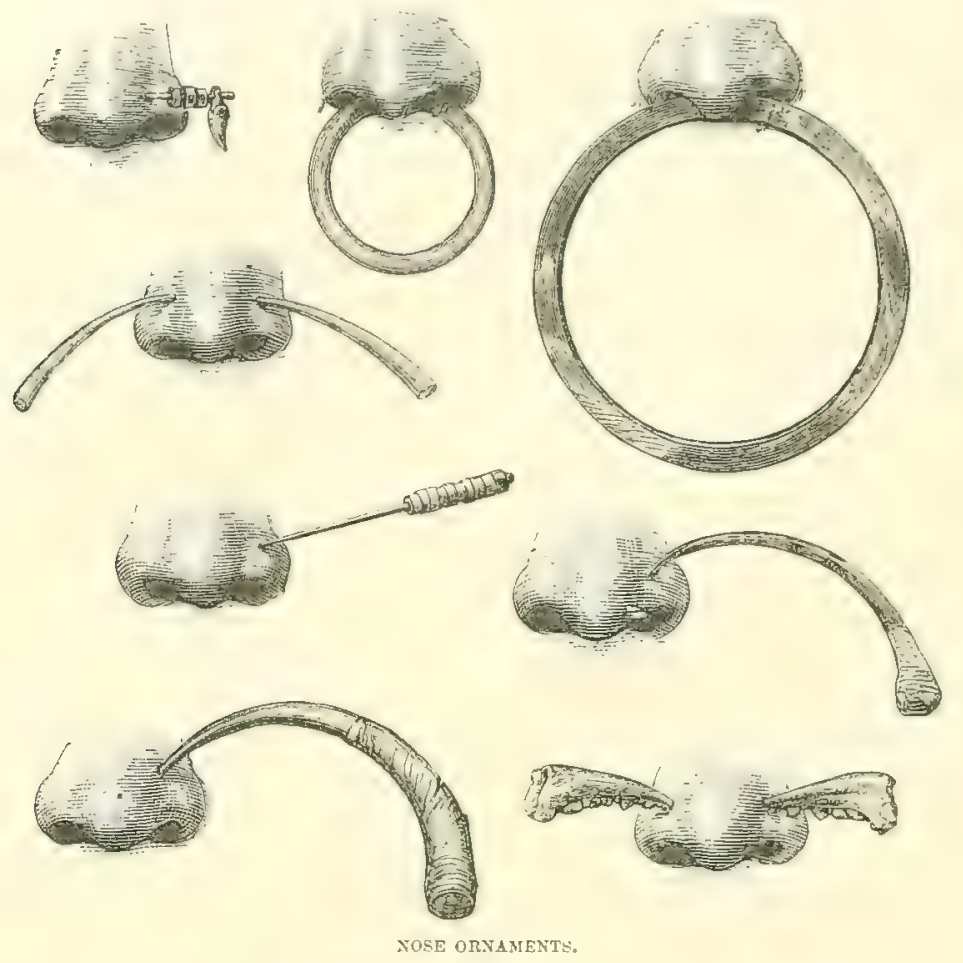

perforating the cartilage of the nostrils, into which are inserted externally pins prettily made with bead handles, ${ }^{1}$ crabs' claws, \&c. ; another variety is figured farther on. ${ }^{2}$ They had also bands of a good sized white shell worn round the head, just above the eyes which they shade; another

1 The ornament in the first figured nostril is a bead-handled pin with a porpoise tooth strung upon it. The one figured below it has a species of Dentalium inserted on either side.

${ }^{2}$ Infra, p. 254. 
sort of shade was made of a fine matting on the forehead, held in its place by fitting tightly round the head. A great number of them wear also necklaces of dogs' teeth and human teeth strung on string. I could never get them to part with one of them for any of my wares. The Commodore offered two muskets for one but could not get it ; fortunately the Bishop got him a very fine one and two small ones. These people seem to have more ingenuity than I have seen elsewhere in these islands. It is noteworthy what a variety of materials, what a diversity of designs exhibiting a remarkable combination of taste and skill, characterise the workmanship of their personal and other ornaments. Shells of various descriptions, corvrie shells, clam shells, mitre shells, a kind of land shell, the Helix tricolor, the Bulimus, mother of pearl shells, seeds, bamboo and woods of different kinds, birds' bones, boars' tusks, sharks' teeth, porpoise teeth, human teeth, and dogs' teeth ; plaited cocoanut fibre or sinnet, banana and pandanus leaves, grasses, feathers of birds, as of cockatoos and parrots. All these materials, ingeniously wrought into different patterns, enter more or less into their necklaces, armlets, ear and nose ornaments, knee ornaments, waist belts, bracelets, \&c. The necklaces are most varied in their designs, some of them being composed of boars' tusks burnt into several pieces, with tortoise-shell figures in the centre representing birds; others of beautifully made rings of black and white shell work, occasionally of black rings made of a kind of seed mixed with red and white shell work, or shell work of different colours, with human teeth as pendants; some of 
them of open shell-rings fastened to a bamboo rib, and others of small mitre shells attached to a cocoa-nut fibre braid; some again of porpoise teeth strung in lumps, with a few
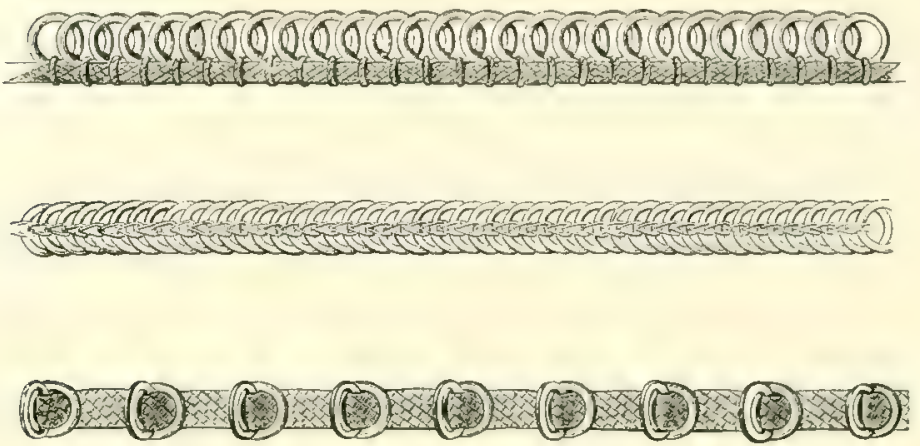

SPICIMENS OF NECET,ACES.

beads at the bottom, or others composed of a piece of shell nicely rounded, from one inch to one and a half in width,
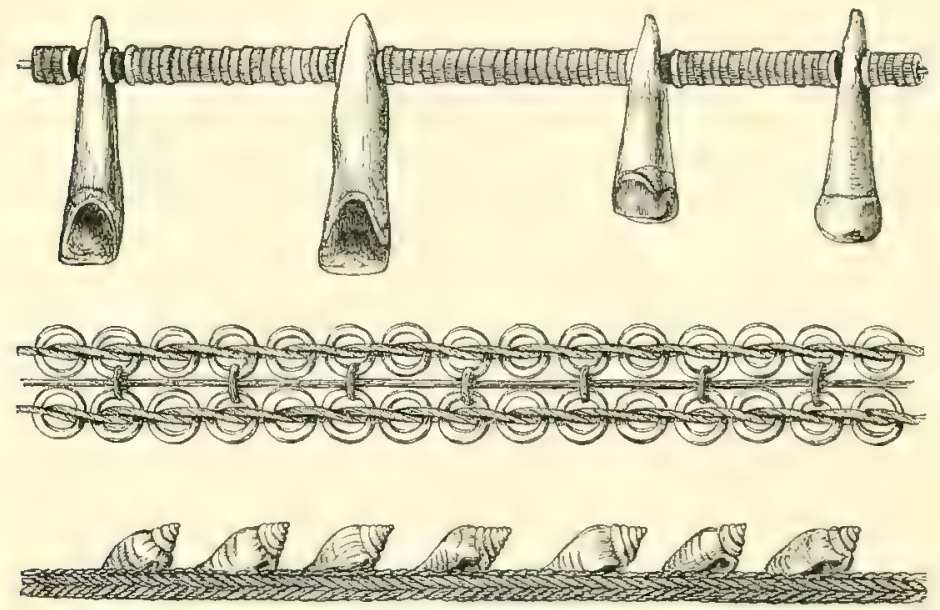

SPECLIEYS OF NECKLACES.

and very white, arranged in patterns sometimes very simple and pretty. Occasionally they have an especial value; such, for instance, as those made of black, red, and white shell 
rings, ten yards of which will in Florida Island purchase a wife; or those that are made of the incisor teeth of dogs, in which form they are so much valued by the natives that it is extremely difficult to procure them, they being handed down from father to son as heir-looms. Sometimes they are made of small disks of shell and human teeth, perforated and strung together upon a thin strip of bamboo, the teeth being placed about an inch apart.

Great attention is paid to the composition of their head ornaments, which exhibit great variety of patterns, forms, and materials. Some of them are made of a piece of thin rounded clam shell, faced with a very thin circle of tortoiseshell beautifully carved, in which form they are worn at the side of the head and cover the ear. They also take the form of frontlets, made of the teeth of porpoises and dogs; of rosettes, made of the red and yellow feathers of the cockatoo and parrot, relieved with ornamental shell work; sornetimes they are made of a kind of red dyed grass affixed to the head by a large comb. Their knee ornaments have a pretty effect, being made of neatly braided dyed grass, of red, black, and white shell work, or of the shells of a kind of nut, which are intended to make a rattling noise in their dances. Their waistbands, armlets, \&c., exhibit the same general character of ornament. Of their ear ornaments, specimens of some varieties of them have been given. But the most remarkable are those made of light or heavy wood of a circular form, and worn in the lobe of the ear. A slit is made in it to which a weight is attached, or pieces of 
wood graclually increasing in size, are inserted in it, until this part of the ear is stretched to so preposterous a size as to admit a disk of $3 \frac{1}{8}$ inches diameter, and $\frac{1}{2}$ to $\frac{7}{4}$ of an inch in
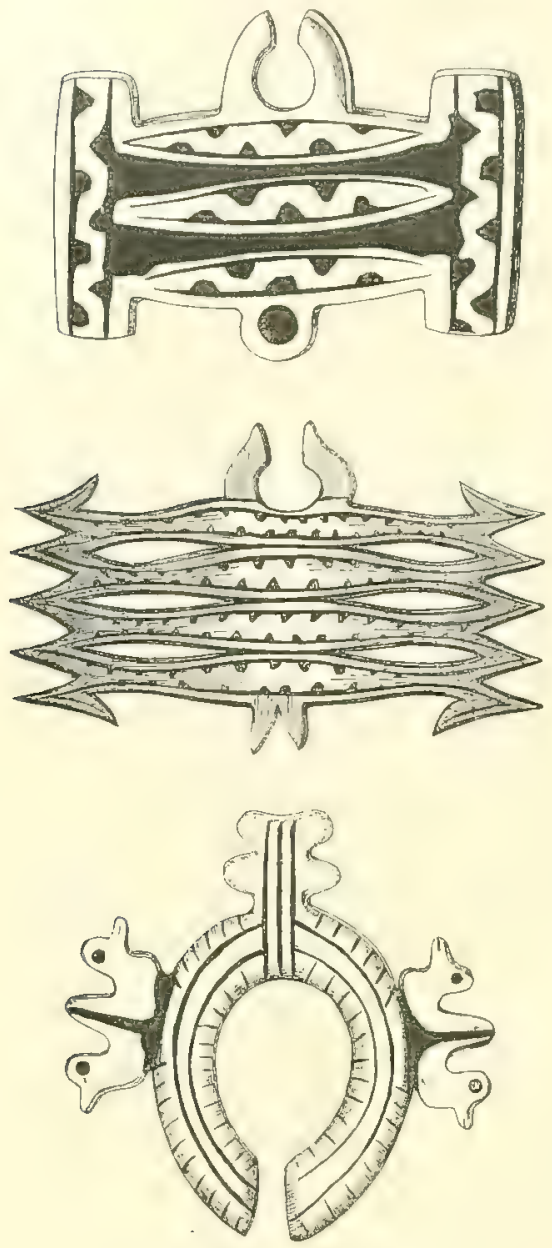

MOTHET OF PEARL NOSE ORNAMENTS. thicknesis. ${ }^{3}$

Their nose ornaments are made sometimes of mother of pearl, and take the forms of these represented in this woodcut.

After some barter with them we went ashore in the long boat, the Bishop taking the lead in his whale boat. Our boat could not get into the narrow channel through which the Bishop easily passed, but by turning a little to the right as advised, we finally found a place in which we could conveniently land. There the Bishop expressed some apprehensions respecting the disposition of the people near us, of

1 I had one of this kind taken from the ear of Sasara, a native of Guadalcanar, one of this group; also one of pale-coloured wood 
whom he had had only bad reports, and begged us not to go shooting round about this village, but to make for another where he was known. After having lost nearly half an hour in conferring, we returned to our boat, and went and landed on a nice coral beach near a village situated to the left and facing the first village, where we went ashore.

The island of Ulakua is low and uniformly flat, not the least eminence being visible. The shore, as far as I could see, is very rough, with coral rock in most places. There is a cliff along the shore some 15 or 20 feet high, from which huge blocks of coral have been detached in many places. The island seems to be more of coral formation than any I have seen, except Savage Islaud. It has evidently been upheaved, and probably rather roughly too. I picked up on the beach a great many pieces of flint scattered about among the broken up coral; one wonders how it got there. I could find no lava or other kinds of rock, and there does not appear to be any great depth of soil. The cocoa-nut trees, however, are in great profusion, grow very high, and yield large quantities of fruit, of which we had our share, the natives giving us on our way as much of it as we could possibly desire. On that part of the beach where we landed we found a great number of fish-stakes put up in a curious

covered with a black varnish, one end of which was engraved with a Hlower of nine petals enclosed in a Vandyke border, the incised parts being filled with white paint. Both are now in the Christy Collection, together with a larger and more ornamented one which Mr. Franks, of the British Museum, was fortunate enough to meet with at Hamburg, and which no donbt belongs to this group. 
way, through which we passed by an opening between them. The natives were tolerably numerous on the shore, and appeared to be more peacefully disposed than those of the first village we saw, though each of them was armed with two or three spears, very thin and light compared with those of the Fiji people. Not a woman was to be seen among them. The Bishop explained that we had merely come to kill a few birds; no objection was made, and we pushed on inland. Only three of us had guns, I was one of them, but the boy who had charge of my ammunition bag had stupidly left it on board the schooner, so that my gun was useless, and I was done out of my shooting. We saw some parrots, and a species of new fern for my collection. We reached a village consisting of a dozen of tolerably large huts, several of which seemed to me to be sunk a foot in the ground, which so darkened them that I could with difficulty discern anything inside; and moreover I did not venture to be too prying, because the women appeared to me so timid and shy, that I did not choose to run the risk of annoying them. The huts were roofed with wild sugar cane leaves, and had but one opening for a doorway.

The natives are a small puny race, and have about their mouths an offensive appearance from chewing betel-nut, which grows here, as well as another palm with a very pretty foliage. The men seemed friendly enough, and when Brazier shot a parrot they were delighted to see the bird fall, and laughed a good deal. All these people seemed very excitable, and as if, on the least thing happening, they would be like madmen in a minute. The women were 
naked, or partially covered with a narrow fringe but little better than no covering at all, not above four inches wide, and called lavalava. The men were also either naked, or with a band round their loins, to which was attached a fantastic appendage that according to their views is modest. ${ }^{1}$ They have thick, bushy, woolly hair stained yellow with lime, and are not so ugly as the Tanna or Eramanga people.

On returning to the beach we came upon a stream which might almost be called a river, where we were glad to quench our thirst. Besides some ferns and a handsome black lizard, I brought back from this trip three species of parrots, of which one was so remarkable, by the brilliancy and variety of its colours, that I must devote a word or two to it. The top of the head was black, the beak red; on each side of the neck a spot of black coming down to a beautiful yellow ring on the breast; the back of a deep red; a bright red from the throat to the tail; wings of a beautiful green with pale red on the inside, and on the point of the pinion a patch of a very pretty light blue; tail feathers green; feet black; feathers on the legs also green; eyes pale orange in both male and female. On opening the stomach of this bird, I found in it small red seeds and caterpillars.

About half-past five we returned to our boats, on our way to the 'Curaçoa,' stopping, as we went, alongside the 'Southern Cross,' where the Bishop obligingly refreshed us with wine and biscuits.

${ }^{1}$ It will be found figured at p. 332 of Erskine, as worn by the men of Vate. 


\section{CHAPTER XVI \\ UII-SOLOMION GROUP.}

(AUnUst 29 AND 30.)

Alarm on board-Pigeon Shooting in the Trees-Natural History.

ON August 29, about two A.M., we left Ulakua and made for the island of Uji, which has likewise the names of Guelph and Gulf Island. At daybreak we saw land before us, and soon passed by three little islands called the Three Sisters, lying to the south of Ulakua. About three o'clock P.M. we anchored in twenty-four fathoms on the coast of Uji, with the 'Southern Cross' made fast to our stern.

In the evening, just as we were sitting down to our dinner, we were alarmed by an explosion in the ship's stern. The fire bell rang, every man was instantly at his post, but fortunately it turned out to be of little or no consequence. One of the steward's boys, drawing some brandy from a cask that was almost empty, put his candle too close to it and set fire to the spirit, thus causing an explosion which burst the barrel without doing any material damage.

The next day at an early hour I went ashore with Doctor Picken. It had rained during the night, and the ground 


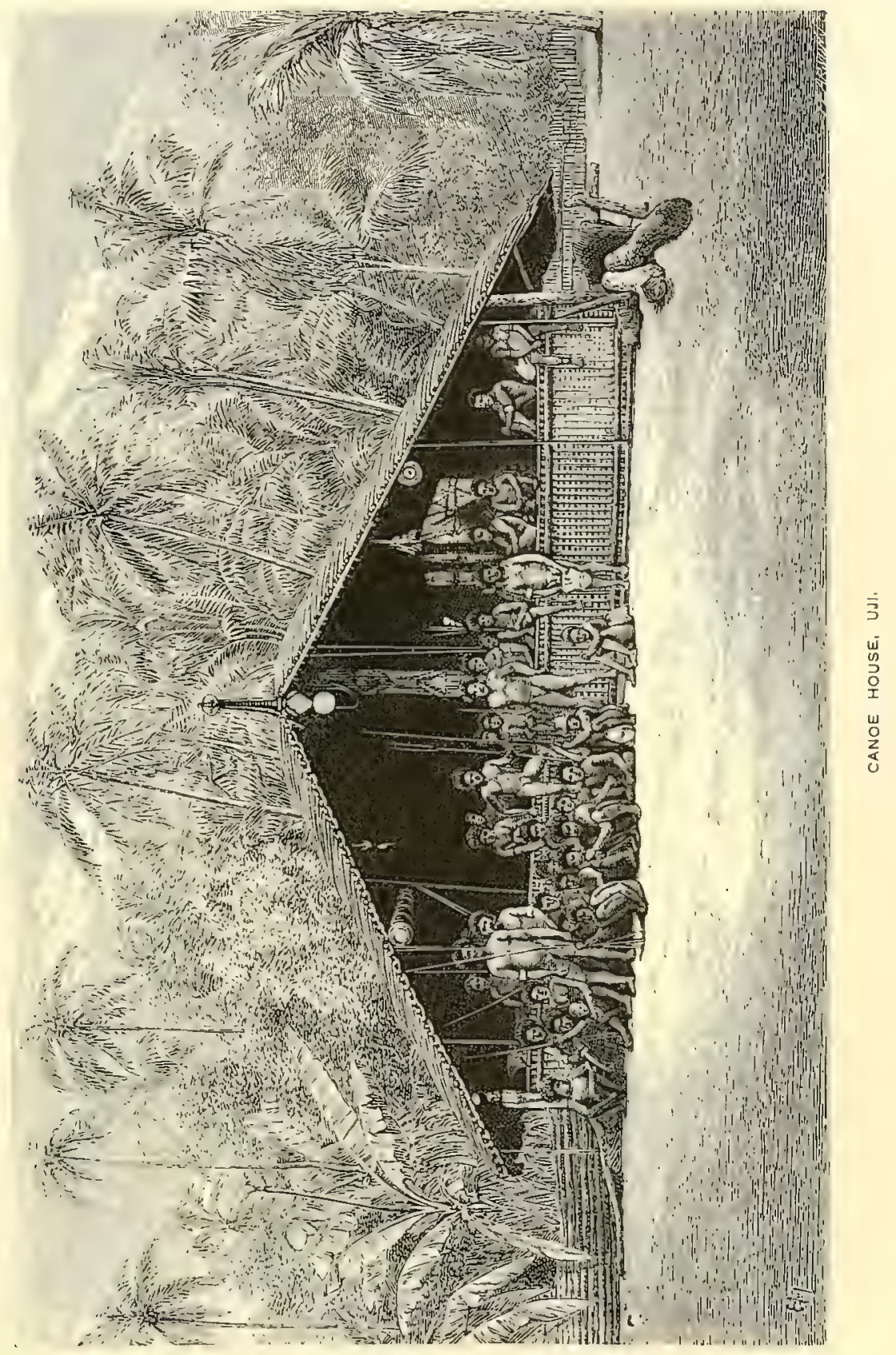



was saturated. Some natives followed and assisted us in finding the pigeons concealed in the breadfruit and other much taller trees. I killed several superb parrots, a small kingfisher, a fine eagle with white head, neck and breast of a bright brown, as were also the wings; some pretty green doves with orange breasts, and heads of a slate colour on

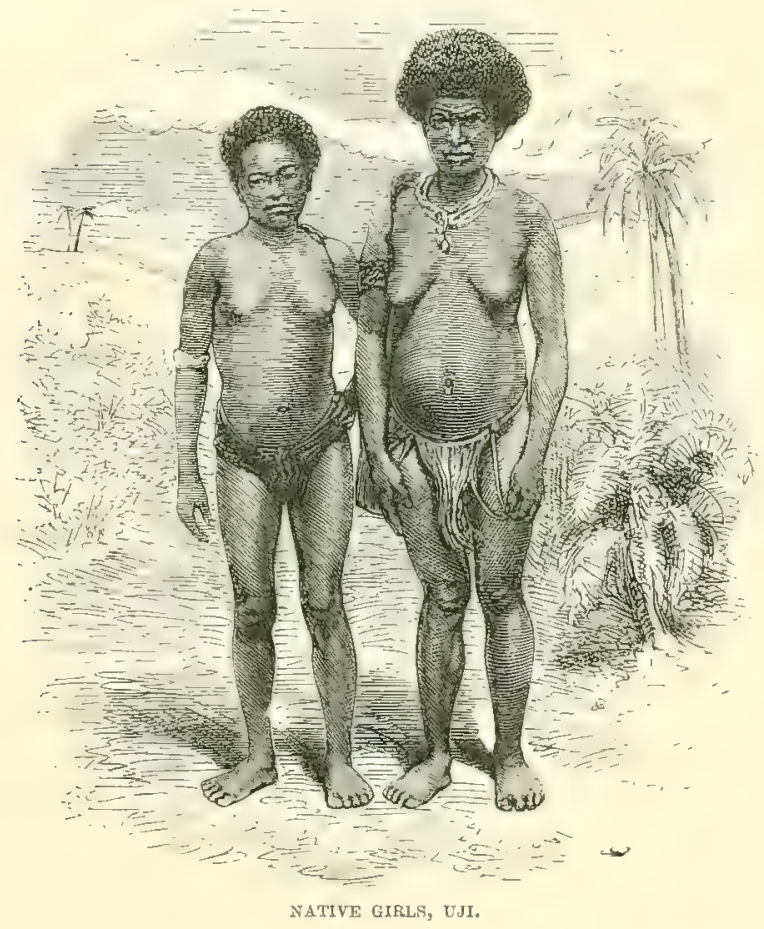

the top. Large heavy pigeons, of a light brown, abounded, but it was difficult to distinguish them when pointed out to us, and it was unpleasant to have to throw the head back as far as it could go to see the birds, and then to have to point your gun straight up in the air to fire at them. You cannot often see them from more than one spot; there is no sport 
in it. I remarked that these pigeons fed on a threecornered nut with a dark purple flesh over it, a thick hard shell, and a kernel sweet and agreeable to the taste. These birds must have a large swallow and a good digestion to eat these hard nuts. All those I have seen had one or more of them in the stomach. I did not gather any new ferns, owing perhaps to my attention being fixed on the birds. I found some fine land shells, looking beautifully green, but when the animal was taken from them it was evident that it was this which imparted its colour to the shell. One other small shell I found had a curious animal in it; the shell was covered with a fine membrane, except on the top; the animal was red, and when touched or pulled about on paper deposited a red stain on it, throwving its tail about, which was very long, and resembled an eel's. The shell did not go near the ground, and was very delicate.

The most interesting object we met with in Uji, and procured through the kindness of Bishop Patteson, was an ornamental tie-beam from the roof of a public hall or council house. On one side the ornaments are in relief, consisting of seven birds supposed to represent frigate birds (Tachypetes aquila), and eight fish, the two centre ones of which are sharks and the six others bonitos. The birds are placed with their heads downward, six of the fish horizontally beneath them. On either side of the centre bird is a bonito placed vertically, the head of each meeting a shark. The birds are alternately light and dark, and the fish all of the same brown colour; the ground exhibits a singularly 
well executed zig-zag pattern tinted red, white, and black, as well as other ornamentation, the whole evincing a remarkable appreciation of symmetrical arrangement and capacity for executing it. 'The reverse side, on which there is nothing in relief, represents four highly ornamented canoes manned, one of them bottom upwards and part of the crew upon it struggling to keep off the sharks, several of which are busily engaged in devouring such of their less fortunate companions as have been unable to regain the canoe. The groundwork is black, and the canoes, fish, men, \&c. are engraved upon it, and painted white, relieved here and there with red and black. Among the fish regaling themselves on the remains of the bodies which they have partially devoured, are to be found more than one species. The long central fish is the Sphyrona, popularly known as the Barracuda; of the others, the larger are sharks, the smaller Ballistes. ${ }^{1}$ The groundwork is divided into two compartments, ornamentally separated from one another, each containing two canoes. In one of the canoes of either group is to be seen a raised platform, the one in the right group bearing a bowl, the other in the left group being without one. It has been surmised that there is here a reference to a custom among some of these islanders of propitiating the sharks by an offering in the shape of a libation, and that the canoe not upset or attacked has performed the ceremony. The two canoes in the right compartment may be

I I am indebted to Dr. Günther, of the British Museum, for the names of the fish. 
supposect to be moving on with the protecting bowl. But all this, of course, is mere conjecture. Most of the men in the canoes are represented as wearing high combs projecting from their heads, and one, singularly enough, is decorated with the by no means delectable hat, which, I suppose, I may be permitted to call the hat of civilisation. The whole subject of this side of the beam is contained in ornamental borders, and the extremities are curved downwards with a circularshaped opening by which they are attached to the two purlins, one on each side of the roof, as will be seen by a reference to the illustration copied from Mr. Codrington's interesting sketch of part of one of these buildings. ${ }^{1}$

The sketch in question represents an interior with a raised platform at one end; the walls are low, and support a sloping roof. At a certain height on either side is a massive beam or purlin resting on a kind of story-post going down to the floor, the upper portion of which is carved to represent a human figure resting on a column. To the purlin is attached an ornamental tie-beam, evidently of the same character as that just described. Slung from the roof, or resting on the platform, are some very large wooden kava bowls, two of which only are represented here, particlly inlaid with pieces of cone shells. The rafters and purlins are decorated with different designs in various colours, the

1 The length of this tie-beam, now in the Maidstone Mruseum, 18 fifteen feet two inches, the width one foot three inches, not including the extremities of the birds' tails, which extend nine inches byyond the beam. 


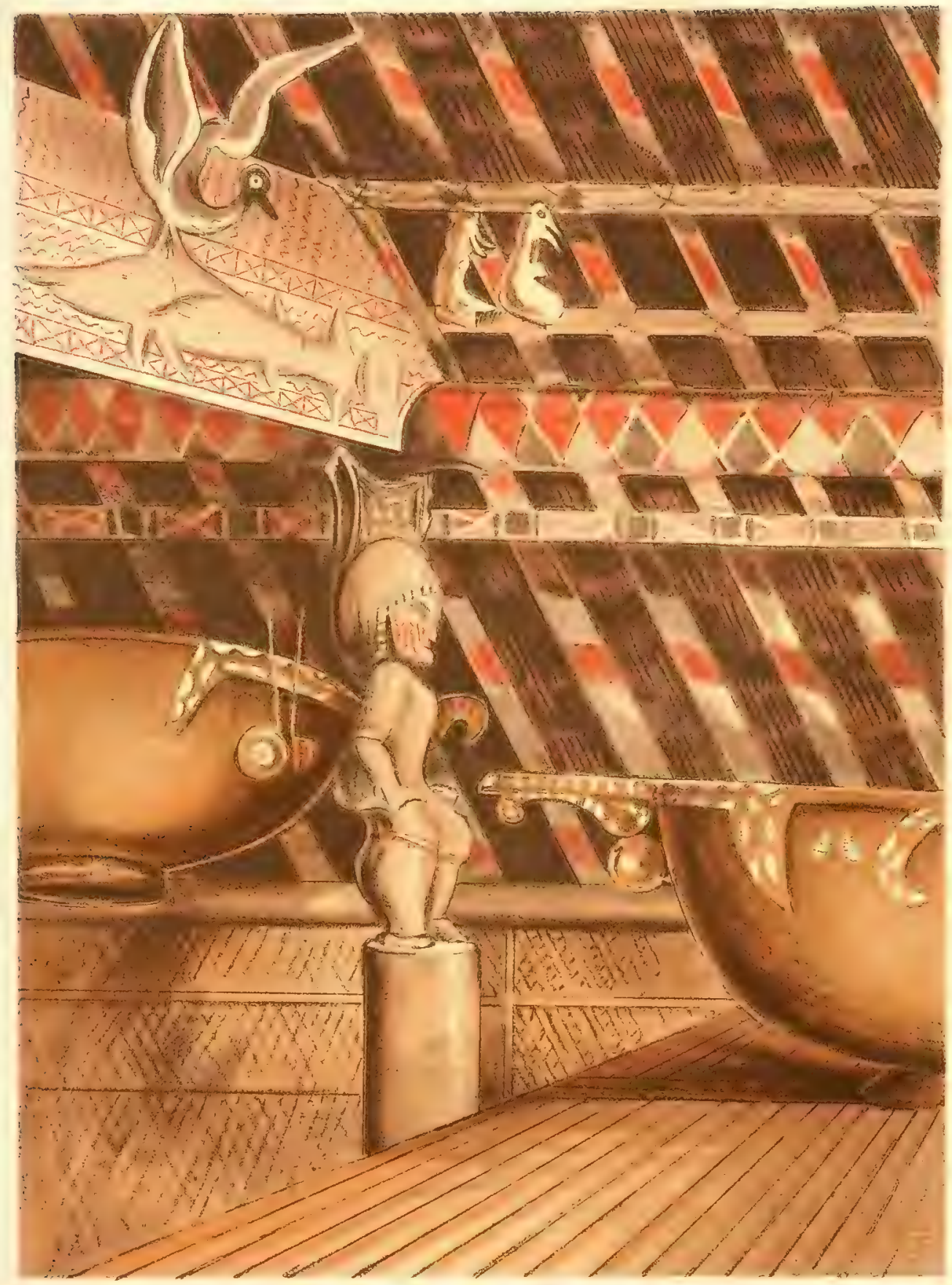

Mintern Bros. Chrorno - lith 

whole indicating a place of much parade and pretension." It would be greatly to be regretted should not this rude artistic skill be developed by. instruction into something of a superior kind. But if it turn out otherwise, as most likely it will, these works will remain, and are worthy of remaining, as evidence of a degree of intelligence and of capabilities certainly remarkable in what we call a savage race.

As the 'Curaçoa' was to weigh anchor at an early hour we were obliged to retrace our steps very soon, and hence we had no opportunity of learning anything respecting these islanders, who seemed to be friendly enough. It was nine o'clock when we got to the beach and seated ourselves in our boat to return to the shio.

1 I am indebted to the kindness of Mr. Franks of the British Museum, for obtaining for me the obliging permission of the Rev. Mr. Codrington's brother to copy and insert this interesting sketch. 


\section{CHAPTER XVII.}

\section{SAN CHRISTOVAL-SOLOMON GROUP.}

(August 30 to September 4.)

Anchor at Wanga-Arrival of Canoes-Barter-A Walk in the IslandOpossum-A glutinous Fruit-Village-Women entirely naked-Human Skulls-Curious Group of Natives_Constant State of Warfare-Fishing in a River-Anchor at Hada-A self-styled King-A Nigger who treats the Natives as Niggers-The Bishop and the Murderer of one of his Teachers -Appearance of the Natives.

ON August 30, about one P.M., we weighed anchor, and sailed for San Christoval, the largest of the Solomon Islands, which is only twelve miles from our anchorage at Uji. On leaving we had taken in tow a large canoe manned by natives, but the speed at which we moved soon compelled it to let go, and trust to its own exertions. The 'Southern Cross ' had weighed some minutes before the 'Curaçoa,' and kept company with her. About three o'clock we anchored in twenty-one fathoms at Wanga, on the north-east coast of San Christoval. The place seemed densely wooded, and we could see a high range of hills, which ran not very far from the shore. We had scarcely dropped anchor, when our ship was surrounded by more than one hundred canoes, for the most part without outriggers, the crews of which had the same peculiar arrangement about their middle already 
alluded to as adopted in other islands. We had all sorts of barter, which so occupied us that no one but the Bishop went on shore that day.

Early the next morning I went on shore. The beach appeared to me to be entirely composed of coral, and was completely covered with cocoa-nut trees.-Having met two natives who spoke a little English, I immediately engaged them to serve me as guides. These men, who are passionately fond of smoking, had eyes like lynxes, and could discover from a great distance, though the day was anything but clear, the pigeons which were in the trees hidden by the leaves. They were capital climbers, too. Whenever I expressed a wish to drink they whisked deftly up the cocoa-nut trees, and threw down as much fruit as I wished for: The heat was very great, of which I was especially sensible when going up and down a hill near the coast. Among other large trees, I remarked many betel-nut palms, and another prettier species of palm tree, which was unknown to me. I gathered several species of ferns, unlike any I had before met with. I noticed the same sort of eagle, with white and brown plumage, that I had seen at Uji. My gun had served me tolerably well; I brought back a dozen pigeons, of which, by the way, the flesh was not very well flavoured, two pretty parrots, a curious species of kingfisher, and a pretty little black and white bird.

I met in the wood a group of three men and a woman, whom the ship's arrival had attracted towards the shore. The men, armed with spears, were carrying a dead opossum, 
intended, I imagine, for food. This marsupial has no tail beyond a sort of stump; it is of a light brown, and diffuses a stench like that of the American skunk, but not quite so strong, and differs from the Australian opossum in having shorter and wider feet, in being smaller, and of a colour much less deep, \&e. The same species is found at Uji, as I learnt from some live specimens which the natives of that island had brought on board the 'Curaçoa.' Besides the dead opossum, the natives were also carrying a fruit they called buri, and with which they cement the planks of their canoes together; it seemed a soapy sort of fruit inside, and did not appear to me very adhesive, but yet it must be so, though when I pressed some of it between my fingers they did not stick together; but this sometimes happens with other glutinous substances. This fruit is oval, rather flattened on the sides, brown outside, speckled with a darker brown, about 3 or $3 \frac{1}{2}$ inches long, 2 or $2 \frac{1}{2}$ inches in thickness, and 2 to 21 in width.

I crossed a village, situated not far from the sea, where some forty huts were so arranged as to form narrow streets. Several of them were of a good size, and had a species of verandah in front; the woodwork or sticks of which the fronts of the houses were made being crossed like basketwork, was sometimes painted with curious devices. A figured piece of wood in the centre of the roof, going up from the front to where the two sides of the roof met at the top, was carved and painted with some strange figures, surmounted by a man with a hat on 
his head, like a quaint style of European hat. Some of the houses were raised two or three feet from the ground. There were a great many women about, some not bad looking, some perfectly naked, others with a lavalava which imperfectly covered their nakedness. They did not appear to have any shyness, or mind being looked at. The men seemed here and elsewhere never to go about without clubs or spears.

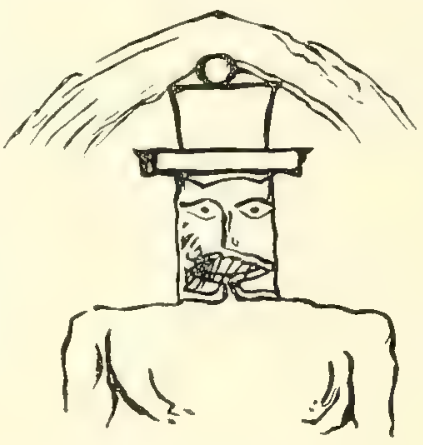

There was a large canoe house supported by wooden pillars, on which strange figures were sculptured of men and sharks, many of the latter in the act of swallowing men. Just under the roof, in front, there were about twenty-five skulls hanging up of unfortunate bushmen who had been eaten by these people, and all I saw showed the effects of the club or tomahawk; and at the side under the roof were a number of the under jaws of boars' heads, mostly with the tusks taken out, and with them human jaws without teeth, which probably belonged to the skulls of the bushmen; from these jaws, too, leg and arm bones were suspended. In contrast with this strange exhibition, implying a very rude state of society, was the village road, which seemed as carefully swept and attended to as in the most civilised village. On my way back I again passed through the same village, and a little way farther on came to another tolerably large one, where I saw the same sort of shed ornamented with 
bones of divers sorts. The 'Curaçoa's' boat was waiting for me, and I found several of our officers bartering with natives of both sexes, about 150 of whom were gathered under a tree. What a curious picture was this crowd of savages, armed with spears and tomahawks, picturesquely grouped in the most charming confusion, busy in exchanging their weapons, ornaments, and produce, for the gewgaws of Europe! The things most in request by the natives were tobacco, pipes, and fish-hooks. I myself procured several curious things-among others, a skull taken from the canoe shed, where it was hung up, and which as usual wanted its teeth and lower jaw. It was the skull of a bushman; it is thus they style the dwellers inland to distinguish them from those of the coast, who are called fishermen. The fishermen and the bushmen are continually at war with each other; one party commits an aggression on the other, and then retaliation follows. It was in one of these fights that the legitimate and first proprietor of my skull came to grief. This skull has not a piece knocked out, as in my New Hebrides skull, but it has a crack in it. The coup de grace is given with a club or tomahawk, but it is a spear wound in general that is the act precedent which leads the way to it.

On September 1, at daybreak, the boat again took us ashore, Mr. Millman, the paymaster, and myself, also Brazier, the shell collector, whom the sailors jocularly nicknamed Jack Shells. Two natives followed us, quite of their own accord, and rendered us some services. We went up 
the banks of a river, through woods for a mile and a half. After crossing and recrossing the river several times, I stopped at what seemed a suitable spot, and went to work with a good will in search of fresh-water shells. The appearance of the country round was pleasing; a line of hills commanded the river, while about us were lofty trees, and some of them with branches hanging in festoons. There were several varieties of pigeons living in these trees, one especially handsome, which had a red lump or comb on his head by the upper mandible, and a blue and greenish tint in the back feathers. I have reason to think this kind pervades the Solomon Islands. At times I heard a loud buzzing about my head, which was that of thousands of hornets busy in building themselves a nest. Desiring to be respected by these formidable insects, I showed them, on my part, a most profound respect, and took care not to disturb their labours. The water, at first clear, was soon made muddy by my movements, so that I was obliged to trust entirely to my touch, and grope about with head and arm, a great part of the time under water. I obtained several kinds of shells-small and average-sized cones, a large bivalve, almost round, of a yellowish red, and with a large and prominent hinge muscle. I also picked up a sort of fresh-water periwinkle and other shells, one of which had sharp points or spikelets on a part of its circumference. The water, which was pleasant at first, began after a couple of hours to feel rather cold, and so I was not sorry to warm myself by going to my provision bag and finding wherewith 
to breakfast. In a part of the bed of the river which was dried up I found a handsome dead shell, an Auricula. From all I saw of this river, I am inclined to think that it must during great floods discharge into the sea a very considerable quantity of water, in spite of its little width.

About eleven o'clock I returned on board the 'Curaçoa' with my basket half filled with shells. Almost immediately the Commodore gave orders to weigh, with the intention of going to Hada or Recherche Bay, where, after five hours, we anchored in fourteen fathoms, alougside the "Southern Cross,' which had left before us, but which we came up with on our way, and took in tow. The bay, though very small, is snug and safe; the high cliff on either side is picturesque, and densely covered with wood, and at the bottom of it there is a flat, well-wooded beach backed by lofty hills. A native, calling himself the king, an oldish looking fellow, came on board, and showed the Commodore some certificates which did by no means tend to recommend him to his notice. One certificate said 'he was a bore,' another that he was 'an old knave, and the less you have to do with him the better;' so, in spite of the dubious character of these certificates, I owe it to truth to say, that this self-styled king, whatever may have been his virtues or his vices, sent the Commodore a pig and some other presents. Another native came also who spoke English. A nigger, too, came on board, and said that 'there was only one other white man living on shore besides himself, an American!' Both had been wrecked, the latter on Indispensable Reefs 
with nineteen others in a whale ship. A few natives came off in their canoes, holding generally three or four persons, being larger than at Wanga, where they rarely take more than two men each. These natives seemed shy of us, because it was here, a little way in the bush, that they killed, a short time ago, one of the Bishop's boys, which grieved his lordship very much. The antecedents of that boy were those of the bush, and he was foolish enough to talk of his former bush life, and hence his death, and he was eaten afterwards, of course. One of the natives who went on board the schooner, and knew the Bishop, asked his lordship "if he was to be afraid of him this time.' The Bishop told him "he thought he had very good reason to be so, and others also, for having killed his poor boy.' This did not prevent the Bishop from going on shore the same evening, and he had the gratification of ascertaining that there was no necessity for visiting the whole people of the village with punishment for the crime that had been committed, seeing that but two individuals were engaged in it.

The next day I went on shore in a canoe which let in water on all sides, and got thoroughly wet. I landed on the banks of a small river at the end of the bay, on the right, by the side of a large rock which, in all probability, had broken away from the cliff on the other side of the river. The river seems to wind round between the hills; the water was very thick, and the stream full from the rains. There I found many of our men doing a little barter with a great crowd of natives, men and women, who 
appeared to me to be neither so well looking nor so well disposed as the Wanga people. It was a very close, damp, disagreeable day, and very unhealthy; one felt almost as if in a vapour bath. Rain fell heavily, the natives looked as if they meant mischief, so I could not, or at least I did not, venture to go as far as the village, one or two miles distant at the point of the bay. To protect ourselves from the rain, we sat down as well as we could under the protection of a rock. Almost immediately on landing an elderly native, using coarse Hawaian gibberish, no doubt derived from traders, made me a proposal touching the other sex which I declined, an abstinence on my part which seemed evidently to surprise him. The articles which were offered for sale were principally their spears and models of canoes; what they most of all desired to get in exchange was tobacco. They looked a wretched, poor, and emaciated people. Many of the women had the appearance of perfect hags; they wore the lavalava; the very young girls had nothing at all. The men had the same appendage as at Wanga, and, like the people of the latter place, their woolly hair looked yellow. Some of the women had their hair partly shaved off, or cut close, so as to leave a roadway across the head. Many of them had a scaly appearance all over their bodies, as though their skin were peeling off, leaving a sort of whitish look, and, in some instances, there were actual sores. I mention as an illustration of savage life, that I saw a young girl in a certain periodical condition, who sat down a minute in the water to perform an ablution, and 
then came out among us again, eviclently unconscious of doing anything either immodest, or dangerous, as we think it. The next day being Sunday we could do nothing on land, and we remained on board, where the Bishop came to say prayers and to give us an excellent sermon. 


\section{CHAPTER XVIII. \\ GUADALCANAR-SOLOMON GROUP.}

(SEPTEMBER 4 TO 5.)

Mtardu Suund-Curaçoa Harbour-Visit Ashore-Mir'shes-Dwellings-Men and Women-The Island of Malata in the Distance.

ON September 4, about six P. sf., just before the 'Southern Cross' weighed, the 'Curaçoa' left the pretty little bay (Recherche Bay) and steered a north-east course. As we were on the point of leaving, we were surrounded by a great number of canoes, and there was a request for more barter, which the Commodore did not think proper to gratify: We cante out of the bays leaving on the left, towards the point; a reef and a rock. As soon as we had got from under the land we were aided by a fresh breeze from the south-east, arid it was not long before we sighted on oux larboard bow the highlands of Guadalcanar, which, un a clear day, can be easily seen froth San Christoval. We saw several small isles at the entrance of Marau Sound, which presented to us a fine sheet of water as calm as a lake. Though the atmosphere was hazy, we could never. theless get a glinpse of the mountains of Guadalcanar, the highest of which, Mount Lammas, has, according to the Admiralty charts, an absolute altitude of 8,000 feet. 
About one oclock P.M. we came to anchor on the const of Guadalcanar, at a point which we named Curaçoa Harbour, in honour of our ship, which probably was the first man-of-war that ever entered Maru Sound. The "Southern Cross' anchored at the same time. The boat in which we lasstened to land not being able to get near enough to the beach, we were obliged to make use of the shoulders of the sailors. The only person I suw on landing was a native, quite willing to accompany me, but who refused to carry my game-bag, which I had to take care of myselt. A small river ran through a swamp, along which I tramped, in the midst of great pandanus trees, which cannot be called serew-pines, inasmuch as the leaves are not arranged in spirals on the branches, but have at the end of each branch a tuft of long leaves. There were in the marsh, and on the highlands, various species of large trees, but I was astonished neither to see nor hear a single bird. The ground was full of hoies sunk by the hemini-crab, whose big claw was of a very pale purple with a pink hue. On the cocoa-nut trees I saw something which I took at first for a globe-shaped bulb, but which turned out afterwards to be a nest of small harmless ants. A curious form of red mushroom was growing about. I also saw a pretty orchid with white flowers, sweetly perfumed. Of land-shells I saw but two species. On such a soil it was next to impossible to go far, and so I retraced my steps without having got over much ground; and crossed the river on a tree which was thrown over it at a spot where it might be one foot deep. At the entrance to a 
little village I had the opportunity of seeing and killing one of those superb parrots with a gold and yellow ring round the breast. Dr. Picken and some officers were already at this village, the huts of which were low, small, oblong in shape, with low gables to the roof, the low sides made with thin strips of wood and crossed; each had a door in front facing the sca. There were some women in these huts, but being alarmed at us, they had closed their doors, and so baulked our curiosity. One, however, I did see who was entirely naked, and exquisitely formed she was. The men were all armed with spears, and though they did not seem much to like our being there, they made no difficulty in giving us cocoa-nut milk to quench our thirst. This district seems thinly peopled; the greater part of the men had yellow heads of different shades, some reddish, and seemed about the same in appearance as those we had seen before, but less ornamented. I found some large flat round fresh-water mother-of-pearl shells, and sorne sea shells, red inside, both of which were lying in a heap under a tree in the water, and looked as if they had not been long taken. Brazier shot fifteen parrots of a dark red colour, and oî a species of which I have never seen a live specimen. Before six in the evening I got back to the 'Curiçoa.'

After sunset I could make out very distinctly the outline of the Isle of Malata separated from Guadalcanar by Indispensable Strait. It lies high, and according to the chart it must be pretty nearly of the same extent as Guadalcanar. 


\section{CHAPTER XIX.}

\section{FLORIDA-SOLOMON GROUP.}

(SEPTEMBER 5 TO 7.)

Aspect of the Island-Gulf of Mboli and Anchorage in Port Wiseman-Native Canoes-Ornaments-Barter-Judicious Advice not to land-Fishing on the Reef-Uneasiness caused by the Prolonged Absence of our Hydrographic Officer.

ON September 5, at claybreak, we left Curaçoa Harbour, preceded by the 'Southern Cross,' which was still to keep company with us. For some time we coasted along the island of Guadalcanar, and passed in sight of the small islands of Nura and Rua-Sura, all to the north of us. This

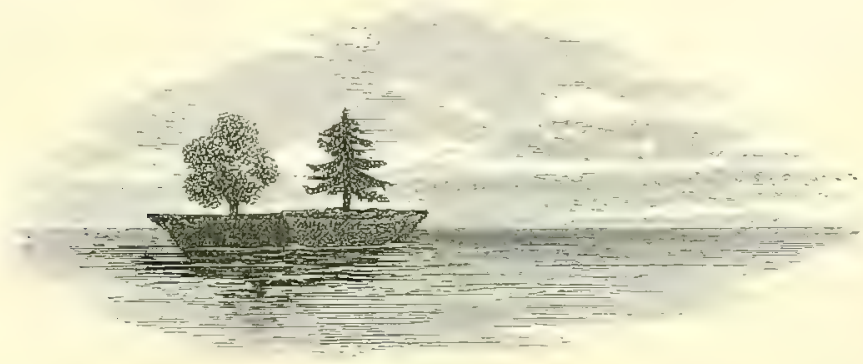

TWO-TRFE IRLAND.

part of the northern coast of Guadalcanar looked very pretty. About two o'clock in the afternoon, we saw on our starboard side the island of Malanta or Malata; and soon afterwards a singular boat-shaped island, known as "Two- 
tree Island.' We then passed some rocks, called the 'Ass's Ears, lying at the eastern end of the island of Florida, which we were soon coasting along. This island, with its belt of trees on the northern coast, is very striking. We observed no mountains that appeared to exceed 2,000 feet; it somewhat reminded me of Norfolk Island, with its undulations and scattered clumps of trees intermingled with a good deal of grass land. The grass, accorling to Bishop Patteson, is long and coarse. I could see plantations of

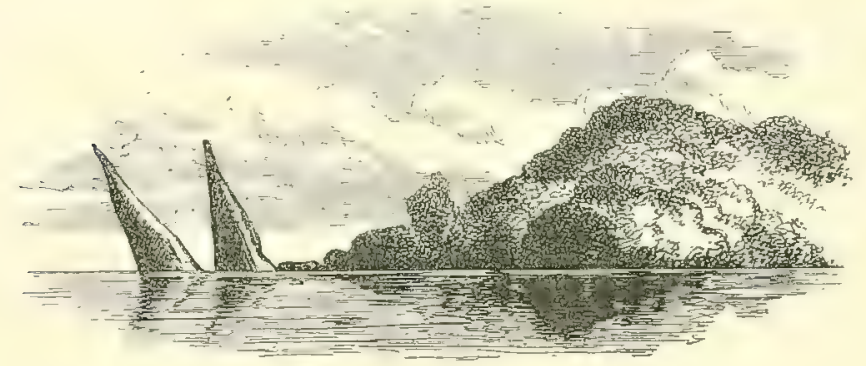

ASS'S EAIF, FLORIDA ISTAND.

bananas on the hill-sides, as well as cultivated grounds and houses on their tops and slopes. Several of the hills had one or more conspicuous trees upon them, and there were many round pit-like looking places, resembling punch-bowls, which appeared as if they had been craters. Numbers of canoes came out after us, some very large ones full of people. I saw two large canoe-sheds on shore before we came to the point, and a great many natives sitting on their haunches looking at us, a position in which, like animals, they sit and gaze for hours. We passed the point which forms the gulf on one side. There is a reef lying out a 
long way farther on round the point which we had to clear before the ship's head could be brought round so as to get to the anchorage. In the middle of this reef there is a dome-shaped rock 60 or 70 feet above the water, covered with trees, which had a very pretty effect. Some of the highest hills have a good deal of wood upon them.

Before six P M. we had entered the Gulf of Mboli in Florida Island, and dropped anchor in Port Wiseman; so Mboli Harbour was named at the Bishop's suggestion, in compliment to our gallant Commodore. There is a good deal of shallow water in the gulf, and patches of reef. The 'Southern Cross,' which had shown us the entrance into the port, remained outside, intending to beat about all night, in order to be ready next morning early to tonch at several villages on the coast we had observed in passing. We could very well see the farther end of the gulf, which was not much more than a mile from our anchorage. The gulf, measuring it on the side of the point which we passed, is not, I think, more than fire or six miles in depth. Scarce had we anchored when we were surrounded by a great number of canoes, among which I observed two large ones, the one carrying twenty-two men and the other eighteen; the object of course was barter. These canoes, instead of being alike, or nearly so, at both ends, as those we had seen elsewhere, had only one of their ends termirating in a high point. I saw two canoes in each of which the bow was about ten feet high. I have never seen a sail to a canoe in the New Hebrides, or the Solomon Islands. These canoes, 
even the large ones, are weak; the planks, generally six in a canoe, are thin for the size of it, but then they are lighter and sail faster than those made of one piece of wood.

The natives seemed very timid, and looked upon the big ship with wonder and awe. They had curiously carved spears, tipped with human bone. They appeared a much finer race than at Marau Sound. Their hair was yellow, short, and curly. They wore the peculiar covering we have before mentioned. No women came off, but with the glass we could see they wore the lavalava. The men whom we saw did not seem to chew betel-nut so freely as in other places, and they are better-looking also. They had large round white shell ornaments, some of them six inches across, quite flat, and about an eighth of an inch thick, over which was a very thin circle of open carved tortoise-shell, resembling Chinese work. This tortoise-shell circle was nearly as big as the other, and was loosely attached to it by a string passing through the centre of both, and secured by a knot; it was worn by the men at the side of the head. Very few had rings in their ears, as at Marau Sound and other places; some of them wore circular pieces of wood in them three inches across; when these pieces are taken out the end of the ear hangs down, and there is a long gaping slit which looks very ugly. This was a great place for cheap and good curiosities. They use shields here, light but strong; Sir William got one, afterwards in my possession, ${ }^{1}$ beautifully made, covered on one side with work

\& Since presented to the Christy Nuseum. It is figured in the woodcut. 
presenting a variety of patterns consisting of small thin flat circles made from shells rubbed down and tied on. There was only one more shield of the kind, and the native bolted when he found that Sir Willian's coxswain wanted it. The

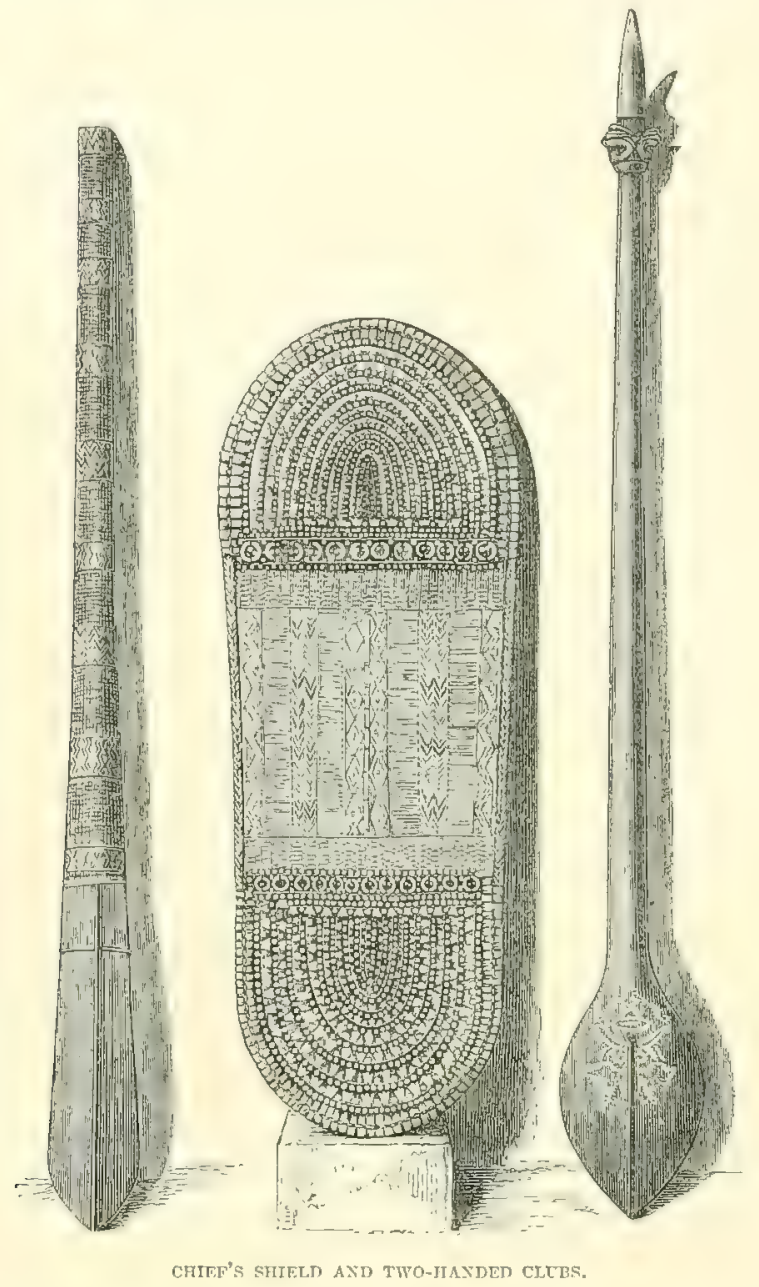

spears were long and thin; some had very nicely worked white bone tops, with long prongs neatly made and carved. The handles of their clubs were prettily worked with grass dyed yellow and other colours. 
'There were a great many white cockatoos, but mizch smaller than those of New South Wales, and with a topknot far inferior in beauty and colour. On both sides of the gangways there were a number of anxious curiosityhunters bartering away, and busy pulling up by cords the curiosities bought, after the bottle, or piece of iron hoop, or anything else as purchase-money, had been passed down. There must have been seventy or eighty canoes lound us, which remained till sundown, when of course they had to be oft. No women came off with them, but they could be seen on shore in their lavalavas.

The natives were evidently startled when the two muskets were fired at sundown. But it is clear they must have trembled with fright when they heard the nine o'clock gum, for, on the following moming, when, after daybreak, the canoes came off, they stopped as they neared the ship, then approached very slowly and cautiously, as if they thought the vessel was a sleeping giant that might awake at any moment and devour them. The 'Sonthern Cross' made her appearance the same morning, and was made fast to out stern. We were impatiently awaiting the Bishop to know whether it would be prudent to take a little ramble in the island which I had projected. He told us he would advise no person to try it, having that very morning learnt that a trading vessel had killed two natives on account of some trifling theft, and everything induced him to think that the islanders would avenge themselves for these two deaths on the first white man who rentured within their clutches. This 
was the second time the Bishop had visited these seas. On the first occasion he had taken arvay with him some young people whom he now brought back, and with whom he had landed early that morning in order to visit some villages on the slopes of the const. He had met with excellent plantations of banamas and yams, large and handsome dwellings, enclosures surrounded with well-made palisades, and natives who had shown themselves well-disposed and even civil.

Not venturing to land, I took advantage of low tide to examine the Madrepore Reef at a little distance from the ships, in the company of Messrs. Veitch and Brazier. This reef seems to be a sort of coral beach, made of broken-up coral sprigs, to some depth; the water rums through as well as over it. I sank in up to my hips in this soft coral. I got on this reef a ferv seaweeds and shells; one of the latter, three or four inches long, was like a much-twisted mussel shell. There were very small fish of a beautiful deep blue swimming about, but I could not catch them. I caught a shrime with one claw, and found a tridacna about one foot across. This large shell was imbedded in the broken coral, with the lips about six or eight inches apart, filled with a leathery sort of nembrane covered with an endless number of very bright green spots in straight lines-these spots were holes or valves of some kind, I have no doubt; in the centre of the open space, and about the middle of the two lips, taking them lengthwise, there was a somewhat raised aperture, from which, when I touched the membrane, issued 
a rather loud sound, like the escape of high-pressure steam. It then closed up, and the lips of the shell were within an inch of each other. I think it is able to close itself quite up when it pleases; it would, therefore, be an unpleasant thing to tread upon, for it might catch hold of you, and if it did it would be a hard matter to extricate your foot. I found another tridacna about six inches across, and also alive. When the tide rose we were obliged to return to the ship.

Florida is a beautiful island, one, I think, of the prettiest we have seen. It has a volcanic red soil. Close to our anchorage, on the slope of the hill-side near the shore, there were three holes, the first of them round and apparently very deep, in which large trees were now growing, probably three extinct craters. I think these islands of the Pacific are much older formations than they are usually supposed to be. There seemed to be on the hills of Florida many decent-looking villages, with better houses apparently than we have lately seen, with long lines of fencing, which appeared both high and strong.

The Commodore, at daybreak, had dispatched several officers ashore to make soundings and hydrographical observations. When erening came on, and there was no appearance of them, he, as we all did, began to feel very uneasy. At nine o'clock, unable to endure longer suspense, he sent off the life-boat, in charge of Lieutenant Meade, in quest of the hydrographical party under the command of Mr. Sculamore; the Bishop at the same time setting off in 
his own boat. Both boats were provided with long blue lights, \&c., to burn if necessary as signals to the absent party. They went up the harbour as far as the creek. A rocket was fired from the 'Curaçoa, and a long light. The moon was bright. They had not been gone more than half-an-hour when the three boats were seen returning; and they reached the 'Curaçoa' at 9.40 P.M. Mr. Scudamore explained to Sir William how it was he returned so late; he had been surveying and sounding, and having come to the creek, he had followed it up, and discovered that the bay was connected with the sca on the southern side of the island by a channel that opened out into a splendid sheet of water, in which there was not less than five fathoms anywhere he had sounded, affording a better harbour and anchorage than where we were lying. He would have taken advantage of this outlet, and would have returned by the sea, had he not thought the Commodore would be uneasy about him. This survey of his proved that instead of there being one island, as everyone imagined, there were, in fact, two islands divided by a creek. 


\section{CHAPTER :XX.}

\section{YSABEL-SOLOMON GROUP.}

(SepteMber 7 to 10.)

At Anchor in St. George's Bay-Cockatoo Island-Barter-Ebony Trees-Trip inland-Difficult Walk-A Convoy of Women-Houses perched in TreesPigeon Island.

ON September 7 , in the morning, some minutes after the Bishop's schooner, we weighed and proceeded on our course to Ysabel Island. We ran for some time along the coast of the fine island of Florida, then passed before the island of Buena Vista, and soon sighted on our starboard bow the outline of Ysabel Island, which appeared prettier and more and more picturesque the nearer we got to it. At two P.n. we anchored under Cockatoo or Eastern Islet, in St. George's Bay; this island did not appear to have any grass land nor open ground, but it certainly was covered, as far as I couid see, with a dense forest. The fine expanse of water at this spot might have been taken for a large lake surrounded by mountains, with islands in it of different sizes and forms beantifully wooded. There is a reef which runs off the N.W. point of Cockatoo Island, to which we had to give a wide bertl. Round St. George's Bay there are no mountains that, as I could judge, exceed 2,000 feet. 


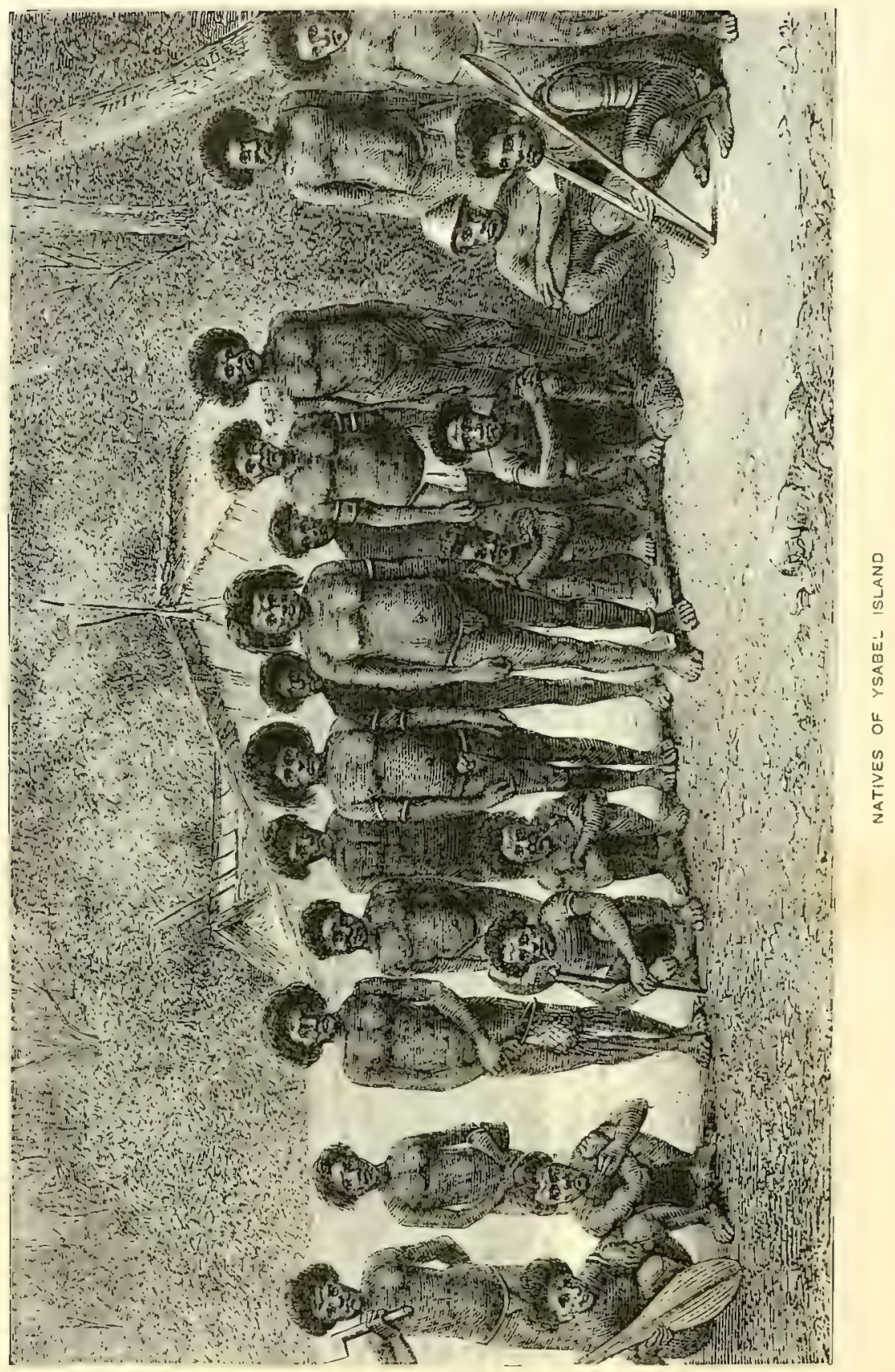


Cockatoo Island is very small, not half a mile long, flat and very little above the sea. 'Th and there are large trees.

As soon as we anchored, the canoes came as usual, in form the same as those of Florida Island, but swaller in general. The natives in them had yellow-coloured hair dyed with lime, short and woolly. They are as strong and well-grown as at Florida Island, and they scemed cheerful and friendly. Here also they disfigure their ears with wooden rings inserted in large slits. They all wore a maro, made of a kind of leaf kept up by a band round the waist. They at once took to bartering with considerable pleasure, speaking with astonishing rapidity, and chattering incessantly. They brought a great many white cockatoos, different kinds of parrots, some with the golden yellow ring on the brcast; others with a red head and red and blue body; also a handsome bird, but a heavy ant anything but a lively one; some black birds, with yellow under the tail, yellow flaps round the eyes, yellow beak, large strong feet and claws, which seemed very wild. There were no toucans, though they lave them in this island. 'They brought shells, spears, a few light and nearly sharp-edged clubs; some fine yellowish-white orchids; some very curious star-fish of a reddish and yellowish colour, covered on one side with short thick round-pointed dark brown knobs; and some things about two inches in thickness, with a hard sort of plate or shield at the top or bottom, which were laid on deck, and got unfertunately smashed there. The surface of 
the plate was divided, as far as I can recollect, into quarters by two lines crossing each other. There were also a great many shields of a sort of wicker-work, and some ornaments made of shell-beads.

We went ashore several times during our stay, either to cut ebony-wood, to shoot, or to examine the country. In our search for ebony we had to row a good way before we came to the place which the natives selected for us, because there was a big tree near the water. We could not get the boats within a hundred yards of the shore, as there is a long straight line of reef running out below at some distance, through which, by the colour of the water, we could see there was no opening; and where we were it was all coral and no passage, so we had to jump out; the water was sometimes up to my middle, and every now and then, when the coral, \&c, gave way under my feet, I sank up to my watch-pocket, gun in hand, which was rather inconvenient. The boy that carried my bag fell, and got it wet. There was a great variety of zoophytes, corals, starfish, actinir, sea eggs, corallines; also the Holothuria, a species whicli seems very similar to that called the 'Nigger' or 'Cotton spinner' by the Cornish fishermen, from its throwing out what they call cotton; it was of a dark colour, and ejected a quantity of very white-looking thread-like cotton, which was very tenacious and strong. I had some difficulty in pulling it off my trousers, over which, by the agitation of the water, it had spread into numerous long threads. There were also many Radiata. When we reached the shore we went about 
half a mile up through the bush, following a stream, and then up a steep, little hill till we came to the ebony trees. There were a good many of them, but only one large one, about eighteen inches diameter, and forty feet long in the stem, on a steep bank. The sawdust was not black, and the wood seemed very hard. The other trees measured six to ten inches through. There was a lignum vita tree, which was also cut down.

We then started in order to look at a village on the hill, where the Bishop had once been, and where there were houses in the trees, in which the people lived, or rather slept at night, for protection. We bolted off through the bush. The first part of the way was swampy with mangroves close to the sea. I had my gun which I found dreadfully in my way when going fast. The Bishop, a good many officers, and two natives were of the party. We came to a stream with a good deal of water in it, and the bed at places partly dry. The sun was very bright, and of course hot. We had to ascend the stream often up to our knees in water, then into the bush back to the stream, up it, back again to the bush, often along the stems of large dead trees which were lying on the ground. I had to wait every now and then for the boy and got behind the others. I had no one to show me the way, which was not very easy to find, especially by one in a hurry, so I overshot the track, and had to make a cut across the bush on the flat, at the end of which the ascent commences, before I could regain it. A second 
time I lost it by going up the stream too far; then tried back some distance and found it again. A native with his spear suddenly coming upon me in the bush, I asked him by signs to show me the way, and that he did by bolting on. I called to him to stop, but I saw nothing of him till some time after. He had a little boy with him, who, when he found he was alone, cried out as long and lustily as he could. About the same time missing my boy, I shouted for him and at last he appeared. When I saw the native again $h$ ? had been back and picked up his squalling offspring, who seemed to be horribly afraid of me. On my way I remarked some palms new to me, with fine broad leaves. Many of the stones in the river seemed very green, and there was a good deal of hard whitish stone, which looked like a hard limestone or marble.

At length I came to the ascent, which was up the waterfall over slippery stones; then up little falls, but always in the water. I found it not very easy climbing up some of these places with my gun in my hand, and it seemed to me that with bare hard feet one could get over them much easier than with thick boots with round nails in them. Some three or four other natives came up; I gave them some tobacco, and we went on again together. I kept on rising and rising, and went a considerable way up the stream, which, never easy to ascend, must be nearly impassable in the rains. I came at last to a nice spot on the stream under a large tree, and there I found some of our officers. The stream was rushing down over the rocks, and 



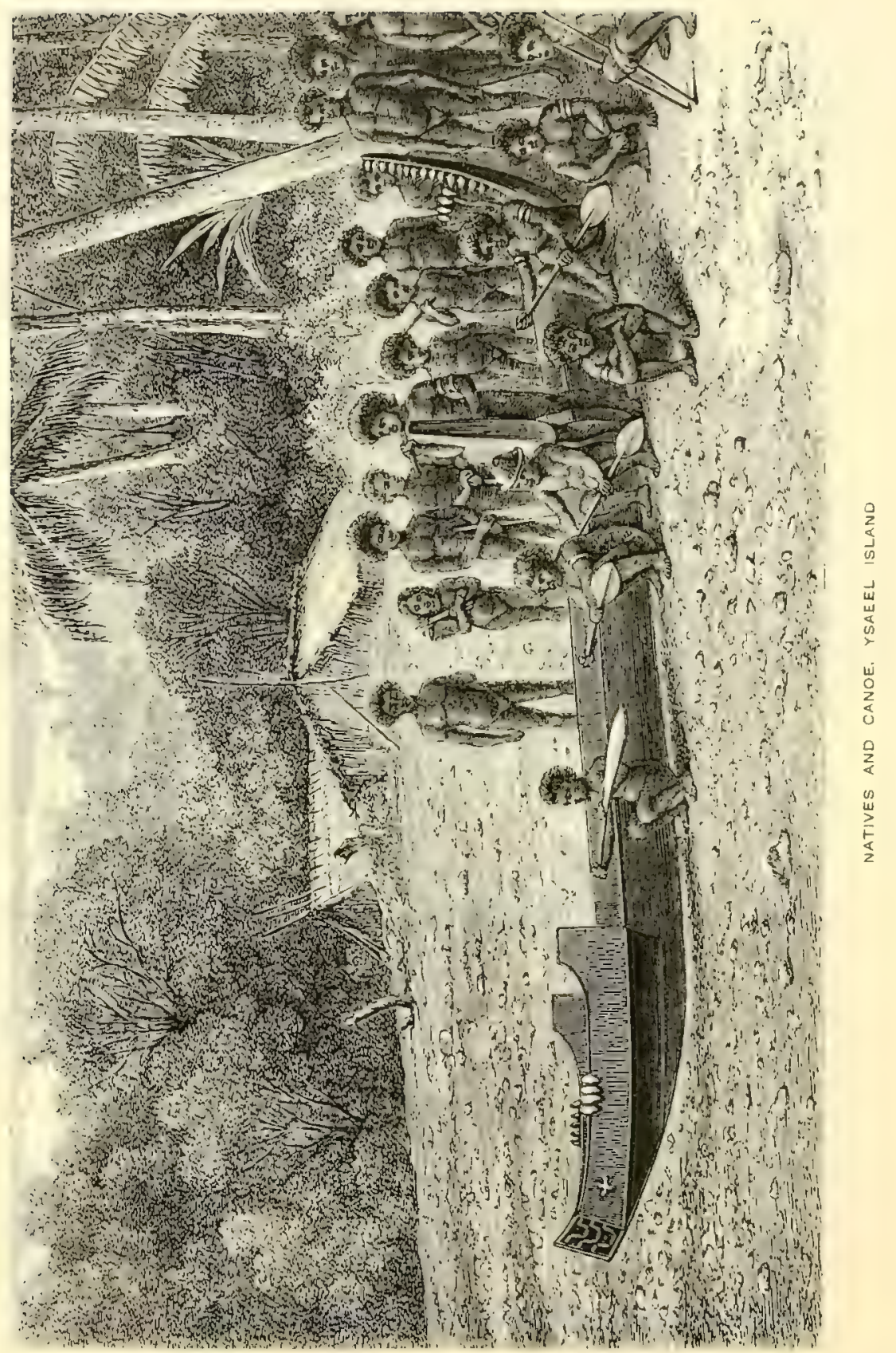


a spur of the same range as the hill we were bound for was opposite to us. We had understood that this point was only a fourth of the way, and consequently, thinking it impossible that we could go to the top and be back in time for the boat, we did not feel disposed to proceed under the circumstances, and therefore went gently down again. We saw natives chewing betel nut, but not to the extent they do in other places; and some ten or eleven women coming up in a line, carrying large bundles or packages on their backs. They all wore a tapa of bluish tint round their loins, which came down within six inches of their knees, and had short yellow woolly hair like the men. They seemed very shy, and went on without stopping, apparently as if they did not see us; at all events they did not seem to look at us at all, though perhaps there might be a peep or two out of the corners of their eyes.

I did not observe any birds but killed a snake. We could discern the top of the hill at places, but could see no houses in the trees. We met a native who had been to Auckland with the Bishop and could speak English.

On reaching the spot where we had landed, thunder was rolling, and a heavy rain falling upon us: while we were waiting for our companions, we were drenched from head to foot. The Bishop regretted he had been misunderstood; what he had said was, that the point at which I turned back was a quarter of the ascent, not, as I had understood, a quarter of the whole distance from our landing-place to the spot I was in search of. We were, it seems, not far from 
it, and should have had time to go up and remain an hour among the tree houses. The Bishop informed me that he had found the place very much changed; the houses in the trees had fallen down or dropped to pieces, the people having been away fighting; many houses on the ground were deserted, and the cultivated grounds had gone to waste.

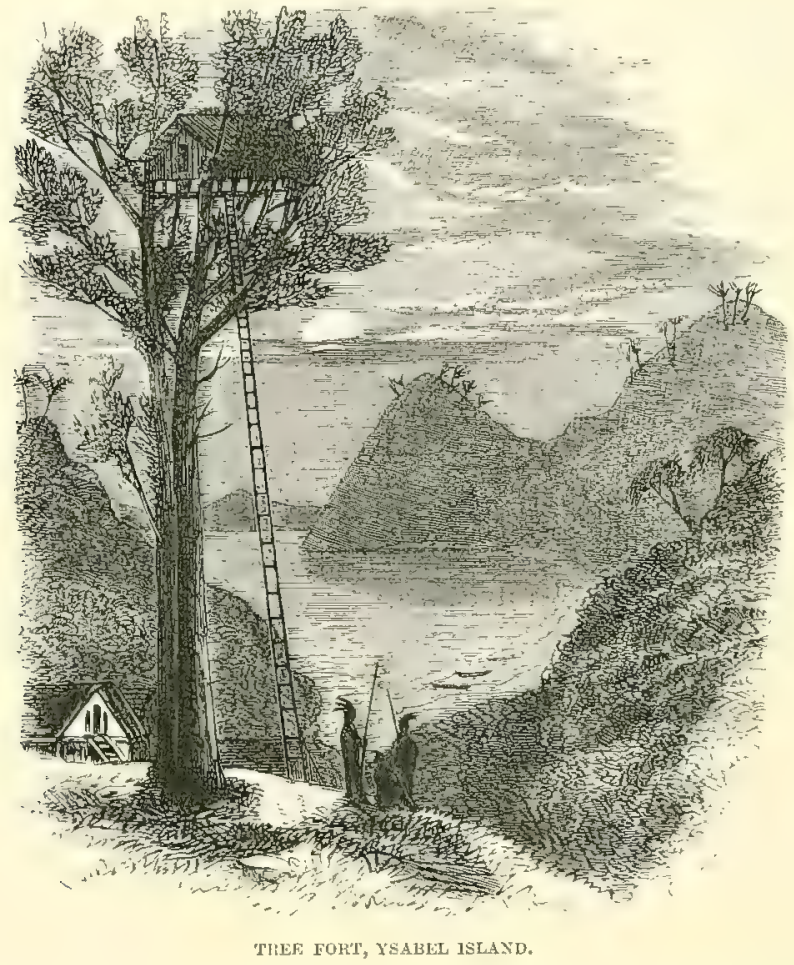

The natives remaining seemed to have lost most of their ornaments, and were in a very different plight from what they were when he last saw them. He said he was three quarters of an hour coming down. A drawing, represented by the woodcut, was made by Mr. Foljambe, of a house perched in a large tree. It was about fifty feet from the 
ground, and reached by a ladder which could be drawn up at night. In the event of their cnemies attacking them for the purpose of pillaging or destroying their houses beneath, they could then fire down upon them with safety to themselves.

Another day I went with some officers to examine the isle called Pigeon Island, which we could see from our deck at about five miles distance, and to the south-west of Cockatoo Island. We rowed by turns, and in an hour and a half got to land, where we made fast our boat to a tree. We at once went to work shooting the bird that has given its name to the island, and which is like one of the kinds I shot at Wanga. The place seemed alive with pigeons, which were in numbers on every tree, but not so easy to shoot in the bushy large-leaved lofty trees, as on the big casuarinas. We killed, however, more than a hundred in the space of two hours, and what was remarkable was, that our frequent discharges did not seem to deter the birds from cooing. We found no water in the island, which, like Cockatoo, is very little above the sea. On our return we hoisted, after a good deal of preparation, the jib, and had to rig up an oar for a sprit to the other sail. The wind was almost clead ahead, and we could only get over by breaking off. We went on till we were almost becalmed under Cockatoo, and then we rowed to the ship.

Barter had been carried on largely every day by our men on board the 'Curaçoa.' I got for my share many things, among them a large quantity of good land and sea shells. 


\section{CHAPTER XXI. \\ FRAMANGA-NEW HEBRIDES.}

(SEFTEMBER 25 to 26.)

View of a fortified Village and a Tree-house-Man overboard-Tedious Navigation-A Gale-Calms-At anchor in Dillon's Bay--News from Land-Trade in Sandal Wood-Mr. Henry-Lime from Coral-A Bombshell in the Hands of Savages-The Rev. Mr. Gordon-Hostile State of 'T'hinge-Two ill-diaposed Chiefs-The Master of the 'Curaçoa' attacked by Natires-The Village of Sifu bombarded by the 'Curaçoa' - A Missionary who never laughed-Notes on the Island-Epidemics-Missionary Labours -Government-Manners and Customs-Religious Creeds-Trade in Wood and Women-Productions-Industry.

ON September 10, early in the morning, we left Ysabel Island, having the 'Southern Cross' in tow, which we subsequently bore away from after mutual adieus, and bent o'r course towards Eramanga distant 900 miles. The day being clear it was possible, with the aid of a glass, to see the village which the Bishop had visited. It seemed a very compact, closely-built place. The Commodore could distinguish with his glass that the village was regularly fortified all round. To me all the houses looked, from the effect of the light upon them, as if they were built of stone; some of them appeared of good size. A little way from the village, and perhaps not more than a mile and a half off, was a tall 
tree, and perched up high in it was a house, which seemed very large; an interesting sight, especially to me, as I had not had the chance to see, when on shore, one of these aërial houses.

On the 10th and 11th the winds varied from south to south-west, and sent us on at a good rate. On the 13 th we were disturbed by an awkward accident. A man fell overboard from the main chains when we were going at a brisk

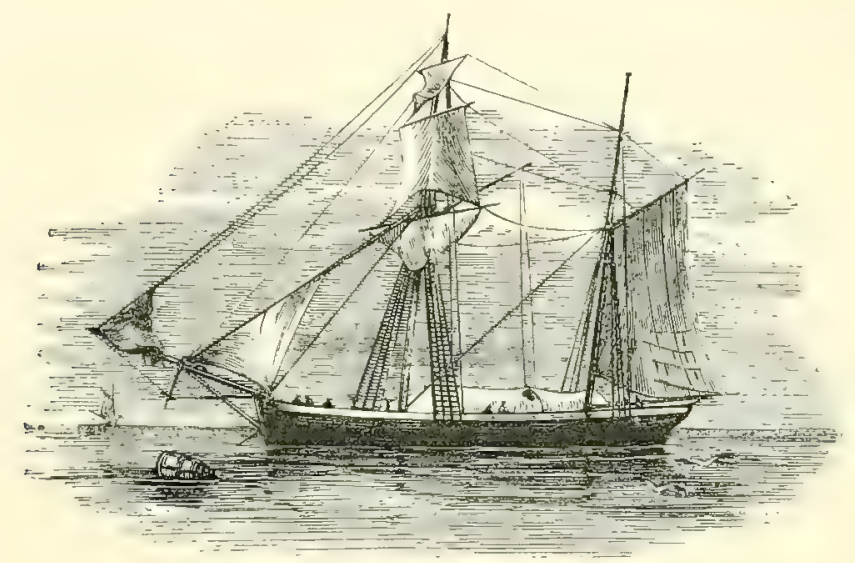

SOCTHERN CROSS.

rate. A life-buoy was thrown over to him, and it was a great comfort to see the unfortunate fellow contrive to get hold of it. A boat was lowered; he was soon brought on deck safe and sound. This was the second accident of the kind that had happened to the "Curaçoa" since she had been in commission.

For some days the officers had been without fresh provisions, and had to fall back on 'salt-horse.' This no doubt tended to make them extremely anxious for the end of the 
voyage. They all seemed to be in a desperate hurry to get back to Sydney. During this passage from Ysabel to Eramanga, which was prolonged much beyond what we wished or calculated, there was nothing to vary our daily monotony, unless, on my part, I am to reckon as exceptions the trouble and worry I had in taking care of my collections, of which I nearly lost a considerable portion by the ship's heeling and rolling in rough weather, which embarrassed me while busy drying my plants, and also by my dog's mania for lying down on my ferns after scratching and tearing the paper in which they were placed to make himself a comfortable bed. The poor little Megaporlius on board was found dead one morning, and my little turtle died too. One of our middies had the misfortune to lose, by a trifling accident, a pretty little opossum, of which he was very fond, and which he had been in the habit of carrying in one of the breast pockets of his jacket. It was said that the loss of his little favourite brought tears.into his eyes; very likely, on board ship these trilling companionships are much prized.

One evening a sailor caught a good sized sea bird in the jib-boom where he had perched with two others. It was a white and brown web-footed bird, with a long pointed beak, and a neck thick in proportion to the size of its body; the eyes were large with a yellow ring round the iris of each; its upper mandible was hooked a little at the point. Another day a 'man-of-war bird' of good size was canght, having fallen into the bowsprit netting. It was, I 
believe, the Tachypetes Aquila of the South Pacific, and was killed on board the 'Curaçoa' in lat. S. $19^{\circ} 15^{\prime}$ and in long. E. $161^{\circ} 40^{\prime}$.

On September 20, soon after we sat down to dinner, the wind then blowing N.E. by N., shifted all at once to south ; the ship was taken aback by the lee in a heavy squall with rain, and we went astern sometime. The officer of the watch turned up the other watch on deck. One would have noticed nothing in the cabin to indicate what had happened had it not been for the noise made by the men on deck. Part of the mast had gone overboard; it broke in three pieces, two or three feet above the cap and also farther up. The men got very wet, as well as the main deck and hammocks, and must have passed an unpleasant night. The next day an enormous quantity of rain fell, and the day after there were again some squalls.

Calms on the following days induced the Commodore to have recourse to steam, and a lucky thing was it for us that there were on board 100 tons of coal ; for without that we should have spent a considerable time in reaching our destination.

On September 25 a magnificent sunrise lit up for us the mountains of Eramanga, and at a still greater distance on our starboard bow the hills of Tanna. At about eight o'clock in the morning we cast anchor in fifteen fathoms in Dillon's Bay, on the western coast of the island. The water in the bay was calm and smooth as glass. There was a little green schooner, called the 'John Knox,' riding at 
anchor, belonging to Mr. Henry, and used for bringing up sandal-wood. Large bonitos. were seen swimming about the 'Curacoa,'some ten or twelve feet below the surface. The Commodore received a letter from Mr. Gordon the missionary, informing him of what was doing on land. A Mr. White, a clerk of Mr. Henry's, the sandal-wood trader, came on board, and from what he said things were not going on satisfactorily. The natives, he told us, were divided into two parties at war with each other, and threatened to fall upon the Whites as soon as they had settled their own differences. Mr. White seemed to have great fear that he would be roasted, and so was anxious to get back to Sydney, which he had left eighteen months before. We also leant that Mr. Henry intended leaving with all he had in the course of the following January. Also that he had shipped between 700 and 800 tons of sandal-wood since he had been here, which was sold at 40 l. a ton, and some lately had been sold which brought him $45 \mathrm{l}$ a ton clear of freight, commission, \&c. The wood I saw looked yellow outside, and was a light coloured wood. There are young sandal-wood trees in the bush, plenty of them, but it will take many a year before they are fit to cut. The native name for sandal-wood is Waullo, and for Kauri pine Nitju. There is a great deal of fine timber of this kind on the island, where they do not exceed fifty or sixty feet in height, with a straight stem. I was told you conld not find straight trees higher than that, but some are to be found of five and six feet diameter. At Eramanga 
a shell called Nunpuri, the Cyprea moneta, passes as money, as aiso in New Caledonia.

The Commodore went ashore immediately after our coming to anchor, and soon returned accompanied by Mr. Henry, with whom I had a little conversation. He told me that there were about 100 tons more sandal-wood to be got here, but that it would cost as much as it was worth to get it in these warlike times. Mr. Henry said he is going to live in new Caledonia, after he leaves in January next, and that he has made a contract with the French authorities there, which will enable him to procure sandal-wood in that island. He has already sent away a part of his people to put up some buildings for him.

There are large blocks of coral or stone along the shore, and on either side of the river, which is called by the natives Bunka River. Towards the points the cliffs look very rough and rugged, but the island is all covered with vegetation down to the water, except the precipitous sides of the cliffs and rocks towards the point on the port side; looking from the ship towards the river. On the top of the cliff there is a grassy slope of some extent reaching down to the point, and the same thing is observable on the top of the hills on the starboard side. I landed for a few hours in the afternoon, and picked up some specimens of lava as well as coral, which the natives turn to account in making chinam, and which Mr. Henry employs as a lime of excellent quality. I picked up also fresh-water shells of several kinds, and a yellow shell found under dead wood 
near the sea, of which there were two kinds. As to the birds I saw or killed, they were the same I met with when here before.

We learnt from Mr. Henry that a vessel, which had arrived here after our departure from Tanna, had brought intelligence that a terrible account was given there by the natives of the action of the 'Curaçoa,' and its effects upon them. We heard, too, that the natives had found an unexploded shell on the ground in the bush with the brass percussion fuse in it; that they all, at least a good many, sat round it, and that one of them then commenced lammering away at the fuse with a stone, when the shell exploded, and killed six or seven of them. It is easy to conceive how horror-stricken the survivors must have been when they looked round and saw their shattered and wounded friends.

The Missionary of the island came to see the Commodore, and made an exact report as to the proceedings of the two hostile parties. This Missionary, about thirty years of age, tall, thin, rather well-looking, with a long beard of a fine reddish-brown, was unmarried, and is said to have been by occupation a fisherman on Prince Edward's Island. He was a cold austere man, and so serious that it was said of him that not only did he never laugh, but that he even regarded laughter as a sin. His report to the Commodore may be summed up thus: 'Warres-Darke,' the friendly chief, the first to encourage and solicit the landing of white men, the only one to whom the Missionary can look for any 
protection, had been warred against for some time past by Warres-Nangré, his uncle, and by Kauiau. There is a cessation of hostilities between them, and a truce, they say, for a short time; but it was reported that, as soon as their fighting was over, they intended to come down and kill all the Whites.'

I heard that one or both parties had had a great feast lately. Sir William got the Missionary to send for the two hostile chiefs, but they declined to come. Mr. Henry, also, reported that a white man belonging to a vessel that had gone to the other side of the island, had been killed by the natives.

The next morning the master was sent away to the northward in the cutter to take soundings in the little bay in front of Sifu, a village with sixty or seventy people in it. The master reported that he was fired at, while sounding, by a native with a musket from the shore.

Mr. Gordon was sent again early to the two chiefs, but they would not come; they seemed to give sorry pretexts for not coming: one said he was not well, the other said he would come if the other would; and therefore, as neither would come, the Commodore resolved to gro to them or their villages round the point in Elizabeth Bay. He did not wish to do them much harm, but he thought it well to give them a little lesson, that they might know what he could do, and that they were not to fire with impunity on the crew of one of Her Majesty's ships, which alone was a sufficient reason for firing upon them. 
It had been at our first visit here intended to land a force for the purpose of inflicting punishment on one of the chiefs' villages; but Lieutenant Meade having volunteered, with a native for his guide, to examine the interior during the night, reported it, after a trip attended with much risk, to be so entirely impracticable for military objects, that the Commodore felt bound to abandon a land-attack. Accordingly, as soon as he now learnt through the Missionary that the hostile chiefs doggedly refused to come, he ordered to weigh at one P.M., and proceeded to the northward under steam along the land, until he came to anchor in fifteen fathoms at about 350 yards off the village of Sifu, which it was his intention to bombard. Mr. Gordon had told the crew of his whale boat, after he came on board the 'Curaçoa,' to return to Dillon's Bay, but they seemed to prefer following us to see the firing. The Missionary begged the Commodore to spare the school-house. The women had been warned to clear out with their children, but it appeared they had not availed themselves of it, for many were seen making their escape along the water-side with men also, after the first shot was fired.

At a quarter past two o'clock fire was opened on the village of Sifu with the port guns, and Sub-Lieutenant Bolitho, who was sent away in the cutter, threw rockets upon the village and its environs. The firing was not so good as at Tanna; there being a good deal of swell on ; six or seven rounds of shells from the 112-pounder Armstrong were fired.

On the shore I could see some of the natives walking 
about with guns, one of them with a red feather on his head, and who was said to be Warres-Nangré, went behind the large rock on the shore and disappeared; others were by the houses under the cocoa-nut trees, or sitting down talking together. They soon changed their quarters after the firing began, and they had witnessed the bursting of the first shell, which cut some of the cocoa-nut trees in half. The rockets, too, went hissing away, and dashing through the bush. There was a fortified cave on the right of the village, having a fence, with a gate closing its entrance, and in the middle of this fence was a long pole with a flag upon it, which appeared to be made of several strips of calico or tapa. The way up to the cave seemed to be between two large rocks, and was filled up with: small trees. A shell from the big Armstrong went straight up the passage and burst at the entrance of the cave at the foot of the largest rock, judging from the smoke that rose from that spot. Another struck against the rock on the left of the entrance. I saw a shell go right through a house, which of course did not offer much resistance, followed by a hollow shot which burst among the trees. The port guns, only, of the upper and main decks, with the big Armstrong gun in the bows, were used, together with rockets. Mr. Gordon did not remain on deck during the shelling, but he made his appearance at three o'clock, as soon as the firing ceased. From what he said, he did not think enough had been done; he was of opinion that the natives would imagine we had done all we could do, and which they would probably find 
was not much.' Whether it be true that this reverend gentleman thinks it a sin to laugh or not, I cannot say; but this I can, that during the time he was with us, this was the only occasion on which I saw in him even the faintest approach to a sinile.

The firing over, the Commodore, however, was disposed to take a more lenient and hopeful view, otherwise there was nothing to prevent his sending a boat on shore without the slightest risk, and destroying all the houses and the few canoes, if he had so wished. I could see, on the steep side or slope of the range, several houses in different directions, one or two under a big precipitous cliff. Wherever the bush had formerly been burnt, there seemed to be one or two houses raised upoz it; the underwood here and there appeared to have grown up again, but the big trees in all these places invariably seemed dead.

Having nothing more to detain us, the 'Curaçoa ' weighed and proceeded to sea, and at half-past three o'clock P.M. we again anchored in fifteen fathoms in Dillon's Bay. Messrs. Henry and Gordon dined with the Commodore. Before leaving they gave us one of those semi-transparent circular rings of calcareous spar or feldspath, called 'navalae,' five or six inches in diameter, and about one and a half in thickness, which serve for sacred money, and with which the purchases of women for wives are generally made; one of them, together with a spear, or a bow and arrows, constituting the market price.

Mr. Gordon sent his men off twice in the afternoon to 
Sifu, to see if they could get any tidings of the effects of the firing upon the natives in the way of either injury or intimidation, but they came back saying that the natives had not returned, so they had not been able to see any. Mr. Gordon thought the present time a crisis, as far as he was concerned; but if able to weather it now, he trusted things would go on very well eventually, and that there might be some hopes. The Commodore asked the missionary to send him a report of the results of the hostilities, addressed to him, 'On H.M.'s Service, New Caledonia, to be forwarded.'

Before taking leave of these disagreeable proceedings, I will avail myself of the opportunity, as these pages are preparing for press, to make a comment or two upon them. It is manifest that public opinion in this country is beginning to be more cututious and exacting respecting the accuracy of the statements which are made the grounds and justification of these penal inflictions, and that there is an increasing disposition to be humanely and justly critical with respect to the causes of the outrages committed by the natives of these various islands. A memorable illustration. of this is to be found in the impression produced by the murder of Bishop Patteson. If there was ever a case in which public sympathy might be expected to manifest itself with an angry spirit, and to demand severe retaliatory acts, this decidedly was one. The esteem everywhere felt for this admirable prelate; the remembrance of his unswerving, untiring devotion to his self-elected duty; of his gentle, 
amiable, and engaging manners; of his deep-rooted interest -recalling that of his distinguished predecessor Bishop Selwyn-in the object of his missionary labours, which liad been exerted for the benefit of some of those by whom he was unexpectedly slain, was but too well calculated to arouse an indiscriminating resentment and desire for vengeance. Nevertheless there was immediately discernible a disposition to enquire if the proximate authors of the crime were the primary authors, and whether the ends of justice would not be best answered by active measures against the ruffian whites, who, by their frightful provocations, madden the natives into the commission of these murderous acts? But what is of the highest importance to know is, that the directors of the missionary enterprise especially connected with this affair, do themselves participate in this improved feeling, of which they have given marked evidence in a strong protest against the conduct of the missionaries responsible for the proceedings which have just been narrated. As the reply to this protest by the person chiefly answerable for them gives an insight into the way in which they too often originate, it may perhaps be interesting to refer to it.

As far back as 1862 there had been meetings in Sydney praying Sir John Young to take such steps as he should think proper respecting certain occurrences which had taken place in Tanna and Eramanga. In the same year H.M.S. 'Pelorus,' touched at these places, but no action of any kind was taken. But when, in 1565, the 'Cura- 
çoa' was ordered to cruise in these seas for the purpose of settling difficulties in various islands, and of course in these two, the missionaries in connection with the latter made active preparations for turning the expected visit to account. Accordingly, just previous to our arrival at Anatom, a meeting of missionaries took place under the chairmanship of the Rev. Mr. Inglis-one of the most experienced amongst them-the result of which was a document, unanimously agreed to, setting forth the various acts of maltreatment to which the missions of Tanna and Eramanga had been exposed, which was sent to the Commodore, urging him 'to take such discriminative measures' as would convince the natives "that British power would be employed for the protection of British subjects, otherwise no man's life would be safe.' The missionary movement in Sydney, and this strong appeal from persons whose statements he felt bound to receive, but had no means of thoroughly testing, were, of course, imperative reasons for his attending to their advice; and, on his showing a disposition to do so, he was not long in learning that the phrase 'discriminative measures' was, in missionary language, an euphuism meaning the use of powder and shot. To him, of course, no blame was or could be, in any quarter, attached; but his experienced advisers did not come off quite as well. In a number of the 'Record,' published under the auspices of the "Board for Missions for the Presbyterian Church, there appeared, it seems, a very severe article reflecting especially upon $\mathrm{Mr}$. 
Inglis as the person most responsible for what iad happened. To this censure this gentleman made an elaborate reply (a copy of which I have) which, I think, furnishes within itself the means of testing the character and value of lis advice.

In the first place, as respects Tanna the charge was, it appears, that Mr. Paton had been advised' by the elder missionaries 'to quit the island for awhile, and that had he done so the mission would not have been broken up; and, moreover, that what had wounded him most deeply, as the chief of his hardships, was the injury done to his furniture. ${ }^{1}$ Then with regard to the two great crimes at Eramangathe murder of Williams and Harris in 1839, and that of the Gordons in 1861_it was alleged, in reproof of these proceedings, that the former was the result of misconception; the latter of misrepresentation by white men, who were thus, in fact, the instigators of the outrage, and the worst culprits in the affair. To these unpleasant criticisms Mr. Inglis replies with the usual tale of horrors, laying down as a postulate that it is of no use to attempt to palliate the conduct of the natives by throwing discredit on the whites. Having settled this point to his satisfaction, he makes, in justification of his penal policy,

1 Mr. Meade, in his interesting work, "New Zealand and South Sea Islands,' p. 231, confirms this view; where, after observing ' that the impression left on our minds by the missionaries of this socicty was not altogether favourable,' he adds, 'in recounting their grievances and suffering's, too much stress was laid, to my thinking, on the loss of private and mission property.' 
the customary vague accusations, ignoring contradictory evidence based upon ascertained facts.

Thus the murder of Williams and Harris, in Dillon's Bay, was, according to him, an inexcusable atrocity, though he must have been perfectly aware that the well-known missionary Mr. Murray, in his report of his visit to that island in 1854, ${ }^{1}$ had expressed his opinion on the subject when giving an account of his interview with a chief who had been previously anxious to have a teacher placed upon the island, and who, to his surprise, turned out to be the man who killed Williams. When questioned upon the subject the chief 'looked sorry and ashamed,' but said, "he did not know Mr. Williams was a missionary.' To the question why he killed him he replied, 'it was on account of outrages committed by foreigners some time before.' And does Mr. Murray credit this statement? He does, and adds significantly, "who can wonder at what he did when it is remembered that, in the affray referred to, between the foreigners and Eramangans, his own son was murdered?' (the italics are his); and such was the confidence he and $\mathrm{Mr}$. Sunderland had in him, that, in compliance with his request, it was arranged that one of the teachers, in another part of the island, should be transferred to his part of the bay. But of these important statements Mr. Inglis seems to know not a word. Then again, as respects Tanna, there are allusions to asserted acts of violence by the natives, while

' 'Missions in Western Polynesia,' p. 195. 
not a single reference is made, by way of accounting for them, to the exasperation caused among them, first, by the introduction of small-pox in 1853 by a trading vessel (as reported by Messrs. Murray and Sunderland); ${ }^{1}$ and, secondly, in 1861, when large numbers were swept into the grave by the introduction of measles, ${ }^{2}$ under the influence of which they were easily induced to believe the story of some intriguing whites, who, as Mr. Paton himself declares, had been busy in persuading them that he was the cause of these scourges. But Mr. Inglis can see no extenuating circumstances in all this; nothing to divert 'British power' from inflicting punishment, ' inspiring the greatest amount of terror,' without stopping to take counsel of British justice before it did so.

Let us now turn to Eramanga and the murder of the Gordons, which Mr. Inglis's critic ascribes, it seems, to the ignorance of the natives worked upon by the misrepresentations of white men; but this Mr. Inglis himself treats with contempt, attributing the crime to the savage ferocity of the native character, combined with an irrepressible desire to molest, pillage, and destroy the mission. Now we must be able to conceive that some great and unexplained change must have taken place in the disposition and the deportment of the inhabitants of Dillon's Bay within a few years, if this theory is to be sustained. For we have the testimony of two missionaries to the extreme tranquillity of the island and the orderly behaviour of the natives in 1854. Not

$$
1 \text { Ibid. pp. 153-155. 2 Ibid. p. } 399 .
$$


only were they received and treated with kindness, but they were assured by the captains of two traders lying in the harbour, that foreigners might travel anywhere with safety, one spot only excepted (Cook's Bay), and that the natives around could be justly praised for their 'harmlessness, docility, honesty, ${ }^{1}$ \&c. Three years later, in 1857, Mr. Gordon and his wife were landed at Dillon's Bay. The tribes around had been at war with each other; but, in spite of the excitement which would, more or less, survive such a state of things, so manifest was the peaceful disposition of the natives, that, after a long deliberation, the 'New Hebrides Missionaries,' who had accompanied the Gordons, came unanimously to the conclusion, that the moment was propitious for the commencement of missionary labours. It is clear that the explanatory change required to justify Mr. Inglis's policy of retribution had not yet taken place. Again, in 1859, another missionary, Mr. Turner, visited the island, and, though he discovered nothing alarming, he found that, as far as missionary success was concerned, 'there had been a reaction.' Reports were current ' that the Anatom people were all dying, and that the scourge was ascribed to the new religion.'2 Now here was unquestionably a most dangerous source of excitement, angry remembrance of ravages caused by epidemics introduced by the whites, embittered by an infusion of religious hate! And what was the result? Nothing more serious than an order from the chiefs to their people not to attend "the 
Sabbath services' of the mission, and that not rigidly insisted on. Indeed, such was the state of tranquillity that Mr. Murray alluding to this period, or a little later, 'discerned the earnests of success, the precursors of a glorious day destined ere long to dawn on Eramanga.' Soon after this occurred the murder of the Gordons. Whether it was the act of a few natives stimulated by their own fanatical excitement, or, as is supposed, by the suggestions of foreigners, one thing is perfectly clear, that there was nothing in the general attitude of the natives that could suggest any apprehension of such a disaster. It is indeed said that Mr. Gordon reccived an intimation of some intended mischief; yet such was his feeling of security that he had quitted the bay and built a cottage at some distance from it, on an eminence about 1,000 feet above the level of the sea. Close to it was a chapel with ' a firie bell, which echoed from hill to hill.' He seems to have been an unsocial and self-willed man, and it is the avowed opinion of his fellow missionaries, that he owed his death to his having withdrawn himself from the protection of his friends in the bay. ${ }^{1}$ But his separating himself from them is plain evidence that he creaded no enemies elsewhere. Better proof than this of the peaceable disposition of the natives it is impossible to desire. It must be observed too that when, soon after the death of the Gordons, Messrs. Murray and Geddes visited the island, they landed without any risk, and were well received by the chiefs. Moreover they learnt that the

1 Ibid. p. 423. 
bodies the missionaries had been buried not only without any adverse manifestation, "but amid the tears and lamentations of all around.' And farther, that the 'peal of the church bell and the sound of morning and evening prayer' every Sunday continued to be heard as before. ${ }^{1}$

Now it is utterly incredible that this should have occurred in the midst of an ill-disposed and ferocious people connected either by deed or sympathy with the authors of the recent crime. That nothing had occurred to induce the natives to abandon their peaceful policy is clear, but it is also clear that it had been resolved in missionary quarters that the murder of the Gordons should be regarded and punished as a general offence. Soon after it occurred H.M.S. 'Pelorus' was, as has been observed, sent to enquire into the state of affairs; but, as her commander, Commodore Seymour, did nothing in the way of punishing, the presumption is he discovered nothing to justify a general punishment. But when the approach of the 'Curaçoa' presented an opportunity of carrying out the retributive system, then were active preparations made for biassing the Commodore's mind in the desired direction. The resolutions already referred to, passed at Anatom, together with 'memoranda' affirming the commission or intent of outrages, though resting on no better authority than that of exaggerating teachers, made their appearance. Indeed nothing had been left untried. Mrs. Henry, apparently pressed into the service, was induced to write a letter to Sir John 
Young complaining of the natives, and of their ill-intentions towards herself, though she and her husband had lived unmolested there since 1861, and she had herself, only the year before, in a letter to Mr. Inglis, expressed herself as follows: "With regard to personal safety I think there is no danger on this side of the island. We have lived in perfect peace amongst them, and we find them a quiet and inoffensive people. I am at present almost alone with them, Mr. Henry being in Sydney.' A more effective attestation in favour of the natives, confirmed, moreover, by what I find recorded in my journal of $\mathrm{Mr}$. Henry's unconsciousness of any danger, could not possibly be desired. And yet we are to believe that in a single year, without provocation, without any alleged cause, they should have become malevolent, mischievous, and murderous. But it is obvious that Queen Mab, in the shape of Mr. Gordon of silent celebrity, had been at work with Mrs. Henry getting up this and other materials to justify an appeal to British guns. A paper, by this gentleman, dated Eramanga, September 25, 1865, and presented to the Commodore as 'information only, will furnish an excellent illustration of the quality of the information concocted for the guidance of our officers.

Beginning very solemnly with a quotation from 'Hodge on Cor. xii. 11, affirming it to be every man's duty to 'vindicate the righteous,' it proceeds with much impertinence to contradict Messrs. Henry and Edwards, who, being at Sydney when two missionaries, misled by teachers, 
presented a petition to Sir John Young requesting the removal from the island of a Malay named Rangi, whom they represented as a most dangerous character, and the instigator of the Gordon murder, had dared to forward to the Governor a counter-statement positively denying the alleged fact. Now Mr. Gordon's zeal was clearly not a 'zeal according to knowledge, and had he no other means of information he might have derived it from Mrs. Henry, who, a year before, had informed Mr. Inglis by letter that this Rangi was ' an ignorant, harmless fellow, who had not the slightest influence in the island.'1 But, of course, Mr. Gordon preferred relying on the vague evidence of teachers, the value of which we may estimate by the fact of his having since, as Mr. Inglis tells us, felt compelled to acknowledge that 'Hodge on Corinthians' had been wastefully cited, that the 'righteous' were in the wrong, and their audacious gainsayers in the right. Such were the misleading influences brought to bear on the Commodore's mind; and if, unfortunately, he had been somewhat of the fanatical temperament of the assailant of Bea, ${ }^{2}$ there would have been a very pretty chance of bloody reprisals. Of course no one would suppose that these missionaries had a thirst for blood, but, exaggerating the importance of their work, and especially the privileges attached to it, they believe every offence against

1 The letters, \&c. that have been alluded to are, copies or originals, in the possession of Admiral Sir William Wiseman.

2 Captain Croker whose proncedings were noticed at p. 113. 
their mission is an offence against God. But that such a persuasion can make men, not personally cruel, sanction crucl acts, history teems with proofs.

The moral to be deduced is this: if this country thinks it necessary to place the commanders of its ships of war at the disposal of the missionaries in their feuds with the natives, it should not only be careful in its selection of its officers, but should also take care that they be provided with the means of communicating, through reliable interpreters, with the natives themselves. In point of fact the inspection of these islands should be made a special service, not to be left to the random visits of ships of war commanded by officers who have not had an opportunity of qualifying themselves for the task. For, assuredly, it is a solemn duty incumbent on the Government of this country, when stretching forth its arm whether for protection or punishment, in these or other regions, that it should use the most jealous caution in determining whom it ought to punish, and whom to protect.

There is reason for bearing this in mind. Mr. Inglis, in his defence, after protesting against any palliation of 'offences against missionaries on the score of ignorance,' suggestively adds, 'the principle of blood for blood, life for life, the lex talionis, is a principle which every native understands; ' consequently, when their offences against life are not punished on this principle, they are agreeably or otherwise disappointed; and their surprise, we are assured, is mingled with contempt for those who having the oppor- 
tunity of applying it do not do so. Unfortunately our English law does not permit us to meet their views. It recognizes three varieties of life-taking, as between man and man, first, in self-defence, justifiable homicide; secondly, under sudden momentary excitement - manslaughter; thirdly, with malice prepense-murder. The first it sanctions; the second it punishes with shorter or longer terms of imprisonment; the third alone is punishable with death. It is clearly incapable, therefore, of dealing with the natives on their own principle, and moreover, it requires that those who execute it should carefully determine in which of its three categories any act of life-taking must be placed. A nice distinction, which seems never to enter into the heads of those who call for punishment on the natives for crimes of violence. In a word, however inconsistent with native usages, and however incompatible with missionary safety its policy may be, it, nevertheless, cannot permit its representatives to adopt the 'principle of blood for blood,' ' life for life.'

It is satisfactory to be able to infer from the protest under consideration that, in the opinion of the more enlightened missionaries, and conductors of missionary enterprise, the strict application of the just and cautious requirements of British law in criminal matters to offences, real or imputed, by the inhabitants of these islands, will furnish the most effectual check on the misdeeds of the natives, and, by augmenting the respect entertained for the missionary, will 
largely contribute to the safety and success of the mission. Thus much it has been thought proper to say.

The island of Eramanga measures thirty-five miles in its greatest length, sixteen miles in its greatest width, and is about one hundred miles in circumference. The population is from four to five thousand, not living together in villages, but scattered about in clusters of houses on the seaside. Its temperature has not been well ascertained, but it is known that the thermometer will sometimes vary $20^{\circ}$, and even $24^{\circ}$ Fahrenheit in the course of twenty-four hours. With the exception of the most elevated parts of the island, the climate is not healthy; elephantiasis and intermittent fever are frequent. About the year 1840 an epidemic was introduced by a sandal-wood trading vessel, which caused great ravages, sweeping off the people by what was called red dysentery; again in 1861 the measles cut off a great number of people; and it is a question whether the population can ever recover from the exterminating results of these two attacks.

The after effects are still visible in various forms : deserted houses, numerous 'weeping places,' extinct tribes, or tribes whose only representatives are a few dying people. All bear mournful testimony to the havoc made. The last epidemic was brought by the 'Bluebell,' Captain Bruce, to Dillon's Bay. Captain Bruce, or one of his crew, informed the late missionary of the fact as soon as he had anchored; and the missionary, the first who had settled there, the Reverend Mr. Gordon, at once gave notice to the natives, 
many of whom were then at a feast, urging them to remove speedily inland, and remain there, which some did, and others did not. Eventually, however, the introduction of the disease was fastened upon him, and he and his wife were murdered six months after in consequence. It is clear that if missionaries are to look for safety in these islands, they must be relieved from the risk of being held responsible for the infamous acts and exterminating policy of the traders. In the face of these it is a marvel that they can even for a year exercise their unpopular functions, and effect even as much as they do. Up to 1865 , two women and eleven young men had been baptized, and were in full communion. Four young men are now candidates for baptism, sixty are reading in the Gospel of St. Luke, and two hundred are in the primer.

The government is patriarchal. Chieftainship is hereditary. Since the decimation of the population, the island has been in the hands of petty chiefs, who have usually much power for evil, and but little for good.

Infanticide is uncommon, occurring only when the mother has died in child-bed, before the infant can take to the breast, in which case the little unfortunate is buried alive with the mother. In spite of the various causes of mortality, however, aged men, it seems, are not unfrequent in the island. The women tattoo their faces, and wear a girdle of leaves round their loins. They are generally chaste, yet breaches of the seventh commandment frequently occur, though death is the penalty. The wives of deceased 
brothers fall to the eldest surviving brother. Incest is probably rare; but instances it is said can be found.

Two different languages are spoken, the one, it is alleged, more generally than the other.

The great god of the Eramangans is called Nabu, and strangely enough they call all strangers by this name, whether black or white. They suppose the paradise of souls to be in the West. They have a tradition which says that men originally walked like pigs, and that pigs walked erect. They say the first of the human race was a woman, then came her son, and from them sprang the race of men. The Nabu, after having created the human race at Eramanga, went away to another land. They worship the moon, having images in the form of the new and full moons, made of a kind of stone. They do not pray to these images, but cleave to them as their protecting gocls. They practise circumcision, and believe in witcheraft. The graves of the dead are known by a depression in the earth of a few inches, and by two sticks placed erect. Some of the dead are placed in caves without any earth or covering. The natives do not eat anything which grows within about one hundred yards of a place where their own dead are buried. I heard nothing about their temples, if they have any.

Articles exported are sandal-wood and women. A Captain Edwards is spoken of, who in one year embarked 15,000 tons of sandal-wood, and in a short time realised a fortune of $€ 75,000$. This Captain Edwards has improved 
some of the paths about Dillon's Bay, but there are no roads. A little wood has been purchased from time to time, but the greater portion is cut and carried off by force. The last load of sandal-wood was shipped from this illfated island, in the 'Amateur,' Captain Long, for Hongkong, August 29, 1865.

The trade in women is extremely singular. The price of a damsel is two guns, say £5. A woman, at present under Christian instruction, was bought some years ago gy a person engaged in the trade, and again sold by him to the present owner. One Jonas-the Missionary says-a native of Manilla, bought three girls, and has also recently left the island, carrying off two women. Another Malay, named Joe, who shot a native of Sifu at Dillon's Bay, in June 1865, has likewise gone, and dragged off his slave, a fine little girl, to New Caledonia, in spite of her tears, entreaties, and her father's wishes. Another young girl, about twelve years of age, is at present the property of a native of Tongatabu, named Moses, and her fate is not doubtful; both are at present at Dillon's Bay. Not one half is known of the oppression and violence of the proceedings in a trade noted for a quarter of a century for its enormities.

During the closing months of 1864 , and the first of 1865 , there was a European family of seven or eight persons all told, and seven or eight white men, besides those on board vessels, living on the island.

Indigenous to the island are the cocoa-nut tree, the bread- 
fruit tree, banana, plantain, the chestnut of the Pacific, the yam, arrowroot, and taro in small quantities; these three last plants are, together with an edible root resembling taro, only very much larger, and called Nevya, the stand-by in times of scarcity and famine. There are four species of indigenous palms. The papau has been introduced.

Pigs appear to have been introduced from Tanna several years ago. Captain Edwards brought in horses, cattle, and goats, but none are in the possession of the natives; and the stock was to be removed to New Caledonia in a shor't time.

The natives give distinct names to sixty birds. Among them are pigeons, and several small birds, some of gay, others of gorgeous plumage. There are two species of snakes. There are native names for ninety-five salt-water, and for sixteen fresh-water fish; a few are edible.

Their weapons are bows, arrows, spears, \&c., and recently guns and hatchets.

They make the rings of stone, already alluded to, the largest of which weigh some forty pounds, and the smallest two and a-half pounds. They also make out of stalactites, or sometimes of clay, images of the new and full moons; they are considered sacred, used perhaps as idols, and are only exhibited at feasts; at all other times they are kept hidden in the ground. Numpuri shells, principally bought by traders, and boar's tusks, are used for similar purposes in barter. 


\title{
CHAPTER XXII
}

\author{
NEIV CALEDONIA.-LOYALTY ISLANDS.
}

(SEPTEMBER 28 to OCTOBER 8.)

Loyalty Islands-Aspect of New Caledonia-Havannah Passage-Prasline Bay-Canoes-At Anchor in Port-de-France-Visit from the GorernorVisit Returned-Madame Guillain-M. Guillain-Government House and Gardens-The Governor and the Protestant Missionaries-The Capital of the Colony-The Hodel Farm of Yahove-A New Kind of Plongh--Coffee Trees-The Aborigines-Religion-Manners and Customs--Infamous Usage of Natives by Whites-Captain Cook's Farourable Notice of them-Basset, Chief of Yengen-IIis House in the Interior-Appearance of the CountryTrimly-lept Houses-Poles Surmounted by Skulls--Remarkable Irrigation-Remains of Ancient Aqueducts-Return to Sydney.

ON September 26, the day of the shelling of Sifu, the 'Curaçoa' weighed at eight P.M., and stood away for New Caledonia. Favoured by a steady breeze from ESE., we made an excellent passage, and on the morning of the $27 \mathrm{th}$, reached Maré, one of the Loyalty Islands, a low level land apparently neither wooded nor fertile. After leaving Maré, where we received a supply of cabbages from the natives, who brought them off from the island, which we did not get near enough to land, we stood away for Sifu, ${ }^{1}$ which

I It is painfully illustrative of the brutality of manners disgracing our vaunted superiority over heathenism, that when H.M.S. 'Havannah ' anchored off Sifu, the natives, both men and women, who swam to the ship in a swarm, eagerly saluted the crew with the foulest English oaths, of the purport of which thcy were manifestly ignorant, and for 
we passed in the evening, and at ten o'clock next morning reached Uea, the smallest of the group, where we stayed till one o'clock. Of course I had no opportunity of making any observations myself, but, as there are some interesting facts furnished by former visitors, I am tempted to introduce them.

A Mr. Edwards who had been wrecked on the coast of Uea, and resided some time on the island, gave Captain Erskine a favourable impression of the people. He represented them as superior in moral qualities to any other islanders he had met with. The women (and there is corroborative testimony to this fact) are chaste before marriage and faithful afterwards. Their influence with the men is said to be considerable, and such is the respect paid to them that the slander of a woman would be regarded as a casus belli between tribes. Hood ${ }^{1}$ mentions a most gallant and humane act of the natives in saving the lives of fourteen English seamen, the crew of a ship that had foundered, and who had constructed a raft on which they were seen drifting helplessly past the island. Having been rescued with much difficulty, they were, on reaching the shore, taken to the huts, and most hospitably entertained for three weeks, until they were received on board H.M.S. 'Esk.' It was a

which they were indebted to wrecked crews that had resided some months among them. Another donation from these favoured visitors was the plague of a certain disease (Erskine, p. 363). What an unquestionable right have these ill-used sarages-as we call them-tc say to Christianity, "Physician, heal thyself."

1 Cruise of H.M.s. 'Fawn,' p. 164. 
sorry requital for such services that the captain of the 'Esk,' deceived by the misrepresentation of some knavish trader, imposed a most heavy fine on the island as a compensation for some alleged injury to this person, to be paid within a certain time. It was to collect this fine that the 'Fawn' visited the island, but on investigation it was found that the claim for compensation was groundless; all, however, that Captain Cator could do, without infringing his orders, was to extend the time of payment of one-half; and Mr. Hood expresses the hope that 'in the interim those before whom the matter may come will preserve the reputation we have in these regions for justice and honesty by remitting this portion of the cruel and unjust exaction.' He regards the case as one of the most flagrant illustrations they had yet met with 'of the unfair treatment which the natives too often experience at the hands of the Papalangis.'

According to Mr. Hood, the Ueans resemble the Samoans, but are of rather a darker hue, and with noses less flattened; they have their frizzled hair hanging down their shoulders, and embellish their faces with yellow ochre and red paint, the ochre being preferred. Those he saw sitting in church with their frizzled heads of hair all squared at bottom, reminded him of the Nineveh marbles. He adds, ' in some of the islands to the westward the women have a way of dressing their hair in a multitude of little ringlets twisted with fine cocon-nut twine, and the men have their beards arranged in the same manner, also cut square, giving 
them almost identically the same appearance with the Assyrian figures."

About noon we came in sight of New Caledonia, which as we advanced disclosed to us more and more distinctly its east coast. The island appeared to be very mountainous, and the coast at one part near the Havannah Passage was very precipitous. The land that was visible looked very barren in every direction, and in a great many places there was apparently no verdure of any kind on the clark red soil; where there was any wood, it seemed confined to small spots. There were a good many islands, some of them covered with lofty pines, which were very thick at places, and looked almost like cypresses. There are a great many reefs'also about these islands. Before, coming to Havannah Passage I saw a fine waterfall, which, though not precipitous, was of considerable height, coming down a channel it had worn for itself on the mountain side, and finally fall ing over a steep cliff into the sea; its name, I was informed, is Undiania. We took the Havannah Passage, which is near the SE. extremity of New Caledonia, between a great number of islands, reefs, \&c., extending from thirty to forty miles at the S. extremity of the island and about two and a-half degrees at the $N$. end, and appears indeed to encircle the island. After getting round Cape Queen Charlotte, and entering Havannah Passage, we soon came to Port Goro, which is the first bay on the starboard side; the sea was as smooth as a lake as soon as we came among the reefs and islands of New Caledonia. 
The soil as before appeared to be all red, and the configuration of the country was pretiy, though it appeared very poor. There were many bare red places on the hills; the pines were here also confined to certain spots; they grew high, and had a peculiar appearance, from their branches being short below and gradually increasing to the top, thus presenting the reverse of that conical form we associate with pines. The country looked very mountainous, but the highest elevation which any mountain attained did not appear to exceed 3,000 or 4,000 feet. After passing Port Goro, we went by two small bays or ports, and then came to Good Cove, in Praslin Bay.

We anchored at half-past six P.M., in twenty fathoms, in the pretty bay of Praslin. There were spots on the hills of a whitish appearance, like sulphur beds. The point of Praslin Bay had a pretty clump of pines upon it, nearly down to the water's edge, and still farther on were the islands that formed the first part of Havannah Passage. On the shores round Good Cove, the vegetation was very sparse and of a very stunted appearance; the woods were in patches only, and the trees not large. A splendid sunset added beauty to the scene, and the effect of the nine o'clock gun was extremely fine, as it aroused echo after echo among the hills. We saw no canoes, natives, nor houses, and very few cocoa-nut trees.

We remained the whole of the next day at this capital anchorage, the crew being busily engaged in setting the ship to-rights. There were a good many small birds about on 
shore, which I could hear singing in the morning. I saw a white crane under a tree at the bottom of the cove; also two large brown birds, which looked like a species of heron when on the wing. Fish were jumping out of the water, and pretty large ones, too.

On the morning of September 30, a missionary in a large whale-boat, rowed by natives, came on board, and asked if we wanted a pilot; finding we did not, he went off immediately. Shortly after, three canoes with outriggers, one of which had a platform, hailed the 'Curaçoa'; they were manned by unarmed natives, who seemed rather a fine set of men; they were all more or less dressed, or aspired to be dressed, in European style; one had a military jacket on, another a great coat, another a cap and guernsey, \&c.; in the matter of trousers the prevailing fashion was native, most of them had none. In one of the canoes was a decentlooking native woman, with some boys who were naked and looked rather cold.

We weighed a little before noon, and made for Port-deFrance. From the chart the navigation seems intricate, but it appears to have been all surveyed. It was pretty enough passing among all these islands. The weather was line, and the water quite smooth; we conld distinguish pretty accurately the shoals and reefs from the deep water by the dark blue colour of the latter. We often ran within a short distance of the shore, and could see streams of fresh water and waterfalls running or tumbling down the mountain sides, and near the spots where these waters ran into the sea 
might generally be seen one or more native houses, amicl the broad belt of wood that skirts the base of the mountains. There were a ferw cocoa-nut trees at these places, but no groves of them. I saw but a very few canoes, and those were small and drawn up on the sandy beach. The soil seemed very red, except at the white patches and the ravines. The upper parts of the mountains were generally covered with grass or fern. One could see from the strata of the rocks that this part of the island had been upheaved; as we went on, the tall pines became more and more rare. We soon came in sight of the lighthouse at Amedée on the Island of Amed, and saw a pilot who was coming off to us. The lighthouse is painted white and red in some parts, and seems very high; it is made of cast iron; the different sections are joined together with masonry. We stopped to take in a pilot, a Frenchman, who spoke a little English. We soon came in sight of the semaphore on a hill at the back of the town, a square tower which signals the arrival of vessels long before they can be seen at Port-de-France; it was not long before we saw the masts of a man-of-war, and then the hull, which, as the pilot informed us, was H.M.S. ' Ealcon,' Captain Parkin, arrived five days previously. We noticed a few houses of settlers, as we came along, most of them pretty near the sea, and not very far from the port, of a small wooden bungalow style. We could now see the town of Port-de-France. At last, after passing a rocky point with a cliff, we came to the mouth of the port, across which there is an island of some size, more than half a mile 
in length. We went through the passage nearest to the point, which is by far the widest of the two, and the water about it deep. We had a fine view of the port and of the town, which is built upon a slope, the lower end of which comes down to the water. It is a very fine harbour, and the entrance apparently easy for ships. There were in port two French men-of-war, the 'Gazelle' and the 'Fulton' (a paddle steamer' with the pennant of the Governor), and the 'Falcon,' which from her size appeared to advantage near them. The mountains in the background, covered with wood and grass

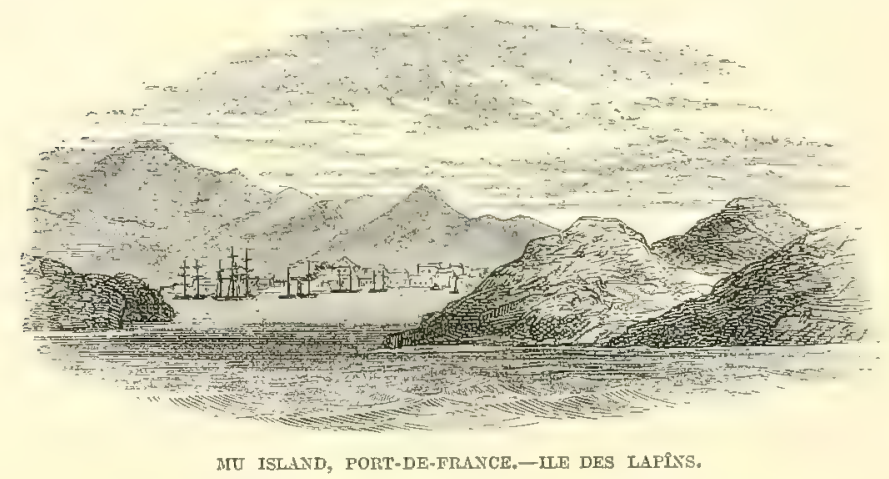

had a fine effect. The pilot pointed out to me Mont $\mathrm{Mu}$, 4,000 feet high, the highest in this part of the island, which seems very mountainous. There is a chain of hills running nearly from one end of it to the other, which is said to be about 150 miles long. We passed a new battery, which the pilot said was the Artillery Battery; it appeared to be merely a piece of wall with a platiorm on which there were a few mounted guns; the artillerymen were scattered about near some houses a short distance above it. We could see 
the Govermment House very well, and the town also, which looked a poor place, very small, with little wooden houses. Ve stopped at half-past three P.M., and dropped anchor in ten fathoms; immediately after, we were visited by the Health officer. We then saluted the French flag with twenty-one guns, which was returned by the battery. Captain Mathieu, the aide-de-camp of His Excellency M. Guillain, a captain in the navy, Governor of the colony, came on board the 'Curaçoa,' to invite the Commodore to dinner that day at Government House, which he accepted, and had great reason to be pleased with the manner in which he was received.

During our stay, our relations the whole time with the French officials were of the most pleasing kind, and we carried away with us the most agreeable recollections of our visit to Port-de-France. There we made the acquaintance of Count Adam Kulczycki, the Government astronomer, a Polish gentleman, as obliging as highly informed, and whom I had the satisfaction of finding was acquainted with my friend, Jules Remy, the companion of some of my former wanderings, whom he had known at Tahiti.

On October 1, the day after our arrival at Port-deFrance, the Governor came on board the 'Curaçoa' in full dress, to pay his official visit, and received on leaving it a salute of seventeen guns. To our great surprise, the land battery, contrary to our English practice, returned the salute, it not being usual to return personal salutes.

In company with the Commodore, Captain Parkin. 
Lieutenant Meade, Mr. Veitch, and myself, had the opportunity of visiting the Governor, by whom we were cordially received.

M. Guillain has been for many years on the western const of Africa, Madagascar, \&c., and has published a work with plates and maps on those countries. He is a moderatesized man, about fifty-three years of age, and said to have a great deal of energy. His wife, Madame Guillain, is a pleasing little woman, very gay and sprightly, and a good deal younger than her husband. She told me that when they first came here, it was with a party of seventeen, all of whom, strangely enough, were unarmed, an act of confidence or carelessness in these regions of an unusual kind. With a most remarkable absence of mistrust, they went off for some reason or other, leaving her alone in the boat, which presently was surrounded by natives, who attempted to carry her off, from which peril she was saved by hercrinoline! How this much criticised decoration or garment became a defensive weapon was not explained; possibly in the struggle, the steel ribs being broken protruded in a variety of points, which thus formed a complete chevaur $x$-defrise; luckily, however, while the fray was going on, and her alarm at the highest, the Governor with his party came back to her assistance, and vowed, in the fulness of his indignation, he would be revenged upon them for causing her this fright. And she had just had the pleasure of knowing that this row had been fulfilled. For he had but a few days before our arrival returned from an expedition 
from the Northern coast, which had for its object the punishment of the natives for killing and eating five or six Frenchmen, together with part of a crev of a trading vessel; the discharge of his vow of course not being overlooked. The punishment was certainly very effective. Having landed a force at the proper spot on the coast, he marched by night to the village where the cannibals lived. The march must have been a puzzling one, especially to him, as he was dragged occasionally through the bush on all fours by his party, a kind of advance that was neither military nor pleasant. The result, however, was everything that could be desired. They attacked the village, and shot, burned, or bayonetted every soul in it, sixty in number; those who were not shot or cut down having been burnt in the houses, men, women, and children of course; not a soul survived to tell the tale. He felt this was a terrible vengeance, but had little doubt it would have its effect for a long time. It is, in fact, likely that the most eager cannibal would be disinclined to feast upon forbidden flesh at this price. On our return to Sydney we heard that the Governor had made a second raid upon the natives in another place, attended with the same merciless success.

The Governor's house is a square wooden building, whitewashed outside. It was within five minutes' walk of the new-built pier or jetty, that looks very short, but is, I believe, long enough for any conster or trader of the island to lay alongside. One of the rooms is panelled with acacia, and another with pine; both are done by the soldiers 
and have a very neat effect. There is a garden attached to it, which lies on a slope that goes down to the sea, and under the hill on which the telegraph is placed, up which there is a walk. It is well stocked with trees and plants of the country, as well as exotics, and yields grapes of an excellent quality, fruits such as strawberries and pineapples, and vegetables of various kinds. There was a trellis-work covered over with pretty creeping plants, and a profusion of roses and mignonette, which gave a home character to the spot.

While walking together in his garden, in which he takes great pleasure, the Governor gave me an account of the circumstance which caused so much noise some years ago, connected with the missionaries of the isle of Sifu. He attributed everything that had taken place there to the Rev. Mr. MacFarlane, who, he said, would not admit that the Loyalty Islands were under French rule, notwithstanding that this missionary had previously lent him a book written by himself, or one of his own body, which acknowledged the fact. He added that Mr. MacFarlane had excited and stirred up the native Christians against him and the French Govermment; that these came down upon him all armed, fired on the French soldiers, and were, in consequence, fired upon in return, by which several of them were killed and wounded. The Governor then forbade Mr. MacFarlane and the missionaries to make any more proselytes (not wishing in other respects to interfere with their religion), but insisted that they should confine themselves 
to the Christians already under their charge, and no longer attempt to govern the island, but submit to his authority. He told them that there was a French ordinance or law forbidding the further extension of the Protestant religion in the country, because, as it was French, the Catholic faith its religion, and French its adopted language, they would have to undo what he might do, and to teach French in the schools, and propagate the Catholic religion in the place of Protestantism. He said Mr. MacFarlane was compelled to give in, and, though he felt sore, he saw he was wrong; that they met afterwards, and parted amicably. This was altogether a very long story; and certainly seemed not to be in accordance with the decision of the Emperor, to whom the matter was referred; and who ordered the Governor, I was told, to come to an amicable arrangement with the missionaries, and to abstain from any further interference with them. M. Guillain spoke in strong terms against the French missionaries here, saying they had hitherto governed the natives, and were attempting still to do so, but that he could not and would not permit it; he instanced a missionary living towards the north that actually allowed the natives to call him 'Governor,' which, as the natives had never seen M. Guillain, and knew no better, it was easy enough to do.

The town of Port-de-France is a very small straggling place; its streets are unpaved, the houses not continuous. Most of them very small, nearly all built of wood, having generally a little verandah in front; they are, with one or 
two exceptions, low-pitched, and have all their rooms on the ground floor. The greater part of them appear to be grog-shops, cafés, or stores; of the latter I think the best belongs to Martin, an Englishman; there is another kept by Gubert, a Frenchman; but both very indifferent, and something like the common run of those I saw in New Zealand. The Imperial Hotel, said to be the only hotel

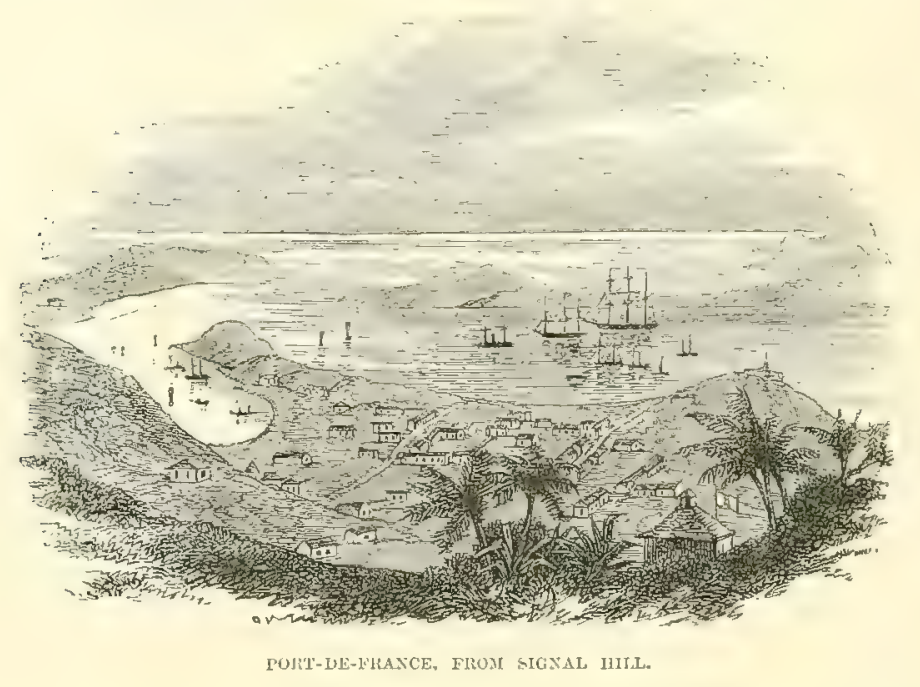

in the place, is kept by an Englishwoman called Madame Beck. There are a good many straggling houses on the outskirts of the town by the Marine Artillery barracks. The quarters for the troops are near Government House. There are, I believe, about 1,000 men here, counting the Marine Artillery. There is only one church that I know of, and it is very small and built of wood. Almost the best house in the place is the priests' on the hill, not very far from the Governor's. The roads and almost everything 
else have been made by soldiers and convicts. It is a dear place; beef costs tenpence a pound, and of mutton there is none, thongh there are a few sheep in the island.

The situation of Port-de-France is very picturesque; it stands on the edge of a beautiful hill, with a gradual slope to the water. The bay, seen from the top of it, looks nearly round, and they say there is water enough for a large ship or man-of-war in any part of it. The anchorage is very good, in a mud bottom. The Governor told me that ships would hold their ground in a hurricane. The hills around seemed covered with coarse grass, with a few trees here and there. The land does not appear to be much cultivated in the environs of the town; occasionally you may meet with small bits of ground used for vegetable gardens. The soil is red, being a ferruginous clay. In the Governor's garden, however, it is blackish, and has been all brought there, which is no doubt the reason the produce is better than elsewhere. There is good brick earth to be found near the town, as I heard, but as yet they do not appear to have made use of it, all buildings being of wood, except barracks and buildings belonging to Government. A great deal in the way of supplies, \&c., cones from Australia at present, it being cheaper than procuring them from the mother country.

About five miles and a half from the town is the model farm of Yahove or Yahoue belonging to the Government. The Governor took us out one day in his omnibus drawn by a pair of good Australian horses, driven by M. Boutan, the 
manager of the model farm. 'Two gendarmes trotted in front, and two other horsemen, the Procureur Impérial and the chief engineer, kept close by us. The road had not long been made and was consequently very rough. The scenery was very pretty, the mountains before us in the distance looked beautiful. We passed a few small places in which settler's were living upon their land, but did not appear to have done much beyond building their houses and planting their cabbages. We passed some mangrove swamps, a part of one of which the road traversed; the sea at high water runs up at this place to the roadside, but there are only a few inches of water on the mud, and at low water the swamp lies bare. It is a good distance from the sea, and the mangrove bushes are pretty thick upon it.

We reached the farm buildings in about three quarters of an hour. We were shown the stables first, all of stone, consisting of a long shed quite open in front. There were about a dozen decent-looking horses imported from Australia. The Director's house, also built of stone, adjoins the stables and contains three or four rooms, one of which is kept for Madame Guillain, who often stays here when the Governor goes away from Port de France. There is a large sitting-room in which M. Boutan has a case containing a dozen or more gold and silver medals which he had won in France. There was a bookcase also, full of agricultural works. The rooms were all panelled with native woods. All kind of work upon the farm is done by convicts and disciplinaires; the latter have all been soldiers who, having 
committed some military offence, are sent out to the colony to work out their time of service, unless this be nearly completed when convicted, in which case they are kept at lome. But those that are sent out can never re-enter the French army.

There is a large carpenter's shop in which there were several of them at work; one young man was very goodlooking; another working alongside of him had, though rather good-looking too, no small amount of devilyy in his face. There is a large blacksmith's shop also. I saw a plough invented by M. Boutan; the centre piece-rumning from one end to the other, and to which the other parts are attached, - is of wood and therefore supposed to be better than if of iron, as then it might get bent, and could not be easily set right again. But the novelty in this ingenious plough consisted in the handle turning over from one end to the other, so that on arriving at the end of a furrow, the handle is turned over back again to the other end of the plough, and thus there is no occasion to lift and turn the plough round, but you merely bring round the team or oxen from one end to the other, hook them on, and change the coulter, which turned on a hinge or pivot to cut either backward or forward, accordingly as the plough was drawn backward or forward; there was a cutter to precede the coulter, a fixture, whichever way it went.

In the land under cultivation there were two ploughs at work, four oxen to each. The oxen were harnessed so as to pull with their heads. A strap was placed across their 
foreheads just below the horns, a better plan, says $\mathbf{M}$. Boutan, than yoking them up when it was not for any length of time, as in long contiuuous work. The oxen, however, were resting a little and panting away as if they did not find it very easy work. The land seemed pretty stiff, with a clay subsoil.

The garden and plantation part is a good-sized piece of ground, very level, but on a slight incline. On the edge of it, looking towards Port-de-France, there is a deep gully, down which some time ago, during the rains, the water had descended like a mountain torrent, as it really was, entirely overflowing the ground in that place, washing a good deal of soil and vegetation away, and covering the land with stones. This has been all rearranged, and in order to prevent, if possible, a similar occurrence, a bank has been thrown up along the side of the gully.

M. Boutan showed us some coffee trees which had not been planted more than eighteen months or two years, that were covered with an amount of bloom which Mr. Veitch said he had never seen equalled in any other place. I was told that the coffee berry was very fine, and that the soil and climate were well adapted for the cultivation of coffee. Everything appeared to flourish in the garden; vegetables of many kinds showed vigorous growth, and some European fruit trees that had been planted there, also looked as if they would do well. The Government allows the Director only 9,000 francs a year for the farm, of which he has to return to the Government between 3,000 
and 4,000 francs, the estimated value of the proceeds of the garden.

The views from the farm-house are very pretty; the deep wooded gorges and valleys on the sides of the mountains look beautiful from it, and the foliage resembles rich darkgreen velvet. There is a mountain at the back which terminates in a curious peak. I was told by the Director

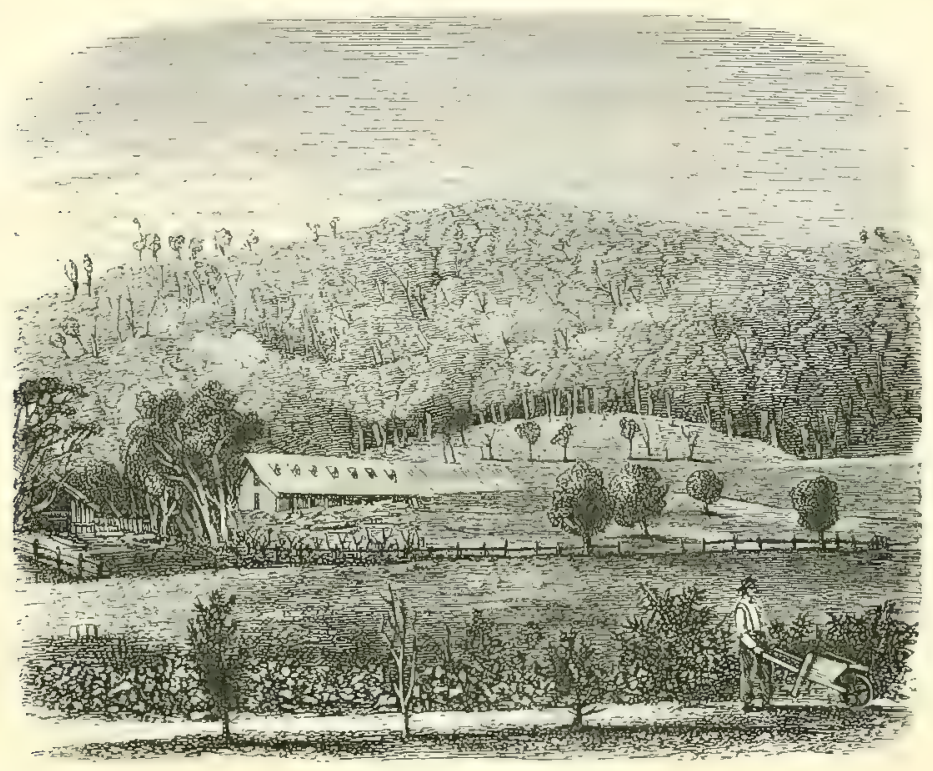

MODET, FARM, NEW CATEDONLA.

that the French missionaries, whose land adjoined the farm, had much better land than he has on the other side of the garden-gully, and that they generally managed to get the best everywhere; a sagacity of choice that missionaries of all creeds possess in their selection of lands.

I saw but few natives. They are a rather tall, muscular people. They are said to be courteous and friendly, and 
have less the habit of pilfering than any of the other islanclers. Many of both sexes go quite naked; some of the women wear the small lavalava which scarcely covers their nudity. The men use the same grotesque wrapper we have already spoken of in connection with other natives, and which Mr. Murray says he has never seen elsewhere than in the New Hebrides.

A few of them were more or less clothed in European dress. They are said to work very well under European stupervision.

Nothing scems to be known about the population; what strikes me as singular is that till now no. native name has been found for the entire island. Very little is known of their religion. Their gods are their ancestors, whose relics they keep and idolize. They have in some places wooden idols. They pray to their gods and to the gods of other lands before going to fighting, fishing, planting, housebuilding, feasting, and doing anything of importance. Almost every family has its priest whose office is hereditary, There is a rain-making class of priests. The spirits of the departed are supposed to go to the bush, and at certain periods in the year they have feasts in which they prepare heaps of food for the spirits. They think white men are the spirits of the dead and bring sickness, and they give this as a reason why they kill them. They throw over the eliffs into the sea anyone among themselves suspected of witchcralt, or supposed to have caused the death of any person. At the birth of a child, if a girl, she is betrothed forthwith 
to some one present, and leaves home for the house of her future husband when seven or eight years of age ; if a boy there are great shouts and rejoicings, and the priest cuts the navel-string on a particular stone, that the new-born may be stone-hearted in battle. Circumcision is practised when the boy has become quite adolescent. Common people have one or two wives; chiefs have from ten to thirty. They intermarry without troubling themselves about consanguinity, even between the nearest relatives. They cut off the finger and toe-nails of the dead to preserve as relies, and bury all the body but the head, the skull of which they leep for different purposes. They migrate from place to place, never long occupying the same piece of ground for cultivation; hence there are no permanent villages. As they had only stone axes until recently, they felled their trees by means of a slow fire close to the ground. The chiefs have absolute power of life and death. The law of private revenge allows the slaying of the thief and the adulterer. They live principally along the coast. They fight with clubs, spears, and slings. Women go to battle, keeping in the rear, and when they see an enemy fall it is their business to rush forward, to pull the body behind, and to prepare it for the oven. The priests go to battle too, but sit in the distance, fasting and praying for victory. Their appetite for human flesh is never satisfied. They have no pigs, and but few bread-fruit trees. Taro, yams, cocon-nuts, sugar-cane, fish, pigeons, bats, rats, and human flesh are the prevailing articles of food. They cook 
in earthenware pots manufactured by the women, and it is a curious fact that carthenware jars are not found in any other islands except the Fijis and Espiritu-Santo. They have no intoxicating ava, but drink enormous quantities of salt-water. It appears that they have only one meal a day.

The missionaries are so little inclined to attribute the defects, vices, or crimes of the natives to any other cause than their heathenism, that it is with some surprise we find the Rev. Mr. Murray declaring that if the New Caledonians of the present day no longer deserve the encomiums which Captain Cook passed upon them, the probability is that the 'altered conduct of the natives is to be charged chiefly to the account of their visitors;' and such is his opinion of that conduct as to make it seem to him 'a wonder that they do not kill every white man that places himself in their power.' 1 Nothing, indeed, could be more courteous and friendly than the reception which Cook and his party met with. They were guided and accompanied in their excursions by the natives, who evinced not the least uneasiness at their presence. He found the flat plain between the beach and the hills filled with villages 'finely cultivated,' and 'watered 'by little rills, conducted by art from the main stream, whose source was in the hills.' 'The huts, which resembled beehives in shape, were found to be insupportable within. In their general effect they had a neat appearance externally, with ornamental work on their

1 Missions in Western Polynesia, p. 269. 
tops, and sometimes with carved door-posts. This description reminds us of the pretty little sketch of a native chief's house, in Captain Erskine's work, ${ }^{1}$ corresponding externally with the account above given. This chief, Basset, is described as being an intelligent man, who with his brother had visited Sydney, and spoke English well enough to keep up a conversation. He was a man of about thirty, of quiet and rather dignified manners, very anxious to introduce a higher civilization. In a little excursion, during his two days' stay, to visit another house of this chicf's about five miles inland, Captain Erskine met with 'trimly kept houses beautifully situate on the river banks, with good landingplaces, and a few trees placed in regular order on what appeared to be mown lawns.' The country struck him, as it had Cook, as deficient in natural fertility, but he found a degree of care in its cultivation he 'had never expected to see among savages.' By a system of irrigation which appeared to be most scientifically conducted, the slopes of the hills were covered with rectangular fields, surrounded by channels of water that flowed at intervals into the river. Like Cook he found the natives about Basset's village goodhumoured, though poor and ill supplied with provisions. On his way were observed some poles with skulls upon them, and when the meaning was asked, Basset, it is said, looked confused, and said 'they were heads of friends kept as mementoes.' But Mr. Hood ${ }^{2}$ supplies another explanation;

\footnotetext{
1 Cruise of the 'Havannah,' p. 353.

2 Cruise of the 'Fawn,' p. 218.
} 
he tells us that the teeth of old women are sown in yam patches as a charm to procure good crops, and their skulls set on poles for the same purpose, and this is probably the explanation of the practice. The women at first were much alarmed at the appearance of the white men, but on receiving a present or two lost all their fears, and chatted away as freely as the men, to whom it was manifest they were in great subjection. In fact all accounts agree that women are at a great discount here. Mr. Hood speaks of them as 'the most degraded of all the South Sea Islanders,' and as 'leading a life of drudgery.' He tells us a story which, whether it be true or not, illustrates the utter disrespect in which woman is held, and that is, that a wellknown chief in the North used to set up a row of women as targets, and to shoot them down one by one. This depreciation of the sex explains a fact which Cook reports. It appears that when he landed, a native who had accompanied him to shore, indicated to him the persons to whom the presents he had with him should be given, and who, when he was about to offer something to the women, held back his hand. Either, therefore, a gift to the women would have been indecorous as putting them on the same level with the men, or a lorvering of the value of the gift as being mean enough for them.

The men do not in general suffer their beards to grow, but cultivate whiskers, which are so essential that a man without them is said to be cursed by the gods. War is reported to be constant, and the pricsts are alleged to 
encourage it as much as they can; their interest in it arising from their desire to be furnished with the hands of the enemies, which are their perquisites. When the supply falls off, they threaten the people with disease if war be not renewed or actively carried on. Another illustration this of the mischievous use to which religion has been, and is sometimes, put by those authorised to direct it. It would appear from what Mr. Hood tells us, that a more advanced civilisation must have at one time existed on this island. Remains of ancient aqueducts are to be found; one eight miles in length; also of paved roads and fortifications. 'We are not,' they say, "like our ancestors; we cannot build large houses as they did; they were numerous and wise, we are neither the one nor the other." It is evident that the skilful irrigation which has so much surprised those who saw it, must be a practice that has been transmitted from better times.

On September 8, at half-past seven A.M., we took leave of Port-cle-France, on our return to Sydney, which we reached on the 13 th, after rather a stormy passage.

Thus came to a close our interesting cruise. It had extended in time over nearly nineteen weeks, and in distance some 9,284 miles. I looked back upon it with pleasure not unmingled with regret,-pleasure at having had the opportunity of secing what I saw,-regret that the opportunity had been so fleeting and brief. In my various wanderings I had met with many rude, inert, and imperfectly developed races of men. I had seen the 
Australian, brutishly incapable of civilised development I had sojourned among the North American Indians, living in sullen hatred of that powerful civilisation which, in its origin, had expelled them from the soil it now occupies, and on the ever-encroaching confines of which they moodily roam; doomed apparently to vanish out of existence with the features of their primitive rudeness uneffaced. But what in this excursion was new and engaging to me, was the spectacle of these island communities, exhibiting incontestable evidence of their power of spontaneous development, made manifest in their social organisation, their creditable agricultural industry and skill, their progress in certain industrial arts, their peculiar ceremonies of public consultation, the decorum, and even refinement, of their manners, and above all, in their capacity for absorbing the instruction and influence of a more advanced civilisation. What I could not but lament was that I could only glance at what I should have liked to have examined, record rapid impressions instead of reporting careful experience, and depend on statements and descriptions which require to be accurately tested before we can accept them as verified. In Sir John Lubbock's very interesting work on 'The Origin of Civilisation and the Primitive Condition of Man, nothing is more remarkable than the confused and contradictory character of the judgments that are passed on uncivilised communities, and how constantly the statements he makes use of to support a conclusion are positively contradicted by other statements, which with exemplary fairness he 
adduces. And good reason is there to be on one's guard. From the brutal trader who boasts that he has shot down the natives in sport, and who occasions, for trade purposes, the ferocity he trumpets and exaggerates, up to the selfsatisfied missionary, who persuades himself and others that all that is good in them is of his own donation, there is a combination of misreport which makes a just estimate of their real character, as long as we are dependent on such interested authorities, next to impossible. It is deeply to be regretted, in the interests of ethnological science, that competent observers have not made them the subject of study, and, in their own interest, that the more advanced civilisation by which they are being instructed comes to them unfiltered, and tainted with overmuch that is vilest and most degrading in itself. That the Missionaries are doing much, though not unmixed, good, seems to be the general testimony; but how much more beneficial would be their action if with their zeal they combined knowledge, if they were men of more cultivated intellects, and of a greater social refinement, in one category of which, that is manners, they are often much inferior to those they teach, and thereby, as we have seen, abridge their own influence. Hence it is much to be regretted that the standard of native refinement will be lowered instead of raised, by those who will have the power of moulding it. But it is useless to complain. The rough work of a higher, but inefficiently imparted, civilisation will go on as it has begun; and it will be a matter of interest hereafter to 
know the character of the materials out of which its results have been wrought. Enquirers will naturally turn for information to those who have stood by the cradle of these nascent societies, and noted some of the phenomena of their infant development. $\Lambda$ s a slight contribution to the object they will have in view, my little work may not be without its use.

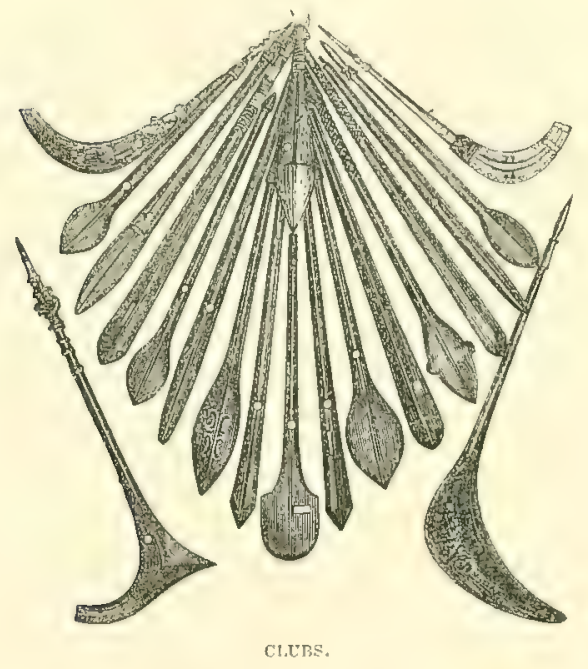


NATURAL MISTORY NOTICES. 



\section{B IRD S.}

BY G. R. GRAY, F.R.S., \&c, ite.

The Ornithology of the South Sea Islands is peculiar, and local in many of the groups; but space confines the treatment of the subject within narrow limits. It is, therefore, proposed to notice only those birds that are new, or especially rare to science, and thus to convey some idea of their singular formation and richness of colour. 
PLATE I,

ACOIPITER ALBOGULARIS.

(Accipiter albogularis, G. R. Gr. Ann. and Mag. of N.H. 1870, p. 327.)

Male. The upper surface plumbeous black tinted with grey; the base of the feathers on the hind head white; the entire surface beneath the body also white, but irrorated with plumbeous on the chest and thighs.

Length $17^{\prime \prime} 6^{\prime \prime \prime}$, wings $10^{\prime \prime}$, bill $1^{\prime \prime} 1^{\prime \prime \prime}$, tarsi $2^{\prime \prime} 4^{\prime \prime \prime}$.

This bird, of which there is only a single specimen, might at first sight be taken for the Accipiter haplochrous of New Caledonia; but it is larger and possesses a white throat, which at once distinguishes it from the last-mentioned species. It was obtained at Hada, or Recherche Bay, San-Christoval Island. 
IPL.

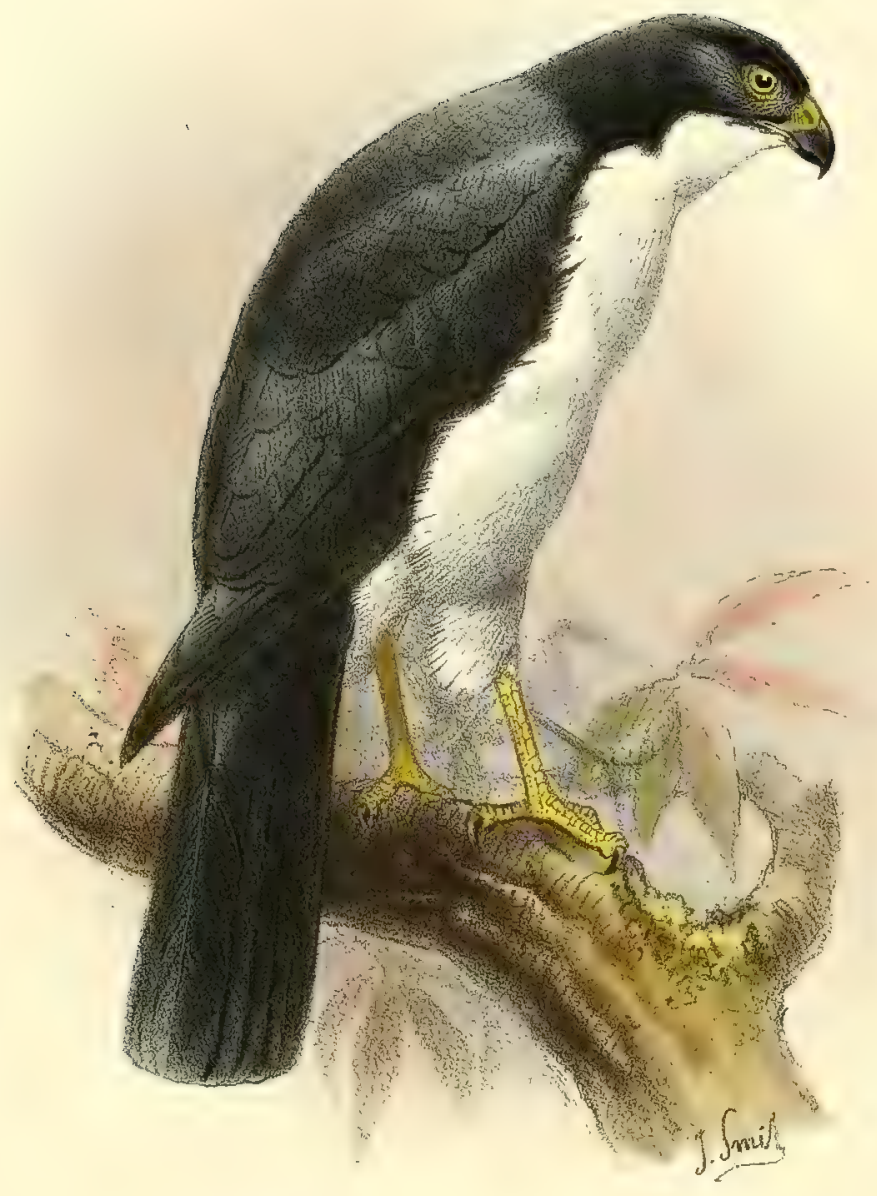

J Sme del et hth.

Mintem Bros.imp.

ACCIPITER ALBOGULARIS 
PLATE II. FIG, I.

COLTOCALIA HYPOLEUCA.

(Collocalia hypoleuca, G. R. Gr. Proc. Zool. Soc. 1858, p. 170.)

The upper surface of a glossy green-black; side of head, throat and breast fuscous black, with each feather margined with white, the lower part of breast and abdomen pure white ; the under tailcoverts glossy greenish black; the tail metallic black, the inner web of each lateral feather with a prominent white space near the base.

Length $4^{\prime \prime}$, wings $4^{\prime \prime}$.

Specimens were obtained at Uji or Gulf Island, which is one of the Solomon group.

'Eyes black. Contents of stomach, very small insects."

This species is also found in New Guinea, Mysol and Aru Islands. It is closely allied to Collocalia Linchi, Horsf., but is larger in all its measurements.

PLATE II. Fig. 2.

COLLOOALTA UROPYGTALIS,

(Collocalia nropygialis, G. R. Gr. Ann. and Mrg. of N. H. 1866, p. 123.)

Upper surface metallic black, with a broad band of pure white on the rump; throat and breast greyish; abdomen pure white; under tail-coverts metallic greenish black, with the smaller ones margined with white; quills and tail-feathers above metallic greenish black, the latter with a white spot on the inner web of each of the three lateral feathers, that on the first and third less in size, sometimes only found on the second and third lateral feathers; under wing-coverts metallic greenish black, with the larger ones margined with white.

Length $4^{\prime \prime}$, wings $3^{\prime \prime} 9^{\prime \prime \prime}$, tail $1^{\prime \prime} 9^{\prime \prime \prime}$.

This bird has hitherto only been obtained at New Hebrides (Anatom), where it is called by the natives 'Nahawpgag:'

These two species belong to the genus Collocalia, all the species of which form the well-known edible bird-nest, so much sought after by the Chinese for culinary purposes. 
PIls. 2 .

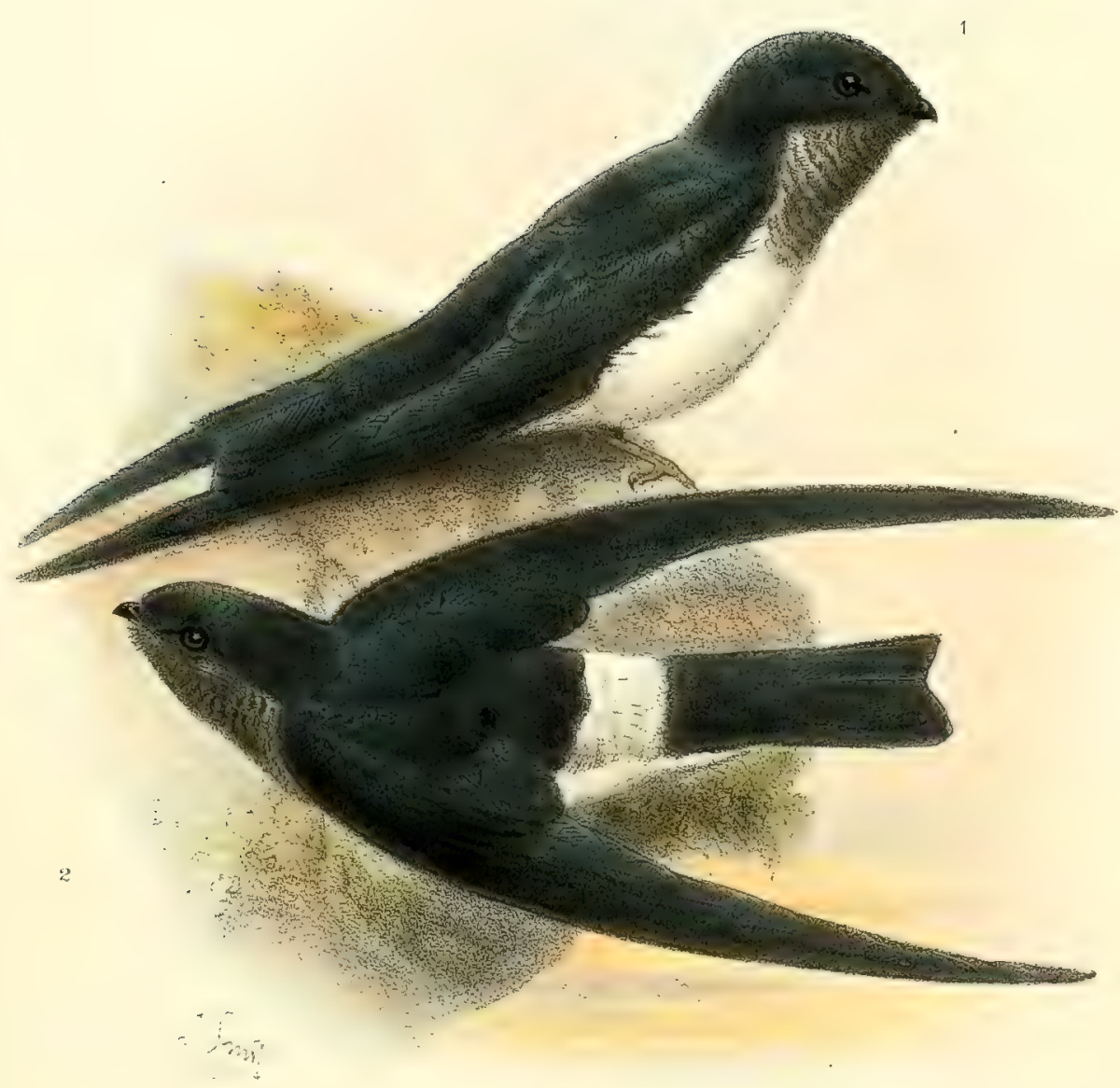

J.Sinit del et lith

1 COILOCAIIA FYPOLEUCA

2. $\rightarrow$ UROPYGALIS 

PLATE IV. FIG. 1.

\section{GLYOIPHITA OALEDONIOA.}

(Glyciphila modosta, G. R. Gr. Proc. Zool. Soc, 1859, p. 160 ; Glyciphila caledonica, G. R. Gr. Hand. list of B. I. p. 155.)

Upper surface obscure cinereous, darker on the head; back varied with olive; quills and tail fuscous black, margined externally with olive; throat, breast, and sides greyish brown, varied with cinereous white; abdomen pale greenish brown, tinged with yellow; ear-coverts shining grey.

Length $5^{\prime \prime} 6^{\prime \prime \prime}$, wings $3^{\prime \prime}$, bill $10 \frac{1^{\prime \prime \prime}}{2}$.

New Caledonia is the abode of this sombre species.

PLATE IV. Fit. 2.

\section{GLYOIPHILA FLAVOTTNOTA.}

(Gilyciphila flarotincta, G. R. Gr. Ann. and Mag. of N. H. 1870, p. 331.)

It is very like Glyciphila modesta, Gray, of New Caledonia; but it is rather larger in all its proportions, and it has a prominent tinge of yellow on the back and beneath the body, which is not found on the bird referred to.

Length $6^{\prime \prime}$, wings $3^{\prime \prime} 3^{\prime \prime \prime \prime}$, bill $12^{\prime \prime}$, tarsi $10^{\prime \prime \prime}$.

'Eyes black. Contents of stomach, honey. Male and female.' Three specimens were obtained at Eramanga Islaud. 
PIIS.II.

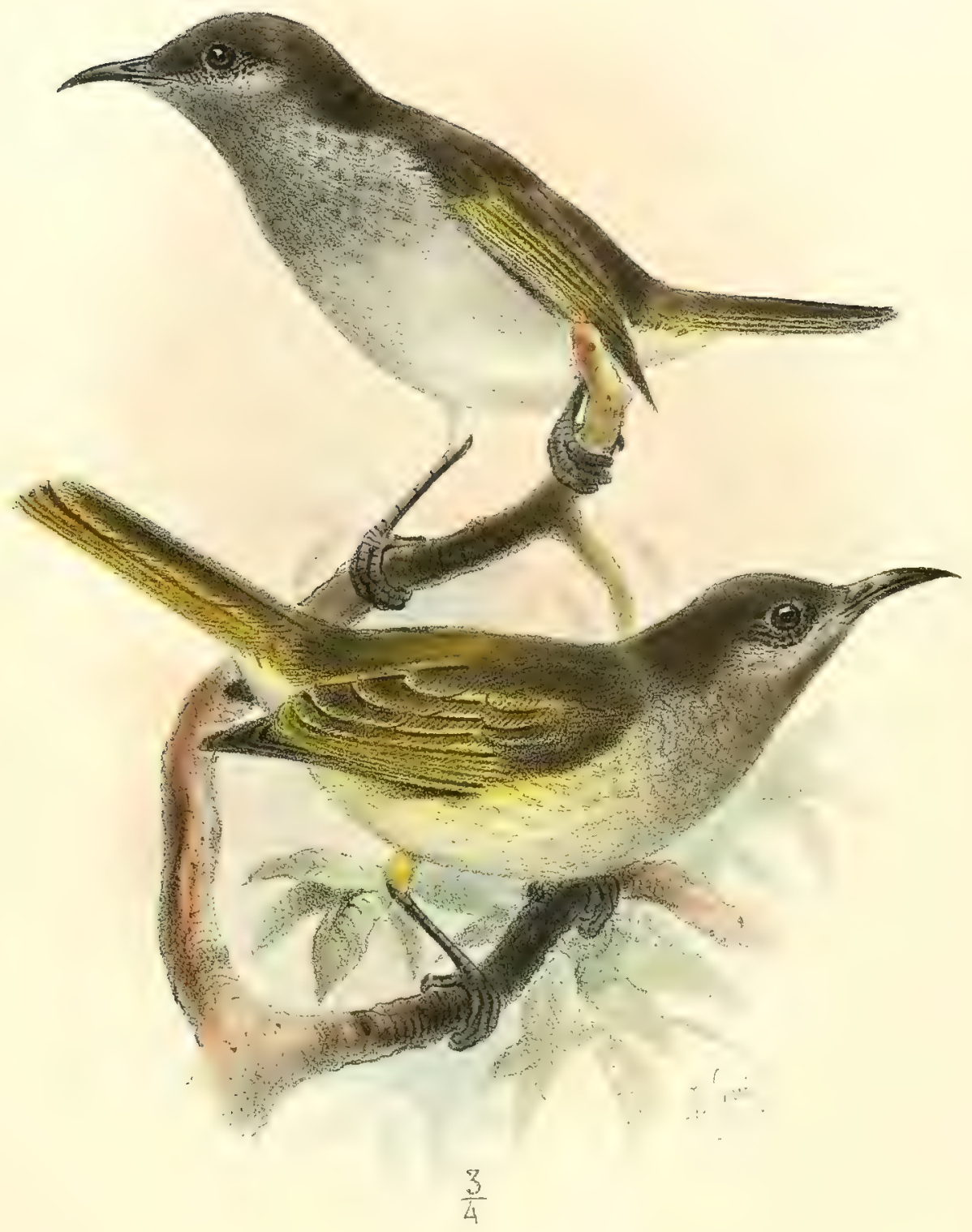

J.Sinit del. et hth.

2 FLAVOTINCTA. 


\section{-}



PIATE V.

\section{PIILEMON SCLATERI.}

(Philemon Selateri, G. R. Gr. Ann. and Mag. of N. H. 1870, p. 327.)

Female. Above brown, with an olive tinge; rump and tail dull rufous brown, each feather of the latter margined with yellowish olive; wings fuscous black, with the outer margins of quills yellowish olive, especially of the tertials; top and sides of head fuscous black, each feather broadly margined on its sides with yellowish white; throat white, tinged with grey, with a broad line of black on each side, proceeding from the ears; breast white, with black dashes down the middle of each feather, the black fading into brown on the upper part of the abdomen. Bill yellowish white; feet plumbeous.

Length $11^{\prime \prime}$, wings $5^{\prime \prime} 6^{\prime \prime \prime}$, bill $1^{\prime \prime} 6^{\prime \prime \prime}$, tarsi $1^{\prime \prime} 4^{\prime \prime \prime}$.

'Eyes dark brown. Contents of stomach, honey.'

A single specimen only is in the collection, which was obtained at Wanga, San-Christoval. 'This bird was recorded by Mr. Selater, in his list of Solomon Islands' birds, under the name of Philemon vulturinus, Homb. \& J. Through the kindness of that gentleman, I am enabled to rectify, by comparison, this error, which was entirely occasioned by the wretched state of the specimen he had under examination. 
$\mathbb{P} \mathcal{L}_{0}$.

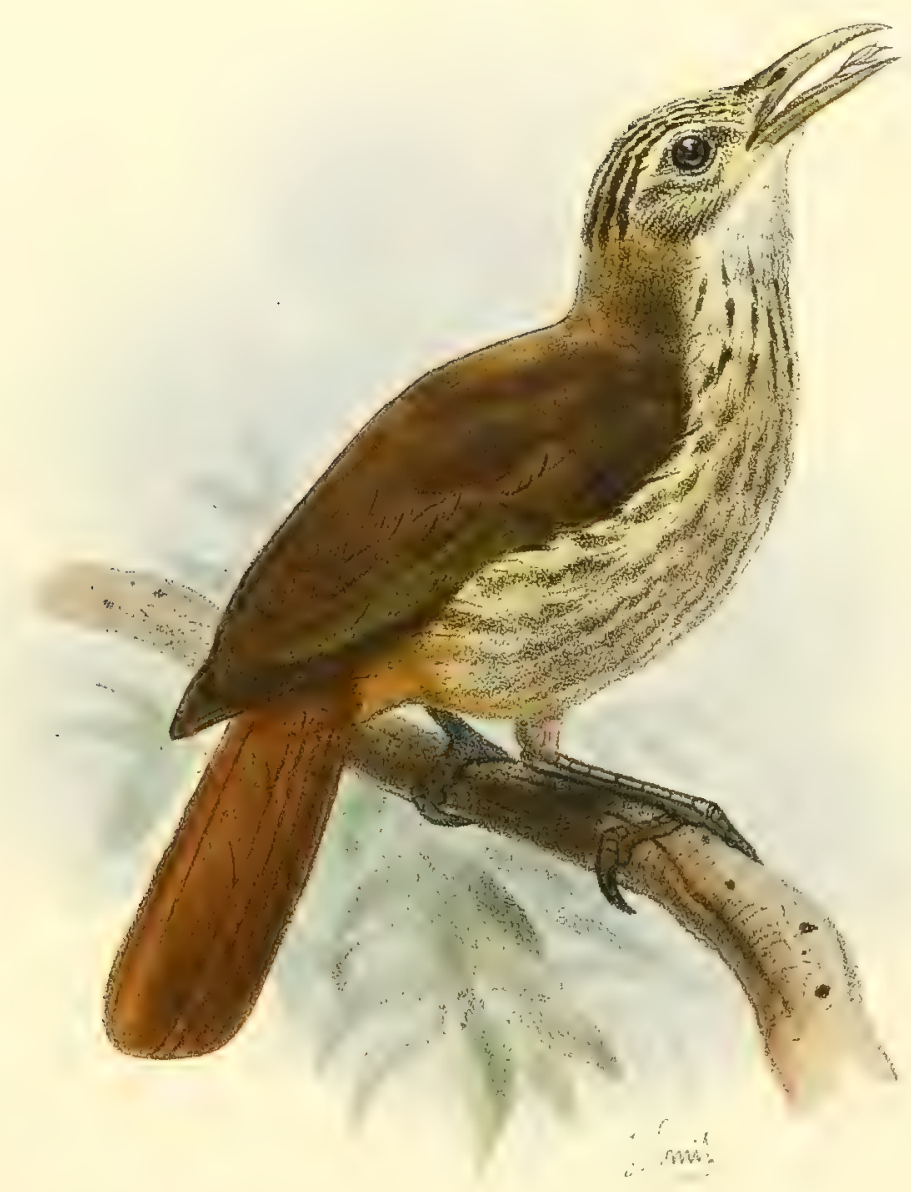

J.Stnit del et Jith.

Mintern Brog Jimp. 


PLATE VI.

ANTHOOIIARA AUBRYANUS.

(Leptornis aubryanus, J. Verr. and Desn, Rev. and Mag. de Zool. 1816, p. 16.)

Uniformly black, but this colour is duller on the wings, with the shaft of each feather black and shining; the sides of the head naked and of a clear reddish colour, which is divided in the naked space by a sub-superciliar and narrow band of black feathers, springing from behind the eyes to the plumes of the hind head, there is also an abbreviated, band beneath the eyes; the lores and mentum are partially clotbed with black bristly plumes. Upper mandible black and the lower one mostly yellow, except on the upper margin, which is black.

Length $17^{\prime \prime} 6^{\prime \prime \prime}$, wings $7^{\prime \prime} 6^{\prime \prime \prime}$, tail $7^{\prime \prime} 6^{\prime \prime \prime}$, bill from the gape $2^{\prime \prime}$.

This singular bird is peculiar to New Caledonia, where it is stated to be rarely met with. 
PL.

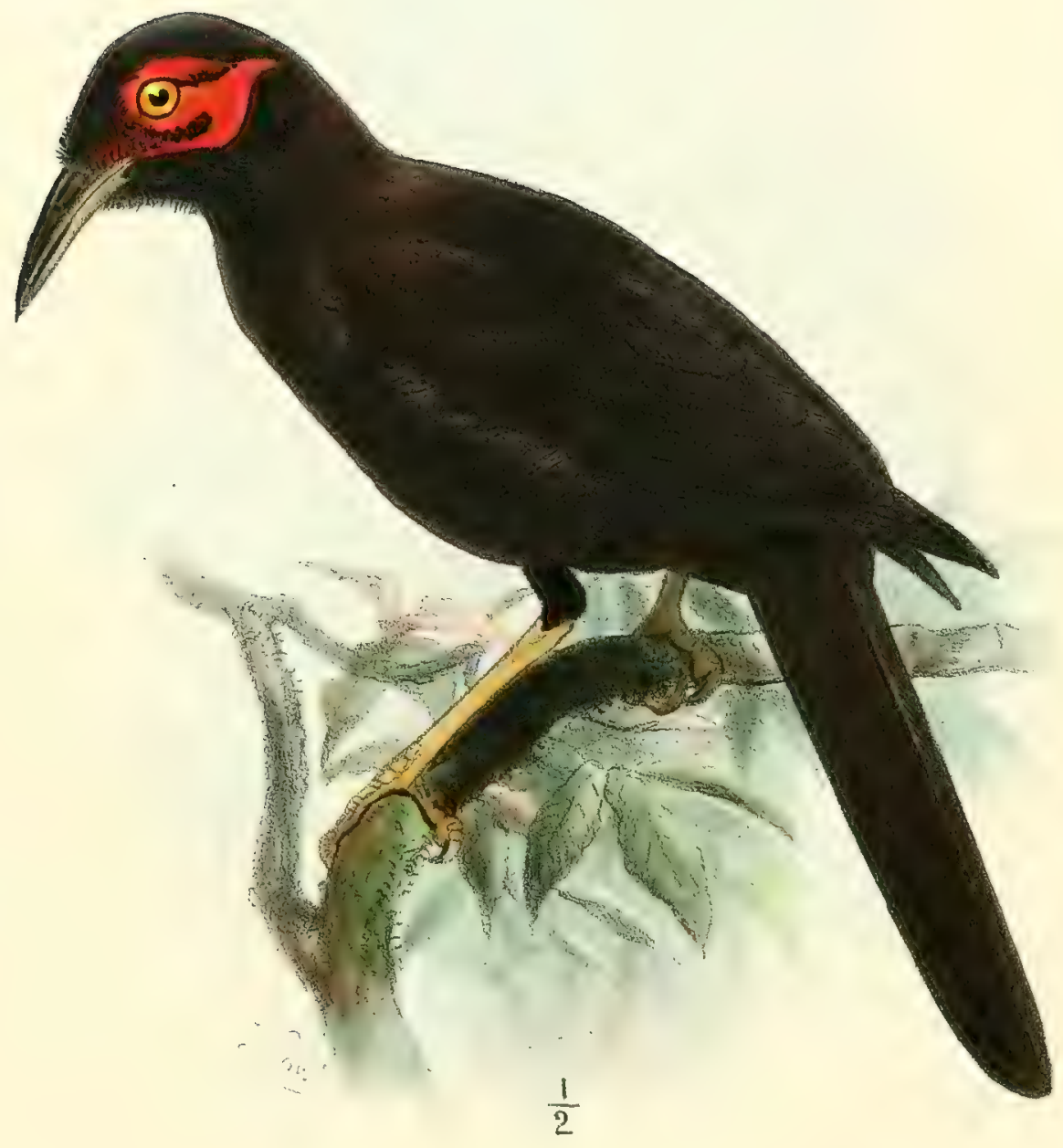

J. Snot del et lith.

Mriterm Bros. imp

AITTHOCHZLA AUBRYANUS 


\section{.}



PLATE VII. Fia. 1.

\section{ZOSTEROPS FLAVIFRONS.}

Musciceipa ftarifrons, Gn. S. N. I. p. 914; Zosterops flarifrons, G. R. Gr. Cat. B. Trop. Isl. Pacif. Ocean I. p. 15.)

Upper surface pale yellowish olive; the forehead and under surface yellow; sides olivaceous; round each eye a broad white ring; a mark between the gape and eyes black; quills and tail greyish fuscous black, slightly edged with yellowish olive, paler at the ends.

Length $5^{\prime \prime} 6^{\prime \prime \prime}$, wings $2^{\prime \prime} 6^{\prime \prime \prime}$, tarsi $9^{\prime \prime \prime}$, bill from gape $8^{\prime \prime \prime}$.

This species is found on the various islands forming the group of New Hebrides.

PLATE VII. Fig. 2:

\section{ZOSTEROPS XANTHOCHROA.}

(Zosterops zanthochroa, G. R. Gr. Proc. Zool. Soc. 1859, p. 161.)

Dark yellowish olive; the lores and beneath the eyes black, the latter surrounded with a broad white ring; throat and under tailcoverts yellow; middle of the abdomen white, tinged with yellow, and the sides rosy grey.

Length $4^{\prime \prime} 3^{\prime \prime \prime}$, wings $2^{\prime \prime} 4^{\prime \prime \prime}$, tarsi $9^{\prime \prime \prime}$.

'Eyes light brown. Contents of stomach, seeds and insects.'

This bird inhabits New Caledonia, where it is known under the name of 'Ti-ri-ri.' 


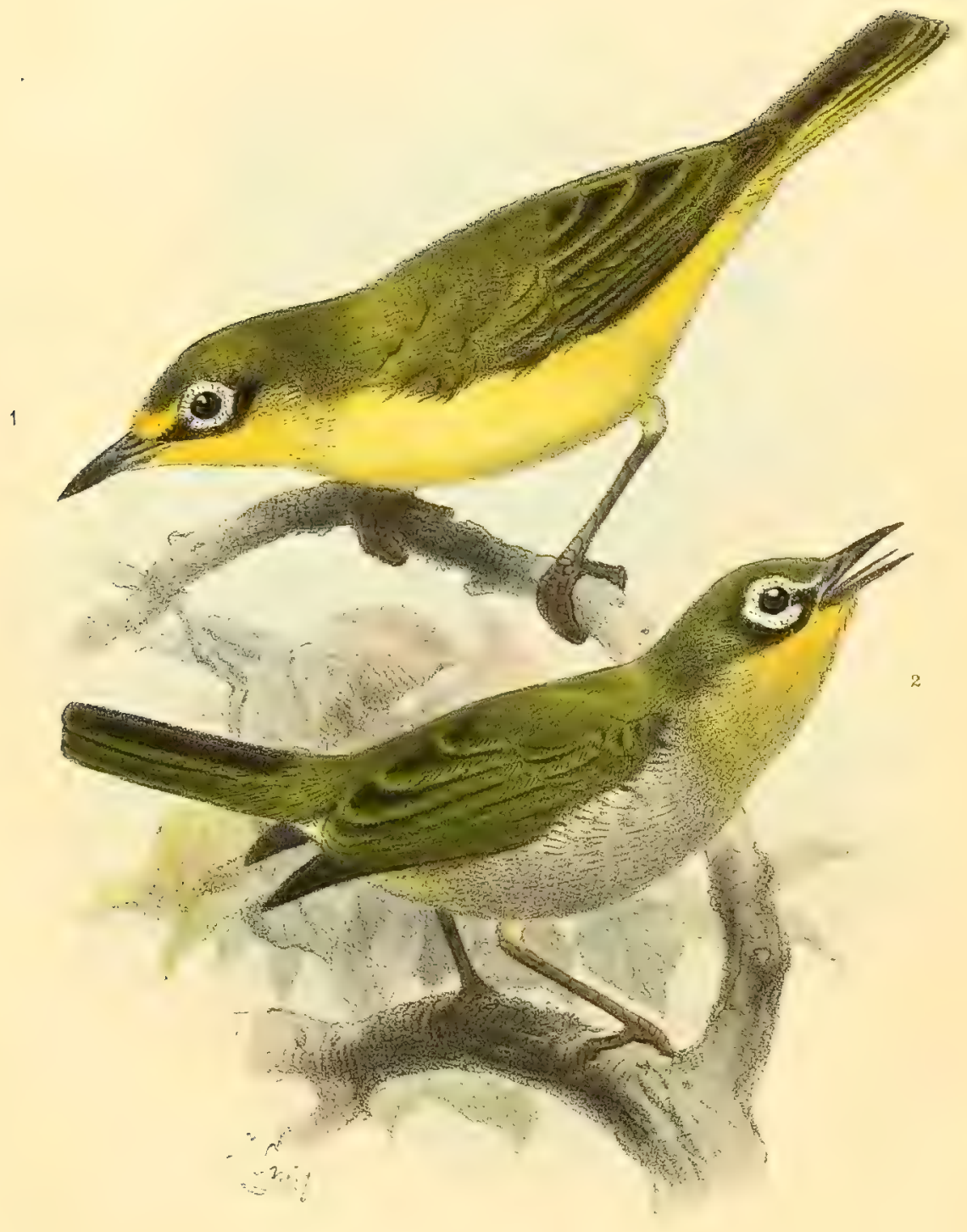

J. Smit del et lith.

Mintcon Bros imp

1. 1. ZOSTEROPS FLAVIFRONS

2. "XANTHOCHROA 
. 
B B 
PLATE IX.

\section{RHIPIDURA SPILODERA.}

(Rhipidura spilodera, G. R. Gr. Ann. and Mag. of $N . H .1870$, p. 330.)

Fuscous black; eyebrows white; throat and breast white, each feather triangularly marked in the middle with black; abdomen pale fulvous white; quills dark fuscous black; tail fuscous black, with the tips and inner margins more or less white.

Length $7^{\prime \prime}$, wings $3^{\prime \prime}$, bill $7^{\prime \prime \prime}$, tarsi $12^{\prime \prime \prime}$.

'Eyes black. Contents of stomach, insects. Female.'

This bird, of which there is only one example, was obtained at Vanua Lava, Banks' Group. It is like Rhipidura pectoralis, Homb. \& Jacq., of the island of Vanikoro; but the spots on the breast extend up to the chin. 
PL. 9.

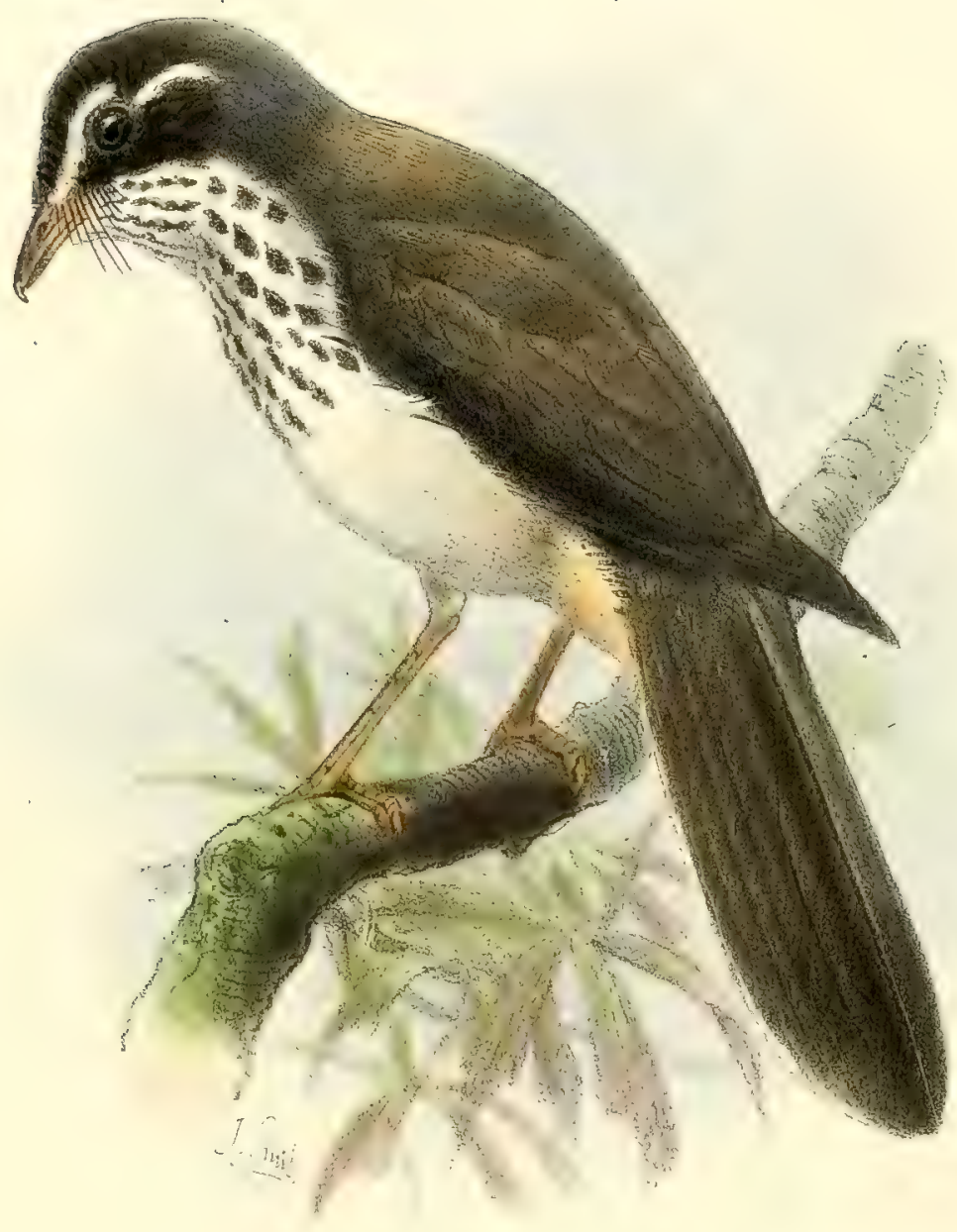

J. Smit de]. at lith

Mintem Bros immo

RHIPIDURA SPILOIERA 


PLATE X.

\section{LALAGE BANKSTANA.}

(Lalage banksiana, G.R. Gr. Ann. and Mag. of N. H. 1870, p. 329.)

Top of the head, back, part of wings, and a transverse pectoral band black; lore, eyebrows, sides of head, and throat pure white; beneath the body, part of great wing-coverts, tertials, rump, and tail buffy white; the latter has the middle feathers mostly, and outer margins of the others more or less, black.

Length $6^{\prime \prime}$, wings $3^{\prime \prime} 3^{\prime \prime \prime}$, bill $10^{\prime \prime \prime}$, tarsi $10^{\prime \prime \prime}$.

'Eyes black. Contents of stomach, insects. Male and young male.?

This bird was discovered at Vanua Lava, one of the Banks' Group. 
$\mathbb{P} \mathbb{L} \cdot \mathbb{Z}$ D。

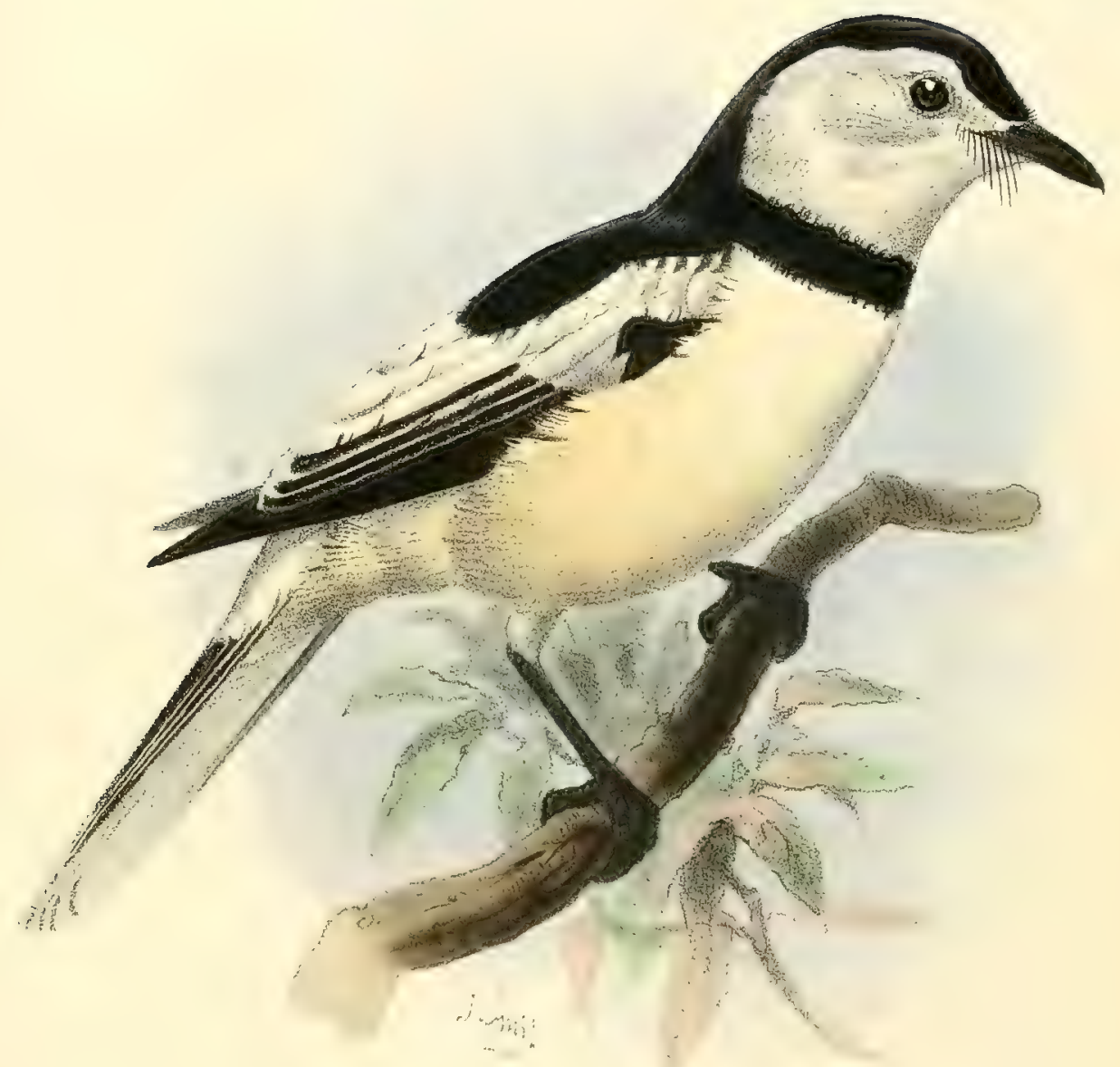



Head and band that margins the white throat, black; upper surface dark olive; wings, fuscous black, with the quills more or less margined with dark olive; under surface bright yellow; tail yellowish green, varied with black on the upper surface, while the tips of the feathers are obscure grey.

Female. Upper surface olivaceous brown; head rufous brown; throat white, breast and abdomen brownish white, tinged with yellow; under tail-coverts ochreous yellow.

Length $6^{\prime \prime} 3^{\prime \prime \prime}$, wings $3^{\prime \prime} 5^{\prime \prime \prime}$, tarsi $1^{\prime \prime} 1^{\prime \prime \prime}$.

This species is peculiar to the islands forming the New Hebrides Group. 
PI. IR.

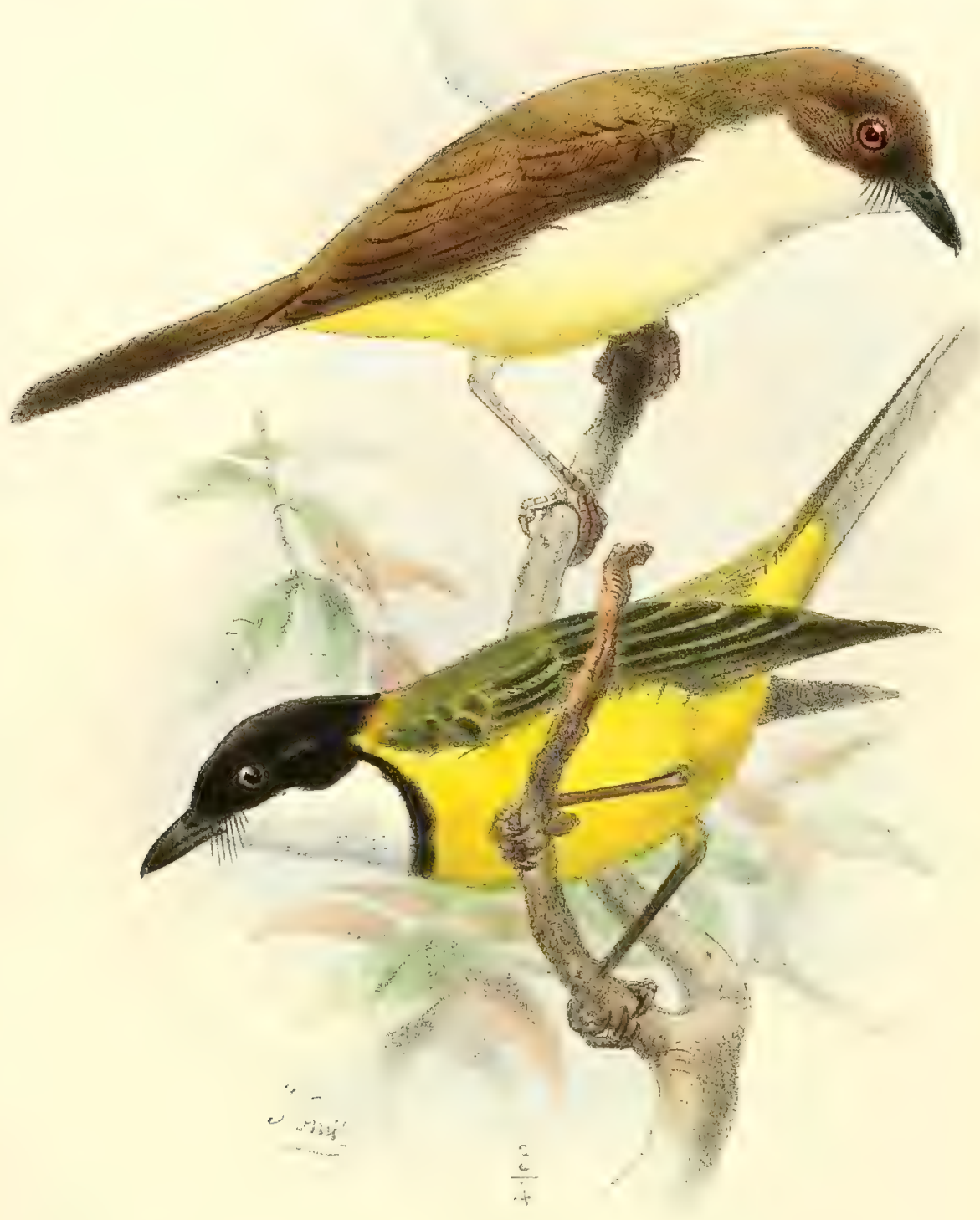

J. Smit del. et Inth 


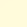



PLATE XIII. Fig. 1.

\section{LOPSALTRIA OALEDONICA.}

(Olive Flycatcher, Lath. Syn. 11, p. 342; Muscicipa caledonica, Gm. S. N. I.

p. 944; Eopsaltria? caledonica, G. R. Gr. Proc. Zool. Soc. 1859, p. 162 ;

Eopsaltria? rariegata, $G, R . G r$. tom. cit. p, 162.)

'I'op of the head, back, and upper surface of the tail, olivaceous green; under surface white; quills fuscous black, broadly margined with dark rusty colour; throat pale yellow narrowly and obscurely lunulated on the edges of the feathers, with dusky thighs and under tail-coverts yellow.

Length $5^{\prime \prime} 9^{\prime \prime \prime}$, wings $3^{\prime \prime} 3^{\prime \prime \prime}$, tail $2^{\prime \prime} 11^{\prime \prime \prime}$.

This bird is an inhabitant of New Caledonia.

PLATE XIII. FIG: 2.

\section{EOPSALTRIA OUCULLATA.}

(Eopsaltria cucullata, G. R. Gr. Cat. B. of Trop. Isl. Pacif. Ucean I. p. 21.)

Top of the head and ear-coverts rufous brown; back, margins of quills and tail, brownish olive; beneath the body yellowish white; throat white, with the feathers narrowly margined with rufous brown; bill black; feet pale plumbeous.

Length $6^{\prime \prime} 3^{\prime \prime \prime}$, wings $3^{\prime \prime} 3^{\prime \prime \prime}$, tarsi $1^{\prime \prime}$, bill from gape $9^{\prime \prime \prime}$.

This species is found in the New Hebrides Group. 


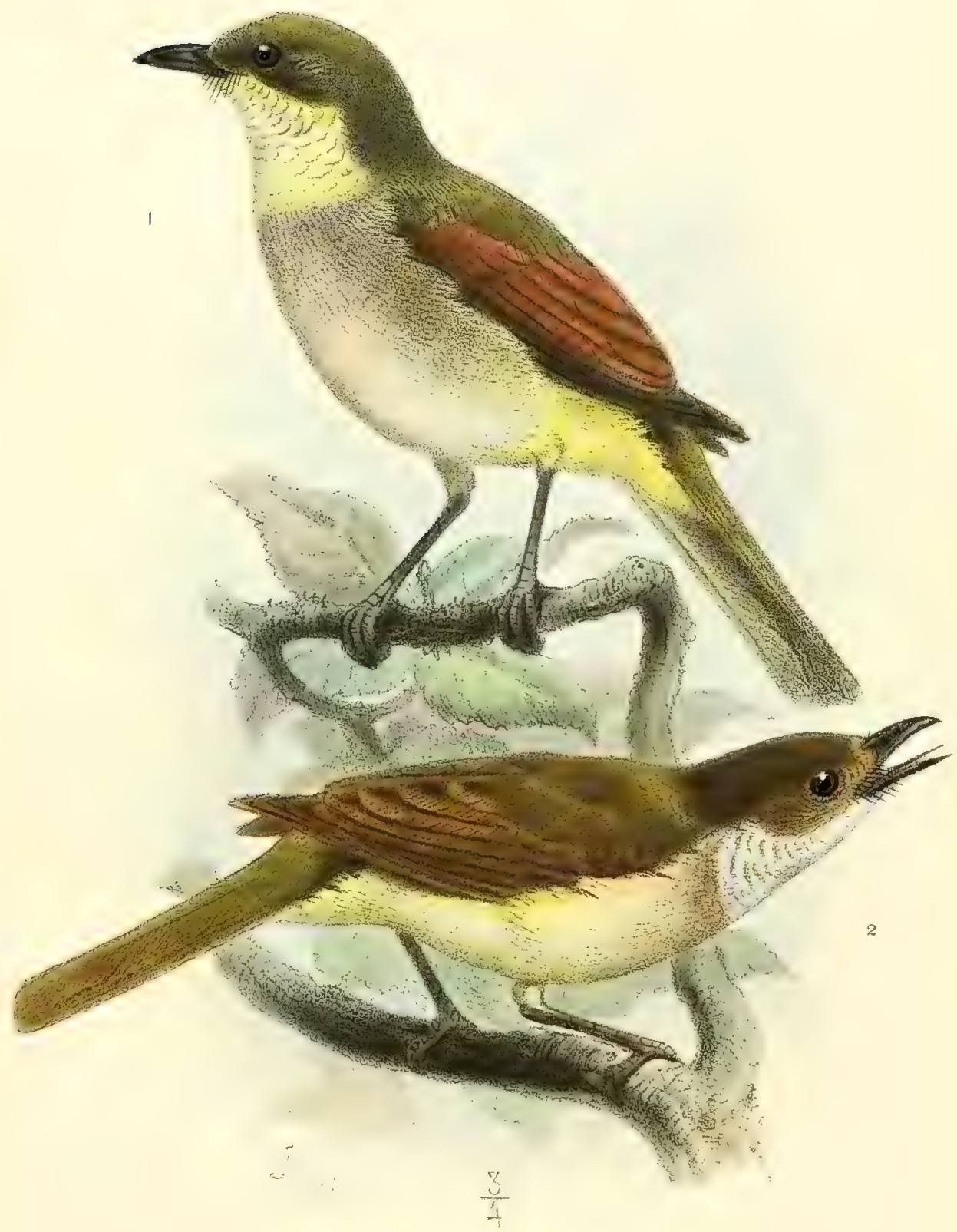


,

- 

PLATE XIV.

LORIUS IIYPOINOCHROUS.

(Lorins hypoinochrous, G. IR. Gr. List. Psitt. p. 49.)

T'op of the head black; upper and lower surface rich crimson; wings green, partly bronzy; quills bluish black with the outer margins green, and the inner webs at base rich yellow; under wing-coverts rich crimson; the abdomen, thighs, and under tailcoverts dull purple; the tail above with the basal half crimson, and the apical half dull green with a transverse striated appearance, beneath dull yellow.

Length $10^{\prime \prime} 6^{\prime \prime \prime}$, wings $7^{\prime \prime}$, tail $3^{\prime \prime} 10^{\prime \prime \prime}$.

This bird was originally known by a specimen being received as from the Louisiade Group; it has since been found in the Solomon Islands. 
PIL.11

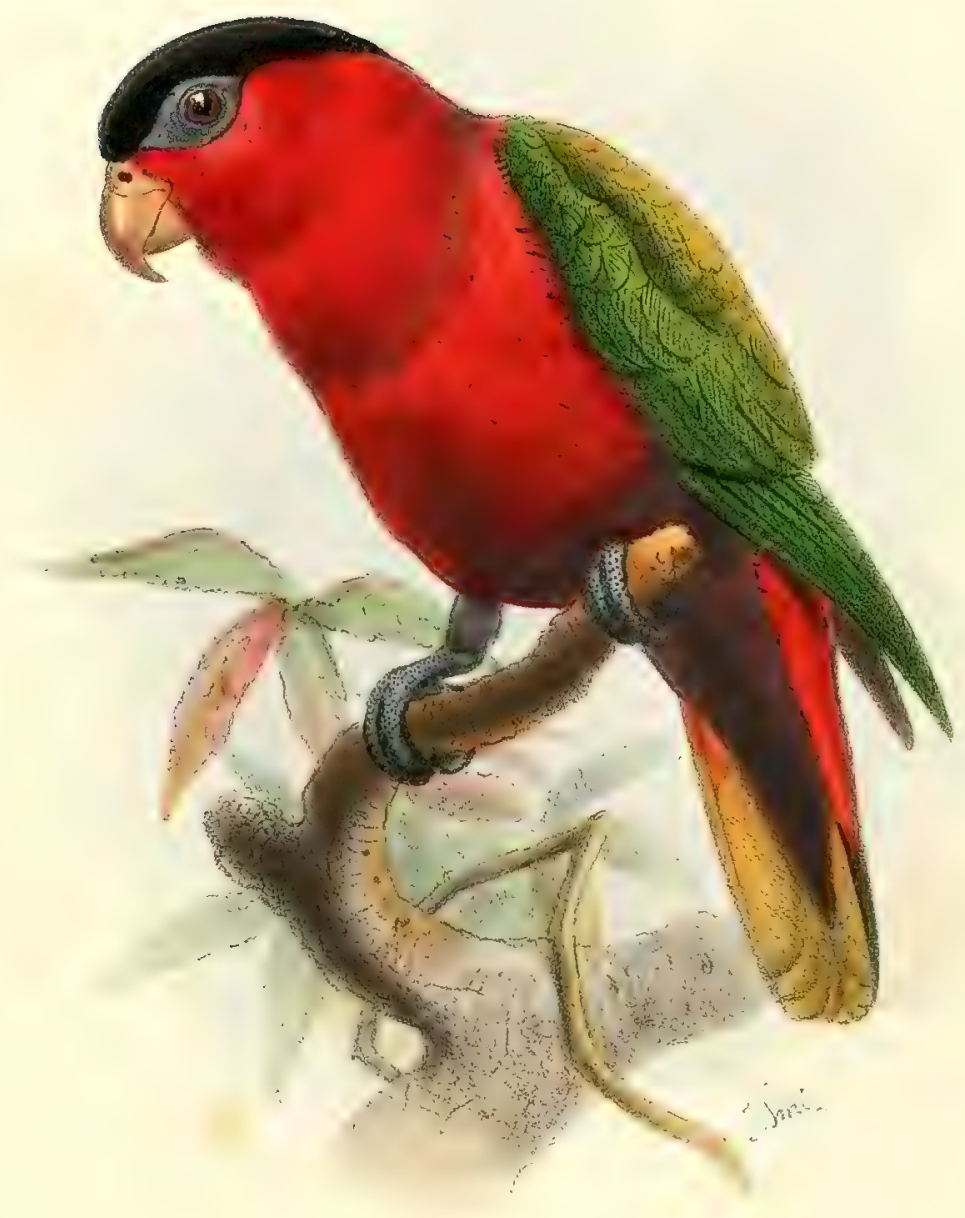




\section{.}



PLATE XV.

TRTCHOCLOSSUS MASSENA.

(Trichoglossus massena, Bp. Rev. and Mag. de Zoob. 1854, p. 157; Triehoglossus massena, G. R. Gr. Cat. B. Trop. 1st. Pacif. Ocean i. p. 33.)

Top of the head and throat bronzy purple, striated down the shaft of each feather with dull green; front and lores pale blue; nape with a narrow band of yellowish green; upper surface bright green; the base of the feathers of upper part of back and abdomen pale crimson, those ont he abdomen and under tail-coverts varied with yellow; quills black, margined externally with green, the inner webs of quills at the base pale yellow; tail green, more or less inclining to yellow; breast and under wing-coverts crimson, the former very narrowly banded on the edge of each feather with blue-black.

Length $10^{\prime \prime}$, wings $5^{\prime \prime} 6^{\prime \prime \prime}$, tail $4^{\prime \prime} 9^{\prime \prime \prime}$.

'Eyes red. Contents of stomach, honey.'

A specimen of this species was obtained at San-Christoval, one of the Solomon Islands; it is also an inhabitant of the New Hebrides Group. 
$\mathbb{P} \mathbb{L} \cdot 15$

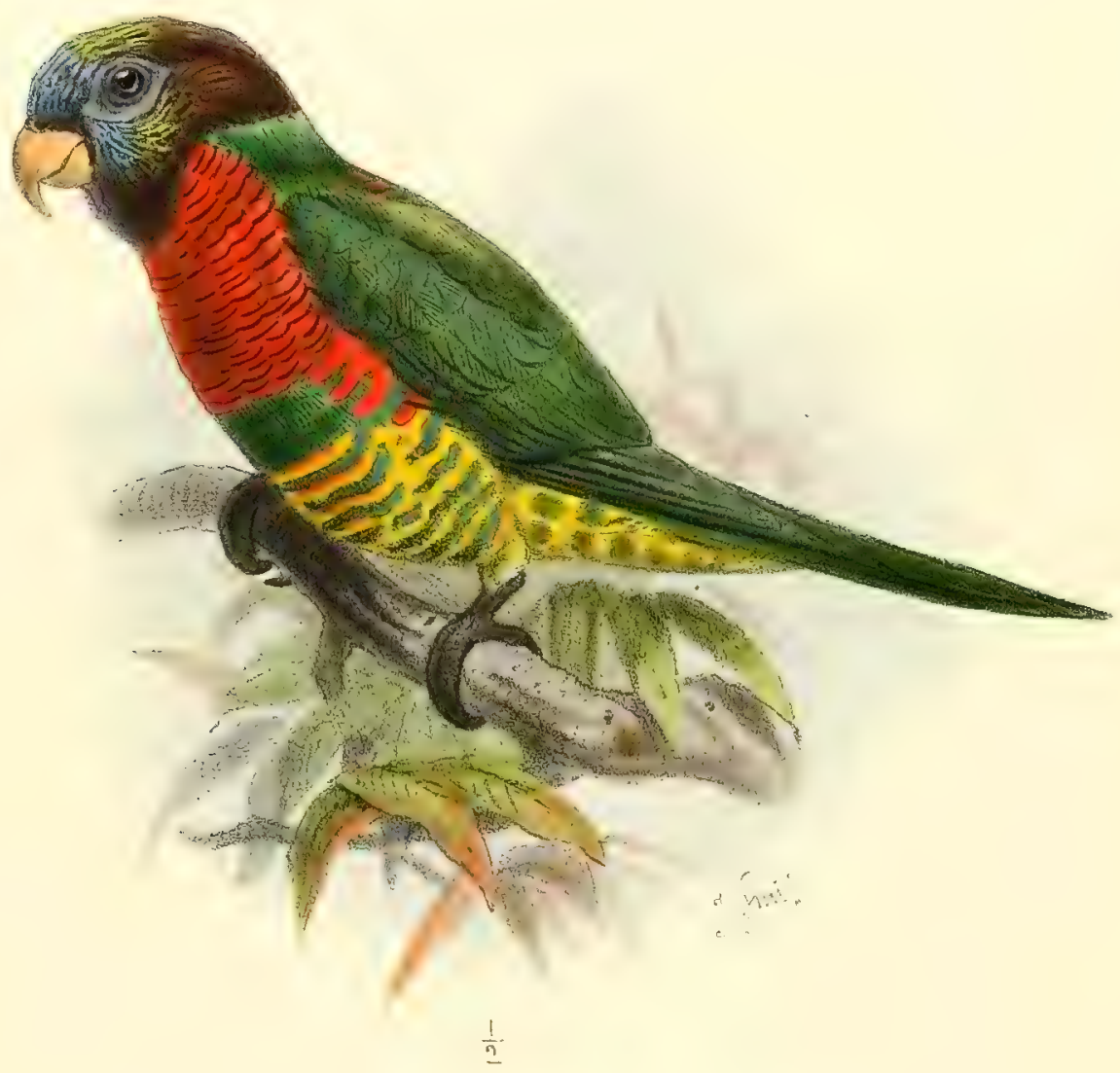

J Snzt del et hith.

Mintern Bros.ims.

TRICHOGLOSSUS MASSENA 
. 

PLATE XVI.

\section{TRIOHOGLOSSUS PALMARUM.}

(Palm Parrot, Lath. Synz. 1, p. 253; Psittacus palmarum, Gm. S. N. 1, p. 329 ; Trichoglossus palmarum, Wagl. Monogr. Psitt. p. 546.)

Uniformly emerald green, duller on the back, beneath the body pale green, with the feathers of the throat and abdomen yellow at their bases; a line of dull crimson proceeds down the sides of the bill, and extends on the chin; tail green with the tips bright pale yellow.

Length $7^{\prime \prime}$, wings $3^{\prime \prime} 7^{\prime \prime \prime}$, tail $3^{\prime \prime} 6^{\prime \prime \prime}$.

This rare species is peculiar to the islands composing the New Hebrides Group. 
$P \mathbb{R} 16$

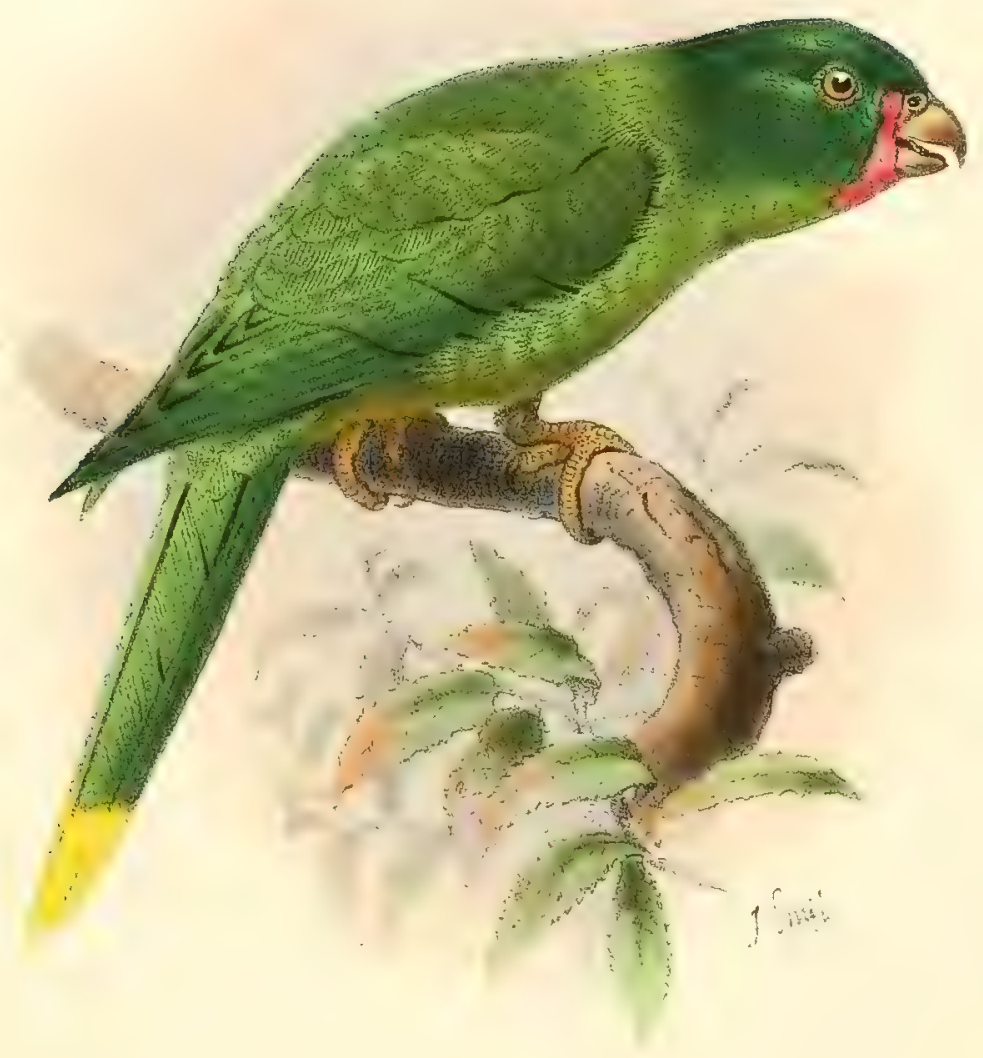


C C 


\section{PLATE IVII.}

\section{CUOULUS BRONZINUS.}

(Cuculus [Cacomantis] bronzinus, G. R. Gr. Proc. Zool. Soc. 1859, p. 164.)

This species is allied to $\mathrm{C}$. cineracens, Vig. \& $H$., but the bill is larger, and it is altogether of a deeper colour, especially beneath the body, which is of a rusty colour; the white spots on the sides of the tail-feathers are very small, and unconnected with one another.

Length $10^{\prime \prime} 9^{\prime \prime \prime}$, wings $5^{\prime \prime} 6^{\prime \prime \prime}$.

The specimen was obtained in New Caledonia.

\section{PTILONOPUS SOLOMONENSIS.}

(Ptilonopus solomonensis, G. R. Gr. Ann. and Mug. N. H. 1870, p. 328.)

Female, young. Bright golden emerald-green; quills bluish black, with the tips dark shining green; tertials emerald-green, all narrowly margined with yellow; abdomen and under tailcoverts bright king's-yellow.

Length $8^{\prime \prime}$, wings $5^{\prime \prime}$, bill $9^{\prime \prime \prime}$, tarsi $6^{\prime \prime \prime}$.

"Eyes yellow. Contents of stomach, large seeds and fruits."

The single specimen of this bird was procured at Wanga, SanChristoval. It is probable that the mature male of this species, when obtained, may prove to possess a showy plumage, as is the case with most of the species. 


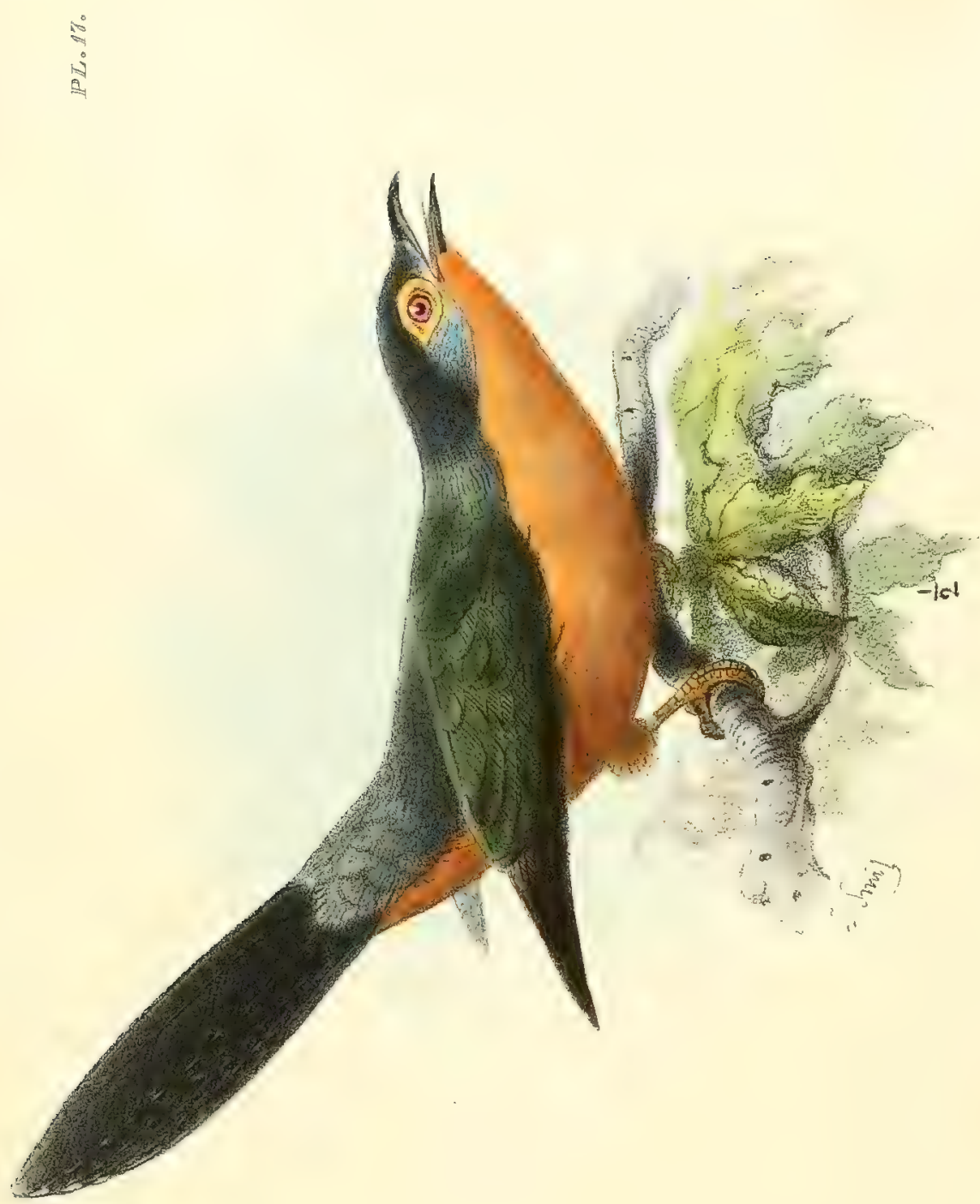

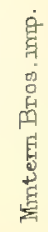




PLATE XVIII.

OARPOPIIGA BRENCIILEYT.

(Carpophaga Brenchleyi, G. R. Gr, Ann. and Mag. N. H. 1870, p. 328.)

Front of head greyish white, with the hind head grey; cheeks and throat pale chestnut; upper surface plumbeous black, tinged with grey; tail above, when closed, black, with the outer feathers, when expanded, and beneath all the feathers rufous chestnut; beneath the body of a very dark rufous chestnut, shading into a lighter colour on the lower abdomen and under tail-coverts.

Length $16^{\prime \prime}$, wings $8^{\prime \prime} 9^{\prime \prime \prime}$, bill $1^{\prime \prime}, 2^{\prime \prime}$, tarsi $1^{\prime \prime}$.

'Eyes yellow. Contents of stomach, large seeds and fruits. Male.'

This fine bird, of which there is only a single specimen, was collected at Wanga, San-Christoval, where it feeds on various kinds of seeds, amongst which are those of a species of Canarium. The soft pulp that surrounds the hard shell wherein the seed is placed must be the portion that nourishes the bird during the period it can be obtained. 
PIS.18.

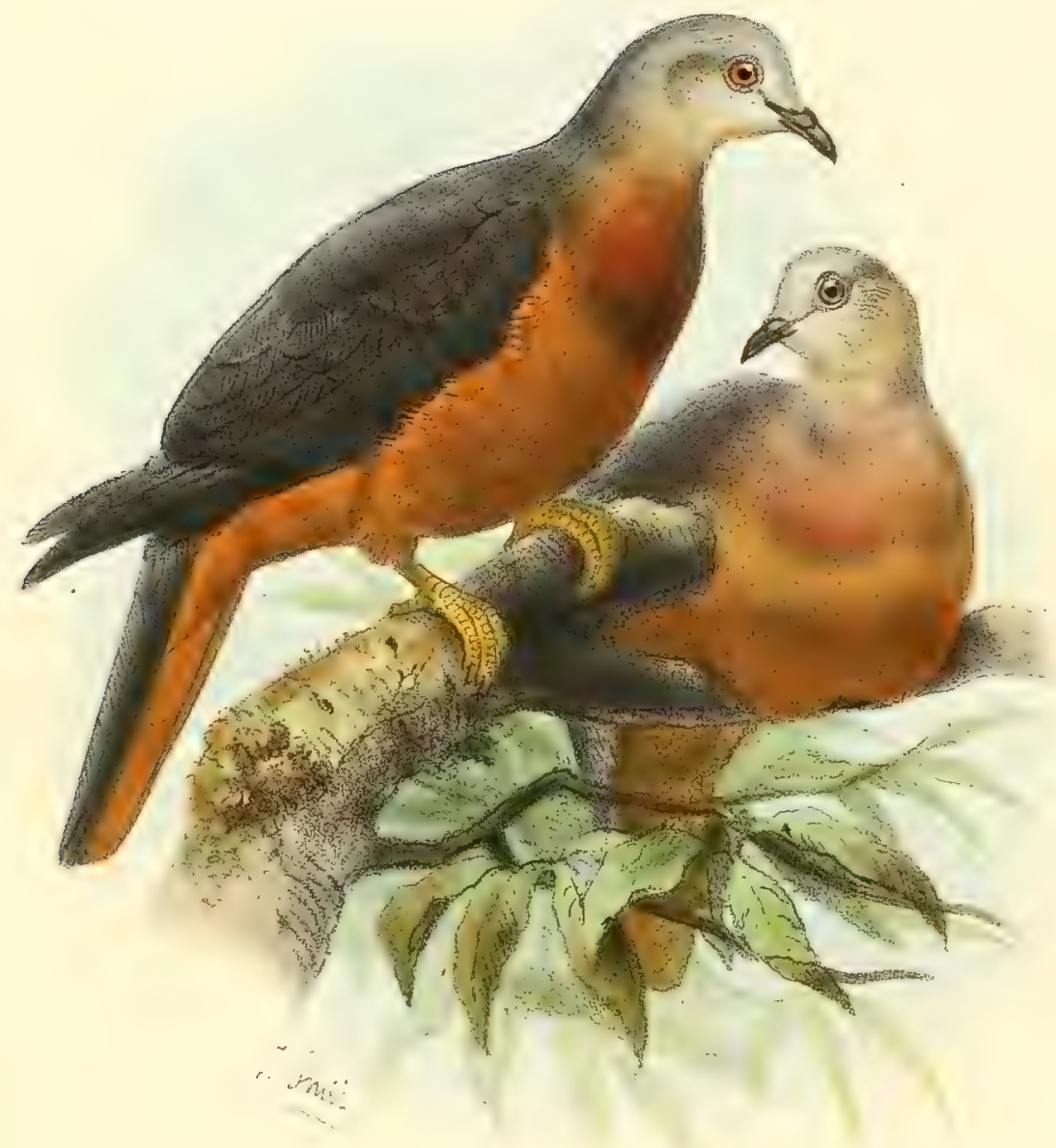



PLATE XIX.

MAOROPYGIA ORASSTROSTRTS.

(Turacrena crussïnostris, Gould Proc. Zool. Soc. 1856, p. 136.)

Head, all the upper surface, wings and tail dark slaty black, the feathers of the back margined with a deeper black; a broad band of grey across the lateral tail feathers near the base, and the outer feather on each side tipped with darker grey; throat greyish white; moler surface sooty, washed with grey on the sides of the neck, breast, and centre of the abdonaen.

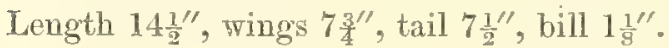

This rare bird was discovered on the Istand of Guadalcanar, one of the Solomon Group. It is very remarkable for the great size and form of its bill. 
.PR.19.

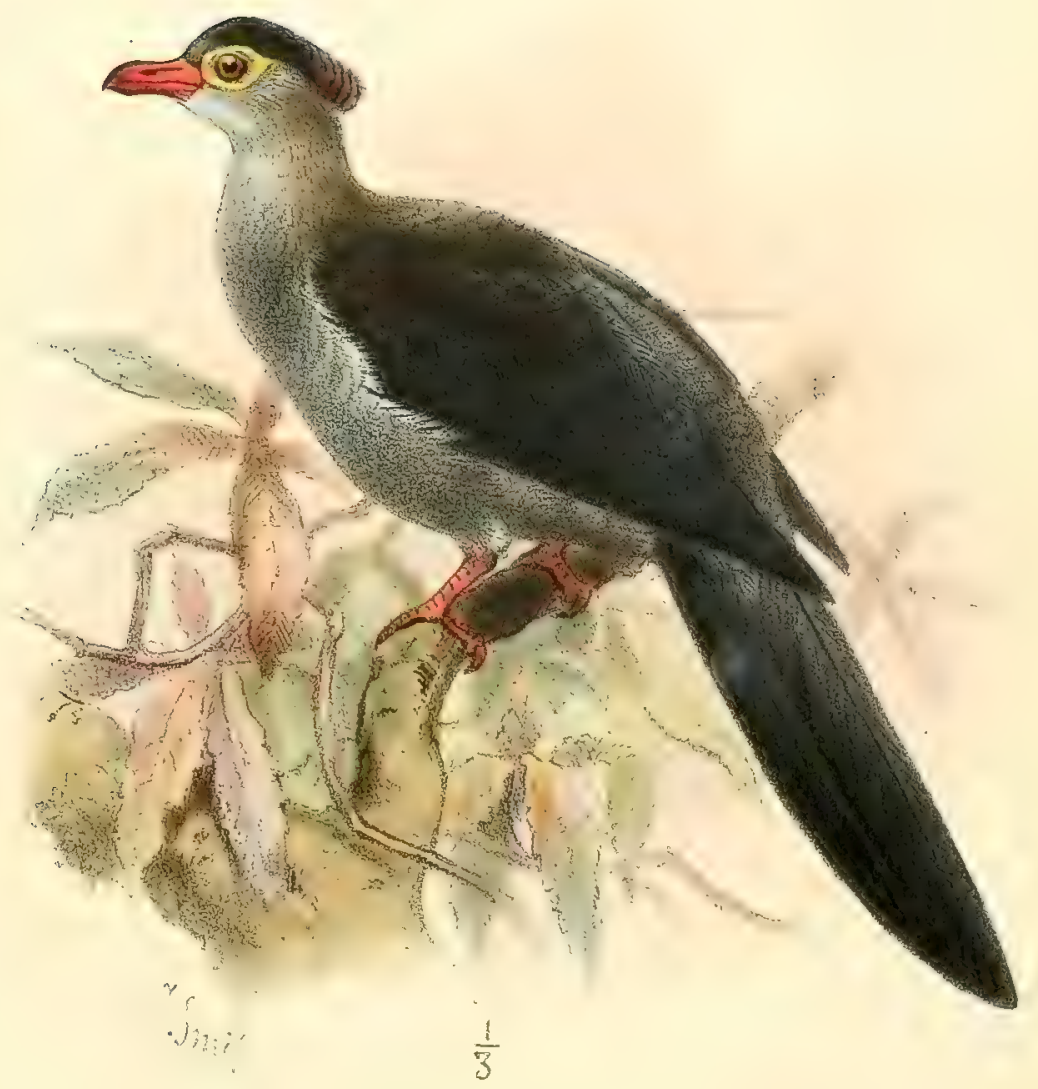

J. Srant del et lith. 


PLATE XX.

\section{MEGAPODIUS BRENCHLEYI.}

(Megapodius Brenchleyi, G. R. Gr. Ann. and Mag. N. II. 1870, p. 328.)

Young. Chestnut brown, with transverse narrow bands of yellowish brown on the back and wings; throat and cheeks fulvous white; beneath the body more rufous than on the upper surface, but without any narkings.

Length $5^{\prime \prime} 6^{\prime \prime \prime}$.

'Eyes dark hazel.'

A single specimen of the young bird, and two eggs (unfortumately in a broken state), were ohtained at Gulf Istand, where they were diseovered in the month of septemler 1865. These egess are, both in size and colou, very similar to that of the Megupodius Brazien', described by Mr. Sclater in Proc. Zool. Soc. 1869, p. 528. In 1864, I observed, in the Proc. Zool. Soc. p. 42, that an egg (very similar in every respect to those above referred to), had been brought from San-Christoval Island. As Gulf Island lies close to this last-nentioned island, it is therefore very probable that the birds of these two islands may eventually prove to be of one and the same species.

I have named this species after Julius Brenchley, Esq., as a small acknowledgment for the opportunity he has given me of describing the new species contained in his highly interesting collection.

Mr. Sclater has recorded that an egg of a Megapode which he has described, under the name of Megapodius Brazieri, in the Proc. Zool. Soc. 1869, p. 528, has been found and brought from Banks's Islands. Mr. Brenchley's collection contains three specimens of eggs of a Megapode that were obtained at Vanua Lava, two of which are similar in colour and size to that deseribed by Mr. Sclater; but the third example is a dirty white. Mr. Brenchley has a note in reference to them, that they were found in the vicinity of the hot springs on the mountains during the month of August 1865.

The neighbouring group of islands, the New Hebrides, is also the abode of a species of Megapode; and we are told by Capt. MLLeod that they are found abundantly, especially on Tanna and Sandwich Islands. Both these islands are also referred to by Mr. Brenchley, who remarks that on the first-mentioned island a large birc is spoken of as living in the vicinity of the volcanoes; while in the second island eggs of a Megapode had been offered for sale.

It may be remarked that the mature state of the bird of both these groups of islands is at present unknown to ornithologists. 
FE.20.

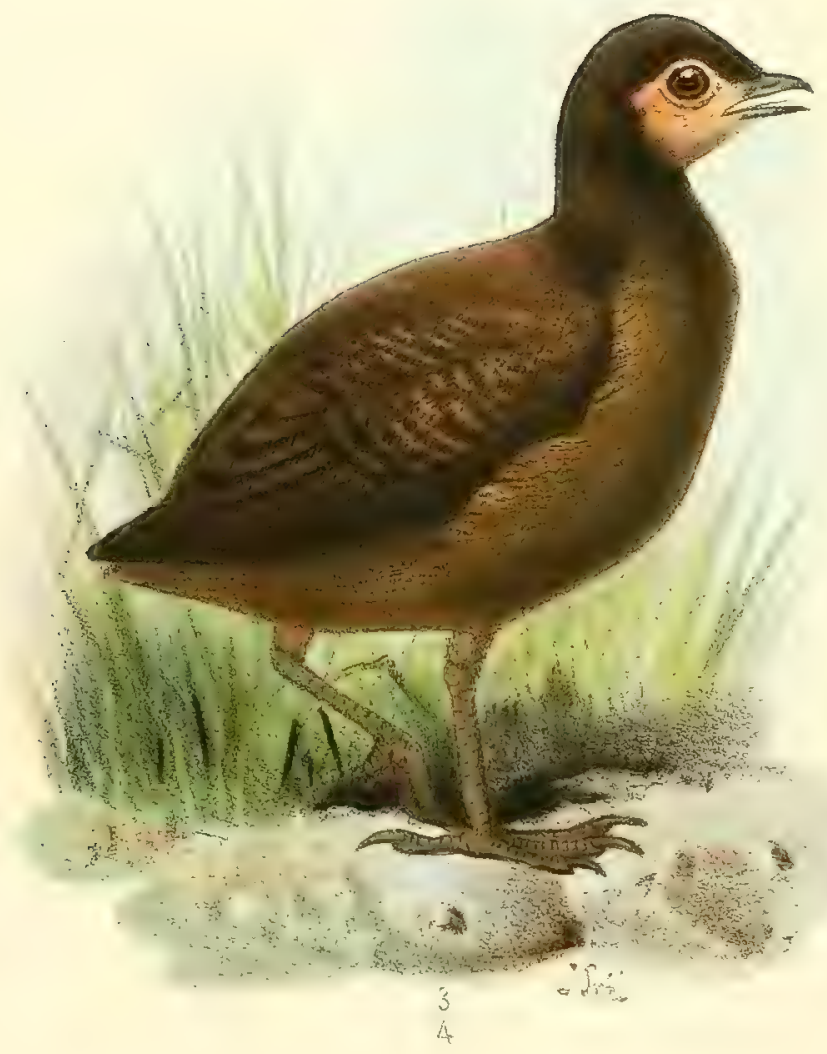

J. Smat del et hth. 


(Gallirallus lafresnayanus, Term. and Desm. Rev. and Mag. de Z.1860, p. 437; Iegapodius? Andersoni, G. R. Gr.; Ocydromus lafresnayanus, Sclat. Proc. Zool. Soc. $1869, p p .431,472$.

Inufous brown, with a slight tinge of olivaceous on the lower part of the back; top of the head dull slate colom; eyebrows and chin pale rufous grey; beneath the body dull slate colour, tinged on the neck and upper part of breast with rufous; wings armed with a blunt tubercle and a sharp spine on the shoulder; quill fuscous black, under wing-coverts and axillaries black, transversely banded with white.

Length $19^{\prime \prime} 6^{\prime \prime \prime}$, wings $8^{\prime \prime}$.

This bird is found, though of rare occurrence, in New Caledonia; its chief food appears to consist of insects. 
पू

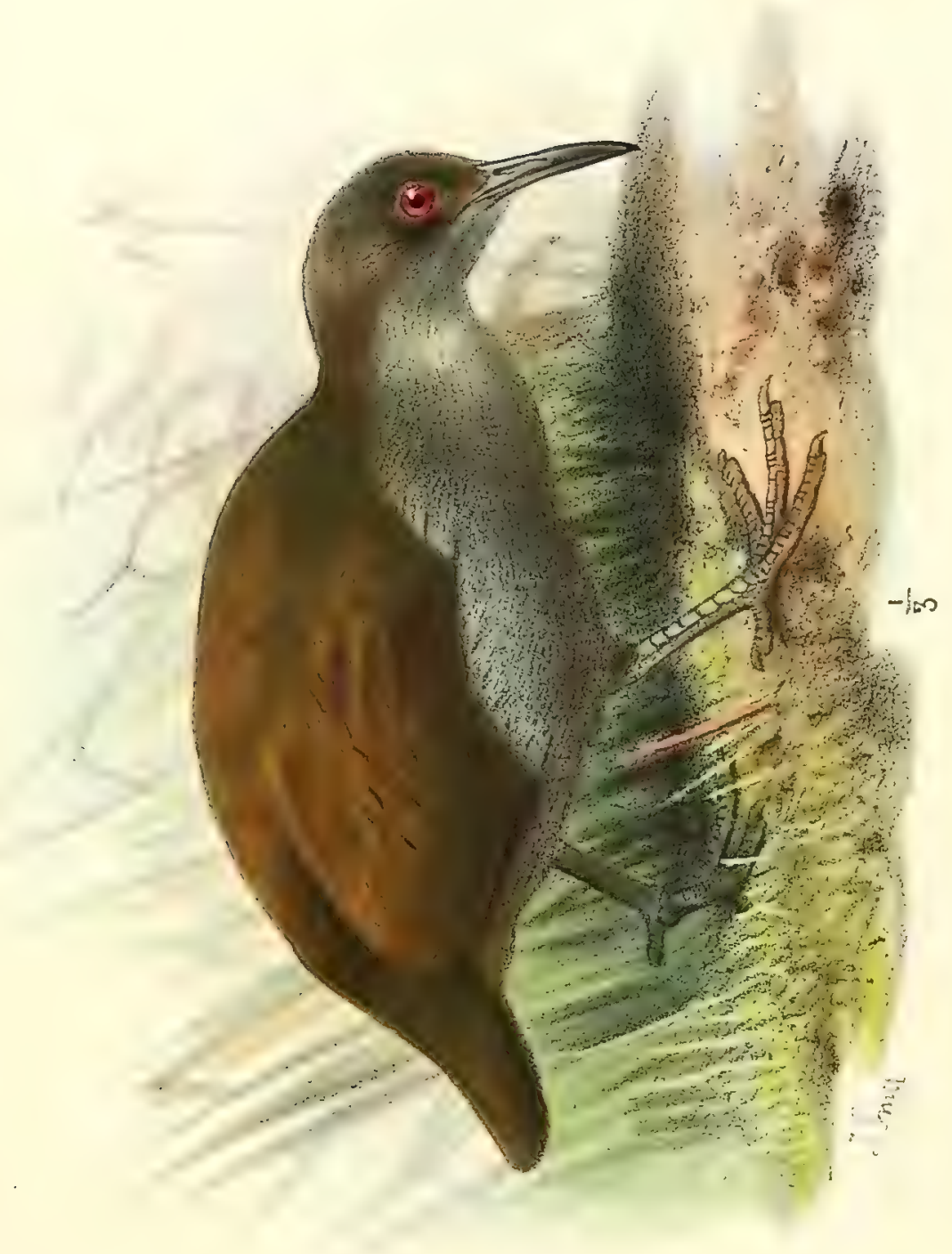

点

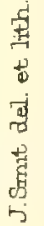





\section{REPTTLES.}

BY ALBERT GÜNTHER, M.A., PHD., M.D., F.R.S.

Mr. Brenchley's collection of reptiles is especially rich in the smaller kinds of lizards; they were obtained in various islands of Polyuesia and the North of Australia, and in Mongolia. However, as the materials are not sufficient to give a complete account of the reptilian fauna of some locality, I limit myself to the descriptions of the new forms discovered by Mr. Brenchley. 
PLATE XXIT. Fig. $A$.

\section{TREMIAS BRENUILEYI.}

'The supranasals meet, soparating the profrontals from the rostral; profrontals not confluent; a small azygos shield between the post frontals. Six upper labials in front of the infraocular, which forms a part of the free margin of the lip. The sixth labial, only about half the size of the infraocular. Eyelid entirely sealy. Collar formed by eight scales subequal in size. Ventral scutes forming 31 transverse and 12 longitudinal series. Præanal region covered with small seales. Fore-limb reaching nearly the extremity of the snout when stretched forwards; hindlimb extending to the axil of the fore-limb. Upper parts brownish olive, with an indistinct series of light-coloured ocelli on each side of the back; a well-defined whitish band commences behind the eye, passes through the tympanum and runs along each side of the body to the axil of the hind-leg. Hinder side of the thighs with a few whitish ocelli on a black ground.

A single adult female was obtained in a district of Mongolia, called "the Land of Grass.'

\begin{tabular}{|c|c|c|c|c|c|}
\hline \multicolumn{3}{|c|}{ Length of the head to the eye } & - & . & - $4 \cdot 5$ \\
\hline " & $"$ & tymрами & $u m$ & - & . 10 \\
\hline , & $\eta$ & collar & - & . & .16 \\
\hline Distance & e between collar ar & nd vent & . & . & .35 \\
\hline Length & of fore-limb & . & . & . & .18 \\
\hline , & third and fourt & h finger's & . & - & - 5 \\
\hline 9 & - hind-limb & $\cdot$ & - & - & . 31 \\
\hline , & third toe & $\cdot$ & - & - & . 7 \\
\hline 9 & fourth toe & $\cdot$ & - & - & .10 \\
\hline ", & tail & . & . & . & .80 \\
\hline
\end{tabular}




$$
1
$$



PLATE XXII. Frg. B.

EUPRLPES HAPLORHINUS.

This species rrould appear to represent a distinct generic division, but more than enough generu have been distinguished by names in the Scincoid family, and I am unwilling to increase their number, if I am not fully convinced of the generic value of the distinctive characters.

This species, then, differs from Euprepes by lacking supranasa! shields; it would be a Mocoa, but it has the scales distinctly provided with three or four keels.

The præfrontal forms a broad suture with the rostral as well as with the vertical. Only one fronto-parietal, notched behind to receive the front part of the central occipital. Vertical five-sided, nearly as long as broad. Nostril wide, in the centre of the nasal. Ear opening with two or three short lobules in front. The middle of the body is surrounded by 28 longitudinal series of scales, subequal in size; there are 38 scales in a longitudinal series between the fore and hind legs. Six præanal scules, the middle of which are rather larger than the others. The fore-leg extends to the middle of the eye, if stretched forwards; third finger a little shorter than the fourth. The hind-leg covers about two-thirds of its distance from the fore-leg; the fourth toe one-fourth longer than the third.

With regard to coloration this lizard is very similax to Mococ trilineuta. The dorsal parts are brownish, uniform or with dark markings, more or less confluent into a pair of longitudinal 
bands. Sides black, with a well-defined white streak, one scale broad, from the tympanum, above the shoulder to the axil of the hind-leg. Lower parts uniform white.

Two examples from the Fiji Islands.

\begin{tabular}{|c|c|c|c|c|c|c|}
\hline Distanc & between the & sno & ut and & eye & - & . 4 \\
\hline & " & , & & tympanu & & .10 \\
\hline & , & " & & fore-leg & . & .17 \\
\hline & " & " & & vent & - & . 32 \\
\hline Length & of tail & & . & . & - & .68 \\
\hline " & fore-leg. & & . & . & . & .12 \\
\hline$"$ & fourth finge & & . & . & - & - $3 \frac{1}{2}$ \\
\hline "9 & hind-leg & & . & . & . & $\cdot 21$ \\
\hline , & thind toe & & . & : & . & . 5 \\
\hline , & fourth toe & & . & . & . & . $7 \frac{1}{3}$ \\
\hline
\end{tabular}





\section{EREMIS MULTIOCLLLATA.}

The supranasals meet, separating the single præfrontal from the rostral; priefrontals confluent into a single shield; a small azygos shield between the postfrontals. Six upper labials in front of the infraocular, which enters the free margin of the lip, with its narrow lower corner. The sixth labial as large as the infinocular. Eyelid entirely scaly. Collar formed by a central larger, and numerous smaller lateral shields. Ventral scutes forning 30 transverse and 18 longitudinal series. Praanal region covered with small scales. Fore-limb reaching nearly the extremity of the snout, when stretched forwards; hind-limb extending to the axil of the fore-limb. Greenish olive above, with numerous more or less perfect black rings enclosing a lighter centre. A somewhat irregular whitish black-edged band along each side of the body, from the eye to the axil of the hind-limb.

A single specimen was obtained in the desert of Grobi, on the route from Sumé to the Tola River.

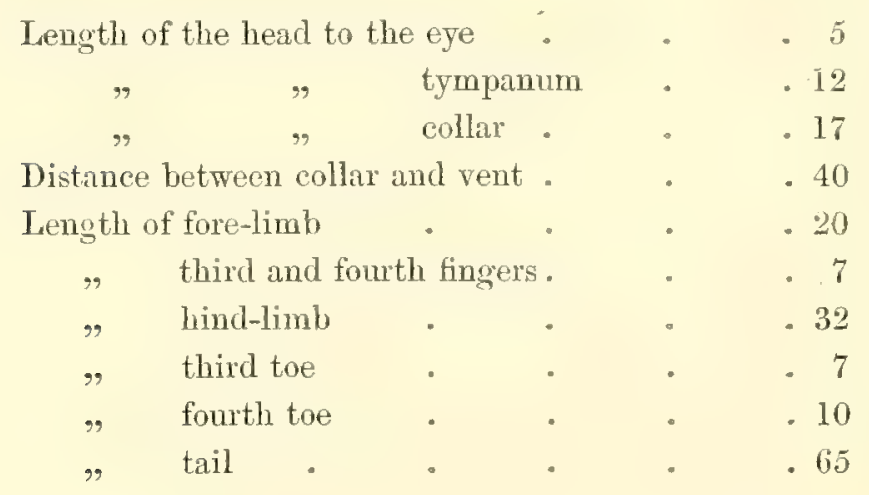


D D 
PLATE XXIII.

MIOCOA MICROPUS.

Præfrontal shield single, in contact with the rostral as well as with the parietal. Five occipitals, of which the central is as large as one of the anterior. Ear-opening very small, without any lobules. The middle of the body is surrounded by 21 longitudinal series of smooth seales; six series are dorsal and rather larger than the others. There are 35 scales in a longitudinal series between the axils of the fore and hind limbs. Four præanal scales, the two middle of which are twice the size of the lateral. Legs very feeble, but five-toed; the fore leg does not reach the ear-opening, if stretched forwards ; fingers very short, subequal in length. The third and fourth toes equal in length. Back light greyish-olive, with a few minute black specks, bordered on the side by a deep-black band, which gradually passes into the greyish coloration of the lower parts; the latter are indistinctly marbled with whitish.

Two specimens, apparently young, from the Fiji Islands.

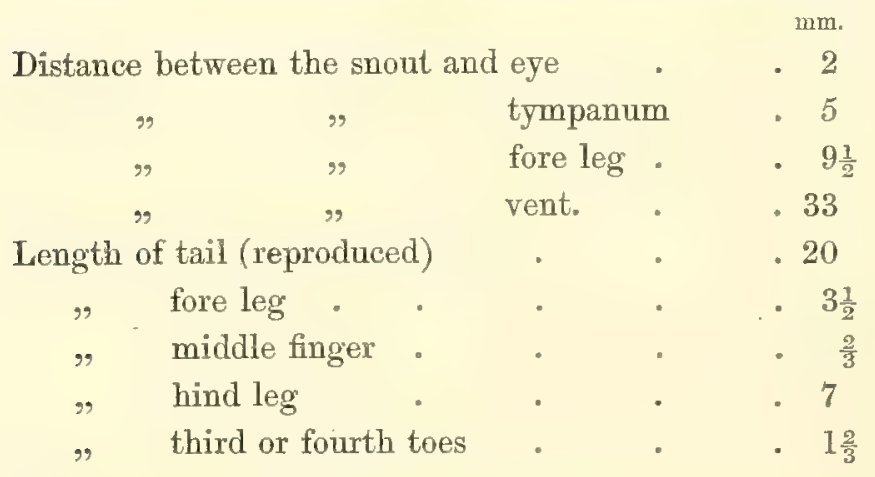

The figure represents the animal of thrice the natural size. 

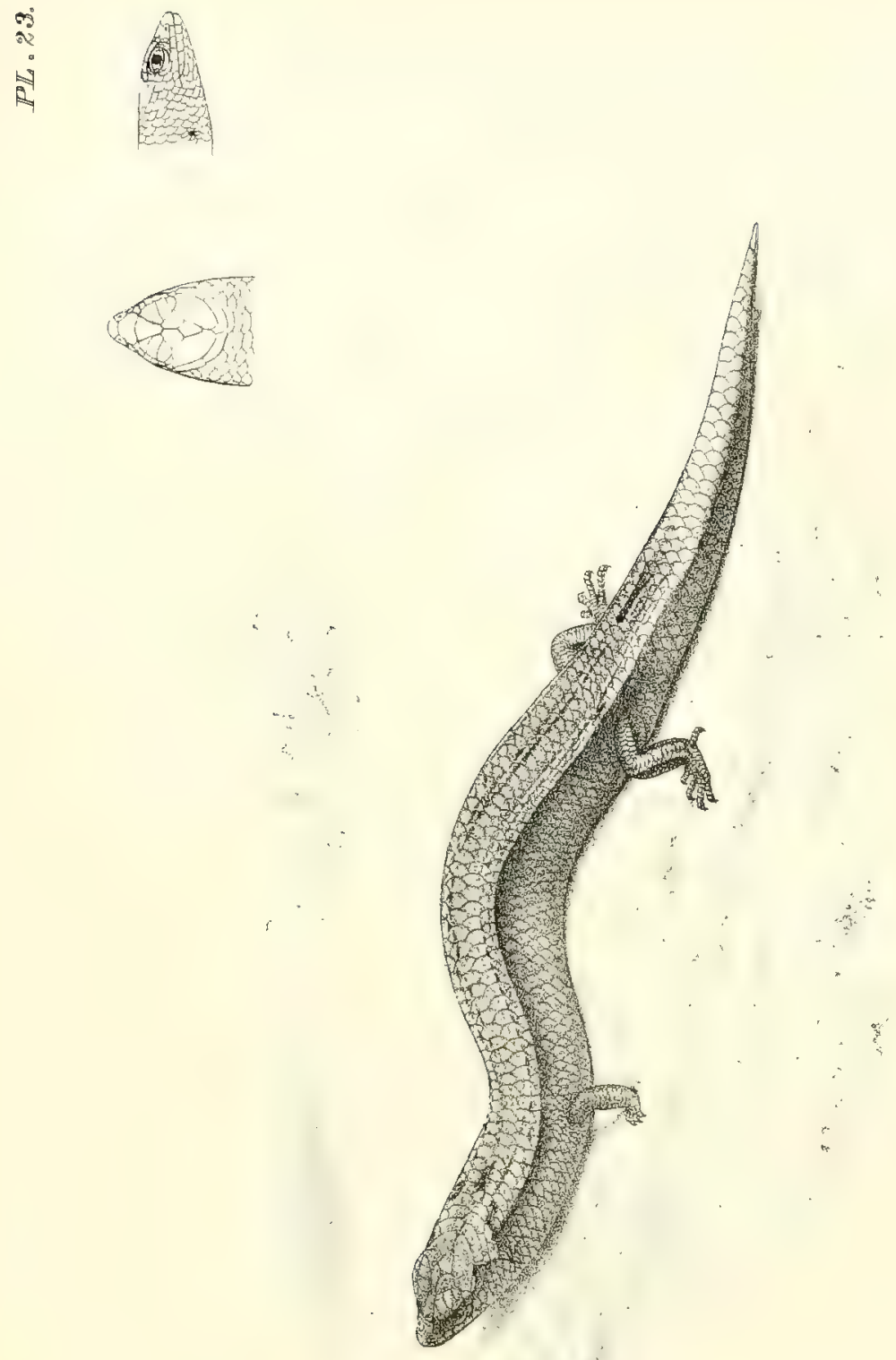



\section{MOCOA NOVAR正。}

Euprepes novare, Steindachner, Novare, pl. 47, tab. 2, fig. 4 .

Præfrontal shield single, in contact with the rostral as well as with the parietal. Five occipitals, of which the central is nearly as large as one of the anterior. Ear-opening without any denticulation. The middle of the body is surrounded by 28 longitudinal series of perfectly smooth scales; eight series are dorsal and conspicuously larger than the others, especially the two central series. There are 37 scales in a longitudinal series between the axils of the fore and hind limbs. The two middle præanal scales large. The fore leg reaches to the front margin of the eye, if stretched forwards, and the hind leg covers about twothirds of its distance from the fore leg. The third and fourth fingers conspicuously longer than the second and fifth; fourth toe only one-fourth longer than the third. Upper parts brownisholive; a light band along the median line of the back: it commences from a white spot in the middle of the neck. Both the spot and band have an irregular broad black margin. Sides of the body and tail marbled with black, these markings forming an irregular broad band. Lower parts uniform white.

The British Museum possesses an example found on the Fiji Islands by the Naturalist of H.M.S. Herald; and Mr. Brenchley has brought three other examples from Tongatabu. Three other examples from the Samoan Group were presented by the Rev. T. Powell. It occurs also in Otaheiti.

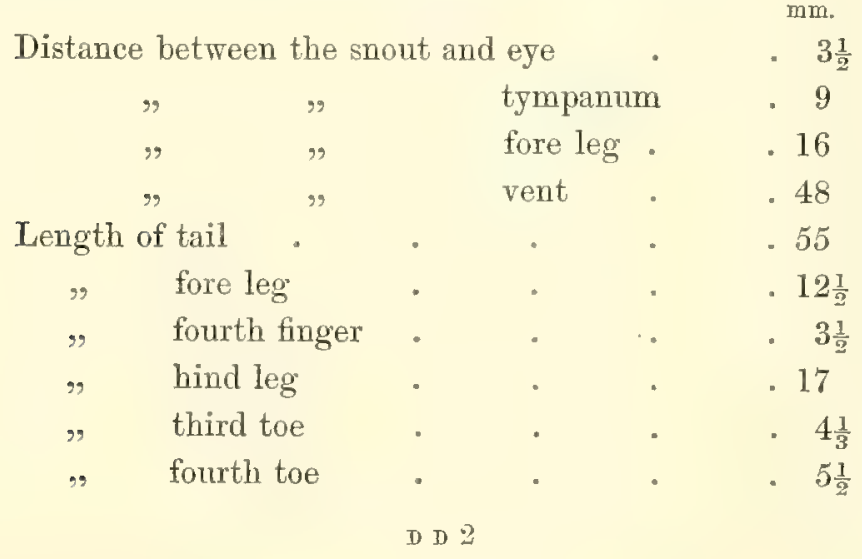


PLATE XXIV, Fig, A.

\section{GYINODAOTYLUS MULTICARINATUS.}

Snout broader than long. Head without any larger tubercles, except in the occipital and temporal regions. Six upper labials; the middle lower labial large, without mentalia, or with a pair of only rudimentary ones behind. Back with from 16 to 20 regular longitudinal series of small conical tubercles; the series are equidistant from each other, and the tubercles closely set and ribbed. The abdominal scales are very small, strongly keeled, and gradually reduced to minute tubercles in the direction towards the vent. The tail of all our specimens is more or less reproduced, and uniformly granular, without tubercles or scutes. The upper side of the hind limbs with scattered, strongly ribbed tubercles. No pores. Upper parts brownish, uniform, or with dark transverse markings; sometimes a blackish streak from the eye to above the tympanum.

Several examples from the New Hebrides (Anatom), and Tongatabu.

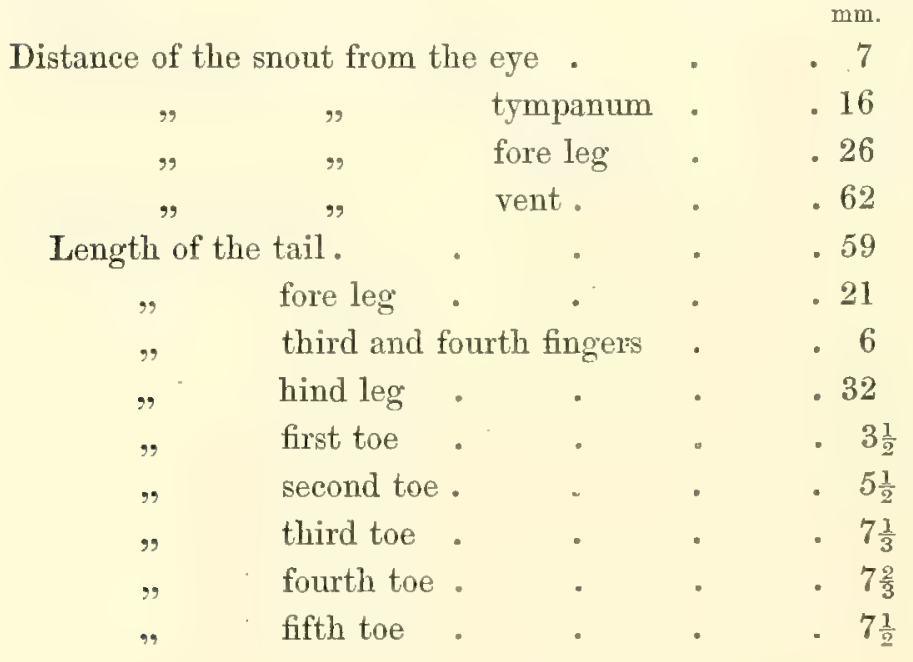


FT. 24.

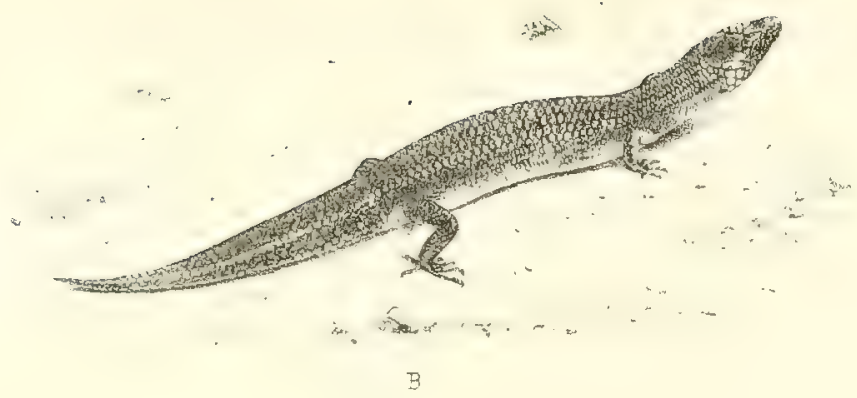

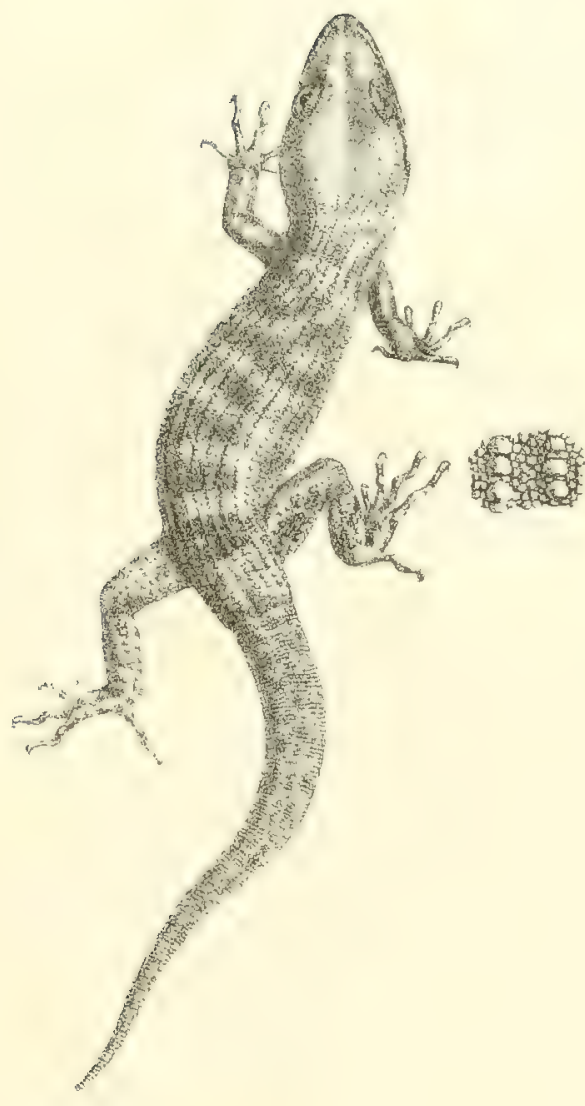

GHFord

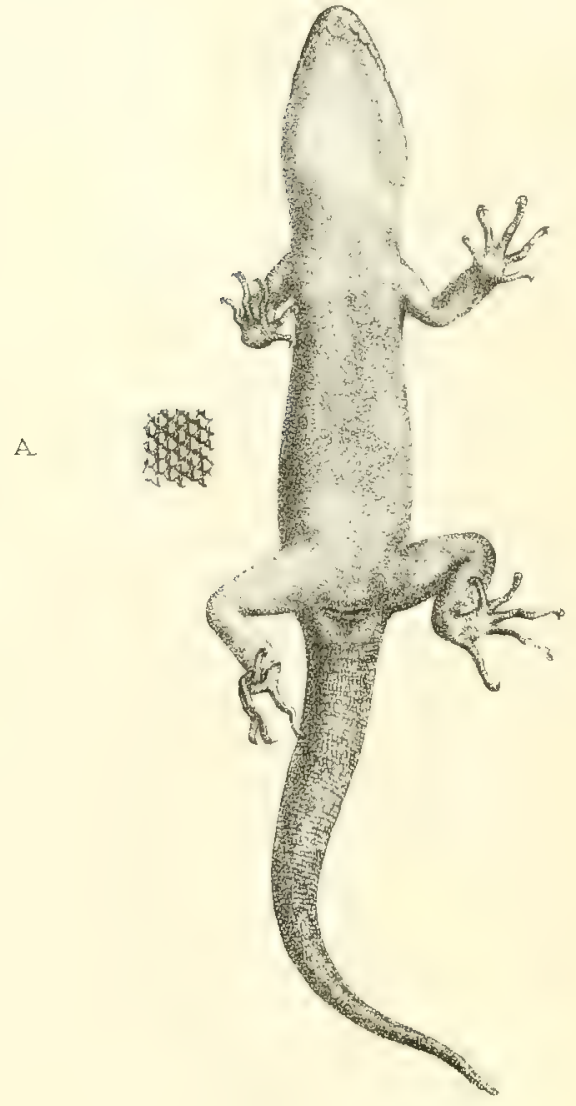

Whtern Bros. InTP.

A.GYMNODAOTYLUS MULTICARTNATUS

B. HINULIA TETRAGONURUS 


\section{HINULIA TETRAGONURUS.}

The præfrontal forms a broad suture with the rostral as well as with the vertical. Vertical five-sided much longer than broad. Only one fronto-parietal, notched behind to receive the front part of the central occipital. Nostril in the centre of the nasal, with a lunate groove behind. Ear-opening without lobes in front. The middle of the body is surrounded by 28 longitudinal series of scales, those on the back being rather larger than those on the sides and abdomen; there are 40 scales in a longitudinal series between the fore and hind legs. Four præanal scales, subequal in size. Tail strong, tetrahedral. Legs feeble; the anterior extends to the ear-opening, if stretched forwards; fingers very feeble and short. The hind leg covers about one-lalf of its distance from the fore $\mathrm{leg}$; the fourth toe one fourth longer than the third.

Upper parts light-brownish, finely marbled with darker; sides lighter; lower parts white.

One example, apparently adult, from the Fiji Islands.

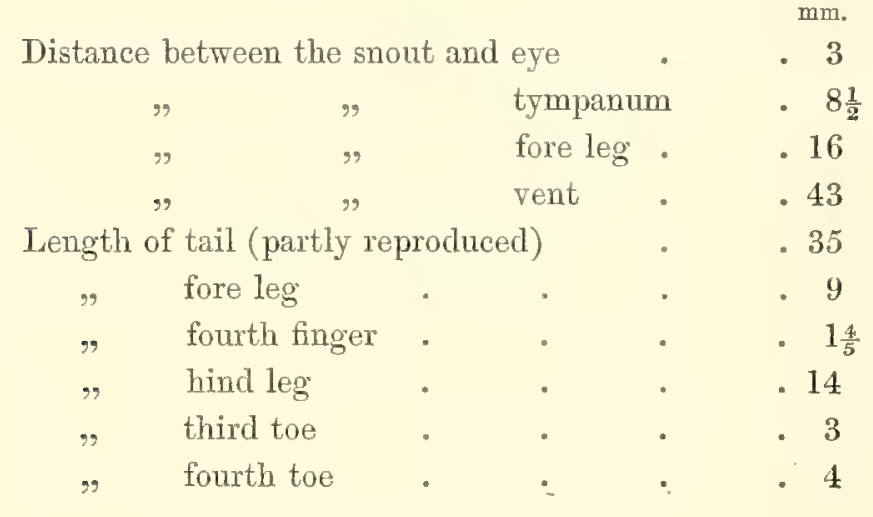




\section{NANNOSOINCUS.-(g.n.Scincid.)}

Appears to be allied to Cophoscincus (Ptrs.), but differing by having keeled scales. Body of moderate proportions; legs feeble, five-toed. Eyelid narrow, scaly. Not supranasal. Ear-opening externally not visible, entirely hidden by scales.

PLATE XXV.

\section{NANNOSUINCUS FUSCUS.}

Rostral shield depressed, flat, somewhat wedge-shaped. Præfrontal forming a broad suture with the rostral as well as vertical. Vertical much longer than broad, tapering behind. Four supraciliaries. Five occipitals, the middle of which is smaller than one of the anterior. Nasals rhomboid, with the anterior and posterior angles acute, perforated in the middle by the nostril. Five or six supralabials. Scales with three or four keels, in 22 longitudinal series, the dorsal not being comspicuously larger than the lateral. There are 38 transverse series of scales between the fore and hind legs. Four præanal scales, the middle being somewhat the larger. Anterior toes almost rudimentary; the third and fourth hind toes rather longer than the second. Upper parts uniform shining blackish-brown; lower parts speckled with greyish.

One example from the Fiji Islands.

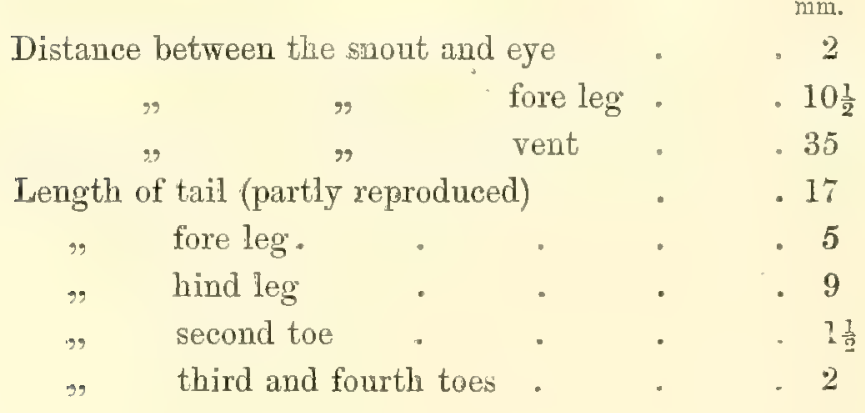


बे

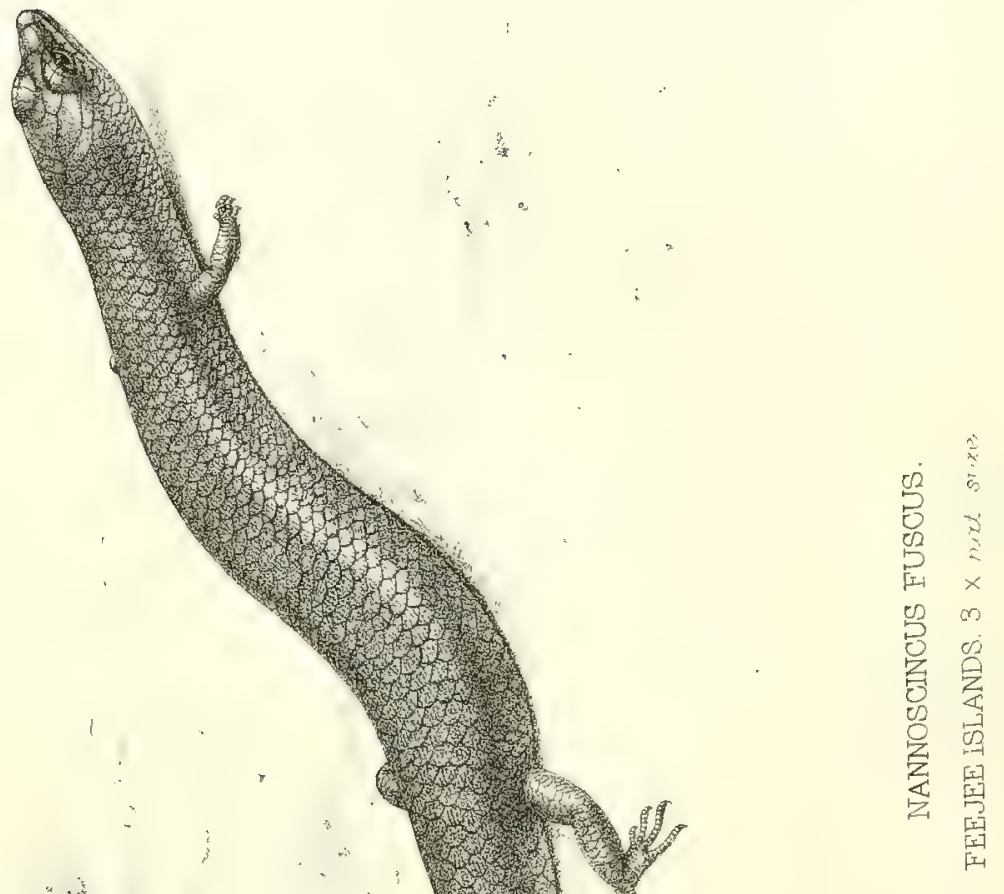

Af
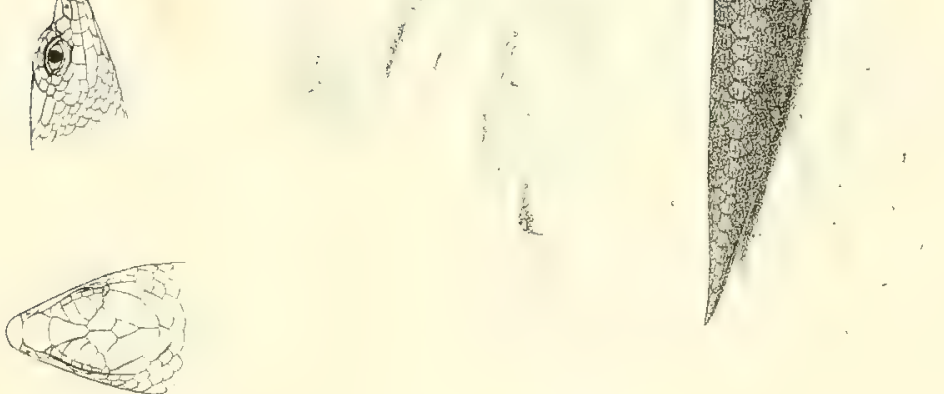

0
5
5
5 



\section{PERIPIA CYCLURA.}

Back uniform granular, without any tubercles. Scales in the middle of the belly in about 45 longitudinal series. Tail rounded, not depressed, very narrowly verticillated, without enlarged subcaudals. Nine upper and eight lower labial shields. Front lower labial elongate, but the two adjoining labials are still longer; the chin is covered with very small shields, of which one

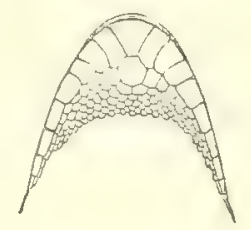

in the centre, immediately behind the front labial, is generally the largest. Brownish-grey above, with more or less irregular brown bands across the back, each band being ornamented with some small white spots. The brown bands are sometimes replaced by a dark marbling.

Several specimens from New Caledonia; all agreeing in the peculiar pholidosis of the chin and in the form of the tail. The longest is $4 \frac{3}{4}$ inches long, of which the tail takes 2 inches.

I have no doubt that Professor Peters is perfectly right in supposing that Peripia peronit is identical with Peropus mutilatus of Wiegmann (Monatsber. Berl. Acad. 1867, p. 14). 



\section{FISHES.}

By ALBEPT GƯNTHER, M.A., PH.D., M.D., F.P.S.

THe majority of the fishes collected by Mr. Brenchley, belong to known species, and were obtained at previously-ascertained localities; therefore I have considered it superfluous to give a complete list of the species collected by him, selecting for description in this account those forms only which are imperfectly known or appear to be new. It so happened that the Trustees of the British Museum obtained, nearly at the same time, two other collections, which, together with Mr. Brenchley's specimens, supplied sufficient materials for forming an idea of the character of the ichthyological fauna of two localities, the fishes of which have been hitherto unknown or nearly so, namely, of the Solomon Group, and of the Molucca island of Misol. The following two lists contain the result of my examination of these three collections.

\section{A. IISHES FROM THE SOLOMON ISLANDS.}

1. Teniura lymma, $C w$ \%

2. Chiloscyllium ocellatum, Gmo

3. Lates, sp.?

4. Grammistes orientalis, B'

5. Serranus urodelus, Forst.

6. Diagramma lessonii, $C . V$.

7. Scolopsis bilineatus, $B$ l

8. Chætodon vittatus, $B l$.

9. Chætodon vagabundus, $L$.

10. Chætodon citrinellus, Brouss."
11. Chætodon eplippium, C.V.

12. Chætoçon kleinii, $B$.

13. Holacanthus bicolor, $B$.

14. Holacanthus wrolikii, Blkr.

15. Upeneus oxycephalus, $B l k r$.

16. Upeneus trifasciatus, Lae.

17. Upeneus barberinus, Lac.

18. Cirrhites arcuatus, $C \cdot V$.

19. Sуnяnсеia verrucosa, $B l$.

20. Teuthis vulpina, Schleg. 
21. Teuthis striolata, Gtler.

22. Holocentrum spiniferum, Forst.

23. Acanthurus triosteous, $L$.

24. Acanthurus lineatus, $L$.

25. Acanthurus celebicus, Bllir.

26. Acanthurus ctenodon, $C . \& V$.

27. Caranx ciliaris, $B l$.

28. Zanclus cornutus, $L$.

29. Gazza equulæformis, Rïp.

30. Percis hexophthalma, $C . V$.

31. Percis cancellata, $C . V$.

32. Pseudochromis adustus, $M . \&$. $T$.

33. Antennarius pinniceps, $C \cdot V$.

34. Dactylopterus orientalis, $B l$.

35. Gobiodon histrio, C.V.

36. Eleotris fusca, $B l$.

37. Salarias coronatus, $s p . n$.

38. Amphiprion percula, Lac.

39. Amphiprion bicinctus, Rüpp.

40. Amphiprion melanopus, Blkn:

41. Dascyllus aruanus, $L$.

42. Pomacentrus scolopsis, $Q$. \& $G$.

43. Glyphidodon cœlestinus, $C . V$.

44. Glyphidodon assimilis, Gthr.
45. Chilinus fasciatus, $\boldsymbol{B l}$.

46. Stethojulis axillaris, $Q . \& G$.

47. Platyglossus trimaculatus, $Q$. \& $G$.

48. Platyglossus opercularis, Gth.

49. Julis trilobata, Lac.

50. Julis jansenii, Blkr.

51. Julis aneitensis, Gthr.

52. Julis lunaris, $L$.

53. Julis giuntheri, Blkr.

54. Coris multicolor, Rüpp.

55. Coris cingulum, Lac.

56. Pardachirus pavoninus, Rüppp.

57. Exocoetus speculiger, C.V.

58. Muræna fimbriata, Benn.

59. Muræna nubila, Rich.

60. Ophichthys pinguis, $s p . n$.

(j1. Anguilla, sp.?

62. Balistes aculeatus, $L$.

63. Balistes verrucosus, $B l$.

G4. Balistes undulatus, $B$.

0J. Balistes erythrodon, Gthr.

60. Balistes niger, M.P.

67. Ostracion cubicus, $L$

68. Monacanthus pardalis, Gthr.

\section{B. FISHES FROM MISOL.}

1. Dicerobatis draco, $s p \cdot n$.

2. Carcharias dumerilii, Blkr.

3. Triænodon obesus, Rüppp.

4. Anthias hechtii, Blkr.

5. Grammistes orientalis, $B l$.

6. Pogonoperca punctata, C.V.

7. Serranus gilberti, Rich.

8. Serranus lineatus, $C . V$.

9. Serranus hœvenii, Blir.

10. Serranus urodelus, Forst.

11. Chilodipterus tíncatus, $s p . n$.

12. Dules, $s p$.?

13. Diagramma polytæuioides, Blkr.

11. Diagramma punctatum, C.V.

15. Diagramma affine, Gthr.

16. Scolopsis bilineatus, $B$.

17. Scolopsis xenochrous, sp. $n$.
18. Chætodon punctato-fasciatus, $C . V$.

19. Chrtodon octofasciatus, $G m$.

20. Chrtodon benuetti, $C \cdot V$.

21. Chrtodon oligacanthus, Blkr.

22. Chrtodon dorsalis, $C \cdot V$.

23. Chætodon kleinii, $B$ t.

24. Holacanthus melanosoma, Blkr.

25. Holacanthus leucopleura, Blkr.

26. Holacanthus lamarckii, Lac.

27. Holacanthus nararchus, C.V.

28. Holacanthis imperator, $B l$.

29. Holacanthus diacantbus, Bodd.

30. Holacanthus nicobariensis, $B l$.

31. Heniochus varius, $C . T$.

32. Toxotes jaculator, Pall.

33. Upeneoides tragula, Rich.

34. Tetraroge longispinis, $C . V$. 
35. Holocentrum sammara, Forsk.

36. Holocentrum caudimaculatum, Rüppp.

37. Acanthurus glaucopareius, C.V.

38. Acanthurus hypselopterus, Blk\%.

39. Acanthurus hepatus, $L$.

40. Acanthurus ctenodon, C.V.

41. Naseus tuberosus, Lac.

42. Zanclus cornutus, $L$.

43. Lactarins delicatulus, $C . V$.

44. Cubiceps pauciradiatus, $s p . n$.

45. Scomber australasicus, C.V.

46. Percis alboguttata, $s p . n$.

47. Antemarius moluceensis, $B l k r$.

48. Antennarius pinniceps, C.V.

49. Antennarius marmoratus, $G t h r$.

50. Eleotris strigata, $C . V$.

51. Eleotris helsdingenii, $B l k r$.

52. Amblyopus brachygaster, Gthr.

53. Petroscirtes rhinorhynchus, Blkr.

54. Amphiprion perideraion, Blkr.

55. Chorops brenchleyi, sp.n.

56. Cossyphus anthioides, Benn.

57. Cossyphus bilunulatus, $L a c$.

58. Anampses geographicus, $C . V$.

59. Anampses diadematus, Blkr.
60. Stethojulis trilineata, $B l$.

61. Platyglossus hortulanus, Lac.

62. Platyglossus scapularis, Bern.

63. Platyglossus marginatus, Rüpp.

64. Coris pulcherrima, Gthr.

65. Fierasfer homei, Rich.

66. Belone choram, Forst.

67. Exocœtus bahiensis, Ranz.

68. Exocœtus opisthopus, Bllz;.

69. Clupea pinguis, $s p . n$.

70. Clupea venenosa, $C . T$.

71. Engraulis boelama, Forste.

72. Nuræna flavomarginata, Rüpp?

73. Ophichthys filaria, sp. n.

74. Ophichthys misolensis, sp. $n$.

75. Hippocampus guttulatus, Cubv.

76. Triacanthus biaculeatus, $\mathrm{Bl}$.

77. Monacanthus scriptus, Osb.

78. Ostracion solorensis, Blkr.

79. Ostracion sebæ, Blkr.

80. Ostracion punctatus, $B l$.

81. Ostracion renardi, $B l k r$.

82. Ostracion gibbosus, $L$.

83. Ostracion cubicus, $L$.

84. Tetrodon nigropunctatus, $B l$.

85. Tetrodon papua, Blkr. 


\title{
C. DESCRIPTIONS OF NETH OR IMPERFECTLY KNOWN SPECIES:
}

\author{
PLATES XXVI. $\triangle \mathrm{ND}$ XXVII.
}

DTCEROBATIS DRACO.

Teeth tessellated, those of the upper jaw in 46 series, each tooth being much broader than long, and trenchant behind; the band of teeth terminates laterally at a short distance from the angle of the mouth; body and tail smooth; the distance between the mouth and dorsal fin is one-half of the greatest width of the body; tail more than twice as long as the disk, without spine; upper parts uniform brown; top of the dorsal fin white.

Misol Island.

Greatest width of the disk, 15 inches; distance between the front margin of the head and dorsal fin, $7 \frac{1}{3}$ inches. 


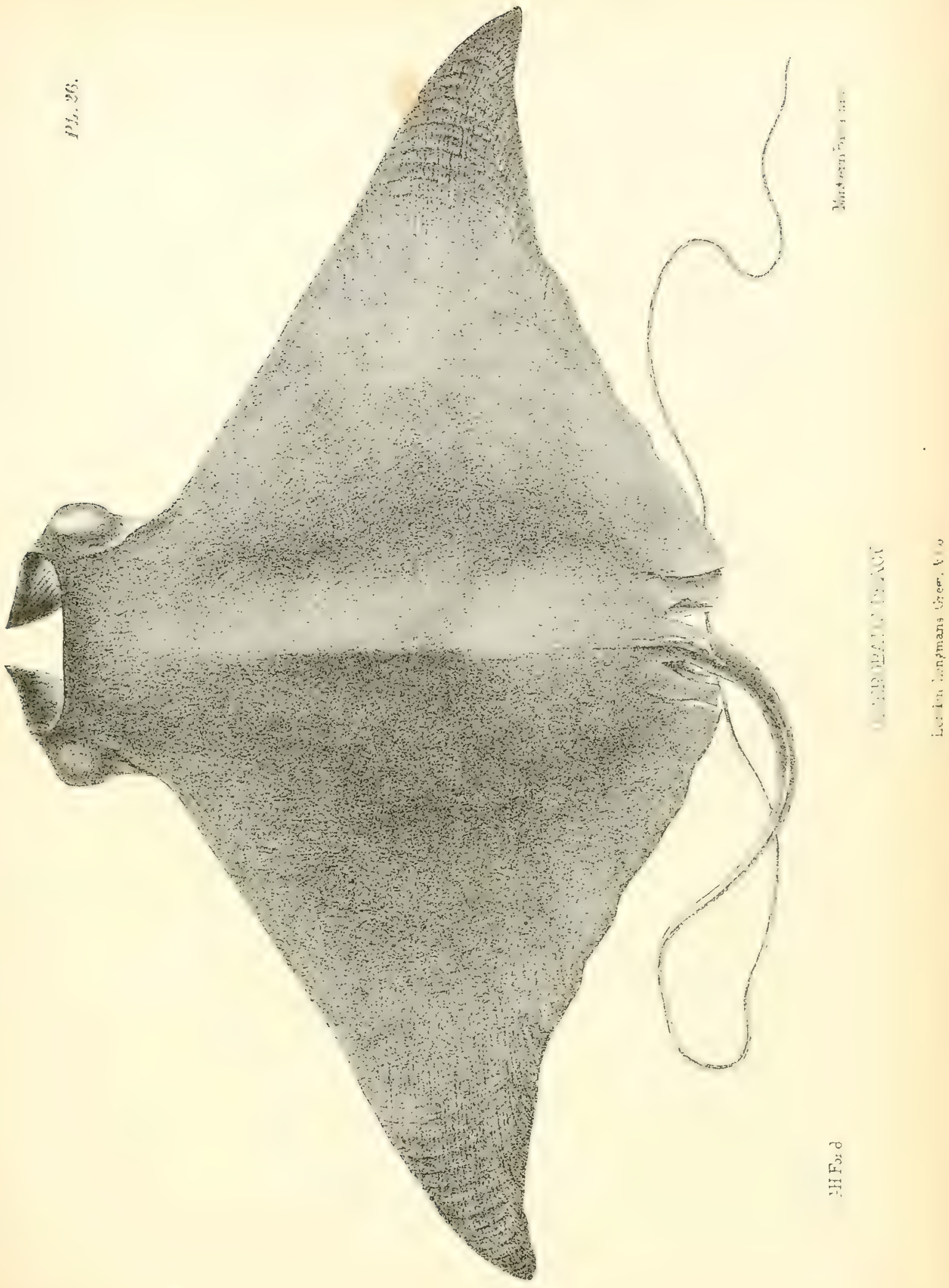





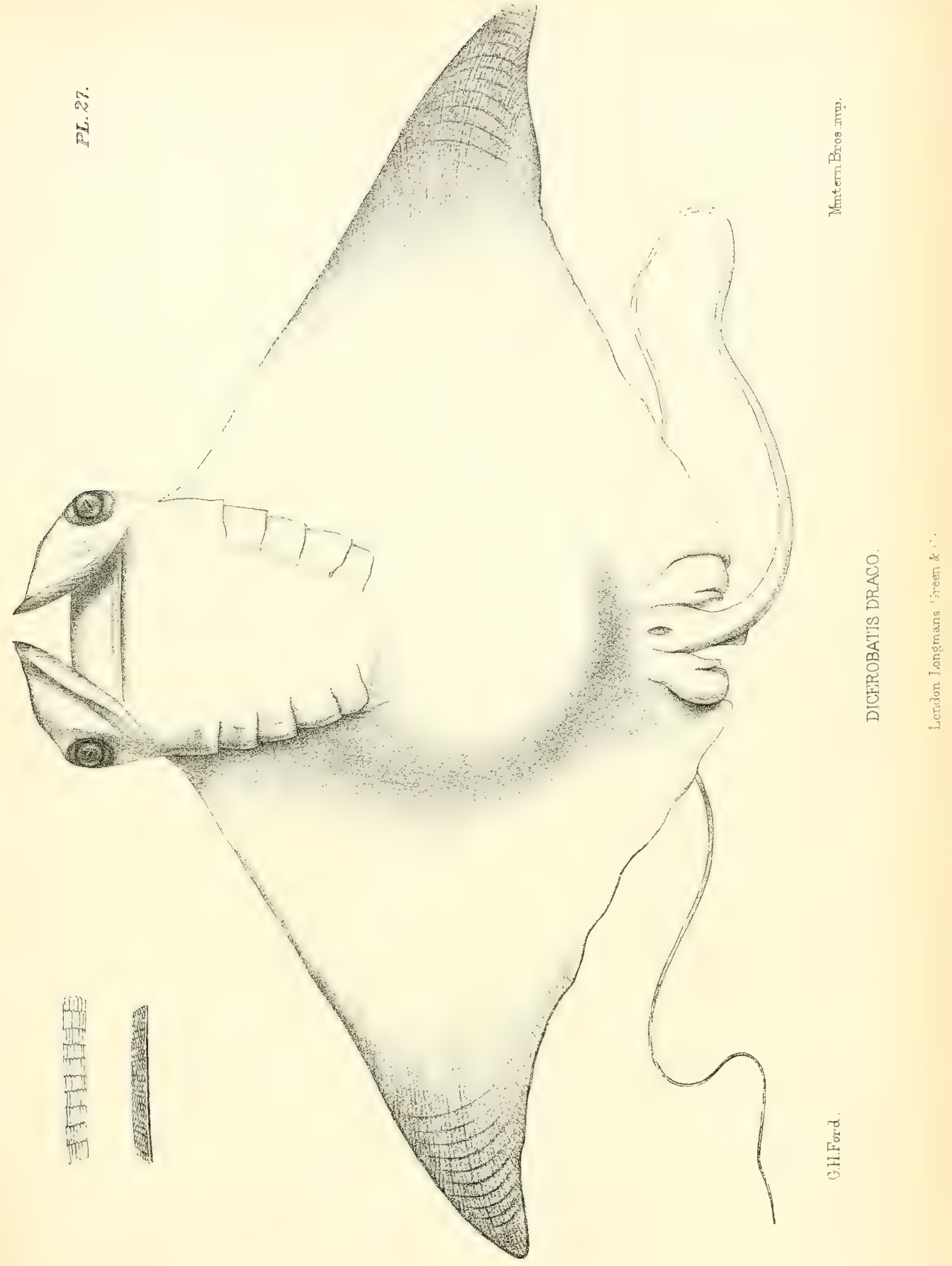



PLATE XXVIII. FrG, $A$.

\section{SERRANUS CYLINDRICUS.}

(Günth. Fish. vol. i. p. 151.)

D. $\frac{1}{1} \frac{1}{7}$. A. $\frac{3}{8}$. L. lat. 100 .

Body elongate, rounded, subcylindrical, its deptris being twosevenths of the total length (without caudal); its width is threefourths of the depth. The length of the head is one-third of the total (without caudal); caudal fin rounded; præoperculum rounded, finely serrated, with some rather stronger denticulations at the angle; the maxillary extends beyond the hind margin of the orbit; the spinous and soft portions of the dorsal fin are nearly equal in height, and the former is not much longer than the latter; the pectoral reaches as far as the ventral, terminating at some distance from the vent. Body with large hexagonal brown spots, separated by a white net-work; five or six of these spots along the back are of a darker colour; fins with scattered round large brown spots, and with a narrow whitish margin.

\section{Indian Ocean.}

Specimens up to 16 inches in length have been obtained. The figure is of half the natural size. 

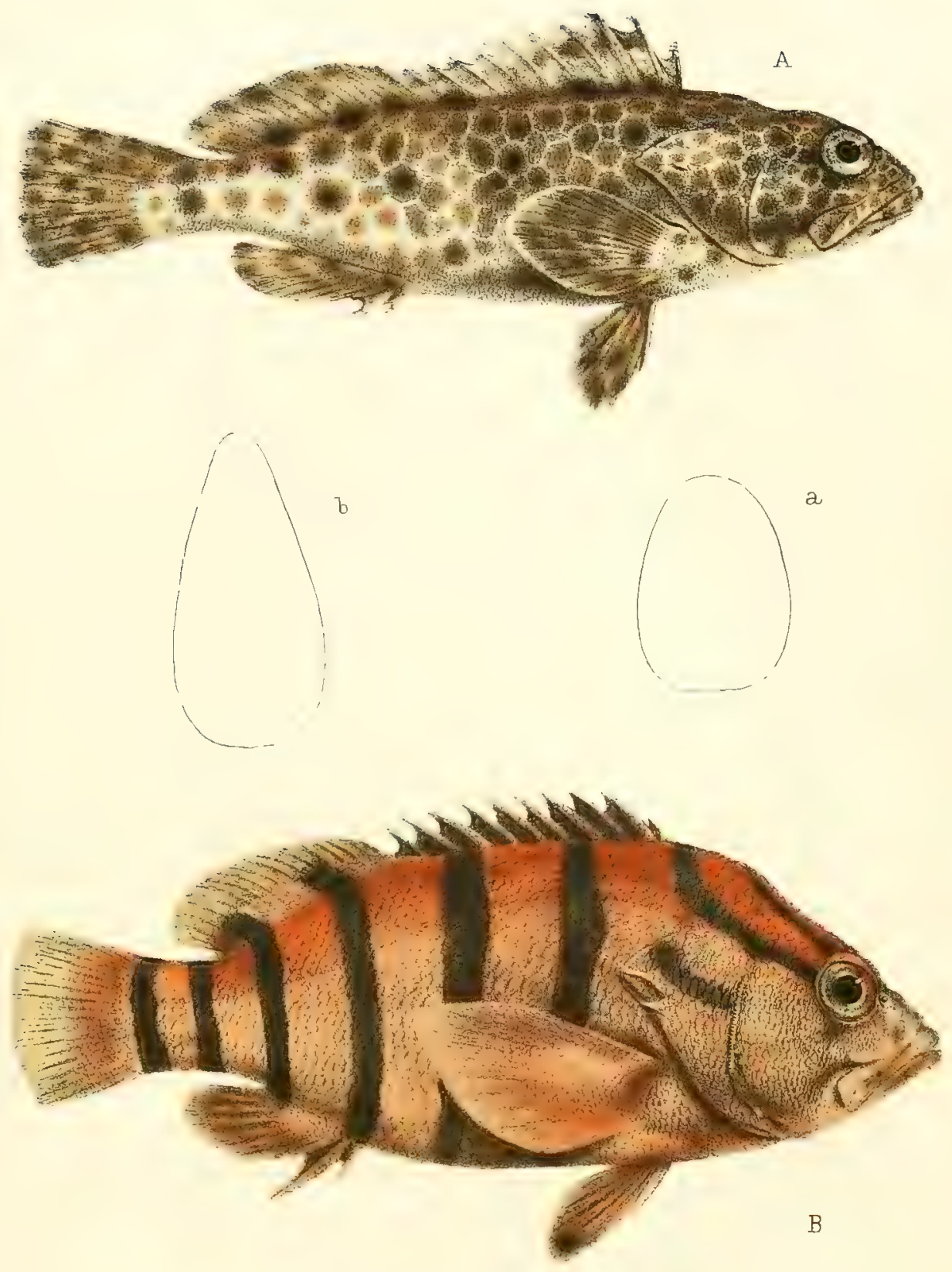

A.SERRANUS · CYLINDRICUS.

B PLECTROPOMA ANNULATUM.

G.F.Fond

Yontedrn Bros. Chromo lith 

PLATE XXVIII. Fig. B.

\section{PLEOTROPOMA ANNULATUM.}

(Günth. Fish. Tol. i. p. 158.)
D. $\frac{1}{1} \frac{0}{8}$.
A. $\frac{3}{7}$.
L. lat. 50 .
L. $\operatorname{trans} \cdot \frac{7}{20}$.

The length of the head equals the height of the body, and is two-fifths of the total (without caudal); scales very rough; præoperculum finely serrated behind, and with three spines below, one being placed at the angle. Red, with six black cross-bands, narrower than the inter-spaces, occupying the whole depth of the body and tail; sides of the head and nape with three black bands obliquely descending forwards.

\section{Sydney.}

Specimens 7 and 8 inches long. 
PLATE XXIX:

PLEOTROPOMA OOELLATUM.

(Plectropoma cyanostigma, Günth. Fish. rol. i. p. 161 ;

Plectropoma ocellatum, Günth. i6id. p. 504.)

D. $\frac{13}{1} \frac{3}{5}$ A. $\frac{3}{8}$. L. lat. 100 .

The height of the body is nearly equal to the Iength of the head, and two-fifths of the total (without caudal); præoperculum with three spines beneath, the anterior of which is the strongest, and sometimes bifid. Brownish : head, body, and base of the fins with numerous roundish spots, bluish in the centre, and black round the margin; they are more numerous, and also relatively smaller in old examples than in younger ones; those on the head and fins without bluish centre.

Sydney.

The largest specimen obtained is 16 inches long. 


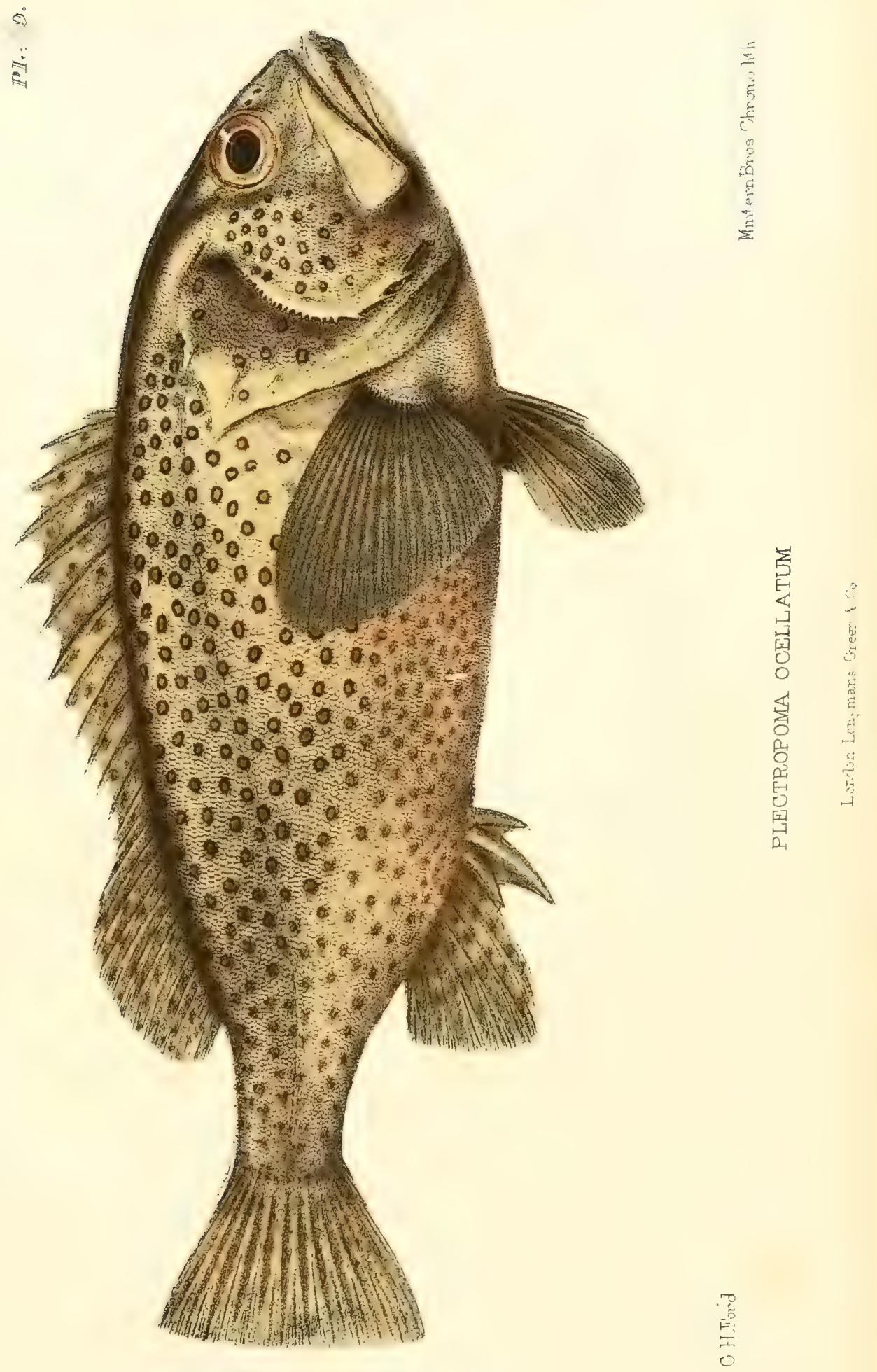



卫 $\mathrm{E}$ 
PLATE XXX.

CHILODIPTERUS TRUNCATUS.

D. $6 \mid \frac{1}{9} \cdot$ A. $\frac{2}{8}$. I. lat. 26 . L. trans. $\frac{2}{8}$

The height of the body is one-third of the total length (without caudal), the length of the head two-fifths; the diameter of the eye equals the length of the snout, and is one-half of that of the postorbital portion of the head; the maxillary extends to below the hind margin of the orbit; the third dorsal spine (which is the longest) is two-fifths of the length of the head; caudal fin truncated, with the angles rounded, the two central rays being not much shorter than the outer ones; uniform purplish-brown, with scarcely a trace of longitudinal bands, a round black spot at the end of the lateral line; the spinous dorsal black; ventrals blackishbrown.

Misol Island.

Tength 7 inches. 
ล่

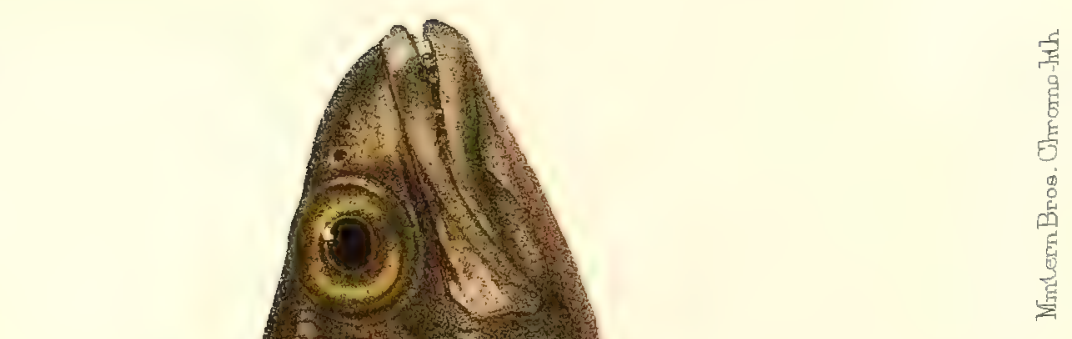

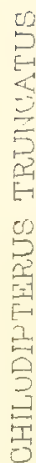

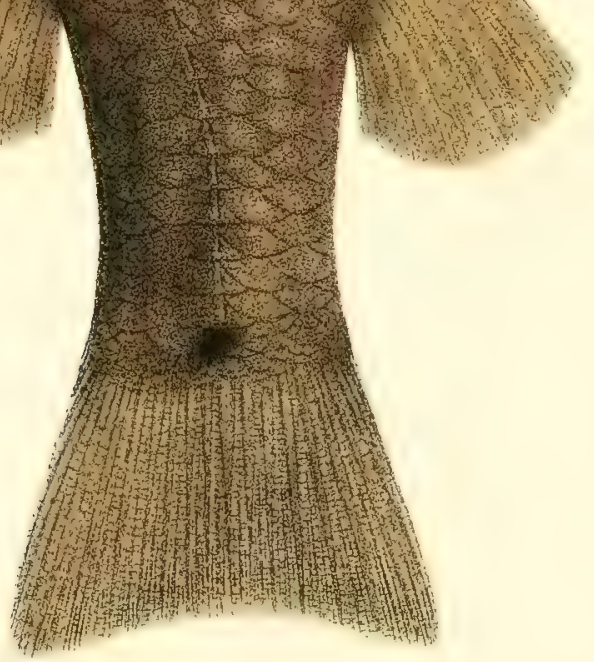

है 
E T. 2 
PLATE XXXI.

SCOLOPSIS XENOCHROUS.

Allied to Scolopsis ghanam.

D. $\frac{10}{9}$ A. $\frac{3}{7}$. L. lat. 44 . L. trans. $\frac{3}{14}$

The height of the body is contained thrice in the total length (without caudal), the length of the head thrice and a third: the diameter of the eye is one-third of the length of the head, and a little more than that of the snout, and equal to the width of the interorbital space; infraorbital arch with two strong spines, one pointing forwards, the other backwards, two or three small denticulations below the strong spine; præoperculum with the angle projecting; dorsal spines rather strong, but less so than those of the anal fin; second and third anal spines nearly equal in strength and length. Brownish-olive, a narrow pearl-coloured band along the uppermost dorsal series of scales; a large blackish-brown spot on the posterior part of the gill-cover; a broad silvery band, three scales broad, along the trunk below the lateral line; the anterior part of the band is crossed by a pair of short oblique brown streaks, the middle part with a brown spot on the base of each scale, the posterior portion uniform pearl-coloured; præorbital with a narrow silvery band; fins colourless.

Misol Island.

Iength 7 inches.

OUBTOEPS PAECIRADIATUS (not figured).
D. $10 \mid \frac{1}{1} \bar{q}$.
A. $\frac{1}{14}$.
L. lat. 50.

The height of the body is one-fourth of the total length (without caudal), the length of the head tro-sevenths; abdomen compressed into a ridge in front of the ventral fins which are received 
ค่

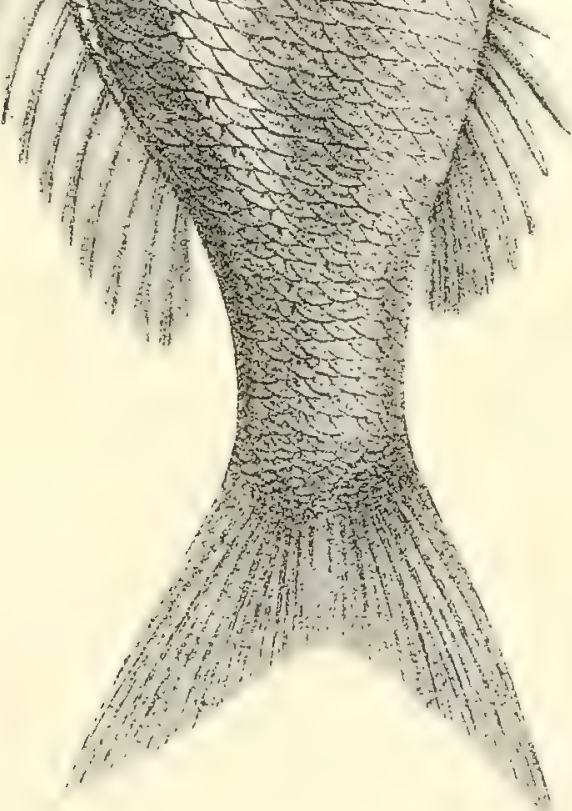


, 
into a groove of the posterior part of the abdomen; the diameter of the eye is equal to the width of the interorbital space, and onethird of the length of the head; snout shorter than the eye; jaws with a series of minute teeth; the vomer and tongue are armed with a long elliptical patch of very small obtuse teeth; no teeth on the palatine bones; maxillary hidden below the præorbital, and extending to the front margin of the orbit; humeral plate much developed, triangular; pectoral fin very long, longer than the head, and extending to the vent, not quite thrice as long as the ventrals; caudal fin forked nearly to the base, the lobes can overlap each other. Uniform brown; inside of the mouth and gill-cavity black.

Misol Island.

Length $5 \frac{2}{3}$ inches, 
PLATE XXXIr. Frg. B.

\section{PEROIS ALBOGUTTATA.}

D. $5 \mid 22$ A. $\frac{1}{18}$ L. lat. 60 . L. trans. $\frac{5}{13}$.

The height of the body is contained $6 \frac{1}{2}$ in the total length (without caudal), the length of the head $3 \frac{1}{2}$; the width of the interorbital space is one-third of the diameter of the eye, which is two-sevenths of the length of the head, and not quite equal to the length of the snout; lower jaw slightly projecting beyond the upper; the maxillary extends somewhat behind the vertical from the front margin of the orbit; cheek covered with minute scales to below the middle of the eye; the fourth dorsal spine is rather longer than the third, and about twice, as long as the fifth; the ventral fins reach to the vent; caudal truncated. Brownish-olive with a series of five small pearl-coloured spots on each side of the back, along the base of the dorsal fin; a series of indistinct brownish spots along the lower half of the side; caudal fin with a pair of brown spots on the base, the lower spot being followed by an ovate white spot; fins without distinct markings.

Misol Island.

Length 6 inches. 
สู่

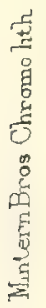
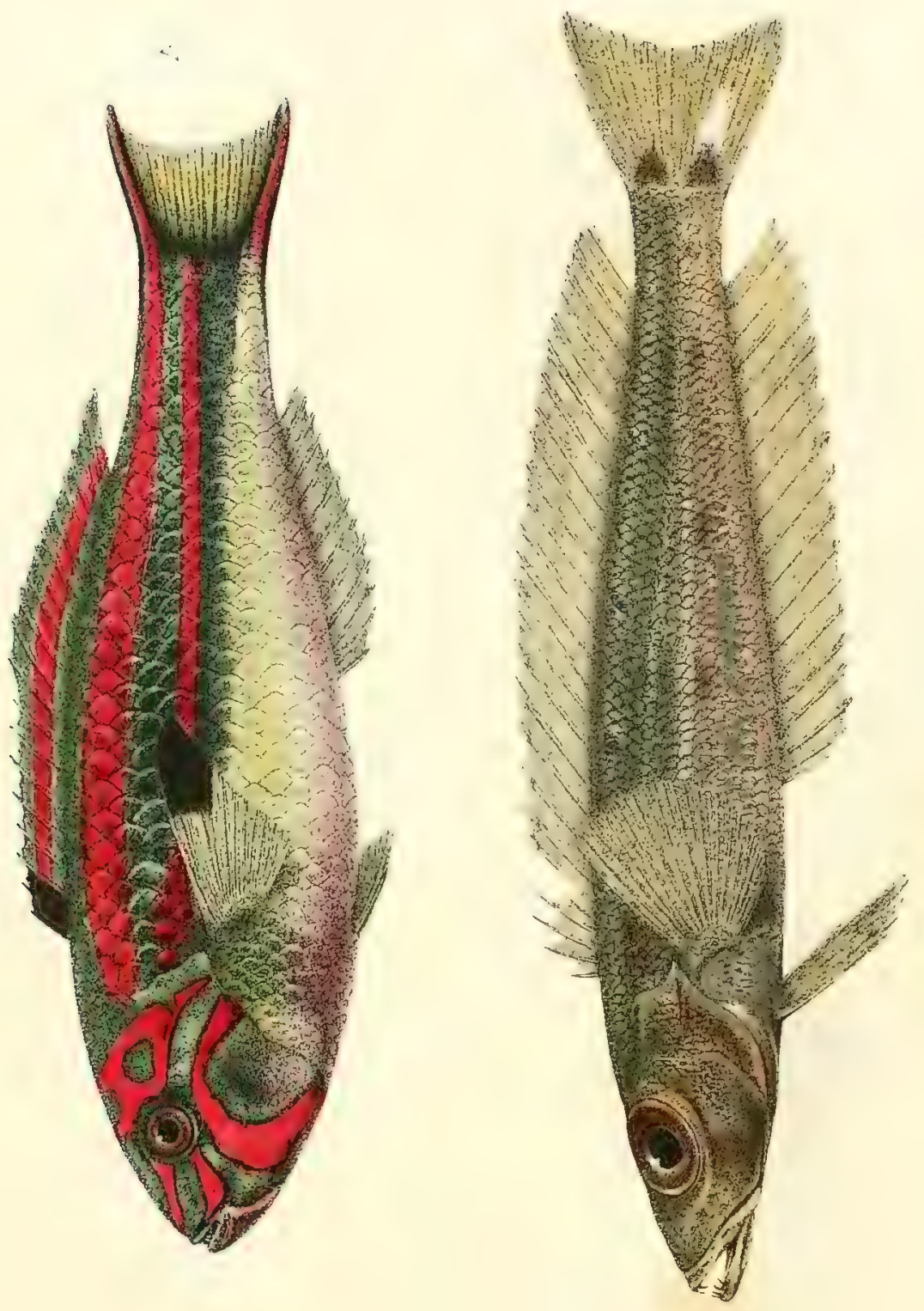

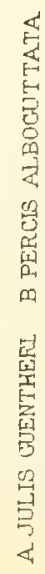




\section{.}



PLATE XXXIII. Frg. B.

\section{SALARTAS CORONATUS.}

D. $12 \mid 20$. A. 20 .

The height of the body is contained six times in the total length (without caudal), the length of the head five times and a third; the forehead projects a little beyond the mouth; the supraciliary tentacle is about as long as the eye, and terminates into several fringes; nuchal crest none; a pair of canine teeth in the lower jaw; dorsal fin deeply notched; pectoral nearly as long as the head. Flesh-coloured, with eight dark cross-bands as broad as, or. broader than, the interspaces, darkest on the edges; back with scattered brownish-violet spots smaller than the pupil; sides and upper surface of the head with round small yellow spots; a group on the crown of the head being placed in a circle; throat with three brownish-violet cross-bands; vertical fins nearly immaculate, and with a blackish margin; pectoral finely dotted with black.

Solomon Islands.

Length $3 \frac{2}{3}$ inches. 

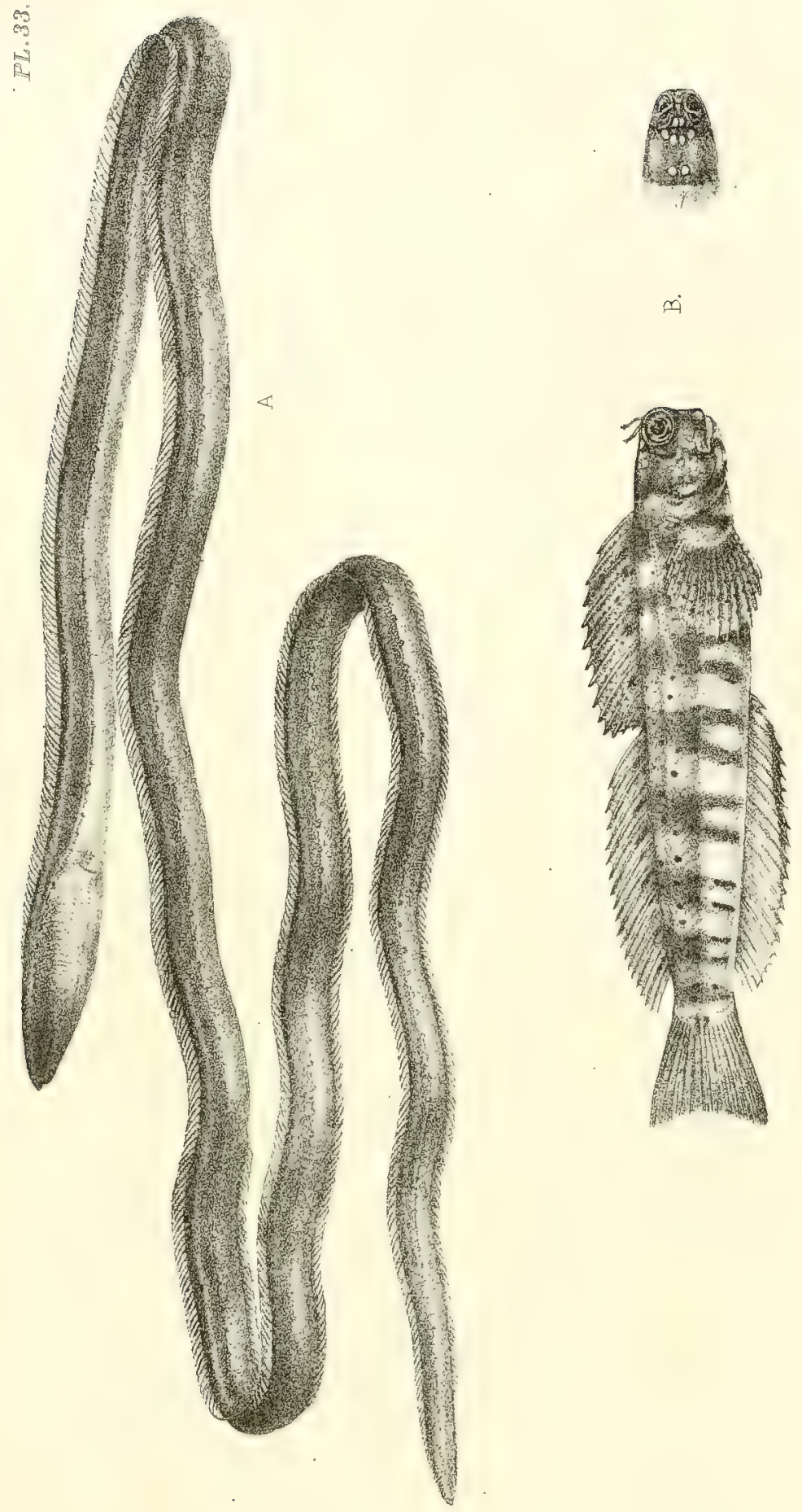

号

筫

8

है

蛋

告 


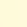


PLATE XXXII, Frg. A.

\section{JULIS GUENTHERI.}

(Julis Guentheri, Bleeker, Versl. Ak. Wet. Amsterd. vol. xiii. p. 279.)
D. $\frac{8}{13}$.
A. $\frac{2}{11}$
L. lat. $27-28$.

The height of the body is equal to the length of the head, and two-sevenths of the total (without caudal); no posterior canine tooth; two canine teeth of the lower jaw are received between those of the upper; dorsal spines pungent, shorter than the rays; caudal lobes somewhat produced; the length of the ventral is three-fifths of that of the pectoral, which is shorter than the head. Upper parts greyish-green, lower of a lighter colour; a greyish band, one scale broad, commences on the side of the neck, runs along and above the lateral line, and is continued to the end of the upper caudal lobe; a second band of a lighter colour commences above the pectoral, and runs along the middle of the side of the body to the root of the cardal; caudal fin yellow, blackish at the base, with a greyish black-edged band along the upper and lower lobes; head dark-violet, with two curved bluish bands, the lower from the chin towards the lower part of the orbit, to the opercular lobe, the upper across the præorbital through the upper part of the orbit to the upper end of the gill-opening (the bands are red during life); the pectoral with the hinder portion blackish; dorsal fin with a deep black spot anteriorly, and with a blackish margin; anal without markings, or with a faint blackish lower edge.

\section{Solomon Islands.}

Length $5 \frac{1}{4}$ inches. This species is known also from Celebes and the Cape of Good Hope. 
PLATE XXXIV.

OTICROPS BRENCHLEYI.

D. $\frac{13}{7}$. A. $\frac{3}{5}$. L. lat. 28 . L. trans. $\frac{3}{10}$.

The height of the body is equal to the length of the head, and one-third of the total (without caudal); head much longer than high; the depth of the præorbital is more than the width of the orbit; scales on the cheek small, scarcely imbricate, in four series; operculum terminating in a membranaceous flap behind; posterior canine tooth present; præoperculum not serrated. Reddisholive; a broad pearl-coloured band ascends obliquely from above the axil of the pectoral towards the origin of the soft dorsal; its upper half is surrounded by a broad brown margin, which is spread over the base of the last dorsal spines and anterior rays; root of the pectoral silvery; no other markings in a preserved state.

Misol Island.

Length $7 \frac{1}{2}$ inches.

CLUPEA PINGUIS (not figured).

B. 5. D. 17. A. 19. I. lat. 43. L. trans. 13 .

The height of the body is one-fifth of the total length (without caudal), the length of the head one-fourth; scales deciduous; lower jaw but slightly projecting beyond the upper; maxillary 
i

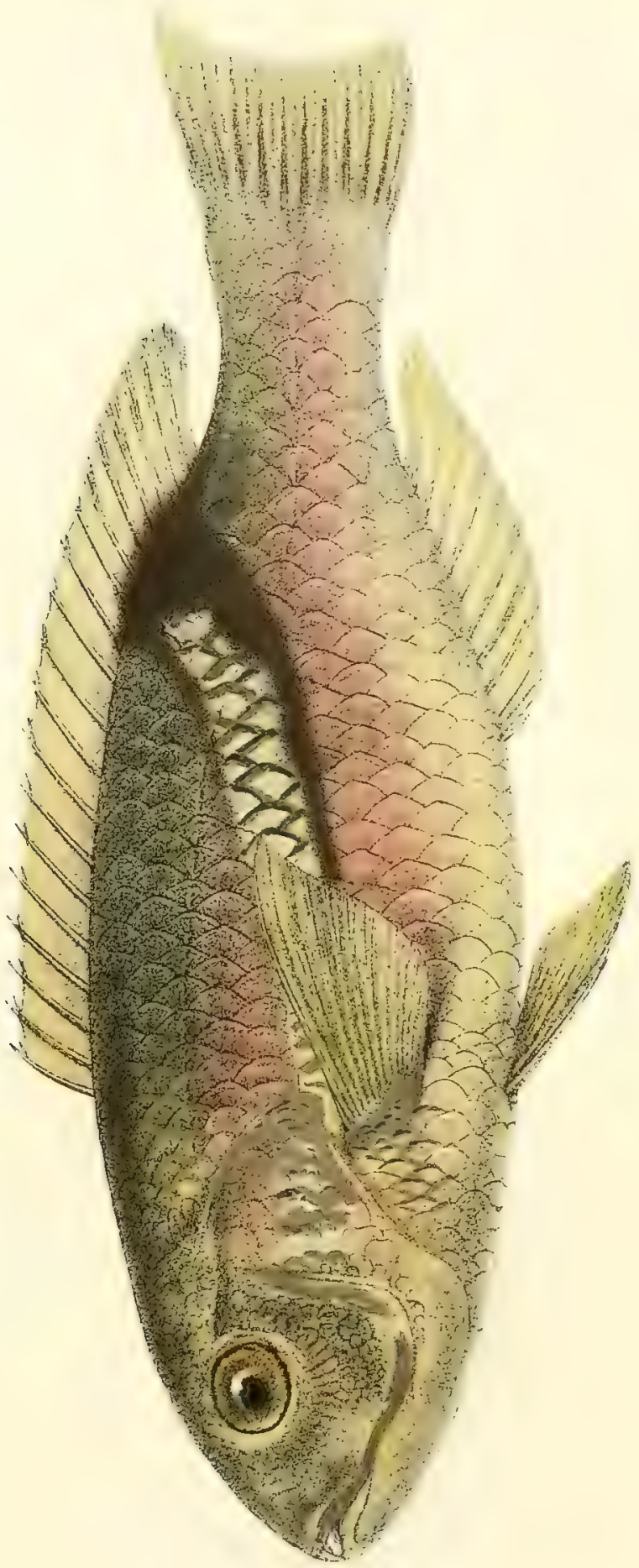

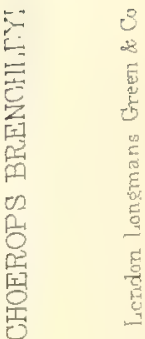



extending to below the front margin of the eye; teeth none; snout longer than the eye, which is one-fourth of the length of the head; ventral fin inserted below the anterior third of the dorsal fin, the base of which is midway between the root of the caudal and the end of the snout; caudal fin deeply forked; there are fourteen abdominal scutes behind the base of the ventrals. Back bluish-green, side silvery, both colours being sharply defined from each other.

Misol Island.

Length 5 inches. 
PLATE XXXIII. FIG. A.

\section{OPHIOHTHYS FILARIA.}

Allied to 0 . longipinnis and 0 . kirkiz, but distinguished from both by the considerably greater slenderness of the body, the depth of which is two-ninths of the length of the head, whilst it is rather more than one-third in those two species.

'The length of the head is one-tenth of the distance between the gill-opening and vent; tail almost as long as the body; cleft of the mouth of moderate width, extending to some distance behind the eye, which is small and somewhat nearer to the corner of the mouth than to the end of the snout; snout pointed, more than twice as long as the eye, projecting beyond the mouth; anterior nostril with a small tube, posterior on the inner side of the lip, below the front margin of the eye; teeth pointed, uniserial; gillopenings lateral; pectoral fin reduced to a minute filament; the dorsal and anal are about half as high as the body, the former commencing midway between the gill-opening and the eye. Coloration uniform.

Misol Island.

Length 24 inches, the tail being $11 \frac{1}{2}$ inches long; depth of the body 3 lines. 
, 
PLATE XXXV.

OPHIOHTHYS PINGUIS.

Teeth pointed, in a single series in the maxillary, mandible, and on the vomer; head small, pointed, its length being contained five times and a half in the distance of the gill-opening from the vent; eye about half the length of the snout, the cleft of the mouth extending considerably behind its hinder margin; dorsal and anal fins low, nearly entirely hidden in a groove (the former commences somewhat in advance of the gill-opening); the length of the pectoral fin is about one-third of that of the head. Reddishbrown with eight large broad black spots across the back of the trunk, and fifteen across the back of the tail; they extend downwards to the middle of the side; head with numerous small round blackish spots: no other spots.

Solomon Islands.

Length 16 inches, the tail being $9 \frac{1}{2}$ inches long.

\section{OPHICHTHYS MISOLENSIS (not figured).}

The length of the head is one-seventh of the distance between the gill-opening and vent; tail as long as the body; the depth of the body is one-third of the length of the head; eye small, above the middle of the cleft of the mouth, which is of moderate width; snout pointed, twice as long as the eye, projecting beyond the mouth; anterior nostril with a very short tube, posterior on the inner side of the lip, below the front margin of the eye; teeth equally small, pointed, uniserial; gill-openings somewhat oblique, lateral; pectoral fin none; dorsal and anal fins low, the former commencing at a very short distance behind the gill-opening, the latter immediately behind the vent. Coloration uniforro.

Misol Island.

Length 11 inches. 


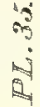

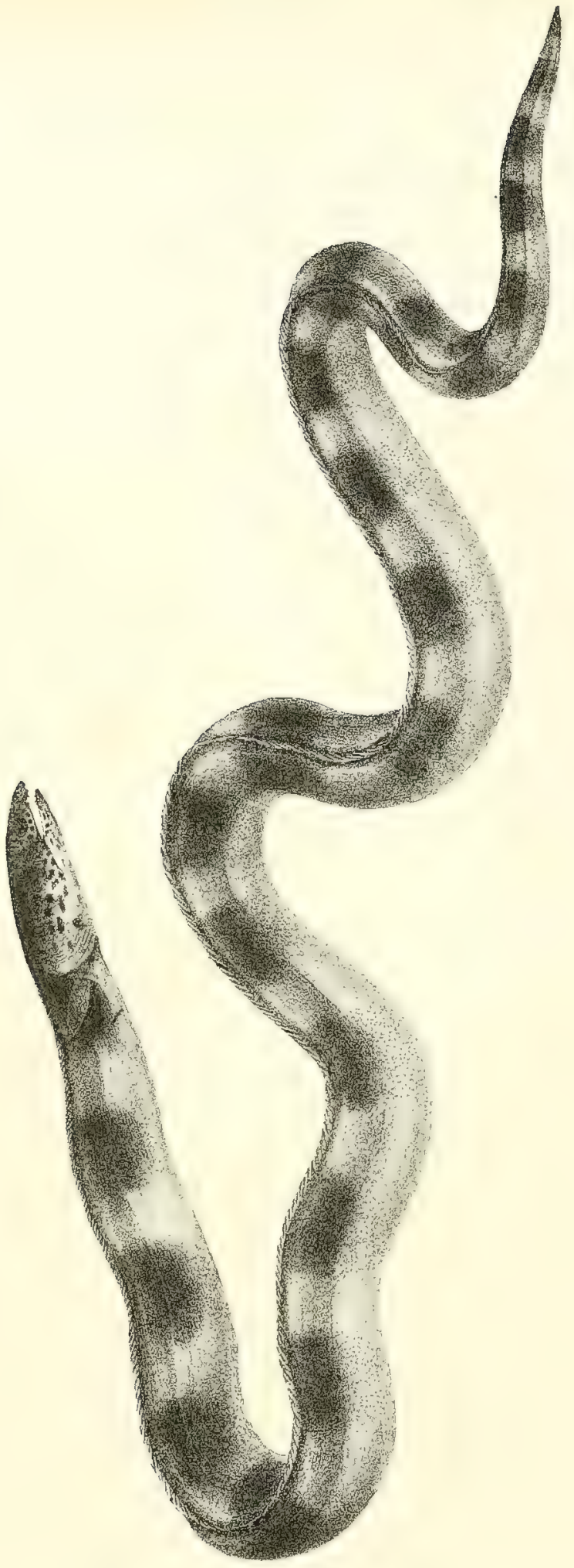



SHELLS. 
PLATE XXXVI.

\section{FUSUS (COLUS) SIMILIS, Baird.}

Shell elongately fusiform, spindle-shaped, moderately thick, rather solid, somewhat deeply grooved and ridged throughout transversely, and finely striated across the ridges longitudinally; spire acuminated; whorls slanting round the upper part, noduled in the middle; nodules moderate-sized, not distant from each other, about $10 \mathrm{or}^{11}$ in number in each whorl; interior of the aperture pure white, sharply ridged in the throat, guttately noduled at the inferior part, columella callus slightly wrinkled. Rostrum long, bent about the middle of its length; canal twisted. of a dull white colour throughout, externally.

The spire in the specimen we described is broken at the tip.

Length of remainder 6 inches.

Breadth of body whorl 2 inches.

Hab. New Caledonia. 
PE. 36.
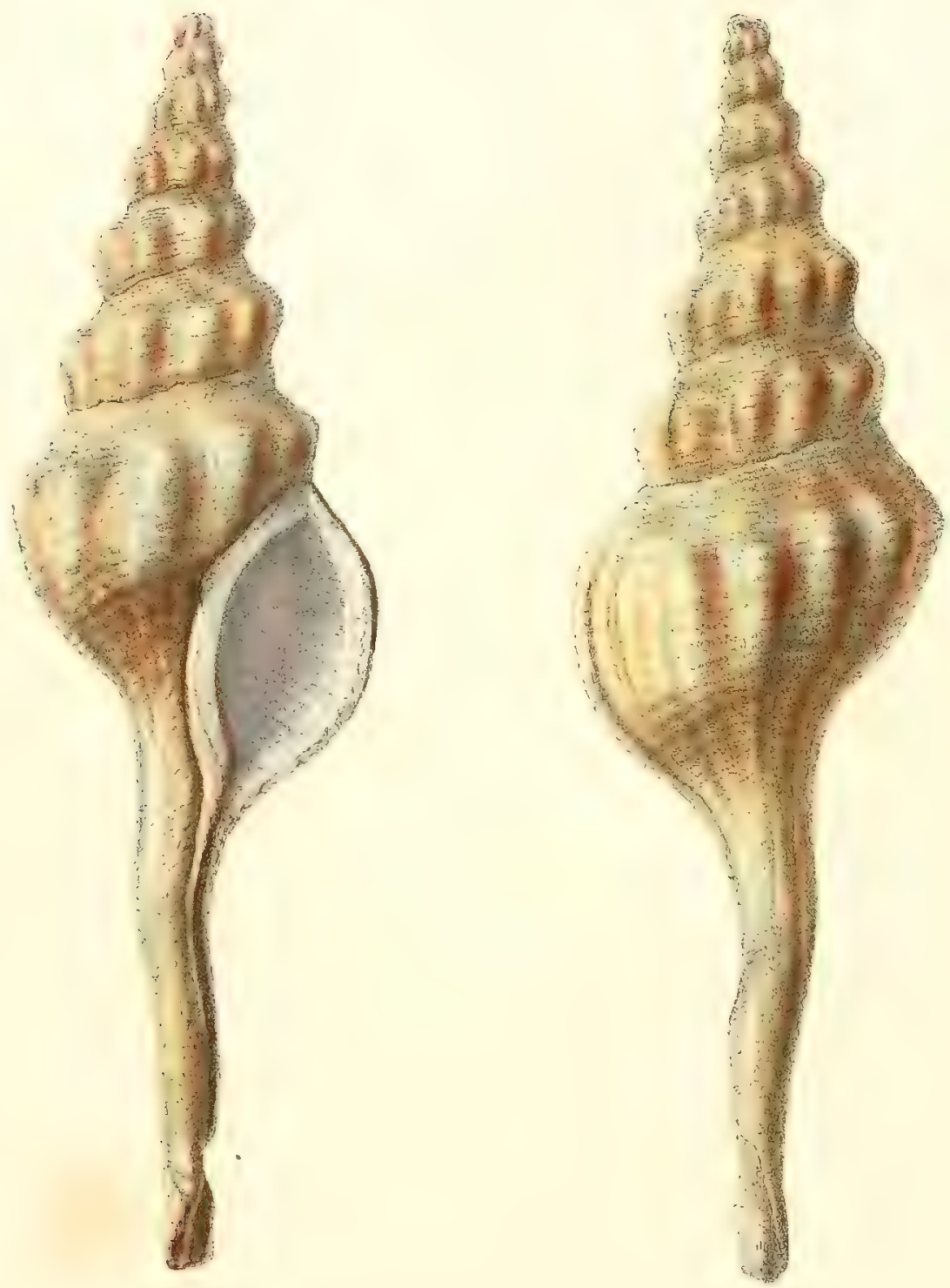

GHFord

FUSUS SIMILIS.Baird 
, 


$$
\text { F F }
$$


PLATE XXXVII. Figs. 1, 2.

FUSUS (COLUS) BRENCHLEYI, Baird.

Shell fusiform moderately ventricose in the middle, spire and canal about equal in length; whorls 11 or 12 in number, closely noduled round the centre of each, spirally grooved and ridged; ridges irregular, some consisting of 2 striæ, others of 3 or 4 spiral ridges crossed longitudinally with numerous, small, raised striæ, giving them the appearance, under a low power, of being reticulated. Shell white with numerous chesnut-coloured blotches and lines, the blotches more decidedly marked between the nodules and outside of canal; lower extremity of canal marked with a large deep orange-coloured spot.

Length $3 \frac{1}{2}$ inches.

Greatest breadth 1 inch 3 lines.

Hab. South Sea Islands.

PLATE XXXVII. Figs, 3,4 .

DEFRANCIA ALBO-STRIGATA, Baird.

Shell turreted, fusiform, white; whorls $8 \frac{1}{2}$, longitudinally costate, the costro or ribs transversely striated; the first $2 \frac{1}{2}$ whorls very small, smooth, and very gradually increasing, the rest rough with prominent ribs and striæ, increasing rapidly, the succeeding 
PL.37.
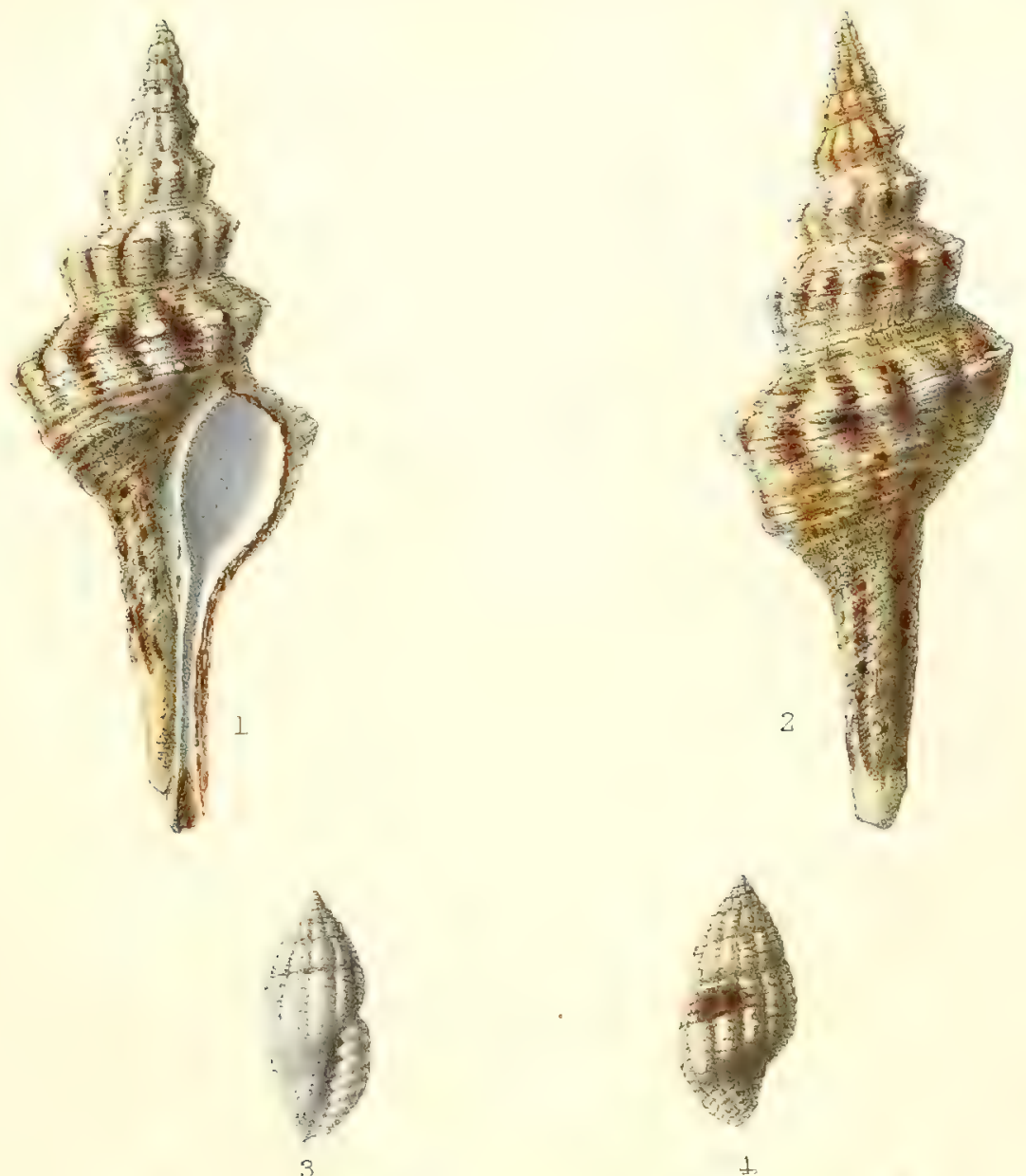

1

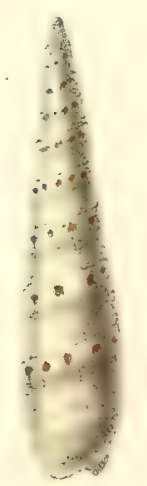

5.

GHFor $\alpha$.

JinteruB Bos.im

1.2.FUSUS BRENCHTEYI.Bä̈Z.

3.4.DEERANCIA AIBO-STRIGATA Baird

5.6. TEREBRA PARVA. Baind. 

4 crowded upon each other, the last nearly half the length of the whole shell. Near the centre, on the back of this whorl, it is distinctly marked with a pure white chalky looking band, and in some instances with an interrupted band of brown; aperture rather narrow; outer lip thickened, toothed on inner margin; canal rather short, sub-flexuose.

Length 3 lines.

Breadth $1 \frac{1}{4}$ lines.

Hab. New Caledonia.

Approaches somewhat to Pleurotoma apicalis of Montrouzier, but is only about half the size, and is distinguished by the white band on the back of the last whirl.

PLATE XXXVII. Figs, 5, 6.

TEREBRA (LEIOSTOMA) PARVA, Baird.

Shell elongately subulate, rather thick, whitish-coloured, marked with a row of somewhat square-shaped reddish-brown spots beneath the suture; whorls 13, shining, longitudinallygrooved at the sutures; groove extending half-way down each whorl; last whorl marked with two bluish bands, one near the suture, and one near the mouth; penultimate whorl with one band near the suture; mouth white inside, except where the bluish bands shine through; columella straight; outer lip sharp, simple.

Length of shell from 8 to 11 lines.

Greatest breadth 2 lines.

Hab. New Caledonia. 
PLATE XXXVIII. FIGS. 1, 2.

NASSA BIFARIA, Baind.

Shell ovately conical, rather solid, light-coloured, stained here and there with brown; whorls 7 in number; last whorl smooth, shining, flexuosely ribbed; ribs distant, coronated round the suture, sulcated at the base with 5 or 6 grooves; the other six whorls small densely granosely reticulated; penultimate whorl coronated, others not so; sutures distinct; columella smooth, not callous, twisted at the base; outer lip simple, grooved interiorly, emarginated and toothed at its junction with the body whorl.

Length of shell from 6 to 7 lines. .

Breadth from 4 to $4 \frac{1}{2}$ lines.

Hab. New Caledonia.

? An Nassa acuticostata, var. Montrouzier"

PLATE XXXVIII. Figs, 3, 4.

\section{PHASIANELLA WISEMANNI, Baird.}

Shell small, oval, polished; whorls $5 \frac{1}{2}$; apex rather obtuse and blackish; the remaining whorls yellowish with transverse pink bands, the body-whorl having 7 or 8 of these, and also marked 

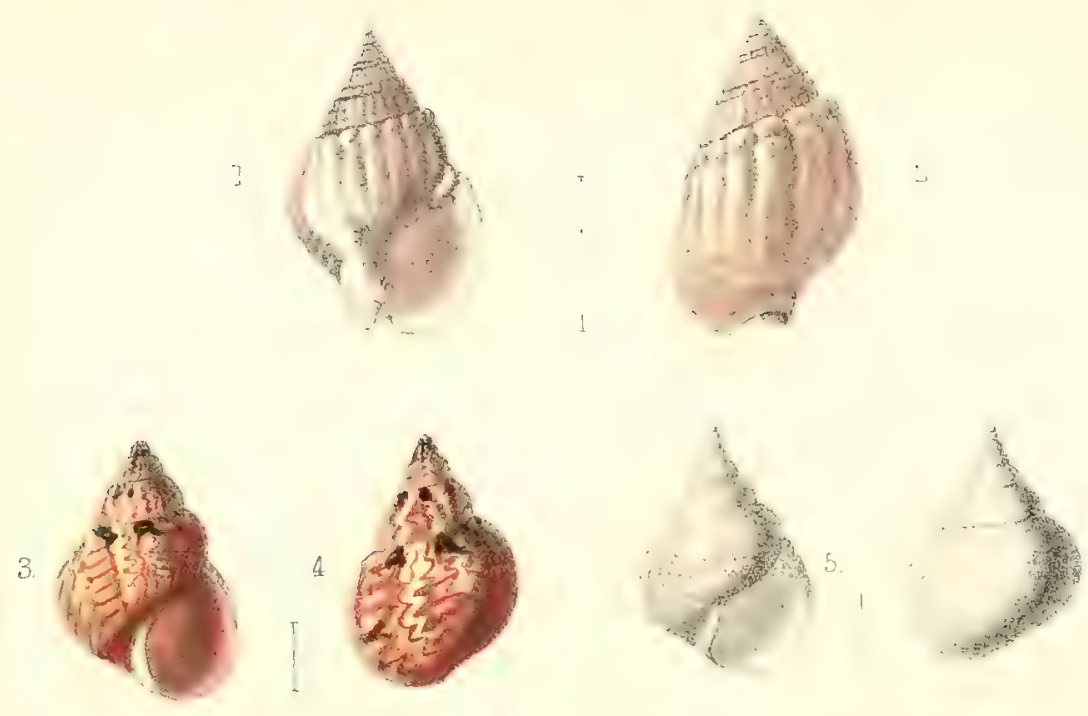

6.
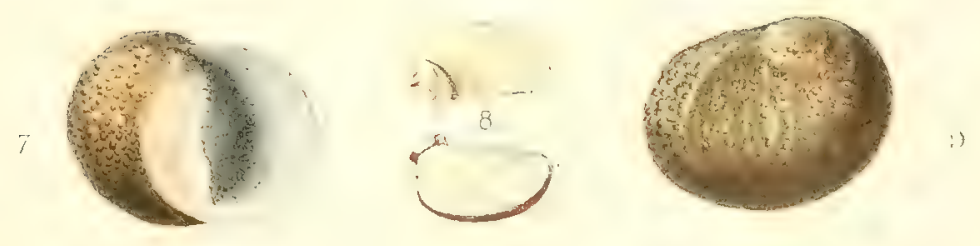

10.
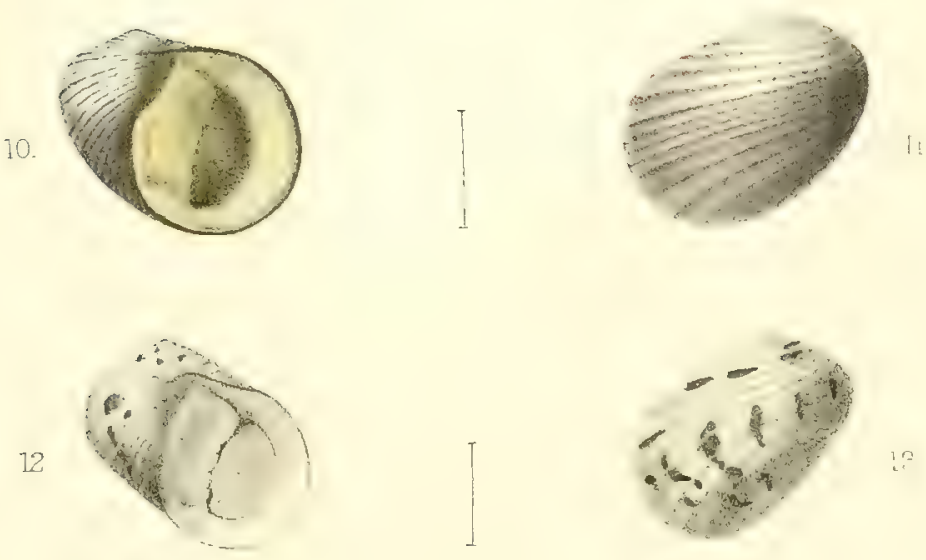

C.HFord.

Nintem Bros .jmp

1.2. NASSA BIFARIA. Boird.

7.8.9. NERTTINA SUBRUGATA BaIT2.

3.4. PHASIANELIA WISEMANNI Batd 10.11. NERITA STRIC TA.Batd

5.6. STYYIFER DUBIUS.Baird. 12.13. "NOVFA CALEDOIVIE. Baird. 


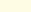


throughout with brown spiral hair-like lines. Beneath the sutural line there are alternately blackish and white blotches, the latter being produced zigzagly over the whorls; aperture subcircular, equalling the spire in length; columella white.

Length $3 \frac{1}{3}$ lines.

Breadth 2 lines.

Var. Shell of lighter colour, with only slight indications of the transverse pink bands; but having the alternate blackish and white sutural blotches, and of the same size and proportions.

Hub. Anatom, New Hebrides.

PLATE XXXVIII. Frgs, 5, 6.

STYLIFER DUBIUS, Baird.

Shell sub-globose; whorls 7 in number exclusive of sinistral nucleus, smooth, shining, white; last whorl globose, large, exceeding in length all the rest of the shell; spire rapidly and suddenly diminishing in size, and terminating in a sharp point; mouth ovate; columella somewhat produced at the base; outer lip simple, acute.

Height 3 lines.

Breadth nearly 2 lines.

Hab. New Caledonia.

Approaches in shape and structure the Stylifer ovoideus of A. Adams, but differing from it in habitat, shape of the mouth, and form of the columella. 
PLATE XXXVIII. Figs. 7, 8, 9.

NERITINA SUBRUGATA, Baind.

Shell very obliquely-ovate, sub-globose; spire much eroded, scarcely exserted, spirally ridged round the whorls, which are distinctly angled, rudely wrinkle-striated longitudinally, rather rough, of a dark olive colour, the wrinkled strix pale yellowish; columella area slanting, sinuated in the middle, finely toothed, last tooth much larger than any of the others, lip thin, slightly channelled at the upper part, bluish-coloured within; operculum bluish-stained, with a reddish margin, and bisected with a somewhat raised rib.

Height 9 lines.

Breadth $7 \frac{1}{2}$ lines.

Hab. Upolu, Samoan group.

?An Neritina humerosa, Mousson, var. without spines. See 'Journ. de Con., xiii. p. 188.

PLATE XXXViII. Figs. 10,11.

NERTTA STRIOTA, Baiod.

Shell narrow, ovate; spire not exserted, flatly depressed, small; whorls spirally ribbed; ribs rather thin, numerous, interstices densely lined with very fine striæ which sometimes extend over the ribs; columella area rather narrow, yellow, edge toothed with only 3 or 4 teeth; inner part of mouth yellowish-green, 
outer edge of lip dark and crenated. Shell of a dark colour without spots; operculum covered with fine grains.

Height $7 \frac{1}{2}$ lines.

Breadth 6 lines.

Hab. South Sea Islands.

PLATE XXXVIII. Frgs. 12, 13.

NERITA NOVA-CALEDONLD, Baird.

Shell obliquely narrowly ovate, rather ventricose; spire very small; whorls 3 in number, first minute but rather prominent smooth and shining, last whorl large, constituting by far the greatest part of the shell, spirally ribbed; ribs rather large, interstices densely concentrically striated; columella area glassy, smooth, indistinctly toothed; labrum with a yellowish margin, somewhat channelled at top. Shell itself of a dull yellowish colour, tesselated with spots of: black; operculum densely granulated.

Height about 6 lines.
Breadth 4 lines.
Hab. New Caledonia.

Resembles somewhat in shape $N$. musiva, Gould. 
PLATE XXXIX. Figs. 1, 2.

HYDROCENA STMLIS, Baird.

Shell small, ovate, smooth, of a horny colour; whorls 5 in number, apex rather pointed, last whorl rather more than half the length of the shell, rounded, mouth semilunar, rimate, not perforated; peristome simple; columella thickened, rather rereflexed, edges not continuous.

Height $1 \frac{1}{4}$ lines.

Breadth scarcely 1 line.

Hab. Samoan group.

REALIA (OMPHALOTROPIS) LEVIS, Bård.

Shell conical, oval, of a light amber colour, perfectly smooth ; whorls $5 \frac{1}{2}$ in number, last whorl exceeding in length all the others combined; äpex blunt; suture defined, narrow; umbilicus of a moderate size, surrounded with a rather strongly elevated carina; mouth oval, peristome continued, outer lip doubled externally; interior of month of same colour as external surface of shell.

Height 2 lines.

Breadth 1 line.

Hab. Samoan group. 
$P I .39$.
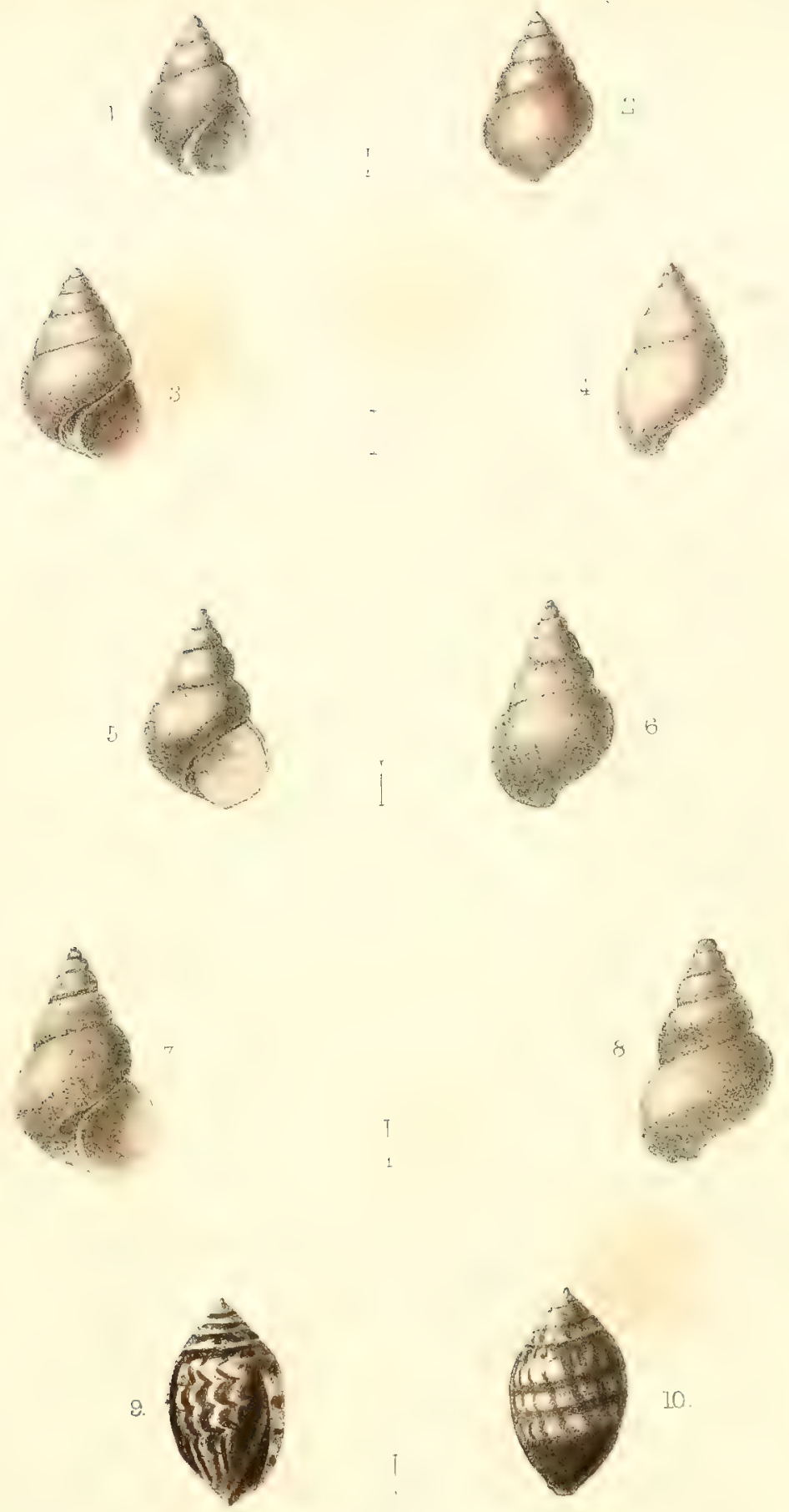

G.HFord.

1.2.HYDROCENA SIMILIS. Baird.

3.4. REALIA IEEVIS Baira

9.70. MET.AMPUS OVULOIDES. Baird.

Mrotern Bros . irme

5.6.REALIA VAVATENSTS. BatTd.

7.8. " BICARINATA. " 

PLATE XXXIX. Fras, 5, 6 .

REALIA (OMPHALOTROPIS) VAVAUENSIS, Baird.

Shell conically oval, of a dirty white colour; whorls 6, obscurely longitudinally striated, apex rather blunt, last whorl about equal in length to all the others combined, very obscurely carinated; suture well defined; mouth ovate, umbilicus restricted, surrounded by a raised keel, peristome continued, outer lip slightiy expanded; interior of mouth of a slightly reddish colour.

Height $2 \frac{1}{4}$ lines.

Breadth $1 \frac{1}{4}$ lines.

Hab. Vavau, Friendly Islands.

PLATE NXXIX. Figs. 7, 8.

REALIA (OMIPHALOTROPIS) BICARINATA, Baird.

Shell ovate, conical, rather stout, smooth, horn-coloured; whorls 6 in number, apex rather obtuse, last whorl with two keels, one surrounding the middle of it, the other immediately beneath the suture; umbilicus distinct, and surrounded by a rather strong raised $\mathrm{keel}$; mouth rounded, oval, peristome simple, the outer lip above nearly touching the median keel.

Length 2 lines.

Breadth $1 \frac{1}{4}$ lines.

Hab. Savage Island, and Tongatabu. 
PLATE XXXIX. Figs. 9, 10.

MIELAMPUS (TIFATA) OVULOIDES, Baird.

Shell small, oval, contracted at both extremities; spire consisting of 8 whorls, rapidly increasing; last whorl nearly double the length of whole shell; spire short, acute, upper whorls finely striated, last smooth; shell of a dark coffee colour with white zigzag longitudinal lines; mouth narrow, inner lip exhibiting only one plait, outer lip grooved within.

I.ength $2 \frac{1}{2}$ lines.

Breadth 1 $\frac{1}{2}$ lines.

Hab. Tutuila, Samoan group. 


\section{.}


PLATE XL。 Frgs, 1, 2.

\section{MELANIA BRENCHLEYI, Baird.}

Shell ovate, pyramidal ; apex much corroded, remaining whorls, 4 or 5 in number, rounded, lower ones perfectly smooth, upper delicately concentrically grooved; colour greenish-yellow with occasional longitudinal streaks of dark brown; mouth oval, of a leaden hue within; columella white, small, and suddenly turning into the inner body of shell.

Length from $6 \frac{1}{2}$ to $7 \frac{1}{2}$ lines.

Breadth about $3 \frac{1}{2}$ or 4 lines.

Hab. Upolu, Samoan group, and Tongatabu, Friendly Islands.

Var. delicatula Baird, Plate XL., figs. 3, 4.

Shell smaller and more delicate, thin, transparent, and dark brown, streaks more decidedly shown; apex much corroded, remaining whorls only 3 or 4.

Length about 5 lines.

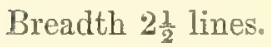

Hab. Tutuila, Samoan group. 


$$
\begin{aligned}
& 11 \\
& 1103 \\
& \infty \\
& \infty
\end{aligned}
$$



PLATE XL. FISS. 5, 6 .

MELANIA CYLINDROIDES, Baird.

Shell rather small, of an olive colour, smooth, finely longitudinally striated; apex corroded, remaining whorls only 3 in number, very ventricose and rounded, last whorl longer than the two preceding; mouth oval, inside of a bluish colour; columella peculiarly twisted, somewhat callous at upper part.

Length nearly 9 lines.

Breadth $4 \frac{I}{2}$ lines.

Hab. Niue or Savage Island.

PLATE XL. Frg. 7.

OHITON (ONITHOCHITON) AMICORUMT, Baird.

Shell oval, nearly equal at each extremity; mantle margin covered with numerous chaffy-looking scales; first valve larger than any of the others, marked with numerous granular lines; centre valves strongly striated, lateral areas with 2 or 3 granular lines; last valve small and striated. A line of a red colour runs along the top of all the valves, whilst one or two others run along the lateral areas.

Length 8 lines.

Breadth $5 \frac{1}{2}$ lines.

Hab. Niue or Sarage Island. 
PLATE XL. Figs. 8, 9.

\section{HELIX LAQUEATA, Baird.}

Shell small, depressly orbicular, thin, pellucid, shining, smooth, flattened underneath, imperforate, with a slight umbilical pit; whorls $4 \frac{1}{2}$, rather flattened above, fluted and carinated, the fluting very conspicuous on the last two whorls; sutures distinct; aperture lunate; labrum simple, sharp; columella with a white callus within.

Breadth $2 \frac{1}{2}$ lines.

Height $1 \frac{1}{2}$ lines.

$H a b$. Samoan group.

PLATE XI. Figs. 10, 11.

\section{HELIX VAVAUENSIS, Baird.}

Shell small, orbicular, rather depressed, thin, pellucid, shining, of a horny colour, quite smooth, rounded underneath, imperforate, with a slight umbilical pit; spire of $4 \frac{1}{2}$ whorls, last rounded, convex; suture marginated; aperture lunate; labrum thin, sharp; columella margin white, thickened, with a slight white callus at. its junction with the body of the shell.

Breadth 3 lines.

Height 2 lines.

Hab. Vavau, Friendly Islands。 
PLATE XL. Figs. 12, 13.

HELIX SAMOENSIS, Baird.

Shell small, depressly globular, thin, pellucid, shining, of a light horny colour, paler beneath, quite smooth, rather flat underneath, imperforate, with an umbilical pit; whorls $4 \frac{1}{2}$ in number, last convex; suture margined; aperture lunate; labrum thin, sharp; columella with a small white callus at its junction with the body of the shell.

Breadth 3 lines.

Height $1 \frac{1}{2}$ lines.

Hab. Samoan group. 
PLATE XLI. Figs, 1, 2.

\section{IIELICINA BRENOHLEYI, Baird.}

Shell globosely lenticular, flattened underneath, conoidal above; whorls 5 in number, slowly increasing, covered with a brownish epidermis, under which the surface is marked with rather waved reddish lines above and beneath; last whorl sharply keeled, penultimate nearly as large as the last; mouth semi-lunate, oval; columella at the point where it comes from the shell marked by a red spot; callous extending, with an impressed line round it.

Greatest width 4 lines, least $3 \frac{1}{2}$.

Height $2 \frac{1}{2}$ lines.

Hab. Samoan group.

PLATE XLI. Figs. 3,4 .

HELICINA FULGURATA, Baird.

Shell rather globose, of a reddish colour; whorls 5 in number, peculiarly rounded, smooth, under the lens minutely punctured, last one vividly marked with several lightning-like white lines, the two last of about equal size; mouth semi-lunar; callus limited in extent from tip of columella, and bordered with an impressed line; lip simple, not reflected.

Greatest breadth 2 lines.

Smallest breadth $1 \frac{1}{2}$ do.

Hab. Samoan group. 

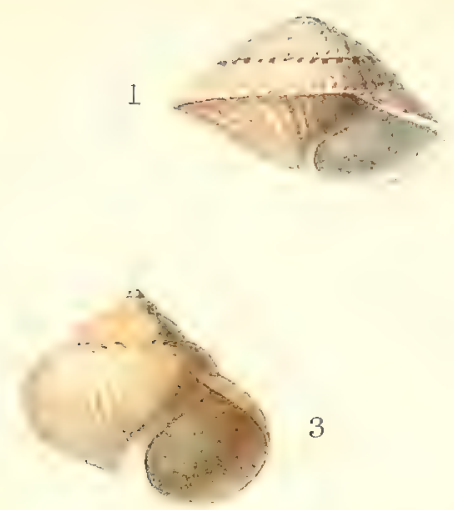

5
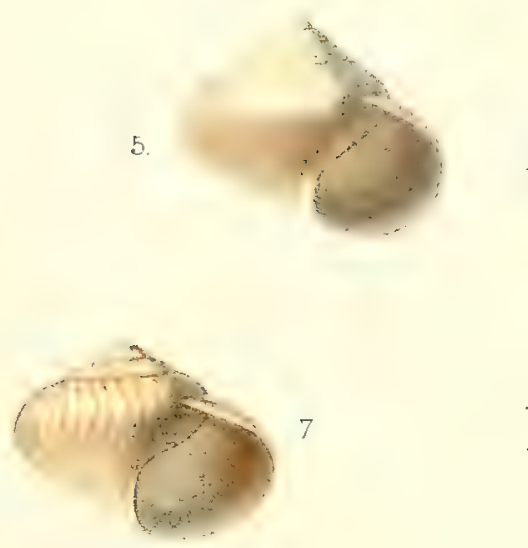

9

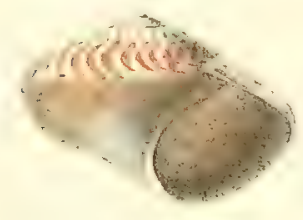

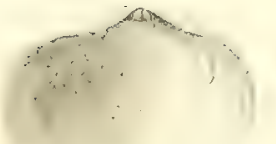

교 12

G.Fi. Ford

1.2. HELICINA BRENCHLEYI. Boird .

3.4.HELICINA FULGJRATA.

5.6. HELICINA MULTIFASCIATA..
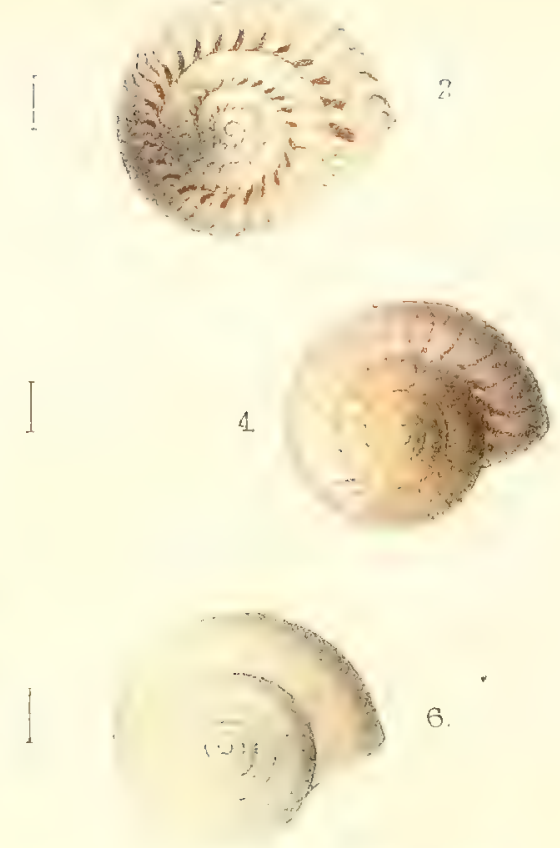

8.
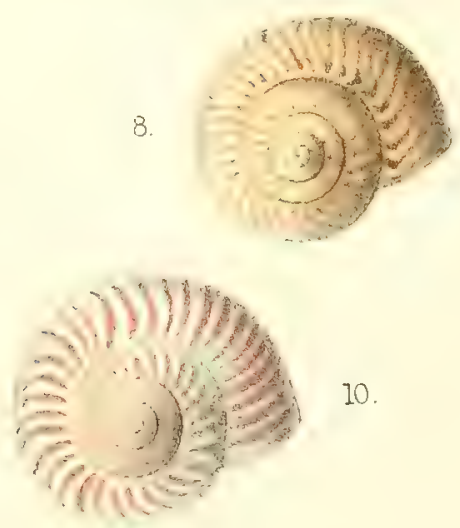

13. TELIINA BIFARIA. Baind 

PLATE XLI. Figs, 5, 6.

\section{HELIOTNA MIULTIFASCIATA, Baird.}

Shell depressed conic, thin, marked, especially on last whorl, with numerous narrow faintly-coloured circular bands, finely striated longitudinally, and marked concentrically with a few impressed lines, of a pale flesh colour throughout; whorls 5 in number, rather rapidly increasing, last whorl rather rounded on periphery; mouth somewhat triangular, peristome sharp, not reflexed.

Greatest width $3 \frac{3}{4}$ lines.

Narrowest $3 \frac{1}{3}$ lines.

Height $2 \frac{2}{3}$ lines.

Hab. Samoan group.

PLATE XLI. Figs. 7, 8 .

HELIOINA JULII, Baird.

Shell conically globose, shining; surface finely striated, and decussated with delicate concentric lines, marked, especially near the suture, with rather broad arrow-head lines; whorls 5 in number, rapidly increasing, last large, and angularly rounded at periphery; mouth semi-lunar, rounded; under surface smooth, shining, and uni-coloured; callus expanded, but very thin, white.

Greatest breadth $3 \frac{1}{2}$ lines.

Smallest breadth $3 \frac{1}{4}$ lines.

Height 3 lines.

Hab. Cockatoo Island, Solomon group.

Approaches in shape to $H$. gratiosa, Pfeiffer.

$G G$ 
PLATE XLI. Frgs, 9, 10.

\section{IIELICINA STRIGATA, Bairo.}

Shell depressed, rather thin, smooth with the exception of a few remote circular strix on upper surface of two lower whorls, white, with straight reddish lines or bands running longitudinally over the upper surface of the two last whorls; under surface brown coloured, lines not appearing on it; mouth semi-lunar; callus circumscribed, rather thick, surrounded with an impressed line; whorls $3 \frac{1}{2}$ in number, last whorl obscurely keeled on periphery.

Greatest diameter 2 lines.

Least diameter $1 \frac{8}{4}$ lines.

Height $1 \frac{1}{2}$ lines.

Hab. Upolu, Samoan Group.

Like musiva of Gould, but the white lines on the body of the shell are differently disposed, and the shell itself is much more depressed.

\section{HELICINA NOVE CALEDONIE, Baind (not figured).}

Shell conic, somewhat top-shaped, of a dirty white or reddish colour; whorls $4 \frac{1}{2}$, convex, smooth, marked with very fine strix running longitudinally, and obliquely crossed with exceedingly fine lines only visible under a lens; apex pointed, last whorl large, rounded on peripheral margin; under surface striated like the upper; callus very large, dirty white, extending from the tip of columella to external margin of peristome, very thick and sharply defined; mouth oval, lip expanded, white, sharp edged; operculum shelly.

Greatest breadth 3 lines.

Least breadth $2 \frac{1}{2}$ lines.

Height $2 \frac{3}{8}$ lines.

Hab. New Caledonia。 
PLATE XLI. FIGS, 11, 12.

TELLINA NOV开 CALEDONIA, Baird.

Shell small, pure white, smooth, nearly shining though very finely concentrically faintly striated, as if from lines of growth, rounded subtrigonal, solid, inæquivalve; posterior margin shorter than anterior; beaks rather prominent and whiter than the rest of the shell; ventral margin rounded; white within, not ventricose; fold rather indistinct.

Length (transverse) 4 lines.

Height $3 \frac{1}{4}$ lines.

Hab. New Caledonia.

Approaches in general shape and appearance to Tellina robusta of Hanley.

PLATE XLI. Fig. 13.

\section{TELIINA BIFARIA, Baird.}

Shell elongated, narrow, thin, moderately convex, inæquilateral white; ventral edge rounded in the middle; anterior side much longer, its exiremity rounded, obiuse, dorsal edge rather sloping; hinder extremity short, with a truncated acumination; flexure distinct; ligament rather prominent; valves curiously striated; anterior and posterior extremities subimbricately circularly striated, the centre of the valves beset with minute numerous decussated strix, not extending to the ventral edge, which is marked with oblique, distinct striæ alone; teeth very small; white within, somewhat iridescent.

Length 9 lines.

Breadth $5 \frac{1}{2}$ lines.

Hab. New Caledonia.

Resembles very much T. pura of $H$. Adams, from the Gulf of Suez.

$$
\text { G : } 2
$$




\section{VENUS ROSEO-TINCTA, Baird.}

Shell sub-cordately orbicular, dull white, concentrically laminated; laminx broad, distant, 16 in number, the upper very small, and tipped at the umbones with rosy red, the lower very large and wide, reflected upwards, more or less striated, the interstices striated; ligamental area moderately excavated; lunule cordate ; interior of valves of a pink colour, except the margin, which is white.

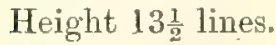

Breadth nearly the same.

Hab. New Caledonia.

PLATE XLII. FIG: 4.

\section{AROA NOVDE CALEDONIE, Baird.}

Shell very swollen, obliquely ovate, equivalve; anterior side very slightly angled, extremely short, posterior obliquely extended to an acuminated point; of a dull white colour, apparently covered with a close epidermis; radiately ribbed; ribs about 36 in number, rather flat and close set, densely wrinkled-noduled, not divided by a sulcus or groove, interstices closely crossed with raised lines; umbones small; ligamental area moderately large, bent inwards.

I uength, from anterior to posterior side, nearly $2 \frac{1}{2}$ inches.

Breadth about 2 inches.

Hab. New Caledonia. 


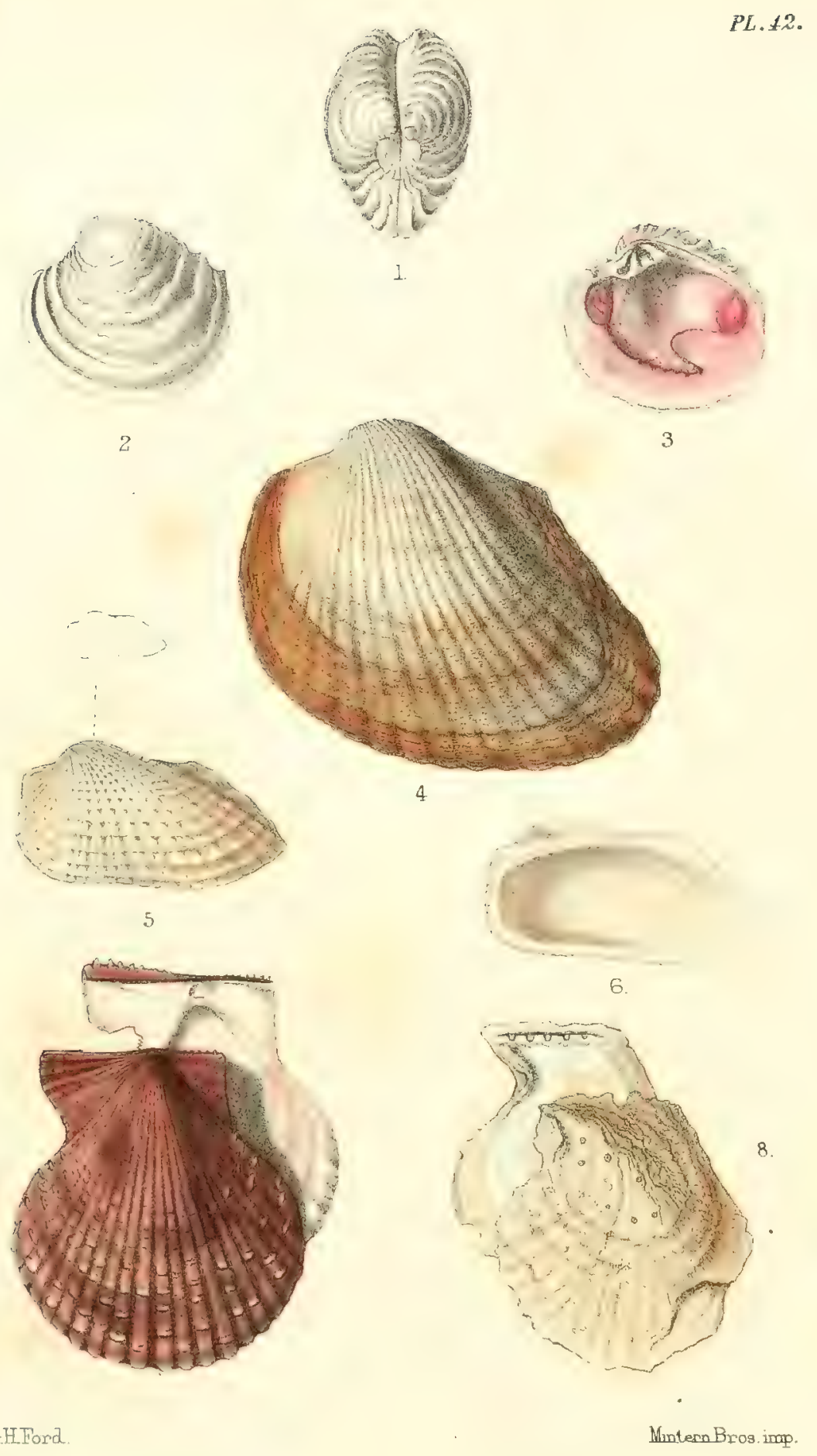

1.2.3. VENUS ROSEO TINCTA,Baind. 5.6. ARCA DUBIA. Baird.

4. ARCA NOVE CALEDONIE, Boird. 7. FECTEN SIMILIS. Baird.

8. PERNA SAMOENSTS Baird. 


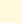


PLATE XLII. Frgs, 5, 6 .

AROA (BYSSOARCA) DUBIA, Baird.

Shell ovately oblong; posterior extremity rather acute; anterior rather squarely rounded; keel well marked, running down from beaks to end of posterior extremity; of a dull white colour without any markings; longitudinally ribbed, ribs small till they reach the keel, crossed with strong transverse raised ridges which are almost beaded; posterior concave and divaricately rayed with 4 or 5 strong ribs; umbones situated near anterior extremity; ligamental area very small and narrow, colourless; ventral margin slightly sinuated.

Length nearly $\frac{1}{2}$ an inch.

Greatest breadth 3 lines.

Hab. New Caledonia.

Approaches A. divaricata of Sowerby from west coast of America; but the shell is narrower, the anterior extremity less rounded, the hinge area more narrow; and the body of the shell is not fimbriately ribbed.

PLATE XIII. Frg. 7.

PECTEN SIMILIS, Baird.

Shell somewhat orbicularly ovate, a little longer than broad, equilateral, equivalve; valves rayed with 25 ribs; ribs ratber narrow, squamate: scales very minute at upper part, larger on ower portion and at the sides, standing almost erect, thin, and rather broad. Shell externally of a dull reddish colour, internally of a pale red and somewhat iridescent; ears unequal, ribbed and 
slightly scaled; inner portion of left valve below the ear with 5 or 6 scale-fike teeth.

Length 1 inch 7 lines.

Breadth 1 inch 5 lines.

Hab. Tongatabu, Friendly group.

Approaches, in general appearance, to the dull variety of $P$. varius, a European shell.

PLATE XLII. Fig. 8.

\section{PERNA (ISOGNOMON) SAMOENSIS, Baird.}

Shell sometimes orbicular, sometimes ovate, rather thin, concentrically laminated and longitudinally rather obscurely ribbed; ribs on upper valve tinged with a purple hue, especially near the umbo; on under surface the shell is of a uniform dead white colour; beaks incurved; teeth pits on ligamental hinge about 5 in number; inner surface of valves dull pearly.

Length from 1 inch 4 lines to 1 inch 6 lines.

Breadth 1 inch $2 \frac{1}{2}$ lines.

Hab. Tutuila, Samoan group.

Note.-The specimens upon which all the preceding species have been founded, have been presented to the British Museum by Julius Brenchley, Esq. Unfortunately, the examples of Helicina fulgurata have been lost by the artist. 
INSECTS. 


\title{
HYMENOPTERA ACULEATA.
}

\author{
Family Thrmalde. Genus Thymos, Fabro
}

PLATE XLIII. FIG. 2.

\section{THYNNUS BRENOHLEYI, Smith.}

Length, 14 lines. Black, with the head and prothorax yellow. Head smooth and shining, the antennæ black as well as the tips of the mandibles. Thorax: the prothorax smooth and shining, its anterior margin elevated. The meso- and metathorax black above, both smooth and shining; two small ferruginous angulated spots in the middle of the anterior margin of the mesothorax which has a few scattered delicate punctures; the scutellum finely, but not closely punctured, and having in the middle, posteriorly, a pointed tubercle; the metathorax with a small pale spot on each side behind the insertion of the posterior wings; the wings hyaline, dark brown at their base; the anterior pair with a paler cloud at their apex. The mesothorax ferruginous beneath; the anterior leg's ferruginous, with the coxæ and the femora beneath yellow; the intermediate and posterior legs ferruginous; their coxx with fuscous stains beneath; the posterior tibire above, and their tarsi, black. Abdomen cylindrical, shining and finely punctured, with the base abruptly truncate; a minute indistinct ferruginous spot at the base of the second segment in the middle, and a similar spot in the middle of the fourth, fifth, and sixth segments; there is also a minute lateral ferruginous line, indistinctly visible, on the first four segments; the seventh segment 
PIL. AR?
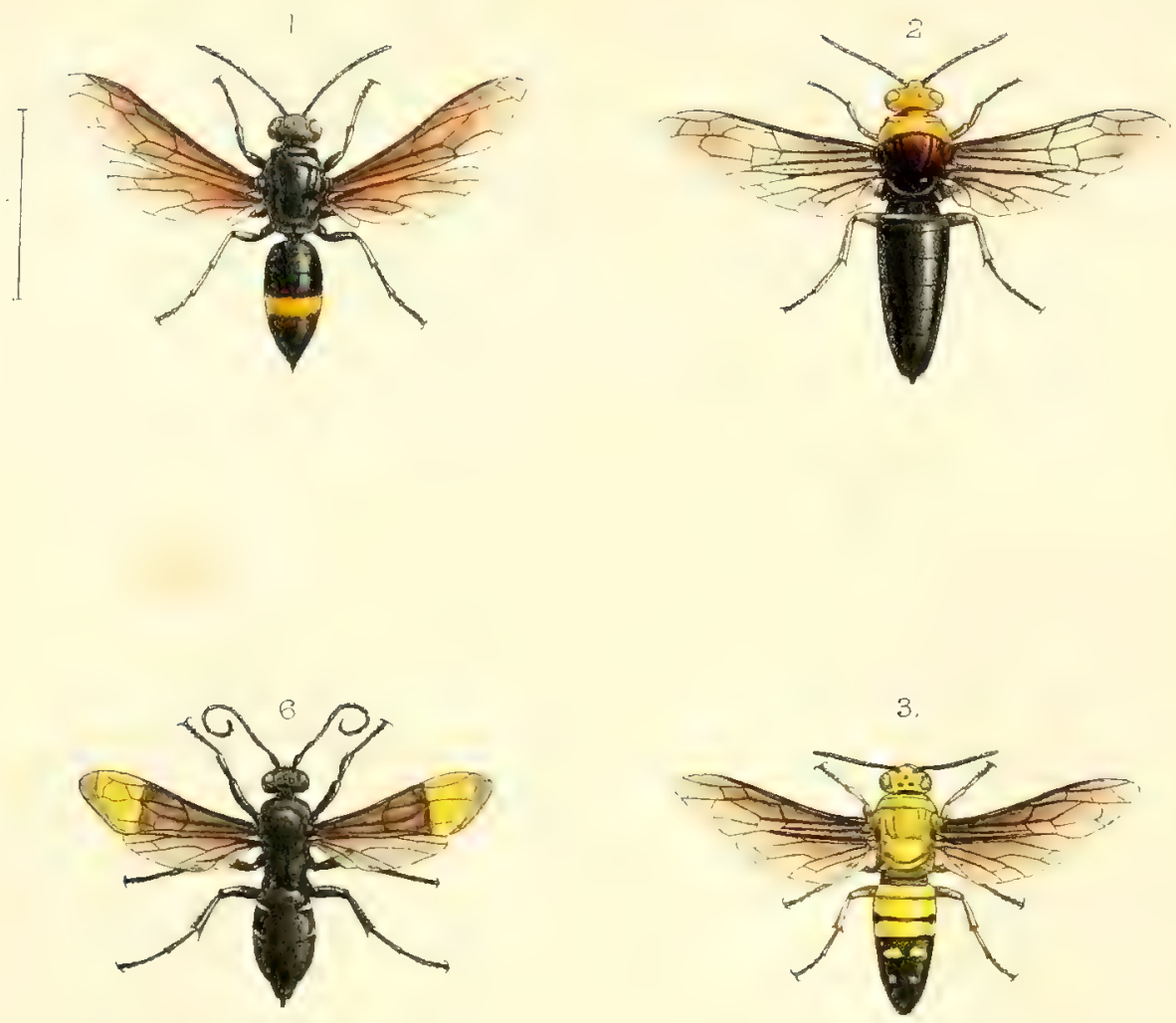

3.

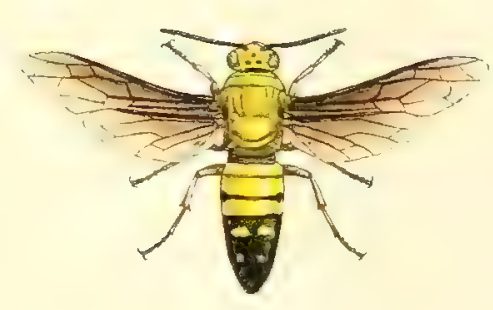

5
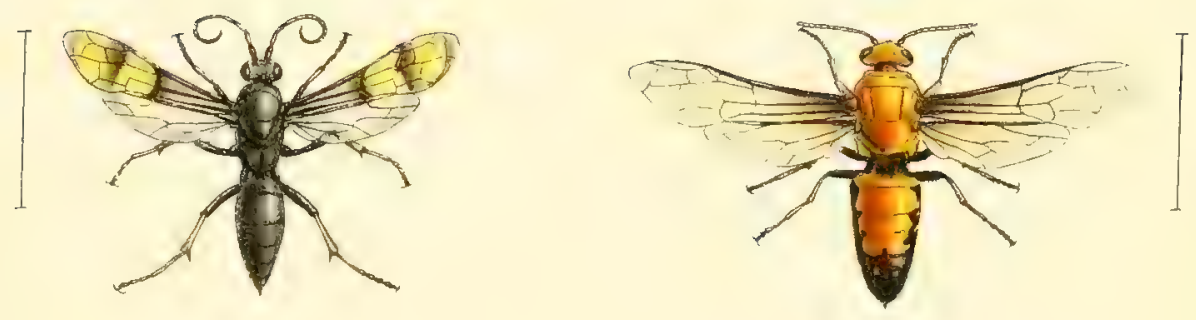

G.H.Ford.

Mintern Bros.intp

I THYNNUS UNIFASCIATUS. Smith.

4. THYNNUS PULCHRATIS.Smith.

2. THYNNUS BRENCHLEYI.

5POMPILUS PTCTIPENNIS.

3.THYNNUS CONSPICUUS.

6. PRIOCNEMIS POLYDORIS. 

longitudinally striated; beneath : a ferruginous spot, more or less visible, in the middle of all the segments, which are strongly punctured.

Hab. Western Australia (Champion Bay).

In Coll. Brit. Museum.

PLATE XIIII. FIG. 3.

\section{THYNNUS' CONSPIOUUS, Smith.}

Length 12 lines. Luteo-testaceous, with the apex of the abdomen black. The antennx, ocelli, and tips of the mandibles black; the scape yellow in front. Thorax shining; the wings dark fuscous, the apical margin of the anterior pair, and the posterior margin of second pair, subliyaline; the legs slightly ferruginous, the intermediate and posterior tarsi, except the base of the first joint, black. Abdomen beneath, and the four apical segments above, black; the fourth segment with two small transverse yellow spots; the fifth segment has sometimes two smaller spots of the same colour; the seventh segment longitudinally striated above.

Hab. North-West Coast of Australia.

In Coll. Brit. Mnseum.

PLATE XLIII. FIG, 4 , ठ

THYNNUS PULCHRALIS.

(Smith, Cat. Hym. Ins. Pt. VII. Appendix, p. 68.)

$H a b$. Adelaide.

In Coll. Brit. Museum. 
PLATE XLIII. Fig. 1.

THYNNUS UNIFASCIATUS, Smith.

Length, 9 lines. Black, with an orange band on the abdomen. Head closely and finely punctured, slightly shining; the face and cheeks with hoary pubescence; on the sides of the thoras, and also beneath, there is a short pubescence of the same hue, on the metathorax it is longer and more dense, the latter is transversely striated; the mesothorax above and the scutellum are shining, and have a few shallow scattered punctures; the legs have a short hoary pubescence; the wings dark brown; the apical margins of the anterior, and the posterior margins of the inferior pair, hyaline. Abdomen, smooth and shining, with a few scattered fine punctures; the fourth segment yellow above, with its apical margin narrowly black; the basal segment rounded.

Hab. Queensland.

In Coll. Brit. Museum.

Family Pompminx. Genus Pompise, Fabr.

PLATE XLIII. Fig. 5.

PONPILUS PIOTIPENNIS.

(Smith, Cat. Hym. Ins. Pt. III. Mutilidæ and Pompilidæ, p. 165, + ).

Length, 8 lines. Hab. Moreton Bay.

In Coll. Brit. Nuseim.

Genus Priocnems, Schiödte.

PLATE XIII. FIG. 6.

PRTOCNEMIS POLYDORUS.

(Smith, Trans. Ent. Soc. (1868), p. 246, 子.)

Length, 11 lines. Hab. Moreton Bay.

In Coll. Brit. Musenm. 
PLATE XLIV. FIG. 1.

PRIOCNEMIS AFEEOTATUS.

(Smith, Trans. Ent. Soc. (1868), p. 146 , 오.)

Length, $8 \frac{1}{4}$ lines. In Coll. Brit. Museum.

PLATE XLIV. FIG. 2.

PRIOCNEMIS EPHIPPIATUS.

(Smith, Trans, Ent. Soc. (1868), p. 246, ‥)

Length, 8 lines. In Coll. Brit. Museum.

Fanily Splegidas. Genus Sphex, Linn.

PLATE XLIV. Fig. 3.

SPHEX AURIFEX, Smith.

Length, 121. Black, the head, and thorax above, clothed with golden-coloured pubescence; the legs and two basal segments of the abdomen ferruginous. The scape of the antennæ and base of the flagellum beneath, ferruginous; the clypeus and mandibles ferruginous, the latter black at their tips. Thorax, the wings flavo-hyaline, with a dark fuscous border on their apical margins extending along the posterior border of the inferior wings. Abdomen, the apical margin of the second segment and all the following segments black.

Hab. North-West Coast of Australia.

In Coll. Brit. Museum. 
PL. 14 .

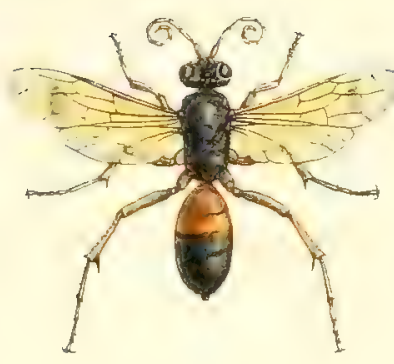

6.

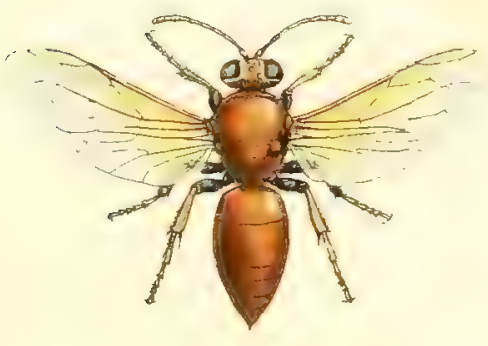

4

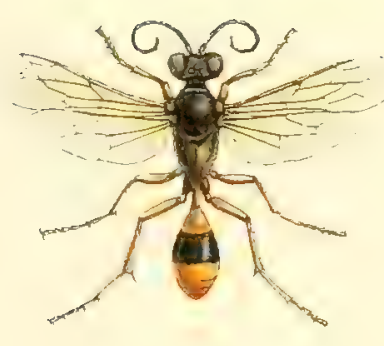

G.H.Ford.

1. PRIOCNEMIS AFFECTATUS. Smith. 2.PRIOCNEMIS EPHIPPIATUS

3. SPHEX AURIEEX

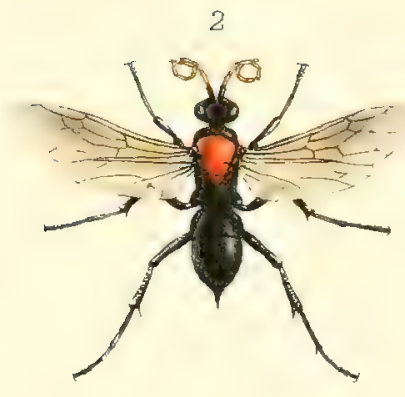

3.

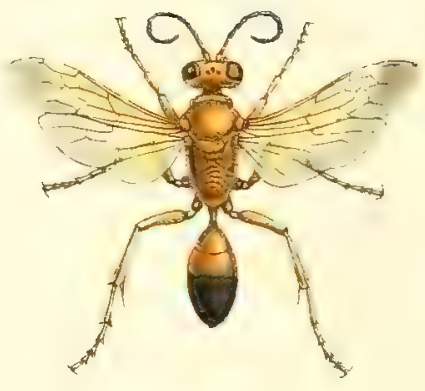

5.

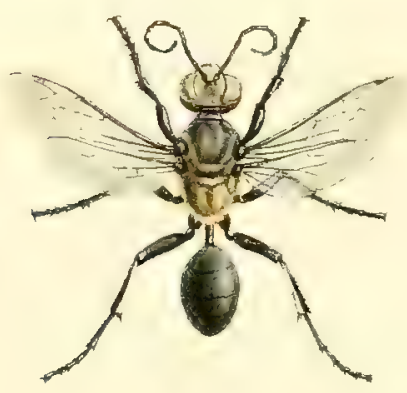

MinternBros imp 4 SPHEX DECORATA. Smith.

5. SPHEXPRETEXTA.

6. STIZUS PECTORALIS. 

PLATE XLIV. FIG. 4.

\title{
SPHEX DFCORATA, Smith.
}

Length, 12 lines. Black, the base and apex of the abdomen ferruginous. Head: the scape and two or three of the basal joints of the flagellum ferruginous; the clypeus and mandibles ferruginous, the latter black at their tips; the face and cheeks with golden pubescence. Thorax covered with a fine short changeable golden pubescence, most dense on the metathorax; the tegulæ, nervures of the wings, and the legs ferruginous, the claws tipped with black; the wings fulvo-hyaline. Abdomen ferruginous, with the second segment black above, and with two large black maculæ beneath.

Hab. North-West Coast of Australia.

In Coll. Brit. Museum.

PLATE XIIV. FIG. 5.

SPHEX PRATEXTA, Smith.

Length, 12 lines. Black: the face and metathorax clothed with golden pubescence; the cheeks and the vertex with long thin pale yellow hair; the wings sub-hyaline with their apical margins slightly bordered with a fuscous cloud; the posterior tibiæ with fine golden pile within; the basal segment has a pale changeable golden pile.

Hab. Moreton Bay.

In Coll. Brit. Museum.

\author{
Family Nyssontde. Genus Strzos, Latr. \\ PLATE XLIV. Fig. 6. \\ 'STIZUS PEOTORALIS. \\ (Smith, Cat. Hym. Ins. Pt. IV. p. 336.)
}

Length, 12 lines. Hab. Australia.

In Coll. Brit. Museum. 


\title{
DIPLOPTERA.
}

\author{
Family Masaridx. Genus Paragia, Shuck.
}

PLATE XLV. Frg. 2.

PARAGIA VESPIFORMIS.

(Smith, Trans. Ent. Soc. 3rd ser. ii. 393, \& ; and Idem. vol. (1868),

$$
\text { p. 250, उ.) }
$$

Isength 7 lines. Hab. Champion Bay, West Australia. In Coll. Brit. Musenm.

Genus Disceelies, Latr.

PLATE XIV: Fig. 1.

DISCELIUS INSIGNIS.

(Sauss. Mon. Guepes, Sol. supp. p. 125, ․)

Length 8 lines. Hab. New Holland.

Genus EtMenes, Latr.

PLATE XLV. FIG, 3, 우

EUMENES SINENSIS, Smith.

Length 11 lines. Black: the clypens, a spot between the antennæ, the scape in front and a narrow line behind the eyes towards their summit, yellow; the mandibles ferriginous, their base black. Thorax punctured; the prothorax, an ovate spot 


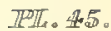
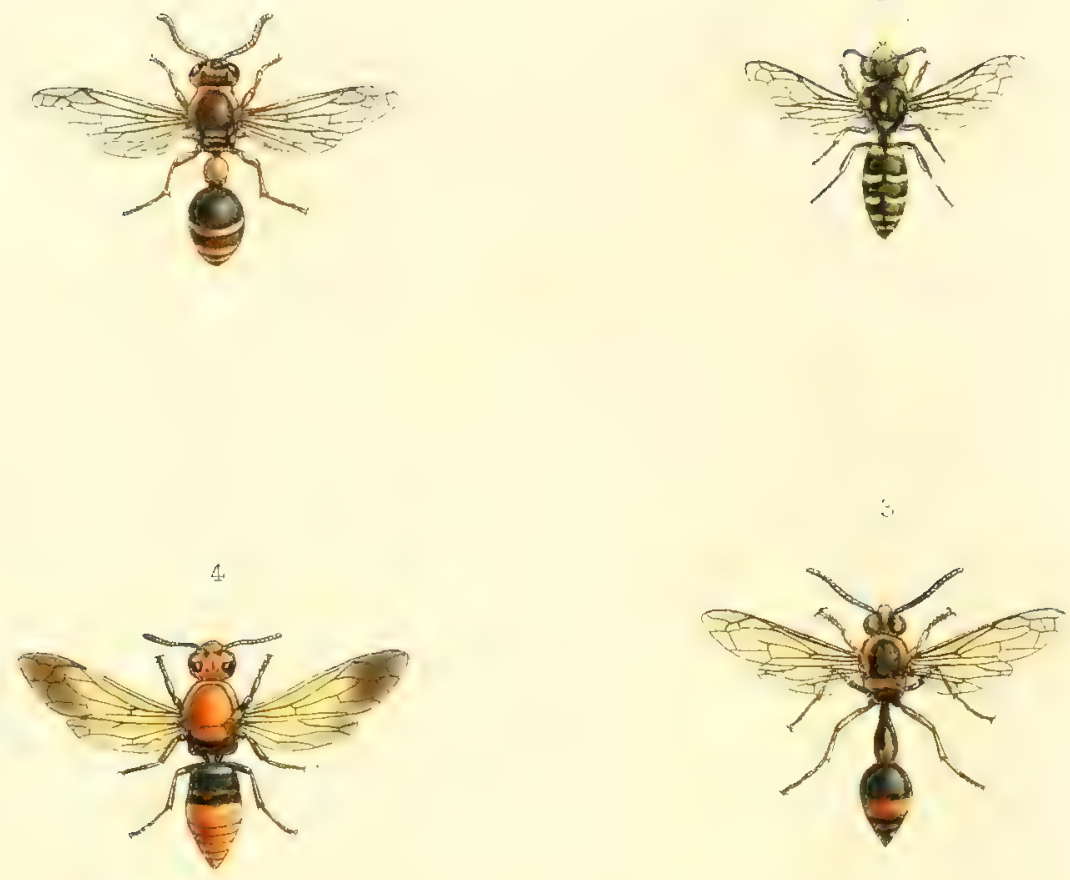

6.
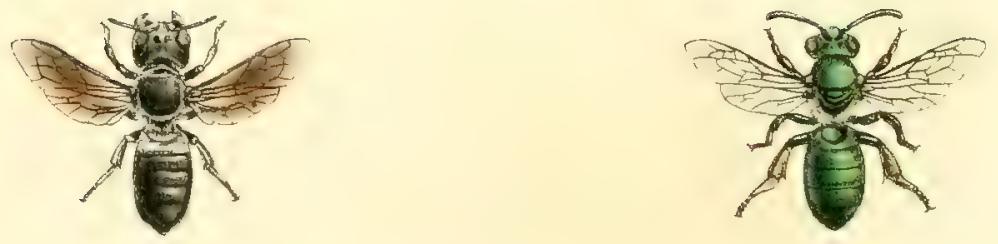

1 DISCELIUS INSIGNIS, Sarfs.

2. PARAGIA VESPIFORMIS, Smith

3 EUMENES SINENSIS, Smath.
4. RHYNCHIUM MAGNIFICUM, Smith.

5. MEGACHILE MONSTROSA, Smith

6 STENOTRITUS SMARAGDINUS, Smith

Nintern Bros. irup 

beneath the wings, the tegulæ, post-scutellum and lateral margins of the metathorax reddish-yellow; the anterior legs, the intermediate and posterior tibix, and the tips of the femora ferruginous; the outer margins of the intermediate and posterior cozæ reddish-yellow; the tarsi more or less fuscons. Abdomen smooth and shining; the petiole punctured; apical margin of the petiole and a broad fascia on the apical portion of the second segment, reddish-yellow; beneath, the second, third, and fourth segments have a narrow yellow fascia on their apical margins.

Hab. North China.

In Coll. Brit. Museum.

Genus Rhynchidm, Sauss.

PLATE XLV. Fig. 4.

RHYNCHIUM MLAGNIFICUI.

(Smith, Trans. Ent, Soc. (1866), p. 310, ․)

Hab. Nicol Bay, West Australia. In Coll. Brit. Museum.

Family ANdrendd d. Genze Stemotritus.

PLATE XLV. Fig. 6,

STENOTRITUS SMARAGDINUS.

(Smith, Trans. Ent. Soc. (1868), p. 254.)

$H a b$. Champion Bay, West Australia. In Coll. Brit. Museum.

\author{
Family Apidz. Genus Megachile, Latr. \\ PLATE XLV. FIG. 5, 9 . \\ MEGACHILE MIONSTROSA. \\ (Smith, Trans. Ent. Soc. (1868), p. 256.)
}

Hab. Champion Bay, West Australia. In Coll. Brit. Museum. 


\title{
lEPIDOPTERA.
}

\author{
Family Nxmphatinde (Westwood). Sub-Family Danatnde Bates). \\ Genus Eupica (Fabricius). \\ PLATE XLVI. Frgs. 1-4.
}

EUPLEA BRENCHLEYI, BUtler. Ann. and Mrg. Nat. Hist. s. 4, rol. ₹., p. 357, n. 2 (1870).

\& Wings above pitchy-brown : front wings with white external area; the outer margin broadly brown; a silky streak below the first median branch : hind wings brown, the outer anal area paler; costa silky pale brown.

Wings below paler than above, external area white: front wings with three central violet-tinted points, the largest within the discoidal cell, and a white discal point: hind wings with pale brown costa; a discoidal spot and an angulated series of five discal points, all violet-tinted; base white-spotted: body blark, whitespotted.

o Differs from the male in having a broad white extermal area to all the wings and a white internal streak on the under surface of the front wings. Expanse of wings 3 inches 2 lines.

Five specimens (four $\delta$, one $q$ ). South Sea Islands. Colls. Brit. Museum and Maidstone.

Allied to E. lapeyrousei and $E$. sepulchralis, and interesting as being one of a double series of parallel species resembling one another in colour but differing in form. 
PL. 46 .
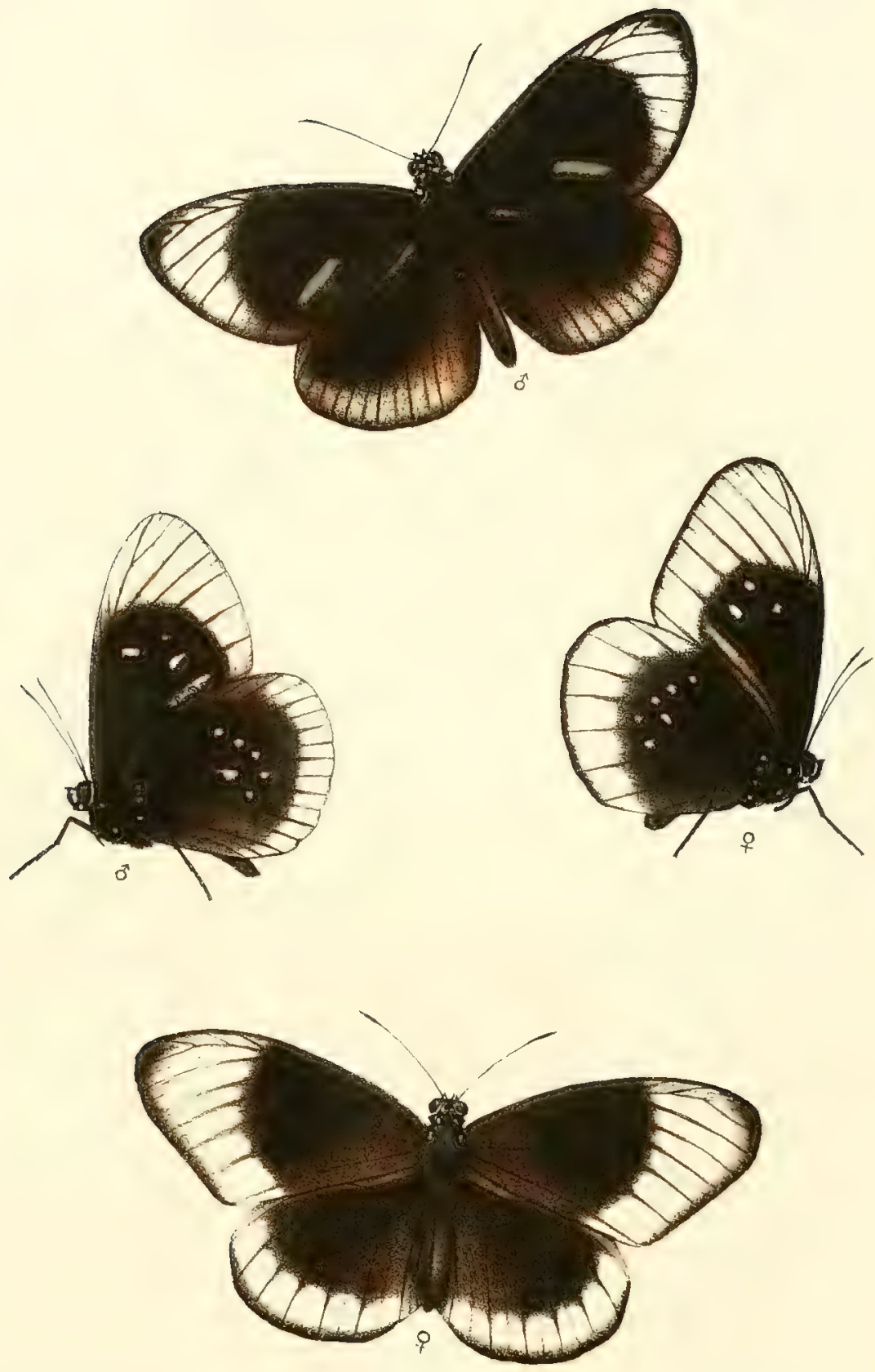

EUPLCEA BRENCHLEYI. 

II II 
PLATE XLVII. Figs, 3,4 .

EUPLEA LORENZO, Butler.

Ann. and Mag. Nat. Hist. s. 4, Fol. F., p. 359, n. 7 (1870).

o Allied to E. Jessica (Butler, in Lep. Exot. pl. viii. fig. 3) Wings above black, shot with blue; front wirgs with a white spot between second and third median branches, and an internodiscal greenish streak: hind wings with brown costal area; seven creamy discal spots as in $E$. Jessica.

Wings below blackish-brown with purple reflections; front wings with a discoidal spot, a discal point beyond it, and the discal streak of the upper surface white; internal area brown: hind wings with base white-spotted; three central spots in a nearly straight series, a minute point near them, and the seven discal spots of the upper surface, white. Body brown, whitespotted. Expanse of wings a inches 7 lines.

One specimen. South Sea Islands. Coll. Brit. Museum.

A third species of the group to which E. Treitschkir belongs.

PLATE XLVII. Fios, 1, 2.

DUPLEA IMITATA, Butler.

Ann. and Mag. Aat. Hist. s, 4, rol. v., p. 359, n. 8 (1870).

of Wings above pitchy brown; front wings with white external area, tinted with rosy-opaline; a spot of white on costa near external area; anal area and costa ochre-tinted; a rosy-white oval spot below first median branch; outer margin slenderly black- 

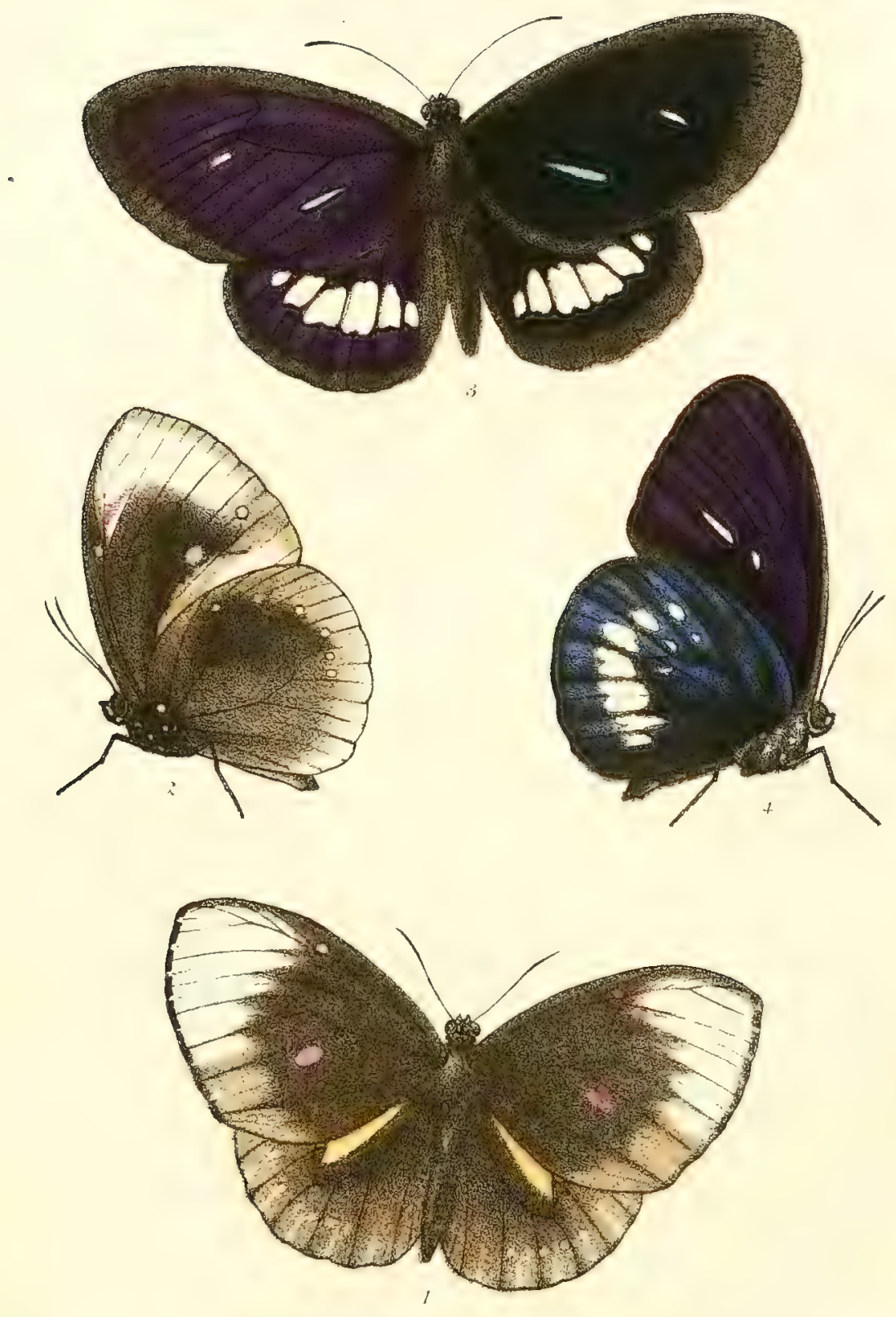

A G Butler de et lath

Wutern Bri 'TI

1. 2. EUPLEA IMTAATA

3. 1 FUI EA LORENZO. 

brown; hind wings with a large whitish-ochreous subcostal pearshaped patch, partly covering the discoidal cell; the costal area silky; external area ochraceous; the internervular folds terminating in white points; eight obsolete discal white spots; body black-brown; head and prothorax white-spotted.

Wings below paler; front wings with the internal area dirty white; the oval spot of upper surface obsolete, a second rounded rosy-white one below second median branch; two white points near outer margin; hind wings brown; a large cloud of a deeper tint towards apex; outer area whitish, ten decreasing white points, zoned with purplish, near outer margin; body black, white-spotted; expanse of wings 3 inches 3 lines.

One example. South Sea Islands. Coll. Brit. Museum.

Allied to $E$. assimilate of Felder and parallel to E. Brenchloyi. 
Genus Danais, Latreille.

PLATE XLVIII, Figs, 1, 2,

DANAIS INSOLATA, Butler.

Ann. and Mag. Nat. Hist, s. 4, rol, ro, p. 360, n. 2 (1870).

\&, $q$ Wings above brown, the disc obsoletely streaked with fulvous between the nervures; front wings with the external area snow-white, divided by the nervures (especially at anal angle), interrupted by an oblong costal patch, and separated at apex into five marginal points; hind wings with a white marginal band, separated by the nervures into eight subdivided square spots; margin black.

Wings below paler; hind wings more fulvous than above, the marginal spots entire; expanse of wings 2 inches 11 lines.

Two specimens ( o, o ). South Sea Islands. Coll. Brit. Museum.

Genus Dradema, Boisdural.

PLATE XIVIII. Figs. 3, \&.

DIADEMA BOTINA, Linnceus, rar.

+ Very like the female of the variety P. Lasinassa Fabr., but with the black suffusion of front wings confined to the discoidal and anal areas; hind wings without dusky scaling on dise, and with central spot perrly white; it differs below in being paler, 


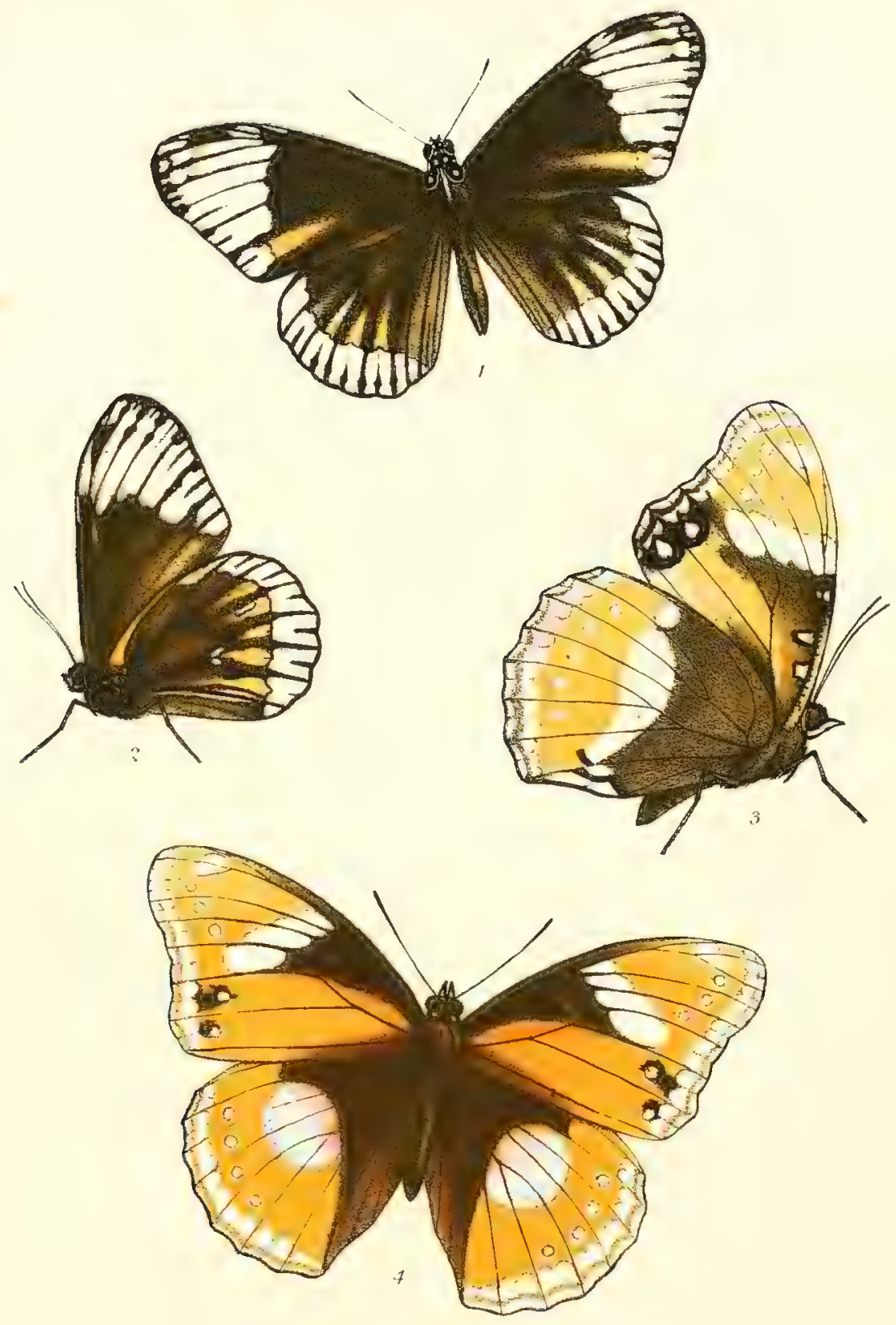

1 2. DANAIS INSOLATA.

3.4. DIADEMA BOLINA. rar. . 
and having a white band across hind wings; expanse of wings 3 inches 5 lines.

Two specimens. South Sea Islands. Colls. Brit. Museum and Maidstone.

This variety is most interesting as it is the lightest form of this very variable species which is yet known; the female of the form $P$. Lasinassa has never been figured, therefore it is important that this insect, which better exhibits the extent of modification to which the species is subject, should be made known. 


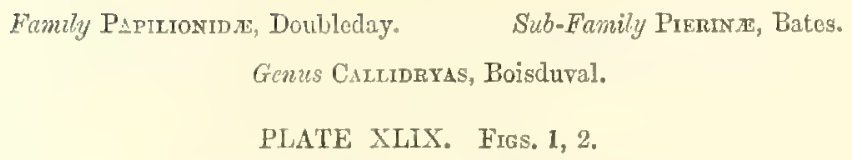

CALLIDRYAS LACTEA, Butler. Ann, and Mag. Nat. Hist. s. 4, vol. $\nabla .$, p. 361 (1870).

s, ㅇ Wings above white, the apex tinted with brown; males with a very minute brown discocellular point, females with a larger one; body above grey, head somewhat greenish.

Wings below pale ochraceous, hatched with ochreous; a minute brownish discocellular ring-spot; front wings with the internal area whitish; body below whitish, antennæ ochraceous; expanse of wings 2 inches 7 lines.

Three examples $(2 \delta, 1$ q). South Sea Islands. Colls. Brit. Museum and Maidstone.

This species also occurs in various parts of Australia; in India it is replaced by $C$. Gnoma, Fabricius, but I have seen nothing like it from the Malayan Archipelago; a very similar form also occurs in Africa (C. Pyrene, Swainson).

Genus Terias, Swainson.

PLATE XLIX. FIG. 3.

TERIAS INGANA, Wallace.

Trans. Ent. Soc, s. 3, rol. iv., p. 322, n. 10 (1867).

\& Wings above sulphur-yellow; front wings with a minute black discocellular point; outer margin to first median branch broadly brown; suddenly narrowed and bisinuate from third median; hind wings with abdominal margin whitish; nervures 

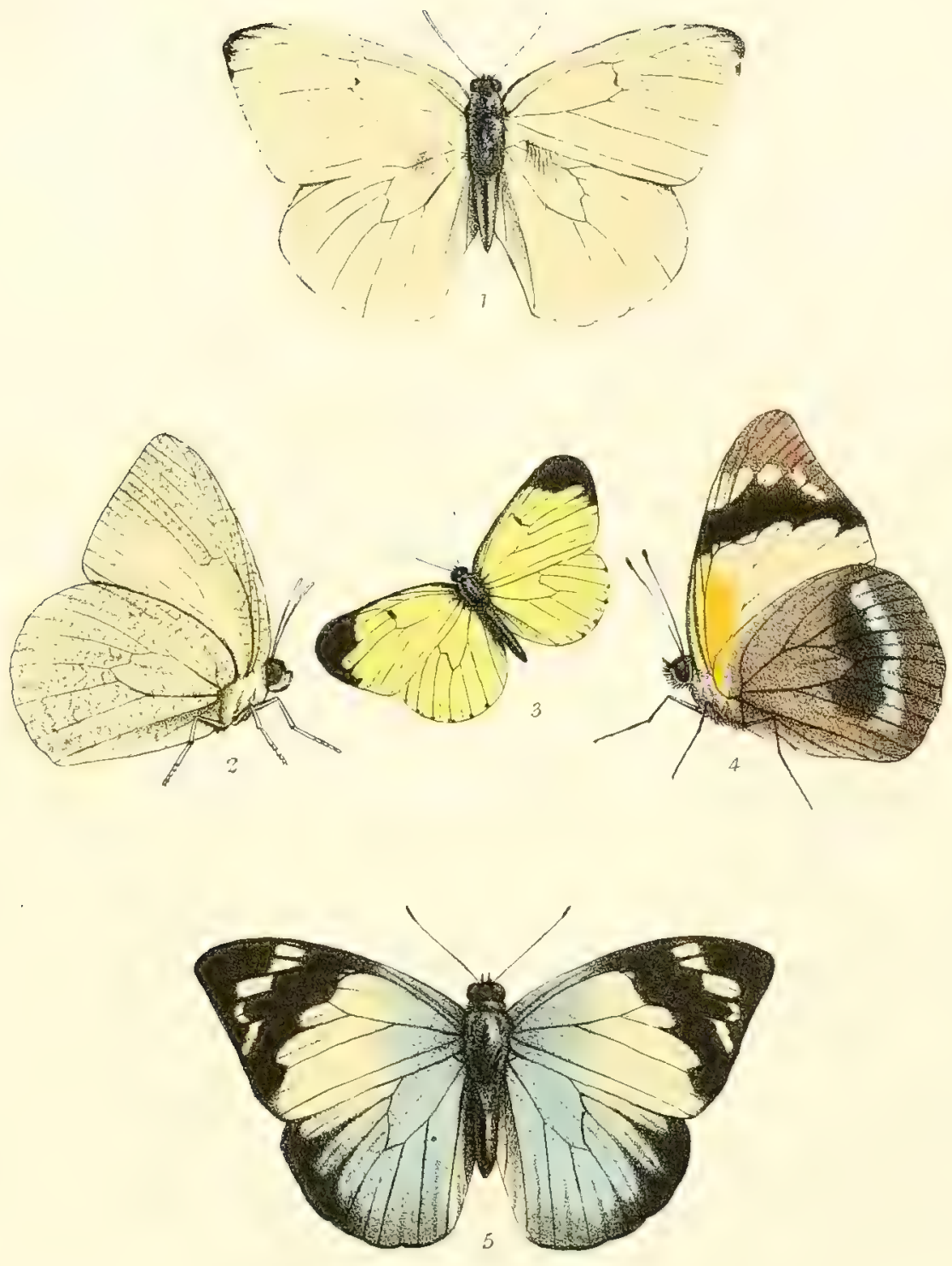

A. G.Butler dol etlith

Mrntern Bro. amp

1.2. CALTIDRYAS IACTEA.

3. TERIAS INGANA.

4.5.APPIAS MELANIA 
$$
\text { , }
$$ 
terminated by minute brown marginal points; body blackish-grey above; head and prothorax greenish olivaceous; antennæ brown with orange tip.

Wings below golden yellow, with black discocellular point; basal costa sparsely irrorated with dark brown; brown markings of hind wings as in the various mearly allied species of the Drona group; body below yellow, antennæ white; expanse of wings 1 inch 7 lines.

Sydney. Coll. Brit. Museum.

This little species has never before been figured; in the margin of its fore wings it forms a distinct section of the genus, and comes near the group to which T. Drana, Libythea, Venata, and others belong.

Genus Afpias, HëBNer.

PLATE XLIX. Figs. 4, 5.

APPIAS IIELANIA, Fabricius.

Syst, Ent, p. 473, n. 128 (1775).

o Front wings above creamy-white, pale blue-grey at base; apical area broadly blackish-brown, deeply bisinuate between the median branches, and almost divided through the centre by an oblique, somewhat arched series of five creamy spots; hind wings pale blue-grey, a large patch of creamy-white covering costal area, apex and apical part of outer margin broadly blackish-brown and deeply sinuated between the nervures; body above greenishgrey, abdomen brownish.

Front wings below creamy-white; base broadly orange-yellow; basal half of costa sulphur-yellow; apex rosy-brown; otherwise as above; hind wings rosy-brown, base of costa orange-yellow; a broad diffused discal olive-brown band, and outside it a series of 
five to six diffused whitish spots; body below dirty-white ; expanse of wings 2 inches 8 lines.

Australia.

The original type specimen of $A$. Melania has long been unique in the Collection of the late Sir Joseph Banks, now in the possession of the Trustees of the British Museum; the original figure in Donovan's Insects of New Holland is so poor that Lepidopterists who were not aware of the existence of the type in the Banksian Collection had given up all hope of ever determining the species, the Fabrician description not being sufficiently detailed to enable them to correct the errors in Donovan's drawing; it is therefore important that this beautiful butterfly should be correctly delineated. 


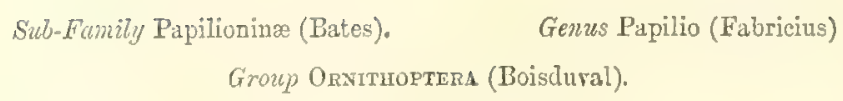

PLATE L.

\section{PAPTLIO (ORNITHOPTERA) CASSANDRA, Scott.}

of Nearly allied to $P$. Richmondia Gray, but nearly as large as P. Priamus Linn, which it resembles in the pattern of the front wings above; hind wings as in P. Richmondia, but the uppermost spot sometimes enlarged; the green bands of front wings and the whole of hind wings exhibiting strong coppery reflections in certain lights as in $P$. Richmondia; abdomen of a deeper yellow than in P. Richmondia or P. Priamus.

Front wings below nearly as in $P$. Priamus, but the discal row of black spots broader and connected into a band, and the green patch in cell reduced to two small spots; hind wings nearly as in P. Richmondia, but the costal area, up to the yellow submarginal spots, filled in with black; body below with black thorax spotted with crimson at junction with wings; abdomen yellow; expanse of wings 6 inches 4 lines.

Queensland. Coll. Brit. Museum.

The female of this species was described and figured by $\mathbf{M r}$. Scott (Tr. Ent. Soc. N. S. W. 1, 2, p. 131, pl. 10), but the male was then unknown to him; there are two males and a female in the Collection of the British. Museum, and also a female, from Lizard Island, of what I take to be a variety of the same species: as will be seen, from the above comparative description, this species is clearly intermediate between $P$. Priamus of Linnæus and P. Richmondia of G. R. Gray. 

INDEX. 
, 


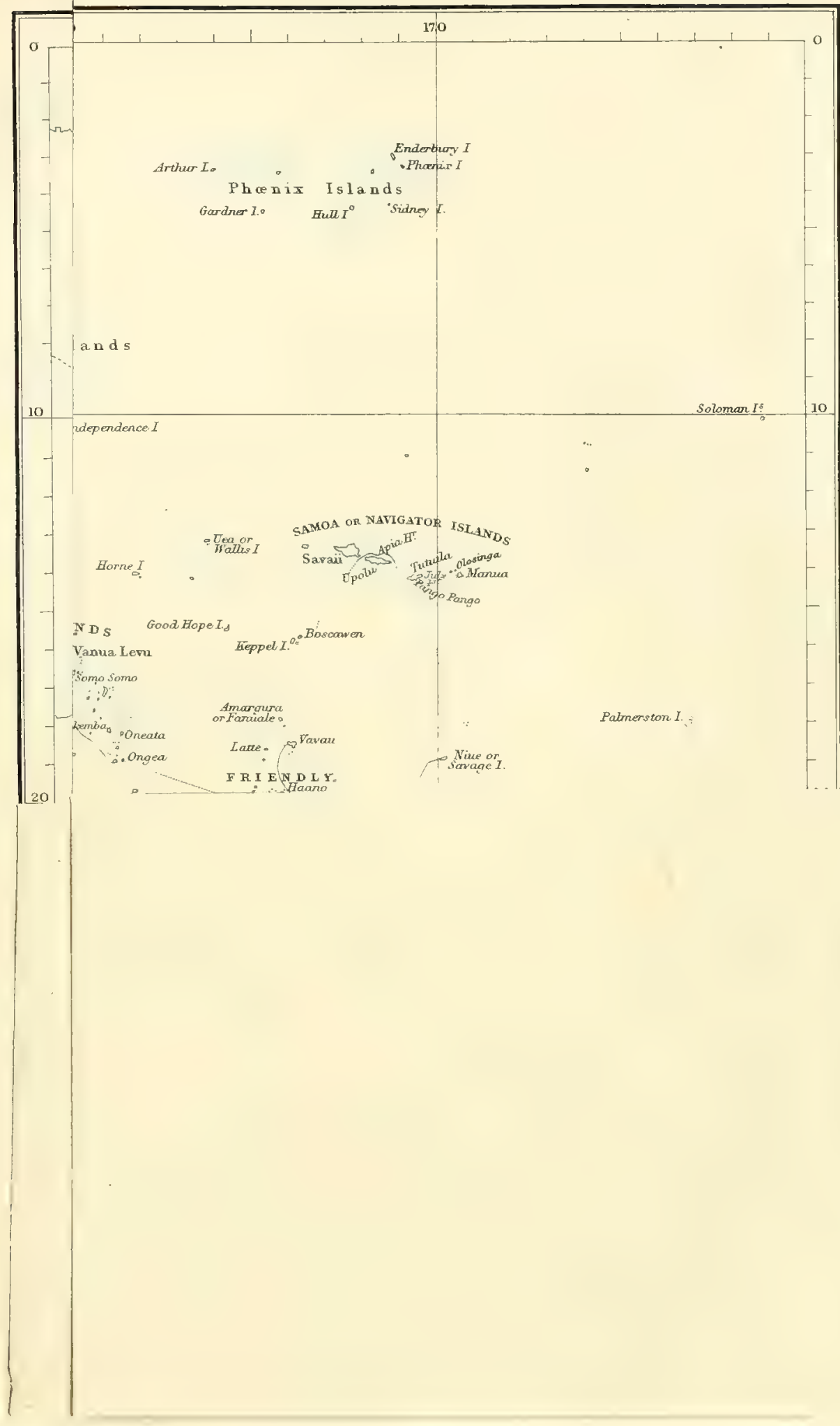


, 


\section{.}




\section{INDEX.}

ADA

AAMS, George, son of a mutineer of A the 'Bounty,' 4

Alofi, a village in Niue Island, 20

Ambrym Island, 233

Amedée, lighthouse of, 320

Amed, island of, 329

Anatow, island of, vigit to, 193. Beauty of, 193. Whale fishery of, 105, 199. Climate of 195. Huricanes of, 195. Population of, 195. Diseases of, 196. Causes of a decrease of the population of, 196. Lauguage of, 196. Character and acquirements of the natives, 196, 197. Missionaries and their work, 197. Government of, 198. Fruits and vegetables of, 198, 199. Exports from, 199. Indigenous rat of the island, 199. Birds of, 199. Reptiles of, 200. Fish of, 200. Insects of, 200 . Common articles of barter, 200. Red earth of, 207

Animals in Upolu, 86

Ants of Guadalcanar, 275

Anuu, or Cocoanut Island, 37

Aoloau, village of, in Tutuila Island, 57

Api Island, 233

Apia Bay, in Upolu, 61, 62. Food to be obtained at, 85

Arrowroot in the Fiji Islands, 189

Ass's Ears on Florida Island, the rocks so called, 278

Asur, an active volcano of, 211

Ava made on Tutuila Island, 50. For-
BUK

bidden by the missionaries in the Hawaiian Archipelago, 51. Ara (Piper mephysticum) plentiful in ''anna, 213

PALISTES, native bas-relief of, 261 Ball's Pyramid, 2, 3

Banks" Islands, visit to, 233, 234. Natives of, 240

Bea, Captrin Croker's siege of, and death at, 113

Beche-de-Mer, yield of, in the Fijilslands, 189

Birds of Niue Island, 25. Of Tutuila, 49. In Upolu, 86. Of Tongatabu, 112, 135. Of Ovalau, 152. Of San Christoval, 269. Found at sea, 296. Found in the South Sea Islands, 353.

Bligh Island, 234

Bocatatanoa, or the Great Argo, 144

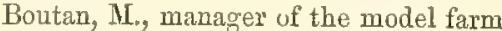
at Yahove, 337. His plough, 339

Boscawen, or Cocos Island, 89

Braidwood, Mr., on Tutuila Island, 50, 51

Brazier, Mr., accompanies the cruise of the 'Curaçoa' as shell collector, 2

Bread-fruit wood never attacked by worms, 85

Buena Vista, island of, 286

Buke-Levu, mountain cliff of, 177 
$\mathrm{BUT}$

Buri, a fruit found at San Christoval, 260

Byron, Lord, scene of an adventure in his poem of "The Island,' 98, 101

CALEDONIA, New, view of, from the sea, 326. Waterfall at Undiana, 326. Havannah Passage, 326. Port Goro and Good Cove, 326, 327. Vegetation of, 327. Birds of, 327. Canoes of, 328, 329. Affairs of the Isle of Lifu, 334. Visit to the model farm of Yahove, 337. Natives of, 341. Religion of the people, $3 \pm 2$. Their wars, 343. Women of, in battle, 343. Customs of, 343,344 . The Rev. Mr. Murray's account of the people, 344. Captain Cook's visit to, 344. Careful cultivation of, $3 \pm 5$. Remarkable system of irrigation, 345 . Women in, 346. Remains of ancient aqueducts, 347

Cannibalism, suppression of, in Fiji, 165. Conjecture as to origin of, 165. Of the natives of Tanna, 209

Candle-nut tree (Aleurites triloba), 134

Canoe, a double war-, 56. Canoes of Vavau, 90. Of Tonga, 136. of Florida Island, 279

Cares, curious, on coast of Varau, 97, 99

Cascade Bay, 4, 5. Beauty of, 5

Cascade Station, Norfolk Island, 6

Cascade in Upolu, 84. Of Waitoba, 150

Centipedes of great size on Norfolk Island, 11

Cherron, M., French missionary at Tongatabu, 119. Visit to him, 120

Clubs of the natives of Florida Island, 281

Cockatoo, or Eastern, Islet, in St. George's Bay, 286. Smallness of, 287 . Natives of, 287

Cocoa-nut fibre, great quantity to be had in the Fiji Islands, 189

Cocoa-nut trees of Eramanga, 321
DIV

Cocoa-nut ail in Upolu, 85. Of Tongatabu, 135. Of Tutuila Island, 46. Of the Fiji Islands, 187

Cocos Island, or Boscawen's Island, 189 Coffee, cultivation of, in the Fiji Islands, 89. Of New Caledonia, 345

Cole, Mr., the American Consul at Upolu, 65

Contrariétés Island. See Ulakua

Coral beach of the island of San Christoval, 265

Cotton planting at Tongatabu, 136. At Ovalalu, 146. Cultivation in the Fiji Islands, 187, 188. Grown and exported from Anatom, 199

Crabs, land, in Upolu, their peculiar habits, 86

Crater, an ancient, in Upolu, 84. One in the Island of Savaii, 81

Creelman, a cotton planter, his petition to the captain of the 'Curacoa,' 154, 155

Croker, Captain, his siege of, and death at, Bea, 113

'Curáçoa,' accident to the, 297. Visit from Iring George of Tonga, 115, 117. Visited by two French missionaries, 117

Cypræa moneta, or Nunpuri, passes as money in Eramanga, 299

'DAY SPRING' accompanies the 'Curaçoa' to Havannah Harbour, 216, 218. Goes to port of Vila, $23: 3$

Deception Isle, 216

Deification of warriors and friends among the Fijians, 181

Dent, Commander, leads the men of the 'Curaçon' at the attack on Tanna, 202, 203

Dillon's Bry, 297. Visit to, 304. Cost of a woman at, 304

Diploptern of the South Sea Islands, 468

Diseases of Tutuila, 57. Of the Samoans, 83

Diring of the natives of Vavau, 99-101 
$\mathrm{E} A \mathrm{~A}$

TAR ornaments of the natives of Santa

1 Cruz Islands, 246, 247

Ebony trees of Ýsabel Island, 289

Ffat, island of. See Vate

Eleanor, Queen of Golea, 174. Her dress, 174. Her arguments in defence of polygamy, 175

Elephantiasis in Tutuila, 57. Among the Samoans, 83

Eor, island of, 112. Vegetation of, 134

Eramanga, risit to, 294, 297. Nountains of, 297. War among the natives of, 298. Sandal-wood and Kauri pine of, 298, 299. Shells and birds of, 299, 300. The village of Sifu bombarded, 302. Visit to Dillon's Bay, 304, 305. Area of the island, 318. Diseases of, 318. Government of, 319. Infanticide in, 319. Their god Nabu, 320. Captain Edwards and his fortune, 320. Articles exported, 320. Vegetation of, 321. Birds and weapons of, 322

Eramanga, island of, 194

Erronan, or Fotura, island of, 201

Erskine, Captain, his account of the Niue Islanders, 31

Tispiritu-Santo, island of, 233

Eutassa, or Auricaria excelsa, the Norfolk Island pine, 5,11

TALATELE, or public house of reception at Feleasau, 37

Fala-teles, 78

Fate, island of. See Vate

Feleasau, rillage of, 36,78

Fijian idols, 146, 147

Fijians, model of a buri, or temple of the, 147. Suppression of cannibalism among them, 165. Jackson's praise of them, 168. Capt. Erskine's confirmation of it, 168. Their intelligence and acuteness, 169. Their songs and hymns, 169. Their proverbs, 170. Their capacity of conversing, 170. Their love of fun and jest, 170. What value they attach to
FRE

truth, 171. Their readiness to welcome foreignel's, 172. Notices of the islands, 179. Population of all the islands, 179. Government of, 179. Dialects of, 180. Iythology of the Fijians, 180. Progress of the islanders in civilisation, 182. Their food, 183. Temperature of Fiji, 183. Diseases of the people, 183. Depopulation of the islands, 183. Rapidity of the regetation of, 184. European population of the group, 184. Contact of the islanders with Europeans, 184. Land in the islands, 185. Offer of the islands to Britain, 185. Internal trade, note 185. Native notions respecting property in land, 186. Value of the exports in 1863 and 1864, 187. Articles of commerce, 189. Introduction of the sugar-cane and coffee, 189. Articles most in demand in Fiji, 190. Land purchasable in, 191. System of scanty cultivation, 191. Climate of, healthy, 191 Excellence of the wool of, 192. Rapid increase of the flocks of, 192

Fire, method of igniting wood, 151

Fishes of Niue Island, 25. Of Tutuila, 60. Flying fish, 144. Found in the South Sea Islands, 411. Of Tongatabu, 135. Poisonous fish, 214 Florida, island of, 277. Natives of, 278, 280, 282. Gulf of Mboli, 279 . Canoes of the island, 279. Shield and two-handed clubs, 281. Beauty of the island, 284. Madrepore, reef at, 283, 289. Villages of, 284. Is divided by a creek or channel, 295

Flying fish, swarms of, 144

Foljambe, $\mathrm{MI}_{\mathrm{l}}$, meets with a waterfall at Waitoba, 150. Goes up to Viria and Naitasiri, 157

Fotuna, or Erronan, isle of, 201

France, Port-de-, visit to, 328, 329. Town of, 335,337 . View of, 336

French lady, and her turn for natural history, 147. Supplies the author with a collection, 148 
THI

Friendly Islands, islands comprised in the, 94

Fruit of Tongatabu, 135. Of Anatom, 198, 199. Of San Christoval, 266

Fuvga-loa, or Deep Bay. See Pangol’ango Bay

Funga-tele, village of, 50, 51

Funga-sa, or Sacred 13ay, or Massacre Bay, 49,50

\section{GEORGE, King of Tonga. See Tuboa, A George}

George's Bay, St., mountains of, 286

Golea, king of Wariki, 174

Good Cove, in Praslin Bay, 327

Gordon, Rev. Mr., a missionary, at Anatom, 194. Murder of his brother and his wife, 195

Goro Port, in New Caledonia, 326

Gower, Mount, 2

Graciosa, Port, 244

Graphite found in the Fiji Islands, 190

Grottoes of Varau, 98, 99

Guadalcanar, visit to, 274. Mountain of, 274. Houses of, 276. Natives of, 276 . Birds of, 276

Guillain, Madame, 332

Guillain, MI., governor of Port-de-France, 331. Visit from him, 331. Notice of him, 332. His house, 333. His punishment of the natives, 333 . His account of matters in the Island of Lifu, 334. Goes with the visitors to the model farm of Yahore, 337

Gum, or resin, from the Daliua, or Fijian Kauri-pine (Dammara vitiensis), 158

\section{TAAFUluHAO Islands, 94}

1 Hada, or Recherche Bay, visit to, 270. The self-styled ling of, 270. Natives of, 272

Hapai Islands, 94. Under the sway of King George, 141.

Hat Island, entrance to Havannah harbour, $216^{\circ}$
KAN

Havannah harbour, entrance to, 216. Visit to, 216. Appearance of the natives of, 217. Their dress and ornaments, 217

Ilawaii, manners of the half-castes of, 12 Ieathcote, midshipman, at the attack on Tanna, 208

Hebrides, New, island of, 233

Henry, Mr., of Eramanga, 299

Iremit-crabs of Guadalcanar, 275

Hinchinbrook Island, $2: 33$

Holland, a seaman of the 'Curaçoa,' falls at the attack on Tanna, 203

IIolothuria found on Ysabel Island, 288

Hood, Mr., his visit to Niue, 34. And to Tutuila, 37. His account of Samoan houses, 42

Hymenoptera aculeata of the South Sea Islands, 462

TNDISPENSABLE Reefs, wreck of a I whale-ship on, 270, 271

Indispensable Strait, 276

Inglis, Rev. Mr., holds a meeting of missionaries at Anatom, 307. They recommend decisive measures ngainst Tanna and Eramanga, 307. Mr. Inglis reproved for sanctioning these proceedings, 308. Defends himself in a letter to the Presbyterian MissionBoard, 308. Facts on which he relies in his defence examined, 308-316. His policy of retaliation criticised, ย16. Value of the reproof, 317.

Insects of Guadalcanar, 275. Found in the South Sea Islands, 453

'Island,' the scene of the adrenture iu Byron's poem of, 98, 101

ACKSON, the English sailor, his account of the Fijians, 168

Jones, Capt., consul at Levuira, 145

TANDAVU, island of, visit to, 176. Size of the island, 176. Resident. 
ISAV

missionaries of, 176. Isthmus of Yarabali, 177. Population of, 177. Mountain cliff of Bulre-Levu, 177. Pottery of the village of Yawe, 177. Visit of II.M.S. 'Esk' to, 177. Letter to the captain of the "Esk" from native boatmen, 178. Population of the island, 179

Kava, fields of, at Tongatabu, 125. Preparation of in the Kava ring, 125-129. Ceremonies in partaking it, 132

Kava bowl of Fiji, given by King Thalambau to the Commodore, 163

Kauri pine, native name for, 298

Keppel Island, 89

Kermedac Islands, 17

Koya-ne-Kululn, the chief, the Commodore's letter to, 158

IKingston, town of, in Norfolk Island, 9

Kulczycki, Count Adam, the Government astronomer at Pcrt-de-France, 331

T AMMAS, Mount, height of, 274 Language of Niue, 28. Of Tutuila, 45. Languages of Tanna, 211

Latte, island of, rolcano of, 97, 104

Lawes, Rev. Mr., his house at the village of Alofi, 20. The missionary himself, 20, 21

Lemon trees and lemons in Norfolk Island, 6

Leone, village of, in Tutuila, 56

Lepidoptera of the South Sea Islands, 470

Levuka, visit to the port of, 144

Levulka Bay, visit to, 176 . Village of, 176

Lifuka, a chief at, rudely treated by a missionary, 111

Lord Howe Island, 2

Low Island, 234

Luce, Captain, his visit to a natural cave in Vavau, 99. His visit to Kandavu, 177

Lying condemned by the Fijians, 171, 172
MBA

VAAFU, son of King George of 11 Tonga, 107. Gives himself up to drink, 143

MacFarlane, Rev. Mr., compelled to submit to the Governor of New Caledonia, 334

Madrepore Reefat Florida Island,283,284

Malachite found in the Fiji Islands, 190

Malapoa Point, Sandwich Island, 215

Malanta, or Malata, island of, 276. Position and extent of, 276,277

Nalicolo, island of, 233

Malietoa, 72; and notes. Signification of his name, 74

Manono, Island of, 86

Manners, influence of, according to Burke, 81

Maofanga, visit to French missionaries at, 120

Larau Sound, visit to, 274. Curaçoa Harbour, Guadalcanar, 275

Maré, one of the Loyalty Islands, visit to, 323

Marriage among the natives of Tutuila Island, 58

Nanumai, Tannese chief, adheres to Christianity, 211

Massacre Bay, 49, 50, 57

Mataku, island of, submits to Tongan supremacy, 140

Mbau, island of, 144. Roadstead of, 153, 154. The residence of King Thakumbau, 154. Complaint of a cotton planter of the name of Creelman, 154. Visit to the town of Rewa, 154. Houses of, 155. Visit to the Rev. Mr. Carey, 157. Journey of Mr. Foljambe up to Viria, 157. And to Naitasiri, 157. Natives of, 158. The city said to be dirty, 163. Eleven rillages or towns taken by the King's warriors, 164. The Akautabu, or sacred tree, of Mbau, 164. The braining stone of, 164. Cruel practices of the Fijians, 167. Not unparalleled in civilisation, 167. The strangers' house at, 172 
MinO

Mboli, Gulf of, in Florida Island, 279. Its harbour named Port Wiseman, 279

McFarland, Mr., at Upolu, 65. His complaints against the missionaries, 66

Meade, Lieut, his account of cares on the coast of Vavau, 97. Transferred to the 'Esk,' 99, note. Takes command of an expedition to the town of Rewa,155

Megapodius, egg of $a, 241$

Nele, language of the isle of, 225

Melata, isle of, 276. Position and extent of, 276

Mice in Tutuila Island, 60

Minerals, absence of, in the Samoan group, 84

Moalo, island of, submits to the Tongan supremacy, 140

Moore, Rev. Mr., at Ovalau, 149

Moss, Mr., secretary to King George of Tonga, 109, 118, 124

Mlota, or Sugal-loaf Island, 234. Population of, 241

Mothe, reef of, 144

Moturikir Island, from the sea, 153

Moulton, Rev.Mr., 105. His wife, 111, 112

Mu Island, Port-de-France, 330

Murray, Mr. A. W., his visit to the Island of Niue, 30

NABU, god of the Eramangans, 320

1 Nairai, isle of, 144

Naitasiri, journey of Mr. Foljambe up to, 157. Dense population of, 158

Nakoai, palm nuts, 199

Neau, island of, 144

Necklaces of the natives of Ulakua, 251

Neiafu, village of, 90 . Natives of, 92 Chapel at, 93. Townhall at, 94

Nettleton, Rev. Mr., resident missionary at Kandavu, 176

' Neuha's Cave,' Byron's poem of, 98

Now Caledonia. See Caledonia.

Niua, or Immer, island of, 201

Niue, or Savage Island, 17, 18, 24. Natives of, 19. An Albino at, 19. House of the Rev. Mr. Lawes at the village
PAN

of Alofi, 20. The natives, 21, 23, 27, 28, 31. Vegetation of, 22, 23. Roads in, 24. Birds and animals of, $25,26$. Fishes of, 25. Dress of the women,'28. Language of, 28. Goternment of, 28. Morality of the people, 29. Cook's visit, 29. Why he called it Savage Island, 29. Misrepresentations of native character, 28-33. Mr. Hood's testimony, 34

Nobbs, Rev. Mr., 6, 7. His chequered career. Death of his son, 14

Norfolk Island, 3. Pitcairn settlers at, 4, 5. The old convict prison and barracks 7, 8. Coral reef at Sydney Bay, 10. Scenery of, 11. Character of the settlers on the island, $11,12$. Their amiability and hospitality, 1113. Their diversions, 13. The American and his flag, 15. Mr. Hood's testimony, 16, note.

Norfolk Island pine, specimens of, 5,11

Nose ornaments of the natives of Ulakua, 250,554

Nowar, Tannese chief, adheres to Christianity, 211

Nukualofa, education of the children at, 131

CILI, port of, 243 Oportuno, the Samoan chief, 75

Opossum killed in San Christoval, 265. Death of a pet one on board, 296

Oralau, visit to, 144. The coast at the port of Levula, 144. Absence of the consui, Captain Jones, 145. Cotton cultivated in the island, 146. Russell and his wares, 146. Waterfall at Waitoba, 150. Vegetation of, 150, 151. Method of kindling wood, 151. People of, and their appearance, $151,152$. The island from the sea, 158 Oysters of Tongatabu, 135

DALUALE, island of, 89 Pandanus trees of Guadalcanar, 275 
PAN

Pango-Pango Bay, anchorage of, 37. Maunga, the chief of, 40 . Dines with his wife on board, 53. Her likeness, 53. Effect of an ice-cream upon him, 54. Enjoys potted salmon, 54

Papalangi Jonah Polahorse, the Englishman of Vavan, 90,95. Appointed guide to the party, 96

Patteson, Bishop, 6. Confirms some of the settlers on Norfolk Island, 13. Vitnesses a painful affair at Santa Cruz, 14. In the 'Southern Cross,' 235. One of his boys lilled at Hada, 271. Comments on the murder of, 305

Patteson, Port, 234. See Vanua-Lava

Paum Island, 233

Paton, Rev. Mrr, at Tanna, 194. His sufferings there, 194

Peruvian pirates at Niue, 26

Philip Island, 3. Colours of the corst, 3. Thronged with rabbits, 4

Philo, on the at tributes of the Deity, 181

Pigeon Island, visit to, 293. Immense numbers of the pigeons at, 293

Pigeon, tooth-billed (Didunculus strigirostris), 86

Pigs in Niue, 26. In Tutuila, 60。 Reserved for public festivals, 60 , note. In Tanna, 213

Pine, Eutassa, or Norfolk Island, 5, 11. Dakua, or Fijian Kauri pine. Eramangan name of Kauri pine, 298

Pishi-tali (the Great Cascade), in the Island of Tutuila, 56

Pitcairn settlers, 4, 9

Policemen in Niue Island, 27

Potato, the principal food of Norfolk Island, 6

Pottery of Mran, 158

Pottery, Fijian, best made at the village of Yawe, 177

Powell, Rev. Mr., his house at Tutuila, 44. His wife, 44. His work, 45

Praslin Bay, in New Caledonia, 326

Presbyterian mission vessel, "Day Spring;' at Anatom, 194. At Tama, 201
SAN

Pritchard, Mr., at Upolu, 71. Mischief done by his horses and mares, 72

Protection Isle, 216

UEEN Charlotte, Cape, in New Caledonia, 326

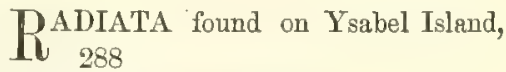

Raoul, or Sunday Island, 17

Recherche Bay. See Hada

Reid's Islands, 144

Reptiles, venomous, unknown on Norfolk Island, 11. And on Niue, 26. In Tutuila, 60. In Upolu, 87. In Tanna, 213. Found in the South Sea Islands, 395

Rewa, visit of an expedition to the town of, 154. Visit to the king, TuiDrakiti, 156

Roman Catholic missions, 121-124

Rossiter, Mr., at Norfolk Island, 5, 7. His daughter married to an American, 16

Rura-Sua, island of, 277

Russell, an old sailor, and his wares, 146

GAGANA, neatness of, 77

S Samaze, M., French missionary at Tongatabu, 119. Visit to him, 120

Samoan chief in war costume, 73

Samoan houses, Mrr. Hood's account of, 42. Villages, 77. People, 78-81. Deities, 82. Absence of minerals in the islands, 81

San Christoval, island of, 248. Visit to, 264. Vegetation of, 264. Coral beach of; 265. Natives of, 265 Cocoa-nut trees of, 265. Houses of 260. Native carving resembling a European hat, 266. Canoe-house of, 267. Roads of, 267. Birds of, 267 
SAN

Sandal-wood of Eramanga, 208, 320. Native name for, 298

Sondwich Island. See Vate

Sandwich Islands, wail of the people of, 173 , note

Sandy Point, anchorage at, 89

San Just, Don Edouardo, 1

Santa Anna, island of, 248

Santa Cruz, painful affair at, narrated by Bishop Patteson, 13. Island, 243, 244

Savaii, island of, 62,89

Scorpions and snakes of Tongatabu, 135

Scudamore, Mr., master of the 'Curaçoa,' destroys the Tannese canoes, 203

Sharks devouring drowning men, native bas-reliefs of, 261. Tiger-sharks, off Niue, 18

Shells found in the Sonth Sea Istands, 437

Shields of the chiefs of Florida Island, 281

Silver, high value of in Tutuila Island, 58

Sifu, village of, bombarded by the 'Curaçoa,' 304

Solomon Islands, visit to the, 248

Somo-Somo, how it became tributary to Mibau, 173. View from the summit, 174

'Southern Cross,' the, 295

Sphyraena, or barracuda, native basrelief of, 261

Stalagmites found in Niue Island, 25

Sugar-cane, cultivation of, in the Fiji Islands, 189

Sydney Bay, 4, 10. Return to, 347

TANNA, treatment of a missionary

1 there, 194. Visit to, 201. Punishment of the natives of, 202. Incidents of the attack, 203. NIarm caused by it, 204. Declaration of the offending chiefs, 204. Signification of the name, 205. Extent and population of the island, 205. Native mode
TON

of trarfare, 205. Climate of, 205. Woodcut representing the natives of, 206, Diseases of, 206. Their burial of the dead, 207. Ornaments of the men and women, 207. Low character of their morality, 208. Their cannibalism, 209. Their religion, 209. Villag'e chiefs, 209. Theil marum, or place of public meeting, 210. Christianity in, 210, 211. Languages peculiar to, 211. Volcano of Asur, 211. Hot springs in the island, 212. Natural products of, 213. Vegetation of, 213. Animals of, 213. Fish of, 214. Insects of, 214. Native barter, 214

Tapa cloths of the people of Niue Island, 57. Of the natives of Tutuila, 57. Mode of preparing it, 93. Worn by King Thakumbau, 160

Tapioca of the Fiji Islands, 189

Thakumbau, King, visits the commodore with his queen, 159. His appearance, 160. His son, 160. Lieut. Pollard's description of him, 161. Gives the great Kava bowl to the commodore, 162. Takes a contribution of firewood to the strangers' house at Mbau, 173. His brother Golea and his wife, 174 .

Tie-beam, from the roof of a public hall, Uji, 260. Figures represented on it in relief, 260,261 Seefrontisprece

Tinakoro, Volcano of, 244. Probable shocks from, 248.

Toa, or ironwood (Acacia heterophylla), 51

Tobacco, value of, in Tutuila, 58. Grown in the Fiji Islands, 184

Tombs at Tongatabu, 118

Tona, disease of the natives of Varau, so called, 102

Tonga Islands, 94. Under the sway of King George, 141

Tongatabu, island of, 4. Visit to, 105. The houses of, 109. The 'Institution' at, 109. Corporal punishment 
TRI

of the natives by the missionaries, 110. Protestant church at, 112. Tomb of Captain Croker at, 113. Catholic and Protestant Missionaries, their mission-houses, 121, Their mutual criminations and recriminations, 123, 124. Plantations of coffee trees at, 124. Fields of kava at, 125. The kava ring, and ceremonies in partaking it, 125-129. Public school examinations at, 129. Native diversions, 131. Stone monument at, 132, 133. Extent of the island, 133. Roads, 133. Fertility of the soil, 133. Vegetation of, 134. Animals of, 134. Fish and reptiles of, 135. Productions of, 135. Articles in request by the natives, 136. Double canoe of, 136. Climate and diseases of, 186. Population of, 137. The race and its customs, 137. Laws respecting the women of, 138. Effects of Christianity, 138, 139. Diffusion of primary instruction, 139. No progress in industrial pursuits, 139. Trxation in, 140. States of King George, 141. Cutter on its way to Tongatabu, 144

Tridacnas found on Florida Island, 283, 284

Tree-fort at Ysabel Island, 292. Treehouse on Ysabel Island, 294

Tuboa, George, king of 'Tonga, 94. His house at Tongatabu, 106. His children, 100. His queen, her likeness, 107. Likeness of him, 108. Interviews with him, 108, 109, 114. Dimes on board the 'Curaçoa,' 115, 117. His return dinner, 118. He presides in the council-house, 124. His states, 141. His royal title, 141. His successor, 141. His government, 141, 142

Tuikanakubulu, the royal title of King George of the Friendly Islands, 141

Tuikilakila, chief of Somo-Somo, believed to be a god, 181
UPO

Tui-na-Virir, the chief, the commodore's letter to, 158

Turtles of Tongatabu, 135

Tutui, or candle-nut (Alerrites triloba), 46,48

Tutuila Island, 36. View of from the sea, 37. Natives of, 37, 39, 52. Lieut. Mead's description of, 38. Mr. Hood's description, 38. The commodore declines to hoist the English flag on the island, 41. Visit to the island, 42. Cocoa-nut oil of, 45. Language of, 45. Vegetation and birds of, 46-48, 51 . Marshes of, 47. Dances of the natives, 54, 55. School and church at, 56. Extent of, 56. Villages of, 56. Population of, 57. Climate of, 57, Diseases of, 57. Character of the people of, 57, 58, 59. Christianity in, 59. Vege. table products of, 59. Animals of, 60. Poisonous fishes of, 60

Twelve-foot Rock, not observable, 18

Two-tree Island, view of, 277. Its shape, 277

JEA, island of, 324 . Natives of, Uji, or Guelph, or Gulf, Island, '258. Birds of, 259. Native girls of, 259. Pigeon-shooting at, 259. Tie-beam from the roof of a public hall, 260, 261. A village hall, 262

Ulakua, or Ulana, or Contrariétés Island, 248. Visit to, 248. Natives and canoes of, 249. Their dress and ornaments, 249-254. Formation of the island, 255. Huts of, 256. Parrote of, 257

Ulana, island of. See Ulakua

Unga, David, son of King George of Tonga, his house in Vavau, 91. His personal appearance and dress, 95. His children, 95

Upolu, view of, from the sea, 61. Vegetation of, 62, Effects of a storm 
$\nabla A N$

at, 64. Baptism in the island, 66. Sunday at, 67. A native teacher at, 67. Visit to the Roman Catholic bishop of, 68, 69. Visit to Mr. Murray, 69. Missionary disputes in, 70. Unfair treatment of natives, 71, 72. Singular dread of horses, note 72. Inconsistent appreciations of national character, 74, 77. Remarliable testimonies in favour of the Samoans, 78, 81. Why called 'Godless,' 81. Population of Upolu, 82. Temperature and climate of, 83 . Tokens of virginity in, 83,84 . Internal communications in, 84. Absence of minerals in, 84. Natural curiosities of, 84 . Tegetation of, 85. Chief commercial products of, 85. Value of the exports, 85. Articles most in request among the natives, 85. Animals of, 86

TANIKORO Island, visit to, 243. Natives and canoes of, 245. Their dress and ornaments, 245-247

Vanua-Lava, island of, submits to the Tongan supremacy, 140. Visit to, 234. Port of, called Port Patteson, 234. The natives, and their desire for empty bottles, 235. Vegetation of, 236. Animals, birds, and insects of, 237, 238. Huts of, 238. Curiosities obtained at, 239 . A hot river at, $239,240 . \quad$ Natives of, 241. Population of, 241. Climate of, 241 . Disease and regetation of,242

Vanua-Levu, or North Fijian Island, superficies of, 179

Vate, or Sandwich Island, or Fate, or Efat, visit to, 215. Native house at, 215. Appearance of, from the sea, 216. Vegretation of, 219. Bones of animals, 220, 221. Natives of, 221, 222. Women and their dress, 223. Treachery of the men of Vila Island, 224. Discovered by Captain Cook, who named it Sandwich Island, 225.
VIT

Extent of, 225. Fertility , 225. Population of, 225. Decrease in the population, 225. Diseases of, 225. Variety of dialects, 225. Government of, 226. Cannibalism in, 226. Alleged execrable practices of, 226. The Rev. Mr. Tumer's account of the natives, 227. Commendatory notices by various visitors to them, 227. Teachers and their extravagant tales, 228-230. Feligion of the natives, 230. Christianity among them, 230. Animals, birds, fish, and insects in the island, 231. Fruit of, 231. Articles offered or obtained in baxter, 232

Vavau, visit to, 89. Vegetation of, 90, 92. Natives of, 90. Missionaries of, 91. Excursion in, 91. Shells and birds of, 92. Natives of, 92. Roads of, 94, 96. Vegetation of, 96, 103. Prisoners and their punishments in, 96. Soil of, 97. Curious natural caves of, 97. Population of, 101. Diseases of, 102. Form of government, and laws of, 102. No indigenous mammifers, 103. Birds, 103. Products of the island, 103. Under the sway of King George, 141

Vegetation of Niue, 22, 23, 25. Of Tutuila, 46, 59. Of Upolu, 85. Of Vavau, 90, 92, 96,103. Of Anatom, 193. Of Vate, 219. Of Vanua-lava, 242. Of San Christoval, 264. Of Guadalcanar, 275

Veitch, Mr., accompanies the cruise, 2

Vila, port of, in Sandwich Island, visit to, 215

Vila Island, treacherous attack on the men of, 224

Viria, in Viti-Levu, journey of Mr. Foljambe up to, 157. Dense population of, 158

Viti-Levu, outline of the coast of, 144

Viti-Levu, the Wai-Levu, or Great River of, 155

Viti-Levu, or South Fijian Island, superficies of, 179 
VOL

Volcano Island. See Tinakoro

Voleaso of Latte, 97. Of numerous small islands, 104. An active one in the Isle of Tanna, 201. Of Asur, 211

WAI-LEVU, or Great River of VitiLevu, 155

Waitoba, waterfall of, 150. Natives bathing at, 150

Wall, Mr., accompanies the cruise as taxidermist, 2

Wanga, visit of the 'Curaçoa' at, $26 t$. Vegetation of, 264. Canoes of, 271

Water-snakes of Tongatabu, 135

Weapons, Tongatabu, 135. Group of, South Sea Islands, 222

Webber, Mro, the Hamburg consul at Upolu, 65

Wesleyan and other missions in the South Sea Islands, their jealousies of each other, 121-123

Whales found near the coast of the Fiji Islands, 189, American whalers calling at $\mathrm{Fiji}, 190$

Whale Island, 193, Whales and whalefishing at, 195. Extent of, 195

Whewell, Rev. Mr., 105, 110. His wife, 111
YSA

White, Rev. Mr., resident missionary at Kandavu, 176

Wilkes, Captain, his account of the Samoans, 75, 77

Williams, Mr., the British consul at Upolu, 62. His father's death, 62. His varied resources, 63. A dinner at his house, 65. A memoxial slab to his father, 68

Wise, Charley, taken on board the 'Curaçoa,' 153

Wiseman, Port, visit of the 'Curaçoa' to, 279

Women, cost of one at Dillon's Bay, 304. Trade in women at Eramanga, 321

Wool of the sheep in Fiji, 192

VAHOVE, model farm of, 337. The 1 managex, M. Boutan, 337. Views from the farm-house, 341. Coffeetrees of,340. M.Boutan's plough at, 339

Yankee Sam, 51, 56

Yarabali, isthmus of, 177

Yawe, pottery of the village of, 177

Ysabel Island, visit to, 286, 288. Trees of, 289. Houses in the trees of, 289, 202. Vegetation of, 289, 290. Treefort at, 292 




(2) 2.

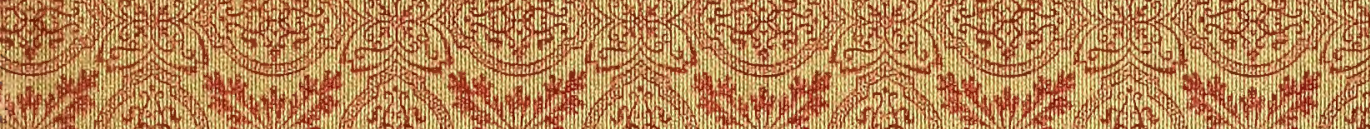

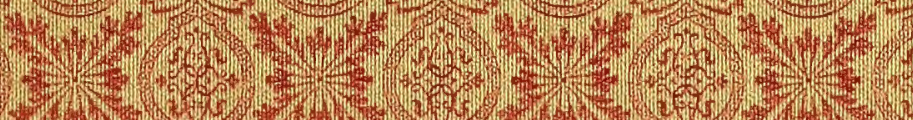
3) (2)

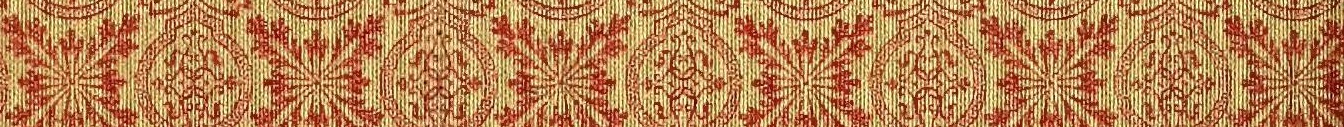

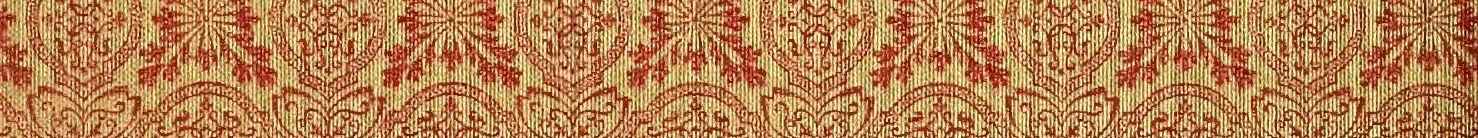
H.t. (6) H.

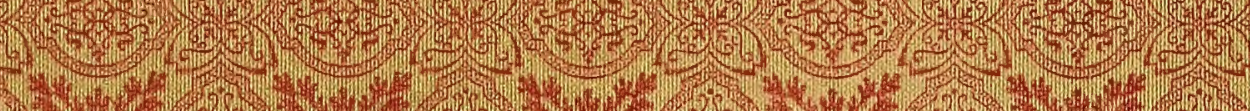

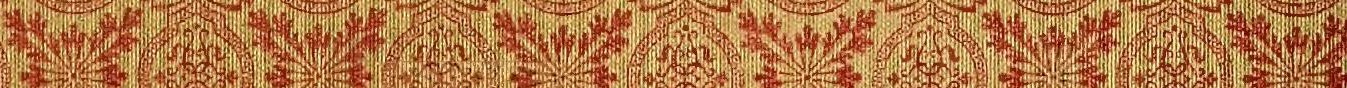
3 (2) (a) (a)

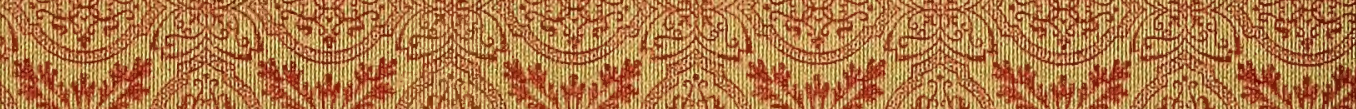
3. (H) (3.

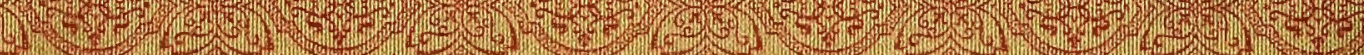
(1)

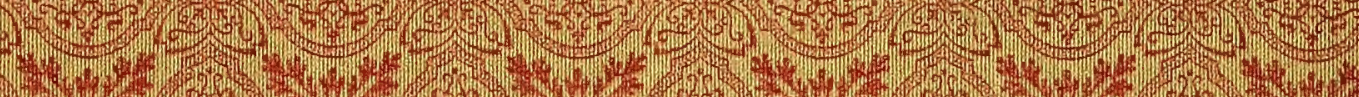

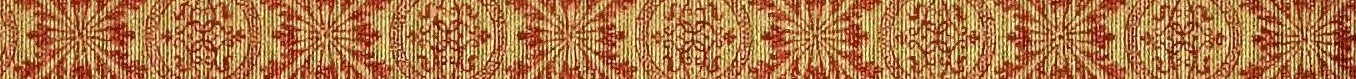

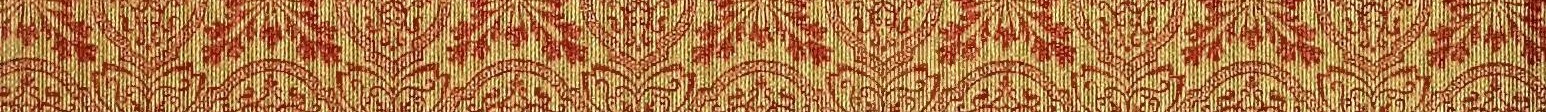

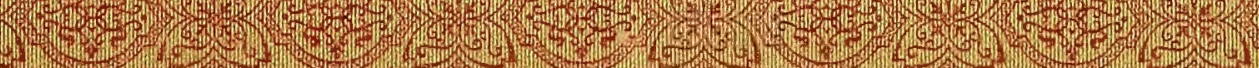


(6)

0.7.

6. 



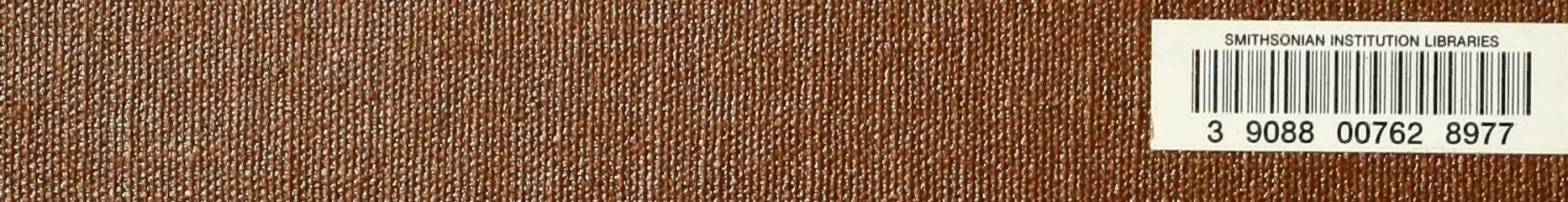

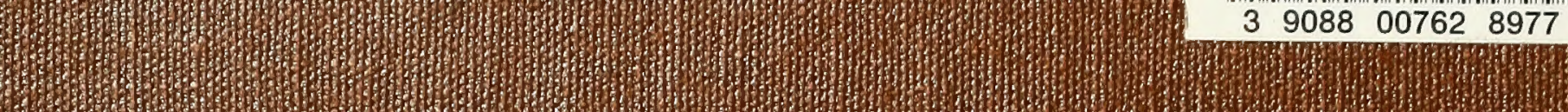

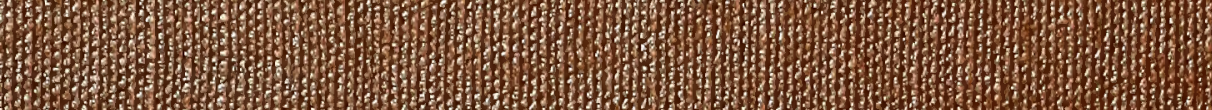

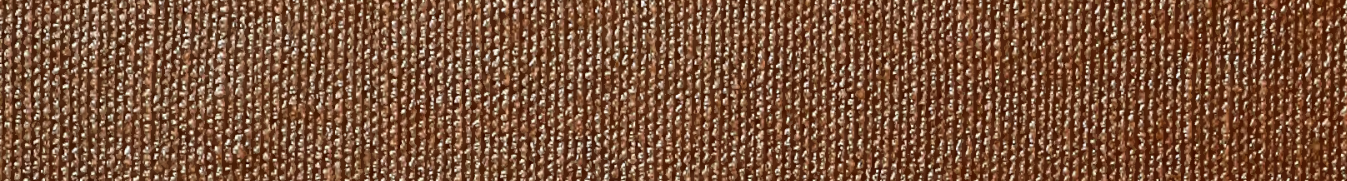
3.3.

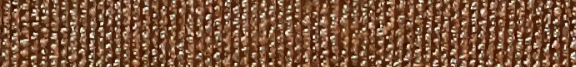

